
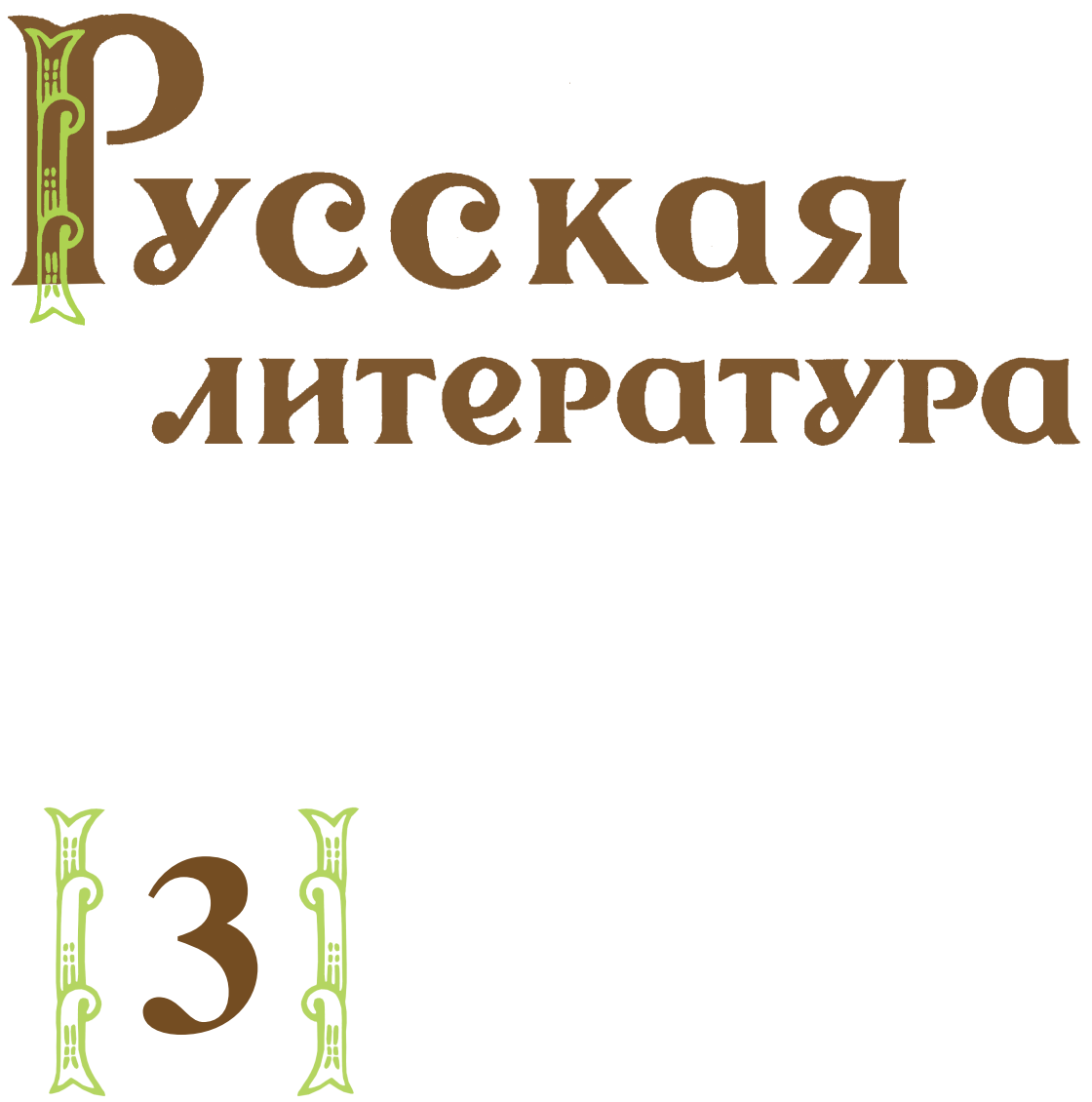

\title{
2020
}

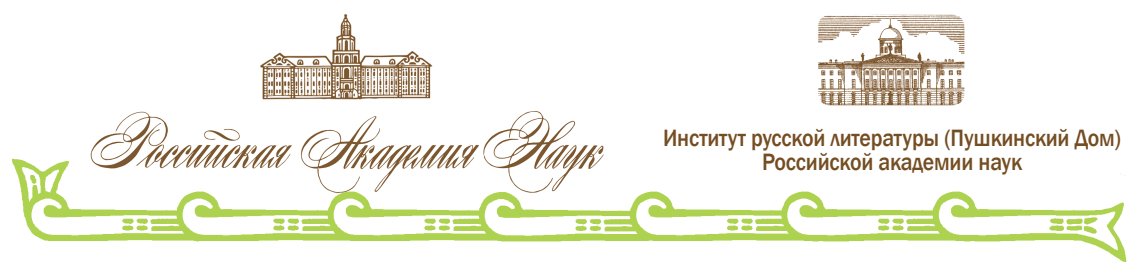




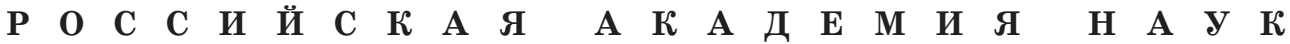

ИНСТИТУТ РУССКОЙ ЛИТЕРАТУРЫ (ПУШКИНСКИЙ ДОМ)

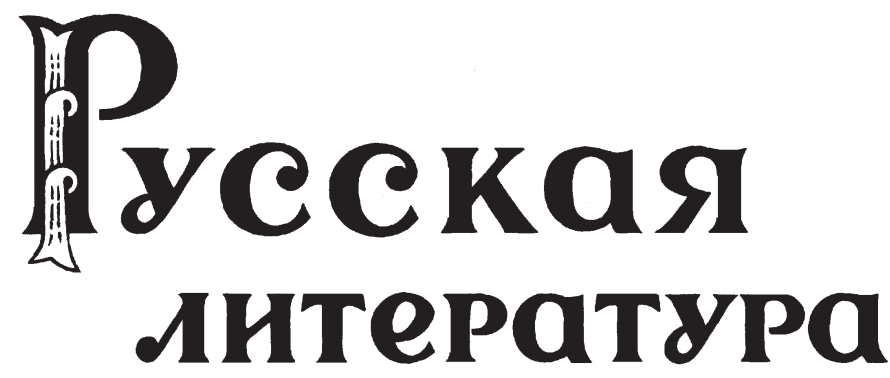

№ 3 Историко-литературный журнал

Издаетсясянваря 1958 года

Выходит 4 раза в год

\section{СОДЕРЖАН ИЕ}

П. Е. Бухаркин, Е. М. Матвеев. Антропонимы в русской литературе XVIII века: о некоторых аспектах функционирования имени в оде и трагедии . . . . . . . . . . . .

Т. Н. Степанищева (Эстония). Дебют А. А. Бестужева-прозаика (к характеристике «марлинизма») . . . . . . . . . . . . . . . . . . . . . . . . . . . .

Стр.

\section{К 220-ЛЕТИЮ СО ДНЯ РОЖДЕНИЯ Е. А. БАРАТЫНСКОГО}

Н. Н. Мазур. «Подобие того-сего»: коннотации шампанского в русской поэзии 18101830-х годов . . . . . . . . . . . . . . . . . . . . . . . . . . . . . . . .

А. С. Бодрова. Неизвестное письмо Е. А. Баратынского к А. И. Тургеневу (к истории литературных отношений) . . . . . . . . . . . . . . . . . . . . . . . . . . .

Н. Г. Охотин. Из комментария к «Приметам» Е. А. Баратынского . . . . . . . . . . . . . . . . 58

\section{В ПРЕДДВЕРИИ ГОДА ДОСТОЕВСКОГО}

Н. В. Чернова. «Любите вы уличное пение?»: осуждение Раскольникова народным хором . .

В. Е. Багно. Ясные поляны и петербургские углы России и русской литературы (прогнозы и пророчества Э. Пардо Басан) . . . . . . . . . . . . . . . . . . . . . .

М. Б. Плюханова (Италия). О значении параллельных сцен и сквозных мотивов в «сверхромане» Ф. М. Достоевского: поиски метода между Иннокентием Анненским и «новой критикой» . . . . . . . . . . . . . . . . . . . . . . . . . . . . . . .

В. М. Димитриев. «Достоевский» Андре ЖКида в Русском Зарубежье . . . . . . . . . . . $\quad$. 93

\section{К 150-ЛЕТИЮ СО ДНЯ РОЖДЕНИЯ И. А. БУНИНА}

О. А. Коростелев. «Смерти нет!»: Г. В. Адамович о И. А. Бунине . . . . . . . . . . . . . .

А. В. Бакунцев. Неизвестные автографы И. А. Бунина в фондах Театрального музея имени А. А. Бахрушина . . . . . . . . . . . . . . . . . . . . . . . . . . . .

Т. М. Двинятина. «За стенами разрушенного и поруганного Сиона»: И. А. Бунин в 19171921 годах . . . . . . . . . . . . . . . . . . . . . . . . . . . . . . . . .

С. Н. Морозов. Рассказ И. А. Бунина «Цикады»: история текста • • • • • •

Е. Р. Пономарев. Рассказы «круга „Темных аллей“» . . . . . . . . . . . . . . . . . . . . . . . . . . . . . 


\section{ПУБЛИКАЦИИ И СООБЩЕНИЯ}

Л. В. Соколова. История возникновения и особенности памятников Куликовского цикла . . 153

А. Ю. Веселова, М. П. Милютин. Мемуары А. Т. Болотова: история создания ... . $\quad 165$

М. Э. Баскина (Маликова), А. В. Волков. Что же писал о переводах Жиитель Выборгской стороны . . . . . . . . . . . . . . . . . . . . . . . . . . . . . . . . . .

Д. А. Луговская. В. Ф. Ходасевич в 1905-1907 годах: стратегия критика и становление литературной репутации . . . . . . . . . . . . . . . . . . . . . . . . . .

Е. Р. Обатнина. Избранные страницы из альбома А. М. Ремизова «Зарубежная цензура»: политика и этика .

А. А. Кобринский. Мастер Петр: несколько штрихов к биографическим мифам Даниила Хармса . . . . . . . . . . . . . . . . . . . . . . . . . . . . . . . . . .

Задумано Сталиным - сделано Хрущевым (Еще раз о Втором Всесоюзном съезде советских писателей СССР) (публикация В.Ю.Вьюгина) . . . . . . . . . . . . . . . . . .

К. Л. Филимонова (Эстония). Эпизод из истории лагерной литературы: неизвестная рецензия Варлама Шаламова . . . . . . . . . . . . . . . . . . . . . . . . .

\section{ЗАМЕТКИ}

О. А. Лекманов. Растительный код рассказа Федора Сологуба «Ничего не вышло» . . .

С. А. Дубровская, О. Е. Осовский. О цитатах из Герцена в исследовании М. М. Бахтина о Рабле . . . . . . . . . . . . . . . . . . . . . . . . . . . . . . . . .

\section{ОБЗОРЫ И РЕЦЕНЗИИ}

П. Р. Заборов. Ценный источниковедческий труд . . . . . . . . . . . . . . . . . . . . . . .

Г. Е. Потапова. Курс лекций В. М. Марковича о русской литературе первой половины ХІХ века . . . . . . . . . . . . . . . . . . . . . . . . . . . . . . . . .

О. А. Клинг. Разгадка тайн Н. В. Гоголя . . . . . . . . . . . . . . . . . . . . . . . .

С. В. Федотова. Достоевский в ракурсе академической метакритики ........ . 261

\section{ХРОНИКА}

Е. Н. Григорьева, А. А. Карпов, Н. А. Карпов. Петербургское университетское литературоведение в его прошлом и настоящем . . . . . . . . . . . . . . . . . . . . .

Л. В. Спроге (Латвия), Т. С. Царькова. Международный Балтийский семинар «Георгий Адамович и... (к проблеме изучения культуры русской диаспоры)» . . . . . . . .

С. А. Кибальник. Международный научно-исследовательский семинар «История текста и творческая история произведений Достоевского» . . . . . . . . . . . . . . . .

Д. М. Буланин. Симпозиум «Загадка в средневековой славянской культуре» в Кёльне . .

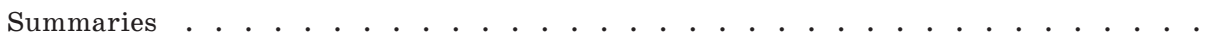

\section{Журнал издается под руководством Отделения историко-филологических наук РАН}

Редакционный совет:

Н. А. БОГОМОЛОВ, М. ГАРДЗАНИТИ, С. ГАРДЗОНИО, Ж. Ф. ЖАККАР, ЛЮ ВЭНЬФЭЙ, ДЖ. МАЛМСТАД, Ж. НИВА, ДЖ. СМИТ, Р. Д. ТИМЕНЧИК, В. ШМИД, Т. В. ЦИВБЯН

Главный редактор В. Е. БАГНО

\section{Редакционная коллегия:}

М. Н. ВИРОЛАЙНЕН, Е. Г. ВОДОЛАЗКИН, В. В. ГОЛОВИН, А. М. ГРАЧЕВА, И. Ф. ДАНИЛОВА (зал. главного редактора), Н. Н. КАЗАНСКИЙ, А. В. ЛАВРОВ, А. М. МОЛДОВАН, А. Ф. НЕКРЫЛОВА, С. И. НИКОЛАЕВ, М. В. ОТРАДИН, А. А. ПАНЧЕНКО, В. В. ПОЛОНСКИЙ, Н. Н. СКАТОВ, А. Л. ТОПОРКОВ, Т. С. ЦАРЬКОВА

Адрес редакиии: 199034, Санкт-Петербург, наб. Макарова, 4. Телефон / ракс (812) 328-16-01; e-mail: rusliter@mail.ru «Русская литература», 2020 


\title{
$\begin{array}{llllllllllllllllllllllll}\mathbf{R} & \mathbf{U} & \mathbf{S} & \mathbf{S} & \mathbf{I} & \mathbf{A} & \mathbf{N} & \mathbf{A} & \mathbf{C} & \mathbf{A} & \mathbf{D} & \mathbf{E} & \mathbf{M} & \mathbf{Y} & \mathbf{O} & \mathbf{F} & \mathbf{S} & \mathbf{C} & \mathbf{I} & \mathbf{E} & \mathbf{N} & \mathbf{C} & \mathbf{E} & \mathbf{S}\end{array}$ INSTITUTE OF RUSSIAN LITERATURE (PUSHKIN HOUSE)
}

\section{$\mathbf{R}_{\text {USSKaya }}$ \\ LITERATURA}

№ 3

Historical and Literary Studies

2020

\author{
Founded in January 1958 \\ Published Quarterly
}

\section{CONTENTS}

P. Ye. Bukharkin, E. M. Matveev. Anthroponyms in the Eighteenth-Century Russian Literature: Certain Aspects of Apellatives' Functionality in Ode and Tragedy . . . . . .

T. N. Stepanishcheva (Estonia). Alexander Bestuzhev as a Prosaic Narrator: The Initial Point (Towards the Concept Marlinism) . . . . . . . . . . . . . . . . . . 20

\section{E. A. BARATYNSKY: 220s ANNIVERSARY}

N. N. Mazur. A Simile of This and That: Connotations of Champagne in the Russian Poetry

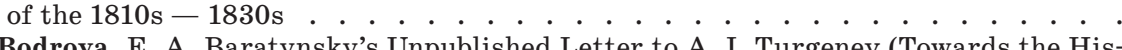

A. S. Bodrova. E. A. Baratynsky's Unpublished Letter to A. I. Turgenev (Towards the History of a Literary Relationship) . . . . . . . . . . . . . . . . . . . . . . . .

N. G. Okhotin. From the Commentary to E. A. Baratynsky's Omens . . . . . . . . . . . 58

\section{FORTHCOMING YEAR OF DOSTOEVSKY}

N. V. Chernova. Do You Like Street Singing?: Raskolnikov Condemned by the Choir of the People. . . . . . . . . . . . . . . . . . . . . . . . . . . . . . . . . .

V. Ie. Bagno. Yasniie Poliany and Petersburg Corners of Russia and Russian Literature (Prophesies and Prognostications of E. Pardo Bazán) . . . . . . . . . . . . . .

M. B. Plyukhanova (Italy). On the Meaning of Parallel Scenes and Cross-Cutting Motives in F. M. Dostoevsky's «Super-Novel»: The Search for a Method Between Innokenty Annensky and the "New Criticism» . . . . . . . . . . . . . . . . . . . . . . .

V. M. Dimitriev. Dostö̈evski by André Gide in Russia Abroad ． . . . . . . . . . . . . 93

\section{A. BUNIN: 150S ANNIVERSARY}

O. A. Korostelev. There's No Death!: G. V. Adamovich on I. A. Bunin . . . . . . . . . .

A. V. Bakuntsev. I. A. Bunin's Unknown Autographs in the Archives of A. A. Bakhrushin Theatre Museum . . . . . . . . . . . . . . . . . . . . . . . . . . . . . .

T. M. Dvinyatina. Outside the Walls of Zion Destroyed and Defiled: I. A. Bunin in 1917-1921 . . 117

S. N. Morozov. I. A. Bunin's Story The Cicadas: History of the Text ． . . . . . . . . . 129

E. V. Ponomarev. The Stories of the «Circle of the Dark Avenues» . . . . . . . . . . . 141 


\title{
RELEASES AND REPORTS
}

L. V. Sokolova. Origins and Special Features of the Texts of the Kulikovsky Cycle • . . $\quad 153$

A. Iu. Veselova, M. P. Miliutin. A. T. Bolotov's Memoirs: History of Creation . . . . . . .

M. E. Baskina (Malikova), A. V. Volkov. What the Dweller of the Vyborg Side Has Said about Translation . . . . . . . . . . . . . . . . . . . . . .

D. A. Lugovskaia. V. F. Khodasevich in 1905-1907: Strategy of a Critic and the Emergence of a Literary Reputation . . . . . . . . . . . . . . . . . . . . . . . . . . .

E. R. Obatnina. Selected Pages from Alexey Remizov's Album Foreign Censorship: Politics and Ethics . . . . . . . . . . . . . . . . . . . . . . . . . . . . . . . . .

A. A. Kobrinskii. Master Peter: A Few Sidelights on Daniil Kharms's Biographical Myths . . Conceived by Stalin - Implemented by Khrushchev (More on the Second Congress of the Soviet Writers) (Published by V. Iu. V'iugin) . . . . . . . . . . . . . . . . . .

K. L. Filimonova (Estonia). An Episode from the History of the Camp Literature: Varlam Shalamov's Unknown Review . . . . . . . . . . . . . . . . . . . .

\section{NOTES}

O. A. Lekmanov. Botanical Key to Fedor Sologub’s Short Story It Didn't Work . . . . . .

S. A. Dubrovskaia, O. E. Osovskii. Quotes from Herzen in M. M. Bakhtin's Study on Rabelais . . . . . . . . . . . . . . . . . . . .

\section{REVIEWS}

P. R. Zaborov. Valuable Work on Source Criticism . . . . . . . . . . . . . . . . . .

G. E. Potapova. V. M. Markovich's Lectures on the Russian Literature of the First Half of the $19^{\text {th }}$ Century . . . . . . . . . . . . . . . . . . . . . . . . . . . .

O. A. Kling. The Key to the Secrets of N. V. Gogol _. . . . . . . . . . . . . . . . . .

S. V. Fedotova. Dostoevsky from the Perspective of Academic Metacriticism . . . . . . .

\section{NEWSREEL}

E. N. Grigoryeva, A. A. Karpov, N. A. Karpov. Literary Studies at St. Petersburg University: Past and Present . . . . . . . . . . . . . . . . . . . . . . . . . . . .

L. V. Sproge (Latvia), T. S. Tsar'kova. International Baltic Seminar George Adamovich and... (On the Problem of Studying the Culture of the Russian Diaspora) . . . . .

S. A. Kibal'nik. Text History and Creative History of Dostoevsky's Works International Research Seminar . . . . . . . . . . . . . . . . . . . . . . . . . . . . .

D. M. Bulanin. Enigma in Medieval Slavic Culture Symposium in Cologne . . . . . . . . 274

Summaries . . . . . . . . . . . . . . . . . . . . . . 277

\section{Published under the Auspices of History and Philology Department Russian Academy of Sciences}

\section{Editorial Council:}

N. A. BOGOMOLOV, M. GARZANITI, S. GARZONIO, J. F. JACCARD, J. MALMSTAD, G. NIVAT, V. SCHMIDT, G. SMITH, R. D. TIMENCHIK, T. V. TSIVIAN, WENFEI LIU

\author{
Editor-in-Chief $V$. E. BAGNO
}

\section{Editorial Board:}

I. F. DANILOVA (Deputy Editor-in-Chief), V. V. GOLOVIN, A. M. GRACHEVA, N. N. KAZANSKY, A. V. LAVROV, A. M. MOLDOVAN, A. F. NEKRYLOVA, S. I. NIKOLAEV, M. V. OTRADIN, A. A. PANCHENKO, V. V. POLONSKY, N. N. SKATOV, A. L. TOPORKOV, T. S. TSARKOVA, M. N. VIROLAINEN, E. G. VODOLAZKIN

Editorial Office: 4, Makarova Embankment, St. Petersburg 199034. Phone/fax (812) 328-16-01; e-mail: rusliter@mail.ru 


\section{АНТРОПОНИМЫ В РУССКОЙ ЛИТЕРАТУРЕ ХVIII ВЕКА: О НЕКОТОРЫХ АСПЕКТАХ ФУНКЦИОНИРОВАНИЯ ИМЕНИ В ОДЕ И ТРАГЕДИИ*}

В филологической науке в течение уже нескольких десятилетий активно развивается антропоцентрический подход к языку и литературе; можно говорить о все большем распространении антропоцентрической парадигмы, «в которой изучаемая система рассматривается с учетом того, что обязательным компонентом либо самой системы, либо среды, в которой она функционирует, является человек». ${ }^{1}$ Соответственно, в разных аспектах словесной культуры видят прежде всего различные проявления речемыслительной деятельности человека. Подход этот базируется на достижениях лингвистики текста, лингвистической прагматики, теории речевых актов, неориторики, он также связан с концепцией языковой личности и, с другой стороны, с культурно-антропологическими исследованиями в области литературы. ${ }^{2}$ Распространение антропоцентризма в области филологических изысканий требует пристального рассмотрения целого ряда проблем на другом, нежели прежде, уровне, уровне, учитывающем современные научные достижения в перечисленных сферах гуманитарного знания. Одной из таких проблем является проблема антропонимов, которая приобретает здесь особое значение, так как появление антропонима в тексте является сигналом диалога языковой личности с другими. ${ }^{3}$

Рассматривая функционирование антропонимов в языке и литературе, следует всегда памятовать о том, что каждая эпоха формирует свой корпус антропонимов, а также о том, что базовые принципы номинации исторически изменчивы. В истории русской письменности как раз в этом разрезе несомненный интерес представляет XVIII столетие; проблема личных имен в словесной культуре того времени является крайне важной по многим причинам. Во-первых, антропонимы XVIII века менее изучены по сравнению с антропонимами древнерусской словесности и литературы XIX-XX веков.

* Исследование выполнено при финансовой поддержке гранта РФФИ 18-012-00321A «Антропонимы в русской словесной культуре XVIII века (историко-литературный и лингвистический аспекты)» (рук. П. Е. Бухаркин).

1 Арнольд И. В. Парадигма антропоцентризма, прагмалингвистика и стилистика декодирования // Арнольд И. В. Семантика. Стилистика. Интертекстуальность. СПб., 1999. С. 172-173.

2 Из ярких примеров последнего времени здесь можно привести недавнюю книгу: Зорин А. Л. Появление героя: из истории русской эмоциональной культуры конца XVIII — начала XIX века. M., 2016.

${ }^{3}$ Из относительно недавних коллективных исследований в области литературной антропонимики, охватывающих широкий круг проблем, укажем: Namen in der russishen Literatur. Имена в русской литературе / Hrsg. von M. Freise. Wiesbaden, 2013 (Opera Slavica. Neue Folge. 57). 
Об этом свидетельствуют, в частности, данные двух обширных библиографических указателей работ по русской литературной ономастике - С. И. Зинина и Г. Ф. Ковалева: ${ }^{4}$ в первом указателе насчитывается 1326 наименований, во втором - 3244 наименования, при этом работ, непосредственно связанных с антропонимикой в русской словесности XVIII века, не более тридцати. Важно отметить, что имена собственные обычно не включаются в словник исторических словарей XVIII века («Словарь Академии Российской», «Словарь русского языка XVIII века» и др.), тем более не учитываются словарями и случаи апеллятивации (т. е. перехода имен собственных в имена нарицательные), хотя необходимость этого осознавалась уже в XVIII веке. Известно, например, что Д. И. Фонвизин в письме О. П. Козодавлеву, которое имело во многом публичный характер (письмо в защиту «Начертания для составления толкового словаря славяно-российского языка», 1784), настаивал на включении имен собственных в «Словарь Академии Российской»: «Я желал бы, например, чтоб в словаре нашем было истолковано, что имя Нерон заключает в себе идею лютого тирана, Тит - государя милосердого, Сарданапал - тирана сладострастного; что Зоилом именуется злобный и презрительный критик; что имя Катилина сделалось титлом высокомерного врага отечеству». ${ }^{5}$

Во-вторых, именно в XVIII веке русская культура активно усваивает общеевропейский антропонимический культурный тезаурус - имена мифологических персонажей, исторических и культурных деятелей, который органично соединяется с национальной традицией. Процесс такого слияния занял длительное время и проходил в несколько этапов, каждый из которых представляет большой культурный интерес. На исходе века мы видим уже достаточно гармоничную картину, выразительным свидетельством чему может, в частности, служить рассуждение А. Н. Радищева из «Жития Федора Васильевича Ушакова»: «Равно имяниты для нас Нерон и Марк Аврелий, Калигула и Тит, Аристид и Шемяка, Картуш, Александр, Катилина и Стенька Разин; все славны, все живут на памяти потомства и не возмущаются тем, что о них мыслят» ${ }^{6}$ Следует отметить здесь большую роль, сыгранную переводной литературой; значение и удельный вес переводов и переделок в русской литературной жизни XVIII столетия трудно преувеличить. Вместе с тем вопрос о передаче имен персонажей русскими переводчиками исследовался крайне мало, хотя он сам по себе представляет важную научную проблему.

B-третьих, к концу XVIII века создается культурно-исторический антропонимический канон, т. е. формируется круг значимых для национального сознания исторических персонажей. Наиболее полно он представлен в «Истории государства Российского» Н. М. Карамзина, но начало его формирования относится к предшествующим историческим трудам (М. В. Ломоносов, В. Н. Татищев, М. М. Щербатов). Важным представляется, что этот канон нашел отражение в художественных текстах XVIII века (торжественной оде, трагедии, ораторской прозе, героической поэме).

B-четвертых, в завершающие век десятилетия начинает складываться новая номенклатура имен литературных героев. До 1780-х годов большинство

4 Зинин С. И. Поэтическая ономастика (собственные имена в художественной литературе и фольклоре). Библиография литературы на русском языке 1905-2006 гг. См.: http://imja.name/ poehtonimy/poehtonimy.shtml; дата обращения: 30.04.2020; Ковалев $Г$. Ф. Библиография ономастики русской литературы по 2010 год. Воронеж, 2014.

5 Фонвизин Д. И. [В защиту «Начертания»] // Фонвизин Д. И. Собр. соч.: В 2 т. М.; Л., 1959. Т. 1. С. 254. Благодарим С. С. Волкова за напоминание об этом высказывании Д. И. Фонвизина.

${ }^{6}$ Радищев А. Н. Житие Федора Васильевича Ушакова // Радищев А. Н. Полн. собр. соч.: [В 3 т.]. М.; Л., 1938. T. 1. C. 178. 
литературных героев носили или условный и заимствованный характер, или были «говорящими» и содержали в себе однозначную оценку героя. В эпоху сентиментализма имя героя принципиально меняется: антропонимы из живого языка (например, Лиза, Евгений, Юлия, Маша, Нина и др.) активно проникают в литературу, получая своеобразный эстетический статус, что требует специального изучения. Кроме того, в литературных произведениях конца XVIII века обнаруживаются примеры заимствования имен из других текстов в целях литературной игры (хрестоматийным примером этого является Фелии, Г. Р. Державина).

Мы указали лишь некоторые, основные причины, обуславливающие особое значение XVIII столетия для дальнейшего исследования истории русской антропонимики. Однако и их достаточно для осознания важности проблематики такой направленности; изучение антропонимов в языке и литературе XVIII столетия сможет существенно обогатить наши представления о словесной культуре той эпохи. Следует отметить, что важность подобных штудий осознавалась; несмотря на относительную малоизученность антропонимов в языке и литературе XVIII века, они все же привлекали к себе внимание исследователей. Достаточно назвать (даже не указывая их конкретных работ и нисколько не претендуя на полноту) имена таких ученых, как Т. Е. Абрамзон, П. Н. Берков, В. М. Жиивов, Г. Кайперт, О. Б. Лебедева, Ю. М. Лотман, С. И. Николаев, К. В. Пигарев, И. З. Серман, Ю. В. Стенник, В. Н. Топоров, Б. А. Успенский. В исследованиях и только что перечисленных, и других филологов были произведены сбор и систематизация антропонимов и их дальнейший анализ во многих и весьма различных аспектах.

И вместе с этим перед исследователями личных имен в русской словесности XVIII столетия стоит еще немало вопросов самого серьезного свойства. Так, дальнейших разысканий и даже просто уточнений требует комментирование антропонимов в произведениях XVIII века; целый ряд существующих комментариев (даже в самых авторитетных изданиях) содержат в себе не только пропуски, но и прямые неточности. В качестве примера приведем досадные ошибки подготовки текста и комментария к «Оде российскому воинству в феврале 1769 » М. М. Хераскова. Здесь, в обращении к туркам, читаем:

\footnotetext{
Ты в гордых мыслях и словах

Прямую славу заключаешь,

Вселенную разрушить в прах

От стен Византских угрожаешь;

Продерзкий род! иль ты забыл,

Каков у россов Минин был,

Свою напасть и их победы? ${ }^{7}$
}

Антропоним прокомментирован следующим образом: «Минин - Кузьма Минич Захарьев-Сухорук (ум. 1616), один из руководителей русского народного ополчения, освободившего в 1612 г. Россию от польских интервентов» ${ }^{8}$ Возникает вопрос: почему турки должны вспомнить о Кузьме Минине, который не имеет никакого отношения к русско-турецким войнам, о которых идет речь в оде? Недоумение разрешается при обращении к тексту оды в Полном собрании сочинений Хераскова, в котором вместо имени Минин напечатано Миних. ${ }^{9}$ То есть в оде речь идет о генерал-фельдмаршале Б. К. Минихе,

7 Херасков М. М. Избр. произведения / Вступ. статья, подг. текста и прим. А. В. Западова. Л., 1964. С. 65 (Библиотека поэта. Большая сер.).

8 Там же. С. 377.

9 Херасков М. М. Творения: В 12 ч. М., 1796-1803. Ч. 7. С. 136. 
участнике русско-турецкой войны 1735-1739 годов, главнокомандующем русской армией в ходе знаменитого взятия Хотина (1739), воспетого М. В. Ломоносовым. События этой войны, связанные с самыми громкими победами русского оружия, упоминаются в следующей строфе:

Хотин еще в крови стоит,

Бендерских стен верхи дымятся,

Азов разрушенный лежит,

Брега дунайски гробом зрятся... ${ }^{10}$

Эти реалии прокомментированы вполне корректно («Хотин, Бендеры, Азов - турецкие крепости, взятые штурмом русскими войсками в войну 1736-1739 гг., но затем снова возвращенные Турции» ${ }^{11}$ ), что делает предыдущий комментарий особенно странным. В той же оде Хераскова чуть ниже помещен следующий фрагмент:

Летите, росские орлы,

Карать рушителей спокойства!

Во всех странах гремят хвалы

И слухи вашего геройства;

Весь свет бы Фридрих победил

И больше б Александра был,

Коль россов не было бы в свете:

Победоносной их рукой

Европе мир дан и покой;

Их слава ныне в полном цвете. ${ }^{12}$

К имени Фридрих приводится следующий комментарий: «Фридрих прусский король Фридрих-Вильгельм II (1712-1786)». ${ }^{13}$ В действительности речь, конечно, не о Фридрихе-Вильгельме II (1744-1797), а о его дяде, Фридрихе II Великом (в комментарии приведены его годы жизни: 1712-1786, ошибочно приписанные Фридриху-Вильгельму), именно он, увеличивший территорию Пруссии вдвое, мог сравниваться с Александром Македонским.

Подобные случаи среди прочего ясно демонстрируют необходимость дальнейших и многоаспектных исследований в области русской антропонимики XVIII столетия. К числу малоизученных вопросов относится и проблема образно-переносного употребления имен собственных в русской литературе XVIII века, т. е. способов преобразования их семантики в художественном (поэтическом) контексте. Как раз на этом круге вопросов мы и остановимся в дальнейшем, сосредоточившись на двух «высоких» жанрах - на трагедии и торжественной оде. Именно эти жанры принадлежат к наиболее известным и художественно выразительным достижениям русской словесности XVIII столетия в высоких ее регистрах, они содержат богатый и выразительный материал для исследования, который, между прочим, объединен многими общими особенностями, в частности - отчетливостью тех семантических преобразований, которые претерпевало имя собственное в поэтическом тексте.

Термин «антропоним» в настоящем исследовании понимается широко: для нас это, во-первых, собственно антропоним в узком смысле, «любое соб-

\footnotetext{
10 Херасков М. М. Избр. произведения. С. 65.

11 Там же. С. 377.

12 Там же. С. 66.

13 Там же. С. 377.
} 
ственное имя, которое может иметь человек», во-вторых, мифоантропоним, т. е. имя мифологического героя; в-третьих, теоним, «собственное имя божества в любом пантеоне». ${ }^{14}$ Причиной такого широкого понимания термина «антропоним» является то обстоятельство, что для русской литературы XVIII столетия типично объединение реальной и нереальной ономастики.

Приступая к рассмотрению антропонимов в трагедии русского классицизма, следует прежде всего отметить, что в абсолютно преобладающем количестве случаев они являются прямыми обозначениями непосредственно выступающих на сцене героев. Так, в первой русской классицистической трагедии - в «Хореве» А. П. Сумарокова - из 282 встречающихся там имен собственных только один случай не связан с наименованиями действующих лиц - упоминание Перуна в реплике Оснельды (3 явл. 1 д.):

Перун! Почто меня от смерти ты избавил,

$\mathrm{A}$, жизнь оставя, дал ты чувствовати честь ${ }^{15}$

«Хорев», правда, не вполне типичный пример, точнее, - крайнее выражение отмеченной тенденции; в других трагедийных текстах антропонимы, не указывающие на действующих лиц, появляются значительно чаще. Например, в самом начале трагедии М. М. Хераскова «Освобожденная Москва», в одном лишь 1 явл. 1 д., названы имена патриарха Филарета, Владислава (сына короля Речи Посполитой Сигизмунда III Вазы и впоследствии - тоже польского короля (Владислава IV), в момент же действия пьесы - претендента на московский престол), бывшего царя Василия Шуйского, донского атамана Ивана Заруцкого; никто из них непосредственно на сцене не появляется на протяжении всей пьесы. Нередки подобные внесценические персонажи и в других трагедиях: в «Тамире и Селиме» М. В. Ломоносова, где, в частности, названы великий князь Литовский Ольгерд и великий князь Рязанский Олег Иванович, или в «Димитрии Донском» В. А. Озерова, где встречаются упоминания Мамая, Олега Рязанского, предков Димитрия - Ивана Калиты и Симеона, киевских князей Владимира и Ярослава (сознательно указываю на трагедии, разделенные значительным временным периодом). Не участвующих в действии героев можно обнаружить и в некоторых трагедиях Сумарокова; например, в «Димитрии Самозванце» названы имена Бориса Годунова, Ивана Грозного, московского патриарха Игнатия, папы римского Климента VIII, мифологической Мегеры. И все же, повторимся, антропонимы, относящиеся к действующим лицам, полностью доминируют в тексте трагедий классицизма, бесспорно составляя большинство встречающихся в них личных имен. Они представляют собой или самообозначения персонажей, или же указывают на других героев, как правило присутствующих тут же, на сцене, т. е. оказываются наименованиями собеседников, находящихся в ситуации прямого общения. Частотность этих номинаций достаточно велика, о чем свидетельствуют тексты трагедий Сумарокова: в «Артистоне» обнаруживаем 262 случая прямого или косвенного обозначения антропонимов, в «Димитрии

14 Подольская Н. В. Словарь русской ономастической терминологии. 2-е изд., перераб. и доп. М., 1988. С. 30, 125, 131.

15 Сумароков А. П. Драматические сочинения. Л., 1990. С. 44. Далее ссылки на это издание приводятся в тексте с указанием номера страницы. 
Самозванце» - 141 случай; уже отмечалось, что в «Хореве» зафиксировано 282 употребления личных имен. Именно драматические сочинения Сумарокова и будут служить основным материалом для дальнейшего анализа. Их выбор обусловлен прежде всего ролью поэта в формировании и развитии трагедийного жанра в литературе русского классицизма; он не просто был первым русским трагиком, но и определил во многом дальнейшее развитие жанра. Поэтому его пьесы в достаточной мере репрезентативны для трагедии в целом, и, хотя произведения других авторов, несомненно, отмечены индивидуальным своеобразием, рассмотрение текстов Сумарокова дает определенное основание для выводов, касающихся всего жанра в целом; во всяком случае, в отношении употребления антропонимов.

Одной из сразу же бросающихся в глаза особенностей функционирования личных имен в трагедиях является вариативность номинации героев: для указания на них далеко не всегда используется антропоним, очень часто вместо него появляется его синонимический заместитель, связанный с семантическими трансформациями разных типов. Некоторые текстовые фрагменты вместо прямой номинации персонажей наполнены косвенными их обозначениями (или самообозначениями). Так, в 7 явл. 5 д. трагедии Сумарокова "Артистона» герои названы 13 раз, причем только 2 раза мы видим прямую номинацию: Федима произносит имя Дария («Уж таинство свое я Дарию открыла», с. 184), и Гикарн тоже один раз поименован прямо («...К чему, Гикарн, так поздно лицемерить?», с. 185). В других же 11 случаях действующие лица обозначаются через тропологические замены личного имени именем нарицательным или же словосочетанием, т. е. посредством антономазии в самом широком ее понимании ${ }^{16}$ и перифразы. В первом же стихе этого явления Гикарн назван «проклятой душой» («Проклятая душа, что днесь ты сотворила?», с. 184), затем «разбойником» (с. 185). Артистона определяется как «княжна» и «царевна» (с. 185), а Оркант - как «супруг» (с. 185) и «брат» (c. 186) и т. д. И пример финала «Артистоны» достаточно в данном отношении показателен.

Стилистическая функция подобных замещений достаточно очевидна, они продиктованы стремлением автора избежать неизбежных повторов. Бо́льший интерес представляют их семантические функции, дополнительные художественные смыслы, которые они вносят в содержательное поле трагедийного текста. Наиболее очевидным здесь является то, что тропологические замещения личного имени четко очерчивают аксиологические параметры текста, оценки, которые получает в пьесе тот или другой персонаж. Эти оценки могут быть ситуативными и способствовать развитию интриги: например, в 1 д. «Артистоны» заглавная героиня названа «злодейкой» и «изменницей», что никак не связано с сущностью ее характера и ее поведением в пьесе. Такая

16 См., например, определение антономазии в «Кратком руководстве к красноречию» М. В. Ломоносова: «Антономазия есть взаимная перемена имен собственных и нарицательных, что бывает, 1) когда употребляется имя собственное вместо нарицательного, например: Салпсон или Геркулес вместо сильного, Крез вместо богатого, Цицерон вместо красноречивого; 2) нарицательное вместо собственного: Апостол пишет, то есть Павел; стихотвореи, говорит, то есть Виргилий; 3) когда предки или основатели полагаются вместо потомков, напр.: Славен вместо славян, Иуда вместо еврейского народа; 4) имя отечественное вместо собственного: арпинянин вместо Цицерона, троянин вместо Енея; 5) стихотворцы нередко полагают свое собственное имя вместо местоимения $я$, как Овидий нередко называет себя своим прозванием Назон» (Лолоносов М. В. Краткое руководство к красноречию... // Ломоносов М. В. Полн. собр. соч.: В 10 т. М.; Л., 1952. Т. 7. Труды по филологии 1739-1758 гг. С. 248). Ср. также современное исследование, в котором используется широкое понимание термина: Арутюнян $M$. А. Структура, семантика и прагматика стилистического приема «антономазия» на материалах немецкого языка. Дис. ... канд. филол. наук. М., 2010. 
оценка, связанная с сюжетными коллизиями драматического текста, свидетельствует о непонимании Артистоны ее возлюбленным - Оркантом, непонимании, во многом спровоцированном сестрой Орканта Федимой, стремящейся Артистону погубить.

В других случаях оценочный компонент, заключенный в антономазии / перифразе, ${ }^{17}$ может оставаться неизменным на протяжении всего действия. Так, заглавный персонаж в «Димитрии Самозванце» Сумарокова в реплике Ксении из 6 явл. 1 д. определен так: «Сей варвар аспида и василиска зляй» (c. 257). Это - взгляд боящейся и ненавидящей Димитрия героини, однако он отражает общее отношение к Самозванцу, повторяясь в других косвенных номинациях: «тать венца, убийца и тиран» (с. 261), «мучитель» (с. 261), «злодей» (с. 266), «враг общества» (с. 267). Уместно указать в этой связи на то, что последняя отсылка к имени в трагедии, относящаяся к Димитрию - «тиран» (c. 292). Подобная аксиологическая константа по отношению к персонажу обусловлена уже не интригой, но постоянством перспективы в мире трагедии, в котором герои всегда и всюду равны самим себе; всем им ясна ценностная иерархия Вселенной, в соответствии с которой они оцениваются автором, сами оценивают окружающих, да и себя тоже.

Но, как было сказано, данное семантическое обогащение достаточно очевидно. Более интересным кажется другое явление, также связанное с антономастическими и перифрастическими заменами имен собственных; его можно определить как актуализацию - посредством тропологических замещений темы рода, родовой судьбы, родовых связей. Надо отметить, что данный тематический комплекс выражается в трагедии и другими средствами: словами и поступками действующих лиц, т. е. их прямым общением и развитием действия. Но в большинстве случаев тема рода предстает в сценическом пространстве в локальном, усеченном виде - она выступает преимущественно как взаимоотношения родителей и детей: дочь / сын (брат / сестра) выбирают между любовью к своему избраннику и требованиями сыновнего / дочернего / братского долга (Кий - Хорев - Оснельда в «Хореве»; Синав - Трувор - Ильмена в «Синаве и Труворе»; в несколько усложненном варианте: Олег - Оскольд - Ростислав - Семира в «Семире»). Семантические трансформации антропонимов смягчают эту ограниченность; они, так сказать, расширяют тему рода и делают родовую принадлежность героя важной не в одни отдельные (пусть и поворотные) моменты его жизни, но всегда. Это достигается, в частности, тем, что антономазии и перифразы имени сопровождают героя на протяжении всего текста, они принадлежат не только ему (как, обыкновенно, прямые рассуждения о родовом долге), но и другим персонажам. Более того, они указывают на позицию автора, на его понимание героя; а именно в зоне автора герой классицистической трагедии обнаруживает собственную цельность и внутренне свое существо. ${ }^{18}$ Тем самым понятие рода приобретает особо важный смысл.

Актуализация этой темы происходит, как правило, уже в начале пьесы и сохраняется на протяжении всего действия. В «Димитрии Самозванце» уже в 4 явл. 1 д. заглавный герой обозначен как «сын монарха Иоанна» (с. 254),

17 Антономазия и в особенности перифраза являются важнейшими стилистическими приемами классицистической поэзии. См. тонкое исследование: Жирлунский В. М. Задачи поэтики // Жирмунский В. М. Теория литературы. Поэтика. Стилистика. Л., 1977. С. 39-47. О теории перифразы см., в частности: Бытева Т. И. Очерки по русской перифрастике: Монография. М., 2008.

18 См. об этом: Бухаркин П. Е. Автор в трагедии классицизма (предварительные замечания) // Петербургский сборник. СПб., 1996. Вып. 2. Автор и текст / Под ред. В. М. Марковича и В. Шмида. С. 84-104. 
причем тут же указан и его, так сказать, родовой враг - «злонравный Годунов» (с. 254): Димитрий вернул себе то, «что отнял Годунов» (с. 248). И в «Артистоне» сразу же выделяется родство Артистоны с Киром - «дочь Кира» (с. 139), и впоследствии это определение применяется к ней постоянно: «дочь Кирова» (с. 174), «царска дщерь» (с. 175), «дочь великого царя» (с. 177). Это придает дополнительную сложность ее взаимоотношениям с Дарием, не только царем, желающим на ней, против ее воли, жениться, но и человеком, в конечном счете занявшим трон ее отца. То, что предполагаемое замужество должно возвести героиню на отцовский трон - «Киров трон» (с. 150), несколько раз акцентируется в тексте, что вносит в трагедию тему династических, т. е. родовых отношений, при этом - весьма острых. То же обнаруживается и в «Хореве»; в нем, с первых же сцен, имя Завлоха, «бывшего князя Киеваграда» (с. 36), заменяется указанием на его родственные отношения с Оснельдой - «бесчадный отец» (с. 37), «родитель мой» (c. 38), «отец» (с. 39), снова «родитель» (с. 39). Отблеск темы рода при этом падает прежде всего на Оснельду - именно она оказывается носительницей родовой памяти, с ней в семантическое поле текста входит уже не просто родовая тема, но тема борьбы родов, отчасти - и родовой мести.

Нечто похожее можно заметить и в трагедии «Семира». Связь с родом, тем самым, начинает выходить за границы сыновне-братско-дочернего послушания; осознание себя членом того или иного рода становится одним из определяющих все существование героя начал. Стоит в этой связи обратить внимание на то, что выбор персонажем родового долга, т. е. его поведение, продиктованное прежде всего интересами рода, а не личных страстей (любви), свидетельствует о правильности его выбора, в то время как нарушение этого долга говорит о его экзистенциальной ошибке, наделяющей его трагической виной, которая им самим отчетливо осознается. Финальные сцены «Хорева» и «Синава и Трувора» оказываются здесь предельно выразительными.

Только что отмеченные смысловые обертоны начинают звучать в трагедии русского классицизма преимущественно в связи с тропологическими вариациями антропонимов. Благодаря им происходит, в частности, содержательное обогащение текста, придающее ему многонаправленность. Надо сказать, что тема рода, особенно в варианте родовой (династической) борьбы, в контексте политической жизни Российской империи середины XVIII столетия приобретала отчетливый политический оттенок. ${ }^{19}$ Однако рассмотренные выше примеры говорят, что - не только политический: тема рода в классицистической трагедии вовсе не исчерпывается одной злободневностью, она там поворачивается и совершенно иной своей стороной, уводящей к истокам жанра, в ней начинает проступать одна из главных основ архаического варианта трагедии (т. е. трагедии античной, в первую очередь древнегреческой) - тема рода как такового, родовой судьбы и вины. Здесь, впрочем, необходимы некоторые комментарии. Во-первых, соотнесенность родовой темы в русских пьесах XVIII века с жанровой памятью о древних ее истоках лишена отчетливости, напротив, она скорее затушевана и, главное, крайне модифицирована. ${ }^{20}$ Во-вторых, актуализация темы рода нисколько не препятствует политической направленности пьесы. Не препятствует, однако

19 Из последних работ о политическом звучании трагедий Сумарокова см.: Ospovat $K$. Terror and Pity: Aleksandr Sumarovov and the Theater of Power in Elizabethan Russia. Boston, 2016.

${ }^{20}$ См. новые работы о родовой памяти и родовой вине в античной культуре: Gagné R. Ancestral Fault in ancient Greece. Cambridge, 2013 (о данной проблематике в греческой трагедии см. p. 344-445); Kyriakou P. The Past in Aeschylus and Sophocles. Berlin; Boston, 2011. 
существенно обогащает: трагические герои делают свой выбор не просто как граждане; на их поступки и особенно на выраженные в их словах размышления оказывает воздействие родовая память, их осознание себя представителями тех или иных родов. Само по себе это, возможно, не так уж и важно и не выводит принципиально трагических героев из области сугубо политических пристрастий и замыслов. Более того, чувство рода важно для художественных миров и других жанров, в частности торжественной оды. Но там семантическое обогащение, связанное с темой родственных отношений, не приводит к значительному расширению и трансформациям смысла, к перенаправлению магистрального смыслового сюжета; оно лишь дополняет то, что и так лежит на поверхности - в оде экспликация родовых связей «героев» полностью соответствует политическим интенциям текста и ими, в целом, ограничивается. А вот в классицистической трагедии ситуация сложнее.

В трагедийном мире, благодаря памяти жанра, понимание героем самого себя как прежде всего человека рода не только усложняет его образ, но и расширяет и принципиально модифицирует драматический конфликт, подымая его над политической конкретностью и перенося в область больших, отчасти - и вечных, пространств. Это позволяет увидеть в галантно-политической трагедии классицизма, в том числе и русского, не пастиш, но органичное и равноправное звено в сложной эволюции жанра.

Другие аспекты проблем, связанных с семантикой и функционированием антропонимов в высоких литературных жанрах XVIII века, обнаруживает обращение к похвальной оде. В этом жанре особенно ярко ощутимо функционирование антропонимов в качестве формульных элементов поэтических произведений эпохи «готового слова». ${ }^{21}$ Рассмотрение функционирования имен в торжественной оде позволяет увидеть особую «антропонимическую формульность» в русской поэзии XVIII века, причем эта формульность часто связана с устойчивыми употреблениями антропонимов в переносном значении. Рассмотрим основные формы и примеры семантических переосмыслений личных имен в одической поэзии В. К. Тредиаковского, М. В. Ломоносова, А. П. Сумарокова, В. П. Петрова и М. М. Хераскова. ${ }^{22}$ Несколько схематизируя достаточно разнородный материал, можно выделить в нем семь основных типов семантических преобразований.

21 О формульности русской торжественной оды писали многие исследователи, которые обращались к анализу этого жанра: О. Покотилова, Е. Гречищева, В. Дороватовская, И. И. Солосин, Г. А. Гуковский, Л. В. Пумпянский, И. З. Серман, Е. А. Погосян, Н. Ю. Алексеева, К. Ф. Тарановский, М. Л. Гаспаров, М. И. Шапир и др. Ср. также любопытное новейшее стиховедческое исследование: Tverianovich K. Rhythm and Syntax in Aleksandr Sumarokov's Odes // Quantitative approaches to versification / Ed. by Petr Plecháč, Barry P. Scherr, Tatyana Skulacheva, Helena Bermúdez-Sabel, Robert Kolár. Prague, 2019. P. 255-262.

${ }^{22}$ Ниже цитаты из од этих авторов приводятся по следующим изданиям: Лолоносов $M . B$. Полн. собр. соч. М.; Л., 1959. Т. 8; Петров В. П. Выбор Максима Амелина. М., 2016; Сумароков А. П. Оды торжественныя. Елегии любовныя / Изд. подг. Р. Вроон. М., 2009; Тредиаковский B. К. Сочинения и переводы как стихами, так и прозою / Изд. подг. Н. Ю. Алексеева. СПб., 2009 (сер. «Литературные памятники»); Херасков М. М. Творения: В 12 ч. М., 1796-1803. Ч. 7. Ссылки даются сокращенно, с указанием фамилии автора и номера страницы издания. 


\section{1. Антропоним вместо нарицательного существительного}

Антономазия в основном понимании этого термина - собственное имя в значении нарицательного ${ }^{23}$ - является весьма продуктивным приемом русской оды. Приведем наиболее частотные антропонимы этого типа.

Алиид (Алкид), Ахиллес, Геркулес, Иракл 'храбрый воин, герой': «Зришь, Алииды уж готовы» (Тредиаковский, 154); «То не матерь басней Троя / Не один тут Ахиллес: / Каждый рядовой из строя / Мужеством есть Геркулес» (Тредиаковский, 152); «Под инну Трою вновь приступит / Российский храбрый Ахиллес» (Ломоносов, 106); «Един лишь может устремиться / Российский может Геркулес» (Ломоносов, 563); «Иракль новы и Язоны» (Петров, $222)$; «Пойдет Российский Ахиллес» (Сумароков, 139); «Российский будет Геркулес» (Херасков, 172; о великом князе Александре Павловиче).

Марс 'армия, военные силы государства и государство в целом': «И Марс Российский не гремел» (Сумароков, 45); «Покойся Марс Российской ныне, / Под тенью мира отдыхай, И песни ко Екатерине / В безранной тишине внимай» (Херасков, 87). ${ }^{24}$

Моисей 'великий законодатель': «Щедроты окиян излей / Помазанный святым елеем; Мафусаилов век владей, / В законах буди Моисеел» (Херасков, 204).

Невтон 'ученый-естествоиспытатель', Платон 'философ': «...может собственных Платонов / И быстрых разумом Невтонов / Российская земля раждать» (Ломоносов, 206). ${ }^{25}$

Пиндар ‘одический поэт': «Там новый возгремит Пиндар» (Петров, 52).

Сололон 'мудрец': «Меж них он был бы Сололон» (Петров, 82); «А Ты яви нам Сололона , / Будь Павел Первый, Первый Петр» (Херасков, 198).

Фаетонт 'безрассудный самонадеянный человек или народ': «Там, видя выше горизонта / Входяща Готфска Фаетонта» (Ломоносов, 86; о шведах); ${ }^{26}$ «Уа!. упали Фаетонты / Стремнистых с высоты оград!» (Петров, 160; о турках); «А я с горяща горизонта, / Низпадша вижу Фаетонта» (Сумароков, 96); «Низвержен гордый фаетонт» (Сумароков, 187).

\footnotetext{
${ }^{23}$ Ср. цитируемый выше фрагмент из «Краткого руководства к красноречию» Ломоносова.

24 В русской одической поэзии обнаруживается большое количество мифологических имен в контекстах, представляющих собой иносказание. Важной особенностью их функционирования является то обстоятельство, что часто, наряду с иносказательно-аллегорическим смыслом, эти контексты сохраняют и прямое значение мифологического имени. Приведем пример из ломоносовской оды: «...Mарс кровавый не дерзает / Руки своей простерти к нам, / Твои он силы почитает / И власть, подобну небесам» (Ломоносов, 219). Марс - римский бог войны - оказывается таким же героем ломоносовской оды, каким является императрица Елизавета Петровна; с другой стороны, в этом образе можно усмотреть аллегорию войны, воинственности. Такая двойственность интерпретации является неотъемлемой чертой мифа как вида поэтического иносказания, при котором некая общая идея мыслится в виде живого существа (Лосев А. Ф. Проблема символа и реалистическое искусство. М., 1995. С. 174). Ср. несколько сходных примеров: «В полях кровавых Марс страшился, / Свой мечь в Петровых зря руках, / И с трепетом Нептун чюдился, / Взирая на Российский флаг» (Ломоносов, 200); «Тобою (Екатериной. - П. Б., Е. М.), с нами обитает / Драгой неоцененный мир: / Безстрашно на лугах летает / По царству Флорину Зефир: / Косою смерти, Марс не машет, / Спокойно земледелец пашет» (Сумароков, 107-108). О семантике мифологических имен в русской литературе XVIII века см., в частности: Войнова Л. А. Функционально-семантические особенности мифологических собственных имен и показ их в историческом словаре XVIII в. // Проблемы исторической лексикографии / Отв. ред. Ю. С. Сорокин. Л., 1977. С. $121-129$.

25 Ср. развитие приема у Сумарокова: «Твоя сияюща корона, / В России Локка и Невтона, / И всех премудрых оживит» (Сумароков, 39); см. ниже еще один пример из оды Сумарокова, в котором сохраняется ломоносовская антропонимическая рифма.

${ }^{26} \mathrm{Cp}$. также уподобление Фаетонту Мемеля у Ломоносова: «Там Мемель, в виде Фаетонта / Стремглав летя, Нимф прослезил» (Ломоносов, 652).
} 
Мифологические имена в значении нарицательных существительных могут в некоторых случаях получать вторичное - метафорическое - переосмысление. Например, имя Аврора 'заря' в одической поэзии может получать значение 'о начале новой эпохи': «Породы Царской Ветвь прекрасна, / Моя Надежда, Радость, Свет, / Щастливых дней Аврора ясна, / Монарх-Младенец, райской Цвет» (Ломоносов, 35; к Иоанну Антоновичу); «Прекрасно солнце на восходе / Приносит нову жизнь Природе / Аврора тако Ваших дней, / Любовь и качества душевны / Сулят нам радости полдневны» (Херасков, 145; к сочетающимся браком Павлу Петровичу и Наталии Алексеевне).

\section{2. Антропоним, замещающий другой антропоним}

Следующим распространенным приемом поэтического языка русской оды является использование антропонима вместо другого антропонима. В этих случаях имя выполняет функцию устойчивого эпитета или «имени-титула», ${ }^{27}$ который присваивался тому или иному историческому персонажу.

Об Александре I: «Тебе родился Аполлон» (Петров, 120; обращение к музе).

О Екатерине II: «О честь тебе, Орлов, / Содейственник Астреи!» (Петров, $64)$; «Россия оком умиленным <...> Младому Павлу говорит: // „О ты, цветущая отрада, / О верность чаяний моих! / Тебя родила мне Паллада / Для продолженья дней златых...“” (Ломоносов, 798); «Мы именем Селиралиды / Разсыплем пышны пирамиды» (Сумароков, 143); «Минерва, царствующа нами» (Херасков, 186).

О П. А. Румянцеве: «Подносит лавры и оливы, / Екатерине ахиллес» (Сумароков, 187); «Перикл, алькивияд российский» (Сумароков, 187).

\section{3. Антропоним в значении этнонима или топонима}

В одической поэзии XVIII века встречаются примеры, когда антропоним заменяет собой топоним или этноним (последнее - второй, по Ломоносову, тип антономазии: «когда предки или основатели полагаются вместо потомков» $\left.{ }^{28}\right)$. Чаще всего такой тип преобразования используется при обозначении Туриии и турок:

a) «И изгнанна Агарь из врат» (Сумароков, 143); «И тешишь плачущу Агарь» (Петров, 76);

б) «Ражженный яростью Маглет» (Ломоносов, 773); «Где нет Магледа, тамо мир» (Петров, 56).

У В. К. Тредиаковского встретился пример необычного использования мифонима Нептун: «Станислава (Лещинского. - П. Б., E. М.) принимает, / Ищет дважды кой венца, / В свой округ и уповает / Быть в защите до конца / Чрез востекшего Нептуна» (Тредиаковский, 153; о Гданьске). Здесь мифологическое имя обозначает топоним - реку Вислу (Тредиаковский, 584).

\section{4. Антропоним в составе перифразы}

Перифраза - одна из характерных особенностей поэтического языка русской оды. Наш материал показывает, что в большинстве случаев в состав перифраз входит антропоним, например:

О Екатерине II: «О волн евксинских Алфитрита!» (Петров, 161). C. 59.

27 Проскурина В. Мифы империи. Литература и власть в эпоху Екатерины II. М., 2006.

28 Лолоносов М. В. Краткое руководство к красноречию... С. 248. 
О турках: «А ты, агари плеля, знай» (Сумароков, 183); «Готовься Aгареин род» (Херасков, 140). ${ }^{29}$

Об Алкивиаде: «Сократов ученик и друг» (Сумароков, 96). ${ }^{30}$

Значительное число перифраз в одах включают в себя знаковое для русской панегирической поэзии XVIII века имя Петр, которое включается в целый ряд перифрастических моделей: Петров град, Петров дом, Петровы стены и др.

О Петербурге: «Из всех градов везде Петрову граду» (Тредиаковский, 164); «Красуются Петровы стены» (Ломоносов, 60).

Об императорской семье: «Господь умножил дол Петров» (Ломоносов, $632)$; «Что вносиши в Петров ты дол?» (Петров, 113). ${ }^{31}$

Во многих случаях основой перифраз с именем Петр являются термины родства (дочь, дед, внук, правнук).

О Елизавете: «Мы славу Дщери зрим Петровой» (Ломоносов, 82); «О Монарх наш, дочь Петрова» (Сумароков, 31).

О Петре Федоровиче: «И тем почти Петрова внука» (Ломоносов, 104).

О Екатерине II: «Что ныне, чтя Петрову Внуку / Пою, как пел Петрову Дщерь» (Ломоносов, 789).

О Павле I: «К нам Правнук шествует Петров!» (Херасков, 201).

Разумеется, перифразы с терминами родства могут содержать и другие исторические имена (о Екатерине II: «России всей и Павла Мать» (Херасков, 222)) или имена мифологические (об Афине: "Дщерь Зевса мысли воздымать, / Охоты вашей приумножит»; о Деметре: «Прекрасной Прозерпины мать, / Свое искусство вам приложит» (Сумароков, 139)).

Двумя другими продуктивными типами являются перифразы с компонентами российский / росский (а) и новый (б).

а) О Екатерине II: «В Российской волю Алфитриды» (Ломоносов, 797); «От стрел Российския Дианы» (Ломоносов, 749); «От Росския Селиралиды / Падут над Нилом пирамиды» (Сумароков, 148); «Минерва Росска громы мещет» (Сумароков, 143); «И славно имя возвышал, / Российской щастливой паллады» (Сумароков, 153); «Российская Фетида вскоре, / Восколебала горы, лес» (Сумароков, 161).

О П. А. Румянцеве: «Перикл, алькивияд российский» (Сумароков, 187).

О П. И. Панине: «Перикла Росска не забудет» (Сумароков, 157).

О русских воинах: «Сыны Российския Альклены, / Проломят самы тверды стены» (Сумароков, 65).

б) О Елизавете Петровне: «Ты новый Александр теперь» (Сумароков, 46).

О военачальнике: «О буди кто из нас готовый, / Нам вождь Перикл, иль Минних новый, / На нуждны казни внешняя зла!» (Сумароков, 96).

О Платоне Левшине: «И слыша нова Феофана» (Сумароков, 157).

О Г. А. Потемкине: «Как в сердце ты моем, Феб новый, ощутился» (Петров, 107).

Встречаются случаи, когда две вышеуказанные перифрастические модели соединяются в одном контексте, например: «...Росския Минервы Внук (Александр Павлович. - П. Б., E. M.) / Умножил древней славы звук» (Херасков, 168).

${ }^{29} \mathrm{Cp}$. также перифразу у Ломоносова, из которой исключен антропоним: «То род отвержен ной рабы, / В горах огнем наполнив рвы, / Металл и пламень в дол бросает» (Ломоносов, 19).

30 Здесь мы сталкиваемся с примером «двойного иносказания»: Сократов ученик и друг это перифрастическое именование Алкивиада, которое используется в переносном значении ‘военачальник, полководец' (см. выше более широкий контекст сумароковской оды). 164).

31 Ср. о Турции: «Исполнил страхом лес, долины / Отчаяньем Махметов дол» (Херасков, 


\section{5. Антропоним в составе устойчивого сочетания}

Антропонимы в русской оде могут входить в состав устойчивых сочетаний, имеющих мифологический или библейский источник.

Век Астреи, Астреины часы, Августовы лета 'золотой век, счастливая пора': «Как пели во златые дни, / Или как в век Астреин пели» (Херасков, 195); «Уже Россия дожидалась / Златых Астреиных часов» (Херасков, 132); ${ }^{32}$ «Настали Августовы лета» (Сумароков, 95). ${ }^{33}$

Затворить Яновы врата, закрыть вход во Янов дол, затворить Янов дом 'прекратить войну': «Твоей затворятся рукою, / Разверсты яновы враma» (Сумароков, 164); «Премудрыя минервы персты, / Закрыли вход во янов дол» (Сумароков, 186); «И янов затворили дол» (Сумароков, 187).

Мафусаилов век 'о долголетии': «Мафусаилов век владей, / В законах буди Моисеем» (Херасков, 204; обращение к Павлу I).

\section{6. Антропонимические рифмы}

В качестве особого поэтического приема поэтического языка русской оды следует рассмотреть антропонимические рифмы, т. е. те случаи, когда на рифменной позиции, представляющей композиционно сильное место поэтического текста, оказываются два антропонима. Например: «...может собственных Платонов / И быстрых разумом Невтонов / Российская земля раждать» (Ломоносов, 206); «Узрим божественна Платона , Сократа, Локка и Невтона , / И хитростям да дастся дань, / В Апелле и во Праксителе: Гомеров дух у Росса в теле» (Сумароков, 124); «Не сладким сном в ночи прельщает / Народы дремлющи Морфей; / Не басни Амфион вещает, / Не камни движет здесь Орфей» (Херасков, 121). Приведенные примеры из од Ломоносова и Сумарокова демонстрируют, что антропонимическая рифма может быть предметом заимствования одного одического поэта у другого. ${ }^{34}$

\section{7. Обыгрывание антропонимов, относящихся к соименным героям}

Актуализация внутренней формы антропонима была излюбленным приемом поэтики барокко. ${ }^{35}$ Один из способов такой актуализации в русской оде - сопоставление имени того или иного героя с соименным ему героем прошлого. О таком приеме на материале русской поэзии XVII века писала Л. И. Сазонова: «Поэтика двоящегося образа, берущая начало в принципе отражения <...> использовала иля как аллегорию. Имя царя Алексея Михайловича - также имя Алексея Человека Божия. Зеркальное отражение имен святого и царя-тезки образует лестный для царя аллюзивный образ, и святой

32 О связях мифа об Астрее с идеологией в эпоху Екатерины II см., в частности: Проскурина В. Мифы империи... С. 57-104.

${ }^{33} \mathrm{Cp}$. у Ломоносова в незавершенном «Слове благодарственном Елисавете Петровне 1760 года»: «Подвигнется Европа; ученые, возвращаясь в отечество, станут сказывать: мы были во граде Петрове, гроб его видели, мы видели Елисаветы, мы видели чудныя дела Божия и Петровы, мы видели там Августово время, Меценатов» (Ломоносов, 684).

34 О других примерах заимствования рифмы (в том числе с антропонимами) одного одического поэта у другого см.: Матвеев E. M. Оды В. П. Петрова и оды М. В. Ломоносова: словесная и ритмико-синтаксическая формульность // Вестник СПбГУ. Язык и литература. 2018. Т. 15. Вып. 3. С. 360-361.

35 О различных формах реализации риторического топоса имени см.: Keipert H. Nomen est omen. Etymologie als Denkform bei russischen Autoren des 17. Jahrhunderts // Sprache, Literatur und Geschichte der Altglaeubigen. Akten des Heidelberger Symposions vom 28. bis 30. April 1986 / Hrsg. von B. Panzer. Heidelberg, 1988. S. 100-132; Сазонова Л. И. Имя в риторике и поэзии XVII века у восточных славян // Славяноведение. 2002. № 1. С. 4-22. 
выступает уже не только как самостоятельный персонаж, но как аллегория» ${ }^{36}$ В русской оде XVIII века встречаем подобные примеры «двоящихся образов». Приведем фрагмент из оды Хераскова на день рождения великого князя Александра Павловича 1777 года: «Се новый Александр родился / И берег Невский возгордился, / Что Росския Минервы Внук / Умножит древней славы звук» (Херасков, 168). Имя новорожденного великого князя не случайно сопровождается прилагательным новый: вторая строка, содержащая топоним Невский, одновременно являющийся прозвищем знаменитого новгородского князя, небесного покровителя будущего императора, вводит сопоставление с Александром древнил. Таким образом, семантика имени, отсылающая одновременно к двум денотатам, раздваивается - реализуется тот самый барочный принцип отражения.

Сопоставления соименных героев в оде зачастую связаны с именем Петр. Например, в оде великой княгине Наталии Алексеевне (1773) Сумарокова есть такой фрагмент: «Наталия Красой прельстила, / И нам Петра произростила; / Яви нам новыя цветы, / Плоды последуют за ними: / Наталия судьбами сими, / Произрости Петра и ты!» (Сумароков, 168). Автор обыгрывает соименство матери Петра I, Н. К. Нарышкиной, и супруги великого князя Павла Петровича (Сумароков, 350). Как видно, здесь в аллегорической функции выступает Петр I: одописец надеется, что у Павла Петровича и Наталии Алексеевны родится младенец, который станет реформатором, выдающимся правителем и будет во всем подобен своему великому прапрадеду.

В одической поэзии в некоторых случаях антропонимы Петр и Екатерина превращаются в нарицательные обозначения свойств идеального госудаpя. Сp. у Хераскова: «Великаго Петра представит / Она (Екатерина II. П. Б., Е. М.) во Павле молодом» (Херасков, 89); «Вселенна Павлу удивится, / Екатерина в Нем явится, / Явится в Нем Великий Петр» (Херасков, 194).

Любопытный пример «антропонимической амплификации», соединяющей различные формы поэтического переосмысления одного мифологического имени в одном фрагменте оды, находим у В. П. Петрова в оде П. А. Румянцеву-Задунайскому: «С высот Фракийских гор то видя, Марс чудится, / Ровнять с собой вождя россиян не стыдится. / „Сколь долго я, - речет, с людьми ни обитал, / Не зрел, кто б так побед на крылиях летал. / Отныне на моей я ввек вселюсь планете, / Руляниев - Марс; почто двоим быть в том же свете? <...>“ / Марс рек, и новый Марс вдруг миром брань венчал» (Петров, 99). В этих строках развивается характерная для русской оды тема соперничества русского XVIII века с античностью: ${ }^{37}$ бог Марс уступает место новому Марсу - Румянцеву и отправляется «в ссылку» на одноименную планету. Имя Марс используется в трех различных функциях: 1) как имя героя оды, обладающего мифологической двойственностью (Марс, как и Румянцев, - персонаж одического мира / Марс - аллегория войны), 2) как антономазия («Румянцев - Марс»), 3) в составе перифразы (Румянцев «новый Марс»).

Проанализированные примеры, во-первых, демонстрируют богатый антропонимический тезаурус русской оды, в который входят мифологические, библейские и исторические имена. ${ }^{38}$ «Имя исторической личности в лириче-

36 Там же. С. 11.

37 См. другие подобные примеры: Матвеев E. M. Антропонимы в торжественных одах М. В. Ломоносова и В. П. Петрова // Литературная культура России XVIII века. СПб., 2019. Вып. 8 / Под ред. П. Е. Бухаркина, Е. М. Матвеева. С. 84-85.

${ }^{38}$ На материале од М. В. Ломоносова это богатство было продемонстрировано Т. Е. Абрамзон. См.: Абралзон T. E. Одический тезаурус антонимов, теонимов и топонимов (на материале 20-ти торжественных од М. В. Ломоносова). Магнитогорск, 2004. 
ском стихотворении - это редкость в принципе», ${ }^{39}$ - заметил С. Г. Бочаров. Русская ода, как жанр риторический, демонстрирует обратное: исторические имена, наряду с именами мифологическими и библейскими, формируют ее поэтику, входят в число ее общих мест. Во-вторых, видно, что как сами имена, так и формы их семантических переосмыслений в представленном корпусе примеров многократно повторяются: на материале антропонимов особенно ярко ощутима специфика блочного одического мышления, при котором «использование одного элемента блока предполагает следующие элементы». ${ }^{40}$ В-третьих, обращает на себя внимание, что большинство выявленных нами форм семантических переосмыслений имен в оде связаны с уподоблением одного персонажа другому. В. А. Кузнецов, который проанализировал характерные для эпохи классицизма поэтические уподобления писателям, «на чей эстетический опыт ориентирована данная национальная литература, с чьим именем связана отправная или функционально важная точка в развитии жанра», отмечал, что «выделимость жанра определяется через отнесенность к лицу, к конкретному имени». ${ }^{41}$ Та же персонифицированность классицистического сознания проявляется и в уподоблениях героев оды мифологическим, библейским и историческим персонажам. Во многом именно за счет этих описанных нами разнообразных по форме уподоблений в торжественной оде, опирающейся на «готовое слово» и «„готовое представление“ о действительности», ${ }^{42}$ формируется образ идеальной реальности.

39 Бочаров С. Г. А мы, Леонтьева и Тютчева... Об одном стихотворении Георгия Иванова // Бочаров С. Г. Филологические сюжеты. М., 2007. С. 416.

40 Алексеева Н. Ю. Русская ода: Развитие одической формы в XVII-XVIII веках. СПб., 2005. C. 296.

41 Кузнецов B. A. Поэтические уподобления в русской литературе XVIII в. (к вопросу о персонифицированности классицистического эстетического сознания) // Вестник СПбГУ. Сер. 2. 1993. Вып. 1. № 2. С. 74.

42 Михайлов А. В. Поэтика барокко: завершение риторической эпохи // Михайлов А. В. Языки культуры. М., 1997. С. 117; Алексеева Н. Ю. Русская ода. С. 197. 


\section{ДЕБЮТ А. А. БЕСТУЖЕВА-ПРОЗАИКА (К ХАРАКТЕРИСТИКЕ «МАРЛИНИЗМА»)"}

Проза Александра Бестужева (Марлинского) на протяжении многих лет была любима читателями и не любима критиками. В рецензии на Собрание сочинений Марлинского 1840 года В. Г. Белинский признал «настоящим родом» его таланта «живой, легкий и шутливый рассказец, без особенных претензий», с «премиленькими подробностями», вроде повести «Лейтенант Белозор». Русские и ливонские повести рецензент определил как «расиновские трагедии в форме рассказов», которые «не выдержат никакой критики», а их героев - как «безличные образы, которым к лицу всякое платье и всякое имя и которые столько же русские, сколько и греки, немцы, и англичане, и татары». ${ }^{1}$ Оценки определялись общими установками Белинского: он стремился к очищению писательского пантеона от устаревших кумиров (с тех же позиций была ниспровергнута слава В. Г. Бенедиктова). Критик не любил препятствий на пути литературного прогресса, а увлечение читателей, диагностированное выпуском Полного собрания сочинений Марлинского, ${ }^{2}$ тормозило и без того затянувшееся, по его убеждению, прощание с романтизмом. ${ }^{3}$

Спустя полтора века сходным образом Бестужева оценивал уже не критик, а исследователь. Л. Бэгби признал успех беллетриста и отказал ему в оригинальности: «...если он и расширил лексические категории, допустимые в художественной литературе, то при этом все же придерживался образцов повествования, установленных Карамзиным. Фактически Бестужев не придумал по части тематики, типов персонажей, построения сюжета, лично-

\footnotetext{
" Статья написана в рамках институционального гранта IUT34-30 Tõlkeideoloogia ja ideoloogia tõlkimine: kultuuridünaamika mehhanismid Eestis vene ja nõukogude võimu tingimustes 19.20. sajandil / Ideology of Translation and Translation of Ideology: Mechanisms of Cultural Dynamics under the Russian Empire and Soviet Power in Estonia in the 19th-20th Centuries.

1 Белинский В. Полное собрание сочинений А. Марлинского // Отечественные записки. 1840. T. VIII. № 2. Отд. V. C. 78, 81, 82 .

${ }^{2} K$ тому же восемь частей из двенадцати выходили уже третьим изданием, что было отмечено в заглавии журнальной рецензии (см.: Там же. С. 52).

${ }^{3}$ Белинский признавал историческое значение за повестями Марлинского, однако ограничивал его коротким временем развития читательского вкуса, см. в заключительной части статьи: «...такие внешние таланты необходимы, полезны, а следовательно, и достойны всякого уважения. Только незаслуженная слава и преувеличенные похвалы вооружают против них, потому что свидетельствуют об испорченности вкуса публики» (Там же. С. 83). Критика была направлена именно на беллетристику; «полемические статейки» Бестужева рецензент, напротив, ставил высоко, так как они способствовали эволюции литературы. Эти «журнальные схватки с тогдашними литературными староверами» отличались, по его мнению, «верностию взгляда на предметы, остроумием и живостию» (Там же. С. 64), за что их следовало бы ценить выше «препрослав ленных повестей», «натянутых» и «перетянутых» «и в изобретении, и в изложении» (Там же. C. 69,82$)$.
} 
сти рассказчика, воздействия на чувства читателей ничего такого, что уже не изобрел бы Карамзин».$^{4}$

Белинский вывел стиль Марлинского из сентиментализма и байронизма, современный исследователь оставил его в том же круге явлений, лишь обозначив границу между ними: Бестужев начинал как последователь карамзинской прозы, а затем изменил курс и пошел за байронической модой. ${ }^{5}$ При этом Бэгби заметил, что возможности раннего романтизма Н. М. Карамзин исчерпал задолго до появления Бестужева, таким образом, не оставив ему шанса на сколько-нибудь значительные изобретения.

Встречается в исследованиях и противоположный подход, основанный на политической аргументации: Бестужев получает патент на авторское достоинство и новаторство как декабрист, ${ }^{6}$ а его сочинения радикализируются как в идейном, так и в эстетическом плане. «Писатель-декабрист» представал совершенно оригинальным автором, его поэтика получала подробное историческое оправдание, а недостатки, которые нельзя было игнорировать, так как их отметил Белинский, искупались «прогрессивной позицией» автора. ${ }^{7} \mathrm{Ha-}$ конец, в рамках такого подхода сентиментализм и Карамзин выводились за рамки авторской генеалогии Бестужева. ${ }^{8}$

Описанные интерпретации нуждаются, на наш взгляд, в пересмотре и дополнении. Бестужевская манера несет отпечаток сентиментализма и байронизма, как ее ни назови - «марлинизм», «бестужевские капли» ${ }^{9}$ "гражданский» или «революционный романтизм»; «быстрые повести с романтическими переходами». Однако в ее формировании следует отметить не только авторские влияния, но и воздействие более общих эволюционных тенденций, что мы и предполагаем сделать в настоящей статье. Возможно, такой поворот поможет объяснить причины популярности Марлинского у читателей. Складывание авторской манеры, на наш взгляд, поможет проследить анализ «Поездки в Ревель» (1821) - «большого дебюта» автора в прозе.

«Нашумевшее» при своем появлении ${ }^{10}$ сочинение Бестужева повлияло на развитие ливонской темы в русской литературе 1820 -х годов. Общие ее очертания определили более поздние «ливонские» повести Бестужева, «Адо»

${ }^{4}$ Бэгби Л. Александр Бестужев-Марлинский и русский байронизм. СПб., 2001. С. 106-107.

5 Там же. С. 12-14.

6 В обширном корпусе советских исследований о «писателях-декабристах» примечательны труды В. Г. Базанова (монография «Ученая республика» и другие), тематические выпуски «Литературного наследства» (Т. 59: Из неизданного литературного наследия К. Ф. Рылеева; Т. 60: Декабристы-литераторы). Характеристику многих исследований той эпохи здесь можно ограничить указанием на используемый в них термин «декабристский / революционный / гражданский» романтизм (который противопоставлялся, прежде всего, «пассивному романтизму» В. А. ЗЖуковского). Оценка Белинского была неполной, так как он не мог писать об идеологических аспектах деятельности Бестужева. Л. Бэгби смотрит на участие писателя в тайном обществе скорее как на еще одно проявление его байронизма (романтическая маска бунтаря и отщепенца предполагала соответствующее поведение).

7 В таком ключе описал место Бестужева в истории русской литературы В. И. Кулешов во вступительной статье к двухтомнику 1981 года (Кулешов В. И. Александр Бестужев-Марлинский // Бестужев-Марлинский А. А. Соч.: В 2 т. М., 1981. Т. 1. Повести. Рассказы. С. 12-14).

8 Например, В. Г. Базанов отверг карамзинистский генезис «Поездки в Ревель», сославшись на суждения Бестужева о Карамзине 1833 года (в рецензии на роман Н. А. Полевого «Клятва при гробе Господнем»), см.: Базанов В. Г. Очерки декабристской литературы: Публицистика. Проза. Критика. М., 1953. С. 290-304.

9 Название популярного в то время лекарства Tinctura tonico-nervina Bestuscheffii (спиртоэфирный раствор полуторахлористого железа) к характеристике стиля Бестужева применил Н. И. Греч (см. об этом ниже).

10 См. об этом: Исаков С. Г. Путь длиною в тысячу лет: Русские в Эстонии. История культуры. Таллинн, 2008. Ч. 1. С. 128. 
В. К. Кюхельбекера и некоторые другие тексты, но, согласно мнению С. Г. Исакова, многие параметры были заданы уже «Поездкой...». ${ }^{11}$

При первой публикации она называлась «Путешествие в Ревель», была представлена читателям как описание поездки в Остзейские губернии на рубеже 1820 и 1821 годов и делилась на части, снабженные эпистолярными атрибутами. Последнее «письмо» датировалось 9 января 1821 года, а уже во второй половине месяца Бестужев читал отрывки из травелога в Вольном обществе любителей российской словесности (далее - ВОЛРС), в которое вступил незадолго до поездки. Весной фрагменты печатались последовательно в журналах «Соревнователь просвещения и благотворения» и «Невский зритель», и 25 июня 1821 года было получено цензурное разрешение на печатание текста отдельной книгой.

Как известно, рост интереса к Остзейским губерниям во второй половине 1810-х годов был обусловлен не столько романтической модой, сколько политическими обстоятельствами - в 1816-1819 годах тамошние крестьяне были освобождены от личной зависимости. ${ }^{12}$ На волне общего интереса Бестужев и обратился к ливонской теме, предварив ее литературное освоение знакомством с историей вопроса. Это общее место в работах о Бестужеве, но, указывая на его переводную статью, опубликованную в «Сыне отечества» осенью 1818 года - «О нынешнем нравственном и физическом состоянии Лифляндских и Эстляндских крестьян,${ }^{13}$ исследователи упоминанием и ограничивались. На наш взгляд, статья должна быть вписана в историю создания «Поездки в Ревель» и потому заслуживает более внимательного прочтения.

Бестужев перевел фрагмент из книги Франсуа Габриэля де Брэ (François Gabriel de Bray; 1765-1832) «Опыт критической истории Лифляндии с картиною нынешнего состояния сей области». ${ }^{14}$ Он дебютировал этой публикацией в прозе, ранее вышел только перевод отрывка из оды ЖК.-Ф. Лагарпа «Мореплавание», под заглавием «Дух бури», в «Соревнователе...» (1818. № 31). Фрагмент из книги де Брэ, очевидно, соответствовал направлению «Сына отечества», журнала «исторического, политического и литературного». Среди разделов для ученых публикаций («Путешествия», «Землеописание», «История», «Наблюдения в отечестве») в журнале находился раздел «Этнография», в нем и была размещена статья. Вероятно, что в выборе материала для перевода свою роль сыграл редактор, Н. И. Греч, литературный покровитель и друг Бестужева. Ему принадлежит примечание к статье: «Сия книга < ...> удостоена высочайшего одобрения, изъявленного автору пожалованием ему ордена Св. Анны 1-й степени. - Сообщаем сей отрывок, полагая, что он, лучше поверхностного рассмотрения, может подать читателям нашим понятие о достоинстве и важности сей любопытной книги». ${ }^{15}$

Кто бы ни был инициатором публикации, книгу де Брэ Бестужев и впоследствии оценивал высоко. Именно к ней как источнику специальных сведений о Лифляндии он отсылал читателей своей «Поездки», хотя его сведения о крае имели и другие источники: «...друзья мои, я пишу не книгу и не из книг, а потому любопытным читателям советую прочесть сочинение: „Essai critique sur l'histoir <e > de la Livonie“, в котором подробно описано настоящее

11 Исаков С. Г. О ливонской теме в русской литературе 1820-1830-х годов // Учен. зап. Тартуского гос. ун-та. Тарту, 1960. Вып. 98. С. 143-145.

12 Отмечено, в частности: Там же. С. 147.

13 Бестужев А. О нынешнем нравственном и физическом состоянии Лифляндских и Эстляндских крестьян // Сын отечества. 1818. № 38. С. 214-254.

${ }^{14}$ [Bray F. G. de]. Essai critique sur l'histoire de la Livonie, suivi d'un tableau de l'état actuel de cette province / Par L. C. D. B., Membre ordinaire de l'Académie Royale des sciences de Munich, President de la société botanique de Ratisbonne etc. Dorpat, 1817. T. 1-3.

15 Сын отечества. 1818. № 38. С. 241. 
положение всей Ливонии». ${ }^{16}$ Автор демонстрировал ученость, но также и то, что свою «Поездку» он помещал в иные жанровые координаты, чем высоко оцененную книгу де Брэ (к этому вопросу мы вернемся).

«Опыт критической истории Ливонии» действительно был основательным ученым сочинением. Его автор, граф Ф. Г. де Брэ, с 1808 года исполнял обязанности баварского посланника при русском дворе. С Лифляндией его связала женитьба на Софии Лёвенштерн, дочери крупного землевладельца Карла Отто Лёвенштерна. Труд де Брэ уже становился объектом исследования, ${ }^{17}$ поэтому ограничимся несколькими чертами для его характеристики. Название первой главы, «Etat de la Livonie avant l'arrivée des Allemands», уже многое сообщает об авторской концепции: «прибытие» немцев стало поворотным моментом в истории края. Следующая глава была посвящена установлению в крае немецких законов и столкновениям с аборигенами-язычниками. История Лифляндии представлялась де Брэ процессом медленного приобщения местного населения к цивилизации - благодаря сначала немецкой, а затем русской власти.

Трехтомный труд продолжал описание Ливонии, начатое де Брэ в «Mémoire sur la Livonie» (1814), посвященном премьер-министру Баварии графу Максимилиану де Монжела, под началом которого служил. «Опыт критической истории Ливонии» был следующим шагом по карьерной лестнице - на нем стояло посвящение Александру I, что свидетельствует о высочайшем одобрении труда. ${ }^{18}$ По выходе книги де Брэ получил орден Св. Анны первой степени, в 1818 году стал почетным доктором философии Дерптского университета, а в $1822-$ м - почетным членом Императорской Академии наук.

Труды баварского посланника существовали в ином культурно-политическом измерении, нежели русские журналы. Статья Бестужева «О нынешнем нравственном и физическом состоянии Лифляндских и Эстляндских крестьян» соответствует началу главки из третьего тома «Опыта...» и посвящена в основном сравнению латышей и эстонцев друг с другом и с русскими. Перевод в ряде фрагментов расходится с оригиналом, смысл текста из-за пропусков изменился. ${ }^{19}$ Этнографические описания у де Брэ сочетались с историческими и политическими оценками, вписывались в очерк сложных отношений коренного населения Остзейских губерний с их восточными и западными соседями, с завоевателями в прошлом и властителями в настоящем, с русскими разных сословий. В переводной же статье остались только этнографические описания и сравнение латышей и эстонцев с русскими, в котором безусловная победа была присуждена последним. Если сокращения были сделаны

16 Поездка в Ревель. Соч. А. Бестужева. СПб., 1821. С. 21. Далее ссылки на это издание приводятся в тексте сокращенно, с указанием номера страницы.

17 См., например: Hellmann M. Ein bayerischer Diplomat als Geschichtsschreiber Livlands // Bayerische Akademie der Wissenschaften. Sitzungsberichte. München, 1978. H. 3.

18 Ф. Г. де Брэ был знаком с императором не только в качестве баварского посланника при русском дворе. После первого визита в Россию он составил обширную записку «Мémoire sur la Russie, composé par M. le chevalier de Bray à Munich on Avril 1800», адресованную баварскому курфюрсту Максимилиану IV и получившую известность в европейских дипломатических кругах. Из нее явствует, что он еще тогда познакомился с наследником и занял его сторону в придворных конфликтах. Неудивительно, что де Брэ был хорошо принят в Петербурге при новом назначении.

19 Исследователи видели в этом результат цензурного вмешательства и следствие запрета на обсуждение крепостного рабства в периодике. Расхождения источника и перевода мы анализировали в специальной статье (Степанищева $T$. К истории «Поездки в Ревель» Александра Бестужева (цензура как двигатель авторского развития) // Идеологические контексты русской культуры XIX-XX вв. и поэтика перевода. Wien, 2016. S. 23-37 (Wiener Slawistischer Almanach. Sdb. 93)), ограничившись этим сопоставлением и оставив реконструкцию цензурной истории будущим исследователям. 
цензором, это свидетельствует о культурно-политической стратификации: ученое сочинение на французском и немецком языках, ${ }^{20}$ за которое высокопоставленный автор был пожалован орденом и почетным званием, не могло попасть в русскую печать без изъятий. Если же хотя бы часть сокращений была сделана переводчиком или редактором, история осложняется и тем более подлежит внимательному изучению.

Публикация в «Соревнователе» не принесла Бестужеву успеха. Заявленное продолжение не было напечатано, как считается, по цензурным причинам. ${ }^{21}$ Более того, когда осенью 1818 года Бестужев ходатайствовал об издании журнала «Зимцерла», отказ был мотивирован, в частности, тем, что представленный в комиссию «перевод в прозе о состоянии эстонских и ливонских крестьян не отличается ни чистотою слога, ни правильностью языка». ${ }^{22}$

Ливонскую тему Бестужев, однако, не оставил. Его брат Николай, морской офицер и литератор, часто бывал в Ревеле по службе, благодаря ему устроилась поездка Александра. Хотя между осенью 1818-го и концом 1820 года он успел зарекомендовать себя в словесности, известность его ограничивалась журнальными рамками, и «Поездка в Ревель» стала настоящим дебютом в новом амплуа.

Исследователи возводят поэтику бестужевской повести к упомянутому в ней травелогу Дюпати «Письма об Италии». ${ }^{23}$ Начало этой традиции было положено в сборнике «Русская проза» - специальной статьей Т. А. Роболи о «литературе путешествий» и статьей Н. А. Коварского «Ранний Марлинский». ${ }^{24}$ Роболи, выделив две линии в «литературе путешествий», обозначила их именами Дюпати и Стерна. Согласно ее схеме, «Lettres sur l'Italie» Дюпати $(1788)^{25}$ задали гибридную форму путешествия, «где этнографический, исторический и географический матерьял перемешан со сценками, рассуждениями, лирическими отступлениями и проч.». ${ }^{26}$ В «Сентиментальном путешествии» Л. Стерна «официальное путешествие» было «пристегнуто к вещам, вовсе не имеющим с ним необходимой связи». ${ }^{27}$ Как отметил автор, оба названных текста могут считаться прецедентными для «Поездки». ${ }^{28}$ Однако, по замечанию Ю. М. Лотмана и Б. А. Успенского, уже ко времени появления ка-

20 В третьем томе перечень лифляндских землевладельческих фамилий и сопутствующие пояснения к нему даны по-немецки (см.: [Bray F. G. de]. Essai critique sur l'histoire de la Livonie... T. 3. P. 378 et passim).

21 Согласно оригиналу оно должно было начаться с приравнивания эстонского характера к азиатскому и апелляции к авторитету А.-В. Хупеля, который счел эстонцев лживыми, хитрыми, злыми и вдобавок равнодушными к религии (Ibid. P. 109-110). Далее речь шла о нравственности ливонских аборигенов, которую де Брэ оценил весьма невысоко.

22 [Б. п.]. Попытки братьев А. А. и М. А. Бестужевых издавать журнал (1818-1823 гг.) // Русская старина. 1900. Т. 103. Вып. 8. С. 376.

${ }^{23}$ Первое издание: Lettres sur l'Italie, par Dupaty, en 1785. Paris, 1788. T. 1-3. Дюпати псевдоним Жана-Батиста Мерсье (Charles-Marguerite-Jean-Baptiste Mercier; 1746-1788).

24 Ссылки на тексты статей приводятся по современному переизданию сборника: Роболи $T$. Литература «путешествий» // «Младоформалисты»: Русская проза / Сост. Я. Левченко. СПб., 2007. С. 104-127; Коварский Н. Ранний Марлинский // Там же. С. 54-72.

${ }_{25}$ Русский перевод И. И. Мартынова вышел впервые в 1800 году, в 1817 году было напечатано уже третье издание.

26 Роболи Т. Литература «путешествий». С. 109.

27 Там же.

28 В конце концов, Стерн был дважды упомянут в «Поездке в Ревель» - как автор романа о Тристраме Шенди, см. разговор путешественника с братом: «О чем ты задумался? Спросил меня, усмехаясь, брат мой; не новая ли критика занимает тебя? Я: Разве ты воображаешь, что я могу, как странствующий Тристрам Шанди, пришивать периоды к несочиненным еще сочинениям?» (с. 107); а также как «живописец прелестей» - наряду с Парни - в сцене новогоднего маскарада (с. 44). 
рамзинских «Писем русского путешественника» эти жанровые фрормы «для русского читателя потеряли прелесть новизны». ${ }^{29}$ Так о каких жанровых ориентирах «Поездки в Ревель» можно говорить, на какой основе строилась ее поэтика? На чей счет путешествовал Бестужев?

Действительно, при своем появлении «Поездка в Ревель» читалась на фоне эпистолярного травелога, в котором фрагменты различного жанрового генезиса объединялись личностью адресанта. Сосредоточенность на субъекте, личности, ставшей центром эстетических поисков во второй половине XVIII века, в свое время сделала эту жанровую форму актуальной, но к концу 1810-х годов новизна уже осталась в прошлом. Бестужев использовал ее как готовую мотивировку для скрепления разнородного материала - на что указывает, по нашему мнению, невнимание к соблюдению жанровых конвенций. Мы видим его в нарушении внутренней хронологии травелога (пятое «письмо» датировано декабрем 1820 года, при том что третье обозначено 31 декабpя, а четвертое - 3-4 января 1821 года), в несоответствии объема «писем» жанровым ожиданиям (пятое занимает около 50 страниц), а также включении нехарактерных для литературного травелога, при всей его пестроте, жанровых фрагментов - прежде всего, драматизированного рассуждения о литературе. В «письмах» ревельского путешественника есть стихотворные вставки - дружеское посвящение, элегические и батальные отрывки; новеллистические - в роде «светской повести» и комические, романтическая «историческая» повесть, исторический очерк, этнографические и топографические экскурсы. Ф. З. Канунова, комментируя «Кавказские повести» Бестужева, заметила, что в «Поездке в Ревель» были «намечены почти все главные темы его будущих повестей». ${ }^{30}$ Это наблюдение можно распространить не только на тематический репертуар. «Поездка в Ревель» содержала конспект жанровых, сюжетных и стилевых решений, которые были реализованы в позднейшем творчестве Бестужева.

Жаанровая и композиционная пестрота текста действительно провоцирует сравнение с «Письмами об Италии» Дюпати. Однако в «Поездке» он упомянут только единожды, в реплике «друзей» из стихотворного вступления, которые побуждали рассказчика писать, ориентируясь на французского предшественника:

Желали вы - я обещал,

Мои взыскательные други!

Чтоб я рассказам посвящал

Минутных отдыхов досуги

И приключения пути

Вам описал как Дю Пати.

(c. 1)

Обещания рассказчик не исполняет:

Теперь совсем иное дело:

Мечты сокрылись, былей нет,

И я, грызя перо с досады,

Напрасно устремляю взгляды

Сквозь наблюдательный лорнет

$<\ldots>$

29 Лотлан Ю. М., Успенский Б. А. «Письма русского путешественника» Карамзина и их место в развитии русской культуры // Карамзин Н. М. Письма русского путешественника. Л., 1984. С. 573 (сер. «Литературные памятники»).

30 Канунова Ф. З. А. А. Бестужев-Марлинский и его «Кавказские повести»// БестужевМарлинский А. А. Кавказские повести. СПб., 1995. С. 563. 
Затем напутный мой рассказ

Без поэтических прикрас

Рука небрежная писала;

Итак, друзья - начнем сначала.

(c. 2)

Апелляция к авторитету предшественника и констатация творческой неудачи ${ }^{31}$ здесь явно конвенциональны, что не проясняет генезис «Поездки» . Первое «письмо» указывает на другой литературный прецедент - оно начинается цитатой из «Писем русского путешественника»: «Я pacстался $c$ в $a$ ми - не надолго, судя по времени, надолго по сердиу ...» (с. 2), ср. у Карамзина: «Расстался я с вали, милые, расстался! Сердие мое привязано к вам...» . ${ }^{32}$ В отличие от карамзинского, адресат «писем» у Бестужева был лишь обозначен: «друзья мои» были названы, но не определялись далее через различные атрибуты и черты, как это сделал Карамзин в «Письмах...». Бестужев использовал повествовательный прием, отсылавший к Карамзину, но фактически оставил от него только словесную формулу. Однако далее, когда рассказчик попал в нарвский дом негоцианта $K$-ра, где ранее провел вечер «не первый русский путешественник, но лучший писатель своего путешествия» (с. 118), т. е. Карамзин, он лишь констатировал пересечение маршрутов, не вдаваясь в жанровую или дискурсивную рефлексию. ${ }^{33}$ Цитату в первом письме можно истолковать как жест авторской вежливости, необходимый при выборе жанровой формы, которая отмечена именем предшественника. ЗЖанр травелога к концу 1810-х годов пережил своей расцвет, прецедентные тексты существовали внутри жанрового корпуса и на фоне наследующих им сочинений теряли доминирующий статус (авторские приемы постепенно «растворялись» в повторах и утрачивали связь с первоисточником). Это позволяло новым авторам травелогов конструировать независимую - по меньшей мере, на уровне интенций - позицию.

Отказ от «поддержки» литературных предшественников повлиял и на образ рассказчика. У Бестужева это не просвещенный славянин, отправляющийся за европейской премудростью, не Анахарсис, не чувствительный путешественник, наконец. Герой «Поездки в Ревель» был офицером и ехал, строго говоря, «по казенной надобности». Этим был аргументирован его отказ живописать путешествие, «как Дю Пати»:

$$
\begin{aligned}
& \text { А на ........ }{ }^{34} \text { петлицы, } \\
& \text { (Замечено из-под руки) } \\
& \text { Не вьют цветочные венки } \\
& \text { Парнаса милые сестрицы. } \\
& \text { (с. } 2)^{35}
\end{aligned}
$$

Бестужев подчеркивал не-литературность своего повествования: «...периоды <...> не выровнены, не блистательны, - я бросал их с пера моего, са-

31 Писать «как Дю Пати» было бы затруднительно еще и потому, что основным содержанием «Писем об Италии» являлось описание памятников искусства. Подобных объектов в Ревеле и по дороге к нему Бестужев мог найти не много.

32 Каралзин Н. М. Письма русского путешественника. С. 5.

33 Перифраз вместо имени - обычный этикетный прием, а не отказ в признании.

34 Слово пропущено в книге. Служба Бестужева в лейб-гвардии Драгунском полку дозволяет разные варианты заполнения лакуны.

35 О возможной соотнесенности, в том числе генетической, «Поездки в Ревель» с «Письмами русского офицера» Ф. Н. Глинки см. в статье: Степанищева T. Н. К истории «Поездки в Ревель» Александра Бестужева. С. 34-35. 
блею очиненного, в быстрые промежутки забав и усталости» (с. 99). ${ }^{36}$ Конечно, такие стилевые декларации тоже условны, но при этом симптоматичны. Профессия определяла не только стилистику, но и тематику рассказа путешественника. В первом письме (которое так же, как у Карамзина, живописует дорогу до границы) он вдавался в воспоминания - о маневрах, учении и фрунте. Повествование перебивается стихотворными фрагментами с отсылками уже не к дружескому посланию, как во вступлении, а к батальной лирике в варианте К. Н. Батюшкова.

Первый фрагмент, картина военного марша, включает мотивы и лексику, характерную для батюшковской поэзии первой половины 1810-х годов (батальный сюжет в элегической рамке): ${ }^{37}$

И всадник, по полю рисуясь на коне,

Скакал, оружием сверкая.

И вдруг стекался к строю строй,

Перун заслыша боевой: -

Пехота двигалась стенами,

Стекались латников полки

И налетали козаки,

И, тихо вея флюгерами,

Уланов приближался рой;

И луч денницы золотой

Дробился на штыках граненых...

(c. 3)

Второй фрагмент содержит мотивные цитаты из элегии Батюшкова «На развалинах замка в Швеции» (пейзажная экспозиция в элегическом регистре, воспоминания о былой славе, юноши, горящие жаждой подвига):

Там с милым Геснером ночь тихую встречал,

И с вечною фантазией крылатой;

Прощальной свет зари, как роза, увядал,

И меркнул Запад полосатой.

$<\ldots>$

И шепчущий тростник, сверкающий ручей,

И небосклон, безмолвием угрюмый:

Все наводило грусть, и все в душе моей

Унылы наводило думы

$<\ldots>$

Внимая подвигам наездников полка,

Душа неведомым огнем воспламенялась,

И взгляд врага искал, и смелая рука

За рукоять меча хваталась.

(c. 4-5)

$36 \mathrm{Cp}$. позднейшую характеристику стиля Д. В. Давыдова в письме Бестужева П. А. Вяземскому от 1-18 января 1824 года: «...его бы слог-сабля загорелся лучом, вонзенный в „Звездочку“» (Письма Александра Бестужева к П. А. Вяземскому (1823-1825) / Публ. и комм. К. П. Богаевской; вступ. статья Н. Л. Степанова // Лит. наследство. 1956. Т. 60. Декабристы-литераторы. Кн. 1. С. 211).

37 Более пристальный анализ, очевидно, выявит и следы внимательного чтения В. А. Жуковского, его «Певца...» и «Песни барда...». В пользу Батюшкова говорит отчетливая «живописность» зарисовки. Пейзаж в следующей стихотворной вставке соотносится и с элегиями Жћковского. 
До 1820 года поэтические опыты Бестужева были либо окказиональными (шарады, куплеты), либо переводными (переложение фрагмента из оды Лагарпа, подражание сатире Буало). Стихотворные вставки в «Поездке...», таким образом, тоже являлись опытом нового жанра и стиля. Если в прозаической части первого письма образ путешественника сходен с авторской маской Дениса Давыдова, ${ }^{38}$ то поэтические фрагменты того же письма были написаны без иронического сдвига и предполагали ассоциацию с лирикой Батюшкова и ЖЖуковского.

Подобные смещения образа и стиля повествователя в «Поездке в Ревель» происходят постоянно. Ссылка на «перо, саблею очиненное», соотносится с обещанием рассказывать о путешествии безыскусно и правдиво ( «...пишу не книгу и не из книг»). Однако далее эта «программа» дезавуирована: из текста читатель понимает, что рассказчик далеко не такой простой служака, каким он представился вначале, и знаком с учеными трудами о Ливонии и их составителями. Он читал хроники Кристиана Кельха и Балтазара Руссова, Софийский временник, первые части труда Э. М. Арндта «Der Geist der Zeit»; в Peвеле беседовал с профессором Г. Рикерсом. Уже после журнальной публикации Бестужев дополнил текст фрагментами из вновь появившегося девятого тома «Истории государства Российского» Н. М. Карамзина, не обозначив источник заимствования. ${ }^{39} \mathrm{~B}$ книжном происхождении своих исторических познаний рассказчик признался в конце большого «письма», представляющего собой очерк ливонской истории: «...вот все, что я смог собрать из книг и от достоверных людей о Ревеле», - войдя, таким образом, в противоречие с собственной «программой» в начале травелога.

Колебания образа повествователя и дискурсивных ориентиров «Поездки» можно трактовать по-разному. ЖКанровая поливалентность и неустойчивая субъектность могут объясняться, в частности, дебютным характером текста. Начинающий автор пытался сразу ответить на различные литературные и культурно-политические запросы - интерес к Ливонии, к этнографии и истории вообще, к географической и исторической экзотике.

Кроме того, выступление в жанре новом для сочинителя, но давно занявшем место в общей иерархии, требовало яркой демонстрации владения материалом и методом. Именно этим можно объяснить противоречивое сочетание в «Поездке в Ревель» признаков стернианского и дюпати-карамзинского путешествий, отмеченное Т. А. Роболи: Бестужев показывал, что уверенно ориентируется в репертуаре жанровых приемов. Начальным фрагментам текста - со стихотворными вставками, офицером-рассказчиком и вставными новеллами комического и почти пародийного свойства (см. истории Евгения Крона и немца Ивана Ивановича Пошмана) - более свойственна стернианская игра, чем следующим. Даже историческим сюжетам Бестужев придавал бурлескный оттенок (ср. эпизод, посвященный битве с русскими рыцарей Вальтера Плеттенберга: они почти победили, но были сражены «презабавной

38 Видимо, предполагать прямое воздействие на Бестужева гусарской риторики Давыдова будет натяжкой, но его более поздний интерес к партизану-поэту неоспорим (см. прим. 36). Л. Лейтон, сравнивая авторский стиль Бестужева и Карамзина, отметил: "The most salient feature is that Bestuzhev's tales are far more virile than Karamzin's. <...> Bestuzhev's tales are vigorously masculine and boldly stated» (Leighton L. G. Alexander Bestuzhev-Marlinsky. Boston, 1975. P. 77). Исследователь, правда, связывает это различие с разными литературными направлениями, к которым принадлежали писатели, а не с заявленной в «Поездке» профессией рассказчика.

${ }^{39}$ См. об этом подробнее: Полякова A. A. 1) Опыты реконструкции творческих замыслов А. А. Бестужева-Марлинского. Выпускная квалификационная работа (рукопись). СПб., 2018. С. 28-31; 2) Творческая история «Поездки в Ревель» А. А. Бестужева // Русская литература. 2019. № 2. C. $73-75$. 
болезнью» и ретировались). Именно в этой части «Поездки» путешественник отказался писать "книгу» и «по книгам», отослав читателя к ученому труду де Брэ (но привел реминисценции его наблюдений, переведенных ранее для «Сына отечества», о варварстве эстонцев, почти побежденном усилиями русского правительства).

Содержание и стилистика первого «письма», особенно отказ от «книжности», позволяют усомниться в ориентации Бестужева на создание «ученого путешествия» - в соответствии с программой ВОЛРС (здесь мы не вполне согласны с заключениями А. А. Поляковой $\left.{ }^{40}\right)$. Не проявляется «ученая» установка и в следующих письмах, где рассказчик представал светским человеком, посетителем балов и маскарадов; выступал в роли театрального критика и далее, в «Дорожных записках на возвратном пути из Ревеля», — в роли критика литературного.

Центральный фрагмент книги, очерк ливонской истории, может претендовать на «ученость» лишь внешне. Как показал комментировавший «Поездку» С. Г. Исаков, очерк изобилует ошибками и неточностями: Бестужев ошибался в именах и датах, путал правителей, восстание Юрьевой ночи перенес на сто лет назад, привел слишком позднюю дату основания Ревеля и т. д. Такое отношение к фактам можно отметить не только в ревельском травелоге, но и в написанной сразу после него, в 1821 году, небольшой повести «Замок Венден». Сопоставление ее с источником сюжета, указанным автором, - фрагментом из «Хроники Ливонии» Генриха Латвийского, приведенным в первой части «Лифляндской хроники» И. Г. Арндта, показало, что Бестужев "совершенно не придерживается известных фактов, характеризующих историю убийства магистра фон Рорбаха <...>. Сюжет повести, характеристика в ней главных действующих лиц настолько отходят от зафиксированных в хрониках фактов, что в данном случае почти не приходится говорить о каком-либо соответствии произведения подлинной правде истории». ${ }^{41}$

Более того, назвав убийцу магистра Вигберт фон Серрат, Бестужев воспроизвел опечатку, допущенную при изложении этого исторического эпизода в книге де Брэ: Serrat появилось случайно вместо de Soest, и в списке errata в третьем томе опечатка была исправлена, однако автор «Замка Венден» туда не заглянул. ${ }^{42}$ Конечно, повесть - фиктивный жанр, и в его установки не входит историческая достоверность, но явное пренебрежение ею и введение фиктивных сюжетов указывают, по нашему мнению, на очевидные расхождения бестужевских повествовательных опытов с программой «ученых путешествий» ВОЛРС.

Таким образом, можно заключить, что жанровые и стилевые ориентиры, установки повествователя и способы их реализации в «Поездке в Ревель» отличаются неустойчивостью. Стернианские фрагменты, поэтические опыты, вплетенные в «напутный рассказ без поэтических прикрас», сменяются беглым и неточным историческим очерком, за которым следует почти транскрипт экскурсии по городу (ср. характерные обороты: «Нам осталось осмотреть только дом Черноголовых братьев $<. . .>$ вот огромные кубки $<\ldots>$ вот самый древний из них» (с. 94-95)) - уже вне имитации стернианской «болтовни». Однако путешественник Бестужева возвращается к стернианским приемам, когда демонстративно обходит вниманием важнейший объект, связанный с ключевыми событиями российской истории и, более того, включенный в список необходимых для описания ревельских памятников в «Соревнователе»:

40 Полякова А. А. Творческая история «Поездки в Ревель» А. А. Бестужева. С. 70, 75-76.

41 Исаков С. Г. О «ливонских» повестях декабристов (К вопросу о становлении декабристского историзма) // Учен. зап. Тартуского гос. ун-та. Тарту, 1965. Вып. 167. С. 38-39.

42 Указано: Там же. С. 39-40. 
«Не буду описывать вам, друзья мои, домика и дворца Петра Великого в Екатеринентале по многим причинам: во-первых, потому что я там не был. За то расскажу анекдот о нем самом» (с. 98).

Кроме «ученичества» и «демонстрации дарования», сложная композиция «Поездки» может быть объяснена через эволюцию повествовательных форм, обусловленную сентиментально-романтической субъектной доминантой, - как это сделала Роболи, и в выводах с ней согласился Коварский. Другое объяснение представил А. Шёнле в посвященной Бестужеву главе своей книги о русской литературе путешествий. Он определил «Поездку в Ревель» как формальную «структуру обрамления», в которой между отчетами о путешествии помещено «своего рода историческое произведение». ${ }^{43}$ Игра с жанром и субъектно-объектной организацией повествования приводит, как заключает исследователь, к появлению «двух совершенно различных и, возможно, даже несовместимых ипостасей в персоне автора» - причем Бестужев делает это намеренно. ${ }^{44}$ Ироническая ипостась отражает исторический пессимизм Бестужева, который изображает прошлое как хаос и последовательно снижает патетические сюжеты. Но этот пессимизм, как отмечает исследователь, не окончателен: ревельскую современность Бестужев предъявляет в тонах сентиментальной утопии, вне иронического регистра. «Взаимодополнение травелога и истории» позволяет Шёнле заключить, что Бестужев «создал убедительную модель для Александра I» в книге, которая «была, несомненно, завуалированным призывом к царю придерживаться здравой внутренней политики». ${ }^{45}$

Трактовка ревельского травелога Бестужева как «имплицитно адресованного» русскому императору, ${ }^{46}$ по нашему мнению, все-таки недостаточно аргументирована. Разумеется, Бестужев мог оценивать состояние страны, политическую ситуацию, действия императора и т. д. Однако нам неизвестны его высказывания об адресации «Поездки» царю - даже косвенные; и Шёнле также не приводит их. Можно возразить, что в самодержавном государстве любое публичное высказывание обращено в конечном счете к самодержцу, однако нам оно кажется преувеличением.

Шёнле выделил еще один полемический аспект бестужевской «Поездки в Ревель». «Межжанровый диалог», созданный в ней (сатира в исторических фрагментах и утопия - в современных), он трактует как выражение антикарамзинского понимания историографии: «Карамзин различал четыре основных добродетели писателя-историка: „порядок, ясность, сила, живопись“, перечисленных, надо полагать, по их значимости. Из них Бестужев может претендовать только на две последние. Ничто столь не противоречит его подходу, как первая пара, поскольку он видит в историческом процессе лишь случайную и хаотическую последовательность событий. <...> В своих замечаниях на „Историю государства Российского“ он решительно одобряет лишь ее литературные достоинства». ${ }^{47}$

Такая интерпретация авторской прагматики «Поездки», на наш взгляд, не имеет достаточных оснований, как и ее адресация императору. Упомянутые в приведенной выше цитате замечания Бестужева на «Историю» Карамзина относятся к началу 1830-х годов, т. е. отстоят более чем на десятилетие от ревельской поездки, и написаны с позиций иного исторического и литера-

43 Шёнле А. Подлинность и вымысел в авторском самосознании русской литературы путешествий, 1790-1840. СПб., 2004. С. 125.

44 Там же.

45 Там же. С. 135.

46 См. также: Там же. С. 234, прим. 69 и 70.

47 Там же. С. 137. 
турного опыта. ${ }^{48}$ Несмотря на системные сдвиги, травелог и ученый труд находились на разных ступенях жанровой и, шире, культурной иерархии, что затрудняет прочтение «Поездки» в антикарамзинском ключе. Еще одним основанием для сомнений в предложенной трактовке является апелляция Бестужева к Карамзину как автору «Писем русского путешественника» и создателю «Истории» (см. об этом упомянутую выше статью Поляковой ${ }^{49}$ ).

Оспаривание выдвинутых ранее толкований «Поездки», очевидно, обязывает к изложению собственной версии. Ранее мы, подобно другим исследователям (Ф. З. Кануновой и Л. Бэгби), трактовали ее как резервуар будущих сюжетных, стилевых и жанровых решений. Для Бестужева текст не имел внутренней целостности, а с течением лет потерял и в достоинстве, о чем свидетельствует позднейшее письмо К. А. Полевому, издателю его собрания: «Как вы думаете: вместить ли <...> Поездку в Ревель? Если не рассудите, то выньте для печати рассказ майора Крона и Гедеона Б<естужева $>$. Располагайте и карнайте все как угодно, - я издаю не для славы». ${ }^{50}$

Как было уже не раз замечено, первоочередной задачей русской прозы в начале века было обновление сюжетного репертуара, и основным его инструментом служила фигура повествователя: «События, поступки, чувства, мысли, подчиненные определенной традиции и нанизанные на одну нитку автора, создают ощущение его как литературного персонажа». ${ }^{51}$ Хотя Роболи не соотнесла наблюдение прямо с Бестужевым, оно представляется значимым именно для него. Дальним предшественником бестужевского «путешественника» был «русский путешественник» Карамзина, ближайшим образцом, как полагает Л. Лейтон, - лорд Байрон, ${ }^{52}$ а материалом и инструментом для конструирования был стиль, настолько своеобразный, что он стал узнаваемым и получил имя. Бестужев вслед за Н. И. Гречем назвал его компоненты «бестужевскими каплями»: «...это в моей природе: кто знает мой обыкновенный разговор, тот вспомнит, что я невольно говорю фигурами, сравнениями, и мои выходки Николай Иванович (Греч) недаром назвал Бестужевскими каплями. Впрочем, иное дело повесть, иное роман. Мне кажется, краткость первой, не давая места развернуться описаниям, завязке и страстям, должна вцепляться в память остротами. Если вы улыбаетесь, читая ее, я доволен, если смеетесь вдвое». ${ }^{53}$ Белинский назвал эту манеру «марлинизмом». В сходных выражениях Бестужев описал ее в письме к братьям, Николаю и Михаилу Бестужевым, от 21 декабря 1833 года: «Что же касается до блесток, ими вышит мой ум; стряхнуть их - значило бы перестать носить свой костюм, быть не собою. Таков я в обществе и всегда, таков и на бумаге; ужели ты меня не знаешь? Я не притворяюсь, не ищу острот - это живой я». ${ }^{54}$

Об особенностях стиля Бестужева-Марлинского написано много, его характерные приемы исчислены и поставлены в связь, прежде всего, с Карамзиным. На наш взгляд, в этих исследованиях недостаточно учитываются специфические черты, которые объясняют не только стилевые приемы, но отчасти

48 Исследователь учитывает ее, однако выстраивает свою линию аргументации - см.: Там же. С. 235, прим. 78. Ср. мнение В. Г. Базанова (см. прим. 9). Н. А. Коварский противопоставил отношение к Карамзину Бестужева в молодости и во второй половине жизни - см. об этом: Коварский Н. Ранний Марлинский. С. 57-58.

49 Полякова А. А. Творческая история «Поездки в Ревель» А. А. Бестужева. С. 73-75.

50 [Полевой К. А.]. Письма Александра Александровича Бестужева к Н. А. и К. А. Полевым, писанные в 1831-1837 гг. // Русский вестник. 1861. № 4. С. 444.
51 Роболи Т. Литература «путешествий». С. 108.
52 Leighton L. G. Alexander Bestuzhev-Marlinsky. P. 85.
${ }^{53}$ Цит. по: Коварский Н. Ранний Марлинский. С. 72.
54 Бестужев-Марлинский А. А. Повести и рассказы. М., 1976. С. 445. 
и сюжетную и логическую (в случае критических статей) организацию текстов А. А. Бестужева. Это ориентация на риторическую устную речь. ${ }^{55}$

В процитированном выше фрагменте о «бестужевских каплях» эстетический эффект описывается через соотнесение чтения с разговором. Бестужев связал свою устную речь и повествовательный стиль: «фигуры», «сравнения», другие «выходки» нашли соответствие в «остротах», на которых строится повествование. Заметим, что не «завязка» и «страсти», т. е. не фабула, а именно «блестки»-остроты являются его опорами. В воображаемый процесс чтения («...улыбаетесь, читая ее») Бестужев вводит рассказчика в качестве свидетеля, наблюдающего читательскую реакцию («я доволен»). Отношения между читателем и писателем описываются - а значит, и строятся - как непосредственный контакт между слушающим и говорящим, речь письменная ориентируется на устную. ${ }^{56}$

Подтверждением этой ориентации, как нам кажется, могут выступать обращения к «друзьям» в «Поездке в Ревель» - прием, характерный для эпистолярного стиля, создающий иллюзию непосредственной коммуникации, диалога. Бестужевский рассказчик нуждался в фиктивном собеседнике, потому что его присутствие давало мотивировку риторическим приемам и жестам. Последние в ряде случаев имитируют приемы прямой коммуникации, например, когда путешественник, описывая Ревель, дополняет эллиптическую фразу воображаемыми жестами: «Нам осталось осмотреть только дом Черноголовых братьев $<. .>$ вот огромные кубки <...> вот самый древний из них» (с. 94-95).

$\mathrm{C}$ ориентацией на устную речь можно соотнести и другие известные особенности бестужевского стиля: эмфатический синтаксис, риторические восклицания и вопросы, введение афоризмов и сентенций, синтаксический параллелизм на фоне неосложненных предложений, специфическую ритмизацию - как за счет введения повторяющихся конструкций, так и за счет чередования повествовательных фрагментов с сентенциями. ${ }^{57}$

Ориентация на устную речь может объяснить озадачившее Белинского утверждение Бестужева, что именно он, «сбросив путы книжного языка, заговорил живым русским наречием», отчего его исторические повести якобы послужили «дверьми в хоромы полного романа». ${ }^{58}$ Кажется, Белинский неверно понял писателя, потому что в его системе понятий «живое русское наречие» уже связывалось с понятием народности - а не означало непосредственную речь того, кто говорит на русском языке (в словаре писателя это выражение сохранило значение и коннотации начала 1820 -х годов, благодаря оторванности от актуальной литературной жизни столиц).

Наконец, об ориентации на риторическую речь и ситуацию произнесения свидетельствует драматизация в ряде эпизодов «Поездки в Ревель». Тенденция к ней выражается во введении «рассказов в рассказе», комических реприз: истории Евгения Крона, эпизода с немцем Иваном Ивановичем Пошманом и с участием самого рассказчика, который не сумел достойно приветствовать встреченную красавицу, запутавшись в снурках шляпы. Одно из писем, «Станция Варгель», целиком состоит из диалога рассказчика и его

55 Стиль Марлинского - риторический, безусловно, но эта риторика со специфической прагматикой, не «убеждения», а «украшения».

56 Специфическая жанрово-стилистическая ориентация «Поездки в Ревель» была отмечена анонимным рецензентом «Сына отечества»: «Это путешествие не ученое, не сантиментальное, а просто рассказ (курсив мой. - T. C.) умного, веселого и любезного человека о поездке в такую сторону, которая мерою отстоит от С. Петербурга в трех стах верстах, а нравами и обычаями жителей в трех тысячах» ([Б. п.]. [Рец. на:] Поездка в Ревель, сочинение А. Бестужева... // Сын отечества. 1821. Ч. 73. С. 84).

${ }^{57}$ См. об этом прежде всего: Коварский Н. Ранний Марлинский. С. 61-67.

58 Из статьи о романе Н. А. Полевого «Клятва при гробе Господнем» . 
брата о литературе. Важность таких вставных «номеров» для Бестужева подтверждается увеличением их числа в книжной редакции (эпизод со шляпой отсутствовал в журнальной публикации).

Предположение о значимости устной речи в формировании бестужевского идиостиля, по нашему мнению, не противоречит устоявшимся концепциям. Оно дополняет картину, объясняя место «Поездки в Ревель» не в общей жанровой традиции, а в авторской эволюции. Можно описать поэтику «Поездки...», апеллируя к приемам литературного путешествия (включение разножанровых фрагментов, риторика псевдодиалога с читателем и т. д.), однако обнаружение тех же особенностей в других текстах Бестужева, литературных и бытовых (повести, очерки, литературно-полемические статьи, переписка), ставит вопрос о причинах их миграции. Ответом на него является введение в генезис бестужевского стиля - кроме эпистолярного путешествия - собственно эпистолярия, бытовой словесности, которая в 1810-1820-е годы стала главным источником пополнения прозаического репертуара - прежде всего за счет элементов устной речи. В процитированном выше письме Бестужев связал свой письменный стиль с речевой манерой. Исторически посредующим звеном между ними служило бытовое и дружеское письмо: «Дружеское письмо ориентируется на формы устной речи, пользуясь одновременно „односторонним диалогом“ и „прерывистым монологом“. Этим оно исторически предшествует сказу». ${ }^{59}$

Отличительной особенностью бестужевского стиля было перенесение приемов личной речевой манеры за пределы бытовой словесности, иными словами - отказ от нивелирующего воздействия литературной нормы ради сохранения индивидуальной манеры. На наш взгляд, это позволяет сблизить его с «воспроизводящим сказом» в терминологии Б. М. Эйхенбаума. Бестужев, в отличие от прозаиков 1830-х годов, вводил сказовую форму не через рассказчика-персонажа, а через рассказчика-автора. ${ }^{60}$ Его целью было не сглаживание риторического эффекта, как у карамзинистов, тоже ориентировавшихся на устную речь, а напротив, его усиление, т. е. максимальная выраженность речевой маски рассказчика в каждой точке повествования. ${ }^{61}$ Перенос внимания на «остроты», риторические «жесты»- метафоры, сентенции, каламбуры - позволяет избежать переоценки идеологической или иной «программы» бестужевского травелога при его толковании и сосредоточиться на специфической «литературности», обозначившей начало нового, романтического периода в истории русской прозы. C. 53.

${ }^{59}$ Степанов Н. Дружеское письмо начала XIX в. // «Младоформалисты»: Русская проза.

60 В связи с этим возможен пересмотр данного Белинским определения повестей Марлинского как "рассказцев»- его можно прочитать не как пренебрежительную характеристику незначительных сочинений или, по крайней мере, не только как таковую, но и как определение особенностей авторской поэтики.

${ }^{61} \mathrm{Cp}$. замечание Л. Лейтона при разборе фрагмента из повести Марлинского «АммалатБек»: «Каждое сравнение и каждая метафора, на самом деле каждое слово и каждая фраза, предназначены для того, чтобы поразить читателя» (Лейтон Л. Г. Марлинизм: история одной стилистики // Russian Literature. 1975. № 12. С. 33). В специальной статье о стилистике Марлинского Лейтон представил каталог ее приемов, что избавляет нас от необходимости подобного описания. Однако, отметив специфическую экспрессивность авторского стиля, Лейтон не связал его с особенностями сказовой формы или эпистолярного жанра, вынес за рамки современной литературы: «...он как бы вышел за все границы литературных законов и стал самостоятельной стилистикой одного ультра-романтического писателя» (Там же. С. 58), - и в итоге дал качественную оценку, в общем созвучную Белинскому, при этом отдав должное многосторонней образованности писателя. Лейтон подробно описал, со ссылкой на Коварского, наряду с грамматическими и фигуративными приемами - «звуковые приемы» марлинизла (Там же. С. 48-51), от которых буквально шаг до вывода об ориентации на устные речевые жанры. 


\section{К 220-ЛЕТИЮ СО ДНЯ РОЖЖДЕНИЯ Е. А. БАРАТЫНСКОГО}

DOI: $10.31860 / 0131-6095-2020-3-34-50$

(C) Н. Н. МАЗУР

\section{«ПОДОБИЕ ТОГО-СЕГО»: КОННОТАЦИИ ШАМПАНСКОГО В РУССКОЙ ПОЭЗИИ 1810-1830-х ГОДОВ}

Пушкинская эпоха проходит, говоря его же словами, под «шипенье пенистых бокалов»: ${ }^{1}$ кажется, никогда в России не пили столько шампанского и не писали о нем так много стихов, как в первой трети XIX века. ${ }^{2}$ Тогда оно было еще в новинку: игристые вина по образцу итальянских в провинции Шампань начали делать в 1660-е годы; в 1720-х полюбившийся аристократам напиток вошел в моду во Франции; в начале 1780-х выпускали уже 300000 бутылок шампанского в год; во время революции его производство и экспорт резко сократились, но вновь расцвели при Наполеоне. К концу 1820-х годов в Шампани закупоривали около 3 миллионов бутылок в год, из которых примерно каждая девятая выпивалась в России. ${ }^{3}$

Символические коннотации шампанского во французской поэзии определил Вольтер в сатире «Le Mondain» (1736):

Chloris, Églé, me versent de leur main

D'un vin d'Aï dont la mousse pressée,

De la bouteille avec force élancée,

Comme un éclair fait voler le bouchon;

Il part, on rit; il frappe le plafond.

De ce vin frais l'écume pétillante

De nos Français est l'image brillante. ${ }^{4}$

Сатира Вольтера пользовалась большой известностью и во Франции, и в России; ее русский перевод Д. О. Баранова под заглавием «Любитель нынешнего света» вышел в карамзинских «Аонидах» (1797) и был перепечатан

1 Пушкин А. С. Полн. собр. соч.: В 16 т. М.; Л., 1947. Т. 5. С. 137.

${ }^{2}$ О потреблении шампанского в России и об откликах на него русских поэтов см. полезнейшие статьи: Невский А. Я. 1) Аи // Онегинская энциклопедия: В 2 т. / Под общ. ред. Н. И. Михайловой. М., 2004. Т. 1. С. 26-27; 2) Вдова Клико // Там же. Т. 1. С. 161-162; 3) Моэт // Там же. Т. 2. С. 143-144; 4) Шампанская бутылка // Там же. Т. 2. С. 715-716. См. также: Забозлаева Т. Б. «Вина кометы брызнул ток...». Шампанское в русской культуре XVIII-XX веков. СПб., 2007.

${ }^{3}$ Об истории шампанских вин см.: Musset B. Vignobles de Champagne et vins mousseux (1650-1830): Histoire d'un mariage de raison. Paris, 2008. Ср. число бутылок шампанского, ввезенных в Россию: 1824 - 374 678; 1825 - 326 071; 1826 - 248 567; 1827 - 396 630; 1828 $345656 ; 1829$ - 337951 (П. Н. [Полевой Н. А.]. Современная библиография // Московский телеграф. 1830. Ч. 34. № 14. С. 229).

4 Voltaire. Oeuvres complètes. [S. 1.]: De l'Imprimerie de la Société littéraire-typographique, 1787. T. 14. Р. 114. Пер.: «Хлорида и Аглая своими ручками наливают мне вино Аи; его стесненная пена с силой рвется из бутылки, молнией выбивает пробку, та летит, мы хохочем, она хлопает в потолок. Искрящаяся пена этого свежего вина - блистательный образ нас, французов» (перевод с фр. здесь и далее мой. - H. M.). 
в «Пантеоне русской поэзии» $(1815) .{ }^{5}$ Баранов перевел описание шампанского так:
Климена, Хлоя, льют лилейной мне рукой
Нектар, которого стесненный дух и пена,
Со треском свободясь, обрызгивая всех,
Звездами, искрами, шипя, летят из плена.
Все вздрогнули смеясь - и пробка скачет вверх!
В кипящем, в пенистом сего вина стремленье
Живое юности я зрю изображенье ${ }^{6}$

Переводчик старался сохранить все смысловые оттенки вольтеровского описания, кроме одного и самого главного - сравнения шампанского с характером французов. Баранов заменил его аналогией с молодостью, в основе которой лежала устойчивая французская рифмопара «jeunesse / ivresse» («молодость / опьянение»). ${ }^{7}$ Что же могло сподвигнуть переводчика на отступление от оригинала, очевидное большинству его современников, читавших Вольтера по-французски?

Сравнение шампанского с национальным характером французов вписывалось в обширный философский и естественно-научный контекст: начиная с эпохи Ренессанса считалось, что почва ( $p p$. terroir) оказывает влияние на растения и в особенности на виноград, а значит, и на вино. ${ }^{8}$ Это представление в XVIII веке было усвоено климатической теорией: ее создатели, аббат Дюбо и Монтескье, утверждали, что от почвы зависит не только состав воды, воздуха и растений, но и характер человека, который дышит этим воздухом, ест плоды земли, пьет воду и вино. Разницу между характерами итальянцев и французов аббат Дюбо в трактате «Критические размышления о поэзии и живописи» (1719) объяснял тем, что первые живут на почве, богатой минералами (квасцами, серой, битумом), а вторые - на почве, состоящей в основном из известковой глины ( $p p$. marne), насыщающей воздух летучими солями, которые возбуждают и острят ум, придают характеру легкость и живость. ${ }^{9}$ Известковой глиной была особенно богата почва регионов Шампани, расположенных между Реймсской горой и рекой Марна, название которой омонимично слову «marne». Там, в окрестностях местечка Аи рос виноград, из которого делали лучшее шампанское. Так в климатической теории летучесть, живость, стремление вырваться на волю - свойства, общие для шампанского вина и французского характера, - объяснялись составом почвы.

Климатический детерминизм смягчался признанием способности человека адаптироваться к новым условиям; в частности, считалось, что употребление вина и специй из южных стран оказывает благотворное воздействие на характер северных народов, вострит их ум и пробуждает воображение. Кроме

5 О популярности этого текста в России и его отзвуках в первой главе «Онегина» см.: Резанов В. К вопросу о влиянии Вольтера на Пушкина // Пушкин и его современники. Пб., 1923. Вып. 36. С. 71-77; Лялина E. Э. Об одном жанровом следе в «Евгении Онегине» // Тыняновский сборник. М., 2009. Вып. 13. С. 76-86.

${ }^{6}$ Баранов Д. Любитель нынешнего света. Перевод из Вольтера // Аониды, или Собрание разных, новых стихотворений. М., 1797. Кн. 2. С. 145.

7 Ср. наблюдение Ахматовой о том, что устойчивые французские рифмопары становятся основой русских поэтических клише (Герштейн Э. Г., Вацуро В. Э. Заметки А. А. Ахматовой о Пушкине // Временник Пушкинской комиссии, 1970. Л., 1972. С. 36).

${ }^{8}$ Наше изложение истории представлений о роли terroir опирается на кн.: Parker T. Tasting French Terroir The History of an Idea. University of California Press, 2015. О климатической теории см.: Ibid. P. 123 et pass.

9 Dubos J.-B. Réflexions critiques sur la poésie et sur la peinture. Paris, 1719. P. 278 et pass. 
того, винам, произведенным в Шампани, с конца XVII века приписывались целебные свойства: они производили мочегонный эффект, а стало быть, очищали кровь и разгоняли меланхолию.

Эти теории были хорошо известны в России, но национальное самолюбие мешало воспроизводить их буквально; скорее всего, именно поэтому Баранов позволил себе «отредактировать» Вольтера. Его примеру последовал Денис Давыдов - «партизан-поэт», как и многие другие русские офицеры, страстно полюбивший шампанское во время заграничных походов русской армии в 1813-1815 годах. ${ }^{10}$ В послании «Другу-повесе» (1815) он, кажется, первым ввел шампанское в мотивный репертуар легкого дружеского послания, "осовременив» анакреонтический мотив вина на дружеском пиру. ${ }^{11}$ Давыдов явно ориентировался на Вольтера, но исключил из своего описания символические коннотации шампанского:

И пробка полетит

До потолка стрелою,

И пена зашумит

Сребристою струею

Под розовой рукою

Резвейших из харит! ${ }^{12}$

Более сложный ход он предпринял в стихотворном тосте во здравие донских атаманов (1826), перенеся физические свойства (связь с terroir) и символические коннотации французского напитка на его русский аналог - донское игристое:

Брызни искрами из плена,

Радость, жизнь донских холмов!

Окропи, моя любовь,

Черный ус мой белой пеной! ${ }^{13}$

В «Гусарской исповеди» (1832) он продолжил «присваивать» шампанское, сделав дорогой напиток атрибутом не светского бала, с которого сбегает измученный притворством герой, а гусарской пирушки. Коннотации веселья, живости и вольнолюбия он перенес с французов на их победителей:

И я спешу в мою гусарскую семью,

Где хлопают еще шампанского оттычки.

Долой, долой крючки, от глотки до пупа!

Где трубки?.. Вейся, дым, на удалом раздолье!

Роскошествуй, веселая толпа,

В живом и братском своеволье ${ }^{14}$

${ }^{10}$ В 1817-1823 годах Давыдов заказал у Моэта почти 4000 бутылок шампанского (Невский А. Я. Моэт. С. 144).

11 Более ранний пример - послание графа Д. И. Хвостова «Приятелю моему, приглашавшему меня на бутылку шампанского 30 августа 1809 года» - не содержит специфических примет шампанского, а воспроизводит общую топику описаний вина. Ср.: «В тебе восторги почерпали / Давно почтенные певцы, / Тобой герои пожинали / Побед лавровые венцы; / Ты сердца тайны объявляешь, / Печали наши потопляешь», и т. д. (Хвостов Д. И. Полн. собр. стихотворений. 2-е изд. СПб., 1821. Т. 1. С. 207).

12 Давыљов Д. В. Стихотворения / Вступ. статья, сост., подг. текста и прим. В. Э. Вацуро. Л., 1984. С. 77-78 (Библиотека поэта. Большая сер.). У Вольтера шампанское разливает Аглая; это имя хариты - вестницы Афродиты. Ср. у Давыдова - «резвейшая из харит».

13 Там же. С. 90.

14 Там же. С. 101. 
Развернутое сравнение по образцу вольтеровского впервые появилось не у самого Давыдова, а в обращенном к нему послании П. А. Вяземского «К партизану-поэту» (конец $1814-1815$ год). Утешая друга, по ошибке разжалованного из генералов в полковники, ${ }^{15}$ Вяземский напоминал ему о целебных свойствах любимого тем напитка (по-видимому, имея в виду способность шампанского разгонять меланхолию, - ср. пушкинское «Как мысли черные к тебе придут, / Откупори шампанского бутылку / Иль перечти „Женитьбу Фигаро“»). ${ }^{16}$ Вяземский подчеркнул две семантические коннотации шампанского, из которых первая (живость ума) восходит к Вольтеру, но лишается французской привязки, а вторая (молодость) - к переводу Баранова:

..С друзьями здесь возобнови
Союз священный и прекрасный,
Союз и братства и любви,
Судьбе могущей неподвластный!..
Где чаши светлого стекла $<. . .>$
Сокрытый в них рукой целебной,
Дар благодатный, дар волшебный
Благословенного $A u$
Кипит, бьет искрами и пеной! -
Так жизнь кипит в младые дни!
Так за столом непринужденно
Родятся искры острых слов,
Друг друга гонят, упреждают
И, загоревшись, угасают
При шумном смехе остряков! ${ }^{17}$

В послании «К партизану-поэту» шампанское - атрибут не просто веселой пирушки: выражение «союз священный и прекрасный» описывает культ дружбы, занимавший почетное место в аксиологии конца XVIII - начала XIX века. У Вяземского этот союз неподвластен не только судьбе, но и смерти: во второй части послания, следуя античной традиции memento mori, он превращает пир в тризну, вспоминая А. П. Бурцова, задушевного друга Давыдова и адресата его посланий, славного военной удалью и любовью к кутежам. Вяземский обещает навестить могилу Бурцова, с которым не успел познакомиться при жизни, и полить ее вином, утолив им «жажду праха». ${ }^{18}$ Так шампанское оказывается связующим элементом между земным и потусторонним миром.

Сходный мотивный комплекс годом позже появился у французского поэта-песенника П.-Ж. Беранже, горячо любимого в России:

15 О служебных неурядицах Давыдова см.: Эдельман О. «Счет Давыдовым» (Эпизод из биографии поэта-партизана) // Россия / Russia. M., 1999. Вып. 3 (11). Культурные практики в идеологической перспективе: Россия, XVIII - нач. XX века. С. 128-134. Эта статья позволяет уточнить датировку послания Вяземского.

16 Пушкин А. С. Полн. собр. соч. Т. 7. С. 132. Представление о целебных свойствах шампанского жило в русской поэзии довольно долго. Ср.: «Услада чувства, бед забвенье, / Отважных помыслов творец, / О нектар жизни, вдохновенье, / Клико, веселие сердец. / <...> Ты нас порой миришь с судьбою, / С людской неправдою миришь, / Играешь важною душою, / В уме, как звездочка, горишь» (Филилонов В. С. Обед. СПб., 1837. С. 130).

17 Вязелский П. А. Стихотворения / Вступ. статья Л. Я. Гинзбург; сост., подг. текста и прим. К. А. Кумпан. Л., 1986. С. 75-76 (Библиотека поэта. Большая сер.).

18 О тесной связи тем пира и тризны в дружеском послании 1810-х годов см.: Виролайнен М. Н. Две чаши (О дружеском послании 1810-х годов) // Русские пиры. СПб., 1998. С. 40-69 (Альманах «Канун»; вып. 3). 
C'est à table, quand je m'enivre

De gaîté, de vin et d'amour,

Qu'incertain du temps qui va suivre,

J'aime à prévoir mon dernier jour. ${ }^{19}$

B песне «Mon Ame» (1816) Беранже просил друзей использовать на его похоронах Аи вместо святой воды ( $\not p$. l'eau benite; буквально «благословенная вода» - этот же эпитет применен к шампанскому в послании «К партизану-поэту», а десятью годами позже - в строфе 4, XLV «Евгения Онегина»). Легкое религиозное вольнодумство в песне Беранже сопровождалось резким вольнодумством политическим: поэт оплакивал судьбу Франции после поражения Наполеона, которой иностранные державы навязали ничтожного правителя.

Шампанское связывает два мира и в стихотворении «В день моего рожденья» (1819) А. А. Дельвига (к слову сказать, большого ценителя и переводчика Беранже):

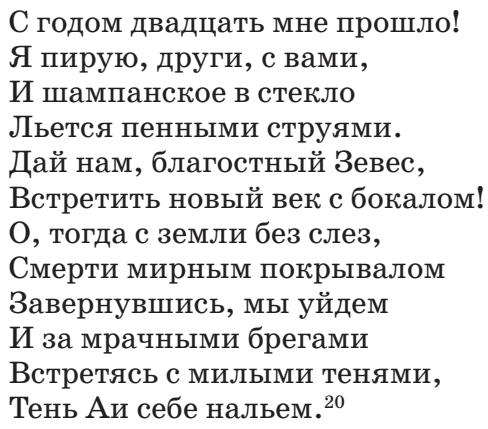

В поэме «Пиры» (1820), созданной ближайшим другом Дельвига, Е. А. Баратынским, развивается сложившийся к тому времени комплекс коннотаций шампанского - к аналогиям с вольнолюбивым умом (Вольтер) и молодостью (Баранов и Вяземский) поэт добавил коннотацию отваги, введя новую смысловую рифму «отвага / влага»:

И между тем, друзья мои,

В простые чаши бог похмелья

Роскошно лил сынам веселья

Свое любимое $A u$.

В нем укрывается отвага;

Его звездящаяся влага

Души божественной полна:

Свободно искрится она;

Как гордый ум, не терпит плена,

Рвет пробку резвою волной -

И брызжет радостная пена,

Подобье жизни молодой.

Мы в нем заботы потопляли,

И средь восторженных затей -

19 Béranger P. J. de. Chansons. Paris, 1821. T. 2. Р. 39. Пер.: «За столом, упиваясь весельем, вином и любовью, полный сомнений в будущем, я особенно люблю провидеть последний день моей жизни» .

${ }^{20}$ Дельвиг А. А. Соч. / Сост., вступ. статья и комм. В. Э. Вацуро. Л., 1986. С. 143-144. 
Певцы пируют - восклицали, Слепая чернь, благоговей! ${ }^{21}$

Эффектной новацией был необычный эпитет «звездящаяся», который напоминал о так называемом «вине кометы» (по-русски комету называли «хвостатой звездой»). В 1811 году дом Клико выпустил очень удачную партию шампанского из винограда, собранного во время приближения к земле кометы Галлея; «вино кометы» особенно активно подделывали, поэтому вдова Клико решила изобразить на основании пробок комету; хвостатая звезда на пробке затем стала фирменным знаком шампанского Клико, помещавшимся и на бутылках других годов. ${ }^{22}$ Обыгрывая характерную визуальную примету самой популярной в России марки, Баратынский решал более сложную идеологическую задачу: он в полном смысле слова оторвал шампанское от французской почвы, заменив влияние «terroir» на влияние «хвостатой звезды», одинаково судьбоносное для всех народов.

Вслед за Вяземским Баратынский преобразил пирушку в пиршество единомышленников, в котором угадывался так называемый «Союз поэтов» (в него входили А. С. Пушкин, А. А. Дельвиг, В. К. Кюхельбекер и сам автор «Пиров»). Введение «небесного» напитка в антураж пира поэтов напоминало о родстве вакхического и поэтического восторга: это античное учение о разных видах божественной одержимости (лат. furor), сформировавшееся еще до Платона, много раз и на разные лады повторенное в его текстах и ставшее общим местом уже в античности, в очередной раз вошло в моду в XVIII веке вместе с категориями «восторга» и «вдохновения», занимавшими почетное место в лонгинианской эстетике. Баратынский смягчил священную одержимость поэтов (furor poeticus) легкой самоиронией, соединив в выражении «среди восторженных затей» два слова из разных стилистических регистров.

В 1825 году, готовя отдельное издание своих поэм «Эда» и «Пиры», Баратынский изменил несколько строк в описании шампанского. Судя по правке, которую он внес в экземпляр книги, подаренный Вяземскому, оно должно было читаться так:

В нем укрывается отвага;
Его звездящаяся влага
Недаром взоры веселит:
Она свободою кипит;
Как пылкий ум, не терпит плена,
Рвет пробку резвою волной,
И брызжет радостная пена,
Подобье жизни молодой. ${ }^{23}$

Цензуру эти строки испугали: в марте 1826 года ведавший этим изданием Дельвиг писал Баратынскому: «„Монах“ и „Смерть“Андрэ Шенье перебесили

21 Баратынский E. A. Пиры // Соревнователь просвещения и благотворения. 1821. Ч. 13. C. $389-390$.

22 См.: Невский А. Я. Вино кометы // Онегинская энциклопедия. Т. 1. С. 186-187. Ср.: «Пойдем шампанское отведать; / По дружбе только мой Антон / Мне уступил его, какое! / На пробке звезды, пять корон, / А имя вдовушки резвое! / Смола вся в искрах! уж вино!»; «Еще в бокале пена бьется, / Еще кометная струя / На волю из бутылки рвется» (Филилонов В. С. Обед. C. 35,73$)$.

${ }_{23}$ См.: Нечаева В. С. Из архива Боратынского. Остафьевский экземпляр сочинений Боратынского и история одного литературного мотива // Утренники. Пг., 1922. Кн. 1. С. 66-71. А. С. Бодрова любезно сообщила нам, что экземпляр с авторской правкой сейчас хранится в Музее Книги РГБ (шифр МК XII.A.7/8; инв. MК IV - 6210). 
нашу цензуру: она совсем готовую книжку остановила и принудила нас перепечатать по ее воле листок „Пиров“. Напрасно мы хотели поставить точки или сказать: оно и блещет и кипит, как дерзкой ум не терпит плена. Нет! На все наши просьбы суровый отказ был ответом! Взгляни на сей экземпляр, потряси его, листок этот выпадет...». ${ }^{24}$

Эта история широко обсуждалась в пушкинском кругу. В. В. Набоков, а вслед за ним и Ю. М. Лотман полагали, что именно на нее откликнулся Пушкин в строфрах IV, 45-46 «Евгения Онегина». ${ }^{25}$ Хронология работы над четвертой главой опровергает эту гипотезу: глава была завершена раньше, чем случилась история с «Пирами». ${ }^{26}$ Однако Пушкин наверняка помнил описание шампанского в «Пирах», когда писал эти строфы:

\section{XLV}

Вдовы Клико или Моэта

Благословенное вино

В бутылке мерзлой для поэта

На стол тотчас принесено.

Оно сверкает Ипокреной,

Оно своей игрой и пеной

(Подобием того-сего)

Меня пленяло: за него

Последний бедный лепт, бывало,

Давал я. Помните ль, друзья?

Его волшебная струя

Рождала глупостей немало,

А сколько шуток и стихов,

И споров и веселых слов!

\section{XLVI}

Но изменяет пеной шумной

Оно желудку моему,

И я Бордо благоразумный

Уж нынче предпочел ему.

К $A u$ я больше не способен;

$A u$ любовнице подобен

Блестящей, ветреной, живой,

И своенравной, и пустой...

Но ты, Бордо, подобен другу,

Который, в горе и в беде,

Товарищ завсегда, везде

Готов нам оказать услугу,

24 Летопись жизни и творчества Е. А. Боратынского. 1800-1844 / Сост. А. М. Песков; подг. текста Е. Э. Ллминой, А. М. Пескова. М., 1998. С. 178. Так в издании 1826 года в описании шампанского появились строки: «Она отрадою кипит, / Как дикий конь, не терпит плена». Ср. дальнейшее развитие этой линии в стихотворении «Шампанское» поэта-самоучки: «Ты, как буян неугомонной / Железом связан, засмолен» (Слепушкин Ф. Новые досуги сельского жителя. СПб., 1834. C. 55).

${ }_{25}$ Ср.: Набоков В. Комментарий к роману А. С. Пушкина «Евгений Онегин». СПб., 1999. С. 389-390; Лотлан Ю. М. Роман А. С. Пушкина «Евгений Онегин» : Комментарий: Пособие для учителя // Лотман Ю. М. Пушкин. Биография писателя; Статьи и заметки, 1960-1990; «Егений Онегин»: Комментарий. СПб., 1995. С. 643-644.

26 Даты окончания работы над четвертой главой указаны Пушкиным в рукописи: 3 и 6 января 1826 года. Неприятности со «Стихотворениями» Пушкина, обострившие внимание цензуры к «Пирам», начались 26 января 1826 года (об этом см.: Бодрова А. С. Цензурная политика А. С. Шишкова и история пушкинских изданий 1825-1826 годов // Русская литература. 2019. № 3. C. $68-71)$. 
Иль тихий разделить досуг.

Да здравствует Бордо, наш друг! ${ }^{27}$

Что могло иметься в виду под словами «подобие того-сего»? Если Пушкин иронизировал над самим приемом развернутых сравнений шампанского, то зачем он снабдил эту строфу примечанием № 25 , в котором процитировал свое неопубликованное «Послание к Л<ьву> П<ушкину>» (1824):

\author{
В лета красные мои \\ Поэтический Аи \\ Нравился мне пеной шумной, \\ Сим подобием любви \\ Или юности безумной, и проч. ${ }^{28}$
}

Игра с коннотациями шампанского этим не ограничилась: Пушкин обновил восходившую к Баранову смысловую рифму «пена / плена», предложив более эффектную рифмопару «пена / Ипокрена», т. е. источник поэтического дара; ввел новое сравнение шампанского с любовницей, а в писавшихся одновременно с четвертой главой строфах из «Путешествия Онегина» уподобил его музыке Россини. ${ }^{29}$ Отказ от сравнений и одновременное сгущение их могли подтолкнуть внимательного читателя задуматься над этим умолчанием, примерив его на устойчивые коннотации шампанского.

Пушкин дописывал четвертую главу, уже зная о восстании декабристов, после которого самой рискованной из этих коннотаций стала любовь к свободе (за нее цензура и вырезала страницу из «Пиров»). Пушкин однажды уже обозначил свободу местоимением «та» в послании к декабристу В. Л. Давыдову (1821), где, как и в песне Беранже, шампанскому доверены сакральные функции:

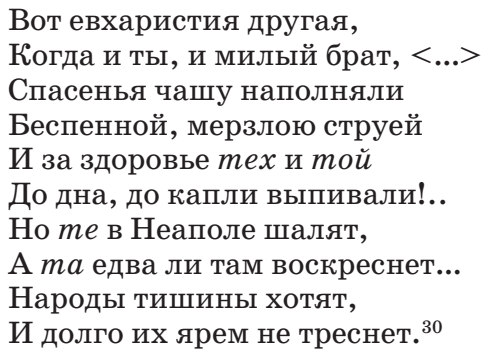

Пушкин и здесь обыграл символические коннотации шампанского («беспенная мерзлая струя» подобна подавленной свободе), но у этого описания имелось и социально-бытовое измерение: и В. Л. Давыдов, и упомянутое в этом же послании сидящим «за бутылками Аи» семейство генерала Раевского действительно были большими любителями шампанского. ${ }^{31}$ То же самое можно сказать о многих других декабристах, значительную часть которых составляли офицеры, вернувшиеся из заграничных походов. В 1825 году вдова Клико

${ }^{27}$ Пушкин А. С. Полн. собр. соч. Т. 6. С. 92.

28 Там же. С. 193.

29 Ср.: «Он звуки льет - они кипят, / Они текут, они горят / Как поцелуи молодые, / Все в неге, в пламени любви, / Как зашипевшего Аи / Струя и брызги золотые... / Но, господа, позволено ль / С вином равнять do-re-mi-sol?» (Там же. С. 204).

30 Там же. Т. 2. С. 149. Под «теми», как известно, подразумевались карбонарии.

${ }^{31}$ См.: Невский А. Я. Моэт. С. 144. 
поставила в Россию рекордное количество бутылок шампанского - 252452 ; результат, которого ей не удавалось добиться ни до, ни после этого года. ${ }^{32}$ В 1826 году общий объем поставок шампанского в Россию по сравнению с 1825 годом упал на четверть. ${ }^{33}$

Если наша гипотеза верна и у описания шампанского в строфе IV, 45 имелись политические коннотации, логично предположить их и у его антагониста - «благоразумного Бордо». ${ }^{34}$ Необычный эпитет напоминает теорию о влиянии terroir на характер вина и людей. Бордоские вина производятся в департаменте Жииронда, от названия которого в начале XIX века было образовано имя умеренного крыла французских революционеров - «la Gironde» . В эпоху революции жирондистов называли по-разному, в том числе просто «бордосцами». О бордоском происхождении многих лидеров Жћиронды упоминает, в частности, госпожа де Сталь в прекрасно известной Пушкину книге «Взгляд на главнейшие события Французской революции» (1818) - cp., например: «La députation de la Gironde était composée d'une vingtaine d'avocats, nés à Bordeaux et dans le Midi: ces hommes, choisis presque au hasard, se trouvèrent doués des plus grands talents $<\ldots>$ Les girondins voulurent la république, et ne parvinrent qu'à renverser la monarchie; ils périrent peu de temps après, en essayant de sauver la France et son roi ». ${ }^{35}$ Для госпожи де Сталь, как и для ряда других историков начала XIX века, Жииронда воплощала либеральное начало революции, уничтоженное якобинским Террором. В этой перспективе предпочтение, которое автор «Онегина» отдает «благоразумному» Бордо перед «своенравным» Аи, может быть истолковано как отказ от радикальных устремлений юности ради взвешенного либерализма зрелых лет. ${ }^{36}$

На связь строф IV, 45-46 с событиями 14 декабря, кажется, указал сам Пушкин, поставив после них в беловой рукописи помету «(Смотр. X)». ${ }^{37} \mathrm{~B}$ десятой, "декабристской» главе романа есть строфа с противопоставлением двух других сортов бордоских и шампанских вин:

\author{
Сначала эти заговоры \\ Между Лафитом и Клико \\ Лишь были дружеские споры \\ И не входила глубоко \\ В сердца мятежная наука \\ [Всё это было только] скука
}

32 Невский А. Я. Вдова Клико. С. 162.

33 См. прим. 3.

34 Кажется, к этому же заключению до нас пришел Сергей Давыдов, использовавший эти образы в качестве метафоры политической эволюции Пушкина (см.: Давыдов С. Между Аи и Бордо: политические взгляды Пушкина // Записки русской академической группы в США. New York, 2000. T. 30 (1999-2000). C. 167-184).

35 Staël A.-L.-G. Considérations sur les principaux événements de la Révolution française. Paris, 1845. Р. 242-243. Пер.: «Депутация от Жиронды была составлена из двух десятков адвокатов родом из Бордо и с юга: эти случайно выбранные люди обнаружили величайшие таланты $<. . .>$. Жирондисты хотели республики, но добились лишь свержения монархии и вскоре погибли, пытаясь спасти Францию и ее короля». Список работ об интересе Пушкина к политическим взглядам Ж. де Сталь см.: Толашевский Б. В., Вольперт Л. И. Сталь // Пушкин: Исследования и материалы. СПб., 2004. Т. 18/19. Пушкин и мировая литература. Материалы к «Пшшинской энциклопедии». С. 320 .

${ }^{36}$ К этому же кругу идей и исторических ассоциаций отсылал эпиграф к четвертой главе, взятый из госпожи де Сталь: «La morale est dans la nature des choses». О контекстах и возможных значениях этого эпиграфа см.: Liapunov V. «La morale est dans la nature des choses»? // Russian Language Journal / Русский язык. 1999. Vol. 53. № 174/176. Р. 43-54. Сталь утверждала, что слова «Мораль в природе вещей» ее отец, барон Неккер, либерал и лоялист, адресовал рвавшемуся к власти любой ценой графу де Мирабо.

${ }^{37}$ Пушкин А. С. Полн. собр. соч. Т. 6. С. 599. 
Безделье молодых умов

Забавы взрослых шалунов. ${ }^{38}$

Набоков истолковал оборот «между Лафитом и Клико» как кальку с французского «entre deux vins» (непринужденно, за бокалом вина), ${ }^{39}$ Лотман как указание на порядок подачи вин за обедом, а стало быть, и на легкомыслие обстановки, в которой рождался заговор. ${ }^{40}$ Не отвергая этих гипотез, добавим к ним третью: "споры между Лафитом и Клико» проецируются на описание умеренного Северного и радикального Южного общества в двух предшествующих строфах десятой главы.

Главный «певец вакхических картин» ${ }^{41}$ в русской поэзии 1820-х годов, Н. М. Языков долго держался в стороне от темы шампанского. Велик соблазн объяснить это воздержание его стремлением дистанцироваться от пушкинского круга и утвердить собственную оригинальность. Основной претензией Языкова к поэзии Пушкина и Баратынского был недостаток «вдохновения» и «восторга» - ключевых ценностей лонгинианской эстетики, воплощением которых стал его собственный лирический герой. ${ }^{42} \mathrm{O}$ «Пирах» Баратынского он писал, что те «не имеют того дифирамбического вдохновения, которое должно бы управлять поэтов, воспевающих пиры, и к чему ирония - тоже не вижу». ${ }^{43}$ Сцена пира поэтов в послании Языкова «Тригорское» (1826) напоминает аналогичную сцену в «Пирах», но очищенную от иронии и самоиронии:

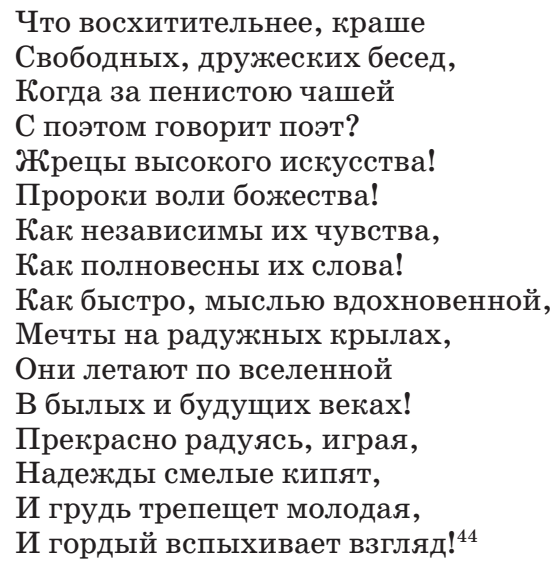

Свободный полет мыслей, их игра и кипение, входившие в стандартный репертуар описания эффектов шампанского, Языков объясняет результатом не столько опьянения, сколько воздействия поэтов друг на друга.

38 Там же. С. 525-526.

39 Набоков В. Комментарий к роману «Евгений Онегин». С. 667.

40 Лотлиан Ю. М. Роман А. С. Пушкина «Евгений Онегин». С. 757.

41 Автохарактеристика в послании к А. С. Пушкину (1825) (Языков Н. М. Полн. собр. стихотворений / Ред., вступ. статья и комм. М. К. Азадовского. М.; Л., 1934. С. 199).

42 См. об этом: Мазур Н. Н. Поэтический диалог Пушкина и Языкова в середине 1820-х годов: новые перспективы // Пушкинские чтения в Тарту. Тарту, 2019. [Т.] 6. Вып. 1. Пушкин в кругу современников / Отв. ред. Р. Г. Лейбов, Н. Г. Охотин. С. 47-93 (Acta Slavica Estonica; XI).

${ }^{43}$ Письмо к А. М. Языкову от 17 марта 1826 года см.: Языковский архив. СПб., 1913. Вып. 1. C. 243 .

44 Языков Н. М. Полн. собр. стихотворений. С. 270-271. 
Первое и единственное развернутое описание шампанского Языков предложил в стихотворении «Кубок» (1831), написанном после переезда в Москву. Несмотря на случившееся там сближение с Баратынским, Языков не изменил своим эстетическим принципам: «Кубок» полон «дифирамбическим вдохновением», а коннотации радости, отваги, свободы перенесены с шампанского на поэта:

\author{
Восхитительно играет \\ Драгоценное вино! \\ Снежной пеною вскипает, \\ Златом искрится оно! \\ Услаждающая влага \\ Оживит тебя всего: \\ Вспыхнут радость и отвага \\ Блеском взора твоего; \\ Самобытными мечтами \\ Загуляет голова, \\ И, как волны за волнами, \\ Из души польются сами \\ Вдохновенные слова; \\ Строен, пышен мир житейской \\ Развернется пред тобой... \\ Много силы чародейской \\ В этой влаге золотой! <...> \\ Горделивый и свободный, \\ Чудно пьянствует поэт! ${ }^{45}$
}

В «Кубке» нам слышится ответ Языкова на поэтический спор между П. А. Катениным и А. С. Пушкиным, развернувшийся в 1828-1829 годах. Посылая Пушкину свою балладу «Старая быль», Катенин присовокупил к ней послание, наполненное двусмысленными похвалами: якобы Пушкину достался старинный «завороженный» кубок, из которого «смело пить тому лишь можно, / Кто сыном Фебовым рожден». Катенин просил у Пушкина позволения напиться из этого кубка при одном условии:

\footnotetext{
Невинным опытом сначала

Узнай - правдив ли этот слух:

Младых романтиков хоть двух

Проси отведать из бокала;

И если, капли не пролив,

Напьются милые свободно,

Тогда и слух, конечно, лжив,

И можно пить кому угодно... ${ }^{46}$
}

По предположению Ю. Н. Тынянова, Пушкин прочел в текстах Катенина ядовитый намек на его стремление понравиться новому царю, поэтому напечатал в «Северных цветах на 1829 год» только «Старую быль» и свой ответ на послание Катенина, начинавшийся строками:

Напрасно, пламенный поэт,

Свой чудный кубок мне подносишь

45 Там же. С. 384-385.

46 Катенин П. А. Избр. произведения / Вступ. статья, подг. текста и прим. Г. В. ЕрмаковойБитнер. М.; Л., 1965. С. 184-185 (Библиотека поэта. Большая сер.). Катенин был возмущен тем, что Пушкин не опубликовал послания, и просил Н. И. Бахтина распространять его в списках. О споре Катенина и Пушкина см.: Тыцяянов Ю. Н. Архаисты и Пушкин // Тынянов Ю. Н. Пушкин и его современники. М., 1969. С. 261-264. 
И выпить за здоровье просишь:

Не пью, любезный мой сосед! ${ }^{47}$

Неизвестно, распознал ли Языков политическую подоплеку этого спора, но выпад Катенина в адрес «молодых романтиков», как и вопрос о том, кому хватит смелости выпить из «завороженного» кубка, подтвердив свое право именоваться истинным поэтом, вряд ли могли оставить его равнодушным. Языковский поэт безбоязненно и безнаказанно осушает кубок за кубком, да еще и раздумывает, не швырнуть ли его оземь:

Кубок взял: душе угодны
Этот образ, этот цвет;
Сел и налил; их ласкает
Взором, словом и рукой;
Сразу кубок выпивает
И высоко подымает,
И над буйной головой
Держит. Речь его струится
Безмятежно весела,
А в руке еще таится
Жребий бренного стекла! ${ }^{48}$

Языков настолько сосредоточился на описании разгулявшегося поэта, что не упомянул ни словом о наличии у него сотрапезников и слушателей. То, что у Языкова могло быть случайным умолчанием, в «Бокале» Баратынского (1835) стало программным утверждением. Баратынский воспроизвел устойчивые коннотации шампанского (источник вдохновения; символ свободы; элемент, соединяющий два мира), но отверг связанную с ними аксиологию дружеского пира. Полемический посыл усилен на грамматическом уровне: «Бокал» насыщен отрицательными формами глагола (9 отрицаний, из которых 7 - в сильной анафорической позиции). Масштаб отрицания нарастает: в строфах I и II критически описана ситуация пира:

Ты не встречен братьей шумной,

Буйных оргий властелин:

Сластолюбец вольнодумной

Я сегодня пью один. ${ }^{49}$

Строка «Я сегодня пью один» перекликалась с дружеским посланием Пушкина «19 октября» («Роняет лес багряный свой убор...», 1825), но эта перекличка носила полемический характер. Одиночество пушкинского героя горькая необходимость:

Печален я: со мною друга нет <...>

Я пью один; вотще воображенье

Вокруг меня товарищей зовет.

47 Пушкин А. С. Полн. собр. соч. Т. 3. Кн. 1. С. 135.

48 Языков Н. М. Полн. собр. стихотворений. С. 385-386. Эффектный финал «Кубка», кажется, отразился в поздней редакции послания к Языкову Д. И. Хвостова - ср.: «Пой резвой юности игры / И хороводы и пиры: / Пусть пробка с потолком сразится, / Веселой теша уголок, / Где в чистом хрустале струится / Вина шипящего поток» (Славянин. 1827. Ч. 4. С. 30) и «ой резвой юности игры, / И хороводы и пиры: / На потолок летают пробки, / Веселость царствует одна; / Заморских хрусталей обломки / Прольют на стол реку вина» (Хвостов Д. И. Полн. собр. стихотворений. СПб., 1834. Т. 7. С. 82).

49 Боратынский Е. А. Полн. собр. соч. и писем. М., 2012. Т. 3. Ч. 1. С. 46. 
Постепенно воображение поэта разгорается и в его памяти оживают образы далеких живых и мертвых друзей:

Я пью один, и на брегах Невы

Меня друзья сегодня именуют...50

Баратынский в строфах III и V отвергает идеал дружбы, устойчивым символом которой в поэзии 1810-1820-х годов служила «круговая чаша»:

Мой восторг неосторожный

Не обидит никого;

Не откроет дружбе ложной

Таин счастья моего $<\ldots>$

О, бокал уединенья!

Не усилены тобой

Пошлой жизни ощущенья,

Словно чашей круговой:

Плодородней, благородней,

Дивной силой будишь ты

Или грезы преисподней

Иль небесные мечты.

В финальной строфе условием поэтического прозрения, родственного дару пророка (тот furor poeticus, который Баратынский первым связал с мотивом шампанского в «Пирах»), объявляется одиночество:

И один я пью отныне!

Не в людском шуму, пророк,

В немотствующей пустыне

Обретает свет высок!

Не в беспутном развлеченьи

Общежительных страстей,

В одиноком упоеньи

Мгла падет с его очей! 51

«Бокал» был остро полемичен по отношению ко всей традиции описания шампанского в русской поэзии, начиная с посланий Давыдова и Вяземского и «Пиров» самого Баратынского. Эта полемичность стала следствием нового мировоззрения и новой поэтики, которые формируются у Баратынского в середине 1830-х годов и находят полное выражение в сборнике «Сумерки». И тем не менее спустя три года Баратынский написал стихотворение «Звезды», в котором, на первый взгляд, вернулся к эпикурейским радостям поэзии 1810-х годов, снова связав их с темой шампанского:

Мою звезду я знаю, знаю,

И мой бокал

Я наливаю, наливаю,

Как наливал.

Гоненьям рока, злобе света

Смеюся я:

Жиивет не здесь - в звездах Моэта

Душа моя!

${ }^{50}$ Пушкин А. С. Полн. собр. соч. Т. 2. Кн. 1. С. 424.

51 Боратынский Е. А. Полн. собр. соч. и писем. Т. 3. Ч. 1. С. 46-48. 


\section{Когда ж коснутся уст прелестных \\ Уста мои,}

Не нужно мне ни звезд небесных, Ни звезд Аи! ${ }^{52}$

Парадоксальную перемену позиций мы предлагаем объяснять рядом совпадений, о которых мы знаем или можем уверенно предполагать, что сам Баратынский считал их знаковыми. Связь между мотивами шампанского, звезд и судьбы он впервые наметил в «Пирах»: образ «звездящейся влаги» подчеркивал связь шампанского с кометой, явление которой в астрологии считали предзнаменованием роковых событий - войн, смерти королей и т. п. Явление кометы Галлея в 1811 году обострило эсхатологические ожидания, а вторжение Наполеона в Россию подтвердило их. О другом знаменательном совпадении сам Баратынский писал Вяземскому, посылая ему элегию «Осень» (1837): «Препровождаю вам дань мою „Современнику“. Известие о смерти Пушкина застало меня на последних строфах этого стихотворения. <...> Многим в ней я теперь недоволен, но решаюсь быть к самому себе снисходительным, тем более что небрежности, мною оставленные, кажется, угодны судьбе». ${ }^{53}$ Одна из последних строф «Осени» включала образ падающей звезды:

\section{Пускай, приняв неправильный полёт \\ И вспять стези не обретая, \\ Звезда небес в бездонный мрак падет; \\ Пусть загорится в них другая. ${ }^{54}$}

Примета, связывавшая падение звезды со смертью выдающегося человека, нашла отражение в русской поэзии, ${ }^{55}$ где ее связали, среди прочего, со смертью поэтов - ср. в «Кончине Шиллера» А. П. Беницкого (1805):

$$
\begin{aligned}
& \text { Зри! - там звезда лучезарна } \\
& \text { В синем эфире, } \\
& \text { Светлой протягшись чертою, } \\
& \text { Тихо померкла. } \\
& \text { Рок то; звезда, путь оконча, } \\
& \text { В бездне затмилась: } \\
& \text { Смертный великий со славой } \\
& \text { В вечность отходит. }{ }^{56}
\end{aligned}
$$

В «Смерти Байрона» В. К. Кюхельбекера (1824):

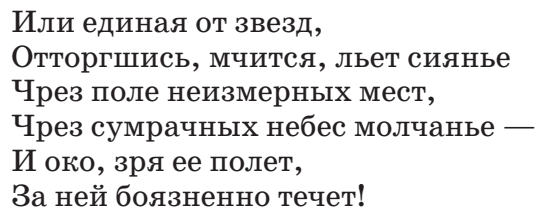

52 Там же. С. 97.

53 Летопись жизни и творчества Е. А. Боратынского. С. 337.

${ }^{54}$ Боратынский Е. А. Полн. собр. соч. и писем. Т. 3. Ч. 1. С. 80.

55 См. «На кончину Великой Княжны Ольги Павловны» Г. Р. Державина (1795), «Ночное размышление» М. М. Хераскова (1806), анонимный перевод песни Беранже «Падающие звезды» в «Северных цветах на 1828 год» и т. д.

56 Поэты 1790-1810-х годов / Вступ. статья и сост. Ю. М. Лотмана; подг. текста М. Г. Альтшуллера; вступ. заметки, биографические справки и прим. М. Г. Альтшуллера и Ю. М. Лотмана. М.; Л., 1971. С. 625 (Библиотека поэта. Большая сер.). 
Упала дивная комета!

Потухнул среди туч перун!

Еще трепещет голос струн:

Но нет могущего Поэта! ${ }^{57}$

Вяземский воспользовался этой же метафорой в стихотворении на смерть Пушкина («На память»), напечатанном в том же томе «Современника», что и «Осень» Баратынского: "Что яркая звезда с родного небосклона / Внезапно сорвана средь бури роковой...». ${ }^{58}$

Из письма Баратынского Вяземскому не вполне понятно, была ли строфа «Осени» с описанием падения звезды задумана до или после известия о смерти Пушкина. Если Баратынский оказался невольным пророком, это должно было произвести на него сильное впечатление.

Еще сильнее его могло задеть напечатанное в самом популярном журнале тех лет «Воспоминание о пиитической жизни Пушкина» Ф. Н. Глинки. Автор сравнил Пушкина с шампанским и по ошибке приписал ему и «Бокал», и две находки из «Пиров» - образ «звездящей влаги» и рифмопару «влага / отвага»:
Не так бокал, воспетый им,
Отсвечивал звездящей влагой,
Как, в заревых своих лучах,
Поэт умом сверкал в речах,
Скропленных солью и отвагой. ${ }^{59}$

Если учесть, что рефреном через все стихотворение Глинки проходила строка «А рок его подстерегал», можно представить себе то впечатление, которое эта ошибка могла произвести на Баратынского (ср. в «Звездах» настойчивый повтор «Мою звезду я знаю, знаю, / И лой бокал» и мотив «гонений рока»). Показательно, что Баратынский планировал включить «Звезды» в «Сумерки», поместив их между обращенным к Пушкину стихотворением «А. С. П......ну» и «Приметами» - двумя текстами, трактовавшими тему роковой любви и пророческого предвидения. ${ }^{60}$

В том же 1839 году, что и «Звезды», было написано другое стихотворение о шампанском, которое задумывалось как возвращение к эпикурейским радостям и к стилистике роésie fugitive - легкой поэзии 1810-х годов, а стало обращением к тени поэта. Историю создания послания «Эперне. Денису Васильевичу Давыдову» (1839) и послесловия к нему, написанного 15 лет спустя, Вяземский изложил в примечании к их первой публикации в сборнике «В дороге и дома» (1862): «В конце 1838 года автор, посещая Эперне, вспомнил рассказ Давыдова о том, как в 1814 году он был с партизанским отрядом в Эперне, где встретил многих друзей, как они прослезились от радости при такой встрече и потом весело пировали. Автор написал там первую часть это-

57 Кюхельбекер В. К. Избр. произведения: В 2 т. / Вступ. статья, подг. текста и прим. Н. В. Королевой. М.; Л., 1967. Т. 1. С. 205 (Библиотека поэта. Большая сер.). Е. Н. Купреянова считала «Смерть Байрона» источником образа падающей звезды в «Осени» (Баратынский E. A. Полн. собр. стихотворений: В 2 т. / Ред., комм. и биографическая статья Е. Н. Купреяновой и И. Н. Медведевой. М.; Л., 1936. Т. 2. С. 275 (Библиотека поэта. Большая сер.)).

58 Вязелский П. А. Стихотворения. С. 262.

59 Библиотека для чтения. 1837. Т. 21. Отд. 1. С. 86.

60 О стремлении позднего Баратынского скрыть значимые интертекстуальные переклички и отсылки см. в публикуемой ниже статье Н. Г. Охотина о «Приметах» . 
го не изданного до сих пор послания к Давыдову, которое и было последним, к нему адресованным. Давыдов вскоре умер, и чувства, возбужденные вестью о его смерти, выражены автором во второй части послания, написанной уже в 1854 году». ${ }^{61}$

«Эперне» открывал фамильярный вопрос «Икалось ли тебе, Давыдов, / Когда шампанское я пил», напоминавший тон посланий самого Давыдова к Бурцову. Содержательно стихотворение делилось на две части: в первой Вяземский использовал символическую коннотацию «шампанское - источник вдохновения» и обыграл псевдосмысловую рифму «Моэт / поэт» :

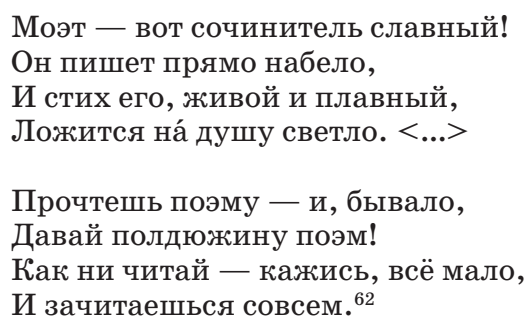

Во второй части, как и в послании «К партизану-поэту», шампанское помогает автору живо вообразить себе события, известные ему только по рассказам адресата. В данном случае речь шла о кутеже русских войск, разграбивших подвалы Моэта после взятия Эперне в 1814 году, в нем принимал участие и сам Давыдов. Похоже, что этой картиной Вяземский собирался окончательно разделаться с вольтеровской аналогией между шампанским и французским характером, перенеся главные достоинства французов на донского казака (этот ход перекликался со стихотворным тостом Давыдова в честь донских атаманов):
Люблю я русского натуру:
В бою он лев; пробьют отбой -
Весельчаку и балагуру
И враг всё тот же брат родной.
Оставя боевую пику,
Казак здесь мирно пировал,
Но за Москву, французам в пику,
Их погреба он осушал.
Вином кипучим с гор французских
Он поминал родимый Дон,
И, чтоб не пить из рюмок узких,
Пил прямо из бутылок он. ${ }^{63}$

В послесловии к «Эперне» Вяземский не упоминает шампанское, но переносит его коннотации на характер Давыдова и его поэзии:

Остыл поэта светлый кубок,

Остыл и партизанский меч;

61 Вязелский П. А. Стихотворения. С. 513.

62 Там же. С. 322. Это стихотворение, как и многие другие тексты позднего Вяземского, насыщено реминисценциями из поэзии 1810-1820-х годов, разбор которых, однако же, не входит в задачи нашей статьи.

63 Там же. С. 323. 
Средь благовонных чаш и трубок

Уж не кипит живая речь.

С нее не сыплются, как звезды,

Огни и вспышки острых слов,

И речь наездника наезды

Не совершает на глупцов.

Струей не льется вечно новой

Бивачных повестей рассказ...

Финал послесловия к «Эперне» перекликался с финалом послания «К партизану-поэту»: в раннем послании Вяземский обещал совершить возлияние на могиле Бурцова вином, утолив им «жажду праха», а в позднем вино заменила песнь:

Но песнь мою, души преданье

О светлых, безвозвратных днях,

Прими, Денис, как возлиянье

На прах твой, сердцу милый прах $!^{64}$

Так последней «звезде рассеянной Плеяды» ${ }^{65}$ выпало на долю начать и завершить развитие символических коннотаций шампанского в поэзии пушкинского круга - поэтической общности, принадлежность к которой определялась не только и не столько личной дружбой, сколько единым интертекстуальным пространством, созданным памятливостью на чужие находки и готовностью подхватить тему и посоревноваться в ее развитии.

64 Там же. С. 324-325.

65 Так Баратынский назвал Вяземского в посвящении «Сумерек» (Боратынский E. A. Полн. собр. соч. и писем. Т. 3. Ч. 1. С. 12).

() А. С. БОДРОВА

\section{НЕИЗВЕСТНОЕ ПИСЬМО Е. А. БАРАТЫНСКОГО К А. И. ТУРГЕНЕВУ (К ИСТОРИИ ЛИТЕРАТУРНЫХ ОТНОШЕНИЙ)*}

Историю литературных отношений традиционно описывают по биографической канве их участников, дополняя анализом прямых высказываний персонажей друг о друге и описанием творческих взаимных влияний или полемики. При этом социальное измерение литературных отношений (социальный статус и связи, положение в служебной или литературной иерархии, институциональная принадлежность и т. д.) редко становится объектом исследовательской рефлексии, как и сюжеты, предполагающие выход

\footnotetext{
* Исследование выполнено при финансовой поддержке РФФИ в рамках научного проекта № 20-012-00306 «Литературное общество как культурный, политический и социальный институт (Вольное общество любителей российской словесности, 1816-1825)».
} 
за пределы автономного поля, когда речь идет о взаимодействии писателя с другими агентами, принадлежащими одновременно к нему и к полю власти или коммерции. ${ }^{1}$ Между тем внимание к социальным диспозициям, их учет при анализе собственно литературных фактов представляются важными для адекватного описания как самого поля, так и поведения разных его участников - особенно в те периоды, когда автономия «république des lettres» только формируется и она находится под влиянием гетерономной модели.

Богатый в этом отношении материал представляет литературная ситуация 1820-х - начала 1830-х годов, когда существенное число ее участников было встроено в другие - прежде всего чиновные и служебные - иерархии, сохранявшие свой социальный и символический вес. В такой конфигурации особую значимость приобретали те «акторы», которые могли способствовать внелитературному поощрению успеха «внутри поля», - в их числе, несомненно, должен быть назван Александр Иванович Тургенев, бывший, по словам П. А. Вяземского, «посредником, агентом, по собственной воле уполномоченным и аккредитованным поверенным в делах русской литературы при предержащих властях и образованном обществе» ${ }^{2}$

Хорошо известна та роль, которую Тургенев сыграл в устройстве дел самого Вяземского, В. А. ЖЖуковского, Н. М. Карамзина, А. С. Пушкина; ${ }^{3}$ не менее ярким примером оказывается и почти двадцатилетняя история отношений Тургенева с Е. А. Баратынским, несомненно заслуживающая специального исследования. В настоящей заметке мы попытаемся описать лишь несколько ее эпизодов, сосредоточившись на некоторых признательно-литературных жестах Баратынского по отношению к Тургеневу.

$$
* * *
$$

Обстоятельства первого знакомства Тургенева с молодым поэтом и унтерофицером Баратынским неизвестны. Наиболее раннее выявленное упоминание о нем - в письме Тургенева Вяземскому от 2 марта 1821 года, свидетельствующее о том, что по крайней мере заочно Тургенев был знаком с начинающим автором: «Третьего дня был я в первый раз в публичном собрании здешнего Вольного литературного общества, которого я и ты почетный член. $<. . .>$ После меня читаны были, как уверяют, хорошие пиесы Боратынского и какого-то Крылова, только не баснописца. Постараюсь прислать их тебе». ${ }^{4}$

Активное участие Баратынского в деятельности ВОЛРС, его многочисленные публикации на страницах «Соревнователя просвещения и благотворения»

1 Если описывать литературную ситуацию методологическим языком П. Бурдье (см. прежде всего: Бурдье П. Поле литературы / Пер. с фр. М. Гронаса // Новое литературное обозрение. 2000. № 45. С. 22-87).

2 Вязелский П. А. Полн. собр. соч. СПб., 1883. Т. 8. Старая записная книжка. С. 281.

${ }^{3}$ Краткую, но насыщенную характеристику деятельности Тургенева и основную литературу о нем см.: Ларионова E. О. Тургенев Александр Иванович // Русские писатели. 1800-1917. Биографический словарь. М.; СПб., 2019. Т. 6. С. 313-317.

4 Остафьевский архив князей Вяземских. СПб., 1899. Т. 2. С. 174. Речь идет о публичном собрании Вольного общества любителей российской словесности (далее - ВОЛРС), состоявшемся 28 февраля 1821 года, на котором была прочитана поэма Баратынского «Пиры», «какой-то Крылов» - поэт Александр Абрамович Крылов, действительный член Общества соревнователей (см.: Базанов В. Г. Ученая республика. М.; Л., 1964. С. 229; Евстифеева Р. А., Зареикий А. Р. Произведения Боратынского, читанные в собраниях Вольного общества любителей российской словесности // Боратынский Е. А. Полн. собр. соч. и писем. М., 2002. Т. 1. С. 457-460). Тургенев был избран почетным членом ВОЛРС 18 февраля 1818 года, Вяземский -27 сентября 1820 года (Базанов В. Г. Ученая республика. С. 446, 447). Впоследствии Тургенев, как и Вяземский, принимали более активное участие в деятельности и проектах ВОЛРС. 
и других петербургских изданий в 1821-1823 годах ${ }^{5}$ упрочили его место в современной поэтической иерархии, при этом служебно-социальный статус Баратынского за этот период не изменился - несмотря на хлопоты родственников, представления непосредственного армейского начальства и ходатайство C. С. Уварова, тогда попечителя Санкт-Петербургского учебного округа и президента Императорской академии наук. ${ }^{6}$

Тургенев, благодаря высокой должности и тесному сотрудничеству с влиятельным министром А. Н. Голицыным в подведомственных последнему Министерстве народного просвещения и духовных дел и Русском Библейском обществе (с 1810 года он был директором департамента Главного управления духовных дел иностранных исповеданий, с 1814 года - секретарем Библейского общества), неоднократно и успешно выступал ходатаем за литераторов, добиваясь для них финансового или символического вознаграждения или улучшения служебного положения. В 1824-1825 годах подобную функцию Тургенев взял на себя и в отношении Баратынского, который впоследствии неоднократно называл его своим главным благодетелем, возвратившим отчаявшегося «обществу, семейству, жизни». ${ }^{7}$ Можно предполагать, что сложная конфигурация прошений за Баратынского в январе-апреле 1824 года, в которых были задействованы министр Голицын, с одной стороны, и военное начальство в лице А. А. Закревского и И. И. Дибича - с другой, была срежиссирована именно Тургеневым, имевшим возможность влиять на обе группы интересов. Об этом свидетельствует, помимо собственно рассказа Тургенева в письме Вяземскому от 24 марта 1824 года, ${ }^{8}$ и тот факт, что записку об обстоятельствах вступления Баратынского в службу, необходимую для письма Голицыну, жћуковский просил Н. И. Гнедича доставить именно «к Тургеневу с надписью нужное». ${ }^{9}$ По убеждению Баратынского, ходатайству Тургенева перед Закревским он был «обязан <...> добрым расположением» ${ }^{10}$ ринляндского генерал-губернатора, который в октябре 1824 года пригласил его прибыть к штабу Отдельного

5 О значении ВОЛРС для литературной позиции и репутации раннего Баратынского см.: Мартыненко А. И. Е. А. Баратынский и «Ученая республика»: К истории формирования литературной репутации поэта // Пушкинские чтения в Тарту. 6. Вып. 2. Tartu, 2020 (в печати).

6 Фактические обстоятельства хлопот за Баратынского см.: Летопись жизни и творчества Е. А. Боратынского / Сост. А. М. Песков; подг. текста Е. Э. Ляминой, А. М. Пескова. М., 1998. C. 103-104; о соотношении служебного положения и литературной деятельности Баратынского в 1821-1824 годах см.: Бодрова А. С. Военная служба Е. А. Баратынского: между биографией и поэзией // Чины и музы: Сб. статей. СПб.; Тверь, 2017. С. 131-155.

7 См. письмо Баратынского Тургеневу от 9 мая 1825 года (Летопись жизни и творчества Е. А. Боратынского. С. 158), а также совместное письмо Баратынского и Вяземского Тургеневу и Жуковскому от 25 февраля - 12 марта 1827 года, где Баратынский, обращаясь к Жуковскому, просил засвидетельствовать его почтение Тургеневу и сказать: «...я пользую семейственным счастием и независимостью, которые он столько желал мне доставить и наконец доставил. Всегда я буду хранить о нем признательное воспоминание. Ничего счастливого не случается в моей жизни без того, чтобы он и вы не пришли мне на память» (Там же. С. 191; текст письма уточнен по автографу: РНБ. Ф. 167. № 26. Л. 1-1 об.).

8 Ср.: «...спешу пересказать о Бор[атынском]. Закр[евский] говорил и просил: обещано или почти обещано, но еще ничего не сделано, а велено доложить чрез Диб[ича]. На этого третьего дня напустил я князя Гол[ицына]; потом принялся сам объяснять ему дело и человека. Большой надежды он мне не подал, но обещал доложить в течение дней всеобщего искупления. Между тем, узнав от него, что он думает, что Бор[атынский] отдан, а не охотой пошел в солдаты, я клялся ему в противном, просил справиться и, занемогши сам в тот же день, вчера призывал Муханова, просил его упросить Закревского объяснить Диб[ичу] это обстоятельство: оно важно и должно более других обратить гнев на милость» (Остафьевский архив князей Вяземских. Т. 3. С. 24).

9 Летопись жизни и творчества Е. А. Боратынского. С. 135; Жуковский В. А. Полн. собр. соч. и писем: В 20 т. М., 2019. Т. 16. С. 227, 764.

10 Слова из письма Тургеневу от 25 января 1825 года (цит. по: Летопись жизни и творчества Е. А. Боратынского. С. 150). 
Финляндского корпуса в Гельсингфорс, ${ }^{11}$ а затем, в феврале-марте 1825 года, вновь подавал - и наконец успешно - представление Баратынского к офицерскому чину,

При этом признательность Баратынского выражалась не только в эпистолярной форме. В 1824 - начале 1825 года Тургенев оказался в числе первых читателей и слушателей новых произведений Баратынского, в том числе не предназначавшихся для скорой публикации. 15 июня 1824 года на даче Тургенева Баратынский читал свое программное послание «Богдановичу», ${ }^{12}$ в начале августа Тургенев получил от Баратынского текст стихотворения «Звезда» («Взгляни на звезды: много звезд...»), ${ }^{13}$ в конце октября 1824 года поэт просил у Тургенева позволения прислать ему «лепту вдовицы» - только что завершенную поэму «Эда», текст которой он отправил в письме от 25 января 1825 года. ${ }^{14}$ Учитывая, что в этот период Баратынский вообще сильно сократил свою публикационную активность, подчиняясь убеждению Тургенева, что появление имени поэта в печати могло повредить делу о производстве, ${ }^{15}$ такое представление новых текстов приобретало эксклюзивный характер, подчеркивая символическую ценность мнения адресата.

Благодарность Тургеневу за участие и покровительство Баратынский сохранит на всю жизнь: показательно, что впоследствии он будет прибегать к схожей, но более конвенциональной форме выражения авторской признательности, стремясь преподнести Тургеневу почти все свои изданные сочинения.

С одним из таких эпизодов связана обнаруженная в архиве Тургеневых неопубликованная записка Баратынского, содержание которой позволяет не только дополнить летопись их социо-литературных отношений, но и прояснить запутанную историю одного из ключевых сборников Баратынского:

«Непременно бы навестил вашу простуду, если-б имел на то время сегодня. Надеюсь, что вы довольно заботитесь о вашем здоровьи, чтобы и завтра посидеть дома часов с 12. Постараюсь выпросить у Семена экземпляр и представить вам в одно время сочинение и почитающего вас автора.

Е. Боратынс $<$ кий $>{ } .^{16}$

Несмотря на отсутствие даты и почтовых штемпелей (записка, судя по всему, была предназначена для посылки с нарочным), представляется возможным определить обстоятельства посылки этого письма с точностью до дня. Основание для датировки дает наиболее интересное в комментаторском отношении упоминание о намерении Баратынского представить Тургеневу экземпляр своего, очевидно, нового издания, выпущенного «у Семена», т. е. в типографии Августа (Огюста-Рене) Семена при Императорской медико-хирургической академии. ${ }^{17} \mathrm{~B}$ этой типографии, имевшей высокую

11 В судьбе Баратынского таким образом был успешно реализован тот сценарий, который Тургенев предполагал и для Пушкина, когда в июне 1823 года способствовал его переводу в канцелярию М. С. Воронцова, недавно назначенного новороссийским генерал-губернатором (см. письмо Тургенева Вяземскому от 15 июня 1823 года: Остафьевский архив князей Вяземских. Т. 2. С. 333-334).

12 Летопись жизни и творчества Е. А. Боратынского. С. 139.

13 Боратынский Е. А. Полн. собр. соч. и писем. Т. 2. Ч. 1. С. 87.

14 Летопись жизни и творчества Е. А. Боратынского. С. 145, 150.

15 См. письма Тургенева Вяземскому от 24 марта 1824 года и 15 марта 1825 года (Там же. С. 137,153$)$; подробнее об этой стратегии см.: Бодрова А. С. Военная служба Е. А. Баратынского: между биографией и поэзией. С. 149-151.

${ }_{16}$ ИРЛИ. Ф. 309. № 3812. Л. 3-4, на л. 4 об. адресация: «Александру Ивановичу Тургеневу». Записка на сложенной пополам четвертушке листа.

17 Об издательской деятельности Семена см.: Модзалевский Б. Л. Август Иванович Семен. СПб., 1903; Маркова А. И. Август Семен, типограф, словолитчик, издатель // Библиофилы России. М., 2008. Т. 4. С. 385-401; Markova A. Auguste-René Semen, imprimeur, éditeur et marchandlibraire parisien à Moscou // La France et les Français en Russie. Nouvelles sources, nouvelles approches (1815-1917). Paris, 2011. P. 263-283. 
репутацию у московских литераторов и издателей, Баратынский напечатал целый ряд своих книг - «Стихотворения» 1827 года, поэму «Наложница» (1831), двухтомные «Стихотворения» 1835 года и, наконец, последний стихотворный сборник «Сумерки» (1842), однако возможность лично вручить экземпляр могла представиться поэту далеко не всегда, учитывая длительное пребывание «европейского странника» Тургенева за границей и хозяйственные дела Баратынского, требовавшие его присутствия в семейных имениях под Казанью, Тамбовом или в Муранове.

В сентябре 1827 года, когда вышел первый поэтический сборник Баратынского, он находился в Маре, в то время как Тургенев путешествовал по Германии и Швейцарии. ${ }^{18}$ Недавно вышедшую книгу Тургеневу обещался прислать ЗЖуковский в письме от 27 ноября 1827 года, ${ }^{19}$ однако, судя по всему, намерения этого не исполнил. Как следует из письма П. А. Вяземского к Тургеневу от 1 марта 1829 года, сборник был ему отправлен существенно позже и уже самим Баратынским, который послал «сочинения и письмо с княгинею Зенеидою», ${ }^{20}$ т.е. с З.А. Волконской, уехавшей из Москвы в Италию 28 февраля 1829 года. ${ }^{21}$

Во второй половине апреля 1831 года, когда был отпечатан тираж поэмы «Наложница», ${ }^{22}$ Тургенев также был за границей, а в Россию вернулся только в июне, ${ }^{23}$ проведши сначала несколько месяцев в Петербурге и лишь осенью приехав в Москву. Баратынский, напротив, провел весну и начало лета в Москве и подмосковной, но во второй половине июня уехал в Казань и казанские имения Энгельгардтов, где пробыл до середины следующего года. ${ }^{24}$ Известия о Баратынском в письмах Тургенева 1831-1832 годов лишь косвенные, полученные главным образом через семейство Елагиных-Киреевских, ${ }^{25}$ с которыми Баратынский поддерживал в то время активную переписку.

18 Гиллельсон М. И. А. И. Тургенев и его литературное наследство // Тургенев А. И. Хроника русского. Дневники (1825-1826 гг.). М.; Л., 1964. С. 463 (сер. «Литературные памятники»).

19 «Пришлю и вышедшие недавно сочинения Баратынского...» (Жуковский В. А. Полн. собр. соч. и писем. Т. 16. С. 529). См. также в письме Вяземского Тургеневу от $12-18$ ноября 1827 года: «Пишу Жуковскому, чтобы он послал тебе стихотворения Боратынскаго и третью часть „Онегина“» (Остафьевский архив князей Вяземских. Т. 3. С. 168).

${ }^{20}$ Переписка А. И. Тургенева с П. А. Вяземским. Пг., 1921. Т. 1. 1814-1833 годы / Под ред. и с прим. Н. К. Кульмана. С. 77 (Архив братьев Тургеневых; вып. 6). Сообщение о Баратынском находится во второй части письма, датированной 1 марта, в то время как в ряде справочных изданий это упоминание приводится под датой начала письма -1 января 1829 года (ср., например: Летопись жизни и творчества Е. А. Боратынского. С. $217 ;$ Арутюнова Б. Ж изнь в письмах. Княгиня Зинаида Волконская и ее корреспонденты. СПб., 2017. С. 54). Вероятно, Баратынский послал Тургеневу не только стихотворный сборник, но и недавно вышедшую поэму «Бал» (СПб., 1828).

21 Арутюнова Б. ЗКизнь в письмах. С. 30.

22 Цензурный билет был выдан 15 апреля 1831 года (Летопись жизни и творчества Е. А. Боратынского. С. 254), книга поступила в продажу к 20-21 апреля 1831 года (Московские ведомости. 1831. 22 апр. № 32. С. 1478; особое объявление о скором выходе поэмы было приложено к выпуску «Московских ведомостей» от 15 апреля: Там же. 15 апр. № 30. Приложение).

${ }_{23}$ Гиллельсон М. И. А. И. Тургенев и его литературное наследство. С. 467.

24 Летопись жизни и творчества Е. А. Боратынского. С. 256, 261.

25 См., например, в письме Жуковскому от 5 октября 1831 года: «Вчера опять провел я приятный вечер у Елагиной и наслушался прелестных стихов Языкова <...> Если успею, то пришлю их и несколько счастливых выражений тоски по прошедшем Баратынского» (Der Briefwechsel zwischen Aleksandr I. Turgenev und Vasilij A. Žukovskij 1830-1845 / Hrsg. H. Siegel. Köln, 2018. S. 78). Упомянутое стихотворение Баратынского - это, по всей видимости, «Бывало, отрок, звонким кликом...», написанное в Каймарах и посланное в письме Языкову, полученном в Москве 28 сентября 1831 года (Боратынский Е. А. Полн. собр. соч. и писем. Т. 2. Ч. 1. С. 261). Его копия, сделанная рукой А. П. Елагиной, сохранилась в архиве Тургенева (ИРЛИ. Ф. 309. № 1191а. Л. 28), в строках 11-14 разночтения, не зафиксированные другими источниками: «Но все проходит: остываю / Я и к гармонии стихов, / И как дубрав не оглашаю, / Так не ищу согласных слов» (курсив мой. - А. Б.). 
В 1842 году Тургенев вернулся в Москву только 9 августа, ${ }^{26}$ в то время как «Сумерки» вышли еще в мае. ${ }^{27}$ Занятый обустройством мурановского дома и отдалившийся от московской литературной среды, Баратынский в город выезжал редко, а экземпляры сборника, «адресованные старым товарищам», он еще в конце мая послал П. А. Плетневу в Петербург «для доставления разным лицам». ${ }^{28}$ Сведения о личном общении Баратынского с Тургеневым в Москве неизвестны. Тем не менее подарочный экземпляр «Сумерек» был получен Тургеневым не позднее начала октября 1842 года, о чем свидетельствуют инскрипты на книге, сначала надписанной «Александру Ивановичу Тургеневу от сочинителя», а затем «от Тургенева г. Фарнгагену фон Энзу», причем последняя дарственная надпись датирована: «Москва $10 / 22$ октября $1842 » .29$

Обстоятельства выхода «Стихотворений» 1835 года, на первый взгляд, также не располагали к возможности одновременного представления Тургеневу сочинения и его автора. Тираж сборника был отпечатан только к 20-м числам апреля, ${ }^{30}$ в то время как Тургенев уехал из Москвы в очередное заграничное путешествие 27 января 1835 года. ${ }^{31}$ Тем не менее из дневника Тургенева известно, что в конце 1834 - январе 1835 года, будучи в Москве, он общался с Баратынским ${ }^{32}$ и интенсивно встречался с организаторами учреждавшегося журнала «Московский наблюдатель», ${ }^{33}$ в котором принимал участие и поэт. В библиотеке Тургеневых сохранился необычный экземпляр «Стихотворений» 1835 года - с датой «1833» на титульном листе и дарственной надписью «Александру Ивановичу Тургеневу». ${ }^{34}$ Наконец, под 22 января 1835 года в дневнике Тургенева помещена следующая запись, прямо перекликающаяся с содержанием новонайденной записки: «22 Генваря. Глазу легче. Баратынск <ий $>$ привез ко мне экз <емпляр $>$ нового издания своих сочин $<$ ений $>$, взяты <й> им ужены; перевел стих Гете <пропуск> и приписал в моем [журнале] письме о Швейцарии, которое отдаю в журнал». ${ }^{35}$

26 Точную дату приезда Тургенева в Москву, зафиксированную в его дневнике, см.: Ocnoват A. Л. Несколько справок о людях и текстах 1830-1840-х годов // Замечательное шестидесятилетие: Ко дню рождения Андрея Немзера. [М.,] 2017. Т. 1. С. 256-257.

27 См.: Боратьцский Е. А. Полн. собр. соч. и писем. Т. 3. Ч. 1. С. 435.

28 Письмо Плетневу от 26 мая 1842 года, см.: Летопись жизни и творчества Е. А. Боратынского. С. 385-386.

29 РНБ. Ф. 865. № 135. Л. 1. В архиве И. А. Шляпкина сохранилась копия, сделанная его рукой с титульного листа и оборота титула экземпляра «Сумерек» из библиотеки К. А. Фарнгагена фон Энзе. Подробнее об этом инскрипте, вероятных обстоятельствах доставки «Сумерек» Тургеневу и пересылки книги Фарнгагену см.: Осповат А. Л. Несколько справок о людях и текстах $1830-1840$-х годов. С. $255-257$.

30 Объявление о выходе сборника: Московские ведомости. 1835. 20 апр. № 32. С. 1580; $3 a$ реикий A. Р., Песков А. М. История подготовки стихотворений Боратынского для изданий 1827 , 1835 и 1842 гг. // Боратынский Е. А. Полн. собр. соч. и писем. Т. 1. С. 466.

31 Гиллельсон М. И. А. И. Тургенев и его литературное наследство. С. 476-477.

$32 \mathrm{Cp}$. опубликованную запись от 19 декабря 1834 года: «Обедал у Орлова с Баратын <ским>, Чаадаев<ым>, Ден<исом> Давыдов<ым> и с Раевскими новобрачными» (Гиллельсон М. И. А. И. Тургенев и его литературное наследство. С. 475; среди перечисленных лиц М. Ф. Орлов и А. Н. Раевский с женой), а также другие дневниковые заметки, свидетельствующие об общении с Баратынским в этот период: «Заезжал к Баратынскому: не застал» (ИРЛИ. Ф. 309. № 305. Л. 13 об.; запись от 27 сентября 1834 года); «Обедал у Орлова с Баратынским, который наконец завез ко мне карточку» (Там же. Л. 34 об.; запись от 18 января 1835 года).

33 Гиллельсон М. И. А. И. Тургенев и его литературное наследство. С. 475-476.

34 Об этом экземпляре, хранящемся в Отделе книжных фондов Государственного литературного музея (инв. номер: 92742), см.: Светлов А. П. Об уникальном экземпляре «Стихотворений» Е. А. Баратынского 1833 г. // Книга: Исследования и материалы. М., 1984. Сб. 49. С. 121-129.

35 ИРЛИ. Ф. 309. № 305. Л. 35 об. (в квадратных скобках - зачеркнутое); Гиллельсон М. И. А. И. Тургенев и его литературное наследство. С. 476. «Письмо о Швейцарии»- отданное в «Московский наблюдатель» «Письмо из Флоренции в Симбирск», опубликованное в двух книжках 
Как в дневниковой записи, так и - в еще большей мере - в тексте записки ( «постараюсь выпросить у Семена экземпляр») подчеркиваются специальные действия, предпринятые для получения книги, которые - при обыкновенной выдаче подарочных экземпляров автору - едва ли могли потребоваться. Однако в данном случае речь шла об очень нестандартном казусе: чтобы успеть подарить Тургеневу книгу до его скорого отъезда, Баратынский должен был раздобыть экземпляр «Стихотворений» 1835 года не только до отпечатания тиража, но и до выдачи билета на выход в свет, что вступало в противоречие с цензурным законодательством. Согласно порядку производства дел по внутренней цензуре, по напечатании книги необходимо было представить в цензуру «два экземпляра <...> со свидетельством директора, содержателя или фактора типографии, что <...> лист или книга напечатаны во всем сходно с прилагаемою при том одобренною в ценсуре рукописью...», и затем цензор, "сличив печатный экземпляр с одобренным», подписывал «позволительный билет на выпуск книги в продажу». ${ }^{36}$ Исключительное разрешение выдавать в свет издания до получения цензорского билета предусматривалось уставом только для «периодических сочинений, составляющих не более одного печатного листа и требующих поспешной выдачи». ${ }^{37}$

Принимая во внимание эти обстоятельства и пытаясь интерпретировать запись в дневнике Тургенева, А. М. Песков (как и ранее А. П. Светлов, опиравшийся на анализ тургеневского экземпляра) осторожно предположил, что Тургеневу был подарен «один из немногих, отпечатанных к январю 1835 года» экземпляров издания, предназначавшийся для цензорского просмотра. ${ }^{38}$ Впоследствии, на основании знакомства с экземпляром из библиотеки Тургеневых, высказывались противоречивые предположения, что первый том издания получил цензорский билет еще в 1833 году (в соответствии с датой, стоящей на титульном листе), ${ }^{39}$ а все издание было дозволено к выходу в свет

первой части журнала (Московский наблюдатель. 1835. Ч. 1. Март. Кн. 2. С. 296-327 (подпись: «Эолова арфа»; с указанием: «конец письма в следующей книжке»); Ч. 1. Апрель. Кн. 1. С. 529550 (подпись: «Эолова арфа»; в оглавлении части указано авторство Тургенева)). По остроумной гипотезе Д. М. Хитровой (Хитрова Д. М. Неизвестный стих Баратынского // Тыняновский сборник. М., 2006. Вып. 12. Десятые - Одиннадцатые - Двенадцатые Тыняновские чтения. Исследования. Материалы. С. 207-209), упомянутый Тургеневым перевод «стиха из Гете», сделанный и приписанный Баратынским в его «письме», - это строка из баллады Шиллера «Кубок», процитированная в описании реки Рейс: «...о ее бурном течении можно сказать с поэтом: — „Es wallet und siedet und brauset und zischt! - И валит и хлещет, ревет и кипит!“ - Кто написал этот стих, тот, конечно, прислушивался к водопадам и к речкам Швейцарии, они почти все быстры, опрометчивы и разрушительны» (Московский наблюдатель. 1835. Ч. 1. Март. Кн. 2. С. 316).

${ }^{36}$ Полн. собр. законов Российской Империи. Собрание второе (1825-1881). СПб., 1830. Т. 3 (1828). С. $465, \S 42$. Существенно, что даже на последней стадии работы над книгой автор имел право внести «перемены и поправки в слоге и выражениях», но в таком случае «важнейшие перемены, сделанные автором, должны быть отмечены в особой записке, подаваемой в ценсуру при представлении печатного экземпляра» (Там же. С. 476, § 144). Такая записка, сохранившаяся, к сожалению, без перечня исправлений (Научная библиотека СПбГУ, шифр Е II 2029), была приложена к печатному экземпляру «Стихотворений» 1835 года, представленному в цензуру для получения цензорского билета (подробнее см.: Бодрова A. C. Несвоевременный сборник: «Стихотворения» 1835 года в литературной карьере Баратынского // Летняя школа по русской литературе. 2018. Т. 14. № 1. С. 56). $\S 43$.

37 Полн. собр. законов Российской Империи. Собрание второе (1825-1881). Т. 3. С. 465,

38 Летопись жизни и творчества Е. А. Боратынского. С. 325 ; ср.: Светлов А. П. Об уникальном экземпляре «Стихотворений» Е. А. Баратынского 1833 г. С. 126-127.

39 Архивные разыскания это предположение не подтвердили: в фиксирующих выдачу цензурных билетов реестрах Петербургского цензурного комитета за 1833 и 1834 годы (РГИА. Ф. 777 . Оп. 27 . № 265,266 ) не удалось обнаружить сведений о представлении в петербургскую 
«к 20-м числам января» 1835 года, ${ }^{40}$ хотя ссылка на запись о выдаче билета не приводилась. Как удалось установить позднее, ${ }^{41}$ билет на обе части «Стихотворений» единовременно был выдан петербургским цензором А. В. Никитенко только 26 февраля 1835 года, ${ }^{42}$ что заставляет вернуться к первоначальной гипотезе комментаторов.

Сопоставление дат не оставляет сомнений, что Тургеневу был подарен еще не окончательно одобренный цензурой, «дотиражный» экземпляр - вероятно, действительно предназначенный для цензурного просмотра. На это косвенно указывают описанные Светловым следы от красных сургучных печатей на форзаце. ${ }^{43}$ Предшествующие исследователи интерпретировали их как следы крепившегося таким образом цензурного билета и на этом основании предполагали, что билет на выпуск книги к моменту вручения экземпляра Тургеневу уже был получен. Однако подобными сургучными печатями крепились и свидетельства из типографии, подтверждавшие идентичность набранной книги уже одобренной цензором рукописи или содержавшие перечень авторских поправок. Исходя из этого, можно предположить, что Баратынскому удалось «выпросить у Семена» подготовленный для отправки в петербургскую цензуру экземпляр «Стихотворений» с уже припечатанным типографским свидетельством, которое могло быть откреплено еще до вручения книги Тургеневу. «Выпрошенный» Баратынским экземпляр, очевидно, был восстановлен - и затем соответствующее число книг отправлено - по стандартной процедуре - в петербургскую цензуру для получения билета на выпуск в свет полного тиража.

Таким образом, записка Баратынского - в соотнесении с «темной» и, видимо, несколько рассеянной записью в дневнике Тургенева ${ }^{44}-$ может быть датирована 21 января 1835 года. Уточняя и дополняя этот экстраординарный эпизод долгой издательской истории «Стихотворений» 1835 года, она еще раз подчеркивает значимость фигуры Тургенева для Баратынского и символическую ценность его необычного книжного подарка.

цензуру отпечатанной первой части «Стихотворений» (о цензурной географии «Стихотворений» 1835 года см. ниже, прим. 42).

40 Зарецкий A. Р., Песков А. М. История подготовки стихотворений Боратынского для изданий 1827,1835 и 1842 гг. С. 466.

41 Бодрова A. C. Несвоевременный сборник: «Стихотворения» 1835 года в литературной карьере Баратынского. С. 55-56.

42 РГИА. Ф. 777. Оп. 27. № 267. Л. 11 об.; ср. также запись на экземпляре из библиотеки СПбГУ (см. прим. 36). В соответствии с Цензурным уставом, билет на издание должен был выдавать тот же цензор, который одобрял к печати рукопись, однако цензор Санкт-Петербургского цензурного комитета Н. И. Бутырский, еще 7 марта 1833 года дозволивший к публикации «Стихотворения» Баратынского (РГИА. Ф. 777. Оп. 27. № 197. Л. 9 об. - 10; об истории прохождения рукописи через цензуру см.: Окслин Ю. Г. Стихотворения Евгения Боратынского в цензуре // Литературный музеум. Пг., 1922. Т. 1. С. 13-17), в том же 1833 году вышел в отставку, поэтому цензурный билет выдавал сменивший Бутырского «университетский» цензор А. В. Никитенко (данные о службе Бутырского и Никитенко см.: Цензоры Российской империи: Конец XVIII начало XX века: Биобиблиографический справочник. СПб., 2013. С. 113-114, 267).

43 Светлов А. П. Об уникальном экземпляре «Стихотворений» Е. А. Баратынского 1833 г. C. 127 .

44 См. прим. 35 о вероятной путанице Шиллера и Гете в той же записи. Подобной небрежностью можно объяснить не раз смущавшее комментаторов указание о «взятом <...> у жены» экземпляре нового издания. 


\section{ИЗ КОММЕНТАРИЯ К «ПРИМЕТАМ» Е. А. БАРАТЫНСКОГО}

«Приметы» (1839) - одно из самых известных стихотворений Евгения Баратынского - первоначально были напечатаны в альманахе «Утренняя заря на 1840 год». ${ }^{1}$ Эта редакция стихотворения несколько отличается от более поздней версии, вошедшей в сборник «Сумерки» (1842) и воспроизведенной в большинстве научных и популярных изданий Баратынского. Приведем здесь полный текст этой редакции:

Пока человек естества не пытал

Горнилом, весами и мерой,

Но детски вещаньям природы внимал,

Ловил ее знаменья с верой;

Покуда природу любил он: она

Любовью ему отвечала;

О нем дружелюбной заботы полна,

Язык для него обретала;

Со древа, пред тайно-грозящей бедой,

Вран каркал ему в опасенье;

Ширяясь над ним в высоте голубой,

Орел ободрял дерзновенье;

На путь ему выбежав из лесу волк,

Крутясь и подъемля щетину,

Победу про <ро> чил, и смело свой полк

Бросал он на вражью дружину.

Чета голубиная, вея над ним,

Блаженство любви предрекала;

В пустыне безлюдной он не был одним,

Приветная жизнь в ней дышала.

Но, чувство презрев, он доверил уму,

Вдался в суету изысканий -

И сердце природы закрылось ему,

И нет на земле прорицаний.

Основные разночтения с версией «Сумерек» сосредоточены в третьей строфе, которая в сборнике 1842 года читается так:

Почуя беду над его головой,

Вран каркал ему в опасенье,

И замысла, в пору смирясь пред судьбой,

Воздерживал он дерзновенье. ${ }^{2}$

Это единственное место, где отличие редакций имеет смысловой характер: ${ }^{3}$ в окончательном тексте был исключен целый микросюжет о явлении

1 Утренняя заря, альманах на 1840 год, изданный В. Владиславлевым. СПб., 1840. С. 117118. Цензурное разрешение от 14 октября 1839 года. Опечатка в слове «пророчил» указана в конце книги.

${ }^{2}$ Боратынский Е. А. Полн. собр. соч. и писем. М., 2012. Т. 3. Ч. 1. С. 26.

3 Остальные изменения, сосредоточенные в предпоследнем четверостишии, носят скорее стилистический характер: «Чета голубиная, вея над ним, / Блаженство любви прорицала: / В пус- 
орла как ободряющем знамении. Вместе со всем микросюжетом исчезло и слово, своей окраской несколько выделявшееся на общем, стилистически довольно нейтральном фоне. Это - деепричастие ширяясь.

Глагол ширять|cя (ширятися = 'парить, рас|простирать крылья'4), в первой трети XIX века еще не зафиксированный в академической лексикографии, ${ }^{5}$ в поэтическом узусе тесно ассоциировался со «Словом о полку Игореве», на что указал еще адмирал Шишков: "глаголы рокотать, ширяться, ныне иногда весьма хорошо употребляемые, до появления Игоревой песни не существовали в языке». ${ }^{6}$ Из «Слова» он, очевидно, и был заимствован Г. Р. Державиным, причем в сочетании не с исходным соколол, ${ }^{7}$ а с новоявленным орлол, возможно, эмблематического происхождения. ${ }^{8}$ Державинский

тыне безлюдной он не был одним, / Нечуждая жизнь в ней дышала» (Там же). Разбиение на строфы появилось только в «Сумерках».

${ }^{4}$ Ср. статью «Ширятися» : Словарь-справочник «Слова о полку Игореве» : В 6 вып. Л., 1984. Вып. 6. С. 184.

5 Впервые глагол появился в академическом толковом словаре 1847 года, а несколько позднее - у Даля (1862). Однако еще при жизни Баратынского слово «ширяться» в указанном значении было включено в расхожий русско-французский словарь: «Ширяться, <...> planer en rond sur une proie» (парить кругами над добычей) (Рейф $Ш .-\Phi$. Русско-французский словарь, в котором русские слова расположены по происхождению, или Этимологический лексикон русского языка. СПб., 1836. Т. 2. С. 1080).

${ }^{6}$ Шишков А. С. Собр. соч. и переводов. СПб., 1825. Ч. 5. С. 8-9 (за указание благодарю Р. Г. Лейбова). К выводу о тесной ассоциации глагола «ширяться» со «Словом» пришел позднее и Ф. Я. Прийма, обследовавший значительное количество литературных и лексикографических источников (Прийла $Ф$. Я. «Слово о полку Игореве» в русском историко-литературном процессе первой трети XIX в. Л., 1980. С. 136-137, 158-159). Появление этой лексемы в литературных текстах начала XIX века в результате прямого заимствования из «Слова» представляется более вероятным, нежели из рукописных памятников XVI века (см.: Словарь-справочник... С. 184) или из украинского просторечия (см: Шарлелиань Н. В. Из реального комментария к «Слову о полку Игореве» // Труды Отдела древнерусской литературы. М.; Л., 1949. Вып. 6. С. 112). Показательно, что в текстах XVIII века, судя по данным большой академической картотеки русского языка в ИЛИ РАН и рабочим материалам «Словаря русского языка XVIII века», этот глагол не фиксируется (пользуюсь случаем посмертно поблагодарить Л. Г. Степанову за эту лексикографическую справку, сделанную для меня в 2008 году). Некоторые из примеров литературного, прежде всего, поэтического употребления глагола «ширяться», приведенных в нашей статье, почерпнуты из указанной книги Приймы, а также из работ В. В. Виноградова «Язык Пушкина» (М.; Л., 1934. С. 81) и «Стиль Пушкина» (М., 1941. С. 128).

7 «А ты буй Романе и Мстиславе! храбрая мысль носитъ васъ умъ на дъло. Высоко плаваеши на дъло въ буести, яко соколъ на вътрехъ ширяяся, хотя птицю въ буйствъ одольти» (Ироическая песнь о походе на половцов удельного князя Новагорода-Северского Игоря Святославича, писанная старинным русским языком в исходе XII столетия с переложением на употребляемое ныне наречие. М., 1800. С. 31). Заметим кстати, что текст первого издания «Слова» используется в данной заметке как первичный источник: реконструкция «подлинного» древнерусского текста, его критика и толкование в задачи настоящей работы никоим образом не входят.

8 «Взлетел маститый Орл, - парит, / Ширяется меж звезд крылами, / Свист бурь, блеск молний под когтями; / И змей, во мгле клубясь, шипит» («На отправление в армию фельдмаршала гр. Каменского», 1806 - Державин Г. Р. Соч. СПб., 1865. Т. 2. Ч. 2. С. 608); орел с молниями в когтях - атрибут Юпитера, символ царственной силы, войны и победы (см., например: $M a \kappa c u-$ мович-Албодик Н. [Избранные] Эмблемы и Символы / Вступ. статья и комм. А. Е. Махова. М., 1995. С. 43, 124-125 (воспроизведение изд. 1811 года); Холл Дж. Словарь сюжетов и символов в искусстве. М., 1999. С. 405-406). Воинская тема (с теми же эмблематическими импликациями) превалирует и в более позднем тексте Державина: «Орлы младые, вожди грома! / Ужель пришла и вам чреда / Парить, ширяться в поднебесной / И молнией дракона жечь?» («На отбытие великих князей... из Петербурга к армии», 1814 - Державин Г. Р. Соч. Т. 3. С. 190). Любопытно, однако, что в самом раннем употреблении данного словосочетания, практически синхронном публикации «Слова» (экземпляр «Слова» был подарен Державину издателем, вероятно, во второй половине 1800 года - дарственный инскрипт см.: Слово о полку Игореве. [Факсимильное воспроизведение 1-го изд. 1800 года] / Авторы сопроводительных статей и комм. Л. А. Дмитриев, Н. К. Гаврюшин, В. П. Гребенюк. М., 1988. С. 8), военная семантика не прослеживается: «Те [птицы и насекомые] в злате, те в сребре, те в розах, те в багрянцах, / Те в светлых заревах, те 
прецедент в немалой степени определил дальнейшую поэтическую практику: в русском стихотворном пространстве орел ширяется куда чаще, нежели сокол или иные птицы; ${ }^{9}$ при этом поэтическая традиция отчасти сохранила батальную семантику словосочетания, свойственную источнику и поддержанную державинским употреблением. ${ }^{10}$ Выбор орла в качестве наиболее устойчивой лексической пары к глаголу ширяться в какой-то мере мог быть обусловлен и возможной контаминацией фрагмента о Романе и Мстиславе («яко соколъ на вътрехъ ширяяся...») с гораздо более известным зачином «Слова»: «Боянъ бо въщій, аще кому хотяше пъснь творити, то растькашется мыслію по древу, сърымъ вълкомъ по земли, шизымъ орломъ подъ облакы». ${ }^{11}$ Именно к последнему фрагменту, скорее всего, отсылают те, весьма частые употребления исследуемого словосочетания, которые прямо или контекстуально связаны с семантикой поэтического творчества (вымысла, фантазии, вдохновения, мечты и т. п.); ${ }^{12}$ наиболее показательно применение этого кру-

в желтых, сизых глянцах / Гуляют по цветам вдоль рек и вкруг озер; / Над ними в высоте ширяется орел!» («Утро», $1800-$ Державин Г. Р. Соч. Т. 2. С. 320; в собственноручных примечаниях Державина содержится определенное противоречие: относя «Утро» к 1800 году, автор в то же время отмечает, что стихотворение «напечатано в том же году на особых листках» (Там же. Т. 3. C. 696), тогда как его отдельное издание вышло двумя годами позже, в 1802 году).

9 Характерно примечание к толкованию слова в словаре Рейфа: «...se dit des aigles et des vautours» (Рейф Ш.-Ф. Русско-французский словарь... С. 1080; пер.: «говорится об орлах и грифах»). Следует отметить, что сокол ширяется собственно в переводах и близких переложениях соответствующего фрагмента «Слова» - см., например, переводы В. А. ЖЖуковского (1817), М. А. Максимовича (1837), М. Д. Деларю (1839) и др. Ср. в качестве исключения: «Буря занесла сокола в землю чуждую; испил Волхова, взглянул на Новгородскую деву, и уже крылья его не ширяют! Не хочет он лететь в родную землю!» (Вельтлан А. Ф. Кощей бессмертный, былина старого времени. М., 1833. Ч. 1. С. 11), однако при этом следует учесть, что повесть писалась Вельтманом одновременно с переводом «Слова» (1833).

10 Из примеров батальной семантики: «И се! На высоте ширяясь / Он (орел. - Н. О.) зрит

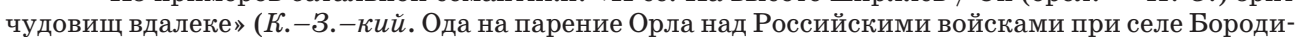
не, в Августе 1812 // Сын отечества. 1812. 2-е изд. Ч. 1. С. 266); «Орел, которому Царь Севера вручил / Свой пламенный перун противу бурных сил, / От Юга дышущих к Полунощи войною, / Орел сей, в воздухе ширяясь под луною, / Держа в когтях чалму, в обширности небес / Паря к бессмертию в подсолнечной, исчез...» (Васильевский Д. Песнь Каменскому второму, написанная по получении известия о его кончине мая 1811 года // Чтение в Беседе любителей русского слова. СПб., 1813. Чтение 9. С. 88); «Вознесся памятник. Ширяяся крылами / Над ним сидит орел младой» (Пушкин А. С. Воспоминание в Царском Селе <1814> // Пушкин А. С. Полн. собр. соч.: В 20 т. СПб., 1999. Т. 1. С. 70); «Он там, где пыл войны кипит, / Орлом ширяясь перед строем» (Рылеев К. Ф. Святослав <1822> // Рылеев К. Ф. Полн. собр. соч. М.; Л., 1934. С. 128); «Смелый орел, отважно ширяясь на ветрах, парит под блеском молний и сражается с тучами!..» (Глин$\kappa a \Phi . Н$. Зинобей Богдан Хмельницкий, или Освобожденная Малороссия <1816-1817> // Предслава и Добрыня. Исторические повести русских романтиков / Сост., вступ. статья и комм. В. Ю. Троицкого. М., 1986. С. 140).

11 Ироическая песнь о походе на половцов... С. 2-3.

12 Из примеров поэтической семантики: «Ширяясь в высоте, и всякой чужд границе, / Как бог - он в Божестве, и как поэт - в Фелице!» (Милонов М. И. Сатиры, послания и другие мелкие стихотворения. СПб., 1819. С. 206; о Державине); «Ломоносов - орел, ширяющийся в небесах медленно, стройно и важно (Мерзляков А. Ф. Рассуждение о российской словесности в нынешнем ее состоянии // Труды Общества любителей российской словесности. 1812. Ч. 1. С. 86); «...гений, / <...> / Ширяясь, как орел, на небеса парит, / И с высоты на низ с презрением глядит» (Рылеев К. Ф. Послание к Н. И. Гнедичу <1821> // Рылеев К. Ф. Полн. собр. соч. С. 112); «Воображение осыпает самыми свежими цветами его (поэта. - H. O.) лиру, и ширяясь горе, навевает на нее легкими своими крылами прекрасные, до бесконечности разнообразные свои мечтания» (Мерзляков А. Ф. О вкусе и его изменениях // Труды Общества любителей российской словесности. 1818. Ч. 10. С. 14); «Певец! Ты выполнил всеобщие уставы; / <...> / Так к царству бурь орел взлетает в дерзновенье / И, с гордым торжеством ширяясь в облаках, - / Вещает смертному: и я земли рожденье, / Но дом мой в небесах!» (Загорский М. П. Слава. Из Ламартина // Полярная звезда на 1824 год. СПб., 1823. С. 194-195); «А дух мой там ширялся, как орел, / За оными блестящими мирами» (Кюхельбекер В. К. Сирота <1833-1834>// Кюхельбекер В. К. 
га значений, нередко связанных с концептом «одического парения», к самому автору «Слова»:

Как в дикости своей пленительна природа,
Подобно песнь твоя, российский Оссиан!
В ней гения видна орлиная свобода;
Орлом ширяться дар тебе природой дан. ${ }^{13}$

Если допустить, что словосочетания с глаголом ширяться в интересующую нас эпоху манифестировали связь того или иного стихотворного текста со «Словом о полку Игореве» (на уровне смысловых аллюзий или всего лишь стилистической маркировки), то подобную связь следует искать и в «Приметах». Действительно, в стихотворении Баратынского без труда обнаруживаются некоторые (впрочем, не слишком точные) мотивные переклички со «Словом». ${ }^{14}$

Прежде всего, это мотивы дурных предзнаменований при выступлении войска в поход: «Тогда въступи Игорь Князь въ златъ стремень, и поњха по чистому полю. Солнце ему тъмою путь заступаше; нощь стонущи ему грозою птичь убуди; свистъ звъринъ въ стазби; дивъ кличетъ връху древа, велитъ послушати земли незнаемъ, влъзъ, и по морію, и по Сулію, и Сурожу, и Корсуню, и тебъ Тьмутораканьскый блъванъ. А Половци неготовами дорогами побъгоша къ Дону Великому; крычатъ тъльгы полунощы, рци лебеди роспущени. Игорь къ Дону вои ведетъ: уже бо бъды его пасетъ птиць; подобію влъци грозу въ срожатъ, по яругамъ; орли клектомъ на кости звъри зовутъ (к), лисици брешутъ на чръленыя щиты». ${ }^{15}$

Любопытно в этой связи и примечание $(\kappa)$, сделанное первыми публикаторами: «Птичий полет издавна был у многих народов предзнаменованием щастия или нещастия в предприятом намерении; и Римляне гадали по птицам. Равномерно примечали, в какую сторону слетались хищныя птицы, и там неминуемой предполагали быть гибели людской. Волчий вой также предвещал кровопролитную войну». ${ }^{16}$

Соответствует такому толкованию и перевод, в котором прямо вводится идея предсказания беды: «Игорь к Дону войска ведет; уже птицы беду ему предрекают, волки по оврагам вытьем своим страх наводят; орлы зверей на трупы сзывают, а лисицы брешут на червленые щиты». ${ }^{17}$

Избр. произведения: В 2 т. М.; Л., 1967. Т. 1 / Подг. текста и прим. Н. В. Королевой. С. 515 (Библиотека поэта. Большая сер.)); «Но орел ширяется выше туч, а он младший брат моей мысли: ей нет высоты недолетной» (Бестужев-Марлинский А. А. Он был убит <1835> // Бестужев-Марлинский А. А. Кавказские повести / Изд. подг. Ф. З. Канунова. СПб., 1995. С. 302 (сер. «Литературные памятники»)); «Так молниеносный орел (творческий дух. - H. О.), ширяясь под небесами, после успокаивается на тенистом дубе, держащем гнездо его» (Надеждин Н. И. О происхождении поэзии, называемой романтической... <1833?> // Надеждин Н. И. Соч.: В 2 т. СПб., 2000. Т. 1. С. 208); «Кто скажет горному орлу: / Ты не ширяй под небесами» (Майков А. Н. Мысль поэта $<1839>$ // Майков А. Н. Избр. произведения / Сост., подг. текста и прим. Л. С. Гейро; вступ. статья Ф. Я. Приймы. Л., 1977. С. 57 (Библиотека поэта. Большая сер.)).

13 Граллиатин Н. Ф. Надпись к портрету неизвестного сочинителя «Слова о полку Игоревом» <1818> // Поэты 1790-1810-х годов / Сост. и вступ. статья Ю. М. Лотмана; подг. текста М. Г. Альтшуллера. Л., 1971. С. 328 (Библиотека поэта. Большая сер.).

14 В самом общем виде эту связь сформулировала в свое время И. Л. Альми: «Почва стихотворения - родные сказания, русский фольклор, „Слово о Полку Игореве“» (Альли И. Л. О поэзии и прозе. 2-е изд., доп. СПб., 2002. С. 185). Ср. также: Рудакова С. В. Системность художественного мышления Е. А. Боратынского-лирика. Дис. ... доктора филол. наук. Магнитогорск, 2014. C. 347.

\footnotetext{
15 Ироическая песнь о походе на половцов... С. 9-10.

16 Там же.

17 Там же.
} 
Эксплицировав мотив предсказания, переводчики первого издания ${ }^{18}$ в то же время элиминировали важный для «Примет» мотив угрозы («Со древа, пред тайно-грозящей бедой...»; ${ }^{19}$ курсив мой. - $H$. О.), отчетливо проявленный в целом ряде ранних переложений: «Предвещают птицы бедствие» $;^{20}$ «Игорь к Дону воинство ведет. Но уже его бедствие пищу готовит птицам; волки по оврагам напастьми угрожают»; ${ }^{21}$ «Игорь ратных к Дону ведет! / Уже беда его птиц скликает, / И волки угрозою воют по оврагам, / Клектом орлы на кости зверей зовут, / Лисицы брешут на червленые щиты...» ${ }^{22}$ "Игорь также полк ведет свой к Дону синему; / Но беды ему вещают птицы вещие, / Грозно воют по яругам волки серые, / Звери хищные сбегаются на клект орлов, / На щиты лисицы брешут, на червленые»; $;^{23}$ «Предвестия гибели хищных уж птиц на него накликают, как волки вытьемъ по оврагам, грозу предвещая» $;^{24}$ «Игорь к Дону войско ведет: уже беды его ждут птицы, и волки грозу предвещают по оврагам; орлы клектом зовут зверей на кости, и лают лисицы на багряные щиты». ${ }^{25}$

18 А. И. Мусин-Пушкин, А. Ф. Малиновский и Н. Н. Бантыш-Каменский. Об особенностях перевода первого издания «Слова» см.: Длитриев Л. А. История первого издания «Слова о полку Игореве». Материалы и исследования. М.; Л., 1960. С. 269-317; Козлов В. П. Кружок А. И. Мусина-Пушкина и «Слово о полку Игореве». Новые страницы истории древнерусской поэмы в XVIII веке. М., 1988. С. 192-217, 232-240.

19 Заметим кстати, что инициальное «Со древа», относящееся у Баратынского к врану, очевидным образом отсылает к фразе «дивъ кличетъ връху древа» (Ироическая песнь о походе на половцов... С. 9). В ранних переложениях Див либо понимается как «филин», либо остается таинственным мифологическим персонажем; при этом, в отличие от оригинала, своим криком он несет угрозу, предвещает беду: «Див, седящий на верху древа, прорицает им беды» (Шиш-

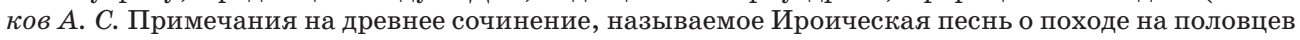
или Слово о полку Игоревом // Сочинения и переводы, издаваемые Российской Академиею. СПб., 1805. Ч. 1. С. 207); «С вершины древа Див беды им прорицая» (Палицын А. А. Игорь, героическая песнь. С древней славенской песни, писанной в XII веке. Харьков, 1807. С. 4); «На вершине древа кличет див, / И, увы! зловещий филин сей / Предвещает зло, несчастие!» (Язвиикий Н. И. Игорь Святославич. Ироическая песнь // Чтение в Беседе любителей российской словесности. СПб., 1812. Чтение 6. С. 37); «Сверьху древа грозно кличет див, зловещий див» (Гралмлатин Н. Ф. Слово о полку Игоревом, историческая поема, ... преложенная стихами древнейшего Русского размера... М., 1823. С. 66).

20 Поход Игоря противу половцов, перевод в стихах русского склада / Пер. [И. И. Сирякова]. М., 1803. Цит. по «Параллельному корпусу переводов „Слова о полку Игореве“» (http:// nevmenandr.net/cgi-bin/trans.py?it=c1; дата обращения: 30.04.2020; пользуюсь оказией выразить благодарность Б. В. Орехову за создание этого чрезвычайно полезного ресурса).

21 Kапнист B. В. Собр. соч.: В 2 т. М.; Л., 1960. Т. 2. С. 101. Перевод Капниста, выполненный в 1809/1810-1813 годах, был напечатан лишь в 1950 году.

22 Жуковский В. А. Полн. собр. соч. и писем: В 20 т. М., 2010. Т. 5. С. 11. Мотив «предвещаний» был специально выделен Жуковским еще на ранних стадиях работы над «Словом» (см.: Иезуитова Р. В. ЖЖковский и его время. Л., 1989. С. 129-130); о месте «Слова» в творчестве Жуковского см.: Тищенко В. И. В. А. ЖЖуковский и «Слово о полку Игореве» // Вопросы русской литературы. Львов, 1984. Вып. 2 (44). С. 98-105. С. В. Рудакова усматривала параллелизм «волчьего мотива в «Приметах» и в переводе Жуковского (Рудакова С. В. Системность художественного мышления Е. А. Боратынского... С. 350). Следует, однако, иметь в виду, что перевод Жуковского (1817), как и перевод Капниста, вряд ли мог быть известен Баратынскому: его первая публикация (под именем А. С. Пушкина) относится к 1883 году.

${ }_{23}$ Гралмлатин Н. Ф. Слово о полку Игоревом... С. 67. В прозаическом переводе Грамматин избегает этого мотива: «Игорь к Дону воинов ведет; уже беды его пасут птиц; волки ужас рождают вытьел по оврагам, орлы криком на трупы зверей зовут, лисицы лают на багровые щиты» (Там же. С. 39).

24 Песнь ополчению Игоря Святославича, Князя Новгород Северского / Пер. А. Ф. Вельтмана. М., 1833. С. 9.

25 Песнь о полку Игореве, сложенная в конце XII века на древнем русском языке / Изд. с пер. М. А. Максимовичем. Киев, 1837. С. 11. Ср. также в пересказе Н. М. Карамзина (1816): «Игорь, вступив в златое стреля, видит глубокую тьму пред собою; небо ужасает его грозою, звери ревут в пустынях, хищные птицы станицами парят над воинством, орлы клектол своим 
Среди мотивов «Слова», возможно, отозвавшихся в стихотворении Баратынского, следует отметить и завершение вещего сна Святослава о поражении Игоря: «Святъславь мутенъ сонъ видъ: <..>> Всю нощь съ вечера босуви врани възграяху, у Плъсньска на болони бъша дебрь Кисаню, и не сошлю къ синему морю. Перевод: будто б во всю ночь с вечера до света вороны каркали, усевшись у Пленска на выгоне в дебри Кисановой, и не полетели к морю синему». ${ }^{26}$

Если носители знамений - вран, орел и волк - пусть и не в точном функциональном соответствии, но встречаются и в «Приметах" Баратынского, и в «Слове», то чете голубиной, на первый взгляд, соответствий в древнерусском тексте «Слова» вообще не находится. Однако в первом его переводе голубиная пара, хоть и разлученная, все же появляется: «Ярославнин голос слышится; она, как оставленная горлица, по утрам воркует: „Полечу я, говорит, горлицею по Дунаю...“». ${ }^{27}$

Наконец, на этом фоне может оказаться значимым и употребление в сильной (рифменной) позиции слова полк, прямо отсылающего к заглавию «Слова».

Однако для сопоставления «Примет» со «Словом» релевантны, кажется, не столько конкретные схождения (подобные мотивы далеко не уникальны), сколько линия знамений и предвещаний как таковая. Собственно говоря, вся эта линия в "Слове» является своего рода инвертированной параллелью к идеологическому сюжету «Примет»: поведение князя Игоря, игнорирующего природные знамения, это и есть поведение человека, «презревшего чувство» и «доверившегося уму».

В то же время даже наличия такого соответствия явно недостаточно для того, чтобы можно было счесть «Слово» ближайшим подтекстом «Примет». Ни национально-исторические атрибуты памятника, ни его жанровые свойства, ни основной сюжет - в «Приметах» отраженья не получили. Похоже, что «Слово» заинтересовало Баратынского лишь как важный пример архаического текста, сохранившего рефлексы пантеизма и ценности интуитивного знания. Для воссоздания «первобытной философии» «Примет» нужен был материал иного уровня - текст, где идеологические потенции «Слова» выявлялись бы и концептуализировались.

Если ограничить поиск кругом интерпретаций «Слова о полку Игореве», то отыскать метатекст такого рода оказывается не слишком сложно. Среди множества трудов, посвященных знаменитейшему памятнику старинной русской словесности, обращает на себя внимание цикл статей (лекций) профессора

предвещают ему гибель, и лисицы лают на багряные щиты Россиян» (Каралзин Н. М. История государства Российского: В 12 т. М., 1991. Т. 2-3 / Под ред. В. Ю. Афиани, В. М. Живова, В. П. Козлова. С. 476).

${ }^{26}$ Ироическая песнь о походе на половцов... С. 23-24. Ср.: «И с вечера целую ночь граяли враны зловещие, / Слетевшись на выгон в дебри Кисановой...» (Жуковский В. А. Полн. собр. соч. и писем. Т. 5. С. 15); «И всю ночь с вечера каркали бесовы вороны у Пленска на болоньи, были в дебри Кисановой, и не слетели к Синему морю» (Песнь о полку Игореве / Пер. М. А. Максимовича. Киев, 1837. С. 27); «Бесовы враны кричали всю ночь на болоньи у Пленска, / Были в Кисановой дебри и не сошли к синю морю» (Песнь об ополчении Игоря, сына Святославова, внука Олегова / Переложение Михаила де Ла Рю. Одесса, 1839. С. 37).

27 Ироическая песнь о походе на половцов... С. 37-38. Рефлексы первого перевода были наиболее сильны в переложениях и подражаниях 1800-1820-х годов: так, Ярославна-горлица встречается в текстах А. А. Палицына (1807), В. В. Капниста (1809/1810-1813), Н. И. Язвицкого (1812), И. М. Левитского (1813), Я. О. Пожарского (1819), Н. Ф. Белюстина (1819), В. А. Загорского (1825), П. П. Шкляревского (1831), Н. Д. Иванчина-Писарева (1837). Позднее начинают преобладать иные толкования: зегзица оригинала переводится как чечетка (Жуковский, 1817) или кукушка - см. переложения Н. Ф. Грамматина (1823), И. И. Козлова (1825), А. Ф. Вельтмана (1833), М. А. Максимовича (1837), М. Д. Деларю (1839) и т. д. 
М. А. Максимовича (в то время ректора Киевского университета), напечатанных в 1836-1837 годах в «Журнале министерства народного просвещения» и переизданных отдельной брошюрой летом 1837 года. ${ }^{28}$ Филологические штудии Максимовича и, в частности, его работы о «Слове» подробно обследованы в специальной литературе, поэтому здесь стоит сосредоточиться на миросозерцании автора «Слова», которое Максимович пытался реконструировать во второй статье цикла («Песнь Игорю, относительно ее духа»), ${ }^{29}$ привлекая для своей реконструкции не только текст исследуемого памятника, но и материал русского и украинского фольклора.

Показательна уже сама рубрикация статьи Максимовича, те черты, которые он считает характеризующими $\partial y x$ «Слова» :

«А. Дух любви:

а) Ратный $\partial y x$;

б) Любовь к линувшелу и скорбь о настоящел;

в) Битва и слерть;

г) Любовь к песнопению;

д) Любовь женская .

Б. Дух Веры:

а) Христианство;

б) Следы язычества;

в) Верования в мире духов;

г) Верование в чудесное;

д) Вера в зналения Природы;

е) Вера в Природу и сочувствие с нею»

(Максимович 1836: II, 439-468).

Напомним, что любовь и вера - два понятия, ключевых для вводных строф стихотворения Баратынского. Однако у Максимовича лишь второе из них соответствует семантике «Примет»: любовь у него прежде всего - понятие исторически и географически локализованное, любовь к родной земле: «Наблюдая Игореву Песнь относительно духа, находим, что отличительный характер оного состоит в соединении двух главнейших начал: любви к зелле Русской и ее славе, и веры в жизнь Природы и глубокого с нею сочувствия. Два начала сии суть основания и господствующие в духе Поэзии Певца Игоря: из них уже проистекают, или ими проникнуты, или под их господством раскрываются другие виды любви и веры, другие чувства и понятия. Потому и обозрение оных мы приведем к этим двум знаменательным началам, из коих первое имело преимущественное влияние на содержание и тон Песни, а второе на образ выражения и краски ее» (Максимович 1836: II, 440).

Однако в интерпретацию понятия вводится, как частное применение, и мотив более универсальный (и более важный для Баратынского): любовь человека к Природе и ее отзыв ( «...она / Любовью ему отвечала») ассоциируется Максимовичем с мотивами женской любви, с плачем Ярославны, который трактуется как заклинание стихий, магический диалог с Природой: «После того, как Певец с напрасною надеждою взывал к Князьям и думою уносился

${ }^{28}$ Максилович M. А. Песнь о полку Игореве. Из лекций о Русской Словесности, читанных 1835 года в Университете Св. Владимира. Статьи 1-3 // Журнал министерства народного просвещения. 1836. Ч. 10. Апрель, Июнь. Отд. ІІ. С. 1-22, 439-470; 1837. Ч. 13. Январь. Отд. II. С. 2958. Отд. изд.: Максилович М. А. Песнь о полку Игореве, критический разбор из лекций о Русской Словесности, читанных 1835 года в Университете Св. Владимира. СПб., 1837. Текст перепечатан в приложении к кн.: Фризлан Л. Г., Лахно С. Н. М. А. Максимович - литератор. Харьков, 2003. C. $374-422$.

29 Журнал министерства народного просвещения. 1836. Ч. 10. Июнь. Отд. II. С. 439-470. Далее ссылки на это издание приводятся в тексте сокращенно: Максимович 1836: II, с указанием номера страницы. 
в минувшее, он обратился к Природе голосом женской любви: и Природа услышала сей голос, и отозвалась на него благотворно своими стихиями, дотоле враждовавшими с Игорем: „Прысну море полунощи; идут сморци (смерчи) мъглами: Игореви Князю Бог путь кажет из земли Половецкой на землю Русскую к отчю злату столу...“» (Максимович 1836: II, 460-461).

Более обширные и точные концептуальные соответствия находим, однако, в тех разделах работы Максимовича, которые объединены рубрикой Дух Bepы. Бегло помянув о «приверженстве Певца Игоря христианству» и отметив наиболее явные рудименты язычества, основное свое внимание исследователь уделяет анимистическим (и антиисторическим) формам миросозерцания и его рефлексам (в частности, разного рода суевериял и прилетал) в «Слове», других книжных памятниках и фольклоре: «Но сильнее осталось в народе прежнее верование в духовный мир, прежние понятия о неведомых существах сего мира. Христианство, положив крест свой на Русина, просветив врожденную, сердечную его веру в Бога понятием о Боге истинном, не изгладило из его памяти тех мечтательных образов, под которыми его воображению являлись злые или добрые духи, души умерших" (Максимович 1836: II, 463; раздел «Верование в мир духов»); «Вера в чудесное свойственна человеку, так же как и сама Природа не чужда оного. Сия вера перерождается в многочисленные, разнообразные суеверия, - неодолимое стремление разгадывать будущее, склонность к ворожбе, волшебству, колдовству, чародейству; вера в сны, встречи, и вообще в прилеты. Суеверию и страсти к чудесному разного рода подвержены были почти всегда люди, даже великие и образованные, вопреки силе своей воли, голосу разума и Религии. <...> $\mathrm{He}^{-}$ много правды в этих приметах, редко сны бывают предвещательные; но эти все виды суеверия, имея основанием своим чудесное, лечтательное, тайное, заключает в себе много Поэзии. Певец Игоря воспользовался этим чудесным для своей Песни, особенно в сне Святослава <...> В этом сне приметы все народные <...> У русских в старину были целые волшебные книги (в XVI веке названные отреченными или еретическими), например, Чаровник, Волховник, Каледник, Еролник, Мысленик, Сносудец: в них излагались волхвования, гадания снов и судьбы, по разным приметам, особенно по зверям и птицам; было также астрологическое гадание судьбы по светилам. В книге Волховник воронограй, страшен сон означали недоброе; щекотанье сороки, волчий вой, появление дятла - считались также приметами, как и в Песни Игоря» (Максимович 1836: II, 465-467, раздел «Верование в чудесное»).

Специально останавливается Максимович на природных зналениях (ср. у Баратынского: «Но детски вещаньям природы внимал, / Ловил ее знаменья с верой»): «Знамения почитались чудесными, предвещательными явлениями Природы, посылаемыми от Бога и к добру и к худу. К числу их принадлежит и полное затление солниа, бывшее в небе перед неудачным походом Игоря на Половцев <...>. И этою чудесною действительностию Природы, лучшею всякого чудесного вымысла, Певец воспользовался для своей Исторической Песни; и не сама ли Природа этим вещим знамением утвердила Певца в той вере, что она принимает участие в его Герое и в делах земли Русской?» (Максимович 1836: II, 467, раздел «Вера в знамения Природы»).

Настойчиво подчеркнув роль анималистической символики в архаическом миросозерцании (напомним, что природные предвещания в «Приметах» построены исключительно на анималистическом коде), Максимович завершает свои рассуждения о мифопоэтических истоках «Слова» пассажем о «языке Природы», лежащем в основе поэтического творчества (ср.: «Язык для него обретала»): «И эта вера в жизнь и сочувствие Природы с человеком есть господствующая вера у Певца Игоря. - Потому и ему даешь столько веры, 
и любуешься не как вымыслом, когда он изображает столь часто живое и так сказать личное участие Природы в судьбе действующих лиц его, когда напр <имер> описав смертельное упоение Русских на реке Каяле, где nycmbl- $^{-}$ ни силу прикрыли, он изображает печаль прибрежной Природы <...> Такая жизнь, такое одушевление Природы является в целой Песни; Певец верно изображает Природу, или лучше сказать живописует; <...> Певцом же Игоря всего более любимы высшие классы Природы, птицы и звери, в коих жизнь Природы развитее и одушевленнее, - особенно птицы, у коих и вещий смысл Природы всего сильнее, и голос настроен так звонко для песни, которые самим полетом своим от земли в вышину согласнее с восторжением души в поэтическом ее вдохновении. В этом восторженном состоянии душа Певца, близкая к Природе, вступает с нею в теснейший союз; тогда Певец живее чувствует ее живые предметы, в них он видит яснее, находит вернее подобие с поэтическими предметами души своей; тогда предметы Природы становятся символами его собственных дум, приходят сами для выражения оных, и певец выражает себя живым, предметным языком Природы. Оттуда непрестанные уподобления и метафорический способ выражения не выисканный, не искусственный, но необходимый и естественный» (Максимович 1836: II, 468-470, раздел «Вера в Природу и сочувствие с нею»).

При сравнении поэтического и прозаического текстов, как бы ни были они концептуально и дискурсивно близки, всегда остается момент сомнения, окончательно устранить которое можно разве что обилием формульных соответствий. Однако в рассматриваемом случае генетическая связь текстов, использующих одну идеологическую платформу и близкий понятийный аппарат, ${ }^{30}$ подтверждается уликой иного рода. В последнем разделе («Вера в Природу и сочувствие с нею»), характеризуя автора «Слова», Максимович пишет: «...про него, как первенствующего Певца Южно-Русского, можно сказать стихами Баратынского (к Гете):

\section{С Природой одною он жизнью дышал, Ручья разумел лепетанье, И говор древесных листов понимал, И чувствовал трав прозябанье»}

(Максимович 1836: II, 469). ${ }^{31}$

Апеллируя к Баратынскому, а через него к Гете, Максимович, вероятно, стремился не только проиллюстрировать собственную мысль, но и косвенно

30 В настоящей заметке рассмотрение идеологического контекста «Примет» намеренно ограничено - и форматом публикации, и нежеланием оспаривать чужой приоритет: этой теме в своей время был посвящен доклад Н. Н. Мазур (СПб., 2012), которая в дополнение к известным параллелям (в частности, к тютчевскому «Нет веры вымыслам чудесным», почерпнутому из сказки Вольтера «Что нравится женщинам») приводила интересные соответствия из Шатобриана, Б. Констана, Шеллинга и поэтов «озерной школы» (источники, заметим, вполне актуальные и для Максимовича).

31 Цитируется стихотворение Баратынского «На смерть Гете» (1832), впервые опубликованное в альманахе «Новоселье» (СПб., 1833. Ч. 1. С. 239-240; ср.: Боратынский Е. А. Полн. собр. соч. и писем. Т. 2. Ч. 1. С. 278). Максимович цитировал эти стихи уже в статье 1834 года: «Она (природа. - H. O.) <...>, непрерывно течет и распускает пеструю ткань свою, забавляя обманчивою надеждою женихов - между тем, как дышащий одною жизнию с ней, ее возлюбленный, борется с волнами сомнений в своем далеком странствии...» (Максимович М. А. О границах и переходах царств природы // Библиотека для чтения. 1834. Т. 1. Отд. III. С. 118; курсив мой. - H. О.). Личное общение Максимовича с Баратынским фиксируется в 1828-1830 годах, несколько произведений последнего появилось в альманахе Максимовича «Денница» на 1830 и 1831 годы (см.: Летопись жизни и творчества Е. А. Боратынского. 1800-1844 / Сост. А. М. Песков. М., 1998; по указ.). 
присвоить Певиу Игоря статус универсального гения (в шеллингианском смысле), каковым в глазах современников обладал недавно умерший немецкий поэт. Но для Баратынского отсылка Максимовича была скорее импульсом к диалогу, поводом развернуть имплицированные в собственном четверостишии смысловые потенции, одновременно расширяя интерпретацию «Слова», предложенную Максимовичем, и достраивая ее до концепции универсального пантеизма, присущего, по мнению Баратынского, человеку архаической ( «дорациональной») эпохи.

Любопытно при этом, что для «Примет» вместо балладных шестистиший Амф434344, которыми написано «На смерть Гете», были избраны четверостишия Амф4343 - строфическая форма, предложенная Максимовичем, который при цитации решительно редуцировал строфу источника. При дальнейшей переработке текста для «Сумерек» Баратынский упрощает композицию: убирает эпизод с орлом, оставляя сакральное, тройственное число знамений, каждому из которых посвящена отдельная строфа. При этом исчезает и лексический сигнал, прямо указывавший на «Слово»: маскировка прямых отсылок к важным для автора подтекстам, - прием, чрезвычайно характерный для поэтики «Сумерек». 


\section{В ПРЕДДВЕРИИ ГОДА ДОСТОЕВСКОГО}

DOI: $10.31860 / 0131-6095-2020-3-68-74$

(C) H. В. ЧЕРНОВА

\section{«ЛЮБИТЕ ВЫ УЛИЧНОЕ ПЕНИЕ?»: ОСУЖДЕНИЕ РАСКОЛЬНИКОВА НАРОДНЫМ ХОРОМ}

Введенное М. М. Бахтиным понятие «смеющийся народный хор» (употребляющееся обыкновенно как определение стихийного противодействия официальной власти) в широком смысле может быть использовано в литературоведении как имперсональное групповое суждение, стихийная ироническая оценка события или персонажа. Р. Г. Назиров отметил, что у Достоевского уличная толпа участвует в действии, в развитии сюжета, «порою напоминая хор античной трагедии, сочувствуя герою, осуждая его, комментируя его поступки». ${ }^{1}$

Представляется важным определить, какую роль «народный слой», «народный хор» в названном выше значении играет в решении авторской задачи - отвержение Раскольникова - на примере одного эпизода (первый выход Раскольникова после преступления на Сенную площадь ${ }^{2}$ ). Для этого мы используем опыт медленного чтения.

Рассматриваемая сцена происходит после ухода Разумихина, от которого Раскольников слышит историю своего преступления: невольно лучший друг превращается в мучителя и палача, а герой - в жертву, и лишь автор не отказывает в милосердии убийце. Так здесь осуществляется авторская поддержка Раскольникова в диалогах с Разумихиным. В следующей, «народной», сцене - такая же осознанная стратегия автора помощи герою, указывающая на единственность выхода для него - только через религиозно-этическое начало «почвы».

Необходимо предварить разбор рассматриваемого эпизода напоминанием о самоприговоре Раскольникова на Конногвардейском бульваре (до сцены на Сенной - 6, 86-87), а именно о непоправимой отрезанности героя от всего живого после преступления (он назовет это «главный пункт» $(6,86))$, без которой невозможно понять вектор движения героя к воскресению. Выход Раскольникова на Сенную - первый шаг на этом пути. Он заканчивается крахом, но знаменует начало движения: впервые болезненную рефлексию внутренних монологов героя сменяет спокойствие, ясность мысли, четкость действий, дикая энергия, «твердое намерение» $(6,120)$. Автор не говорит, куда идет герой, одевшись во все новое, но внушает читателю уверенность в возможности лишь двух исходов для него - признание или самоубийство. Именно к народной общности («толпа», «кучки», «группы») так жаждет он примкнуть впервые: «Его почему-то тянуло со всеми заговаривать. Но мужики не обращали внимания на него, и все что-то галдели про себя...» $(6,122)$. Еще более активно отвергают героя «солисты» народного хора: девочка с шар-

1 Назиров Р. Г. Творческие принципы Ф. М. Достоевского. Саратов, 1982. С. 104.

2 Достоевский Ф. М. Полн. собр. соч.: В 30 т. Л., 1973. Т. 6. С. 120-123. Далее ссылки на это издание даются в тексте сокращенно, с указанием номера тома и страницы. 
манщиком резко обрывает пение и уходит; прохожий, к которому обращается Раскольников: «Любите вы уличное пение?..» $(6,121)$, шарахается от него как от сумасшедшего.

Молодой парень на том самом углу, где герой вспоминает о разговоре Лизаветы с мещанином и принимает решение об убийстве, ведет себя с Раскольниковым надменно, отвечает намеренно бессмысленно, каламбурит, используя устойчивые, подчас рифмованные речевые фигуры народной площади, ернически кладет на лопатки барина:

«- Это мещанин ведь торгует тут на углу, с бабой, с женой, a?

- Всякие торгуют, - отвечал парень, свысока обмеривая Раскольникова.

- Как его зовут?

- Как крестили, так и зовут.

- Уж и ты не зарайский ли? Которой губернии? <...>

- У нас, ваше сиятельство, не губерния, а уезд, а ездил-то брат, а я дома сидел, так и не знаю-с... Уж простите, ваше сиятельство, великодушно» $(6,121)$.

В этой характерной для Достоевского модели диалога образованного героя с персонажем из народа, когда последний одерживает верх (вспомним похожий по форме диалог Коли Красоткина с мужиком на рынке), - проявление «литературного почвенничества». В абсурдном псевдодиалоге «почва» буквально уходит из-под ног Раскольникова, ведь на самый важный сейчас для него вопрос, не из зарайских ли тот мещанин, Раскольников так и не получает ответа. А ведь он только что узнал от Разумихина, что следующая его жертва - Миколка - из зарайских, как и Раскольников - из Рязанской губернии, в которой Зарайск - уездный город: ${ }^{3}$ так земляки одновременно разделены «почвой» - Миколка берет на себя грех неизвестного убийцы, Раскольников, только что узнавший, что из-за него Миколку вытащили из петли, - так и не сознается. В игровых репликах парня «зевающего» угадывается народный приговор герою «страдающему» .

Раскольникова отторгает даже та «живая жизнь», которая является самой низовой в моральном отношении. Народ в «тошнильном» ${ }^{4}$ переулке с нравственным изъяном, подобно герою, но одновременно и не так. Однако даже в самом скверном ухарском разливе народной жизни Раскольников чувствует единственную возможность выхода в другую, «высокую», «живую жизнь», которую пророчит ему Порфирий: «...отдайтесь жизни <...> прямо на берег вынесет и на ноги поставит <...> может, вас Бог для чего и бережет» $(6,351)$.

В сцене на Сенной - редкий у Достоевского случай негативного пространства «живой жизни», при этом все же желанного и спасительного для героя: «Духота стояла прежняя; но с жадностью дохнул он этого вонючего, пыльного, зараженного городом воздуха» $(6,120)$. Это редкая формулировка «живой жизни», так отличающаяся от определений Мышкина (улыбка ребенка для матери), Ивана Карамазова («клейкие, распускающиеся весной листочки» - 14, 210) или Зосимы («Любите животных, любите растения, любите всякую вещь»- 14,289$)$. Она скорее автобиографическая (паук на стене в камере смертника) и напоминает слова Версилова: «...нечто ужасно простое, самое обыденное и в глаза бросающееся, ежедневное и ежеминутное» $(13,178)$ - в смысле открытости к самому простому. В «Преступлении и наказании» понятие «живой жизни» чрезвычайно расширено этим негативным, низовым народным контекстом (в этом смысле показательны слова

3 Тихолиров Б. Н. «Лазарь! Гряди вон»: Роман Ф. М. Достоевского «Преступление и наказание» в современном прочтении. Книга-комментарий. СПб., 2005. С. 168-169.

4 «Он и прежде проходил часто этим коротеньким переулком, делающим колено и ведущим с площади в Садовую. В последнее время его даже тянуло шляться по всем этим местам, когда тошно становилось, „чтоб еще тошней было“» $(6,122)$. 
героя «А что ж, не напиться ли пьяным?» - 6,122$)$ и сопоставимо с аналогичным процессом в понятии «идея героя-индивидуалиста»: в этом романе «идея» как антипод «чувству» разводит всех героев на два полюса в системе характеросложения - Раскольников и Соня, в отличие от «Подростка», где негативная идея «подпольного» трансформируется в спасительную для него «идею-чувство» .

Однако почему разгульная народная толпа на Сенной подчеркнуто веселая толпа? Ведь в ее природе, конечно, мерещится толпа страшная, с совершенно противоположной атмосферой жестокости из сна Раскольникова о забитой лошади. Разница здесь, во-первых, в ракурсе взгляда автора: толпа во сне - «власть тьмы», которой противостоит «живая жизнь» в лице ребенка, а на Сенной она - воплощение самой «живой жизни» как оппозиции «мертвому» герою, толпа с веселым «ребяческим развратом», который присутствует даже в Миколке-маляре: и «хохотать до упаду оттого, что пальчик покажут, и пьянствовать до бесчувствия», и интерес к «женскому полу» $(6,347)$. И вовторых, разница, конечно, в точке зрения героя - невинное дитя во сне и интеллектуал-убийца, обескровленный муками совести и напряженной рефлексией внутренних монологов.

Вот почему при всем реализме сцены на Сенной в ней явственно проступает также и веселое метафорически-низовое, кукольно- «адское» пространство праздничной площади простолюдинов с «лествицей», откуда черти с крючьями сбрасывают грешников в ад («...весь этот стук и гам, там, внизу» - 6,122$)$. Но он - игрушечный в восприятии Раскольникова по сравнению с его собственным адом ( «страдание о том, что нельзя уже более любить» 14, 292), это ад народной площади с разгульными песнями и плясками, с шарманкой и незатейливыми уличными сценками, с шутками, каламбурами и площадным юмором, с акробатами (мужик «кувыркнулся» в бордель) и зазывалами (Дуклида), паяцами, шутами, ряжеными, с костюмированными актерами в утрированно комических масках (группа женщин «в ситцевых платьях, в козловых башмаках и простоволосые <...> почти все с глазами подбитыми» $-6,122$; "рябая девка <...> вся в синяках, с припухшею верхнею губой» - 6, 123; «мужик навеселе, в армяке нараспашку и с хитро смеющейся харей» - Там же), звуками толпы (крики, гам, смех, хохот, взвизги) и голосами "солистов». «Пыль и известка» Сенной вместе с навозом, оседавшие не только на ее зданиях, - это своеобразный грим лицедеев народной площади (ср. с толпой на пожаре во сне Прохарчина в виде представления с актерами в пудре от головешек и искр - 1, 251), антураж карнавального действа, в котором реальные простолюдины одновременно и актеры, ведь типичная черта карнавальной стихии - стирание границ между зрителями и сценой.

Отсюда же и яркая фольклорная речевая природа сцены, заражающая речь героя и даже автора (Раскольникова «даже тянуло шляться по всем этим местам, когда тошно становилось, „чтоб еще тошней было“» - 6,122$)$, с пословицами и поговорками («Кажись, и генеральские дочки, а носы всё курносые!», «Проходи, коль пришел!» - 6, 123), с просторечьем («Ты мой бутошник прикрасной, ты не бей меня напрасно!» - 6, 122), с примитивной рифмой за счет повтора слов в репликах, когда предыдущее слово «цепляет» следующее, что создает эффект незатейливого лексического гомона («Вишь, хорошенькая! <...> Вы и сами прехорошенькие <...> Вишь, веселье!» - 6, 123), с балаганной стилистикой («...всегда с вами рада буду часы разделить <...> Подарите <...> шесть копеек на выпивку!» - Там же) и лексикой («хари», «сласть», «кувыркнулся»).

При этом смешной ад «у сходов в нижний этаж, куда, по двум ступенькам, можно было спускаться в разные весьма увеселительные заведения» $(6,122)$, 
обостряет в Раскольникове ощущение подлинного ада, что создается внедрением его точки зрения в авторский взгляд и в голос веселой народной площади: «Его почему-то занимало пенье и весь этот стук и гам, там, внизу $<. . .>$ Он пристально, мрачно и задумчиво слушал, нагнувшись у входа и любопытно заглядывая с тротуара в сени <...>. Раскольникову ужасно захотелось расслушать, что поют, точно в этом и было всё дело» (Там же). Среди уличных кувырканий «пьяненьких» и «блудниц» движется трагический герой в квазиреальности кругов народного ада, подобно Данте: «Раскольников тронулся дальше» $(6,123)$. Это знак стилистического перебива ярмарочного ритма сцены, где Раскольников хочет быть своим среди чужих, подстраивается под народ, даже пытается говорить на его языке. Однако ни он их, ни они его не понимают. И в этом начало новых кругов ада героя-индивидуалиста.

Толпа безошибочно определяет, что Раскольников - ряженый $^{5}$ («приятный кавалер», «милый барин» (барином он назван на одной странице четыре раза), «ваше сиятельство»), и выносит ему приговор, одновременно жалея: «Какие худые! <...> из больницы, что ль, выписались?» (Там же), при этом народное чутье акцентирует многозначность слова «худой» - больной и плохой. Рябая девка говорит с ним о совести неслучайно, вроде бы в самом низовом комическом контексте, осуждая Дуклиду, взявшую у него деньги, «не отработав»: «Я бы, кажется, от одной только совести провалилась...» (Там же). Авторская ремарка ( РРаскольников любопытно поглядел на говорившую <...> Говорила и осуждала она спокойно и серьезно» - Там же) подтверждает, что убийца слышит, угадывает народное осуждение. Литературное почвенничество мерещится и в обращении Дуклиды к герою: «...а теперь вот как-то совести при вас не соберу» (Там же). Так в сценке вполне бытовой и даже нарочито сниженной проступает трагический смысл благодаря мукам совести героя и философско-этической оценке автора (народное отторжение Раскольникова). Иногда слух и героя, и читателя улавливает в веселом говоре толпы или в голосе автора намек на преступление героя (девочка «пресекла пение $<. .>$ точно отрезала» $-6,121$; ср. с репликой прохожего Раскольникову после убийства: «Ишь нарезался!..» - 6, 70; «две ступеньки вниз» к проституткам могут вызвать в памяти «две ступеньки вниз» в дворницкую с топором $6,59)$, или слово с сакральным значением употреблено для рифмы в поговорке в разговоре с убийцей («Как крестили, так и зовут» - 6,121$)$, символика цвета тоже многозначна (красная рубаха парня, девушка с огненным пером праздничный цвет площади и цвет крови или ада).

В сознании трагического героя природа веселой толпы искажается лишенным «почвы» петровским пространством, а народная площадь трансформируется в замкнутый «кривоколенный», «тошнильный» переулок, где безудержное игровое действие подменяется шествием персонажей с бледно-зелеными и больными лицами, почти трупов, бредущих в сумрачном свете газовых фонарей, в мокром снеге, под механическую музыку шарманки. В этом дьявольском спектакле хохочущего режиссера-кукольника из «Петербургских сновидений в стихах и прозе», дергающего за ниточки марионеток "славного маскарада» $(19,71)$, мерещится особый петербургский народный хор и фантастическая петербургская народная площадь, органичные по своей вписанности в пространство самого «умышленного», «фантастического», «отвлеченного» города на земле. Здесь герой отрезан не только от народной жизни, но и от прекрасной панорамы с «духом немым и глухим» $(6,90)$ европейского города с его доминантой — «Медным всадником», к которому по воле автора обращен

5 Одетый во все новое, в действительности - во все старое, рыночное и иностранное, он лишь переодет Разумихиным, «костюмирован», но не «восстановлен» . 
взгляд Раскольникова на Николаевском мосту. Это всеобщий петербургский карнавал - «Любите вы уличное пение?»: в финале фильма А. Н. Сокурова «Тихие страницы» Раскольников бредет под дождем по фантасмагорическому городу с уродливыми львами, в толпе двойников, и укрывается в чреве каменной монструозной львицы, засыпая в позе эмбриона, как зверь, слизывая с ее сосков дождевую воду вместо материнского молока.

При этом знаковая фраза «Любите вы уличное пение?», произнесенная среди разухабистой народной толпы, как призыв к вселенской жажде воссоединения сопоставима с последними словами Свидригайлова жалкому евреюпожарнику в шапке Ахиллеса: «...брат, здравствуй!» $(6,394)$.

Поэтому отторжение Раскольникова народным хором возвращает герою жажду жизни («Только бы жить, жить и жить!» - 6, 123), однако оторванность от почвы акцентирована и осуждена автором при помощи хронотопа: пространство будущей жизни после преступления представляется герою в аршин, на «узенькой площадке» в две ноги, на скале вместо «почвы» ( «етр» камень), «а кругом <...> пропасти, океан, вечный мрак, вечное уединение и вечная буря...» (Там же).

Имя Наполеона еще не прозвучало в романе, как нет еще для читателя и теории Раскольникова, но образ «статуэточного» тиражированного романтического героя со скрещенными на груди руками уже проступает в мечте героя о спасении. Его неготовность к подлинному спасению подчеркнута и литературностью размышлений ( ...где это я читал?» — Там же), тоже связанной с европейской традицией: «Последний день приговоренного к смерти» и «Собор Парижской богоматери» В. Гюго, ${ }^{6}$ добавлю к этому «Мельмота-скитальца» Ч. Мэтьюрина. Кроме того, нельзя не уловить и в этом видении Раскольникова контур скульптуры на скале - «Медный всадник». В этом едва мерцающем фоне мечты героя о спасении угадывается авторский приговор ему, но, как всегда по отношению к трагическому герою, не бесповоротный и безжалостный, а полный сострадания и милосердия, открывающий ему путь к спасению: «Подлец человек! И подлец тот, кто его за это подлецом называет...» $(6,123)$.

В заключение топографической темы - еще об одной детали - о шарманке. Рассматриваемая сцена имеет конкретный адрес: при выходе Раскольникова с Сенной площади, когда он переходит -ский проспект (Обуховский, сейчас Московский) и сворачивает в «кривоколенный» переулок (Таиров, сейчас Бринько). Почему именно здесь в сознании Достоевского всплывает народная площадь и почему этот адрес связан у него с народной темой? Именно здесь в 1845 году во время случайной встречи бывших однокашников по Инженерному училищу Григорович рассказал о своем очерке «Петербургские шарманщики" Достоевскому, и тот редактировал очерк друга: хрестоматийный «пятак упал <...> звеня и подпрыгивая...». ${ }^{7}$ Возможно, это воспоминание о шарманщиках навсегда связалось у Достоевского с конкретным топосом: здесь Раскольников дает тот самый пятак шарманщице, а потом - три пятака Дуклиде, не воспользовавшись ее предложением, как плату за аттракцион народной площади, где он - чужой, где нет для него веселья. Кстати, шарманщики селились именно в районе Сенной и Подьяческих, это как раз место действия романа и адрес старухи, зловеще указывающий в народной песне «По Подьяческой пошел, свою прежнюю нашел», куда надо свернуть с «канавы» (Екатерининский канал, сейчас канал Грибоедова), чтоб оказаться на месте самого знаменитого убийства в мировой литературе.

${ }^{6}$ См. комм. Г. М. Фридлендера (7, 377).

7 Григорович Д. В. Из литературных воспоминаний // Ф. М. Достоевский в воспоминаниях современников: В 2 т. М., 1990. Т. 1. С. 205. 
Выбором Сенной площади для описания первого выхода Раскольникова после преступления акцентируется народное религиозно-этическое начало, противостоящее герою, и в этом - «литературное почвенничество» как выражение авторской позиции. И не только противостояние народа Раскольникову, но, что очень важно - взаимное непонимание. С этой точки зрения показательна сцена прихода Раскольникова на место преступления к новым рабочим: каждый говорит на своем языке, он фактически сознается в убийстве, спрашивая о крови, они не понимают его: «Да что те надо? $(6,134)$. В спектакле Камы Гинкаса очень точная метафора пропасти между Раскольниковым и народом доведена режиссером до абсурда: Раскольникова играет актер-швед, не говорящий по-русски, к тому же диалог происходит за стеклянной стеной, отделяющей героя от маляров, при этом они говорят по-русски, а он - по-шведски.

Как и в следующем эпизоде романа - в разговоре героя с дворником и простолюдинами под воротами («Чего вам?» - Там же), где его прогоняют, а баба называет «выжигой» (по Далю - «ухорез, пройдоха, опытный и бывалый мошенник» $\left.{ }^{8}\right)$.

Но одновременно именно в этом первом после преступления «выходе в народ» уже присутствует в зародыше начало воскресения героя в авторском замысле о пути Раскольникова: «Принужден, чтобы хотя бы погибнуть в каторге, но примкнуть опять к людям <...> Закон правды и человеческая природа взяли свое...» $(28-2,137)$. Как и дарование автором герою жизни: отказ от первоначального замысла, связанного с крайним отторжением героя, нарушившего кодекс «почвы», - убийство Раскольникова каторжниками в церкви.

В авторском осуждении героя велика роль народного хора во главе с Миколкой, незримо, но отчетливо присутствующим в сознании Раскольникова - простым парнем с природным весельем, детскостью, с особым духовным путем, при этом испорченным городом, но не утратившим связь с почвой. ${ }^{9}$ Именно он - человек из народа - становится «жертвой» не признающегося в преступлении Раскольникова, первым в трагической веренице самоубийц, число которых бессознательно множит герой (баба-утопленница, Мармеладов, Свидригайлов).

Важно в авторской позиции и то, что именно народное осуждение первым обозначает начало прохождения кругов ада героем после убийства. Короткое сюжетное время (14 дней июля) рифмуется и потом закольцуется с большим временем эпилога - семь лет как семь дней творца и начало будущего подвига Раскольникова по созданию «новой жизни», на пороге которой и оставит автор героя. Это лишь начало хождения петербургской души «гениального студента» (определение Вяч. Иванова) по мытарствам, диагноз ему первой выносит именно «почва». Дальше народное сознание будет постоянно пульсировать в вынесении приговора герою, демонстрируя разнообразный спектр реакций - от равнодушия, высокомерия и презрения до сочувствия, однако всегда отрезая возможность установления любого контакта с ним. Особенно в кульминационной сцене неудавшегося покаяния Раскольникова на Сенной, где тоже мерещится балаганный слой с шуточками с обеих сторон: народный смех перечеркивает религиозный жест героя, целующего землю, фиксируя неготовность к высокому акту героя усмехающегося и хихикающего («...я за

8 Даль В. И. Толковый словарь живого великорусского языка: В 4 т. М., 1989. Т. 1. С. 289.

9 Абсурдное и абстрактное, с обывательской точки зрения, принятие Миколкой на себя чужой вины неизвестного собрата есть, по Достоевскому, высшее проявление свободы в христианском понимании как меры ответственности за другого, и в этом высшее выражение почвенного народного сознания, которое так скрупулезно исследуется писателем (ср. с авторским определением сострадания Сони - «ненасытимое» $(6,243)$, в котором духовное сопрягается с физиологическим: сострадать для нее - как есть и пить, иначе умрет). 
твоими крестами, Соня. <...> Это, значит, символ того, что крест беру на себя, xe-xe!» - 6, 403).

Яркая площадная стихия, где смеховое начало утверждает торжество жизни, где даже ад - игрушечный, а сама смерть чревата рождением и обязательным воскресением, воплощает живую жизнь, ту самую простую, веселую человеческую природу, от которой отрезан герой. Стилистика сцены - карнавальна, сюжет и герой - трагичны.

Осуждение Раскольникова народным хором не означает, что оценивать героя такого трагического масштаба следует только с точки зрения этической, ${ }^{10}$ без учета того, как создан этот образ автором, насколько ощущается в нем «вещество искусства» (Д. Мережковский), что так блестяще сформулировал другой литературный герой - Юрий Живаго: «Присутствие искусства на страницах „Преступления и наказания“ потрясает больше, чем преступление Раскольникова». ${ }^{11}$

Отмечу, что я коснулась лишь частного аспекта проблемы взаимоотношений «автор-герой» (в данном случае воплощенного в «литературном почвенничестве») на молекулярном отрезке текста, прибегнув к такому испытанному методу, как опыт медленного чтения. В том отрывке, который был проанализирован выше, происходит, по сути дела, едва ли не первый «тектонический сдвиг» романа: Раскольников, впервые обратившись к людям, оказывается им вовсе не интересным, не нужным. И, пока не зная того сам, делает - еще бессознательный - шаг к воскрешению. Именно такие моменты в тексте ждут (и требуют!) медленного, кропотливого чтения и перечитывания.

${ }^{10}$ И здесь мне близка позиция Б. Н. Тихомирова, который в связи с утверждением Раскольникова о том, что внутри себя «по совести» можно дать себе разрешение «перешагнуть через кровь», предлагает взглянуть на "Преступление и наказание» как на "великую трагедию совести». См.: Тихолиров Б. Н. «Лазарь! Гряди вон»: Роман Ф. М. Достоевского «Преступление и наказание» в современном прочтении. С. 239-240.

11 Пастернак Б. Л. Доктор Живаго // Пастернак Б. Л. Собр. соч.: В 5 т. М., 1990. Т. 3. С. 279.

\section{ЯСНЫЕ ПОЛЯНЫ И ПЕТЕРБУРГСКИЕ УГЛЫ РОССИИ И РУССКОЙ ЛИТЕРАТУРЫ (ПРОГНОЗЫ И ПРОРОЧЕСТВА Э. ПАРДО БАСАН)*}

Прогнозы и пророчества в области культуры поучительны и в тех случаях, когда они обращают на себя внимание и оправдываются, и в тех, когда они остаются несформулированными или незамеченными.

Одним из первых грядущую смену вех на Западе в представлениях о России, с которой со времени создания Священного союза связывали образ врага и с которой ассоциировали «казацкую» угрозу, предсказал Гоголь. В 1846 году в письме к Л. К. Виельгорской, включенном вскоре в книгу «Выбранные мес-

\footnotetext{
* Исследование выполнено при финансовой поддержке РФФИ в рамках научного проекта № 18-012-90014 «Проблемы рецепции личности и творчества Достоевского в мировой культуре: история и современность».
} 
та из переписки с друзьями», он пророчествовал: «Еще пройдет десяток лет, и вы увидите, что Европа приедет к нам не за покупкой пеньки и сала, но за покупкой мудрости, которой не продают больше на европейских рынках». ${ }^{1}$ Прогнозы Гоголя сбылись, правда, пришла в Россию «за покупкой мудрости» не вся Европа, а часть интеллектуальной элиты Запада, разочарованной эволюцией европейской цивилизации, «мудрость» черпали почти исключительно из русского романа, и прошло не десять лет, а сорок.

Наступление эпохи «мирного» завоевания Россией Запада, свидетельством которой было восхищение перед гением русских романистов, предвидел Достоевский. При этом знаменательно, что ближайшим поводом для этого обобщения, казалось еще преждевременного, датируемого серединой 1870-х годов, послужил роман Толстого "Анна Каренина», который именно в это время публиковался на страницах журнала «Русский вестник». Вспоминая порадовавшую его высочайшую оценку, которую дал толстовскому роману Гончаров, заявивший, что "Анна Каренина» превосходит всю современную европейскую литературу, Достоевский писал: «Меня поразило, главное, то в этом приговоре, который я и сам вполне разделял, что это указание на Европу как раз пришлось к тем вопросам и недоумениям, которые столь многим представлялись тогда сами собой. Книга эта сразу приняла в глазах моих размер факта, который мог бы отвечать за нас Европе, того искомого факта, на который мы могли бы указать Европе. Разумеется, возопят смеясь, что это - всего лишь только литература, какой-то роман, что смешно так преувеличивать и с романом являться в Европу. Я знаю, что возопят и засмеются, но не беспокойтесь, я не преувеличиваю и трезво смотрю: я сам знаю, что это пока всего лишь роман, что это только одна капля того, чего нужно, но главное тут дело для меня в том, что эта капля уже есть, если гений русский мог родить этот факт, то, стало быть, он не обречен на бессилие, может творить, может дать свое, может начать свое собственное слово и договорить его, когда придут времена и сроки». ${ }^{2}$ Далее писатель утверждает, что в "Анне Карениной» есть то, что составляет «нашу особенность» перед европейским миром, «такое слово, которого именно не слыхать в Европе, и которое, однако, столь необходимо ей, несмотря на всю ее гордость» .

И наконец, завершает Достоевский главу “Анна Каренина“ как факт особого значения» в "Дневнике писателя» за 1877 год пророческими словами, не оставляющими сомнения в том, что для Достоевского имела значение не столько литература, сколько грядущая смена вех в представлениях мира о России и ее месте в семье народов: «Если у нас есть литературные произведения такой силы мысли и исполнения, то почему у нас не может быть впоследствии и своей науки, и своих решений экономических, социальных, почему нам отказывает Европа в самостоятельности, в нашем своел собственнол слове, - вот вопрос, который рождается сам собою. Нельзя же предположить смешную мысль, что природа одарила нас лишь одними литературными способностями. Всё остальное есть вопрос истории, обстоятельств, условий времени. Так могли бы рассудить наши, по крайней мере, европейцы, в ожидании, пока рассудят европейские европейцы...» ${ }^{3}$

Полностью подтвердив прогнозы русских писателей, Россия пришла в Европу с «романом»: прежде всего с романами Толстого, но также с произведениями Тургенева, Гоголя, Гончарова и Достоевского. Во второй половине 1880-х годов во Франции и в Испании появились две книги о русском романе, которые предвосхитили новые представления как о русской литературе, так

${ }^{1}$ Цит. по: Гоголь Н. В. Выбранные места из переписки с друзьями / Сост., вступ. статья и комм. В. А. Воропаева. М., 1990. С. 184.

2 Достоевский Ф. М. Полн. собр. соч.: В 30 т. Л., 1983. Т. 25. С. 199.

${ }^{3}$ Там же. С. 202. 
и о России, воплотили два основополагающих представления о связи между романом и национальным своеобразием русской культуры, предлагающей миру новые духовные, идейные и эстетические ориентиры. Эти представления, наследуемые из поколения в поколение, из работы в работу, сосуществуют в мире вот уже почти полтора столетия.

Первое из них нашло блестящее воплощение в знаменитом сочинении Эжена-Мелькиора де Вогюэ «Русский роман», которое вышло в свет в 1886 году. ${ }^{4}$

В 1880-е годы вопрос о национальном своеобразии русской литературы и ее воздействии на литературную жизнь Запада был неразрывно связан с вопросом о соотношении между русским реализмом и наиболее влиятельной западноевропейской литературой того времени, французской, точнее литературой французского натурализма. Вогюэ одним из первых со всей определенностью этот вопрос поставил и попытался на него ответить. Французский писатель-католик, сыгравший огромную роль в деле популяризации русской литературы и формирования нового представления о России, видит основное достоинство и бесспорное преимущество русского реализма в силе религиозного чувства, в том, что он пропитан «евангельским духом», согрет любовью к ближнему, состраданием людским несчастьям.

Другой особенностью русского реалистического романа он считает интерес к «мистическому смыслу жизненных явлений». Русские писатели, отмечает он, «изучают действительность так пристально, как не делал никто до них, кажется даже, что им неловко в этом замкнутом пространстве; и тем не менее, они размышляют над невидимым; описывая с крайней точностью знакомые всем вещи, они не забывают уделить особое внимание тому, что, как они подозревают, скрывается за ними». ${ }^{5}$

Книга писателя, озабоченного оскудением религиозного чувства в странах Западной Европы и подчеркивавшего «буддийские» корни русской духовности и творчества особенно ценимого им Льва Толстого, в сущности, взяла на себя ту функцию, которую не могли выполнять для европейской публики доктрины славянофилов, поскольку они воспринимались как пропаганда извне. «Славянская раса, - утверждал Вогюэ, - не сказала еще своего великого слова в истории, а великое слово, которое любая раса призвана сказать, - это только религиозное слово. Под внешними покровами своего православия она его ищет в добросердечии, присущем всем слоям общества». ${ }^{6}$

Уже в 80-е годы XIX века и далее в значительной мере благодаря книге Вогюэ, которая пользовалась огромной популярностью, в центре дискуссий о русской литературе на Западе оказался вопрос о причинах и характере влияния русских писателей. Он теснейшим образом связан с вопросом о сущности русской литературы, о чертах ее отличия от литератур Запада. Для европейского читателя конца XIX века, не в последнюю очередь благодаря Вогюэ, своеобразие русской литературы (если собрать воедино наиболее распространенные суждения) заключалось в следующем: в напряженных поисках смысла жизни, отвечающих глубинным основам национального мироощущения, в неудовлетворенности теми представлениями о счастье, которые бытовали

4 Vogüé E.-M. Le roman russe. Paris, 1886. Книга до сих пор не переведена на русский язык, было опубликовано только авторское предисловие к ней: Вогюэ Э.- . Әе. Русский роман. Предисловие / Вступ. заметка П. Р. Заборова; пер. С. Ю. Васильевой под ред. П. Р. Заборова // К истории идей на Западе: русская идея. СПб., 2010. С. 504-534.

5 Там же. С. 528.

${ }^{6}$ Vogüé E.-M. de. Le roman russe. Р. 343. Перевод с фр. и исп. здесь и далее мой. - В. Б. О жизни Вогюэ в России и о его книге см.: Röhl M. «Le Roman russe» de Eugène-Melchior de Vogüé. Stockholm, 1976 (Acta Universitas Stockholmiensis. Studies in History of Literature; № 16); Eugène-Melchior de Vogüé, le héraut du roman russe. Textes réunis et prés. par Michel Cadot. Paris, 1989 (Bibliothèque russe de l'Institut d'études slaves. T. 284). 
в западноевропейском романе, в активном сострадании человеку, поставленному в крайне тяжелое, унизительное положение, в удивительном богатстве внутреннего мира ее героев, в широте их интеллектуальных интересов.

Несомненно, что Толстой, Достоевский и Тургенев заинтересовали западноевропейского читателя выдвижением на первый план в своих романах нравственных вопросов. Русская литература на протяжении долгих десятилетий воспринималась во всем мире как проникнутая бо́льшим интересом к нравственной стороне человеческой личности, бо́льшей тревогой за судьбу человека, чем другие литературы.

В той или иной мере на изложенные в этой книге взгляды опираются почти все авторы зарубежных историй русской литературы, но также и некоторых русских, созданных как до 1917 года, так и эмигрантских и современных. Большинство из них, ссылаясь на авторитет Вогюэ в интересующем нас вопросе или нет, сознательно или неосознанно, являются наследниками и продолжателями французского критика.

Вторая концепция, по убеждению ее авторов, прежде всего советских, но также значительной части литературоведов стран так называемого социалистического лагеря, восходит к идеям В. И. Ленина.

Теоретической базой для работ советских исследователей о мировом значении русской литературы и ее национальном своеобразии служат статьи Ленина о Льве Толстом. Вождь мирового пролетариата отметил, что русский писатель «поразительно рельефно воплотил в своих произведениях - и как художник, и как мыслитель и проповедник - черты исторического своеобразия всей первой русской революции, ее силу и ее слабость». ${ }^{~}$ «го мировое значение как художника, - подчеркивал Ленин, - его мировая известность, как мыслителя и проповедника, и то и другое отражает, по-своему, мировое значение русской революции».$^{8}$

Как и можно было ожидать, в ответах на интересующий нас вопрос, которые даются в многочисленных «Историях русской литературы», подготовленных в странах так называемой народной демократии, будет много общего с аргументацией и выводами их советских коллег.

В значительно меньшей степени эти взгляды отразились в работах, изданных на Западе. Д. П. Святополк-Мирский, автор одной из самых ярких историй русской литературы, явно выдает желаемое за действительное, утверждая: «Западные историки русской литературы обычно с самого начала оповещают своих читателей о том, что русская литература отличается от всех других литератур мира своей тесной связью с политикой и историей общества. Это просто неверно. Русская литература, особенно после 1905 г., кажется удивительно аполитичной, если вспомнить, каких колоссальных политических катаклизмов она была свидетельницей. Даже разрабатывая „политические“ сюжеты, современные русские писатели остаются по сути аполитичными даже когда они заняты пропагандой (как Маяковский), она в их руках превращается не в цель, а в средство». ${ }^{9}$

Как ни парадоксально, вторая концепция впервые в полной мере была сформулирована и обоснована в лекциях испанской графини Эмилии Пардо Басан «Революция и роман в России», изданных в 1887 году, ${ }^{10}$ т. е. через год

7 Ленин В. И. Л. Н. Толстой // Ленин В. И. Полн. собр. соч.: [В 55 т.] 5-е изд. М., 1973. T. 20. C. 20.

8 Там же. С. 19.

9 Цит. по: Святополк-Мирский Д. П. История русской литературы с древнейших времен по 1925 год. Новосибирск, 2006. Т. 2. С. 2.

10 Pardo Bazán E. La Revolución y la novela en Rusia. Madrid, 1887. Далее ссылки на это издание приводятся в тексте с указанием номера страницы. Подробнее о Пардо Басан и о ее книге 
после появления книги Вогюэ, и не получивших распространения, кроме, конечно, самой Испании и стран Латинской Америки. ${ }^{11}$ Не может быть никаких сомнений в том, что эта книга не была известна Ленину.

Более того, марксистская наука как в СССР, так и в других странах, не подозревая об этом, скорее следовала за испанской графиней, чем за вождем мирового пролетариата. Советские литературоведы, которые впоследствии во всех своих работах повторяли слова Ленина и ссылались на его авторитет, писали о том, что русская литература, теснейшим образом связанная с общественной жизнью, готовила революцию, между тем как, строго говоря, Ленин писал о другом - о том, что Толстой в своем творчестве, будучи большим художником, не мог не отражать революционную ситуацию и надвигающуюся революцию. Между тем, с точки зрения Пардо Басан, русская литература и предвосхищала революцию, и готовила ее.

Испанская писательница предложила совершенно неожиданный для Западной Европы 80-х годов XIX столетия подход к определению национального своеобразия русской литературы. Его отличительной чертой является перенос центра внимания с внутреннего достоинства самих произведений на проблему отражения в русском романе общественной борьбы в России. Благодаря своим русским знакомым Пардо Басан первой в Европе обратила внимание на непосредственную причинно-следственную связь между русской литературой и набиравшим силу революционным движением в России. Писательница ставила перед собой задачу проследить формы отражения исторического развития и социальных идей в современном русском романе и при этом не упустить из виду, что «по венам русской литературы текут социалистические и коммунистические идеи» (р. 102). Более того, романы русских писателей, с ее точки зрения, и отражали предреволюционную ситуацию в России, и участвовали в ее формировании.

Таков в концентрированном виде взгляд Пардо Басан на национальное своеобразие русской литературы. При этом как литература, так и «революция» вызывали у нее, представителя западной цивилизации, двойственное чувство: неподдельного восхищения и тревоги.

Можно лишь удивляться тому, что при всем многообразии подходов и оценок как классического русского романа второй половины XIX столетия, так и русской литературы в целом, ее периодизации и эстетических особенностей, судя по всему в осмыслении национального ее своеобразия исследователи во многом сохраняли верность двум ярким концепциям, двум «текстам-архетипам» (именно «архетипам», поскольку книга «Революция и роман в России» Пардо Басан, строго говоря, не является «источником»), одна из которых возникла в полемике с позитивизмом и натурализмом, а вторая, в свою очередь, полемична по отношению к первой. В то же время очевидно, что сочинение Пардо Басан во многом уступает книге Вогюэ, выдающемуся литературному манифесту XIX века, как глубиной постановки вопросов, так и влиянием на умы нескольких поколений интеллектуалов и любителей литературы во многих странах мира. Однако столь же очевидно, что в России ее имя также не должно быть забыто.

Имеет смысл упомянуть отклик на лекции Пардо Басан, принадлежащий перу ее соотечественника Хуана Валеры, который, в отличие от нее, побывал в России в 1856-1857 годах в составе дипломатической миссии. Более того, в одном из своих «Писем из России», благодаря которым он и осознал себя

см.: Clémessy N. Pardo Bazan, romancière. Paris, 1973; Багно B. Е. Эмилия Пардо Басан и русская литература в Испании. Л., 1982.

11 О первых откликах на книгу Пардо Басан в Испании и в испаноязычных странах см.: Там же. С. 66-70. 
писателем, Валера высказывал сходные мысли: «Мои новые филологические знания мне послужат тем не менее в изучении литературы, хотя почти неизвестной во всей Западной Европе, но богатой и обещающей со временем стать великой». ${ }^{12}$ В 1887 году от взгляда одного из самых авторитетных писателей Испании не ускользнуло, что Пардо Басан преследовала не столько исследовательские цели, сколько цели иного свойства, непосредственно касающиеся современной испанской литературы и, шире, литератур Запада. Зная, что она была сторонницей французского натурализма, влияние которого на испанских литераторов он считал крайне вредным, Валера попытался на всякий случай «приглушить звучание» пропагандируемого ею нового литературного явления. ${ }^{13}$ В то же время в 1887 году, полемизируя с Пардо Басан, Валера не мог не сознавать, что предоставленная ему в 1857 году возможность «пророчества» была упущена. Благодаря своим русским друзьям С. А. Соболевскому, М. А. Корфу и В. П. Боткину, он читал в немецких переводах Пушкина и Лермонтова и во французских - Гоголя, а самым популярным писателем России 1850-х годов признал Тургенева. Нелишне напомнить, что ко времени его пребывания в России уже были опубликованы не только «Мертвые души» Гоголя (1842) и «Записки охотника» Тургенева (1852), но и «Бедные люди» Достоевского (1846) и «Севастопольские рассказы» Толстого (1855), о которых как о вершинах мировой литературы писала Пардо Басан.

Отличие лекций испанской графини от книги ее французского предшественника заключалось не только в том, что она, во многом следуя за Вогюэ, предложила другой взгляд на национальное своеобразие русской литературы. Прежде всего глубоко ошибочно представление о неоригинальности ее тезисов и выводов. Мнению о их полной зависимости от «Русского романа» Вогюэ литературоведение обязано статье мексиканского дипломата и писателя Франсиско де Икасы 1925 года, ${ }^{14}$ в которой, в отличие от утверждений защитников писательницы, фактического материала более чем достаточно. Икаса, приведя длинный список страниц книги Пардо Басан, представляющих, по его убеждению, краткий перевод страниц, параграфов и фраз из исследования французского критика, отказывает «Революции и роману в России» в праве называться самостоятельным произведением. В статье не случайно происходит подмена названия книги Пардо Басан, как если бы она была посвящена только литературе. Икаса не счел нужным обратить внимание на то, что большинство в некоторых случаях действительно почти дословных переводов испанской романисткой отдельных фраз или даже целых отрывков из «Русского романа» Вогюэ относятся либо к биографиям русских писателей, либо к конкретным сведениям, касающимся литературной жизни России, либо к анализу художественных произведений, которые Пардо Басан не могла прочесть сама ввиду отсутствия их переводов на те европейские языки, которыми она владела: французский, немецкий, итальянский и английский.

Пардо Басан действительно многим обязана "Русскому роману». Но ее книга, в сущности, написана на другую тему. Предмет исследования Вогюэ русский роман, в то время как лекции испанской писательницы посвящены «революции» и "роману» в России, причем именно в этой последовательности. Самым же неожиданным, оригинальным и интересным является ее убеждение в том, что революционное движение и художественная литература неотторжимы друг от друга, поэтому необходимо учитывать их взаимозависимость и взаимообусловленность.

12 Валера Х. Письма из России. СПб., 2001. С. 150.

13 Valera J. Con motivo de las novelas rusas. Carta a doña Emilia Pardo Bazán // Valera J. Obras completas. Madrid, 1949. T. 2. P. 715-723.

${ }^{14}$ Cм.: Icaza F. de. Doña Emilia Pardo Bazán y la novela en Rusia // El Sol. 1925. 28 de enero. 
Выводы испанской романистки, никогда не бывавшей в России, не знавшей русского языка, коренным образом отличаются от выводов Вогюэ, книга которого была главным источником ее работы, и обусловлено это было тем, что концепция Пардо Басан рождалась под перекрестным влиянием французских литераторов и русских революционеров-эмигрантов, с которыми она познакомилась в Париже. Двоих из своих русских друзей назвала сама писательница - это Исаак Яковлевич Павловский и Лев Александрович Тихомиров. Из других русских источников следует упомянуть книги С. М. Степняка-Кравчинского «Подпольная Россия» и "Россия под властью царей». ${ }^{15}$ При этом не стоит забывать и о выдающихся трудах западноевропейских ученых XIX столетия, таких как «Россия» М. Уоллеса, «Империя царей» А. Леруа-Больё и «История России» А. Рамбо, из которых испанская писательница почерпнула немало материала, оставаясь независимой в своих выводах (p. 12-13).

Нет ничего удивительного в том, что вполне органичный и цельный, но все же двухфокусный взгляд Пардо Басан как на Россию, так и на русский роман, в немалой степени обусловленный разнохарактерными источниками ее осведомленности в вопросе, сказался на ее оценках.

Много внимания Пардо Басан уделяет форме правления в средневековых русских городах, полагая, что Россия в Средние века обладала республиканским правлением, более свободным и радикальным, чем в остальной Европе. Она весьма подробно знакомит читателя с социально-политическим, бытовым и религиозным укладом России XIX столетия, огромное значение придавая трем «стержням» русской жизни: самодержавию, крестьянской общине и революционному движению. Пардо Басан признается, что не испытывает особой симпатии к революционерам и нигилистам, но если бы ей пришлось выбирать между увлеченностью и верой революционеров в свои идеалы и равнодушием людей, ко всему безучастных, то она, несомненно, выбрала бы первое.

Под влиянием идей своих русских друзей-революционеров о предстоящем крутом переломе в жизни их страны, стоящей на пороге великих, еще не виданных в Европе событий, Пардо Басан заявляет, что «никчемные листки западных конституций» были разорваны в России непрочитанными, и, пророчествуя, утверждает, что «русская революция не удовлетворится тем, чем удовлетворились западноевропейские» (р. 224-225).

Из этого брожения, неслыханных, невиданных и недоступных Западу элементов, с ее точки зрения, и родился великий русский роман. Ни на минуту не забывая о литературе, Пардо Басан делает следующий вывод, основанный на ее раздумьях о будущем Запада и России: «Роман - это самое ясное зеркало, вернейшее отображение общества; я не устану это повторять, и в этом легко удостовериться, просто обратив внимание на нынешнее состояние европейской литературы. Полагаю, что я достаточно ясно показала, что в русском романе отражаются все чаяния, мечты и тревоги этой страны: русский роман - революционный и мятежный, поскольку революционным и мятежным является общее умонастроение интеллигенции и просвещенных людей». ${ }^{16}$

В то же время испанская графиня Пардо Басан настаивает на том, что если французское общество - дитя Великой французской революции, то в России, стране христианской, революция принимает абсолютно иные формы, и, переходя к творчеству Достоевского, впрочем не упоминая его, она с увлечением пишет о накале мистической лихорадки, которым охвачена Россия, о тяге к жертвенности, о болезненной нежности, о пламенном милосердии.

${ }^{15}$ См. об этом: Багно В. E. Эмилия Пардо Басан и русская литература в Испании. С. 41-43.

16 Пардо Басан Э. Из книги «Революция и роман в России» // К истории идей на Западе: русская идея. С. 543. 
«Если в моменты уныния, - признается испанская писательница, - над которыми не властна человеческая душа, померкнет во мне истина и убедительность слова Иисусова, я буду спасаться от своих заблуждений примером его чудесной действенности в России. И здесь не имеет значения печать инакомыслия, лежащая на этом великом утверждении христианства. В голове самого отъявленного еретика много больше правды, нежели заблуждения, если он искренний христианин. Вот только заблуждение подобно греху: одной капли яда достаточно, чтобы отравить стакан чистой воды; и все же неопровержимо, что в стакане больше воды, а не яда». ${ }^{17}$

Вместе с тем Пардо Басан готова верить тому, что Россия решительно отвергла материалистические учения, подобно возвращению морем мертвого тела. Как показала история, это пророчество не вполне оправдалось.

Посвятив большую часть своих лекций описанию природы, погоды, обычаев, истории и общественной жизни России, испанская писательница переходит к литературе, к «зеркалу», вернейшему отображению этого общества. Вслед за Вогюэ, величайшими русскими писателями она признает Гоголя, Тургенева, Достоевского и Толстого, но при этом готова считать, что автор «Обломова» ничем им не уступает. На этом фоне, с ее точки зрения, особенно выделяется творчество двух русских гениев - Достоевского и Толстого. И наконец, так же, как и французский критик, пальму первенства она отдает Толстому, прежде всего потому, что именно в его творчестве обнаруживает черты, которые могут обновить современную ей испанскую и европейскую литературу. Пардо Басан не стала исключением из правил - в споре о Толстом и Достоевском она присоединилась к тем, кто безоговорочно отдавал пальму первенства автору «Войны и мира» .

Среди своих предшественников и современников Толстой выделяется, по мнению Пардо Басан, тем, что его реализм производит полное впечатление жизненной правды. В то же время, хотя и с меньшим энтузиазмом, она приветствовала желание Толстого быть не только художником, но и проповедником общественного обновления: «Видеть фанатика социализма и великого писателя в одном лице <...> настолько интересное для ума зрелище, что я не решаюсь ответить на вопрос, что в Толстом привлекает более пристальное внимание: личность или книги» (р. 413).

Пытаясь выявить отличия между творческой индивидуальностью Толстого, Тургенева и Гончарова, она с удовлетворением находит то, что их объединяет, более того, объединяет их с представителями европейской цивилизации и позволяет Западу у них учиться: сбалансированное состояние души и гармоническое мироощущение.

При исследовании творчества Достоевского и его личности Пардо Басан ставит перед собой совершенно иную задачу - изучить Россию и понять душу русского человека. Естественно, возникает вопрос, какие стороны личности русского писателя, какие особенности его таланта произвели на нее наиболее сильное впечатление? В первую очередь это сгущенность мрачных красок в обрисовке действующих лиц, присущая им лихорадочная жажда деятельности и, наконец, специфический взгляд на человека и на мир, не укладывающийся в общечеловеческие представления о добре и зле. Время показало, что испытания историей эта задача и выводы, при всей проницательности взгляда испанской писательницы, не выдержали, прежде всего потому, что трагедия Первой мировой войны заставила всех признать, что в романах Достоевского мы находим не только Россию и душу русского человека, но человечество и природу человека, которые оказались совсем не такими, какими их ранее видели и изображали.

17 Tам же. С. 544. 
Достоевского, по убеждению Пардо Басан, не следует читать, с одной стороны, людям впечатлительным и нервным, а с другой - воспитанным на традициях "спокойствия, гармонии и света»: «Так видит мир тот, кого лихорадит. Он довел реализм до пределов возможного; и это уже реализм мистический. Он и его герои не от нашего мира, не от нашей расы, влюбленной в свет, не от нашей приветливой цивилизации: это экстравагантное порождение русской жизни, для нас непостижимое» (р. 384).

Несмотря на эти существенные оговорки и «заслоны» для душевного покоя европейской цивилизации, испанская графиня считает творчество русского писателя одной из вершин реализма XIX столетия. Она характеризует Достоевского как первого среди европейских романистов по глубине психологического анализа, а также по той роли, которую приобретает в его творчестве гуманистическое начало: «И это - красота? - спросят меня. Все, что создано Достоевским <...> ранит душу, извращает воображение и до предела расшатывает наши представления о добре и зле <...> И все-таки я утверждаю, что это красота, мучительная, вывернутая наизнанку, дьявольская, но мощная, великая и властная» (р. 378-379).

Удивительна и по-своему показательна общая переориентация мировой культуры с Толстого на Достоевского. Показательна в том смысле, что от актуального во второй половине XIX - начале XX века Толстого после Первой мировой войны Запад в своих идейных и эстетических поисках и пристрастиях

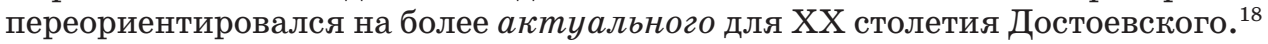

Переводы из Тургенева, Толстого и Достоевского оказались как для первых их читателей, так и для последующих поколений, тех, кто впервые брал в руки книги русских писателей, подлинным откровением. Вне зависимости от того, насколько читатель был способен осознавать дистанцию между действительностью и художественной реальностью, он был вправе, вслед за Стефаном Цвейгом, задуматься о коренных вопросах человеческого бытия, которые ставились русским романом. «Раскройте любую из пятидесяти тысяч книг, - писал Цвейг, - ежегодно производимых в Европе. О чем они говорят? О счастье. Женщина хочет мужа или некто хочет разбогатеть, стать могущественным и уважаемым. У Диккенса целью всех стремлений будет миловидный коттедж на лоне природы, с веселой толпой детей, у Бальзака - замок, с титулом пэра и миллионами. И, если мы оглянемся вокруг, на улицах, в лавках, в низких комнатах и в светлых залах - чего хотят там люди? - Быть счастливыми, довольными, богатыми, могущественными. Кто из героев Достоевского стремится к этому? - Никто. Ни один. Они нигде не хотят остановиться, даже в счастье». ${ }^{19}$ Не только упоминание имени Достоевского, но и последняя фраза подсказывают нам, что речь идет прежде всего о судьбе его наследия в XX веке.

Предсказав движение России к революционным катаклизмам, сосредоточившись на различиях русского общества с его революционным брожением и европейского общества, людей, воспитанных на традициях «спокойствия, гармонии и света», Пардо Басан не смогла предвидеть движение всей Европы к катастрофе Первой мировой войны, а в области литературы - к переориентации, как следствию этой катастрофы, европейской интеллигенции с Толстого на Достоевского как нового властителя умов. В этом смысле большой интерес представляет эссе «Необычный русофил» (1914) М. де Унамуно, испанского мыслителя и писателя, предшественника экзистенциализма, в молодости внимательно прочитавшего книгу Пардо Басан, в творчестве которо-

18 См., например: Толстой или Достоевский? Философско-эстетические искания в культурах Востока и Запада. СПб., 2003.

${ }^{19}$ Цит. по: Цвейг Cm. Полн. собр. соч.: [В 8 т.]. Л., 1929. Т. 7. С. 121-122. 
го Толстой и Достоевский оставили глубокий след. ${ }^{20}$ Эссе представляет собой отклик на события Первой мировой войны, в которой Испания не принимала участия. Прошло четверть века с момента выхода в свет книги Пардо Басан, началась Первая мировая война, и именно то, что испанская графиня, при всем восхищении Достоевским, сочла неприемлемым для западноевропейского читателя, да и для Европы в целом, Унамуно отметил как то понимание жизни и мира, которое его герою, во многом выражающему точку зрения автора, представляется самым достойным.

Во время споров о воюющих державах в некоем мадридском кафе каждый из его завсегдатаев становится на сторону одной из участвующих в конфликте сторон - Франции, Германии, Англии, Австрии, Италии, при этом один из них, предпочитавший до поры до времени отмалчиваться, неожиданно заявляет, что Россию как таковую знает плохо, за изучение русского языка никогда не брался, в России никогда не бывал, с русскими знаком не был, но тем не менее имеет вполне четкое представление о России, почерпнутое из произведений Достоевского. Именно благодаря им он и стал убежденным русофилом. Далее он поясняет, что свое представление о России он вынес из романов Достоевского, и не уверен в том, что реальная Россия такова, какой он теперь ее представляет. Однако поскольку реальную Европу он знает хорошо и ход развития европейской цивилизации его абсолютно не устраивает, он голосует за Россию своих фантазий, своих надежд, своей веры, т. е. за свои представления и идеалы, частично почерпнутые из романов русского писателя: «Я голосую за торжество духа, т. е. за представление и ощущение, которое от жизни и мира имел Достоевский». ${ }^{21}$ И далее: «Все, что мне довелось в эти дни услышать, никак не реагируя, пустые, избитые благоглупости, которыми вы по очереди обменивались в защиту самых значительных и, как принято считать, наиболее передовых народов Европы, вызывало у меня грустную улыбку, и поскольку я больше не мог молчать, я выразил свои чувства, поддержав Россию, Россию Достоевского, „Записок из подполья“, „Идиота“, „Преступления и наказания“, которая, быть может, и отличается от сегодняшней России, которая, похоже, может рассчитывать на победу, с ее Думой, но для меня это не имеет значения». ${ }^{22}$ Знаменательно не только то, что фактически в своем эссе автор предоставляет слово только «русофилу», но также и то, что в контексте споров аргументы "русофила», точнее было бы сказать "достоевскофила», звучат наиболее убедительно.

Унамуно, любитель резких поворотов, в разные годы напоминавший как русских западников, так и русских славянофилов, переболевший в юности идеей «европеизации» Испании, а впоследствии утверждавший, что его «интересует в России все самое русское, самое подлинное, самое исконное, наименее космополитическое», ${ }^{23}$ предложил в зрелые годы концепцию «испанизации» Европы, духовной экспансии Испании. ${ }^{24}$

При этом, если оставить в стороне вопрос о взаимной симпатии славянофилов и испанофилов, разочарованных ходом развития европейской технократической цивилизации, значение имеет и то обстоятельство, на которое обратил внимание А. ЖЖид. Сочувственно процитировав Вогюэ, который утверждал, что если русских царей называли собирателями земли русской,

${ }^{20}$ О творческом усвоении М. де Унамуно наследия русских писателей и мыслителей см.: Корконосенко $K$. Мигель де Унамуно и русская культура. СПб., 2002.

21 Unamuno M. de. Obras completas. Madrid, 1966. T. IX. P. 1248.

22 Ibid. P. 1250.

${ }^{23}$ См.: Gallego Morell A. Estudios y textos ganivetianos. Madrid, 1971. P. 100.

24 Об этом см.: Багно В. E. Пограничные культуры между Востоком и Западом // Багно В. Е. Россия и Испания: общая граница. СПб., 2006. С. 11. 
то Достоевский в области духа стал собирателем русского сердца, французский писатель делает вывод, имеющий уже отношение ко всей Европе, пережившей катастрофу Первой мировой войны: «Такое же собирание сил происходит благодаря Достоевскому и в Европе - медленно, почти таинственно, - главным образом, в Германии, где число изданий его произведений растет, а затем и во Франции, где новое поколение понимает и ценит его лучше, чем современники г-на де Вогюэ. Скрытые причины, замедлившие его успех, обеспечат этому успеху прочность». ${ }^{25}$

В заключение, возвращаясь к Пардо Басан, а также к теме несформулированных прогнозов, стоит привести еще одну ее мысль. Романы Достоевского, полагает она, не годятся для тех, кто берет в руки книгу, ложась спать, чтобы она навеяла сон, равно как и тех, кто открывает книгу во время минут отдохновения, чтобы восславить Господа за его творение. И наоборот, лучше этих романов не придумать для беспокойных умов, уединившихся при свете керосиновой лампы и вбирающих в себя гул и трепет какого-нибудь большого города, такого как Париж или Петербург. ${ }^{26}$ Любопытно, что испанская писательница здесь противоречит сама себе: речь здесь идет не о том, что романы Достоевского - это зеркало русской души, чуждой и недоступной для западного восприятия, а о том, что неравнодушные и беспокойные души любой национальности (а не только русские), с духовными, идейными и нравственными запросами, именно в такой литературе и нуждаются.

25 Цит. по: Жид А. Переписка Достоевского // Русская классика: Pro et contra. Между Bостоком и Западом. СПб., 2018. С. 395.

26 Об эволюции восприятия творчества Достоевского соотечественниками Пардо Басан в XX веке см., например: Арсентьева Н., Морильяс Ж. Испанское достоевсковедение: истоки, итоги, перспективы // Достоевский. Материалы и исследования. СПб., 2013. Вып. 20. С. 305-328.

\section{О ЗНАЧЕНИИ ПАРАЛЛЕЛЬНЫХ СЦЕН И СКВОЗНЫХ МОТИВОВ В «СВЕРХРОМАНЕ» Ф. М. ДОСТОЕВСКОГО: ПОИСКИ МЕТОДА МЕЗДУ ИННОКЕНТИЕМ АННЕНСКИМ И «НОВОЙ КРИТИКОЙ»}

Большие романы Достоевского и сопровождающие их малые произведения созданы в относительно краткий период, за пятнадцать лет. Создававшиеся мощным, почти непрерывным творческим усилием, как воплощения единого, хотя и беспрестанно менявшегося замысла, они значительно менее автономны, чем произведения предшествующего периода или, например, чем трагедии Шекспира или романы Гюго, если смотреть на великих, на которых стремился ориентироваться Достоевский.

Период пяти романов выделяется энергией самоотверженного и саморазрушительного труда, напряжением художественной мысли. Интенсивность работы была обусловлена натурой писателя, лихорадочной активностью духа и интеллекта и до некоторой степени вынуждалась обстоятельствами, которые, в свою очередь, отчасти зависели от личных свойств: непосильные долги, вымаливание и получение от издателей авансов еще прежде, чем начи- 
налась работа над обещанным произведением, и как следствие - спешка в исполнении обещанного - все это делало процесс писания еще более лихорадочным, а самое письмо еще более тесным: замыслы и образы переходили один в другой, повторялись, смешивались, взаимоусиливались. Можно, несколько метафорически перенося на пять романов тыняновское определение стихового ряда, говорить о «единстве и тесноте» романного ряда Достоевского. В единстве пяти романов персонажи, сцены, образы и прочие элементы вступают в сложные связи и соотношения; «сверхроман» идейно достигает богатства диалектики, невозможной в пределах одной романной композиции.

Накопленные в XX столетии опыты описания единства философской мысли Достоевского вместе с богатой традицией исследований его творческого процесса подготовили этап, на котором все сильнее ощущается польза методов, позволяющих описывать большие романы как целое, выявлять в них «сверхроманное» единство.

Вяч. Иванов анализировал единство пяти романов-трагедий на уровне высших задач и замыслов Достоевского: это трагедия «в последнем смысле», «разыгрываемая между человеком и Богом», ее мистически постигает и своим трагическим гением творит Достоевский. Романы в их данности Иванов скорее различает как отдельные композиционно замкнутые трагедии или поэмы, указывая, впрочем, на открытую И. Ф. Анненским возможность анализа их единства в плане чистой художественности. Иванов так описывает этот намечающийся метод во введении к своей статье «Достоевский и роман-трагедия»: «...цикл романов, внешне не связанных прагматическою связью <...>, но все же сросшихся между собой корнями столь неразрывно, что самые ветви их казались сплетшимися такому, например, тонкому и прозорливому критику, каким был покойный Иннокентий Анненский; недаром последний пытался наметить как бы схематический чертеж, определяющий психологическую и чуть ли не биографическую связь между отдельными лицами единого многочастного действа, изображенного Достоевским, - лицами-символами, в которых, как в фокусах, вспыхивали идеи-силы, чье взаимодействие и борьбу являл нам этот поэт вечной эпопеи о войне Бога и дьявола в человеческих сердцах». ${ }^{1}$

Это скорее мечта о будущем методе, чем наблюдение над реально осуществляемым анализом. Анненский в основном исследовал структурные связи внутри одного романа - «Преступления и наказания», который он полагал наиболее совершенной художественной игрой, но полушутя намечал перспективы дальнейшего развития или упадка персонажей: символ Сони имел будущее в образе Софьи, матери Ивана и Алеши Карамазовых, Дуня имела в себе зерно будущего образа Настасьи Филипповны и пр. Исключительное по важности место в системе персонажей «Преступления и наказания» занимал, в глазах Анненского, Свидригайлов, которому было суждено получить «отвратительное» преломление в фигуре намыливающего шнурок Ставрогина. ${ }^{2}$

Развивая и модифицируя два десятилетия спустя эти размышления, П. М. Бицилли писал: «...персонажи Достоевского легко перемещаются из одной его вещи в другую - в отличие от персонажей Толстого или Чехова, ибо в сущности все произведения его составляют как бы один роман». ${ }^{3}$ И Бицилли,

${ }^{1}$ Иванов В. И. Достоевский и роман-трагедия // Иванов В. И. Собр. соч.: [В 4 т.]. Брюссель, 1987. Т. 4. С. 403-404.

2 Анненский И. Достоевский в художественной идеологии // Анненский И. Книги отражений. М., 1979. С. 185.

${ }^{3}$ Бицилли П. К вопросу о внутренней форме романа Достоевского // Пьотр Бицили. Салимбене и Пушкин / Съставителство, предговор и бележки Галина Петкова. Варна: Електронно издателство LiterNet, 2004. 
и М. М. Бахтин открывали особенности поэтики Достоевского, но не столько в единстве пяти романов, сколько в общей совокупности произведений. Здесь вернемся к системному подходу Анненского, но применяя его для анализа не персонажей, а определенных сцен и более частных деталей. Не разделяя его неприязни к поздним идеям и образам Достоевского, к Алеше, Зосиме, будем стараться держать в поле зрения целостность романов. Горячо поддержим идею, что персонаж Свидригайлова - исключительно ценный, структурно ключевой, и будем иметь в виду не только структуру «Преступления и наказания», но и более широкое пространство романного творчества Достоевского.

Как противоположный таким подходам вспомним здесь знаменитый имманентный анализ, положивший основу направления «новой критики», работу Аллена Тейта (1943) о функции мухи в финальной сцене «Идиота». По Тейту, муха, жужжащая в мертвой тишине спальни, где лежит тело Настасьи Филипповны, актуализирует сцену, вовлекает нас в нее, как будто мы получаем приказ приблизиться, муха сохраняет при этом и свое простое значение как locus процесса разложения. ${ }^{4}$

Рассматривая эту сцену в другой, широкой перспективе «сверхромана», увидим соотнесенность, «зарифмованность» ее с рядом родственных сцен, важных и для отдельных романов, но в параллелизмах общей конфигурации получающих гораздо более сложные значения: «Он стоял и всматривался минуту или две; оба, во всё время, у кровати ничего не выговорили; у князя билось сердце так, что, казалось, слышно было в комнате, при мертвом молчании комнаты. Но он уже пригляделся, так что мог различать всю постель; на ней кто-то спал, совершенно неподвижным сном; не слышно было ни малейшего шелеста, ни малейшего дыхания. Спавший был закрыт с головой белою простыней, но члены как-то неясно обозначались; видно только было, по возвышению, что лежит протянувшись человек. Кругом в беспорядке, на постели, в ногах, у самой кровати на креслах, на полу даже, разбросана была снятая одежда, богатое белое шелковое платье, цветы, ленты. На маленьком столике, у изголовья, блистали снятые и разбросанные бриллианты. В ногах сбиты были в комок какие-то кружева, и на белевших кружевах, выглядывая из-под простыни, обозначался кончик обнаженной ноги; он казался как бы выточенным из мрамора и ужасно был неподвижен. Князь глядел и чувствовал, что, чем больше он глядит, тем еще мертвее и тише становится в комнате. Вдруг зажужжала проснувшаяся муха, пронеслась над кроватью и затихла у изголовья. Князь вздрогнул. - Выйдем, - тронул его за руку Рогожин».

Господствуют мертвая тишина и неподвижность, тление, смерть непреодолимая, безнадежная; Рогожин и Мышкин решают не выходить, тело должно тут лежать, и они двое - рядом с ним. Тема тления усиливается и занимает все внимание: «Я ее клеенкой накрыл, хорошею, американскою клеенкой, а сверх клеенки уж простыней, и четыре стклянки ждановской жидкости откупоренной поставил, там и теперь стоят» $(8,504)$. Оба постепенно теряют подвижность и ясность мысли. Вместе с темой тления развивается тема цветов. Рогожин: «...известно, дух... Окна я отворять боюсь; а есть у матери горшки с цветами, много цветов, и прекрасный от них такой дух <...> Купить разве, пукетами и цветами всю обложить? Да, думаю, жалко будет, друг, в цветах-то!» $(8,505)$.

Неподвижность все побеждает в конце: «Рогожин лежал неподвижно <...> но глаза его ярко блистали сквозь темноту и были совершенно открыты и неподвижны. <...> Между тем совсем рассвело; наконец он прилег на подушку

4 Tate Al. Dostoevsky's Hovering Fly: A Causerie on the Imagination and the Actual World // The Sewanee Review. 1943. Vol. 51. № 3. P. 369.

5 Достоевский Ф. М. Полн. собр. соч.: В 30 т. Л., 1973. Т. 8. С. 503. Далее ссылки на это издание приводятся в тексте с указанием номера тома и страницы. 
как бы совсем уже в бессилии и в отчаянии и прижался своим лицом к бледному и неподвижному лицу Рогожина <...> Князь сидел возле него неподвижно на подстилке» $(8,506-507)$.

Многие компоненты, соединившиеся в финальной сцене «Идиота», уже сблизились в конце «Преступления и наказания», в последнем эпизоде истории Свидригайлова.

Последние кошмары Свидригайлова: «...но ему всё стали представляться цветы». Ему видится «деревенский коттедж, в английском вкусе, весь обросший душистыми клумбами цветов». Количество цветов и интенсивность запаха их растет с движением на второй этаж дома: лестница, «обставленная редкими цветами в китайских банках. Он особенно заметил в банках с водой, на окнах, букеты белых и нежных нарцизов, склоняющихся на своих яркозеленых, тучных и длинных стеблях с сильным ароматным запахом». В зале множество цветов и гроб. «Гирлянды цветов обвивали его со всех сторон. Вся в цветах лежала в нем девочка, в белом тюлевом платье, со сложенными и прижатыми на груди, точно выточенными из мрамора, руками. Но распущенные волосы ее, волосы светлой блондинки, были мокры; венок из роз обвивал ее голову. Строгий и уже окостенелый профиль ее лица был тоже как бы выточен из мрамора...» $(6,391)$. Следует патетический период о погубленной и погибшей девочке. Затем - новый кошмар, жертва раздвоилась, теперь это пятилетний ребенок-девочка, постепенно проявляются в ее лице черты развращения и разврата, «это лицо камелии, нахальное лицо продажной камелии из француженок», она нагло смеется. Свидригайлов встает, одевается и готовит револьвер, задумывается: «Револьвер и записная книжка лежали тут же, у локтя. Проснувшиеся мухи лепились на нетронутую порцию телятины, стоявшую тут же на столе. Он долго смотрел на них и наконец свободною правою рукой начал ловить одну муху» $(6,393-394)$.

Истлевание тела в цветах, разложение черт лица пятилетней девочки, наконец мухи на мясе - это все материя в ее распаде, торжество природы, которая в исповеди Ипполита в «Идиоте» названа тарантулом. Эпизод перед смертью Свидригайлова не только связан с финальной сценой «Идиота», но оказывается эссенцией следующего романа, в центре которого - поруганная и развращенная девочка, выросшая в виновную и неповинную Настасью Филипповну, которая в конце станет трупом, застывшим в неподвижной мраморности, с цветами, белым кружевом и мухой, затихающей у изголовья.

Появление мухи в финале «Идиота» находится в отношениях параллелизма со сценой перед смертью Свидригайлова. Имея свое значение и функцию внутри отдельного эпизода, на уровне сверхромана этот элемент обогащается смыслами, достигающими глубины и непреложности мифа. Муха трупная, муха Свидригайлова в «Преступлении и наказании» появляется троекратно, так что этот символ в уже первом романе накапливает богатые значения. Муха предупреждала и сопровождала приход Свидригайлова к Раскольникову. Раскольникову видится кошмар: он оказывается в квартире, где им совершено преступление. «И какая там тишина, даже страшно» $(6,213)$. «И всё тишина», вдруг треск. «Проснувшаяся муха вдруг с налета ударилась об стекло и жалобно зажужжала». "В самую эту минуту» Раскольников в комнате видит в углу сидящую на стуле старушонку и начинает ее бить топором и видит, что она смеется, все ниже опуская голову. Смех слышится и из спальни, смех, как и жертва, раздваивается. "Бешенство одолело его: изо всей силы начал он бить старуху по голове, но с каждым ударом топора смех и шепот из спальни раздавались всё сильнее и слышнее, а старушонка так вся и колыхалась от хохота» $(6,213)$. Муха в тишине становится знаком Свидригайлова в этой же сцене, продолжающейся после кошмара о старушонке. Еще как бы во сне Раскольников видит человека, стоящего на пороге, тот входит и садится на стул: «Прошло минут с десять. Было еще светло, но уже вечерело. В комнате была совершенная 
тишина. Даже с лестницы не приносилось ни одного звука. Только жужжала и билась какая-то большая муха, ударяясь с налета об стекло» $(6,214)$.

Параллелизм в «Преступлении и наказании» кошмара с девочкой в гробу и ее двойником - развратным ребенком и, с другой стороны, сна с избиваемой старушонкой и раздвоенным смехом выявляет общий смысл эпизодов как кошмара вины, в котором муха становится чем-то подобным Эринии, еще одним знаком и ужасом вины. ${ }^{6}$ Свидригайлов является как двойник Раскольникова, он - носитель и воплощение вины, подвергаемый карам, но его кары более жестоки, судьба безнадежна, как будто на него переходит, освобождая Раскольникова, та часть вины, которая не подлежит искуплению. Муха появится в третий раз в конце уже только со Свидригайловым.

Д. С. Мережковский заметил повтор - муха в комнате старушонки и в комнате Раскольникова: «Эта реальная, соединительная символическая черточка - жужжащая в обеих комнатах муха («все что у вас - есть и у нас» - говорит Черт Ивану Карамазову, то есть все, что в мире явлений есть и в мире сущностей - в «обеих колнатах»), связывает сон с явью так, что уже читатель едва может отличить, где кончается призрачное, где начинается действительное». ${ }^{7}$ Интерпретация эта, несколько редуцирующая смысл повтора, поскольку не выходит за пределы одной главы «Преступления и наказания», вместе с тем весьма проницательна, поскольку ведет к пониманию полупризрачной, пограничной природы Свидригайлова: «Свидригайлов выходит из сна; и сам он весь точно сон...». ${ }^{8}$ Переиначим мысль Мережковского: Свидригайлов - человек обеих комнат, он и там, и здесь и снимает различие потустороннего и посюстороннего. Его пространство потусторонности - комната с пауками как символ безблагодатной вселенной, в которой он заключен. Муха в страшной тишине, как Эриния, независимо от того, где он, здесь ли, там ли, сопровождает его и возвращается к нему.

Муха вновь в мертвой тишине жужжит над телом убитой Настасьи Филипповны. В этот раз она сопровождает князя Мышкина, который постепенно переходит в состояние неподвижности и идиотизма, безблагодатное и необратимое. Осмелимся утверждать, что параллелизм сцен ставит в отношения параллелизма и ведущих персонажей - Свидригайлова и князя Мышкина. Если замыкаться в рамки отдельных романов и, особенно, если опираться на декларации Достоевского в частных письмах, сближение Мышкина со Свидригайловым может вызвать только протест, ведь князь Мышкин - Христос, совершенно прекрасный человек, невинный и чистый, Свидригайлов же порождение мрака. Достоевский, и это относится не только к «Идиоту», хотя к нему - прежде всего, во многих случаях разъяснял содержание своего произведения, часто еще только начатого. Эти разъяснения воспроизводятся в ученых трудах и в энциклопедических статьях. Письму о задаче «Идиота» - «изобразить вполне прекрасного человека» в этом отношении особенно повезло, оно вошло в память поколений как догма, определяющая смысл романа $(28-2,241)$. Мы обедняем возможности интерпретации, когда опираемся на такие декларации, «вполне прекрасный человек» - это лишь одна правда в диалектике многих правд творческого создания.

На первый взгляд не Мышкин, а Тоцкий, развративший Настасью Филипповну в ее детские годы, по форме преступления является наследником Свидригайлова, но в общей композиции «сверхромана» и даже отдельного романа Тоцкий - персонаж незначительный, глубоко второстепенный, не удо-

6 Такое значение символа — муха-Эриния - не принадлежит области традиционных представлений и мифов, оно оформлено в миф пьесой Сартра «Мухи», посвященной теме вины и, повидимому, во многом обязанной творчеству Достоевского.

7 Мережковский Дл. Толстой и Достоевский. Вечные спутники. М., 1995. С. 126.

8 Там же. 
стоенный никакой роли в драмах страдания, вины и кары, презренный «букетник», носитель камелий. Полезно здесь вспомнить мысль Вяч. Иванова о Смердякове: Смердяков лишен метафизического характера, это пустой двойник, отделяющийся от Ивана, виновным в убийстве представлен не он, а Иван. ${ }^{9}$ Даже Рогожин - собственно убийца - не носитель вины, он - только стихия. Не случайно Ипполит в своем кошмаре видит Рогожина сразу после тарантула, знаменующего уничтожающую силу природы. Онтологическая вина остается за Мышкиным. Настасья Филипповна, красота мира, мировая душа, поругана и разрушена. Вина за мировую душу - красоту должна быть принята Мышкиным в силу соразмерности его мировой красоте. Ответственность за нее он осознал и принял уже в начале романа при первых встречах с Настасьей Филипповной. Но в конце вина становится неискупимой, в пространстве господствует муха, все мертвенно неподвижно.

Функционируя на уровне «сверхромана», представленные сцены, как и множество других элементов, служат выражением идеи вины. Князь Мышкин невинен и виноват. Образы жертв и символы вины и кары в первых романах цикла соотносились с очерченным кругом лиц, в "Братьях Карамазовых" вина расширяется и приобретает всеобщность со знаменитой формулой «все за всех виноваты». Идея онтологической вины считается едва ли не важнейшей в антропологии Достоевского и от него в значительной степени унаследованной экзистенциализмом XX века. Вяч. Иванов, кажется, первым представил тему вины как центральную для романов Достоевского и на этом основании определил их как романы-трагедии, поскольку именно идея вины составляет сущность трагедии. В 1930-е годы А. Л. Бем, посвящая Достоевскому статью "Проблема вины», следует за Ивановым, но уже приводит довольно значительную немецкую литературу вопроса. ${ }^{10}$ Сейчас библиография об идее онтологической вины у Достоевского, ее восприятии в позднейшей философии и о независимых от Достоевского, но сходных направлениях философской мысли XX века с трудом поддается обозрению. ${ }^{11}$ Мы не ставим перед собой задач углубляться в это направление, наша цель - анализировать некоторые параллельные сцены в композиции романов Достоевского, рассматривая повторение и преобразование ряда деталей.

Установив параллелизм сцен с видениями жертвы в «Преступлении и наказании» и «Идиоте» - избиваемая старушонка и девица в гробу, - мы получаем возможность различить их литературно-мифологическую ретроспективу «Вий». То, что в эпосе находится в отношениях параллелизма, в волшебном мире становится метаморфозой: «Он схватил лежавшее на дороге полено и начал им со всех сил колотить старуху». ${ }^{12}$ Старуха превращается в умирающую девицу, которую Хома потом находит в гробу: «Трепет побежал по его жилам; пред ним лежала красавица, какая когда-либо бывала на земле. Казалось, никогда еще черты лица не были образованы в такой резкой и вместе гармонической красоте». ${ }^{13}$

Если сон Раскольникова об избиении старушонки легко проецируется на избиение старушки Хомой, то свидригайловская девочка в гробу соотносится с панночкой лишь в избранной нами ретроспективе сверхромана, т. е. в той мере, в которой кошмары Свидригайлова ведут нас к образу Настасьи

9 Иванов В. И. Достоевский и роман-трагедия. С. 421.

10 Бем А. Л. Проблема вины // Бем А. Л. Достоевский. Психоаналитические этюды. Ann Arbor, 1983. С. 142-171 (репринт).

11 Довольно интересный обзор литературы дан в книге: Belloli P. G. Fenomenologia della colpa: Freud, Heidegger, Dostoevskij. Milano, 2001. Менее удачна вторая часть с попытками анализа идеи вины в разных произведениях Достоевского.

12 Гоголь Н. В. Вий // Гоголь Н. В. Полн. собр. соч.: [В 14 т.]. М.; Л., 1937. Т. 2. С. 187.

13 Там же. С. 199. 
Филипповны. Героиня «Идиота» в этой ретроспективе обнаруживает довольно близкое родство со сверкающей и страшной мертво-живой красотой панночки и вообще страшной красотой колдовских гоголевских женщин. С этих позиций понятнее может стать возрастающий по ходу романа смешанный с болью страх князя Мышкина перед красотой Настасьи Филипповны. Продолжим цитату из «Вия»: «Но в них же, в тех же самых чертах, он видел чтото страшно пронзительное. Он чувствовал, что душа его начинала как-то болезненно ныть, как будто бы вдруг среди вихря веселья и закружившейся толпы запел кто-нибудь песню об угнетенном народе» ${ }^{14}$

Здесь, особенно в словах об угнетенном народе, Гоголь как будто предчувствует и предсказывает Настасью Филипповну, драму сострадания и вины.

Ближе к началу романа «Идиот» сказано: «...эти два контраста возбуждали как будто даже какое-то сострадание при взгляде на эти черты. Эта ослепляющая красота была даже невыносима...» $(8,68)$. Ближе к концу: «...лицо это еще с портрета вызывало из его сердца целое страдание жалости; это впечатление сострадания и даже страдания за это существо не оставляло никогда его сердца, не оставило и теперь. <...> Если бы, любя женщину более всего на свете или предвкушая возможность такой любви, вдруг увидеть ее на цепи, за железною решеткой, под палкой смотрителя, - то такое впечатление было бы несколько сходно с тем, что ощутил теперь князь» $(8,289)$.

Включаемый в перспективу романов Достоевского «Вий» и сам оборачивается историей преступления-насилия и наказания Хомы Брута.

При всеобщем признании огромной роли Гоголя для творчества Достоевского о влиянии собственно «Вия» говорилось, как кажется, немного. С. Г. Бочаров в работе о сверкающей красоте у Гоголя упоминает и Настасью Филипповну «как плененную злом красоту», наряду с «Незнакомкой» Блока наследующую это свойство у гоголевских героинь. Там же он, что для нас полезно, говоря о Хоме Бруте, соглашается толковать скачку и избиение старухи поленом как иносказательное описание грубого насилия. ${ }^{15}$

Другая проекция «Вия» на «Идиота» сделана А. М. Ремизовым в очерке «Сверкающая красота», где он говорил о сходстве тарантула из сна Ипполита в «Идиоте» с самим Вием. В своей поэтической интерпретации, довольно поздней, уже отмеченной не только образами Достоевского, но и опытами экзистенциализма, Ремизов превращает «Вий» в трагедию вины и кары самого Гоголя, к которому и приходит Вий-тарантул. ${ }^{16}$

По непреодолимой творческой потребности, в нарушение пропорций и даже вопреки логике здравого смысла Достоевский в «Идиоте» к Мышкину подсоединил как двойника Ипполита и поместил его исповедь в центр романа. Этому персонажу отдаются свидригайловские кошмары и мучения - тот свет как комната с пауком, хотя он лишь 18-летний изможденный болезнью юноша, и на него, казалось бы, не за что насылать такие кары. Исповедь Ипполита «Мое необходимое объяснение» кратко эксплицирует трагедию «Идиота»: Ипполит, посетив Рогожина, увидел картину, изображавшую Христа без надежды на воскресенье, тело раздавленное, побежденное природой. Христос - тот, кто победил природу, «который воскликнул „Талифа куми“, и девица встала, „Лазарь, гряди вон“, - и вышел умерший» (8, 339). Но природа победила Христа, она - «глухое, темное и немое существо», «отвратительный тарантул» $(8,340)$. Непосредственно после тарантула Ипполиту видится Рогожин - призрак, вызывающий в нем ледяной страх и бешен-

\footnotetext{
14 Там же.

15 Бочаров С. Г. «Красавица мира»: Жеенская красота у Гоголя // Бочаров С. Г. Филологические сюжеты. М., 2007. С. 160, 163.

${ }_{16}$ Релизов А. М. Сверкающая красота // Ремизов А. М. Собр. соч.: В 10 т. М., 2002. Т. 7. С. 148.
} 
ство, как сама природа-тарантул, и толкающий его к решению о самоубийстве. В словах Ипполита определяется и высший образец сцены с мертвой девицей в гробу, столь важной для Достоевского в его романах - это эпизод воскрешения дочери начальника синагоги, двенадцатилетней девочки, лежащей в гробу, Христом, произносящим слова «Талифа куми» (Мк. 5: 41). Чуду противостоит та реальность, в которой господствует тарантул и смерть побеждает самого Христа. Чудеса победы над разложением и распадом, воскрешение девицы и Лазаря - опровергнуты, отменены безблагодатной силой природы.

Чудо воскрешения девочки, «Талифа куми», образует центр «Легенды о великом инквизиторе». Достоевский вносит в евангельскую сцену свои постоянные детали: гробик белый, множество цветов, «мертвый ребенок лежит весь в цветах». В двойственном символизме цветов актуализируются значения, связанные с возрождением жизни: «Девочка подымается в гробе, садится и смотрит, улыбаясь, удивленными раскрытыми глазками кругом. В руках ее букет белых роз, с которым она лежала в гробу» $(14,227)$.

Почему великий инквизитор отвергает это новое чудо Христа? Каков смысл и назначение «Талифа куми» в «Легенде о великом инквизиторе»? здесь не место обсуждать эти вопросы, для нас важно, что Достоевский поместил эту сцену в центр своего наиболее диалектически сложного текста. Мы рассматриваем эту сцену в череде подобных, проходящих через весь «большой» роман Достоевского, и отмечаем, что в нескольких случаях сцена жертвы в гробу в цветах дана у него в ключе радостном, близком к «Талифа куми», с ней связываются прощение и надежды.

В «Идиоте» в контрастном отношении с заключительной сценой у мертвого тела Настасьи Филипповны находится одна из начальных сцен - похороны Мари. Прощение вины, почти счастье и конечное общее просветление обусловлены участием детей-птиц, к которым цветы, в особенности розы, присоединяются в общем значении светлой, почти райской гармонии. Мари только видела детей - тут же оживлялась и приподнималась. «Через них, уверяю вас, она умерла почти счастливая. Через них она забыла свою черную беду, как бы прощение от них приняла, потому что до самого конца считала себя великою преступницею. Они, как птички, бились крылышками в ее окна...» $(8,62-63)$. «...Мари умерла. Тут детей и удержать нельзя было: они убрали ей весь гроб цветами и надели ей венок на голову. <...> C тех пор могилка Мари постоянно почиталась детьми: они убирают ее каждый год цветами, обсадили кругом розами» $(8,63)$.

Малое произведение Достоевского «Вечный муж», по времени близкое к созданию «Идиота», тоже содержит историю похорон девочки, осыпанной цветами и окруженной детьми, со сходными значениями прощения и гармонии. В «Вечном муже» параллели, связи и соответствия, более или менее скрытые в общей композиции «Преступления и наказания» и «Идиота», выводятся на поверхность и получают довольно открытую авторскую интерпретацию. Герой рассказа Вельчанинов в основном соответствует Свидригайлову (даже и по наружности). За ним в прошлом - тот же ряд преступлений, так же всплывающих в памяти и снах. Образы вины, созданные в других романах, перемещаются в эти сны, в том числе в сон, весьма близкий сну Раскольникова об избиении жертвы, тут же открыто толкуемый как потребность разрушения вины: «Вельчанинов, в бешенстве, ударил этого человека <...> Совсем остервенясь, он ударил в другой и в третий раз, и в каком-то опьянении от ярости и от страху, дошедшем до помешательства, но заключавшем тоже в себе бесконечное наслаждение, он уже не считал своих ударов, но бил не останавливаясь. Он хотел всё, всё это разрушить» $(9,15-16)$. 
«Вечный муж» сводит некоторые мотивы, эпизоды «Преступления и наказания» и «Идиота», которые в этих соседних для него по времени романах разрабатывались в трагическом ключе, здесь же они даны холодно и спокойно, как будто для какого-то повторного экспериментирования. Рассказ оказывается интересен как свод и экспликация мотивов вины у Достоевского и именно для этого был использован А. Л. Бемом в психоаналитическом этюде «Проблема вины». ${ }^{17}$ Вельчанинов, хотя список его прошлых преступлений ставит его в позицию, близкую Свидригайлову и Ставрогину, лишен метафизической сложности и не подвергается трагическим карам. Более того, похороны и могилка девочки, в печальной судьбе которой он был отчасти виновен, вместо того, чтобы стать для него кошмаром, как для Свидригайлова, несут ему освобождение и представлены в идиллических красках, близких к описанию похорон Мари: дети занимаются похоронами девочки, «мертвую убрали, нарядив ее в праздничное белое платьице одной из дочерей Клавдии Петровны, и положили в зале на столе, с цветами в сложенных ручках...» $(9,59)$. Вельчанинов «вспоминал ее и в гробу, в цветах» $(9,62)$. Правда, в отличие от Свидригайлова и Ставрогина, Вельчанинов не совершил последнего худшего из преступлений - насилия над девочкой, но, как мы знаем, Достоевский и без этого насылал Эриний на своих героев. В этом же случае автор неожиданно и легко милует виноватого. Вельчанинов созерцает могилку девочки в приятной атмосфере ясного вечера: трава, цветы, венки, листочки, вместо мухи Свидригайлова ему жужжит пчела. «Какая-то даже надежда в первый раз после долгого времени освежила ему сердце. „Как легко!“ - подумал он, чувствуя эту тишину кладбища и глядя на ясное, спокойное небо. Прилив какой-то чистой безмятежной веры во что-то наполнил ему душу. „Это Лиза послала мне, это она говорит со мной“, - подумалось ему» $(9,63)$.

Этим облегченным вариантом сцены с гробом жертвы не кончается эксплуатация Достоевским собственных материалов. По модели Свидригайлова, но с комическим снижением, как высмеиваемая неудача, представляется намерение второго героя, собственно «вечного мужа», жениться на девочке-подростке. Рассказ, боковая ветвь, уходит в сторону от трагического творчества Достоевского, не включаясь в процесс развития основных компонентов «сверхромана».

Рассматриваемая последовательность параллельных сцен завершается описанием похорон Илюшечки в финале «Братьев Карамазовых». Они невыносимы, душераздирающи, таково основное впечатление, мешающее внимательно следить за литературными подробностями. Но, соотнеся их с другими сценами у гроба, мы с особой ясностью различим стройность композиции «сверхромана»: похороны Илюшечки - заключительный апофеоз, победа над той смертью, которая была явлена в свидригайловском кошмаре и в сцене бдения у тела Настасьи Филипповны. Здесь к описаниям беспредельного отчаяния добавлены детали из гармонических похорон Мари, здесь действуют дети и птицы, и дети-птицы.

В сцене похорон Илюшечки преодолевается та ужасная неподвижность, которая господствовала в свидригайловском эпизоде и в финале «Идиота», все дано в стремительных, порывистых движениях. Снегирев падает, бьется, пускается бежать, бежит, кидается на снег, делает множество жестов. Так сильно нагибается над могилой, что мальчики тянут его назад. Выхватывает корку, разбрасывает кусочки для птиц. Вскакивает и опять бежит. Мальчики бегут, птицы быстро пролетают и взлетают. Илюшечка неподвижен, и руки у него «точно вырезанные из мрамора» $(15,190)$, но почему-то в этом случае они

17 Бел А. Л. Проблема вины. С. 162-164. 
«особенно хороши», к тому же его все время переносят. В руки ему вложены цветы, цветов очень много, их прислали и Лиза, и Катерина Ивановна в двойном количестве, и они упоминаются на протяжении всего описания похорон, но в этом случае и они - в движении: их привезли, ими обсыпают дрожащими руками, белую розочку из рук Илюши мать хочет вытащить, в конце капитан выхватывает из гроба "несколько цветиков», носится с пучком, роняет цветок, бросается подымать, ломает. Завершение похорон: «Мамочка, дорогая, Илюшечка цветочков тебе прислал, ножки твои больные! - прокричал он, протягивая ей пучочек цветов, померзших и поломанных, когда он бился сейчас об снег» $(15,193)$. В речи у камня Алеша отмечает сходство мальчиков с «хорошенькими сизыми птичками» $(15,195)$ и говорит о высокой ценности произошедшего, т. е., похорон, для будущего как хорошего воспоминания. В самом конце Алеша обещает воскресенье из мертвых всем и Илюшечке.

Итак, нами рассмотрена серия сцен с изображением мертвого тела, девочки или другой жертвы - Настасьи Филипповны, Мари, Илюшечки, с цветами в разных функциях, к ним может примыкать эпизод с мухой, или они включают детей, птиц. Такие сцены образуют некие остановки, «станцы» в большом потоке "сверхромана», их связи являются важной составляющей его единой композиции. Они запечатлевают моменты неподвижного отчаяния, высших сомнений и высших надежд. Находясь в отношениях параллелизма и контрастов, взаимодействуя, пересекаясь, взаимоусиливаясь или отменяя одна другую, они служат бесконечно развивающейся диалектике «большого» романа Достоевского.

\section{«ДОСТОЕВСКИЙ» АНДРЕ ЖКИД В РУССКОМ ЗАРУБЕЗЬЕ}

Рецепция Достоевского в эпистолярии, дневниках, эссеистике и художественном творчестве Андре ЖКида хорошо представлена в исследовательской литературе. ${ }^{1}$ Тем не менее на русском языке этот без сомнения магистральный сюжет в истории «открытия» Достоевского за рубежом прокомментирован недостаточно. ${ }^{2}$ «Жид оказался самым проницательным аналитиком творчества Достоевского, и не только во Франции», его «наблюдения и оценки

* Исследование выполнено при финансовой поддержке РФФИ в рамках научного проекта № 18-012-90014 «Проблемы рецепции личности и творчества Достоевского в мировой культуре: история и современность» .

1 См.: Vacquier T. Dostojevski and Gide: A Comparison // The Sewanee Review. Vol. 37. № 4. P. 478-489; Fayer M. Gide, Freedom and Dostoevsky. Burlington, 1946; Moutote D. Dostoïevski et Gide // Revue d’Histoire littéraire de la France. 1976. № 5. P. 768-793; Cadot M. Lectures stratifiée de Dostoïevsky par André Gide // Dostoevsky and the Twentieth Century / Ed. M. V. Jones. Nottingham, 1993; Saggiomo C. Gide face à Dostoïevski, par-delà le mariage du Bien et du Mal. Montpellier, 2018.

2 Например, в своем замечательном во многих отношениях исследовании А. И. Владимирова не в последнюю очередь стремится «разоблачить» Жида как неумелого подражателя Достоевского, вскрывает его несоразмерность автору «Братьев Карамазовых». Такая иерархическая оптика мешает проанализировать, как «переплавляются» (а не недопонимаются) концепты Достоевского в интерпретации Жида. См.: Владилирова А. И. Достоевский во французской литературе XX века // Достоевский в зарубежных литературах / Ред. Б. Г. Реизов. Л., 1978. С. 37-60. 
$<\ldots>$ не утратили своей значимости и по сей день», между тем как его вклад в понимание Достоевского «по меньшей мере, у нас, был недооценен». ${ }^{3}$ Среди немногих работ особенно важны исследования С. Л. Фокина, ${ }^{4}$ в которых «культ избирательного сродства» ЖКида (так Фокин обозначает принцип чтения французского писателя) встраивается в другие центральные сюжеты рецепции.

В статье мы рассмотрим не столько особенности восприятия Достоевского в творчестве Жћида, сколько то, какую реакцию вызвали его работы о Достоевском в русской эмиграции «первой волны». Речь идет о рецепции книги «Dostoïevski» (Plon, 1923), куда были собраны речи и статьи за 1908-1922 годы. При таком ракурсе сам ЗЖид воспринимается в роли медиатора, «передающего" Достоевского русским литераторам в превращенной форме. История же эмигрантской рецепции книги Жида встраивается в более обширный сюжет борьбы за «своего» Достоевского в 1920-е годы, когда западные страны, СССР и зарубежная Россия в разной форме предъявляли права на автора «Братьев Карамазовых» .

В эмигрантской России Достоевский - назначенный союзник самых разных философских, религиозных и политических концепций. ${ }^{5}$ В 1923 году, тогда же, когда выходит книга ЖКида, в эмиграции появляются знаковые работы о русском писателе: «Миросозерцание Достоевского» Н. А. Бердяева (Прага, 1923), «Русская стихия у Достоевского» Б. П. Вышеславцева (Берлин, 1923), «Системы свободы Ф. М. Достоевского» А. З. Штейнберга (Берлин, 1923).

Именно в эмиграции цементируются основные мотивы «мифа» о (не только и не столько) писателе Достоевском: «пророк русского духовного возрождения» и «замечательное религиозное явление», ${ }^{6}$ «не только великий художник», но также «величайший русский метафизик», ${ }^{7}$ «богослов и философ, все творчество которого - сплошная мука над разрешением социально-полити-

${ }^{3}$ Дудкин В. В. «Roman Dostoevskien» как новаторская форма жанра и термин (Достоевский во Франции в первой трети XX в.) // Достоевский. Материалы и исследования. СПб., 2013. Т. 20. C. 391.

${ }^{4}$ Прежде всего глава в монографии, посвященной «Достоевскому» во французской литературе XX века: Фокин С. Л. Культ избирательного сродства в генезисе «Достоевского» Андре ЗЖида // Фокин С. Л. Фигуры Достоевского во французской литературе ХХ века. СПб., 2013. С. 97115. Фокин анализирует книгу Ж ида как плодотворный эксперимент по проживанию «своего» Достоевского. «Фигура Достоевского - мыслителя и романиста - предстает своего рода неотступным двойником, которому французский писатель поверяет самые смелые свои философские идеи и эстетические начинания. При этом ЖЖид не приписывает Достоевскому своих взглядов; он скорее поворачивает взгляды русского писателя интересной, привлекательной и увлекательной для него стороной; он словно бы исполняет роль Достоевского на французской интеллектуальной сцене; точнее говоря, он проживает на ней жизни отдельных его персонажей - Кириллова и Ивана Карамазова, князя Мышкина и Родиона Раскольникова, Версилова и Разумихина - воспринимая их в виде частных, единичных воплощений многосложной личности русского писателя. Речь идет не столько о пресловутом субъективизме трактовок, сколько о сознательном стремлении Зћида достичь - через Достоевского - особого пространства асубъективности, в котором опыт другого может восприниматься как собственный, тогда как последний может выдаваться за заимствованный. Это своего рода „театр жестокости“, в котором писатель, отвергавший саму мысль о „литературных влияниях“, заставляет себя говорить от имени другого, вкладывая в его уста свои самые заветные мысли» (Там же. С. 114).

${ }^{5}$ См.: Белов С. В. Ф. М. Достоевский // Литературная энциклопедия русского зарубежья. 1918-1940. М., 2006. Т. 4. Всемирная литература и русское зарубежье. С. 154-162; Гачева A. . В поисках нового синтеза: Духовное наследие Ф. М. Достоевского и пореволюционные течения русской эмиграции 1920-1930-х годов // Достоевский и ХХ век: В 2 т. М., 2007. Т. 2. С. 3-67.

${ }^{6}$ Струве П. Б. Пророк русского духовного возрождения <1921>// Русские эмигранты о Достоевском / Вступ. статья, подг. текста и прим. С. В. Белова. СПб., 1994. С. 25.

${ }^{7}$ Бердяев Н. А. Миросозерцание Достоевского <1923> // Бердяев Н. А. Философия творчества, культуры и искусства: В 2 т. М., 1994. Т. 2. С. 9. 
ческих вопросов», ${ }^{8}$ «Закон и Пророки» эмиграции. ${ }^{9}$ Все эти элементы мифа о русском классике, с одной стороны, продолжают традиции религиозной философии и литературной критики рубежа веков, с другой стороны, только в эмиграции и могут оформиться по-настоящему, получить силу и вес «сбывшейся» реальности. Один из трикстеров эмигрантской литературы Василий Яновский в свойственной ему язвительной манере и уже после Второй мировой войны так описывал эту логику присвоения автора «Братьев Карамазовых», характерную для межвоенных десятилетий: «Другие цеплялись за беднягу Достоевского и как некие духовные „Очи черные“ хором тянули: Алеша Карамазов, Алеша Карамазов, старец Зосима, старец Зосима... («Идиота» эти джигиты почему-то меньше терзают). Богдан знал, что в каждом большом чекисте сидит маленький Достоевский; отношение последнего к полячишкам, иудеям, французишкам, католикам и Дарданеллам вряд ли враждебно природе партии Ленина-Сталина.

- Русский человек всечеловек! - вещал Достоевский. И это так польстило враждовавшим западникам и славянофилам, что они даже помирились. Те самые здравомыслящие лысины, которых рассмешил немецкий тупоголовый сверхчеловек, отлично уживаются с уютным сознанием собственного всечеловечества, забывая основной урок евразийской истории: не до жиру, быть бы живу!» ${ }^{10}$

Сравнение Достоевского с «Законом и пророками», с одной стороны, и с чекистом - с другой, сосуществовали в эмигрантской публицистике как крайние точки. Притом поздняя интерпретация Яновского в нарочито преувеличенной форме отражает характерный уже для первого десятилетия эмиграции разлом в восприятии Достоевского. Идеологизированный взгляд на писателя, редукция его художественных миров к философским системам, политизация его творчества вызывают у некоторых эмигрантов протест. $\kappa$ примеру, желающие интегрироваться во французскую литературу Борис де Шлёцер, Владимир Вейдле или Владимир Познер ${ }^{11}$ демонстративно отказывались от национальной логики в рассуждениях о Достоевском. Позднее, уже на рубеже 1920-1930-х годов, молодые эмигрантские писатели в Париже, авторы журнала «Числа», преодолевали эту заданность рецепции в своих личных «текстуальных» встречах с автором «Записок из подполья». ${ }^{12}$

8 Степун Ф. А. Пореволюционное сознание и задача эмигрантской литературы $<1935>/ /$ Критика русского зарубежья: В 2 ч. М., 2002. Ч. 1 / Сост., предисловие, преамбулы, прим. О. А. Коростелева, Н. Г. Мельникова. С. 249.

9 «Трудно, почти невозможно сейчас говорить о Достоевском с русскими людьми, со своими, а с чужими, с европейцами - еще труднее, еще невозможнее. Ведь русская литература для нас, потерявших родину, - родина последняя, все, чем Россия была и чем она будет. Но между „была“ и „будет“ — „есть“. Как преодолеть это „есть“? Как его принять или отвергнуть? Кто это может, кто смеет? Русская литература для нас то же, что для древнего Израиля — „Закон и Пророки“. Исполнился ли наш „Закон“? Исполнятся ли наши „Пророчества“? Не только говорить об этом с чужими, но и думать наедине с самим собою - все равно, что перевертывать нож в ране. Русская литература — „Закон и Пророки“ для нас. А для европейцев что?» (Мережковский Д. С. Федор Михайлович Достоевский. 1821-1921 // Руль. 1921. 11 нояб. № 300. С. 4).

10 Яновский В. С. Челюсть эмигранта. Нью-Йорк, 1957. С. 19.

11 В. Познер, сотрудничавший с французским журналом «Новости литературы, искусства и науки», в заметке о Достоевском 1926 года обыгрывает национальные стереотипы, сложившиеся и во Франции, и в России, и, вероятно, специально принижая значение русского писателя, замечает: «Еще раз, Достоевский не пророк и не Мессия, а писатель (я не перестану это повторять), который появился не как deux ex machina» (Pozner V. L'ame slave et l'esprit gaulois // Nouvelles littéraires, artistiques et scientifiques. 1926. № 193. June 26. Р. 6). Здесь и далее, за исключением особо оговоренных случаев, перевод мой. - В. Д.

12 Борис Поплавский ставит в один ряд Достоевского, Л. Н. Толстого и Дж. Джойса: Поплавский Б. Ю. По поводу... // Поплавский Б. Ю. Собр. соч.: В 3 т. М., 2009. Т. 3. С. 83. 
В контексте этого противостояния должен восприниматься и «Достоевский» А. Жида.

Основной костяк книги Зћида составляют шесть лекций, прочитанные французским писателем в театре «Vieux Colombier» («Старая Голубятня») в феврале-марте 1922 года. Толчком к написанию этих лекций послужила просьба Ж Жака Копо выступить на праздновании столетия со дня рождения Достоевского, которое состоялось 24 декабря 1921 года в зале той же «Старой Голубятни». Вначале ЖЖид воспринимал это как обузу, поскольку был занят другими планами. Затем он извлек плюсы из этой затеи, поскольку занятия Достоевским вдохновили его собственную работу над «Фальшивомонетчиками». В конце концов Жид «начинает бояться, что он не сможет сказать достаточно. Копо запланировал в дополнение к чтениям несколько выступлений; 15 декабря Зћид жалуется Алиберу: „Я готовлю речь о Достоевском для Копо; но нас пятеро (из которых трое русских), которые будут выступать; у меня не хватит времени сказать ничего интересного“». ${ }^{13}$

Всего прозвучало четыре выступления: речи Андре ЖЖида и Андре Сюареса (зачитанная Копо), ${ }^{14}$ а также речи двух, а не трех, как в письме Зћида, русских - Константина Бальмонта ${ }^{15}$ и Мережковского. ${ }^{16}$

Текст выступления Бальмонта и краткое описание празднования публикуются в «Последних новостях» 27 декабря 1921 года. Автор обзора - Борис де Шлёцер, музыкальный и литературный критик, писатель, с 1921 года живущий в эмиграции. Он известен также как переводчик, в том числе Достоевского и Льва Шестова, на французский язык.

Шлёцер из всего празднования особенно выделяет речи Сюареса и Жиида. Наиболее ценным в первой ему представляется «настойчивое указание на мировое значение Достоевского; Сюарес не отнимает его у нас, но стремится приблизиться к Западу, пытается показать, что Достоевский, великий русский, был и великим европейцем, что дорог он и нужен западному человеку не менее, чем русскому». ${ }^{17}$ Однако самым значительным событием праздника остается для Шлёцера речь А. ЖКида: «Западный роман, указывает Жид, за редкими исключениями, занимается отношениями людей между собой; Достоевский же занят исключительно отношениями личности к самой себе и к Богу. Существование каждого из героев Достоевского, его поступки, слова, события даже, в которые он втянут, суть функции его интимной сущности. Но для западного психологического или реалистического романа отношение как раз обратное. Величайшее же чудо искусства Достоевского ЗЖид видит в том, что несмотря на перегруженность их мыслью, персонажи его всегда конкретны, всегда полны жизни. У него действуют не типы и не символы, но индивидуумы...». ${ }^{18}$

13 Masson P. Notes // Gide A. Essais critiques. Paris, 1999. P. 1156 (Bibliotheque de la Pleiade).

${ }_{14}$ Cм.: Suarès A. Centenaire de Dostoïevski // Les Écrits nouveaux. 1922. T. 9. № 1. P. 15-31.

15 См.: Бальлонт К. Д. О Достоевском <1921> // Русские эмигранты о Достоевском. С. 20-24.

16 Основываясь на отзыве Шлёцера и обзоре Поля Судэ, можно предположить, что имеется в виду эта речь: Мережковский Д. С. Речь на митинге в Сорбонне // Общее дело. 1921. 25 дек. № 525. C. 2. Ср. с отзывом Судэ: «Но верующие продолжали служение с почтительной преданностью, и проповедники не жалели слов для панегириков. Русский поэт Константин Бальмонт сказал, что имя Достоевского в истории сопоставимо только с именем Коперника. Русский писатель Мережковский воскликнул: „Россия - свет Востока! Франция - свет Запада!“ И именно с Достоевским он связал великую роль, которую приписывает своей родине. Г-н Андре Сюарес, чье выступление было зачитано г-ном Копо, сообщил нам, что автор книги „Преступление и наказание“ стал значимее Вагнера, Бетховена, Ибсена, Л. Толстого и Гете, и, кроме всех прочих, нашего Флобера. Андре ЗЖид принес в жертву Бальзака и объявил Достоевского величайшим романистом. Короче говоря, апофеоз состоялся» (Souday P. Le ceintenaire de Dostoïevsky // Le Temps. 1921. 29 déc. № 22062. P. 3).

17 Шлёиер Б. де. Памяти Достоевского // Последние новости. 1921. 27 дек. № 521. С. 2.

18 Там же. 
Критик в речи ЖЖида выделяет две идеи: 1) у Достоевского центральный сюжет связан не с социальными отношениями, а с обращенностью к внутреннему «я» и связи этого «я» с Богом; 2) персонажи романов Достоевского конкретны, идеи есть выражение их интимной сущности, но не наоборот. Именно эти две идеи станут лейтмотивом в формировании отношения эмиграции к «Достоевскому» Жида.

К речи Мережковского Шлёцер относится настороженно: «Д. С. Мережковский говорил, конечно, о... большевиках, о „сбывшихся“(?) пророчествах Достоевского, о совершившейся „гибели“ (??) России и припомнил слова Достоевского о „ненависти Европы к России“ (было вставлено ограничение Европа за исключением Франции). Сюарес говорил, как талантливый ритор, Андрэ ЖЖид - как художник-психолог и аналитик, К. Д. Бальмонт как поэт, речь же Мережковского была типичной эмигрантской речью» ${ }^{19}$

Поиск «своего» «Достоевского» в эмиграции и будет в некоторой степени движим желанием прекратить такую «типичную эмигрантскую речь», и в этом преодолении дискурсивной инерции Жид сыграет не последнюю роль.

Шлёцер был к концу 1921 года уже вхож во французские круги и, в частности, сотрудничал с журналом «Nouvelle Revue Française». Именно он, как известно, посоветовал Жаку Ривьеру, который на тот момент был редактором журнала, обратиться к Льву Шестову с просьбой предоставить материал для блока, посвященного Достоевскому. В февральском выпуске журнала за 1922 год публикуется речь Жида на столетие Достоевского, эссе Жака Ривьера «О Достоевском и неисследимом», два письма Достоевского и фрагмент «Преодоления самоочевидностей» Шестова в переводе Шлёцера.

Известно, что ЗЖид был по-настоящему впечатлен текстом Шестова и пригласил его на свои лекции в феврале-марте 1922 года. Впоследствии они встречались на декадах в Понтиньи в 1923 году. ${ }^{20}$ В одном письме Шестов пишет, в частности: «И Du Bos и Gide очень интересно говорили. Поразило меня тоже отношение французов к русским и к русской литературе. Всё знают, во всем чудесно разбираются - и как всё любят. Я прислушивался к частным разговорам за столом или в отдельных группах и часто ушам своим не верил. Когда еще восхваляют Достоевского - куда ни шло. Может быть, это мода, да Достоевский уже давно известен. Но послушали бы, что и как говорят о Чехове. „Скучная история“ вышла всего два месяца тому назад, и все уже ее читали, превосходно, до мелких деталей всё помнят и понимают лучше, чем патентованные русские критики». ${ }^{21}$

Шестов на декадах в Понтиньи удивляется проницательности французов, говорящих о русской литературе, в то время как Б. П. Вышеславцев в том же году слагает вариации на тему национальных трюизмов: «Русская стихия она чувствуется каждым русским, как непонятная и непередаваемая иностранцам сущность русской души, русского характера, русской судьбы, даже русской природы». ${ }^{22}$

В 1923 году в «Современных записках» выходит обзор Шлёцера «Новейшая литература о Достоевском», который посвящен трем опубликованным в этом году книгам: «Эстетике Достоевского» И. И. Лапшина (Берлин, 1923),

19 Там же.

20 Баранова-Шестова Н. Жизнь Льва Шестова. Париж, 1983. С. 220, 230-233. Краткое описание отношений Жида и Шестова, а также сравнение их методов в интерпретации Достоевского см.: Tabachnikova O. Dialogues with Dostoevsky from Two Corners: Lev Shestov versus André Gide // New Zealand Slavonic Journal. 2008. Vol. 42. P. 55-76.

21 Цит. по: Баранова-Шестова Н. Жизнь Льва Шестова. С. 263. C. 61 .

22 Вышеславиев Б. П. Русская стихия у Достоевского // Русские эмигранты о Достоевском. 
«Русской стихии у Достоевского» Вышеславцева и «Миросозерцанию Достоевского» Н. А. Бердяева.

«Не юбилейными торжествами, конечно, - начинает он, - объясняется расцвет за последние два, три года литературы о Достоевском и возросший всюду интерес к его творчеству. <...> Все мы, хотим ли этого или не хотим, ориентируемся по Достоевскому, отношение наше к нему является определяющим для каждого из нас...»..$^{23}$ Во всех трех рецензируемых книгах, считает Шлёцер, игнорируется Достоевский-художник, во всех трех книгах идеи разбираются отдельно от персонажей, их выражающих: «Достоевский не есть вовсе художник плюс психолог, плюс метафизик, плюс пророк; нельзя точно так же рассматривать художественные его образы в качестве воплощения его идей, и видеть гений его именно в том, что он сумел придать отвлеченным идеям живую конкретность. <...> Не о воплощении в образах теорий и идей нужно говорить применительно к творчеству Достоевского, но, наоборот, о возникновении теорий, идей через конкретный образ в его развитии, обусловленном эстетически, т. е. формально <...> Когда, следовательно, Бердяев говорит, что „жизнь идей пронизывает его художество“, то, думаю, правильнее было бы сказать: „жизнь его художественных образов пронизывает его идеи “». ${ }^{24}$

Шлёцер противопоставляет бердяевскому тезису ту самую идею ЗЖида, которую он подчеркнул два года назад в очерке по поводу празднования столетия. Ср. в книге французского писателя: «Идеи Достоевского почти никогда не являются абсолютными; они почти всегда соотнесены с его персонажами, которые их выражают, и даже более того: они соотнесены не только с этими персонажами, но и с определенными мгновениями в жизни этих персонажей; они, так сказать, достигаются своеобразным и преходящим состоянием того или иного персонажа; они всегда относительны; всегда находятся в прямой зависимости от факта или какого-либо поступка, который они обусловливают или который обусловливает их». ${ }^{25}$

Жћид, в частности, приводит в пример Ипполита Терентьева и Кириллова, идеи которых не существуют вне персонажей, но рождаются перед лицом смерти, на которую герой обречен или обрекает себя. Он также обращает внимание, что самые пронзительные мысли князя Мышкина окрашены предчувствием падучей. Таким образом, Шлёцер, специально не оговаривая это, противопоставляет трем рецензируемым авторам то, что он почерпнул у Жида.

Ту же мысль о «жизни идей-образов» подхватывает и Владимир Вейдле в заметке 1930 года «Европейские судьбы Достоевского» .

Вейдле отмечает странный парадокс в том, как складывается рецепция Достоевского в Европе. Повсеместному признанию сопутствует повсеместное недопонимание. Виной этому отчасти плохие переводы, отчасти сама манера толкования, которая заставляет авторов объяснять сложности художественных

${ }^{23}$ Шлёиер Б. Ф. Новейшая литература о Достоевском // Современные записки. 1923. T. XVII. C. 451 .

24 Там же. С. 458-459.

25 Жид А. Достоевский / Пер. с фр. А. В. Федорова // Жид А. Собр. соч.: В 7 т. М., 2002. Т. 6. С. 287. Любопытно, что в трактовке жизни идей Жћид сближается с М. М. Бахтиным, в 1929 году издавшим «Проблемы творчества Достоевского». Ср., к примеру: «Поэтому не жизнь идеи в одиноком сознании и не взаимоотношения идей, а взаимодействие сознаний в medium'е идей (но не только идей) изображал Достоевский» (Бахтин М. М. Проблемы творчества Достоевского // Бахтин М. М. Собр. соч.: В 7 т. М., 2000. Т. 2. С. 41). На близость представления о жизни идей у Жида и Бахтина сразу же обращают внимание в исследовательской литературе: Бережков Ф. Ф. Достоевский на Западе (1916-1928) // Достоевский. М., 1928. С. 291 (Тр. Государственной академии художественных наук). 
миров Достоевского падучей или «славянской душой». Но европейцы «заблуждаются относительно Достоевского не потому, что не умеют воспринимать его так, как его воспринимаем мы, а наоборот, именно потому, что они слишком воспринимают его, как мы, слишком заражены некоторым средним истолкованием, некоторой вульгарной догмой о Достоевском, разжеванной, разболтанной уже в России». ${ }^{26}$

Такой комплекс превосходства рождает в русских пренебрежение к европейским книгам о Достоевском. В том числе именно это предубеждение, считает Вейдле, помешало русским оценить по достоинству книгу Жида о Достоевском: «Я говорю о „Достоевском“Андрэ Зћида. Книга эта нова уже тем, что Достоевский для Жида - художник прежде, чем мыслитель, а если мыслитель, то неотделимый от художника. Слишком долго в Европе, как отчасти и у нас интерес к тому, что считали идеями Достоевского, опережал понимание его произведений: слава его надолго приросла к этим тощим результатам рассудочного истолкования. Слишком долго хотели в нем видеть союзника или антипода Ницше, апостола „религии страдания“, проповедника панславизма, даже криминалиста или психиатра. Созданных им людей принимали за подставных лиц философского диалога. Со всем этим порывает Жћид. Он понимает, что мысли Достоевского существуют не иначе, как в его мире и в душах его людей, что борьба этих душ, изображенная им, не обмен отвлеченных мнений. Он не будет отрицать религиозной обусловленности „Братьев Карамазовых“ и „Бесов“, но он знает, что художник, создавая их, не насилует нашего суждения односторонним выводом, а открывается нам и являет нам правду во всей конкретной сложности души. В намерении книги Достоевского могут быть „тенденциозны“; в осуществлении - они сами собой перерастают всякую тенденцию.

Все это не значит, что Жћид понимает Достоевского слишком формально, или „артистично“. Именно потому, что с идей Достоевского он отказывается совлекать их художественную плоть, он так по-своему проникает в них и так питает ими свое искусство». ${ }^{27}$

Вейдле убежден, что всем, и европейцам, и русским, «предстоит окончательно отучиться видеть в Достоевском публициста, идеолога, человека партии». И потому следующий шаг в рецепции должен быть утверждением единого поля интерпретации, когда русские и европейцы откроют, что у них «один и тот же Достоевский».

Итак, кроме того, что Вейдле здесь воспроизводит уже упомянутую мысль Жћида, в его эссе появляется и второй мотив, характерный для восприятия Достоевского, где книга Жида - опосредующее звено. Это мотив общемирового Достоевского, разговор о котором должен быть освобожден от национальной риторики.

В эмиграции в 1920-е годы активно выстраивалась оппозиция русское западное, и Жћида могли критиковать как пошлого писателя на фоне русской традиции, как это делал Кирилл Зайцев, а могли, напротив, как бы придавать ему черты, которые в эмигрантской риторике признавались за русскими писателями. ${ }^{28}$

${ }_{26}$ Вейдле В. В. Европейские судьбы Достоевского // Возрождение. 1930. 20 марта. № 1752. С. 3.

27 Там же.

28 «В 1926 году, как мы видели, Кирилл Зайцев критиковал „Les Faux-Monnayeurs“ за эстетскую изысканность и отсутствие одухотворенности. В 1930 Адамович наделяет роман Зћида „русскими“ качествами, используя ту же логику и терминологию. Критики столкнулись на Франко-русской студии. Оба аргументировали свое мнение, утверждая наличие или отсутствие „русских“ качеств в наследии Жида, и никогда не оставляли систему оппозиций: искренность искусственность, психологическая глубина - эстетская поверхностность, человечность - литература. Оба взывали к Достоевскому как проверке „качества“ Жиида” (Livak L. How It was Done 
К примеру, Константину Мочульскому в эссе «Андре Жһид» 1927 года французский писатель интересен прежде всего не за счет писательского своего таланта, который Мочульский ставит не очень высоко, а за счет искренности и интенсивности переживаемой религиозной трагедии, которую ЖЖид описал в автобиографии. «И в этом зрелище трагедии, в самом чистом ее смысле, трагедии глубоко религиозной - заключается действенность творчества Жида» .

Зћид в литературе «проповедник беспокойства». Из тяготения к беспокойству черпает силы «интерес ЖКида к русской литературе и, в частности, к Достоевскому. В своей книге о последнем Жћид обнаруживает громадную остроту и проницательность. Его волнует проблема зла у Достоевского, его „встревоженность“ и религиозная настороженность. Не стремясь к объективности (Жид неоднократно восставал против этого ложного понятия), он берет у Достоевского только то, что ему близко. В изложении Жћида христианство Достоевского упрощается и теряет свою характерно-православную окраску; но „дух“ Достоевского понятен протестанту Жиид, и образ автора „Бесов“, несколько схематизированный, не искажен». ${ }^{29}$ Жид хоть и упрощает, по мнению Мочульского, Достоевского, но не искажает его.

В схожем ключе высказывается о французском писателе и Георгий Адамович на шестой встрече Франко-русской студии, проходившей 25 марта 1930 года и целиком посвященной Ж Жиду. Между прочим, прочитавший эту речь ЖЖид отметил в дневнике 30 мая того же года: «Запомним имя Георгия Адамовича. Никто не говорил о моих книгах лучше, чем он».$^{30}$

Показательно, что Адамович обсуждает в своей речи прежде всего книгу «Достоевский» .

Вопросы, которых касается ЗҺид в своих лекциях, по наблюдению Адамовича, те же, что волнуют и самого французского писателя. «Что есть человек? Откуда он пришел? Куда он идет? Что было до его рождения? Что станет с ним после смерти? На какую истину он может претендовать? Что есть истина? ${ }^{31}$ Сила Жида и сила Достоевского в том, чтобы снимать постепенно покровы со всех присущих человеку мифологий, пока не останется что-то, "что располагается на самой глубине человеческого сознания, что неподвластно гниению». ${ }^{32}$ Жид, как считает Адамович, черпает эту силу из Евангелия. Но принятие евангельской истины имплицитно для Адамовича предполагает анархизм. «Время от времени Евангелие и его дух почти невыносимой свободы в своей необъятности для человеческой души возвращаются на поверхность жизни. Происходит что-то вроде землетрясения - вся цивилизация разваливается, всё должно быть переделано, всё кажется подозрительным».$^{33}$ В этом смысле для Адамовича ЖЖид христианский писатель, как в той же мере христианские писатели Ницше, Ибсен и прочитываемый под этим углом Достоевский. Адамович полагает, что все они, так же как Толстой и Розанов, в споре между беспорядком и несправедливостью предпочли бы беспорядок. «Если мы хотим назвать это анархией, хорошо, хорошо, - продолжает Адамович. - Но понятие анархии остается неясным, если не принимать во вни-

in Paris: Russian Émigré Literature and French Modernism. Madison, 2003. P. 22). См. также: Morard A. Varchavski, Gide, Dostoïevski: lectures croisées // Modèle de Gouvernement: ouvrage collectif. Lyon, 2011 (см.: http://institut-est-ouest.ens-lsh.fr/spip.php?article294; дата обращения: 30.04.2020).

${ }^{29}$ Мочульский К. В. Андре ЖКид < 1927> // Мочульский К. В. Кризис воображения. Статьи. Эссе. Портреты. Томск, 1999. С. 158.

30 Gide A. Journal. 1889-1939. Paris, 1951. P. 984 (Bibliotèque de la Pléiade).

31 Adamovitch G. André Gide // Le Studio Franco-Russe / Textes réunis et présentés par L. Livak; sous la rédaction de G. Tassis. Toronto, 2005. P. 199 (Toronto Slavic library. Vol. 1).

32 Ibid.

${ }^{33}$ Ibid. 
мание множественность и неистовость элементов, подчиненных организации. Обедневший мир легко поддерживается в порядке». ${ }^{34}$

Адамович предлагает моральный взгляд на Жћида как на писателя, который борется против литературы. Конечно, Адамович на протяжении всей жизни с неизменностью возвращается к Достоевскому и противоречиво о нем высказывается, но многие его идеи наследуют тому, как он здесь, на Франкорусской студии интерпретирует Зћида. ${ }^{35}$ Адамович, как и многие русские эмигранты, воспринимал Достоевского неотрывно от катастрофических событий XX века, именно он в одном фрагменте «Комментариев» с сожалением говорит, что Достоевский поторопился родиться, что он «один нашел бы в наши дни вдохновенье для новых „записок“ из нового „подполья“, которые краской стыда легли бы на целую эпоху и на столь дорогое ей понятие прогресса». ${ }^{36}$ В одном фрагменте он использует для характеристики Достоевского слово déraciné, буквально «обескорененный», ${ }^{37}$ словечко, отсылающее к Морису Барресу, но в 1930-е годы уже применявшееся эмигрантами для характеристики своего принципиально нового положения на границе, «на вечном сквозняке». Приведу цитату из Адамовича: «Уже Достоевский был „déraciné“, был существом, вырванным с корнем из бытия. Это ощущение многим знакомо в наши дни, как настоящая „болезнь века“. Можно по-разному его объяснять и находить для него довольно правдоподобные, хотя все-таки всегда приблизительные, всегда огрубляющие социальные обоснования: это по существу не меняет дела... Если представить себе соединительную резинку между „жизнью“ и „идеей о жизни“, то сейчас даже в среднем сознании - или, пожалуй, именно в среднем - резинка болезненно натянута, до пронзительно-звенящего звука при легчайшем прикосновении, - а иногда уже и оборвалась. В этом отчасти - причина популярности Достоевского, в особенности его популярности общедоступно-психологической, скорей как лирика-художника, чем как мыслителя-художника (популярность нервов, а не мозга). Но если Достоевский сейчас царит над „полмиром“, до абсолютной, тиранической единственности для всех тех, кто живет как бы на вечном сквозняке, то потому, что у него каждое слово еще продиктовано болью (памятью об отрыве?). Отзвук же на боль - самый верный и быстрый». ${ }^{38}$

Наконец, совершенно особо воспринял Ж ида в свете его интерпретации Достоевского молодой эмигрант Владимир Варшавский. В журнале «Числа»

34 Ibid. P. 200.

35 Любопытно, что позднее Адамович высказывается о «Достоевском» Жида не столь однозначно. Отчасти это связано с постоянными колебаниями самого Адамовича в его отношении к Достоевскому. См.: «Андре Жид был чрезвычайно умен, и притом его ум у него был не столько творческий, деятельный <...> А на Достоевском он споткнулся. Он читал Достоевского всю жизнь, он питался им и все-таки его недопонял» $(<1953>)$; «Разговор с Андре ЗЖидом с глазу на глаз я, мож но сказать, предвкушал. Но настоящего разговора не вышло. Началось с Достоевского. Мне показалось, что Жћид связывает с ним свою литературную репутацию, именно на него сделав ставку, и воспринимает малейшее критическое замечание о „Карамазовых“ или „Бесах“ как личную обиду. Предположение: не догадывался ли он тогда, не чувствовал ли через двадцать с лишним лет после знаменитых своих лекций о Достоевском в театре „Вье Коломбье“, что кое в чем все-таки ошибся, кое-что просмотрел и, как в таких случаях бывает, не старался ли сам себя переубедить? $(<1961>)$ (Адамович Г. В. Комментарии // Адамович Г. В. Собр. соч.: В 18 т. М., 2016. Т. 14. С. 53, 102).

36 Там же. С. 60.

37 Выражаю благодарность С. Л. Фокину, который предложил этот более точный вариант перевода вместо привычного «беспочвенный». В исследовательской литературе постепенно формируется различение эмиграции и обескорененности (déracinement), т. е. сознательного нарушения и разрушения национальных границ. См. книгу Анник Морар, посвященную интересующему нас периоду: Morard A. De l'émigré au déraciné: La «jeune génération» des écrivains Russes entre identité et esthétique (Paris, 1920-1940). Lausanne, 2010.

38 Адалович Г. В. Люди и книги: Мережковский // Современные записки. 1934. № 56. С. 284285. 
за 1930/31 годы он публикует эссе-манифест «Несколько рассуждений об Андрэ Жћиде и эмигрантском молодом человеке» .

Интерес Варшавского к ЖИиду не интерес критика прежде всего, он основан на своеобразной мифологии своего поколения (Варшавскому, когда он пишет эссе, двадцать четыре года). «В эмиграции, - пишет Варшавский, больше всего должны любить Жћида совсем молодые люди, уехавшие из России еще детьми, помнящие Россию достаточно, чтобы не стать иностранцами, но недостаточно долго в ней жившие, чтобы по примеру старших наполнить воспоминаниями о прошлом ту фантастическую социальную пустоту, в которой приходится жить эмигрантам».$^{39}$

Варшавский, как и Адамович, называет лучшими, главными книгами Жида «Достоевского» и «Numquid et tu?..». В книге Жиида о Достоевском Варшавского интересует, какие три зоны или области Жиид различал в душах героев русского писателя. Приведем цитату из Зћида: «Достоевский как будто вводит в душу человека или просто обнаруживает в ней разные пласты - нечто вроде геологических наслоений. В персонажах его романов я различаю три слоя, три области: область интеллектуальную, чуждую душе, но являющуюся источником самых опасных искушений <...> второй слой область страстей, область, опустошаемая бурными вихрями, которые, однако, не задевают в собственном смысле души его героев, как бы трагичны ни были события, вызванные этими бурями. Но есть область более глубокая, которую страсти не волнуют. Именно эта область дает нам возможность приблизиться вместе с Раскольниковым к воскресению (я беру это слово в том смысле, какой придает ему Толстой), ко „второму рождению“, как говорил Христос. Это сфера, в которой живет князь Мышкин». ${ }^{40}$ Ум, продолжает эту мысль Варшавский, ставит вопрос «что есть жизнь», но сам, один, никогда не способен на него ответить. Именно это и должно стать материей литературы.

Несомненно, Варшавский перетолковывает и Достоевского, и Жида, чтобы ретроспективно включить их в свою собственную генеалогию. ${ }^{41} \mathrm{~B}$ әссе Варшавского рецепция Достоевского получает новое развитие, во многом про-

39 Варшавский В. С. Несколько рассуждений об Андрэ Жиде и эмигрантском молодом человеке // Варшавский В. С. Ожидание: проза, эссе, литературная критика. М., 2016. С. 339.

40 Жид А. Достоевский. С. 309.

41 Плодотворный анализ этого текста Варшавского в контексте литературы «молодой» парижской эмиграции и в связи с Достоевским и Андре Жидом см.: Morard A. Varchavski, Gide, Dostoïevski: lectures croisées. В частности, А. Морар демонстрирует, что Варшавский старается, как и Адамович, вывести на передний план религиозное беспокойство ЖКида и затушевать преклонение французского писателя перед умом. По мысли Жида, «интеллектуальная зона, по определению „демоническая“, играет определенную роль в литературном творчестве, она даже необходима для него. Однако, если Варшавский решительно настаивает на значении Евангелия в мысли Жида, в частности, на основании анализа совершенно незначительной работы, которая называется „Numquid et tu?..“, он, тем не менее, осторожен, чтобы не отметить важность, которую придает Жид „участию демонического“ в литературном творчестве. Это упущение чревато последствиями, о чем свидетельствует очень ограниченный анализ „Paludes“, который предпринимает Варшавский в той же статье» (Ibid). Не думаю, что это до конца справедливо. Конечно, Варшавский «втискивает» Жида в образ поколенческого героя, который только еще конструирует в эссе, но ведь и Адамович и Варшавский пишут не о Жћиде «Болот» (1895), а о ЖКиде автобиографии «Если зерно не умрет...» (1926) и судят о его творчестве по тем религиозным и мировоззренческим «поворотам», которые сам ЗКид описывает, в том числе в «Numquid et tu?..». Кроме того, Варшавский понимает: «...хотя и зная, что ум не может дать реального знания, ЗЖид был все-таки человеком умственной гордости и не мог поверить в какое-то знание, не умственное, превышающее ум» (Варшавский B. C. Несколько рассуждений об Андрэ Жћиде и эмигрантском молодом человеке. С. 338). Варшавский намеренно решил не касаться «всего сомнительного, что есть в Жиие, например, отравы, иронии и сентиментальности, которые чувствуются почти во всех его книгах» (Там же). 
тивопоставленное религиозно-философской критике. Он, а также и другие авторы «Чисел» стремятся увидеть в Достоевском предшественника не в противопоставлении Западу, а, напротив, в координации с современными западными влияниями: «Скажут, что это и есть признак денационализации. Но мне кажется, что эмигрантский молодой человек, с волнением читающий ЗЖида и плохо знающий русскую географию, может быть, ближе к „великодержавному“ стилю русской культуры и менее денационализирован, чем эмигрантский классик Шмелёв, сравнивший как-то Пруста с Альбовым. Ведь в самом деле слишком многие русские вдруг настолько почувствовали себя в Европе „стрюцкими“, что серьезно стараются доказывать, что в России тоже была письменность и вообще по улицам не ходили белые медведи. Первородство русской литературы настолько утверждено именами Толстого и Достоевского, что вряд ли она нуждается в этом охранительном провинциальном патриотизме, противоречащем самому духу всеобщности, всечеловечности и всемирности русской культуры. <...> И не вина эмигрантского молодого человека, что в современной французской литературе больше о бытии, о „ноуменальных вещах“, о „четвертом измерении“, чем в русской литературе сегодняшнего, вернее, вчерашнего дня, и что, например, Жид, несмотря на свою сомнительность, все-таки ближе к Достоевскому, чем кто-либо из современных русских классиков». ${ }^{42}$

В многообразии приведенных в статье частных историй восприятия можно увидеть определенную логику. Книга Жћида - медиатор, позволяющий судить о некоторых закономерностях в борьбе за литературное влияние в эмиграции. Шлёцер решительно противопоставляет Достоевского-художника всем формам его идеологизации в религиозной и формальной критике и находит поддержку в книге Жида. Вейдле видит в книге преодоление узко-национального взгляда на Достоевского. Адамович считает, что главная заслуга французского писателя в освобождении от узко-литературных интересов. Варшавский использует Зћида, чтобы сделать его своеобразным «переходом» от Достоевского к «молодым» эмигрантским писателям, минуя литературных «отцов». Для тех русских эмигрантов, кто признает книгу Жида важным событием в изучении Достоевского, она - в разной степени - союзник в преодолении того, что Вейдле называет «банализированными формулами русской критики», ${ }^{43}$ и одновременно выход к плодотворному художественному анализу Достоевского. ${ }^{44}$

42 Там же. С. 340.

43 Вейдле В. В. Европейские судьбы Достоевского. С. 3.

44 Книгу А. Жида приветствовали и в советской литературе о Достоевском: «Но наряду с такими исследованиями - и чем дальше, тем больше - являются и другие, где искусство Достоевского и его „художественная психология“ оказываются самоцелью. В таких книгах, как Мэрри, Мейер-Грэфэ и Жид, интересно наблюдать не только за головокружительной высотой оценок искусства Достоевского, но - и прежде всего - за строгими сравнительными анализами. Иностранцы сумели показать нам яснее и нагляднее, что Достоевский - зараз и „наиболее европейский“ русский художник (черты сходства с разными наиболее оригинальными писателями и живописцами Европы), и наиболее замечательный среди соответствующих европейцев, потому что в нем столь же характерны специфически русские черты. И если наши литературоведы признают в современной советской литературе наличность тематических и стилистических влияний Достоевского больше, чем кого-либо еще из классиков, то за границей Достоевский оказывается настоящим законодателем стиля и литературных манер» (Бережков Ф. Ф. Достоевский на Западе (1916-1928). С. 325). Конечно, было бы серьезным преувеличением заявлять, что иленно Зиид «открывает» Достоевского-художника русскому читателю, но его плодотворный анализ не в последнюю очередь помогал перевести ракурс на проблемы романа. Русская эмиграция не была, конечно, бедна серьезными научными исследованиями Достоевского: назовем хотя бы знаменитый «Семинарий по изучению Достоевского» под руководством А. Л. Бема. 


\section{К 150-ЛЕТИЮ СО ДНЯ РОЖДЕНИЯ И. А.БУНИНА}

В октябре 2020 года исполняется 150 лет со дня рождения И. А. Бунина. Чуть раньше, в начале февраля минуло 100 лет с того дня, когда Бунин навсегда покинул Россию. Позади него оставалось полвека жизни на родине впереди было еще 33 года жизни в изгнании и ровно половина его творческой жизни. Предлагаемая читателю подборка статей призвана отметить этот двойной юбилей на страницах «Русской литературы». Авторы статей участники рабочей группы по подготовке научной базы для будущего Полного собрания сочинений И. А. Бунина.

Как ни покажется удивительным нашему современнику, полное научное собрание сочинений первого русского нобелевского лауреата по литературе до сих пор остается делом будущего. Выпущенные в СССР собрания Бунина полными быть не могли. В 2000 году был издан Каталог Бунинской коллекции, ${ }^{1}$ состоящей из материалов так называемого «Парижского архива» Бунина (за исключением тех, которые его вдова передала в свое время советской стороне), и начался новый этап изучения его жизни и творчества. За последнее двадцатилетие вышло множество публикаций и специальных сборников, посвященных Бунину, задачей следующих лет видится дальнейшее освоение его литературного наследия и, в первую очередь, подробная разработка принципов того издания, которым Бунин должен быть представлен в истории русской литературы.

Публикуемые ниже статьи не только соотносятся с разными этапами жизни и творчества Бунина, но и фокусируются на разных аспектах и источниках. В статье О. А. Коростелева о взаимоотношениях писателя с «первым критиком» русской эмиграции Г. В. Адамовичем дан портрет Бунина в зеркале современной ему критики на протяжении всей второй половины его литературного пути. Находка А. В. Бакунцевым бунинских автографов в Государственном центральном театральном музее им. А. А. Бахрушина напоминает о том, что поиск материалов писателя в тех или иных архивах может и должен быть продолжен, в сочетании с документами «основных» архивных собраний Бунина он сулит прояснение прежде отрывочных данных о тех или иных эпизодах и линиях его жизни. В работе Т. М. Двинятиной, с опорой прежде всего на биографические источники, обозначен решающий в жизни Бунина перелом революционных лет, который привел и к новой повествовательной манере, ставшей высшим достижением его творчества. Главный вопрос нынешнего этапа подготовки научного собрания - выбор основного текста для прозаических произведений - положен в основу исследования С. Н. Морозова и решается здесь на материале одного из ключевых бунинских рассказов, «Цикады». На этом примере становится понятной задача, стоящая перед рабочей группой будущего Полного собрания сочинений Бунина: проследив по всем сохранившимся источникам творческую историю каждого произведения, сформулировать общие правила и принципы подачи текстов, которые были бы релевантны для возможно большего числа произведений и сегментов

1 Heywood A. J. Catalogue of the Bunin, Bunina, Zurov, and Lopatina Collections / Ed. by Richard D. Davies, with the assistance of Daniel Riniker. Leeds: Leeds University Press, 2000; последние версии каталога и указателя см.: http://explore.library.leeds.ac.uk/multimedia/6902/ BuninCatalogue2012.pdf; http://explore.library.leeds.ac.uk/multimedia/16934/LRA_MS1066_Bunin_ Index.pdf; дата обращения: 30.04.2020. 
бунинского наследия. То, что в этом наследии скрыты пока малоизвестные и существенные для всего художественного мира и метода Бунина пласты, ясно демонстрирует статья Е. Р. Пономарева: в ней идет речь о рассказах, тематически, стилистически и хронологически примыкающих к тем, которые Бунин объединял названием «Темные аллеи» .

Взятые в совокупности, представленные публикации можно рассматривать как проекцию той систематической работы по собиранию бунинского наследия, которая отражается на созданном недавно сайте ivbunin.ru («Академический Бунин»).

Эти строки, как и публикуемые ниже статьи, писались до страшного известия, пришедшего 20 марта 2020 года. Умер Олег Анатольевич Коростелев, автор одной из нижеследующих работ и крупнейший исследователь русской литературы XX века. Потеря эта невосполнима. Собиратель огромного наследия, разбросанного по разным архивам мира, редактор и издатель фундаментальных серий и томов, инициатор и опора едва ли не всех начинаний, связанных с публикациями текстов и осмыслением судеб русской литературы в изгнании, он воссоздал архипелаг русской эмиграции. И он был не только лучшим ее знатоком, но и абсолютно надежным и легким товарищем, коллегой, который без лишних слов брал на себя наиболее трудные задачи. Рыцарственность, несгибаемая и невозмутимая, деловая и веселая одновременно, превращала совместную работу с ним в радость, внушала уверенность, создавала и основу, и перспективу, необходимые для нынешних и будущих исследований. О. А. Коростелевым была проделана колоссальная работа и для изучения творчества и жизни И. А. Бунина: от публикаций бунинского эпистолярного наследия в редактируемых им альманахах "Диаспора» до капитальных томов редакционной переписки журнала «Современные записки», от сборников «И. А. Бунин. Новые материалы» до академических томов «Литературного наследства» (только что вышла в свет первая книга бунинского тома, отредактирована вторая, готовятся третья и четвертая...). «Когда человек умирает, изменяются его портреты...» - особенно для тех, кто знал его, для кого он жив... Так хочется, чтобы название публикации О. А. Коростелева, которой мы открываем юбилейный бунинский блок, было провидческим...

T. М. Двинятина, С. Н. Морозов, Е. Р. Поноларев, А. В. Бакуниев

()

\section{«СМЕРТИ НЕТ!»: Г. В. АДАМОВИЧ О И. А. БУНИНЕ}

Взаимоотношения Г. В. Адамовича и И. А. Бунина уже освещались в научной печати. Однако сложную эволюцию взглядов «первого критика эмиграции» ${ }^{1}$ на творчество первого прозаика Русского Зарубежья пока что никто

* Работа выполнена при поддержке гранта РФФИ (проект № 19-012-00290).

1 Таким титулом Адамовича наградил именно Бунин, см.: Лит. наследство. 1973. Т. 84: Иван Бунин: В 2 кн. / Ред. А. Н. Дубовиков и С. А. Макашин при участии Т. Г. Динесман. Кн. 1. С. 679. 
подробно не рассматривал. Между тем все было не так просто, как может показаться на первый взгляд.

Адамович писал о Бунине множество раз, его перу принадлежат десятки рецензий, статей, заметок и публикаций, посвященных Бунину, не считая упоминаний в обзорах. ${ }^{2}$ Однако это совсем не значит, что он всегда отзывался о живом классике одинаково ровно.

Во-первых, Адамовичу было свойственно всякий раз, берясь за перо даже по одному и тому же поводу, не повторять то, что он уже говорил, а рассматривать любое литературное явление с разных сторон, открывая в нем, в том числе и для себя самого, все новые повороты и нюансы, так что его подчас считали критиком, который легко меняет ракурсы и оценки.

Во-вторых, Адамович принадлежал совсем к другому поколению писателей, и долгое время разница в мировоззрениях брала верх над теми общими основаниями, на которых они могли бы сойтись.

Формально их знакомство могло бы произойти еще в России, но помешала именно эта принадлежность к разным литературным кругам. Незадолго до своей смерти Адамович вспоминал о встрече с Буниным в петербургском «Привале комедиантов» весной 1917 года: «Помню, у меня и в мыслях не было: подойти к нему, представиться, познакомиться. <...> Стихов Бунина мы недолюбливали: их в нашем кругу, среди друзей и учеников Гумилева, не „полагалось“ любить. Я читал „Деревню“ и „Суходол“, прочел и перечел „Господина из Сан-Франциско“. Да, хорошо, говорил я себе, но не в той плоскости хорошо, как бы не в той тональности хорошо, чтобы именно побежать за ушедшим автором, сказать ему несколько слов, похожих на объяснение в любви. Теперь, вспоминая это, я, конечно, отдаю себе отчет, как условны были эти литературные перегородки, как много было за ними ребячества, самодовольства, игры, слепоты. Но в ранней молодости без игры и заблуждений обойтись трудно». ${ }^{3}$ Настоящее знакомство произошло десятью годами позже, уже в эмиграции, а общие интересы возобладали и вовсе лишь после войны.

Первая статья Адамовича о Бунине появилась в газете «Звено» еще до их знакомства, 11 февраля 1924 года, через несколько месяцев после того, как Адамович приехал в Париж. Это была одна из его первых эмигрантских статей и первая «именная», т. е. посвященная отдельному автору, до этого он публиковал в «Звене» только обзоры, «Заметки поэта» и «Литературные размышления». И открывалась она констатацией факта: «Это единственный из настоящих писателей послечеховского поколения, оставшийся вполне чуждым и даже враждебным тому позднеромантическому вихрю, который пронесся в нашей литературе в последнюю четверть века и который был назван декадентством, модернизмом и многими другими, столь же условными именами». ${ }^{4}$ Это и был главный пункт расхождений, надолго определивший их взаимоотношения и так никогда до конца и не устраненный: Адамович считал себя человеком Серебряного века, а Бунин эту эпоху откровенно недолюбливал. ${ }^{5}$ Конфликты из-за столь разных подходов были неминуемы, и как только предоставлялся повод, Адамович заметно оживлялся. «Митина любовь» показалась ему нехарактерной для Бунина и даже в чем-то модернистской, о чем

2 См. библиографический список (35 позиций): Переписка И. А. и В. Н. Буниных с Г. В. Адамовичем (1926-1961) / Публ. О. Коростелева и Р. Дэвиса // И. А. Бунин: Новые материалы. М., 2004. Вып. 1 / Сост., ред. О. Коростелева и Р. Дэвиса. С. 8-9. 137.

${ }^{3}$ Адалмвич Г. В. Бунин: Воспоминания // Новый журнал (Нью-Йорк). 1971. № 105. С. 115-

4 Адалович Г. В. О Бунине // Звено (Париж). 1924. 11 февраля. № 54. С. 2.

${ }^{5}$ Подробно об этом см.: «Литература последних годов - не прогрессивное, а регрессивное явление во всех отношениях...»: Иван Бунин в русской периодической печати (1902-1917) / Предисловие, подг. текста и прим. Д. Риникера // И. А. Бунин: Новые материалы. Вып. 1. С. $402-563$. 
он тут же не преминул написать: «Я никогда не считал Бунина парнасцем. Но мне казалось после „Розы Иерихона“, что Бунин все ближе подходит к Толстому, в смысле сурового осуждения человека, в смысле неснисхождения к его слабостям, отбрасывания этих слабостей как чего-то недостойного и гадкого. „Митина любовь“ меня удивила. <...> По теме повесть Бунина напоминает гамсуновскую „Викторию“, она так же трагична и слегка „форсирована“, чуть-чуть по-декадентски и уж совсем не по-толстовски» ${ }^{6}$

Вплоть до самой войны Адамович к Бунину относился настороженно. 28 сентября 1935 года Адамович в письме М. Л. Кантору объяснял, что ему не нравится в составляемой ими антологии эмигрантских стихов «Якорь»: «В сущности, дурное впечатление создается не от антологии, а от самих авторов: много дурных стихов (Бальмонт! Бунин! и т. д.) - но что мы тут можем сделать!». ${ }^{7}$

И если такое суждение о бунинских стихах можно объяснить разным пониманием поэзии, то отзыв Адамовича о прозе Бунина списать на отношение конкурента не получится.

Свою статью о Бунине, которой он намеревался открыть цикл статей об эмигрантской литературе в «Современных записках», Адамович начал с неожиданного суждения: «Бунин. Каждый из нас знает, что говорится против него. Кое-что верно. „Декаденты“ не простили ему упорной, насмешливой вражды, и так как в конечном счете за ними осталась победа, Бунин теперь расплачивается...». ${ }^{8}$

Правда, продолжение абзаца ставило под сомнение сказанное ранее: «Впрочем, не совсем ясно, кто победил. (В особенности, если принять во внимание советскую Россию.) Только правильно то, что художник, которому в девяностых годах прошлого столетия было двадцать лет, должен был быть декадентом. Хоть не долго, хоть одним краем души. Был же не только бред, был и опьяняющий воздух братства в открытиях, содружества в служении высокой новизне, были догадки, проблески и „шорохи“, которые потом, много позже, перед войной, мы еще доглядывали и дослушивали. Если из всего этого ничего не вышло, то разве это довод? Ни из чего ничего не выходит: все только приносится в жертву».$^{9}$

У Адамовича не было сомнений, что творчество Бунина «в области чистой „беллетристики“ это лучшее наше достояние со времен Толстого». ${ }^{10}$ Однако он не мог понять, как можно было, оставаясь большим художником, пройти мимо того, что составляло в глазах Адамовича самую суть эпохи. «Серная кислота ничего в душе Бунина не разъела, он ни в чем не усомнился. Иногда за некоторыми бунинскими фразами чувствуется этакий отрывистый, энергичный командирский басок: „здоровье государя императора!“». ${ }^{11}$

Бунина статья возмутила, см. его переписку с В. В. Рудневым в октябреноябре 1935 года: ${ }^{12}$ «Как странно написал обо мне Адамович! Откуда он взял, что меня в молодости „задавила темная, сонная матушка-Русь“ и что истинной бедой было для меня в то время не приобщение мое к тем, кои (будто бы

${ }^{6}$ Адалович Г. В. Литературные беседы // Звено (Париж). 1925. 13 июля. № 128. С. 2.

7 Вокруг «Якоря»: Из архива М. Л. Кантора / Публ. О. Коростелева и А. Устинова // Якорь: Антология зарубежной поэзии / Сост. Г. В. Адамович и М. Л. Кантор; под ред. О. Коростелева, Л. Магаротто и А. Устинова. СПб., 2005. С. 273.

8 Адалович Г. В. Лица и книги // Современные записки. 1933. № 53. С. 324.

9 Там же. С. 324-325.

10 Там же. С. 326.

11 Там же. С. 333-334.

12 «Если хотите меня печатать, терпите»: И. А. Бунин / Публ. и прим. О. А. Коростелева и М. Шрубы; вступ. статья О. А. Коростелева // «Современные записки» (Париж, 1920-1940). Из архива редакции: В 4 т. / Под ред. О. Коростелева и М. Шрубы. М., 2012. Т. 2. С. 871-873. 
одни) чуяли тогда некие „новые шорохи в мире“? Точно только и света в [окошечке] окошке было, что они одни! Точно нельзя было иметь свои собственные „шорохи“!». ${ }^{13}$

Руднев успокаивал Бунина 29 октября 1933 года, заверяя, что ничего дурного редакция и в мыслях не имела: «Правы ли Вы, Иван Алексеевич? Ад[амович] мне тоже достаточно противен, и персонально, и в качестве представителя - даже не течения литературного, а - особой породы литераторов, без гроша за душой. Но нельзя отрицать, он умен, образован, талантлив. Конечно, в душе - он враждебен Бунину, но тем важнее, если и враг должен признать огромность его таланта. Он не во всем справедлив, - Вы совершенно верно отметили вздорность его утверждения о „шорохах“, „стреле“. Но надо было все же журналу помещать такую статью о Бунине? Без колебания говорю - надо. Ад[амович], правильно или неправильно, но все же ищет место Бунина на звездном небе русской литературы. Пусть выполнение не лишено пристрастия, - само задание важно, нужно».$^{14}$

Бунин в результате успокоился и написал Рудневу 2 ноября 1933 года: «Про Адамовича я никак не хотел сказать, что „недоволен“ помещением его статьи, - я, во-первых, никогда не позволил бы себе сказать такую вещь редакции, а во-вторых, разве мало в статье и лестного? Я просто так, честно, по-дружески делился с Вами кое-какими соображениями о некоторых ее глупостях; я Вам как редактору решился заявить только одно маленькое „недовольство“ - насчет „государя-императора“, явно ни к селу ни к городу пристегнутого к моему художеству». ${ }^{15}$

Адамович был человек раннего созревания, но позднего взросления, многие его высказывания дореволюционных и межвоенных лет этим объясняются. Нередко его развязность вызвана застенчивостью, а скороспелые высказывания - необходимостью регулярно сочинять и сдавать в редакцию нужное количество строк. Однако суть расхождений Бунина с декадентами Адамович понимал очень хорошо: «Бунин в этом отношении покорный ученик Толстого, - и если вернуться к его распре с декадентами, не здесь ли придется искать и корень ее? Те, как блудные сыновья, отправились в далекую, изнуряющую прогулку. Он остался дома... Хорошо было уйти и возвратиться. Но мало у кого нашлись на это силы, да и разлюбить прелести и соблазны „тех долин“ нелегко. <..>> Бунин на всех этих путешественников поглядывает искоса, с иронией. Ему-то „возвращаться“ некуда. Он никогда не обманывался насчет того, чем кончатся эти блудные прогулки». ${ }^{16}$

В длительной полемике главными пунктами расхождения были кумиры Адамовича А. А. Блок и И. Ф. Анненский, которых Бунин не желал признавать и частенько подтрунивал над Адамовичем за то, что тот читал лекции о них, С. А. Есенине или О. Э. Мандельштаме.$^{17}$ Но чаще всего Бунин предъявлял претензии не конкретным авторам, а всему Серебряному веку, модернизму; в его записях и маргиналиях, сделанных для себя, а не для печати, ${ }^{18}$ говорится об этом с предельной откровенностью. Бунин был убежден: «Гумилев и все добывали славу позой, ролью, мошенничеством».$^{19}$

13 Там же. С. 871.

14 Там же. С. 872.

15 Там же. С. 873.

16 Адамович Г. В. Лица и книги. С. 329.

17 Переписка И. А. и В. Н. Буниных с Г. В. Адамовичем (1926-1961). С. 50, 70 и др.

18 Подробно об этом см.: Закружная З. С., Коростелев О. А., Фролов М. А. Записи и выписки И. А. Бунина для академического собрания сочинений // Вестник архивиста. 2018. № 1. С. 65-73; Закружная 3. С., Коростелев О. А. «Сундук с вырезками» Ивана Бунина // Новый филологический вестник. 2019. № 1 (48). С. 44-56.

19 РАЛ. MS 1066/10263. 
После войны в переписке с Адамовичем Бунин часто возвращался к этой теме, но настаивал на своем мнении уже как бы не всерьез, то приводя в письмах показавшиеся ему нелепыми строки А. Ахматовой, М. Горького, то присылая шуточные стихи за подписью Иннокентий Иванненский. ${ }^{20}$ Соответственно, и Адамович постепенно стал принимать Бунина таким, каков он был, с юмором относясь к его эскападам.

Послевоенные отношения писателей стали уже почти дружескими, и в переписке, и в общении, благо общаться доводилось нередко. Почти - потому что они оставались непримиримыми оппонентами по целому ряду важных для обоих вопросов, но необходимость совместно противостоять более существенным угрозам была еще важнее. Так что если их и можно назвать друзьями, то только учитывая то обстоятельство, что это были друзья поневоле.

Бунин пробовал вербовать Адамовича в свою веру, тот пытался отстаивать своих кумиров, то и другое не могло привести к полной победе, однако в чем-то Бунин переубедил Адамовича или, по крайней мере, заставил посмотреть на какие-то вещи несколько иначе. Современники это заметили. Н.И. Ульянов, отзываясь в 1967 году на только что вышедшие «Комментарии», написал: «Блок для Адамовича - поэт особенный. Не в Блоке ли открывались ему и сокровенная сущность поэзии, и ее „чудотворное дело“? Он ведь из того поколения читателей, что прочли у Блока „нечто для себя крайне важное и оставались под этим впечатлением надолго“. Для них „всякие другие стихи, даже и те, которые определяются, как «блестящие», «мастерские», казались рядом досужей выдумкой“. <...> Такое благоговение не помешало Адамовичу поддакнуть Бунину, когда тот, истощаясь во всяких способах уязвить ненавистного поэта, сказал однажды про „Куликово поле“ - „да ведь это же Васнецов“. Так ли уж это „убийственно метко“, как показалось Адамовичу? . ${ }^{21}$

Когда Бунин находил в статьях Адамовича высказывания и оценки, совпадавшие с его собственными, он отмечал это с особым удовлетворением. $К$ примеру, ознакомившись со статьей о Леониде Андрееве, Бунин написал Адамовичу 15 сентября 1949 года: «Правильно сказали Вы и о времени, о тех идиотских, истерических годах, когда славились „Андреевы“. Восхитился я, читая Вас, и собою: я и тогда, в эти самые годы, говорил об Андрееве и о прочих „Андреевых“ именно то самое, что наконец говорите Вы теперь, и слыл за то чорт знает кем как слыву теперь, говоря о всех Ваших Блоках. Но дойдет черед и до Блоков» . ${ }^{22}$

Но и Адамович сумел заронить зерна сомнений в душу Бунина, который после войны перечитывал Блока и склонен был по-иному взглянуть на его творчество. ${ }^{23}$

Бунин и Адамович принадлежали к разным поколениям и разным линиям в литературе, но линии сходились в Толстом, Пушкине, в самом понимании того, чем должна быть литература. Оба не принимали авангардистскую игру с литературой и смыслами, литературу как ремесло, литературу как прикладную публицистику, и на этом основании одинаково отвергали как советские литературные эксперименты, так и бессодержательную массовую беллетристику, будь то эмигрантскую или иностранную.

Публикуемый ниже посмертный отзыв о Бунине, который Адамович написал для вечера его памяти, свидетельствует о том, что окончательное примирение было возможно и, по всей видимости, даже произошло.

20 Переписка И. А. и В. Н. Буниных с Г. В. Адамовичем (1926-1961). С. 71.

21 Ульянов Н. О сути // Новый журнал (Нью-Йорк). 1967. № 89. С. 77-78.

22 Переписка И. А. и В. Н. Буниных с Г. В. Адамовичем (1926-1961). С. 90.

${ }^{23}$ См.: Коростелев О. А., Кузнецова Е. В. Поэтические принципы Ивана Бунина и Александра Блока (на материале маргиналий И. Бунина на однотомнике А. Блока 1946 г.) // Вестник Томского университета. Филология. 2019. № 58. С. 196-224. 
В парижском архиве И. А. Бунина отложились несколько страничек без названия, написанные рукой Г. В. Адамовича, ныне они хранятся в Русском архиве в Лидсе (РАЛ. MS 1066/8991).

Текст, вероятно, предназначался для вечера памяти И. А. Бунина, который В. Н. Бунина устроила 23 октября 1955 года на парижской квартире. Повидимому, именно о нем Адамович писал ей из Манчестера 19 октября: «Дорогая Вера Николаевна. Посылаю несколько слов к Вашему собранию 23-го. Может быть, это не совсем то, что надо бы. Но бывает, что сядешь писать одно, а напишешь совсем другое. Надеюсь, что собрание пройдет, как надо, хорошо, в соответствующем тоне и настроении - и даже уверен в этом». ${ }^{24}$

Текст этот до сих пор не привлекал внимания исследователей и публикуется впервые с любезного разрешения The Ivan and Vera Bunin Estate. Печатается в соответствии с правилами современной орфографии и пунктуации. Описки и иные погрешности текста исправлены без оговорок.

ПРИЛОЖЕНИЕ

Г. В. Адамович

\section{<«Смерти нет!»>}

В воспоминаниях Ивана Алексеевича о Толстом есть рассказ о том, как после смерти любимого маленького сына Вани Толстой, - будто стремясь убедить себя в чем-то таком, что было все-таки не совсем достоверно, - настойчиво повторял:

- Что такое смерть! Смерти нет, смерти нет!

Он будто ворожил, заклинал что-то. Он знал, что смерть есть, что своего Вани он никогда больше не увидит, не скажет с ним ни слова. Но знал он и то, что в каком-то смысле действительно смерти нет и что это не самообман, не пустое и жалкое утешение, хотя и трудно объяснить, на чем это чувство держится...

Прошло почти два года со дня кончины И. А., и все мы склонны сказать: что такое смерть? Смерти нет, Бунин по-прежнему с нами. $К$ писателю, к поэту это применимо тем легче, что после него остаются его книги, т. е. то, что было в нем наиболее живого и существенного. Да, Бунин не умер, умереть он не может, он с нами - в «Митиной любви», в «Жћизни Арсеньева», в «Несрочной весне», в «Солнечном ударе».

Да, бесспорно. Но...

И это «но» полно такого непреложного, непререкаемого, непреходящего значения, что к нему и добавлять ничего не надо. Всякому ясно, что за ним должно бы следовать. Бунин жив, но Ивана Алексеевича с нами нет.

Конечно, это истина старая, как мир, это дважды два четыре, и притом это одна из тех истин, о которых в день, когда мы вспоминаем человека нам дорогого, пожалуй, лучше бы не говорить. $К$ чему, в самом деле? Раны, даже глубокие, понемногу затягиваются. Зачем их бередить?

Единственное мое оправдание в том, что, перечитывая книги Бунина, перебирая в памяти все им написанное, обновляя былые впечатления, удивляясь впечатлениям новым, я все чаще спрашиваю себя: о чем он, в сущности, во всех своих книгах говорит, что самое важное у него, самое личное, самое бунинское - разве не именно то, что смерть есть и все-таки, все-таки смерти

${ }^{24}$ Переписка И. А. и В. Н. Буниных с Г. В. Адамовичем (1926-1961). С. 131. 
нет? Он слишком жадно и страстно любил жизнь, со всем, что жизнь может человеку дать, чтобы без содрогания примириться с ее телесным, материальным распадом и исчезновением. Но наперекор этому содроганию у него всегда, в каждой его строчке, слышится торжественная, торжествующая уверенность, что смерть все уничтожить не может, - и удивительно, что с годами, до самых последних его писаний, эта уверенность становилась все очевиднее. Будто две чашки весов: на одной была вся сила смерти, на другой - все ее бессилье или, вернее, вся сила чего-то, на нее восставшего, ей враждебного, - и хоть еле-еле, с каким-то огромным, мучительным напряжением, а все-таки вторая чаша перетягивает первую.

В конце концов, единственное, что Бунин говорит: все хорошо в мире! В самой двойственности своей, в изначальной своей противоречивости мир прекрасен. Чем была бы наша жизнь, не будь в ней того, что нас ужасает, 一 но не должны ли мы ужас этот преодолеть?

С этой мыслью вспомним сегодня и его самого, того, кто именно ее передал нам как свое завещание: вспомним, не стараясь заглушить еще живую боль утраты, но вместе с тем все сильнее утверждаясь в чувстве, что эта боль должна раствориться в радости непрекращающегося общения, присутствия, может быть, даже безотчетного воздействия на наши поступки, дела и решения. Иван Алексеевич не любил громких слов, и, пожалуй, сейчас, слушая эти строки или читая их, покачал бы головой и сказал бы со своей всегдашней притворной ворчливостью: «Бог знает что вы обо мне написали... вовсе я и не думал ничего такого» .

- Но ведь вы никогда не говорите о том, о чем думаете, - сказал я ему как-то в разговоре на такую же приблизительно тему.

Иван Алексеевич усмехнулся:

- Что правда, то правда! Не говорю. А о чем я думаю? Все ведь больше о том, о чем должен бы думать каждый человек.

Каждый человек - по его представлению о человеке, - должен бы думать об этих вечных «да» и «нет». Но думать без колебаний в ответе, т. е. склоняясь именно к толстовскому «смерти нет». Случается, что выбрать надо между низкой истиной и возвышающим обманом. По счастью, в данном случае это не так: именно обман нас унизил бы, а возвышает - истина.

\section{НЕИЗВЕСТНЫЕ АВТОГРАФЫ И. А. БУНИНА В ФОНДАХ ТЕАТРАЛЬНОГО МУЗЕЯ ИМЕНИ А. А. БАХРУШИНА}

$\mathrm{C}$ точки зрения буниноведения, Архивно-рукописный отдел Государственного центрального театрального музея имени А. А. Бахрушина (ГЦТМ) архивохранилище далеко не «профильное»: он не имеет прямого отношения

\footnotetext{
* Статья подготовлена при финансовой поддержке гранта РНФ (проект № 17-18-01410-П) в Институте мировой литературы им. А. М. Горького РАН. Автографы И. А. Бунина публикуются с разрешения The Ivan and Vera Bunin Estate. Автор считает своим долгом поблагодарить за помощь, оказанную при подготовке данной статьи, сотрудников ГЦТМ, Библиотеки Дома русского зарубежья имени А. Солженицына, а также лично С. Н. Морозова (ИМЛИ РАН).
} 
ни к литературе в целом, ни тем более к биографии И. А. Бунина. Однако и здесь - подобно целому ряду других, таких же условно «непрофильных» архивохранилищ ${ }^{1}$ - содержатся материалы, связанные с жизнью и творчеством (а иногда и просто с именем) писателя, в том числе пять его автографов, относящихся к периоду $1902-1938$ годов. ${ }^{2}$

Само по себе присутствие этих автографов в фондах именно театрального музея делает почти неизбежным обращение к теме «Бунин и театр» - теме многоплановой, увлекательной, насыщенной характерными для писателя парадоксами. ${ }^{3}$ Но, как бы ни хотелось углубиться в эту тему, характер собранного материала вынуждает нас коснуться лишь одного ее аспекта - а именно бунинского отношения к актерам.

С одной стороны, как известно, Бунин в своем творчестве актеров не жаловал и не щадил. В прозе изображал их гротескно, шаржево (вспомним соответствующие строки в «Митиной любви», в «ЗКизни Арсеньева»). ${ }^{4}$ В публицистике мог задаться исполненным едкого сарказма риторическим вопросом на их счет: «Откуда у русских актеров такая ненасытная жажда льстить, хвалить без всякой меры, восхищаться до непристойности, быть столь несдержанным в словах? / Чрезвычайно типичная черта вообще для русской натуры, а для актерской (сугубо эмоциональной, женственной) особенно». ${ }^{5}$ В воспоминаниях об А. П. Чехове утверждал, что автор «Чайки» «не любил актрис и актеров», и с явным сочувствием приводил его слова о них: «На семьдесят пять лет отстали в развитии от русского общества. Пошлые, насквозь прожженные самолюбием люди...» ${ }^{6}$

1 Среди таковых - Государственный архив Российской Федерации, Российский государственный исторический архив, Российский государственный архив социально-политической истории, Российский государственный военный архив, Архив Техасского университета, Эстонский государственный архив, Латвийский государственный исторический архив, Государственный исторический архив Литвы, Государственный архив Одесской области, Архив Сербской академии наук и искусств и др. Бунинские материалы из этих архивохранилищ представлены в наших публикациях и исследовательских работах (см.: Бакунцев А. В. 1) И. А. Бунин в Прибалтике: Литературное турне 1938 года. М., 2012; 2) И. А. Бунин и Русский культурный комитет в Белграде (1928-1937) // Литературный факт. 2017. № 6. С. 70-91; Иван Бунин: Неизвестные письма дореволюционного периода (1897-1901) / Публ., вступ. статья, подг. текста и прим. А. Бакунцева // Москва. 2015. № 1. С. 211-217, и др.).

2 Думается, заслуживают отдельного рассмотрения - хотя бы в виде беглого обзора - материалы фондов ГЦТМ, опосредованно связанные с Буниным. В числе таковых: переписанные от руки бунинские стихотворения в фондах М. Н. Ермоловой и М. Ф. Астангова; черновые наброски статьи или доклада о творчестве писателя в фонде критика И. И. Джонсона; киносценарий А. М. Роома «Солнечный удар», переданный дочерью режиссера М. М. Козакову и отложившийся в фонде последнего.

3 Едва ли не главным среди них является сочетание общеизвестной неприязни Бунина к театру, к театральной условности с острым, поистине неистребимым интересом к сценическим новинкам и со страстной, возникшей еще в юности, но так и не сбывшейся мечтой сказать свое, самобытное слово в области драматургии (см.: Бунин И. А. Письма 1885-1904 годов / Под общ. ред. О. Н. Михайлова; подг. текстов и комм. С. Н. Морозова, Л. Г. Голубевой, И. А. Костомаровой. М., 2003. С. 36, 318, 411; Лит. наследство. 1973. Т. 84. Иван Бунин: В 2 кн. / Ред. А. Н. Дубовиков и С. А. Макашин при участии Т. Г. Динесман. Кн. 1. С. 380 ; Бабореко А. К. Бунин: Жизнеописание. М., 2004. С. 187-189; [Б. п.]. Пьеса И. А. Бунина // Последние новости. 1937. 20 мая. № 5899. C. 3 ).

${ }^{4}$ См.: Бунин И. А. Собр. соч.: В 8 т. / Сост., подг. текстов и прим. А. К. Бабореко. М., 2000. T. 8. C. 219-221, 291, 295.

5 Бунин И. А. Публицистика 1918-1953 годов / Под общ. ред. О. Н. Михайлова; вступ. статья О. Н. Михайлова; комм. С. Н. Морозова, Д. Д. Николаева, Е. М. Трубиловой. М., 2000. С. 182.

${ }^{6}$ Бунин И. А. Собр. соч. Т. 8. С. 225. Впрочем, не исключено, что в действительности Чехов ничего подобного не говорил и Бунин вложил в его уста собственные суждения (современные чеховеды Л. Е. Бушканец, И. Е. Гитович, Л. А. Мартынова в ходе частного общения с автором данной статьи выражали уверенность, что бунинские воспоминания о Чехове достоверны далеко не во всем). 
С другой стороны, Бунин, сам обладавший редкой артистичностью (что засвидетельствовано целым рядом современников), лично знал многих театральных деятелей, а с некоторыми из них (например, с Ф. И. Шаляпиным) даже дружил.

Автографы, о которых пойдет речь в нашей статье, также свидетельствуют о более или менее тесных контактах писателя с представителями этой профессии.

$$
* * *
$$

Как указывалось выше, в ГЦТМ хранится пять бунинских автографов. Самый ранний среди них, относящийся к дореволюционному периоду жизни и творчества писателя, был обнародован в 1965 году и спустя почти 40 лет воспроизводился заново. ${ }^{7}$ Об этом автографе мы упоминаем лишь для полноты картины. Он являет собой подпись: «Иван Бунин» - под текстом коллективного поздравительного адреса, преподнесенного Шаляпину в день его бенефиса в Большом театре 3 декабря 1902 года. Помимо Бунина, адрес подписали М. Горький, К. П. Пятницкий, А. Н. Алексин, Скиталец (С. Г. Петров), Н. Д. Телешов, Е. Н. Чириков, Л. Н. Андреев, С. А. Скирмунт. Подпись Бунина стоит первой, однако авторы комментария к этому документу в томе бунинских «Писем 1885-1904 годов» высказывают предположение, «что главным участником написания адреса был Горький». ${ }^{8}$ Сам документ хранится в фонде Шаляпина. ${ }^{9}$

Также был опубликован один из автографов, отложившихся в фондах А. Н. Плещеева - А. А. Плещеева - Е. Н. Рощиной-Инсаровой (Ф. 210) и А. Ф. Городецкого (Ф. 76) - об этом мы скажем в свое время.

Представляется целесообразным предварить рассмотрение этих автографов краткой справкой о каждом из тех, кому они первоначально принадлежали. ${ }^{10}$

Екатерина Николаевна Рощина-Инсарова (урожденная Пашенная, в замужестве графиня Игнатьева, 1883-1970) - потомственная актриса, дочь знаменитого актера Н. П. Рощина-Инсарова, сестра В. Н. Пашенной. До революции служила в московских и петербургских театрах, в эмиграции играла в составе русских трупп в Париже и Риге (в столице Латвии у нее были также собственные Камерный театр и театральная студия), занималась общественной деятельностью. ${ }^{11}$

Бунин как зритель хорошо знал ее отца: еще юношей, в январе 1891 года, в Орле он видел Рощина-Инсарова в роли Чацкого и потом в письме к В. В. Пащенко восхищался его игрой. ${ }^{12} \mathrm{C}$ самой же Рощиной-Инсаровой писатель мог познакомиться в октябре 1912 года, на поэтическом вечере в московском

${ }^{7}$ См.: Лит. наследство. 1965. Т. 72. Горький и Леонид Андреев: Неизданная переписка. С. 164-165, 167 (факсимиле); Бунин И. А. Письма 1885-1904 годов. С. 454-455.

8 Морозов С. Н., Голубева Л. Г., Костоларова И. А. Комментарии // Бунин И. А. Письма 1885-1904 годов. С. 709.

${ }^{9}$ См.: ГЦТМ. Ф. 303. Оп. 1. № 259. КП 166576. Адрес стилизован под древнерусский свиток, с сургучной печатью.

10 При составлении этой справки использовались материалы «Путеводителя по рукописным фондам Государственного центрального театрального музея имени А. А. Бахрушина» (М., 2002) и 3-томного биографического словаря «Российское зарубежье во Франции, 1919-2000» (М., 2008-2010).

11 Подробнее о Рощиной-Инсаровой см.: Литаврина М. Г. Русский театральный Париж: 20 лет между войнами. СПб., 2003. С. 105-120; Максилова В. А. Е. Н. Рощина-Инсарова в Париже (Первые годы эмиграции) // Диалог культур. Проблемы взаимодействия русского и мирового театра ХХ века: Сб. статей. СПб., 1997. С. 72-92.

12 См.: Бунин И. А. Письма 1885-1904 годов. С. 62. 
Литературно-художественном кружке. ${ }^{13}$ Так или иначе, в начале 1920 -х годов писатель и актриса уже были знакомы - об этом говорят дневники В. Н. Буниной. В сделанной ею 2/15 июня 1921 года записи значится: «Вчера у РощинойИнсаровой было приятно: простая квартира, простые хозяева. Муж ее, граф Игнатьев, ${ }^{14}$ мне понравился, типа Николая Ростова, честный, дородный офицер, прекрасный сельский хозяин, к ней очень не подходит. Она прежде всего актриса. Не умеет находить простых слов и говорить не в повышенном тоне».$^{15}$

В той же записи впервые упоминается Александр Алексеевич Плещеев (1858-1944) - прозаик, драматург, мемуарист, театральный и литературный критик, издатель, историк балета, артист, сын поэта А. Н. Плещеева: «Был там и Плещеев <...> кажется, милый, но очень недалекий человек» ${ }^{16}$ Подобно Рощиной-Инсаровой, Плещеев активно участвовал в культурной (театральной и литературной) жизни Русского Зарубежья, печатался в эмигрантской прессе, выпустил ряд книг.

Рощину-Инсарову и Плещеева-младшего связывала дружба еще с дореволюционной поры. «Этот милейший Плещеев-младший, - вспоминал Б. К. Зайцев, - поклонник и почитатель, назывался в дружеском кругу „Пума серебристый“ (за нежную седину волос). Обломок барства-рыцарства прежней России, <...> многое видел он на своем веку. Театрально-артистический и литературный мир, особенно дореволюционный, знал наизусть. Разумеется, бездонный поклонник Рощиной. Лет ему было за семьдесят. „Катю“ обожал как ребенка, дочь и, разумеется, артистку. Она тоже его любила - думаю, считала необходимой принадлежностью бытия своего». ${ }^{17}$ Однако нам представляется, что чувства актрисы были не менее искренними, чем чувства ее поклонника и «летописца» (Плещеев писал о Рощиной-Инсаровой книгу, которая осталась незаконченной). Во всяком случае, именно Рощина-Инсарова сберегла архив Плещеевых - отца и сына, присоединив его к собственному.

Судя по имеющимся документальным материалам, общение Бунина с Рощиной-Инсаровой и Плещеевым-младшим не отличалось интенсивностью: имена обоих упоминаются только в дневниках В. Н. Буниной (и всего по два раза), ${ }^{18}$ а в Бунинской коллекции Русского архива в Лидсе сохранились лишь два послания от Плещеева (1926-го и 1933 годов) и одно - от Рощиной-Инсаровой (1947 года). ${ }^{19}$ В любом случае, и актриса, и ее друг входили в число постоянных, хотя и не близких, знакомых Бунина.

13 См.: Летопись жизни и творчества И. А. Бунина. М., 2017. Т. 2. 1910-1919 / Сост. С. Н. Морозов. С. 281.

14 Игнатьев Сергей Алексеевич (1888-1955) - офицер-гвардеец, правовед.

15 Устами Буниных. Дневники И. А. и В. Н. Буниных и другие архивные материалы: В 2 т. / Под ред. М. Грин; вступ. статья Ю. В. Мальцева. М., 2005. Т. 2. С. 35. В. Н. Бунина проявила редкую проницательность: уже в 1928 году Рощина-Инсарова и граф Игнатьев развелись.

16 Там же.

17 Зайиев Б. К. Отблески вечного: Неизвестные рассказы, эссе, воспоминания, интервью. СПб., 2018. С. 425.

18 Помимо процитированной выше записи от 2/15 июня 1921 года, см. записи от 4/17 июня 1921 года - о Рощиной-Инсаровой и от 24 сентября 1930 года - о Плещееве (Устами Буниных. C. 36,188$)$.

19 Cm.: Heywood A. J. Catalogue of Bunin, Bunina, Zurov and Lopatina Collections / Ed. by Richard D. Davies, with the assistance of Daniel Riniker. Leeds: Leeds University Press, 2011. Р. 108, 112. В то же время в коллекции В. Н. Буниной сохранилось 11 писем от Рощиной-Инсаровой за 1951-1959 годы (Ibid. Р. 273). В. А. Максимова не без оснований называет жену писателя среди «корреспондентов, близких и дальних друзей» актрисы в пору эмиграции (см.: Максилова В. А. Е. Н. Рощина-Инсарова в Париже. С. 82). Ряд упоминаний имен Плещеева и Рощиной-Инсаровой имеется также в переписке Буниных с Тэффи (см.: Переписка Тэффи с И. А. и В. Н. Буниными / Публ. Р. Дэвиса и Э. Хейбер // Диаспора: Новые материалы. СПб., 2001-2002. Вып. 2. С. 499-500, 518, 545, 547, 552, 559, 565; Вып. 3. С. 592). 
В отличие от Плещеева и Рощиной-Инсаровой, актер и коллекционер Александр Федорович Городецкий (наст. фам. - Генварский, 1888-1953), очевидно, принадлежал к числу «окказиональных» знакомцев писателя: его имя не встречается ни в эпистолярии, ни в дневниках Бунина и его жены. В Париже Городецкий играл в театре «Летучая мышь», в Русском драматическом театре, в Русском литературно-артистическом кружке, собрал театральную коллекцию, организовал частный музей «Русская изба»; во время Второй мировой войны участвовал во французском Сопротивлении, а после победы над нацизмом перебрался в Чехословакию.

$* * *$

Как отмечалось выше, в совместном фонде Плещеевых-Рощиной-Инсаровой хранится два бунинских автографа. Оба представляют собой письма: одно из них, «пневматическое», от 5 июля 1921 года, адресовано Плещееву, ${ }^{20}$ другое - обычное, недатированное - Рощиной-Инсаровой.

Содержание «пневматички» на имя Плещеева связано с участием Бунина в деятельности Комитета помощи русским писателям и ученым во Франции - одной из крупнейших эмигрантских филантропических организаций, целью которой была всемерная поддержка русской культуры за рубежом. На практике эта поддержка выражалась не только в финансировании разных проектов, творческих вечеров и т. п., но и в выплате небольших денежных пособий нуждавшимся писателям и ученым по исходившим от них самих или от их доверенных лиц специальным запросам. ${ }^{21}$ Бунин не раз ходатайствовал перед Комитетом за своих знакомых-литераторов, которым требовалось срочное вспомоществование.

В бунинском послании к Плещееву говорится:

«Дорогой Александр Алексеевич,

Наш „Комитет“ постановил выдать Вам то, что был в силах, - Вы, вероятно, эти деньги уже получили (от нашего казначея, которому я дал Ваш адрес). Позвольте посоветовать Вам обратиться еще и в „Союз журналистов“ к Милюкову (5, place du Palais Bourbon).

Ваш Ив. Бунин». ${ }^{22}$

В архиве Комитета помощи русским писателям и ученым во Франции сохранилась расписка Плещеева от 11 июля 1921 года, из которой явствует, что Комитет «ассигновал» Плещееву «ссуду в размере трехсот франков». ${ }^{23}$ Последовал ли Плещеев бунинскому совету обратиться в Союз русских писателей и журналистов в Париже, также оказывавший в особых случаях фринансовую помощь литераторам-эмигрантам, неизвестно.

Что же касается бунинского письма к Рощиной-Инсаровой, то в описях ГЦТМ оно датировано 21 декабря 1926 года - «по дню юбилея РощинойИнсаровой». Музейные архивисты в данном случае имели в виду 25-летний юбилей сценической деятельности актрисы - весьма заметное событие

\footnotetext{
20 Дата установлена по штемпелю на бланке.

21 Подробнее о Комитете см.: Кельнер B. Е., Познер В. Комитет помощи русским писателям и ученым во Франции (Из архива Соломона Познера) // Russian Studies. Ежеквартальник русской филологии и культуры. СПб., 1994. Т. 1. С. 269-313. Архив Комитета сегодня разделен на две неравные части: меньшая находится в Российском государственном архиве литературы и искусства, бо́льшая - в Библиотеке современной международной документации (BDIC, Париж - Нантер). Французская часть архива оцифрована и представлена на сайте: http://www.calames.abes.fr/pub/lacontemporaine.aspx\#details?id=FileId-816 (дата обращения: 30.04.2020).

${ }^{22}$ ГЦТМ. Ф. 210. Оп. 1. № 150. КП 166236. Л. 1.

${ }^{23}$ BDIC. F/DELTA/RES/0832/1/6/119.
} 
в культурной жизни русского Парижа. ${ }^{24}$ Однако, поскольку мы не знаем, когда именно было написано бунинское послание к Рощиной-Инсаровой в день ее чествования или накануне, - этот документ следует датировать «с оглядкой», используя формулировку «около 21 декабря 1926 года».

В своем письме Бунин сообщал:

«Дорогая Екатерина Николаевна,

Страшно жалею, что не могу, по нездоровью, быть на Вашем празднике, поздравляю Вас от всей души, дай Бог много, много лет процветать и здравствовать Вам и Вашему прекрасному таланту. Целую Ваши ручки.

Ваш Ив. Бунин». ${ }^{25}$

Эти строки (в числе прочих «поздравлений, писем, телеграмм, спичей, статей, стихов» ${ }^{26}$ ) с небольшими изменениями были воспроизведены в сборнике, который вышел в Париже через год после юбилея актрисы. ${ }^{27}$

Бунинские автографы, отложившиеся в фонде Городецкого, гораздо менее содержательны, чем только что рассмотренные нами. Тем не менее они также представляют известный интерес - в том числе с точки зрения своего «происхождения».

Например, можно только догадываться, каким образом к Городецкому попал один из них - сделанная рукой Бунина надпись на фрагменте конверта от предназначавшегося А. А. Плещееву (!) письма, которое, видимо, не сохранилось. Должно быть, коллекционер выпросил или выкупил этот клочок бумаги у бунинского адресата для своего собрания автографов.

Судя по почтовому штемпелю, письмо было отправлено из Канн 8 октября 1926 года. В адресном поле значится:

"„La Renaissance“

Quotidien russe

2 , rue de Sèze

Paris IX ${ }^{28}$

Es. C. T. Будагову для А. А. Плещеева от Ив. Бунина». ${ }^{29}$

Второй бунинский автограф в собрании Городецкого являет собой росчерк в особом, коллекционерском альбоме:

«Ив. Бунин 29.III.38

Париж». ${ }^{30}$

Этот росчерк Городецкий мог получить при встрече с писателем в какомнибудь частном или публичном собрании.

Разумеется, хранящиеся в фондах ГЦТМ автографы Бунина - весьма незначительная (и по количеству, и по содержанию) часть гигантского рукописного наследия, оставленного писателем. Тем не менее (в особенности с учетом того, что это наследие разрознено и рассеяно по всему миру) сам факт их обретения представляется немаловажным - причем не только в контексте изуче-

24 См.: Русское Зарубежье. Хроника научной, культурной и общественной жизни. 1920-1940. Франция: В 3 т. / Под общ. ред. Л. А. Мнухина. Paris; М., 1995. Т. 1. С. 296.

${ }^{25}$ ГЦТМ. Ф. 210. Оп. 1. № 973. КП 165597. Л. 1.

26 Максимова В. А. Е. Н. Рощина-Инсарова в Париже. С. 74.

27 См.: Двадцатипятилетие сценической деятельности Е. Н. Рощиной-Инсаровой. Новые характеристики и мысли 3. Н. Гиппиус, Н. А. Тэффи, К. Д. Бальмонта, Георгия Гребенщикова, Бор. К. Зайцева, Д. С. Мережковского, Вас. И. Немировича-Данченко, А. И. Южина, Сергея Яблоновского. Чествование Е. Н. Рощиной-Инсаровой в Париже. Портреты артистки, факсимиле письма к ней А. И. Куприна и пр. Париж, 1927. С. 22 ненум.

28 «Возрождение». Русская ежедневная газета. Улица Сэз, дом 2. Париж, IX округ (фp.).

${ }^{29}$ ГЦТМ. Ф. 76. Оп. 1. № 87. КП 196089/735. Л. 1. Личность С. Т. Будагова установить не удалось.

${ }^{30}$ ГЦТМ. Ф. 76. Оп. 1. № 134. КП 259866/526. Л. 5 об. 
ния личной и творческой биографии Бунина, но и в более общем контексте исследований по истории культуры Русского Зарубежья.

\section{«ЗА СТЕНАМИ РАЗРУШЕННОГО И ПОРУГАННОГО СИОНА»: И. А. БУНИН В 1917-1921 ГОДАХ}

Свойственные Бунину полярность «повышенного душевного строя» и оксюморонная «прошивка» художественной ткани его произведений составляют едва ли не главные отличительные признаки, по которым можно сразу узнать писательский стиль и явленный в нем образ бунинского мира. Эти черты принадлежат самому общему уровню бунинского мира - личности автоpa, и наиболее конкретному уровню его произведений - их образно-стилевым особенностям.

Но и в биографической канве, сочленениях самой жизни те же полюса напряженного счастья и оглушительной, извне настигшей трагедии порой вплотную подходили друг к другу. Вглядываясь в жизнь Бунина с почти вековой дистанции, можно увидеть, что и сам жизненный сюжет его был в существенной своей части построен на череде моментов, максимально ясно и едва ли не одновременно воплощавших противоположные и взаимно усиливающие друг друга переживания бытия.

В этом отношении, может быть, самым насыщенным периодом были первые годы после крушения всей той России, которую Бунин в своей огненной публицистике рубежа 1910-1920-х годов назвал разрушеннылм и поруганнылм Сионол.$^{1}$ Собственная задача стала ясна Бунину уже за пределами отечества: воссоздать, спасти и сохранить живой образ погибшего мира единственным подвластным ему способом - словом. Выражение из его же стихов - «Лишь

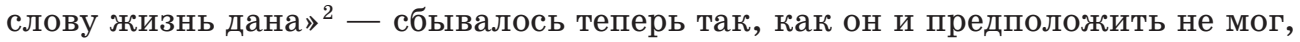
когда писал их в начале 1915 года. Казалось, что между теми зимними днями в Глотове, когда набрасывались эти строки, и осуществлением сказанного в них разверзлась пропасть.

* Работа выполнена при поддержке гранта РФФИ (проект № 20-012-41004). Тексты И. А. и В. Н. Буниных печатаются с разрешения The Ivan and Vera Bunin Estate. Благодарю хранителя Русского архива в Лидсе (РАЛ) Ричарда Д. Дэвиса за постоянную помощь и консультации в работе с бунинским наследием и С. Н. Морозова, чей фундаментальный труд - «Летопись жизни и творчества И. А. Бунина» - является непременной основой при обращении к конкретным периодам жизни писателя.

1 В заголовок работы вынесена цитата из статьи Бунина «В этот день», написанной в 1919 году (Бунин И. А. Публицистика 1918-1953 годов / Под общ. ред. О. Н. Михайлова; вступ. статья О. Н. Михайлова; комм. С. Н. Морозова, Д. Д. Николаева, Е. М. Трубиловой. М., 1998. С. 27-29). Далее ссылки на это издание даются в тексте сокращенно: Публицистика, с указанием номера страницы.

2 Стихотворение «Слово» («Молчат гробницы, мумии и кости...»): Бунин И. А. Стихотворения: В 2 т. / Вступ. статья, сост., подг. текста и прим. Т. М. Двинятиной. СПб., 2014 (Новая Библиотека поэта). Далее ссылки на это издание даются в тексте сокращенно: Стихотворения, с указанием номера тома и страницы. 
В одной из первых заметок послереволюционной поры Бунин писал: «Лето семнадцатого года я помню, как начало какой-то страшной болезни, когда уже чувствуешь, что болен смертельно, что голова горит, мысли путаются, окружающее приобретает какую-то жуткую сущность, но когда еще держишься на ногах и чего-то еще ждешь в горячечном напряжении всех последних телесных и душевных сил» (Публицистика, 27). С мая до конца октября 1917 года Бунин и его жена Вера Николаевна Муромцева (Бунина) живут у родственников (двоюродной сестры Бунина С. Н. Пушешниковой и ее сына, друга Бунина Н. А. Пушешникова) в Орловской губернии, в селе Глотово. В начале июля, после провала наступления русской армии на юго-западном фронте, на фоне кризиса власти и массовых демонстраций в Петрограде по городам прокатывается волна стихийных беспорядков, на укрощение которых присылаются войска из центра. Крестьянские волнения захлестывают и близкие к Буниным уезды, в самом Глотове мужики жгут и случайные избы, и хозяйские постройки, ${ }^{3}$ а вести из столиц усиливают ощущение надвигающегося хаоса. 25 июля 1917 года Бунин пишет своему другу П. А. Нилусу в Одессу: «До ярости, до боли кровной обиды отравляемся каждый день газетами». ${ }^{4}$

А через день оставляет самую поэтическую и самую подробную за всю жизнь запись из всех, что сохранились в его дневнике. Ее одну можно было бы привести, чтобы выразить весь душевный строй и суть его художнической и человеческой личности: «Счастливый прекрасный день. Деревенскому дому, в котором я опять провожу лето, полтора века», — и далее разворачивается медлительное, текучее и завораживающее описание старинного дома, утра, дня, заката, ощущений, мыслей, размышлений о прошлом и вечном («...то о Тиверии, о Капри... Почему о Тиверии? Очень странно, но мы невольны в своих думах» и т. д.), заканчивающееся неожиданным пуантом: «Опять прошел день. Как быстро и как опять бесплодно!» (Устали Буниных, 1, 163166).

Фатальное изменение политической ситуации наступает в самом конце лета: 29 августа приходит известие о «восстании» Верховного Главнокомандующего генерала Л. Г. Корнилова против Временного правительства (на деле это была интрига А. Ф. Керенского с целью смещения политического противника). Последнее обращение Корнилова («Русские люди! Великая родина наша умирает» и т. д.), его арест и последняя краткая победа Временного правительства, прежде всего Керенского, о котором и прежде Бунин отзывался крайне отрицательно, - потрясают: «Таких волнений мало переживал в жизни. Просто пришибло». ${ }^{5}$

327 июня 1917 года Бунин второй раз в жизни пишет стихотворение-«репортаж» (о первом таком стихотворении, «Хозяин умер, дом забит...», 1916, см. ниже). Сначала он дает название «Пожары», затем меняет его на точную временную приуроченность: «Семнадцатый год» (см. стихотворение «Наполовину вырубленный лес...»: Стихотворения, 2, 171, 452 (комм.)).

4 Бунин И. А. Письма 1905-1919 годов / Подг. текстов и комм. С. Н. Морозова; под общ. ред. О. Н. Михайлова. М., 2007. С. 394 (далее ссылки на это издание даются в тексте сокращенно: Письла, с указанием номера страницы); Устами Буниных. Дневники Ивана Алексеевича и Веры Николаевны и другие архивные материалы: В 3 т. / Под ред. М. Грин. Frankfurt a/M., 1977. Т. 1. C. 167 (далее ссылки на это издание даются в тексте сокращенно: Устали Буниных, с указанием номера тома и страницы; фрагменты дневников, не вошедшие в издание, цитируются по архивным источникам).

5 РГБ. Ф. 622. Карт. 3. Ед. хр. 33. Дневник И. А. Бунина (записи 1 августа - 21 ноября 1917 года; 18 января - 1/14 мая 1918 года; далее дневниковые записи Бунина цитируются по этому источнику). Затем из солидарности с Корниловым правительство покинули кадеты, 1 сентября была образована Директория во главе с Керенским и провозглашена Российская республи- 
И в то же самое время - как и в течение всего лета - Бунин по-прежнему много гуляет и ездит по окрестностям, отмечает в дневнике «первые признаки осени» - они перейдут в стихи: за август-октябрь 1917 года написано больше тридцати текстов. В те месяцы он пишет, может быть, самые счастливые свои стихотворения. Собранные вместе, они отдельными штрихами как будто напоминают обо всей прожитой жизни: «Ландыш» - о первой публикации, ${ }^{6}$ «Золотыми цветут остриями...» - о юности в Озёрках (последнем родовом имении разорившейся семьи Буниных под Ельцом), «Свет незакатный» о юношеской любви, «Стали дымом, стали выше...»- о жизни в столицах, «Смятенье, крик и визг рыбалок...» и «Белые круглятся облака...» - о путешествиях в Италию, «Сорвался вихрь, промчал из края в край...» - об Индийском океане, и т. д. В пейзажной лирике тех недель отражается влияние перечитанных и заново прожитых тогда стихов А. М. ЖЖемчужникова и А. А. Фета и звучит лейтмотив невыразимости бытия, один из главных в бунинской эстетике. В дневнике: «И всё мука, мука, что ничего этого не могу выразить, нарисовать!» (20 августа) - и почти теми же словами в стихотворении «Щеглы, их звон, стеклянный, неживой...» (3 октября). Накануне решающих событий в своей жизни Бунин (как было и будет еще не раз) ${ }^{7}$ абсолютно погружен в природное течение жизни. В самом конце жизни в одной из записных книжек, уже неровным почерком он отдельно записал: «Начало осени 17 года было удивительно прекрасно».$^{8}$

К октябрю в Глотове и окрестностях нарастают крестьянские волнения. 7 октября Бунин сообщает П. Нилусу: «Пока сидим в деревне. Скверно и жутко порой, но что делать! В Москву хотим поехать к концу октября» (Письла, 402). ${ }^{9} 10$ октября - пишет стихи о молодости и вечности: «Этой краткой жизни вечным измененьем...» и «Как в апреле по ночам в аллее...». В тот же день вместе с Н. Пушешниковым едет из Глотова в уездный город Ефремов и узнает, что с часу на час ожидается погром: ${ }^{10}$ «В деревне невыносимо и оч <ень> жутко», - признается Бунин в письме тому же Нилусу 16 октября (Письла, 403; Устали Буниных, 1, 167).

ка. Тем самым после быстро сошедших со сцены эсеров и меньшевиков дорога к власти большевикам была открыта.

6 В течение жизни Бунин не раз вспоминал, как в мае 1887 года получил на почте газету «Родина» (17 мая, № 20) со своим стихотворением «Деревенский нищий» (Бунин считал его своим литературным дебютом, вопреки более ранней публикации в той же газете другого его стихотворения, «Над могилой С. Я. Надсона»). Это воспоминание было связано для него с ландышами: «Утра, когда я шел с этим номером с почты в Озёрки, рвал по лесам росистые ландыши и поминутно перечитывал свое произведение, никогда не забуду»; «Чудесный весенний день!» (Бунин И. А. Собр. соч.: В 9 т. М., 1967. Т. 9. С. 260, 527; далее ссылки на это издание даются в тексте сокращенно: Бунин-9, с указанием номера тома и страницы).

7 Самые яркие примеры, которые позволяют говорить о своего рода архетипическом повторении, - лето 1914 года накануне начала Первой мировой войны и осень 1933 года перед присуждением Бунину Нобелевской премии, о них см.: Двинятина Т. М. 1) И. А. Бунин в 1914 году // Русская литература. 2015. № 1. С. 161-171; 2) Нобелевский год И. А. Бунина (по материалам дневников и семейной переписки) // Литературный факт. 2017. № 4. С. 143-161.

8 РАЛ. MS 1066/555.

9 На 12 ноября были назначены выборы в Учредительное собрание, Бунин должен был избираться от Москвы. Оставаясь в деревне, он беспокоился о том, чтобы его имя было внесено в списки, и просил брата Ю. А. Бунина, который уже был в Москве, узнать положение дел (см.: Письла, 403).

10 Это ожидание было вызвано новостями из Петрограда, которые Бунин узнает из газет, прежде всего - о речи Троцкого 7 октября на заседании Временного совета Российской Республики (совещательного органа при Временном правительстве), в которой говорилось о выходе из него большевиков. Тем самым была перечеркнута последняя возможность умеренного развития и декларировался переход большевиков к активной фазе захвата власти; на следующий день Троцкий был избран председателем Петросовета. 
Но стихи идут по нарастающей, в свои последние дни в Глотове Бунин пишет собственный вариант «Exegi monumentum» - «Венком из мирта освежал я...» (ранний вариант стихотворения «Венки») ${ }^{11}$ и самое открытое свое стихотворение, возвышающееся над всем, что он написал до и напишет после:

\author{
Звезда дрожит среди вселенной... \\ Чьи руки дивные несут \\ Какой-то влагой драгоценной \\ Столь переполненный сосуд? \\ Звездой пылающей, потиром \\ Земных скорбей, небесных слез \\ Зачем, о Господи, над миром \\ Ты бытие мое вознес?
}

Дата под текстом - 22 октября. По словам В. Н. Муромцевой, в этот день «в два часа дня, когда Ян сидел и писал стихи», из соседнего имения, где жили ее родственники, «явился <...> мужик и объявил, что начались погромы» (Устали Буниных, 1, 193; запись от 3 ноября 1918 года). На рассвете 23 октября 1917 года Бунины навсегда бежали из Глотова.

26 октября, проведя два дня в Ельце, Бунины приехали в Москву и остановились у родителей В. Н. Муромцевой (Поварская ул., д. 26, кв. 2). Накануне в Петрограде произошла революция: большевики взяли власть и арестовали Временное правительство. На следующий день после приезда Буниных в Москву, вооруженное восстание начинается и в ней. Недалеко от Поварской находилось Александровское военное училище, юнкера которого, главным образом, и защищали Москву от войск узурпаторов. Когда 29 октября Буниным звонит Е. П. Пешкова, за окнами идут уличные бои. На другой день под звуки выстрелов Бунин пишет в дневнике: «Вера говорила с Кат <ериной> Павл <овной $><$ Пешковой. - T. Д. $>$ по телефону. Катерина Павловна < ... $>$ сказала, что $\mathrm{A}<$ лексей $>\mathrm{M}<$ аксимович $>$ у нее, что если я хочу с ним поговорить и т. д. Но мне он так мерзок, что я не хочу». ${ }^{12}$ Это был разрыв отношений. Из задуманного горьковским издательством «Парус» Собрания сочинений Бунина в конце года вышел только один, десятый том, но и о нем Бунин справлялся теперь у А. Н. Тихонова. ${ }^{13}$

11 См.: Летопись жизни и творчества И. А. Бунина. М., 2011. Т. 1. 1870-1909 / Сост. С. Н. Морозов. С. 890 (далее ссылки на это издание даются в тексте сокращенно: Летопись, с указанием номера страницы), а также: Стихотворения, 2, 269, 489 (комм.).

12 Позже, заканчивая этим эпизодом мемуарный очерк «Горький» (1936), Бунин писал так: «Вскоре после захвата власти большевиками он (Горький. - T. Д.) приехал в Москву, остановился у своей жены Екатерины Павловны и она сказала мне по телефону: „Алексей Максимович хочет поговорить с вами“. Я ответил, что говорить нам теперь не о чем, что я считаю наши отношения с ним навсегда кончеными» (Бунин И. А. Воспоминания. Париж, 1950. C. 129).

${ }^{13}$ В долгом послесловии отношений Бунина и Горького было не только тотальное отталкивание, но и точное эхо: название бунинских очерков революционной поры «Окаянные дни» было, возможно, невольно подсказано Горьким, который писал Бунину 18 февраля 1917 года (перед их последней встречей в Петрограде): «Нездоров, вторую неделю торчу дома. Жћить - очень нехорошо! Тихонов говорил мне, что и у Вас настроение скверное. Господи, какая окаянная жизнь!» (Горький М. Полн. собр. соч. Письма: В 24 т. М., 2006. Т. 12. С. 112). См. также стихотворение М. А. Волошина «Стенькин суд» (декабрь 1917), главный герой которого предвещает: «И за мною не токмо что драная / Голытьба, а казной расшибусь - / Вся великая, темная, пьяная, / Окаянная двинется Русь». См. также прим. 37. 
Моментальная точность оценок, которые Бунин дает происходящим на его глазах событиям, поразительна. 4 ноября 1917 года, на следующий день после того, как власть в Москве перешла к Военно-революционному комитету, он в дневнике определяет главное: «Вчера не мог писать, один из самых страшных дней всей моей жизни. Да, позавчера был подписан в 5 ч. „мирный договор“. Вчера часов в 11 узнал, что большевики отбирают оружие у юнкеров. Пришли Юлий <Ю. А. Бунин. - T. Д. $>$, Коля $<$ Н. А. Пушешников. T. Д.>. Вломились молодые солдаты с винтовками в наш вестибюль - требовать оружие. Всем существом понял, что такое вступление скота и зверя победителя в город. <...> Лица хамов, сразу заполнивших Москву, потрясающе скотски и мерзки. <...> / Заснул около 7 утра. Сильно плакал. 8 месяцев страха, рабства, унижений, оскорблений! Этот день венец всего! / Разгромили людоеды Москву!»

В художественном дневнике «Окаянные дни» этой записи нет, ${ }^{14}$ он начинается 1 января 1918 года: «Кончился этот проклятый год. Но что дальше? Может, нечто еще более ужасное. Даже наверное так». ${ }^{15}$

Зимой Москва живет слухами о сдаче города немцам (так, что даже возможный взрыв Кремля перед этим обсуждается серьезно и никого не удивляет), реформой орфографии (декрет был подписан 23 декабря 1917 года), переходом на новый стиль (с 1 февраля 1918 года), ${ }^{16}$ спорами о цензуре, введенной для московских газет президиумом Совета рабочих и солдатских депутатов, и разговорами о том, что Брюсов «все левеет, „почти уже форменный большевик“» (он вступит в партию в 1920 году), что «открыто присоединился к большевикам» Блок (вышла его статья «Интеллигенция и Революция»), ${ }^{17}$ что исключен из «Среды» А. Серафимович (он не отказался от сотрудничества в большевистском издании), ${ }^{18}$ и т. д. Видимо, в декабре происходит знакомство Буниных с М. О. и М. С. Цетлиными (они жили по соседству, в своем особняке на Поварской ул., д. 9), которому еще предстоит долгая, счастливая и драматическая история. ${ }^{9} \mathrm{~B}$ январе продолжаются заседания литературного кружка «Среда», на одном из них (7 января) обсуждается рассказ А. Н. Толстого "День Петра», и в это время приходит сообщение о разгоне Учредительного собрания в Петрограде. 17 февраля на одном из собраний присутствует В. В. Маяковский («щеголявший стоеросовой прямотой суждений»), читают стихи В. М. Инбер и И. Г. Эренбург. ${ }^{20}$ На других собраниях Бунин встречает М. А. Осоргина, С. А. Ауслендера, В. Ф. Ходасевича, Б. К. Зайцева. Дома читает Книгу пророка Иеремии и следом - корректуру своей «Деревни» (для «Паруса», который ее не издаст) и стихов 1916 года «Хозяин умер, дом

14 Стоит подчеркнуть, что разница между личным дневником Бунина и «Окаянными днями» не только стилистическая, но и хронологическая, событийная (так, например, первая запись в сохранившемся дневнике Бунина 1918 года сделана 18 января). Рассматривать «Окаянные дни» как прямой источник сведений о конкретном течении жизни Бунина можно только с осторожностью. См.: Морозов С. Н. «Окаянные дни» И. Бунина: к истории текста // Текстологический временник: вопросы текстологии и источниковедения. М., 2012. Кн. 2. С. 302-311.

15 Бунин И. А. Собр. соч.: В 11 т. Берлин, 1935. Т. 10. Окаянные дни. С. 35.

16 Далее даты приводятся только по новому стилю, кроме особо оговоренных случаев.

17 И в том, и в другом случае - оценки Бунина, см.: Бунин И. А. Собр. соч.: В 11 т. Т. 10. C. 36,39 .

18 Об этом, в частности, см.: Зайщев Б. К. Москва. Мюнхен, 1973. С. 37-38.

19 В позднем (6 декабря 1945 года) письме к М. С. Цетлиной В. Н. Бунина вспоминает «встречи и в Москве, и в Одессе» и «дружббу в Париже» (Новое о Буниных / Публ. Н. Винокур // Минувшее: Исторический альманах. Париж, 1989. <Вып.> 8. С. 308). В мае 1918 года М. О. Цетлин придет к Бунину с предложением участвовать в эсеровской газете «Возрождение» (в ней к тому времени уже сотрудничали И. И. Фондаминский и М. В. Вишняк). Бунин согласится, и это станет прологом их общих издательских проектов в эмиграции.

20 Бунин И. А. Собр. соч.: В 11 т. Т. 10. С. 36. 
забит...» (позже примеряет заглавие «Канун»). ${ }^{21}$ Все происходящее вокруг кажется ему осуществлением ветхозаветных пророчеств о падении царств, и он Уже присоединял к ним свой голос, предупреждая о грозящих России потрясениях - и в 1910 году, когда писал «Деревню», и в стихах последних лет (см.: Стихотворения, 1, 76-78). Вместе с тем Бунин участвует в поэтических вечерах и выступает с чтением своих произведений (Летопись, 912-919). 27 февраля в Политехническом музее проходит «Избрание короля поэтов». Среди прочих читаются и стихи Бунина, но у эпохи другие кумиры: первое место занимает И. Северянин, второе - В. Маяковский, третье - К. Бальмонт..

В начале мая время вновь спрессовывается. На 1 мая 1918 года выпадает Великая Среда, но в Москве (с марта она - столица страны) широко отмечается «интернационалистич<еский> праздник»: на Ходынском поле проходит первый парад Красной армии, на Красной площади - большая демонстрация. Накануне, 30 апреля Бунин оказывается свидетелем свержения памятников, его особенно поражает «стаскивание» памятника М. Д. Скобелеву. В дневнике появляется запись: «А завтра, в день предания Христа - торжество предателей России! <...> Вот уж поистине всё чуда ждешь, - так страшно изболела душа! Хоть бы их гроза убила, потоп залил!» - но на следующий день и погода за новую власть: «Везет им! День очень хороший, солнечный, хотя сильно прохладный». Назавтра, 2 мая Бунин идет к комиссару по иностранным делам московского Совнаркома В. М. Фриче справиться о заграничных паспортах. 3 мая - Страстная Пятница. Утром Бунин и Н. А. Пушешников в толпе горожан стоят на Красной площади: перед праздником трудящихся на Никольской башне Кремля кумачом завесили икону святителя Николая, и прямо во время первомайской манифестации кумач разорвался или, как писал в дневнике Бунин, истлел. Пушешников описывает изумление собравшихся на площади людей: «Все говорят о чуде, говорят разное» (цит. по: Летопись, 925). К вечеру Бунин идет в церковь «Никола на курьих ножках» на Большой Молчановке. Туда же они с В. Н. Муромцевой приходят в Пасхальную ночь. Вернувшись со службы, Бунин открывает дневник: «Красота этого еще уцелевшего островка среди моря скотов и убийц, красота мотивов, слов дивных, живого золота дрожащих огоньков свечных, траурных риз - всего того дивного, что все-таки создала человеческая душа и чем жива она - единственно этим! - так поразила, что я плакал - ужасно, горько и сладко. <...> О, Господи, неужели не будет за это, за эту кровавую обиду, ничего?! О какая у меня несказанная боль и злоба к этим Клестовым, ${ }^{22}$ Троцким, матросам».23 8 мая появляется надежда: «День большого беспрерывного волнения: переворот на Украине» (Летопись, 925). ${ }^{24}$ При поддержке австровенгерских и германских войск к власти в Киеве приведен гетман П. П. Скоропадский, вместо Украинской Народной Республики создано Украинское государство (Держава). С этого момента неотступная мысль Бунина уехать из Москвы приобретает конкретные очертания: он рвется на юг.

Но до отъезда из Москвы в личном мире Бунина происходит событие, которое еще неявным для него образом замыкает собой всю его «русскую» жизнь:

21 Tам же. С. 44.

22 Клестов Николай Семенович (1873-1941) - литературный критик, член РСДРП с 1902 года, один из организаторов большевистского переворота в Москве в октябре 1917 года. В 19121919 годах был заведующим «Книгоиздательством писателей в Москве» (с которым Бунин активно сотрудничал, выпустил в нем несколько книг, а в 1914 году был его редактором).

23 См. стихотворение «Москва» («Темень, холод, предрассветный...»): Стихотворения, 2, $170-171$

24 В художественном дневнике «Окаянные дни» это время пропущено: московская часть обрывается на записи от 24 марта 1918 года, одесская начинается в апреле 1919 года, после того, как город был занят большевиками. 
14 мая 1918 года умирает Варвара Владимировна Пащенко (Бибикова). Пять лет бунинской юности (со знакомства в июне 1889 года до разрыва в ноябре 1894 года) были неразрывно связаны с ней; своей «долгой любовью» Бунин назвал ее в «Автобиографической заметке» 1915 года (Бунин-9, 9, 260) и как о самом мучительном переживании своей молодости вспоминал о ней в поздние годы. Да, в течение двадцати лет после того, как, оставив Бунина, она вышла замуж за их общего знакомого Арсения Николаевича Бибикова, и после того, как Бунин превозмог нанесенные ему боль, обиду, оскорбление, В. В. Пащенко как будто пребывала в тени его творчества, никак не обнаруживая себя в бунинских произведениях. И получив известие о ее смерти, и в следующие дни Бунин может только удивляться собственному бесчувствию. ${ }^{25}$ Однако спустя несколько лет, начиная с рассказа «В ночном море» (1923), построенном как воображаемый «посмертный» разговор двух бывших соперников, ${ }^{26}$ образ юношеской любви, которой были отданы лучшие силы его ранних лет, вновь проступит в бунинских произведениях. И «Жизнь Арсеньева», и многие рассказы «Темных аллей», и прежде всего «Поздний час», будут пронизаны соединением двух образов - умершей возлюбленной и утраченной родины.

Пока же, в ежедневном течении мая 1918 года, Бунин был слишком занят предотъездными заботами. Сначала ему предстояла поездка с Ю. И. Айхенвальдом «в Тамбов и Козлов, где устраивались „Бунинские вечера“» и откуда, как пишет В. Н. Муромцева, «они привезли окорока, муки и круп, а Ян еще твердую и непоколебимую уверенность, что нужно уезжать, и как можно скоpeе, на юг, где с воцарением Гетмана большевики были прогнаны. Его поездка дала ему подлинное ощущение большевизма, разлившегося по России, ощущение жуткости и бездонности» (Устали Буниных $, 1,171) .{ }^{27}$ Затем надо было получить необходимые пропуска для выезда из Москвы (см.: Летопись, 931, 934). ${ }^{28}$ Наконец, 5 июня 1918 года в санитарном поезде, уходящем с Савеловского вокзала, Бунины навсегда покинули Москву и 8 июня пересекли границу между советской и германской зонами в Орше.

17 июня 1918 года Бунины приезжают в Одессу, занятую в то время австровенгерскими и германскими войсками, и вскоре снимают дачу на Большом Фонтане. После напряженного, гнетущего ужаса и отвращения, которые вызывала в нем московская жизнь, Бунин оказывается в родной и счастливой для него жизни одесской, и эта перемена подобна истинному чуду. В конце июня В. Н. Муромцева пишет брату: «Дача у нас хорошая, большая, стоит в фруктовом саду, а сад выходит в степь», «мне кажется, что я живу в раю». ${ }^{29}$

25 Бунин узнал о смерти В. В. Пащенко от А. Н. Бибикова, который пришел к нему в то же утро (с конца 1890-х годов они возобновили приятельские отношения, Бунин посылал свои книги, Бибиков, поэт-любитель, прислушивался к его советам и т. д.). Вечером 14 мая Бунин пишет в дневнике: «Весь день и в момент этого известия у меня никаких чувств по поводу этого известия. Как это дико! Ведь какую роль она сыграла в моей жизни!»

${ }^{26}$ См. также позднюю запись Бунина об А. Н. Бибикове, с которым они «были друзьями первой молодости», и «другой России», которая кажется теперь «сном»: Муролиева-Бунина В. H. Жизнь Бунина. Беседы с памятью / Вступ. статья и прим. А. К. Бабореко. М., 2007. С. 148.

27 В. Н. Бунина относит эту поездку к началу мая, но она считает по старому стилю. См. также: Летопись, 930.

28 В. Н. Муромцева рассказывала об этом в письме к А. К. Бабореко от 13 марта 1958 года так: «Разрешение устроил нам Фриче в благодарность за то, что Иван Алексеевич хлопотал за него у московского градоначальника, чтобы его не выслали из Москвы незадолго до революции" (цит. по: Бабореко А. К. Бунин: Жизнеописание. 2-е изд. М., 2009. С. 232).

29 Письмо В. Н. Муромцевой Всеволоду Николаевичу Муромцеву от 29 июня / 12 июля 1918 года (цит. по: Там же. С. 234). 
Рядом с Буниными живут их давние друзья П. А. Нилус, А. М. и Л. К. Федоровы, приезжают в гости Д. Н. и И. Л. Овсянико-Куликовские, Д. Л. и Ю. Л. Тальниковы, преподаватели Новороссийского университета В. О. Недзельский и В. Ф. Лазурский, художник П. П. Ганский, критик Б. Вальбе, Г. Д. и Т. Д. Гребенщиковы. «Ян все „вьет свое гнездо“», - пишет В. Н. Муромцева. ${ }^{30}$ На этой даче, впервые после бегства из Глотова, Бунин одно за другим пишет стихотворения, в которых его апокалипсические настроения сменяются евангельским упованием на воскрешение прошлого и обретением единства жизни и мироздания: «В дачном кресле, ночью, на балконе...» (9 июля), «И цветы, и шмели, и трава, и колосья...» (14 июля), «Огонь, качаемый волной...» (24 сентября) и др.

В октябре Бунины перебрались в город, в дом их давнего приятеля, художника Е. И. Буковецкого (в феврале 1919 года он напишет портрет Бунина), и там, по словам В. Н. Муромцевой, «несмотря на все несчастья, <...> сравнительно счастливо прожили почти полтора года» (Устали Буниных, 1, 339). К осени 1918 года в Одессу съехались многие столичные литераторы, именно там сложились тесные отношения Бунина с М. А. Алдановым, Н. А. Тэффи, П. М. Пильским, А. Н. и Н. В. Толстыми, М. О и М. С. Цетлиными, В. В. Рудневым, И. И. Фондаминским и др., устраивались вечера, затевались книгоиздательства. В ноябре Бунин наконец выступает в печати, к 100-летию И. С. Тургенева он пишет статью «Страшные контрасты», в которой впервые использует название будущих заметок революционной поры: «Можно ли придумать более страшные контрасты: Тургенев и современная русская литература, годовщина тургеневского рождения - и годовщина так называемого большевизма $<\ldots .>$ говорить о Тургеневе в это ни с чем не сравнимое время, когда Бог привел мне видеть подтверждение моих дум о русском народе в такой ужасной мере $<\ldots>$ нет, говорить и праздновать в эти окаянные дни уже совсем выше моей силы». ${ }^{31}$

В ноябре Одесса оказалась занята англо-французскими войсками, в декабре город ненадолго захватили петлюровцы, через несколько дней их вытеснили войска Добровольческой армии, которая при поддержке французских союзников оставалась в Одессе до начала апреля 1919 года. Для Бунина это время надежд, впервые в жизни он печатает публицистические стихи - поэтическое приветствие добровольцам. ${ }^{32}$ Мотив невозможности и необходимости слова в новом страшном мире развивается в его статье «Не могу говорить», написанной в конце марта 1919 года. Это одно из самых страстных выступлений Бунина против большевизма, задавшее камертон всей его будущей публицистики, выходит в только что основанной газете «Наше слово» 2 апреля (№ 1), 一 а на следующий день ситуация резко меняется.

3 апреля во Франции правительство Ж⿱ Клемансо уходит в отставку, французская армия оставляет Одессу, в городе объявляется срочная эвакуация. Следующие дни наполнены мучительными размышлениями: «...куда бежать? На Дон? Страшно - там тиф! За границу - и денег нет, да и тяжело отрываться от России» (Устали Буниных, 1, 221). ${ }^{33} 5$ апреля из Одессы «стре-

${ }^{30}$ Муролиева В. Н. Дневник // РАЛ. MS 1067/346 (запись от 3 июля 1918 года).

31 Опубл.: Одесские новости. 1918. 10 нояб. № 10893; см.: Публицистика, 22-23.

32 Стихотворение «И боль, и стыд, и радость. Он идет...» Бунин написал, судя по дневнику В. Н. Муромцевой, 28 ноября 1918 года, когда к Одессе подошли английские корабли (РАЛ. MS 1067/352). 22 декабря 1918 года, после того, как Одессу заняла Добровольческая армия, оно было переадресовано ее воинам и опубликовано в газете «Одесский листок» (№ 279) под заглавием«22 декабря 1918».

33 Опасения были тем более обоснованы на фоне только что вышедшей статьи Бунина: «...ведь нужно же было начать издавать газету за 3 дня до ухода союзников!» (Устали Буниных, 1, 226; запись В. Н. Муромцевой от 7 апреля 1919 года). 
мительно бежали морем (в Константинополь и дальше)» А. Н. и Н. В. Толстые (Бунин-9, 9, 437). Тогда же покинули Одессу Н. А. Тәффи, М. О. и М. С. Цетлины, которые горячо уговаривали Буниных уезжать.

Бунины остались. Думается, что причиной стала не только растерянность или надежда на то, что и этот кризис пройдет, но, может быть в первую очередь, та внутренняя сила, которую Бунин нашел и выразил в статье «Не могу говорить», сочетающей страстное, живое свидетельство, библейский пафос и отточенную риторику: «Все же надо говорить - хоть через силу, хоть сквозь стиснутые от боли, отчаяния и негодования зубы, хоть что-нибудь, хотя бы вот об этой невозможности говорить, - если не об общем, не о мировом, то хоть о частном, о нашем, о России, о Москве, где бражничают Емельки и Гришки за своей кровавой пьяной трапезой.

Говорить для чужеземцев, слишком еще мало знающих нас и волею судьбы призванных решать наши судьбы, - чтобы слышали они и мой голос, то, что я говорю, - я, Божиею милостью не последний сын своей родины.

Говорить для будущего историка, чтобы смутить его и заставить нахмуриться, стать строже к своему труду, когда дойдут до него наши загробные голоса - славословия этим дням и мое проклятие им до скончания и по скончании их, равно как и тем, кто творит и кто приуготовлял эти дни, а теперь тоже клянет, забывая, что „не властен ударяющий в барабан удерживать грохот барабана“.

Говорить для тех, - да сохранит Господь их драгоценную жизнь! - что доброю волею идут умирать за нашу Москву, за нашу Россию» (Публицисти$\kappa a, 25-26){ }^{34}$

$* * *$

В апреле-августе 1919 года Одессу занимают банды атамана Н. Григорьева, перешедшие на сторону большевиков, а вскоре и сами большевики. Дом, в котором жили Бунины, находился в самом центре города (Княжеская ул., д. 27), бои, как и осенью 1918 года в Москве, шли прямо под их окнами, и вся обстановка казалась страшным повторением пережитого раньше. ${ }^{35}$ Уже в апреле стала сказываться нехватка воды, продуктов. В мае начались аресты и расстрелы «буржуев», в ответ на это прокатились стихийные расправы над евреями-большевиками и их сторонниками (см.: Устали Буниных, 1, 252253). ${ }^{36}$ Когда в июне был сменен и укреплен состав Одесской ЧК, террор усилился: массово арестовывались профессора, юристы и другие «буржуазные элементы», было убито не менее полутора тысяч человек, новые списки расстрелянных появлялись постоянно. Бунин думал о том, чтобы перейти на нелегальное положение. «Надеялись, что в случае опасности его предупредят. Но все же всякий вечер бывало жутковато» (Устали Буниных, 1, 273).

Отношение к большевикам определяло все жизненное поведение Бунина и не раз ставило его в опасное положение. Писатель неоднократно получал предложения сотрудничать с новой властью, но неизменно их отклонял: «Лучше стану с протянутой рукой на Соборной площади, чем пойду туда. Пусть

34 См. запись в дневнике В. Н. Муромцевой от 28 марта 1919 года: «Вчера Ян кончил свою статью. Все время он был очень серьезен. Даже похудел. Прочел мне <...> Когда кончил, вытер глаза платком. Когда я убирала платок, он оказался мокрым» (РАЛ. MS 1067/364).

35 Первая запись в одесской, наиболее объемной части «Окаянных дней» датирована 25 апреля (12 апреля по ст. стилю) 1919 года. Первая сохранившаяся запись в реальном дневнике Бунина 1919 года - 9 мая.

36 Кроме всего прочего, апрель-май 1919 года - это время интенсивного и дружеского общения Буниных и М. А. Волошина, до его отъезда в Крым, см., в частности, мемуарный очерк Бунина «Волошин» (1930). 
этот факт останется в истории...» (Устали Буниных, 1, 257). В. Н. Муромцева описывает, как 12 июля в особняк Буковецкого нагрянули с обыском, Бунин все время, пока искали в других помещениях, оставался за своим письменным столом, «был в очках, перед ним лежала книга, но он не читал». Когда же красноармейцы появились на его пороге, Бунин «с необыкновенно свирепым видом» воспротивился им так яростно, что они не стали обыскивать его комнаты и «вышли тихо один за другим» (см.: Устали Буниных , 1, 275-278).

В августе 1919 года Бунины, «прожив почти пять несказанно мучительных месяцев под большевиками, освобождены были добровольцами Деникина, - его главная армия чуть не дошла в ту, вторую, осень до Москвы, - но в конце января 1920 года опять чуть не попали под власть большевиков и тут уж навсегда простились с Россией» (Бунин-9, 9, 437). Бунин тянул с отъездом до последней возможности. Осенью налаживается почтовое сообщение с заграницей, и А. Н. Толстой в первых же письмах из Парижа предлагает Буниным помощь и уговаривает уезжать: «Франция - удивительная, прекрасная страна, с устоями, с доброй стариной - обжитой дом», ${ }^{37}-$ но Бунин и тогда отказывается. В это время он пишет лекцию «Великий дурман», 21 сентября и 3 октября читает ее в Новороссийском (Одесском) университете. ${ }^{38}$ Яростный и горький пафос личного высказывания соединен здесь с едким описанием конкретных сцен революционного времени: «Великий дурман» - следующая после «Не могу говорить» ступень к «высокой» публицистике и к «Окаянным дням» как особому произведению. 8 октября в Одессу приезжает А. И. Деникин, и Бунин пишет статью «В этот день», по силе чувства и риторическим приемам сопоставимую с плачем Иеремии. Он вспоминает потрясения последних лет: обвинение в мятеже и отстранение генерала Корнилова, захват большевиками Москвы, пасхальные дни в Москве 1918 года, пересечение границы в Орше и жизнь в Одессе, отрезанной от основной части страны, и заканчивает словами, обращенными к Деникину: «Будь благословен твой ратный путь, Надежда России». ${ }^{39}$

С первых же дней, как Одесса была занята Добровольческой армией, началась работа по выпуску газеты «Южное слово». Бунин принимал участие в ее организации, а с середины октября в непосредственном руководстве: газета выходила «при ближайшем участии академика И.А. Бунина и академика Н. П. Кондакова». В ноябре-декабре Бунин регулярно печатает в «Южном слове» стихи, «Заметки» (см.: Публииистика, 30-44) и несколько старых рассказов, в январе - единственный написанный им в 1919 году рассказ, «Готами». ${ }^{40}$

В конце ноября 1919 года пошло решающее наступление Красной армии на юг. 3 декабря ею был взят Киев. 6 декабря В. Н. Муромцева отмечает: «Мы опять вступили в полосу больших событий. На фронте положение очень серьезное, напрягаются последние силы» (Устали Буниных $, 1,320)$. В тот же день Бунин получает командировочное удостоверение для работы в Париже

${ }^{37}$ РАЛ. MS 1066/5561; цит. по: Летопись, 1041; см. также: Там же, 1056-1057.

38 Полный текст лекции не сохранился, ее фрагменты на основе газетных публикаций 1919-1920 годов см.: Публицистика, 45-63.

39 Опубл.: Южное слово. 1919. 8 окт. № 29; см.: Публицистика, 27-29. См. также речь Бунина на банкете в честь А. И. Деникина (Там же, 29) и более позднюю дарственную надпись на книге Бунина «Чаша жизни» (Париж, 1921): «Антону Ивановичу Деникину в память прекраснейшего дня моей жизни - 25 сент <ября> 1919 г. в Одессе - когда я не задумываясь и с радостью умер бы за Него. Ив. Бунин Париж, 1922 г.» (цит. по: Публицистика, 475; датировка Бунина по ст. стилю). Сохранились и письма Деникина к Бунину 1922-1924 годов: РАЛ. MS 1066/2193-2199.

40 Подробнее о публикациях Бунина этого времени см.: Бакунцев А. В. И. А. Бунин на страницах одесской печати в годы Гражданской войны // Вестник Московского ун-та. Сер. 10. Журналистика. 2014. № 5. С. 55-70. 
в качестве корреспондента одесских газет. ${ }^{41} 20$ декабря В. Н. Муромцева пишет: «Тучей саранчи, как Атилла, идут большевики. На пути своем они уничтожают все, оставляя голую землю <...> / Получили визы на Варну и Константинополь $^{42}<\ldots>$ Ехать нам не миновать, но когда и куда поедем, знает один Бог» (Устали Буниных, 1, 322). Настроение следующих дней - паника.

Но даже теперь, как и перед прошлыми прощаниями, в последние дни перед концом прежней жизни Бунину было дано в полной мере испытать ее гармонию и сладость. Дважды, сначала 1 января, затем 13 января 1920 года, Бунины приходят в гости к своему давнему знакомому А. М. Дерибасу. ${ }^{43} 1$ января (19 декабря по ст. стилю) Александру Михайловичу исполняется 63 года, и в тот вечер всеми владеет чувство счастья и радости за его семью: дети Дерибаса после многих тревог и опасностей только что добрались до Одессы из разных мест, занятых красными. Бунин говорит, что «любит Александра Михайловича за то, что он человек уходящего мира, в котором было так много прекрасного, благородного и настоящего. А грядущий мир ужасен и никогда не примирится он с ним. И что в настоящую минуту, накануне эмиграции, он чувствует минувшую жизнь так остро, что трудно передать» (Устали БуниHbıx $, 1,328) .{ }^{44} 13$ января, на встрече нового, 1920 года (его отмечали по старому стилю), Бунин, вероятно, в последний раз видит свою первую жену, Анну Николаевну Цакни (вторым браком она была замужем за А. М. Дерибасом). ${ }^{45}$

Предотъездную хронику ведет В. Н. Муромцева. 3 февраля в городе слышна пальба. 4 февраля: «С кем бы мы ни встретились, каждый говорит: Иван Алексеевич, уезжайте! <...> / Порт охраняется английскими солдатами. <...> / Город пуст, только патрули». 6 февраля, когда идет погрузка на пароход «Спарта» («маленький, не внушивший доверия»), идут уличные бои: «...выстрелы еще далеко, но надежды уже никакой нет» (см.: Устали Буниных $, 1,336-342)$. На следующий день пароход перешел на внешний рейд и 9 февраля отправился в путь.

Об этих днях Бунин в 1921 году, уже в Париже напишет рассказ «Конец», ${ }^{46}$ в 1922-м - стихотворение «О, слез невыплаканных яд!..». Его центральный образ взят из псалма 136, начинающегося словами «На реках Вавилона, там сидели мы и плакали, когда вспоминали о Сионе...» (ср. также: Ис. 13: 16-18). За полгода до смерти, в мае 1953 года в авторских экземплярах своего последнего собрания сочинений ${ }^{47}$ Бунин от руки впишет над этим стихотворением заглавие - «России Ленина»:

41 Официально Бунин уезжал из Одессы как корреспондент газеты «Единая Русь» и «для организации в Белграде и Париже Отделения Издательства „Русская Культура“» (его удостоверение: РАЛ. MS 1066/1254). См. также: Устали Буниных, 1, 330-332.

42 Визы во Францию будут получены 6 января 1920 года.

43 Дерибас (де-Рибас) Александр Михайлович (1856-1937) - журналист и литератор, внучатый племянник основателя Одессы. Его брат, историк Одессы и библиофил Людвиг Михайлович Дерибас заведовал Городской Публичной библиотекой, где любила заниматься В. Н. Муромцева (она работала там над переводами П. Лоти).

44 Прямая перекличка со сказанным несколько дней назад о себе самом, «о том, что он не может жить в новом мире, что он принадлежит к старому миру, к миру Гончарова, Толстого, Москвы, Петербурга. Что поэзия только там, а в новом мире он не улавливает ее» (Устали Буниных, 1, 325; запись В. Н. Муромцевой от 26 декабря 1919 года).

45 В последующие годы они переписывались. Письмо А. Н. Цакни Бунину, полученное им после смерти А. М. Дерибаса (1937), начиналось словами: «Дорогой мой! Не могу не написать тебе, что я всегда тебя помню и люблю» (РАЛ. MS 1066/5626).

46 Первое название - «Гибель (Из повести)», опубл.: Звено. 1923. 12 марта. № 6; название «Конец» утвердилось в книге Бунина «Роза Иерихона» (Париж, 1924).

47 Бунин И. А. Собр. соч.: В 11 т. Т. 8. Несрочная весна. С. 204. Авторские экземпляры: РАЛ. MS 1066/10171; РАЛ. MS 1066/10172. В третьем, более раннем (март 1951 года) авторском экземпляре вписано заглавие «России» (РГБ. Ф. 429. Карт. 2. Ед. хр. 3). См.: Стихотворения, 2 , 188, 463 (комм.). 


\begin{abstract}
О, слез невыплаканных яд!
О, тщетной ненависти пламень!

Блажен, кто раздробит о камень

Твоих, Блудница, новых чад,

Рожденных в лютые мгновенья

Твоих утех — и наших мук!
\end{abstract}

Блажен тебя разящий лук

Господнего святого мщенья!

Когда в конце марта 1920 года Бунины приезжают в Париж, эмиграция полна слухами и планами свержения большевиков, и пройдет десять лет, прежде чем Бунин простится с надеждой вернуться в Россию. ${ }^{48}$ Но, уже уплывая из Одессы, он знал, что это - изгнание, и ярость, боль, гнев, отчаяние и самая ясная, чистая ненависть переполняют его. Только через полгода после приезда Бунин возвращается к письменному столу, начинает печатать политические и литературные заметки, собирает прежде не публиковавшиеся стихи, однако восстановить свой художественный мир не может. Не только потому, что нет больше той жизни, о которой он писал, но и потому, что чувствует: если он и будет дальше писать, то по-новому.

В течение 1921 года Бунин создает несколько рассказов, в разных сюжетных преломлениях которых звучат мотивы тщеты всех желаний, отречения и просветления. В одном из них звучит «отчаянная скорбь», которая «слаще самой высокой, самой страстной радости» некогда славного, непобедимого и могущественного Темир-Аксак-Хана: «Выньте душу мою, калеки и нищие, ибо нет в ней больше даже желания желать!» (Бунин-9, 5, 35-36). Этот рассказ В. Н. Бунина читала Бунину в одну из его предсмертных ночей - тогда, спустя 32 года он повторил слова своего героя как свои собственные (см.: Бунин-9, 5, 512). Но прежде в бунинской судьбе суждено было исполниться и другим его словам - из рассказа «Ночь отречения». В нем стоящий на берегу океана человек возглашает: «Как дождевая капля с тугого листа лотоса, скатывается с меня Желание!» - и слышит голос Будды: «Истинно, истинно говорю тебе, ученик: снова и снова отречешься ты от меня ради Мары, ради сладкого обмана смертной жизни, в эту ночь земной весны» (Бунин-9, 5, 39-40).

Написанный в том же, 1921 году автобиографически заостренный «Конец» о бегстве из осажденной Одессы, крахе и гибели всей прежней жизни продолжился поэтически ритмизованными «Косцами», уводящими взгляд «в бесконечную русскую даль», в которой «нет, да никогда и не было, ни времени, ни деления его на века» (Бунин-9, 5, 68; историю рассказа см.: Бунин-9, 9, 370). Запись в дневнике Бунина о том, как начинались «Косцы», обозначает зарождение его новой писательской манеры: «Все дни, как и раньше часто бывало и особенно эти последн <ие > проклятые годы <...> бесплодные поиски в воображении, попытки выдумать рассказ, - хотя зачем это? и попытки пренебречь этим, а сделать что-то новое, давным-давно желанное $<. .>$ - начать книгу, о которой мечтал Флобер, „Книгу ни о чел“, безо всякой внешней связи, где бы излить свою душу, рассказать свою жизнь, то, что довелось видеть в этом мире, чувствовать, думать, любить, ненавидеть <...> Нынче неожиданно начал „Косцов“ <...>» (Устали Буниных, 2, 66-67).

48 См.: Двинятина Т. Дневники И. А. Бунина 1920-х гг.: пространство и пределы реконструкции // Avtobiografija. Journal on Life Writing and the Representation of the Self in Russian Culture. 2019. № 8. C. 97-116. 
И тогда публицистика и актуальность отступают, и за тем пределом, который понимается как смерть и конец, приходит освобождение и начинается восхождение Бунина к лирическому эпосу «Жизни Арсеньева». В 1922-1924 годах в этом мире, утраченном въяве и воссоздаваемом творческим сознанием Бунина, постепенно появляются конкретные герои («Далекое», «В некотором царстве», "Сосед») и заново определяются истоки, характер и смысл писательского творчества («Неизвестный друг», «Музыка»). Стремление высказать себя резонирует с обращением к общему, не вполне сознаваемому, но существенному опыту в другом (читателе, адресате, поколении): «Поистине только одна, единая душа есть в мире» (Бунин-9, 5, 91; ср. стихотворения «В горах», «У гробницы Виргилия», оба - 1916). В прошлый раз подобное возвращение к жизни Бунин испытал летом 1918 года в Одессе. Осенью 1923 года круг смерти, перерождения и воскрешения автора и мира завершается рассказом «Несрочная весна». Обретя опору в элегической традиции и поэтической философии памяти (прежде всего Е. А. Баратынского), Бунин словно замкнул свод над прошлым. Теперь оно существовало наравне с его настоящим, и, не в состоянии превозмочь слом между ними в реальном бытии, Бунин совмещает их в своем художественном воображении. Натяжение между прошлой всеохватной гармонией и настоящим одиноким и трагическим мигом образует главную, пронзительную, неутоленную интонацию его позднего творчества.

DOI: $10.31860 / 0131-6095-2020-3-129-141$

(ㄷ) С. Н. МОРОЗОВ

\section{РАССКАЗ И.А. БУНИНА «ЦИКАДЫ»: ИСТОРИЯ ТЕКСТА*}

Исследование текстологии прозы И. А. Бунина уже началось и постепенно развивается. В этом направлении появился целый ряд статей, однако, чтобы получить более или менее обобщающее представление о проблемах и вопросах в данной области, предстоит еще многое сделать.

В настоящей статье мы остановимся на одном из рассказов, исследуя историю его текста, основные варианты и редакции. Рассказ «Цикады» И.А. Бунин написал в Грассе в сентябре 1925 года. Сохранились автографы черновиков (РАЛ. MS 1066/201-206) и чистовая машинопись рассказа (РГАЛИ. Ф. 44. Оп. 1. Ед. хр. 19; судя по качеству печати, это 2-й или 3-й отпуск). Кроме того, до нас дошли три авторских экземпляра 9-го тома берлинского Собрания сочинений с правкой Бунина (РАЛ. MS 1066/10174, 10175; РГБ. Ф. 429. К. 2. Ед. хр. 4).

Впервые «Цикады» были напечатаны в парижском журнале «Современные записки». ${ }^{1}$ Затем включены Буниным в сборник «Солнечный удар». ${ }^{2}$ Последняя авторская публикация этого рассказа появилась в Собрании сочинений,

\footnotetext{
* Статья подготовлена при финансовой поддержке гранта РНФ (проект № 17-18-01410-П) в Институте мировой литературы им. А. М. Горького РАН.

1 Современные записки. 1925. № 26. С. 85-101. Далее ссылки на это издание даются в тексте сокращенно: $C 3$, с указанием номера страницы.

2 Бунин И. Солнечный удар. Париж, 1927. С. 113-130. Далее ссылки на это издание даются в тексте сокращенно: $C У$, с указанием номера страницы.
} 
где девятый том имел название «Цикады» по первому помещенному в нем рассказу. ${ }^{3}$ Во всех изданиях под текстом стояла авторская дата: 17 сентября 1925 года, Приморские Альпы.

Первый частный отзыв появился в письме И. И. Фондаминского, который получил от Бунина рукопись рассказа для публикации в «Современных записках». Он писал Бунину 19 октября 1925 года из Парижа: «Когда я прочел „Цикады“, я пошел к Амалии Осиповне <Фондаминской. - C. M.> и сказал: Это одна из лучших вещей Ивана Алексеевича. Вишняк говорит, что я увлекаюсь - что „Цикады“ не лучше других Ваших произведений. Я же убежден, что не ошибаюсь: художественная проза (не так, как природа или архитектура) редко подымает меня до восторженного состояния. Читая же „Цикады“, я испытывал восторг». ${ }^{4}$

Критика сразу оценила рассказ. Первая рецензия развернулась в целую статью о творчестве Бунина, в центре которой было новое произведение писателя: «Что такое „Цикады“? Скорее всего, лирическая поэма в прозе: в ней много философского, но облеченного не в логические формы рассуждений, а в целый поток настроений, мыслей, образов и чувств. Здесь душа беседует сама с собой. И вместе с тем в ней есть что-то музыкальное, чарующее. <...>

$<. . .>$ Ни в одном, может быть, произведении Бунина так отчетливо, определенно и ярко не выразились его мироощущение и характерный для всего его творчества поэтический пантеизм. Но, повторяю, это не рассуждения мыслителя, а думы поэта. <...> Читая их («Цикады». - C. M.), вы приобщаетесь к тому чувству великого счастья, которое Бунин испытывает „от великого покоя и великой гармонии ночи“, от ощущения красоты, разлитой в природе, в жизни, во всей вселенной. <...>

В русской литературе нет ни одного произведения, в котором „естество“ поэта было бы раскрыто с такой яркостью, как в „Цикадах“. <...> Грани между действительностью и воображением стираются, поэт живет не только своей, но и тысячами чужих жизней. У Бунина эта способность перевоплощения изображена с поразительной отчетливостью <...> .

В „Цикадах“ много личного, но это личное настолько связано с тем общим, что называется „художественным творчеством“, что новое произведение Бунина далеко выходит за те пределы, которые он сам себе поставил. Это одно из произведений, над которым долго будут задумываться не только ценители искусства, но и психологи. <...>

Но в целом „Цикады“ звучат гимном жизни, красоте, добру». ${ }^{5}$

3. Н. Гиппиус в рецензии на свежий номер «Современных записок» в «Последних новостях» благосклонно упомянула произведение Бунина: «...новейший его рассказ „Цикады“, достойный всяческих похвал за неувядаемо-прекрасный бунинский язык, - сам есть передача размышлений поэта, далеко не блещущих новизной, и с которыми, в сущности, нечего делать». ${ }^{6}$

Ю. И. Айхенвальд отмечал: «Под не прерывающийся ни на секунду „хрустальный звон“ цикад <...> возвышенные думы волнуют сердце писателя, и он воспроизводит их в такой прозе, которая звучит торжественной, органной музыкой, и слышится в ней и вся скорбь предстоящей смерти, физиче-

${ }^{3}$ Бунин И. А. Собр. соч.: В 11 т. Берлин, 1935. Т. 9. Цикады. С. 7-23. Далее ссылки на этот том даются в тексте сокращенно: $C C$, с указанием номера страницы.

4 «Если хотите меня печатать, терпите»: И. А. Бунин / Публ. и прим. О. А. Коростелева и М. Шрубы; вступ. статья О. А. Коростелева // «Современные записки» (Париж, 1920-1940). Из архива редакции: В 4 т. / Под ред. О. Коростелева и М. Шрубы. М., 2012. Т. 2. С. 731-732.

5 Кульлан Н. К. «Цикады» Бунина // Возрождение (Париж). 1925. 17 дек. № 198. С. 3-4.

6 Крайний А. [Гиппиус 3. Н.]. «,Течение“ „Современных записок“ (кн. XXVI)» // Последние новости (Париж). 1925. 24 дек. № 1740. С. 2. 
ской разлуки с землею и все счастье того упоительного бессмертия, какое суждено душе поэта, которая в своих созданиях отпечатлевает себя для человечества и томится неутомимой жаждой жизни, вечной жизни в себе и в других, и жаждой вечной памяти. Свое существование перелить в слово, если уже не в плоть, - не в этом ли для поэта одоление смерти $?<$...> явственно ощущаешь - у Бунина переживаемый им восторг слова и сам от него этот восторг перенимаешь» ${ }^{7}$

В рецензии на "Современные записки» М. О. Цетлин, в частности, подчеркивал, что в этом «стихотворении, или вернее поэме в прозе <...>, в его эстетике и философии творчества - ключ ко всей философии Бунина. Философия эта близка к буддизму. Ценны здесь не рассуждения, а переживания, их глубина и убедительность. Как не поверить Бунину, что его предки или он сам в ином воплощении (ибо грань индивидуальности почти стирается Буниным) жили на Цейлоне, что он не видит, а вспоминает южный рай. Богатство художника для Бунина - это богатство памяти, личной и родовой. Чтобы воплотить это богатство, нужна какая-то первобытная страстность мировосприятия...». ${ }^{8}$

В литературной «Анкете „Возрождения“» на вопрос «какие произведения русской зарубежной беллетристики, появившиеся в 1925 году, по Вашему мнению, являются наиболее ценными?» Б. К. Зайцев и И. С. Шмелев назвали среди прочих произведений рассказ «Цикады». ${ }^{9}$

Этот рассказ был отмечен даже советскими критиками. Н. П. Смирнов в статье «На том берегу. Заметки об эмигрантской литературе», в частности, писал: «Все то, чем исполнены последние рассказы и стихи Бунина: любовь к земле, страшная тоска отчуждения, ледяное дыхание смерти, горечь творческой жажды, - все это особенно ярко сказалось в его рассказе „Цикады“.

„Цикады“ один из лучших по своей музыкальной напевности рассказов Бунина». ${ }^{10}$

Д. А. Горбов, упомянув этот рассказ в статье «10 лет литературы за рубежом», отнес его к «новеллам - лирическим монологам». ${ }^{11}$

Первые черновые наброски (РАЛ. MS 1066/201-202), имеющие отношение к будущему рассказу, являются ранними записями под заглавием «Безымянные записки» (авторская дата: «Осень 1921 г. Париж») и «Книга моей жизни» (авторская дата: «Ноябрь, 1921 г.»). Эти тексты были опубликованы с купюрами Л. Ф. Зуровым в «Новом журнале», ${ }^{12}$ а затем перепечатаны оттуда в «Литературном наследстве». ${ }^{13}$ Во вступительной статье А. К. Бабореко, возражая Зурову, который относил обнаруженные автографы к первым наброскам романа «Жизнь Арсеньева», писал: «Зуров исключил из опубликованного текста места, взятые Буниным для рассказа „Цикады“, обозначив пропуски многоточием. Но и в сокращенном виде остается много совпадений с рассказом, что как будто позволяет сблизить „Книгу моей жизни“ в большей

7 Айхенвальд Ю. И. Литературные заметки // Руль (Берлин). 1926. 13 янв. № 1554. С. 2.

8 Цетлин М. О. «Современные записки». XXVI. Париж // Дни (Париж). 1926. 24 янв. № 912 . C. 4 .

9 Анкета «Возрождения»// Возрождение. 1926. 4 марта. № 275. С. 4.

10 Смирнов Н. П. На том берегу. Заметки об эмигрантской литературе // Новый мир. 1926. № 6. С. 149 .

11 Горбов Д. А. 10 лет литературы за рубежом // Печать и революция. 1927. № 8. С. 13.

12 Бунин И. А. Безымянные записки / Публ. Л. Зурова // Новый журнал (Нью-Йорк). 1966. Кн. 84. С. $49-55$.

13 Бунин И. А. Безымянные записки. Книга моей жизни / Публ. А. К. Бабореко // Лит. наследство. 1973. Т. 84. Иван Бунин: В 2 кн. / Ред. А. Н. Дубовиков и С. А. Макашин при участии Т. Г. Динесман. Кн. 1. С. $382-386$. 
мере с „Цикадами“, чем с „Жиинью Арсеньева“. Но некоторые фразы записок можно найти и в „Жиини Арсеньева“ <...> мнение Л. Ф. Зурова, отнесшего на основании найденных им записей начало работы над этим романом к 1921 г., представляется нам ошибочным». ${ }^{14}$ Добавим от себя, именно к данному времени относятся размышления писателя о создании «Книги ни о чем»: «Все дни, как и раньше часто и особенно эти последн<ие> проклятые годы, м. б., уже погубившие меня, - мучения, порою отчаяние - бесплодные поиски в воображении, попытки выдумать рассказ, - хотя зачем это? - и попытки пренебречь этим, а сделать что-то новое, давным-давно желанное, и ни на что не хватает смелости, что ли, умения, силы (а м. б. и законных художеств<енных $>$ оснований?) - начать книгу, о которой мечтал Флобер, „Книгу ни о чел“", без всякой внешней связи где бы излить свою душу, рассказать свою жизнь, то что довелось видеть в этом мире, чувствовать, думать, любить, ненавидеть». ${ }^{15}$

Следующие единицы хранения РАЛ являются уже черновиками непосредственно рассказа «Цикады» (РАЛ. MS 1066/203-204). Кроме них сохранилась машинопись (с правкой) начала рассказа, продолженная рукописью основной части рассказа (РАЛ. MS 1066/205), а также автограф с концовкой рассказа (РАЛ. MS 1066/206).

В результате анализа этих документов можно прийти к следующим выводам. Конечно, «Безымянные записки» и «Книга моей жизни» не являются, точнее, не являлись в момент их написания подготовительными материалами ни для рассказа «Цикады», ни тем более для романа «ЗКизнь Арсеньева». Бунин только в конце марта 1920 года прибыл в Париж после долгой и опасной дороги в эмиграцию. $K$ художественному творчеству писатель начал постепенно возвращаться только в 1921 году. Сохранившиеся автографы 1921 года показывают нам, о чем Бунин размышлял. В этот момент наметился поворот Бунина к поиску новых форм, нового жанра.

Надо особо подчеркнуть, что именно эти записи (РАЛ. MS 1066/201-202) Бунин никогда не публиковал. Во время работы писатель часто поступал так: он начинал стихотворение или рассказ, но не заканчивал их сразу, а оставлял их в своем портфеле. Периодически он возвращался к своим записям, наброскам, которые всегда возил с собой, перечитывал. Таким образом, «Безымянные записки» и «Книга моей жизни» так и остались лежать в его портфеле, но, через несколько лет вернувшись к ним, Бунин написал свой шедевр - pacсказ «Цикады», а позднее частично использовал и в романе «Жизнь Арсеньева». В связи с этим в дальнейших рассуждениях мы будем учитывать только непосредственно автографы рассказа «цикады» (РАЛ. MS 1066/203-206).

Следует отметить, что все многочисленные разночтения между черновыми автографами, машинописями и печатными текстами должны быть приведены в научном Полном собрании сочинений Бунина. Нами будут рассмотрены лишь некоторые примеры.

Первый черновой автограф (РАЛ. MS 1066/203) имеет заглавие «Цикады», которое уже в конце жизни синей шариковой ручкой Бунин изменил на «Ночные цикады», потом это заглавие было зачеркнуто и рядом написано «Ночь?».

В этой первоначальной редакции текста, кроме рассказчика, был еще один персонаж - хозяин дачи, с которым главный герой беседует ночью. Вот начало текста: «На даче было темно, — было уже поздно, — и вся степь вокруг

14 Там же. С. 381.

15 Устами Буниных: Дневники Ивана Алексеевича и Веры Николаевны и другие архивные материалы: В 3 т. / Под ред. М. Грин. Frankfurt a/M., 1981. Т. 2. С. 66-67 (запись в дневнике Бунина от 27 октября (9 ноября) 1921 года). 
струилась непрерывным журчанием цикад. Хозяин и его гость, писатель, сделав длинную прогулку по обрывам над морем, лежали в камышовых креслах на балконе. Они курили, изредка обменивались несколькими словами и слушали, слушали: в этом хрустальном журчании было какое-то наваждение» .

Эта ранняя редакция значительно отличается от текста журнальной публикации: ее текст больше по объему, в нем отсутствует финал, появившийся в печатном варианте, и по своему содержанию и настрою представляет собой молитву Богу, исповедь.

В следующих черновых автографах (РАЛ. MS 1066/204-205) текст меняется: делится на главки, хозяин дачи уже не упоминается, рассказ ведется от первого лица. Как и в случае с первым автографом, в конце жизни Бунин изменил название текста, сделав исправления красной шариковой ручкой: «Ночные цикады»- «Ночь». То же мы увидим в авторских экземпляpax 9-го тома берлинского Собрания сочинений Бунина. Под этим новым заглавием «Ночь» мы знаем этот рассказ по современным изданиям произведений писателя.

По всей видимости, Бунин довольно долго работал над этим рассказом. Разночтения между черновым автографом и первой публикацией многочисленны и разнообразны. Приведем наиболее значительные из них между более полным черновым автографом (РАЛ. MS 1066/205; далее - ЧА) и публикацией в «Современных записках» .

\begin{tabular}{|c|c|}
\hline ЧA & C3 \\
\hline $\begin{array}{l}\text { «...и вся степь окрест струится непрерыв- } \\
\text { ным журчаньем». }\end{array}$ & $\begin{array}{l}\text { «...и все окрест струится непрерывным жур- } \\
\text { чаньем» }(C 3, \text { с. } 85) .\end{array}$ \\
\hline «...желание осознать и запомнить». & $\begin{array}{l}\text { «..желание зачем-то осознать и запомнить» } \\
\text { (СЗ, с. } 86) .\end{array}$ \\
\hline «Может быть, эта корысть есть только & «Откуда тоска? Из тайного чувства, что \\
\hline следствие моего ремесла? Да, но что такое & только во мне одном нет покоя, нет гармо- \\
\hline $\begin{array}{l}\text { ческое побуждение не есть основное свой- } \\
\text { ство человеческой природы?» }\end{array}$ & $\begin{array}{l}\text { корысть? Она есть следствие моего ремесла. } \\
\text { А что такое мое ремесло? Творческое побуж- } \\
\text { дение есть основа человеческой природы" } \\
(C 3, \text { с. } 86) .\end{array}$ \\
\hline «...ведущую к бесплодию, к неделанию & «...ведущую к бесплодию и к старой, как \\
\hline и к старой, как мир, мудрости, что нет че- & мир, мудрости, что нет человеку пользы ни \\
\hline ловеку пользы ни от каких трудов его под & от каких трудов его под солнцем? Разве не \\
\hline $\begin{array}{l}\text { солнцем? / Увы, тут некий заколдованный } \\
\text { круг. / Разве не больше, чем многим дру- }\end{array}$ & $\begin{array}{l}\text { больше, чем многим другим, отпущено мне } \\
\text { сил для этой борьбы?» }(C 3, \text { c. } 87) .\end{array}$ \\
\hline $\begin{array}{l}\text { гим, отпущено мне сил для этой борьбы } \\
\text { со смертью?» }\end{array}$ & \\
\hline «...моей формы. Ибо кому дается больше...». & $\begin{array}{l}\text { «...моей формы. Тут всегда некий заколдо- } \\
\text { ванный круг. Кому дается больше...» (C3, } \\
\text { с. 87). }\end{array}$ \\
\hline «...я, в сущности, ничего не понимаю». & «...я ничего не понимаю» $(C 3$, с. 87$)$. \\
\hline $\begin{array}{l}\text { «...для этого земного „бывания“, как выра- } \\
\text { жается индийская мудрость, погибаю». }\end{array}$ & $\begin{array}{l}\text { «..для этого земного „бывания“, погибаю» } \\
(C 3, \text { с. 88). }\end{array}$ \\
\hline «...вокруг меня южные степи». & $\begin{array}{l}\text { «...вокруг меня южные предгорья» (C3, } \\
\text { с. 88). }\end{array}$ \\
\hline «...роковым знаком „умствования“». & $\begin{array}{l}\text { «..роковым знаком удивления, „умствова- } \\
\text { ния“» }(C 3, \text { с. } 89) .\end{array}$ \\
\hline «...дивный и великий храм ночи». & «...великий храм ночи» $(C 3$, с. 89$)$. \\
\hline
\end{tabular}


«Так подобает ли человеку быть ночью в бодрствовании, в созерцании „бездны“ и в том непостижимом, что есть наше думанье, умствование?»

«...сильное Я, жажда вящего утверждения своей личности».

«Все эти Толстые и Будды...» .

«И несметные степные жизни поют окрест, в поле, в саду, по морским обрывам как будто...».

«Недавно мне как-то случилось проснуться очень рано, на рассвете. Я проснулся и вдруг почему-то поразился мыслью, что мне сорок пять лет. Ах, как велика казалась в детстве, в юности подобная цифра! Казалось, что это какое-то особое...» .

«...случается проснуться на ранней утренней заре: чувство счастья...».

«Вот я прожил почти полвека...».

«Еще ужасно мне Твое безначалие и Твоя бесконечность! / O, я прибавляю к этому стенанию мольбу: „Дай мне запечатлеть мое обманное, а все же несказанно сладостное бывание хотя бы в слове, если уже $<$ не> во плоти: дай хоть это потомство мне!“"

Другой автограф (РАЛ. MS 1066/204) представляет собой черновик середины рассказа с правкой, текст делится на главки (с VI по XII) иначе, чем в ЧА. Разночтений между ними, а также журнальной публикацией довольно много, следовательно, этот текст - более ранний переработанный в уже рассмотренный нами. Оба черновые автографа содержат цитаты из стихотворений Ф. И. Тютчева «День и ночь», «Святая ночь», «Как океан объемлет шар земной...». Возможно, у Бунина была мысль добавить их в текст рассказа, но он отказался от нее.

Третий автограф (РАЛ. MS 1066/206) заключает в себе только концовку рассказа и практически совпадает с опубликованным в «Современных записках» текстом. Однако содержит очень важную деталь - в конце помимо подписи Бунина стоит дата «17/30 сент<ября> 1925. Приморск<ие> Альпы» . Во всех прижизненных публикациях рассказ датировался только по старому стилю: «17.IX.1925» (как и во всех последующих посмертных собраниях сочинений писателя). В Полном собрании сочинений Бунина под текстом рассказа «Цикады» должна стоять полная авторская дата из автографра: «17/30 сент. 1925. Приморск. Альпы». В связи с этим возникает вопрос, относящийся к общей проблеме датировки произведений Бунина: по какому стилю датированы другие его рассказы ${ }^{16}$ Но это тема для отдельного исследования.

Текст сохранившейся машинописи рассказа «Цикады» (РГАЛИ. Ф. 44. Оп. 1. Ед. хр. 19) очень близок к тексту первой журнальной публикации. По всей видимости, Бунин мог внести свою правку в первый экземпляр машинописи перед отсылкой его Фондаминскому. При сверке с текстом «Современ-

16 Подробнее см.: Морозов С. Н. Проблема датировки прозы И. А. Бунина // Литературный факт. 2017. № 4. С. 317-325. 
ных записок» было выявлено 15 незначительных точечных разночтений: замена, вычеркивание, дописывание отдельных слов и т. п. Самая большая поправка с дополнением - последняя в таблице.

\begin{tabular}{|c|c|}
\hline РГАЛИ & C3 \\
\hline $\begin{array}{l}\text { «...люди пустились в слишком большую } \\
\text { затейливость». }\end{array}$ & $\begin{array}{l}\text { «...люди пустились в большую затейли- } \\
\text { вость» }(C 3, \text { с. } 85) .\end{array}$ \\
\hline «Но не важно о чем думал я...». & $\begin{array}{l}\text { «Но не важно о чем именно думал я...» }(C 3, \\
\text { c. } 87) .\end{array}$ \\
\hline «...в неведении о себе». & «...в недумании о себе» $(C 3$, с. 89$)$. \\
\hline «...мерой их удивления». & «...мерой этого удивления» $(C 3$, с. 89$)$. \\
\hline «на некоторый срок». & «на некий срок» $(C 3$, с. 90). \\
\hline «бесплодное мудрствование». & «бесплодное умствование» $(C 3$, с. 90$)$. \\
\hline «...малейшего представления». & $\begin{array}{l}\text { «...малейшего представления, знания» }(C 3, \\
\text { с.91). }\end{array}$ \\
\hline «И хотя вся моя жизнь». & «И хотя почти вся моя жизнь» $(C 3$, с. 92$)$. \\
\hline «Но я знаю, что они есть». & «Но пусть, я знаю, что они есть» (CЗ, с. 95). \\
\hline «...но даже и в течение тысячелетий?» & «...но и в течение тысячелетий?» $(C 3$, с. 95$)$. \\
\hline «...но и отцом». & «...но и своим отцом» $(C 3$, с. 95$)$. \\
\hline $\begin{array}{l}\text { «...навсегда померкнут в той последней } \\
\text { Тьме». }\end{array}$ & $\begin{array}{l}\text { «...навсегда, навеки померкнут, погибнут } \\
\text { в той последней Тьме» }(C 3, \text { с. } 95) .\end{array}$ \\
\hline «И почти те же чувства...». & «И почти те же самые чувства...» (CЗ, с. 97$)$. \\
\hline «...сравнительно малом». & «...сравнительно очень малом» (CЗ, с. 98). \\
\hline $\begin{array}{l}\text { «...своего райского праотца, но, увы, Рая } \\
\text { уже лишенные». }\end{array}$ & $\begin{array}{l}\text { «...своего райского праотца, его телесности. } \\
\text { Это люди райски чувственные в своем ми- } \\
\text { роощущении, но, увы, Рая уже лишенные» } \\
(C 3, \text { с. } 98) .\end{array}$ \\
\hline
\end{tabular}

В дальнейшем Бунин, видимо, приостановил работу над текстом и при подготовке к помещению в сборник «Солнечный удар» внес всего 4 исправления.

\begin{tabular}{|c|c|}
\hline C3 & СУ \\
\hline $\begin{array}{l}\text { «...все как будто растущие и растущие хру- } \\
\text { стальными винтами цветы» }(C 3, \text { с. } 88) .\end{array}$ & «...все как будто растущие хрустальными \\
\hline (1) & 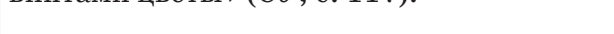 \\
\hline $\begin{array}{l}\text { «Но ведь каждые семь лет весь человек пе- } \\
\text { рерождается...» }(C 3, \text { с. } 91) .\end{array}$ & $\begin{array}{l}\text { «Но, ведь, каждые семь лет человек пере- } \\
\text { рождается...» (CУ, с. 120). }\end{array}$ \\
\hline $\begin{array}{l}\text { «...с его огромной подсознательностью, } \\
\text { а вместе с тем особью, безмерно обогащен- } \\
\text { ной...» }(C 3, \text { с. } 92) .\end{array}$ & $\begin{array}{l}\text { «..c его огромной подсознательностью } \\
\text { и вместе с тем особью, безмерно обогащен- } \\
\text { ной...» }(C У, \text { c. } 121) .\end{array}$ \\
\hline $\begin{array}{l}\text { «..обманной и горькой сладостью бывания» } \\
(C 3, \text { с. } 99) .\end{array}$ & $\begin{array}{l}\text { «...обманной и горькой сладостью Быва- } \\
\text { ния» }(C У, \text { с. } 128) .\end{array}$ \\
\hline
\end{tabular}

В следующий раз при обращении к тексту - уже при подготовке Собрания сочинений в 1934-1935 годах - Бунин основательно переработал рассказ, сильно сократив его. 


\begin{tabular}{|c|c|}
\hline СУ & $C C$ \\
\hline $\begin{array}{l}\text { «Ночная темно-синяя бездонность неба...» } \\
(C 3, \text { с. } 113) .\end{array}$ & «Ночная бездонность неба...» $(C C$, с. 7$)$. \\
\hline «...оно глубоко молчит» $(C 3$, с. 113). & $\begin{array}{l}\text { «..оно летаргически-недвижно, молчит» } \\
(C C, \text { с. } 7) .\end{array}$ \\
\hline $\begin{array}{l}\text { «Но я все мучу себя, все умствую» }(C 3, \\
\text { с. 114). }\end{array}$ & «Но я все „умствую“» $(C C$, с. 8). \\
\hline $\begin{array}{l}\text { «Как всегда, были обрывки каких-то воспо- } \\
\text { минаний, какие-то мысли об окружающем } \\
\text { и желание зачем-то осознать и запом- } \\
\text { нить...» }(C 3, \text { с. } 114) .\end{array}$ & $\begin{array}{l}\text { «Какие-то мысли (или подобие мыслей) } \\
\text { об окружающем и желание зачем-то запом- } \\
\text { нить...» }(C C, \text { с. } 8) .\end{array}$ \\
\hline $\begin{array}{l}\text { «...гармонии ночи и от того, что я вижу, } \\
\text { ощущаю эту красоту, рядом же с этим - } \\
\text { чувство какой-то тоски и какой-то вечно } \\
\text { томящей меня корысти, жажда как-то ис- } \\
\text { пользовать это счастье и даже вот эту самую } \\
\text { тоску и жажду. Вечный крест мой!» }(C 3, \\
\text { с. } 114) .\end{array}$ & $\begin{array}{l}\text { «..гармонии ночи, рядом же с этим чувство } \\
\text { какой-то тоски и какой-то корысти» }(C C, \\
\text { с. } 8) .\end{array}$ \\
\hline $\begin{array}{l}\text { «...во мне одном нет покоя, нет гармонии, } \\
\text { нет покорности и бездумности» }(C 3, \text { с. } 114) .\end{array}$ & $\begin{array}{l}\text { "...во мне одном нет покоя — вечное тайное } \\
\text { томление! - и нет бездумности» }(C C, \text { c. } 8) .\end{array}$ \\
\hline $\begin{array}{l}\text { «Откуда корысть? Она есть следствие моего } \\
\text { ремесла. А что такое мое ремесло? Творче- } \\
\text { ское побуждение есть основа человеческой } \\
\text { природы. ЖЖизнь есть некая форма, некое } \\
\text { воплощение чего-то, нам неведомого. И веч- } \\
\text { но чувствуем мы срочность и зыбкость этой } \\
\text { формы и боимся своей бесследности. „В бу- } \\
\text { дущие...“» }(C 3, \text { с. } 114) .\end{array}$ & $\begin{array}{l}\text { «Откуда корысть? Из жажды как-то исполь- } \\
\text { зовать это счастье и даже эту самую тоску } \\
\text { и жажду, что-то создать из них... Но и тут } \\
\text { тоска, Екклезиаст: „В будущие...“» (CC, } \\
\text { с. 8). }\end{array}$ \\
\hline
\end{tabular}

Далее сделано значительное сокращение. В СУ читаем: «И вот: „Предпринял я большие дела, - построил себе домы, посадил виноградники, устроил сады и рощи... приобрел себе слуг и служанок, собрал серебра и золота от царей и областей“... Зачем? Затем, что, трудясь и в трудах достигая силы, славы, радуется человек этой силе, славе, как плодотворности в своей борьбе со смертью, разрушительницей форм. И тот, кому дано чувствовать их зыбкость и непрочность особенно, особенно и одержим жаждой такой борьбы. И я из числа именно этих особенных. Так что-же я умствую и пускаюсь в „затейливость“, ведущую к бесплодию и к старой, как мир, мудрости, что нет человеку пользы ни от каких трудов его под солнцем? Разве не больше, чем многим другим, отпущено мне сил для этой борьбы? Да, но совсем не в меру моего все растущего чувства роковой непрочности, зыбкости моей формы. Тут всегда некий заколдованный круг. Кому дается больше, с того больше и спрашивается. Чем страстней певец...» (CУ, с. 115). В СС Бунин оставил несколько сжатых строк: «И тут я „умствую“, и тут пускаюсь в „затейливость“, ведущую к бесплодию! Чем страстней певец...» $(C C$, с. 8$)$.

\begin{tabular}{|l|l|}
\hline \multicolumn{1}{|c|}{ СУ } & \multicolumn{1}{|c|}{$C$ C } \\
\hline «...во мне есть нечто, некий придаток - & «...во мне есть, помимо всего моего, еще не- \\
очевидно, не разложимый, основной, - & кое нечто, очевидно, основное, неразложи- \\
поистине частица самого Бога» $(C У$, с. 116$)$. & мое,- истинно частица Бога» $(C C$, c. 9). \\
«Но я же и отвечаю на это утешение: $/-$ & «- Да, но ведь это частица того, \\
То есть частица того, не имеющего ни фор- & не имеющего ни формы, ни времени, \\
\hline
\end{tabular}


мы, ни времени, ни пространства, что для земли, для моего земного существования, и есть моя гибель! Это нечто дает нам мудрость, иными словами - смерть» $(C У$, c. 116).

ни пространства, что́ и есть моя гибель» $(C C$, c. 9$)$.

После этих правок опять последовало большое сокращение текста. В СУ читаем: «...все как будто растущие хрустальными винтами цветы. / И я слушаю, слушаю этот звон и думаю. / Я думаю о том, как я счастлив этими ночами, летом, югом, тем, что вокруг меня южные предгорья, а вот под этими обрывами, в двух шагах от меня, покоится в звездной летаргии то дивное, что называется морем. И еще я думаю о том, как бесконечно я несчастен, томясь своим счастьем, которому всегда не достает чего-то и которое так преходяще, бесследно и так отравлено все растущим во мне безумием: безумием моей отделенности от мира и даже от самого себя, удивления перед ним и перед собственным существованием, непонимания ни себя, ни его. Так в детстве смотрелся я иногда в зеркало: что это такое, кто это тот, которого я вижу, который есть $\Omega$ и о котором $я$-же и думаю, и кто на кого смотрит?» (CУ, с. 117). В CC осталась только измененная концовка абзаца: «...все как будто растущие хрустальной спиралью цветы...» $(C C$, с. 10$)$.

\begin{tabular}{|c|c|}
\hline СУ & $C C$ \\
\hline $\begin{array}{l}\text { «Я всю жизнь живу под страшным знаком } \\
\text { смерти - и все-таки у меня всю жизнь } \\
\text { такое чувство, будто я никогда не умру» } \\
(C У, \text { с. } 120) .\end{array}$ & $\begin{array}{l}\text { «Я всю жизнь живу под знаком смерти - } \\
\text { и все-таки всю жизнь чувствую, будто я ни- } \\
\text { когда не умру» }(C C, \text { с. } 13) .\end{array}$ \\
\hline $\begin{array}{l}\text { «Меня выделили из многих прочих. Вы- } \\
\text { делили мое воображение, память, воспри- } \\
\text { имчивость, умение высказываться. } \\
\text { И хотя почти вся моя жизнь есть почти } \\
\text { сплошное и мучительное сознание слабо- } \\
\text { сти и ничтожества всех моих только что } \\
\text { перечисленных свойств, я, по сравнению } \\
\text { с некоторыми, и впрямь не совсем обыч- } \\
\text { ный человек» }(C У, \text { с. } 120) .\end{array}$ & $\begin{array}{l}\text { «Меня выделили из многих прочих. И хотя } \\
\text { всю жизнь я мучительно сознаю слабость } \\
\text { и недостаточность всех моих способностей, я, } \\
\text { по сравнению с некоторыми, и впрямь не со- } \\
\text { всем обычный человек» }(C C, \text { с. } 13) .\end{array}$ \\
\hline $\begin{array}{l}\text { «...и в то же время ощутители Нирваны } \\
\text { с ее вечным блаженством, все-таки всегда } \\
\text { скорбным для смертного, никогда на зем- } \\
\text { ле не могущего отказаться до конца от } \\
\text { Майи, от сладости „бывания“. Все они } \\
\text { отличаются все возрастающей с годами } \\
\text { религиозностью, то есть страшным чув- } \\
\text { ством своей связанности со Всебытием- } \\
\text { и неминуемого в нем исчезновения» }(C У, \\
\text { с. } 122) \text {. }\end{array}$ & $\begin{array}{l}\text { «...и все отличаются все возрастающим с го- } \\
\text { дами чувством Всебытия и неминуемого } \\
\text { в нем исчезновения...» }(C C, \text { c. } 15) .\end{array}$ \\
\hline $\begin{array}{l}\text { «...ее страшнее и царственнее. - Боже, } \\
\text { как блаженна и как скорбит душа моя, } \\
\text { лишенная Твоего Эдема!» }(C У, \text { с. } 123) .\end{array}$ & «...еще страшнее и царственнее...» $(C C$, с. 16). \\
\hline
\end{tabular}

Затем Буниным вновь сделаны существенные сокращения. В СУ читаем: «И обычно у меня такое чувство, что мои детские дни, которые считаются моими первыми днями, были бесконечно давно. Но стоит мне лишь немного напрячь мысль, как время начинает сокращаться, таять. И так было всегда. Не раз испытал я нечто поистине чудесное. Не раз случалось так: я возвратился из какого-нибудь далекого путешествия, возвратился в те поля, где я был 
некогда ребенком, юношей, - и вдруг, взглянув кругом, чувствую, что долгих и многих лет, прожитых мной с тех пор, как не бывало» (CУ, с. 123). В CC остается несколько строк: «Бесконечная давность! Но стоит мне лишь немного подумать, как время начинает таять. Не раз испытал я нечто чудесное. Не раз случалось: я возвратился в те поля, где я был некогда ребенком, юношей, - и вдруг, взглянув кругом, чувствую, что долгих и многих лет, прожитых мной с тех пор, точно не было» $(C C$, с. 16$)$.

Большой фрагмент в СУ был фактически изъят из текста рассказа: «Увеличив число таких отпечатков, я должен передать их еще кому-то, следящему за мной, как передано великое множество их всеми моими предками - мне. Не раз чувствовал я себя не только прежним собою, но и своим отцом, дедом, прадедом: в свой срок кто-то должен и будет чувствовать себя - мною. / И я думал в такие минуты: богатство способностей, талант, гений - что это как не богатство этих отпечатков (и наследственных, и благоприобретенных), как не та или иная чувствительность их и количество их проявлений в луче того Солнца, что откуда-то падает на них порою, то ярче, то слабее? И я говорил себе: верь спокойно, не пропала и никогда не пропадет ни единая, даже самая малейшая доля твоего существования, — каждая запечатлена и сохранится. Все они и уже навсегда, навеки померкнут, погибнут в той последней Тьме, куда мы все отходим в свой срок? Но разве не казалось тебе не раз, что и при жизни мириады их уже погибли, утратили способность оживать (проявляться) и разве ты не ошибался? И где грань между тьмой могильной и той, в которой и при жизни таится в тебе твоя прежняя, то есть младенческая, детская, юношеская жизнь, только в редкие минуты озаряемая и оживающая?» (CУ, с. 124). В СС осталось нескольких строк: «Великое множество таких отпечатков передано мне моими предками, пращурами. Богатство способностей, гений, талант, - что это как не богатство этих отпечатков (и наследственных, и благоприобретенных), как не та или иная чувствительность их и количество их проявлений в луче того Солнца, что откуда-то падает на них порою?» $(C C$, с. 17$)$.

\begin{tabular}{|c|c|}
\hline СУ & $C C$ \\
\hline $\begin{array}{l}\text { «...цвет глаз, но внутренне, душевно толь- } \\
\text { ко многая опытность отличает меня тепе- } \\
\text { решнего от прежнего, - я чувствую это } \\
\text { всем существом своим!» (CУ, с. } 125) .\end{array}$ & «...цвет глаз... Но что с того?» $(C C$, с. 17$)$. \\
\hline $\begin{array}{l}\text { «И я вспомнил свое, увы, теперь уже дав- } \\
\text { нее, путешествие по Галилее, по Иудее - } \\
\text { и опять пережил совершенно как свое соб- } \\
\text { ственное это далекое евангельское утро } \\
\text { в оливковой роще на каменистом скате } \\
\text { Елеонской горы, это отречение Петра» } \\
(C У, \text { с. } 126) .\end{array}$ & $\begin{array}{l}\text { «Я опять пережил совершенно как свое соб- } \\
\text { ственное это далекое евангельское утро } \\
\text { в Элеонской оливковой роще, это отречение } \\
\text { Петра» }(C C, \text { c. } 18) .\end{array}$ \\
\hline $\begin{array}{l}\text { «..в так называемом двадцатом веке. Да } \\
\text { и в нем ли я живу? За свою все-таки уже } \\
\text { долгую жизнь с ее думами, чтением, стран- } \\
\text { ствиями и мечтами я так привык к мысли } \\
\text { и к ощущению, будто я знаю и представ- } \\
\text { ляю себе огромные пространства места } \\
\text { и времени, столько жил в воображении } \\
\text { чужими и далекими жизнями, что мне ка- } \\
\text { жется, будто я был всегда, во веки веков } \\
\text { и всюду. А где грань между моей действи- } \\
\text { тельностью и моим воображением, кото- } \\
\text { рая...» (СУ, с. 126-127). }\end{array}$ & $\begin{array}{l}\text { «...в так называемом двадцатом веке! } \\
\text { И сколько я жил в воображении чужими } \\
\text { и далекими жизнями, чувством, будто я был } \\
\text { всегда и всюду! А где грань между моей дей- } \\
\text { ствительностью и моим воображением, мои- } \\
\text { ми чувствами, которые...» (CC, с. 19). }\end{array}$ \\
\hline
\end{tabular}


В СУ рассказ заканчивается предложением: «И цикады поют, поют», в $C C$ это предложение отсутствует.

В результате исследования правки, внесенной Буниным при подготовке берлинского Собрания сочинений, можно сделать вывод, что в 9-м томе данного издания опубликована другая редакция рассказа «Цикады». Хотя текст и не претерпел серьезных содержательных изменений, однако он был значительно сокращен и исправлен. Таким образом, существует три редакции этого рассказа: ранняя (РАЛ. MS 1066/203) - сентябрь 1925 года; журнальная декабрь 1925 года; и последняя, в 9-м томе Собрания сочинений - 1935 года, которую и следует избрать источником основного текста в будущем Полном собрании сочинений Бунина, а раннюю редакцию опубликовать полностью в разделе «Другие редакции». Однако возникает вопрос: вносить ли в основной текст правку писателя в авторских экземплярах 9-го тома Собрания сочинений? Прежде всего, рассмотрим характер этой правки.

После своего Собрания сочинений Бунин не публиковал «Цикады», но продолжал работать над текстом рассказа. Сохранилось три авторских экземпляра 9-го тома Собрания сочинений, в них имеется авторская правка, которая вносилась как минимум трижды: в 1947, 1951 и 1953 годах. В подтверждение этого приводим полностью авторские надписи на обложках этих экземпляров 9-го тома.

На одном из них (РГБ. Ф. 429. К. 2. Ед. хр. 4) черными чернилами указано: «12.VIII.35», позднее перед датой вписано синей шариковой ручкой «Вышел», правее поставлен дважды подчеркнутый знак NB. Ниже синей шариковой ручкой помечено: «Вырвал „Прекр<аснейшая> солнца“», далее красной шариковой ручкой: «Воды многие. Первая любовь, Подснежник». Под номером тома синей шариковой ручкой и затем ею же зачеркнуто: «Этот тоже перечитал и поправил недавно, но не этот экземпл<яр>. Октябрь 1951 г.». Над этими словами посередине обложки синей шариковой ручкой отмечено: «Правлю и этот экз<емпляр> в августе 1953 г.» .

На титульном листе название тома «Цикады» зачеркнуто синей шариковой ручкой и выше той же ручкой добавлено новое - «Ночь», то же сделано на шмуцтитуле и перед текстом рассказа. Помимо исправления заглавия, Бунин внес несколько поправок и уточнений в текст рассказа. В конце второго абзаца убрал предложение о звоне цикад: «Завороженный самим собой, он растет, ширится и однако не увеличивается, ни до чего не дорастает - и ничем не разрешается...». В конце пятого абзаца вычеркнуто два предложения: «И тут я „умствую“, и тут пускаюсь в „затейливость“, ведущую к бесплодию! Чем страстней певец Песни Песней, тем верней кончает он Екклезиастом!» В следующем абзаце подчеркнуты волнистой линией слова «понимаю мое непонимание», а на полях написано: «курсив». Ближе к концу рассказа в эпизоде об апостоле Петре волнистой линией выделено начало предложения (с такой же пометой на полях): «То же салое солнце, что когда-то увидел...». Во фрагменте «Да, если бы запечатлеть это обманное и все же несказанно сладкое бывание хотя бы в слове...» слово «бывание» взято в кавычки.

Еще два рабочих экземпляра 9-го тома хранятся в Русском архиве Лидса. На обложке одного (РАЛ. MS 1066/10174) указано: «Исправлено мной для нового издания [26 авг. 47 г.] в сент. 1951. Сохранить мои знаки препинания! Ив. Б.». Под номером тома написано синей шариковой ручкой, а затем трижды зачеркнуто заглавие «Ночь». На титульном листе зачеркнуто название тома «Цикады» и сверху дано новое - «Ночь», так же исправлено заглавие на шмуцтитуле и перед текстом рассказа. В конце первого предложения сделана вставка и на полях написано чернилами: «ночных степных цикад», позднее - 
зачеркнуто синей шариковой ручкой. Помимо этого момента правка совпадает с оставленной в экземпляре РГБ, за исключением следующих деталей: в конце предложения «я, конечно, совершенно живо ощутил, что я и теперь совершенно тот же, кем был и в десять, в двадцать лет» на странице 17 вычеркнуто слово «конечно»; на странице 21 в выражении «сладкое бывание хотя бы в слове» в «бывании» первая буква заменена на прописную.

В другом экземпляре тома (РАЛ. MS 1066/10175) на обложке написано: «С моими поправками. Для нового издания. Ив. Б. <черными чернилами> [Август 47 г.] <написано синими чернилами, позднее густо зачеркнуто синей шариковой ручкой> [Март 1951 г.] <написано синей шариковой ручкой, зачеркнуто красной шариковой ручкой> Май 1953 г. <красная шариковая ручка> NB <знак NB подчеркнут трижды> Окончательно исправлено „Божье древо“. Сохранять всюду лои < подчеркнуто дважды> знаки препинания! Ив. Б. (Notre Dame - стр. 24) NB <синей шариковой ручкой>». На титульном листе тома следующие исправления: к названию тома «Цикады» впереди приписано черными чернилами слово «Ночные», позднее оно было зачеркнуто синей шариковой ручкой и выше ею же добавлено название «Ночь», а потом зачеркнуто красной шариковой ручкой и изменено на «Ночные цикады». Оно в свою очередь было зачеркнуто простым карандашом, которым волнистой линией выделено предыдущее - «Ночь». Таким образом, Бунин, трижды исправляя название тома (и соответственно рассказа), окончательно остановился на названии «Ночь». Те же отметки, теми же ручками и в той же последовательности повторены на шмуцтитуле и перед текстом рассказа. Исправления в тексте совпадают с другим экземпляром РАЛ. Отличаются только два случая: не вычеркнуто слово «конечно», слово «бывание» оставлено со строчной буквы и взято в кавычки.

Таким образом, бунинская правка согласована не полностью. Например, слово «бывание» в экземпляре РГБ и втором экземпляре РАЛ взято в кавычки, а в первом экземпляре РАЛ исправлено с прописной буквы и без кавычек, очевидно, Бунин хотел это слово как-то выделить. Последняя правка, судя по датам на обложках 9-го тома, была внесена в экземпляр РГБ, следовательно, Бунин предпочел оставить это слово в кавычках.

Среди текстологов-буниноведов существует два подхода к определению основного текста произведения. Первый заключается в признании приоритета последней прижизненной публикации конкретного произведения, а вся правка в авторских экземплярах книг Бунина помещается в разделе «Варианты». Второй - в том, чтобы вносить в основной текст авторскую правку, имеющуюся в рабочих экземплярах книг писателя, оговаривая в комментариях все ее характерные детали. Как поступить с рассказом «Цикады» и как вообще принимать решение об использовании того или другого подхода, еще предстоит решить в дальнейшем.

Даже на примере одного рассказа хорошо видно, что текстологические вопросы и проблемы, выявляемые при научной подготовке поэзии Бунина, ${ }^{17}$ распространяются и на его прозу. Для того, чтобы выработать единые текстологические правила для всего будущего научного Полного собрания сочинений Бунина, следует собрать больше фактического текстологического материала, обозначить весь комплекс проблем и выбрать способ или способы их решения. Для этого также необходимо понять, отличалась ли методика работы писателя над прозой в разные периоды его творчества или имела некоторые общие черты. От этого будет зависеть возможность формулировки тексто-

17 Подробнее см.: Двинятина Т. М. Текстология поэзии И. А. Бунина // Бунин И. А. Стихотворения: В 2 т. / Вступ. статья, сост., подг. текста и прим. Т. М. Двинятиной. СПб., 2014. Т. 1. С. 371-418 (Новая Библиотека поэта). 
логических принципов для всей прозы Бунина в целом. Все эти насущные принципиальные вопросы следует решить в ближайшее время для начала работы над первым научным Полным собранием сочинений Бунина.

\section{РАССКАЗЫ «КРУГА „ТЕМНЫХ АЛЛЕЙ““”}

Понятие «круг „Темных аллей“», не так давно предложенное автором настоящей статьи, ${ }^{1}$ практически сразу было принято в буниноведении. ${ }^{2}{ }^{2}$ нига «Темные аллеи» представляет собой свободное текстовое единство. Несколько раз (вплоть до последних лет жизни) Бунин составлял «программы» сборника, включая в них разные рассказы. ${ }^{3}$ В «Темных аллеях» можно выделить три группы рассказов: ядро основных (попавшее во все «программы»); более удаленные от ядра (включавшиеся в сборник часто, но не всегда); и, наконец, попавшие в «программу» один или два раза. Показательно, например, что рассказ «Апрель» вошел в первое издание книги (1943), но был исключен при подготовке второго расширенного издания (1946). Если бы Бунину удалось подготовить третье, состав книги снова претерпел бы изменения: по свидетельству В. Н. Буниной, писатель хотел поместить в нее созданные после 1946 года «Ночлег» и «Весной, в Иудее»; возможно, что в нее вошли бы и другие произведения второй половины 1940-х годов, а может, и более ранние тексты. Помимо трех упомянутых, писатель включал в программы сборника рассказы «Алупка», «„В такую ночь...“», «Крем Леодор», «Памятный бал», «Три рубля», а также так и не опубликованные при жизни "Ахмат», «Au secours!», "„Когда я впервые...“», «Лита», «Новая шубка», «Далекий пожар». ${ }^{4}$

Таким образом, книга «Темные аллеи», с одной стороны, отражает постоянную динамику бунинского письма, с другой - становится осязаемым воплощением современной нам теории литературы, стирающей границу между текстом и контекстом.

Есть еще одна группа текстов, располагающаяся довольно далеко от ядра «Темных аллей», но, тем не менее, ощутимо с ним связанная. Это рассказы, никогда не включавшиеся Буниным непосредственно в сборник, но тематически и стилистически очень близкие ему. Рассказы этой группы, написанные

\footnotetext{
* Статья подготовлена при финансовой поддержке гранта РНФ (проект № 17-18-01410-П) в Институте мировой литературы им. А. М. Горького РАН.

1 Поноларев E. Р. Круг «Темных аллей». Неопубликованный рассказ И. А. Бунина // Вопросы литературы. 2015. № 5. С. 318-330.

${ }^{2}$ См.: Лит. наследство. 2019. Т. 110. И. А. Бунин. Новые исследования и материалы. Кн. 1. C. $79-127$.

3 Процесс формирования книги «Темные аллеи» подробно исследован Х. Реезе: Reese H. Ein Meisterwerk im Zwielicht: Ivan Bunins narrative Kurzprosaverknüpfung. Temnye Allei zwischen Akzeptanz und Ablehnung. Eine Genrestudie. München, 2003.

4 Наиболее длинный список рассказов приложен Буниным к одному из писем Б. К. Зайцеву в июле 1944 года (Bakhmeteff Archive of Russian and East European Culture. Коллекция Б. Зайцева. Вох 1). Этот список, в котором все рассказы третьей части даны с датами написания (последний датирован 27 мая 1944 года), демонстрирует, что рассказы, вошедшие в книгу и не вошедшие в нее, писались друг за другом, на одном дыхании. См. сопоставление различных программ «Темных аллей» в виде таблицы: Reese H. Ein Meisterwerk im Zwielicht. S. 409-411.
} 
как в период непосредственного формирования книги (середина 1940-х годов), так и после него (конец 1940-х годов), частично были опубликованы самим Буниным ( «Легенда» и «Un petit accident»), частично помещались в журналах его наследниками (В. Н. Буниной, затем Л. Ф. Зуровым и М. Э. Грин), а также Ю. В. Мальцевым (с разрешения М. Э. Грин) в эмигрантской периодике: «Аля», «Десятого сентября», «Кибитка», «Крым» (не завершен), «Мария Стюарт», «Модест», «Письма», «Ривьера». ${ }^{5}$ Можно поставить вопрос, попадают ли в этот круг рассказы, далеко ушедшие от основной темы «Темных аллей», но сохраняющие ее в подтексте: «В Альпах», «Полуденный жар», «Ловчий». Мы склоняемся к включению их в круг на самой его периферии.

Таким образом, круг «Темных аллей» может быть четко очерчен временными рамками (время работы Бунина над «Темными аллеями», с конца 1930-х годов и до конца жизни) и тематически. Кругом в узком смысле можно считать все те тексты, которые хотя бы однажды попадали в программы сборника, в широком - все перечисленные выше рассказы.

Каждый из них по-своему уникален.

«Апрель» (1938; 1938 («Варианты»)), ${ }^{6}$ по-видимому, случайно попал в первое издание «Темных аллей» и был выведен из состава книги сознательно. В газетной публикации он разделен на две самостоятельные части. Первоначальное название «Варианты» передает его смысл куда точнее. Это пересмотренный сюжет «Митиной любви», в котором главный герой (здесь у него нет имени, используется обобщенное «он») не так сильно, как Митя, заворожен не пишущей ему возлюбленной и куда внимательнее присматривается к окружающим его в деревне девкам и девушкам: «Да, но не одна же она на свете! - вдруг сказал он себе. - Ведь все это есть и в Ганьке, и в учительнице, и даже в Глашке...»..$^{7}$ Горничная Глашка напоминает о слегка намеченной в «Митиной любви» линии Параши (нежелание героя овладеть Глашкой изза прекрасной ночи за окном сродни Митиным природным озарениям), деревенские девки Машка и Ганька напоминают пары девок из «Митиной любви» (сначала Сонька и Глашка, затем Аленка и Анютка), наконец, линия учительницы функционально тождественна неразвернутой линии Мещерских. Главное отличие героя от Мити - он значительно менее погружен в думы об оставшейся в городе возлюбленной (она не заполняет весь мир вокруг него), значительно более «нагл» с девками и более интересуется физической сторо-

5 Для полноты картины к ним следует присоединить не публиковавшиеся до 2019 года тексты, хранившиеся в бунинском архиве. Во-первых, это три законченных рассказа («На постоялом дворе», «Дура», «О. Никон»), не увидевших свет, вероятнее всего, из опасений, что содержание их будет сочтено крайне неприличным (известно, что и менее откровенные тексты «Темных аллей» эмигрантское общество тех лет воспринимало едва ли не как порнографию). Для рассказов «Дура» и «О. Никон» через несколько лет после первой была создана вторая редакция, смягчающая изначальную смелость сюжета, но и в этом виде ни сам Бунин, ни его наследники не решились рассказы напечатать. Тем не менее рассказы «На постоялом дворе» и «О. Никон» включались Буниным в «программы» «Темных аллей». Во-вторых, это ряд незаконченных текстов, работа над которыми оборвалась на той или иной стадии: «Сказка о солдате» (конспект рассказа сказовой формы), «Иволга» и небольшой набросок «К „Иволге“», рассказы «Лизок», «Раиса», «Замужество», «Княжна Сайтанова» и не имеющий авторского заглавия текст «<Натурщица >». Все эти произведения опубликованы автором настоящей статьи: Лит. наследство. Т. 110. Кн. 1. С. $79-127$.

${ }^{6}$ Здесь и далее для каждого рассказа указывается авторская датировка и дата первой публикации.

7 Бунин И. А. Темные аллеи. Нью-Йорк: Изд-во «Новая земля», [1943]. С. 30. В настоящей статье мы придерживаемся следующего принципа: опубликованные Буниным тексты цитируются по последнему прижизненному изданию (в посмертных советских изданиях текст иногда существенно искажен); тексты, не опубликованные Буниным, цитируются по материалам Русского архива в Лидсе (РАЛ), поскольку качество их подготовки наследниками не выдерживает критики. 
ной любви. Самоубийство ему не грозит. Заглавие «Апрель» указывает на более раннюю стадию природного расцвета, так что и преображение природы, гибельное для Мити, еще далеко. Нет и нагнетания метафор, характерного для «Митиной любви».

Такого рода вариации к уже использованному сюжету Бунин создает впервые. Неудовлетворенность автора «Апрелем» связана, по-видимому, со слишком явным параллелизмом двух сюжетов. Многократное варьирование одного сюжета в иных случаях выполнено автором тоньше: рассказ «На постоялом дворе» $(1942 ; 2019$; предположительная датировка последней редакции: 1946) меняет один из важных эпизодов биографии Арсеньева. ${ }^{8}$ Вариантом эпизода из вероятного продолжения «Жизни Арсеньева» кажется рассказ «Аля» (1944; 1959; датировка последней редакции: конец 1940-х — начало 1950 -х годов). А рассказ «Десятого сентября» $(1951 ; 1961)$ можно посчитать женской версией «Митиной любви».

«Ночлег» $(1949 ; 1949)$ и «Весной, в Иудее» $(1946 ; 1946)$ выводят тематику «Темных аллей» за пределы двойной географии (дореволюционная Россия - эмигранты во Франции). Место действия «Ночлега» - юг Испании (рассказ писался по заказу, непременным требованием которого был испанский колорит ${ }^{9}$ ), о которой Бунин не знал ничего и пытался «увидеть» ее в художественных текстах (перечитывал «Дон Кихота»). Иудея писателю знакома много лучше благодаря путешествиям дореволюционной поры, однако и в этом рассказе сильна стилизация под условный Восток. Оба рассказа этнографичны, особенно отличается обилием экзотических подробностей «Весной, в Иудее». «Ночлег» подменяет любовную историю попыткой изнасилования; «Весной, в Иудее» настолько погружает эротику в быт кочевников, что нам совершенно не удается понять мотивы поведения загадочной женщины. По-видимому, опыт расширения географии не дал нужного толчка для дальнейшего развития цикла. ${ }^{10}$

Рассказы «Три рубля» $(1940 ; 1942)$ и «Памятный бал» $(1944 ; 1947)$ еще весьма традиционны, вполне новеллистичны: в обоих случается некое «вдруг», и это единичное событие оказывает влияние на всю жизнь героев. Кроме того, «Три рубля» кажутся вариантом «Мадрида» - показательно, что эти два рассказа вместе попадут в "программу» «Темных аллей» всего один раз (письмо Б. К. Зайцеву, июль 1944 года): во всех последующих программах «Мадрид» останется, а «Три рубля» будет исключен. ${ }^{11} \mathrm{~B}$ «Мадриде» новеллистичность пропадает, уходит излишняя сентиментальность и, кроме того, добавляется стилизационно-речевой момент (речь героини «Мадрида» - городское просторечие, сохраняющее некоторые диалектные черты; героиня «Трех рублей» закончила гимназию и говорит грамотно).

«Ловчий» $(1946 ; 1946)$ и «Полуденный жар» $(1947 ; 1949)$ продолжают сказовые традиции «Темных аллей», используя жанр народной легенды (рассказы «Баллада» и «Железная шерсть»). Существенное изменение в использовании этого жанра заключается в том, что любовный сюжет в рассказах

8 Подробнее см. вступительную статью к публикации рассказа: Лит. наследство. Т. 110. Кн. 1. С. $82-83$.

9 Подробнее см.: «...Когда переписываются близкие люди». Письма И. А. Бунина, В. Н. Буниной, Л. Ф. Зурова к Г. Н. Кузнецовой и М. А. Степун / Сост., подг. текста, научный аппарат Е. Р. Пономарева и Р. Дэвиса; сопроводительные статьи Е. Р. Пономарева. М., 2014. С. 87-89 (И. А. Бунин. Новые материалы. Вып. 3).

10 Брошенный на середине работы рассказ «Крым» (авторская дата отсутствует; примерно датируется серединой 1940-х годов; первая публикация - 1959) комбинирует экзотическую тему (подробный разговор о языке крымских татар и их быте) и использование литературной цитаты («Бахчисарайский фонтан» Пушкина).

${ }^{11}$ Reese H. Ein Meisterwerk im Zwielicht. S. 410-411. 
круга редуцирован, лишь намечен. Например, в «Ловчем»: «Была у него заветная наложница, девка именем Малашка, - я потом расскажу вам как-нибудь, как я из-за нее погиб, попал под страшный сюркуп... Уж как он людей своих терзал, до чего неприступен был! А эта Малашка просто веревки из него вила, он за нежное ее притворство на все был готов». ${ }^{12}$

До рассказа о Малашке дело так и не дойдет, ее история окажется вынесенной в затекст. При этом нерассказанная история, по-видимому, совсем не тривиальна - но она просто забыта, как это бывает в подлинной, нелитературной беседе. Ибо охота (собаки) - тема более интересная и для самого говорящего, и для его стафражного слушателя, напоминающего наперсников из пьес XVIII столетия, но значительно осовремененного: он становится чем-то вроде интервьюера или ученого-фольклориста, прерывающего речь опрашиваемого только для того, чтобы уточнить значение слова или точность произношения. Речь же бывшего дворового, как и речь странницы Машеньки в «Балладе», исключительно интересна тем, что соединяет в себе элементы народной и барской речи (с ярким привкусом легендарного для автора XVIII века: «апофеоз», «самый главный фаворит» (с. 57); «манкируем» (с. 60)). Экспериментальной можно назвать и лексико-терминологическую специфику разговора. Леонтий и барчук (а также читатель) воспринимают одни и те же лексемы поразному: для Леонтия это такие же слова, как и все прочие, для барчука термины, особенно ценные своим крестьянским происхождением.

«Полуденный жар» усложнен тем, что в нем звучит не просто речь странницы, но юродивой. У нее свое представление о Боге и мире, в которое мы вместе с таким же стаффажным слушателем пытаемся вникнуть. Если Леонтий знакомит нас с лексикой псарни и большой барской охоты, то у юродивой Глаши есть свои индивидуальные словечки, народно-религиозные - тоже почти терминологические, которые она произносит с особым значением. Главное словосочетание такого рода вынесено в заглавие («Полуденный жар, в какой Еву полуденный бес искусил»; с. 51). Эротический сюжет свернут до одного из речевых эпизодов и подан как религиозное искушение: «В церковь венчать привезли меня, папаша. Жених высокий, лютый, а красивый, загляденье. Загляденье, до чего хорош! Свечи зажгли, венцы на нас надели. Народ стоит, а никто ничего не говорит. Боятся, папаша. Боятся. А на мне будто портки черные, пинжак черный, я и рада, хорошая стою. <...> Он блуд со мной сотворил, а у меня сердце зашлось, я аж петухом закричала от той ужасти, проснулась и вся трясусь, плачу, рыдаю, а на меня ангелы крыльями дуют со всех сторон, ничего не видать, темь, погреб, а я вижу, как они белеются, вихрем вьются округ меня...» (с. 51-52). Уравновешивает его погребальный сюжет, которым заканчивается рассказ.

Интересный эксперимент сказового ряда представлен в тексте «О. Никон» $(1944 ; 2019$; датировка последней редакции: конец 1940-х — начало 1950-х годов). Рассказчицей в нем выступает богатая вдова-купчиха со специфической женской речью - ничего подобного ранее в творчестве Бунина не было. Герой - местный священник, довольно молодой и, так сказать, эмансипированный, обладающий совершенно особыми формами речи (впрочем, они передаются опосредованно, через речь рассказчицы). Эпатажно-экспериментальным оказывается и сюжет: соблазнение купчихи священником.

Из общей линии рассказов сказового плана выделяется также "Ахмат» (1944 и 1946; 1981; датировка двух последних редакций: конец 1940-х — начало 1950-х годов), где сказ и эротическая тема неразделимы. Традиционные

12 Бунин И. А. Весной, в Иудее. Роза Иерихона. Нью-Йорк: Изд-во им. Чехова, 1953. С. 55. Далее ссылки на это издание даются в тексте сокращенно, с указанием номера страницы. 
мотивы «Темных аллей» проявляются в портрете случайно встреченной героем бабы (расставленные ноги - как в «Камарге»; «...глаза светят тихим, святым блеском» ${ }^{13}$ - почти как в «Русе»). Рассказ сводится к развернутой реплике богатого купца, которая (сложным логическим путем) сводится к имени окаянного Ахмата, ордынского царя. Формой этот текст похож на «краткий рассказ» 1930-х годов, содержанием на книгу «Темные аллеи», но своей архитектоникой перерастает то и другое. Сутью истории оказывается замена подлинного христианского имени купца (Артемий) на неправедное (Ахмат), которое позволяет ему творить сексуальное непотребство. В модернистской поэтике эта замена была бы проведена с абсолютной серьезностью. Здесь же становится элементом проходного разговора, интересного с точки зрения дискурсивной поэтики: купец формально осуждает себя, но тем самым и похваляется. Для усиления стереофонии вводится подобострастный голос приказчика. Символическое значение текста растворяется в бытовом, и оба звучат единым аккордом.

Максимальный интерес представляет собой россыпь кратких рассказов, ${ }^{14}$ продолжающих те нарративные тенденции, которые наметились в третьей части «Темных аллей» .

Некоторые тексты построены по той же нарративной модели, что и «Качели» из «Темных аллей». Рассказ «„В такую ночь...“» $(1949 ; 1950)$ выносит цитату из «Венецианского купца» в заглавие, и весь дальнейший нарратив это игра цитатами. С другой стороны, «в такую ночь» - вполне бытовая фраза, которая позволяет смешать Шекспира и курортный одесский роман (с легким интертекстовым намеком на ялтинскую «Даму с собачкой»). Усложненность литературной игры в том, что использованные цитаты из «Венецианского купца» и в оригинальном тексте оказываются речевой игрой, которую ведут между собой Джессика и Лоренцо: начав с Тизбы и Медеи, они говорят о себе («В такую ночь с своим любимым Джессика бежала...»). Смена бытовых имен героев (которых мы так и не узнаем) на литературно-мифологические (сначала они Язон и Медея, затем она будет названа Дидоной, что подразумевает Энея) напоминает игру смыслов, использованную в «Ахмате». Иронически противостоит этому локус Конотопа, в русской традиции ХХ века ставший нарицательным наименованием провинциальной пошлости, а также территориально-этнические характеристики разговорного плана: "хохлушка», «казачка» и пр. Мифологизированный литературный дискурс не переходит в символизацию, а используется для психологического сближения персонажей (они оба знают текст пьесы наизусть) и заменяет им объяснение в любви.

Похожая ситуация, включая лунный пейзаж, использована в рассказе «Лита» $(1943 ; 1964$; датировка последней редакции: конец 1940-х — начало 1950-х годов). Необычное имя героини вызывает рассуждения о русалках. Русалочья тематика в процессе разговора и ночного купания перетекает из аллегорически-модернистского дискурса в психологически-бытовой: Лита любит помучить мужчин (фразу «Вы знаете, есть такие. Так вот я из таких» ${ }^{15}$ можно

13 РАЛ. MS 1066/71; РАЛ. MS 1066/72.

14 Показательна программная запись Бунина, сделанная в записной книжке 1944 года: «"Ночевала тучка золотая“, „Белеет парус одинокий“, „Для берегов отчизны дальной“, „Ехал на ярмарку ухарь купец“ - и т. д. Разве это не целые рассказы? Почему же пишущим прозой не писать рассказы в 10, 20, 100 строк? Почему скульптор может изваять женщину, девочку, юношу, живописец написать портрет, пейзаж, двух пьяных в кабаке, а я не имею права делать то же самое словами и только этим ограничиваться?» (РАЛ. MS 1066/548). Отныне Бунин сознательно пишет только эпизод - как зарисовку с натуры. При этом эпизод почти всегда воплощает в себе сложные токи жизни, тайну бытия.

15 РАЛ. MS 1066/164. 
прочитать как «я из русалок»), позволяет лишь посмотреть на себя в воде и поцеловать груди - ничего иного с русалкой нельзя. Предложенная собеседником тема, таким образом, полностью реализована Литой, но его желание совершенно не удовлетворено (отвечая на многозначную фразу «из таких», герой переводит речь на коннотации глагола «помучить»: «Вы из таких. И сколько вас таких!»16). Лита подхватила тему, но выстроила собственный сценарий игры в строгих рамках русалочьего сюжета. В диалоге (как в рассказе «Темные аллеи») хорошо заметна смена коммуникативных ролей. Финальная реплика «Больше все равно ничего не будет» ${ }^{17}$ звучит вариацией последней фразы «Качелей» .

Следующая группа рассказов может быть названа чисто дискурсивной. В сюжетном плане они довольно похожи: это словесные размолвки между любовниками и супругами. Например, рассказ «Алупка» $(1949 ; 1953)$. Первый абзац - подробное описание сцены, на которой будет сыгран весь диалог. Описание комбинирует стилистику ремарки («...доктор один полулежит в качалке в ожидании обеда...») с живописными подробностями, передающими картину переулка, пансиона («...жидкий садик, усыпанный галькой...») и свойства героини, которой присваивается деталь, материализующая психологическое состояние: «...зонтик, которым все вертела на плече...» (с. 47).

Диалог, особенно реплики с ее стороны, с самого начала звучит несколько театрально - что усилено темой: приезд артистов Малого тетра в Ялту. Две фамилии (Лешковская с Южиным) играют роль «ярлычков эпохи» (это функционально близко "Чистому понедельнику», но значительно лаконичнее). Фраза «Не играть, конечно, а так...» (с. 47) сразу обессмысливает весь дальнейший разговор и одновременно указывает на случайность причины, поднявшей душевную бурю в героине. Столь же бессмысленна фраза о жаре и духоте, «в этой милой Алупке». В урбанизированной Ялте жара и духота наверняка сильнее.

Языковая позиция доктора иронична, логична и выдержанна. Он мягко указывает жене на ряд неумных вещей в ее стремительных фразах. Однако в середине диалога наступает пауза, и пожилой доктор вдруг видит преображенную (без религиозно-метафорических коннотаций, которые задавали тон этому слову в «Митиной любви» или «Жизни Арсеньева») жену - молодую женщину, которой чего-то не хватает рядом с пожилым мужем: «Доктор приподнимается и садится, удивленно глядя на нее, в первый раз заметив вдруг, до чего она изменилась за последнее время и особенно за эти три недели в Крыму, чуть не с утра до вечера лежа на гальке у моря под парком и по пяти раз в день купаясь: загорелое лицо окрепло и округлилось, глаза налились блеском, плечи, груди, бедра расширились, что особенно явно под легким платьем из сарпинки, вся горячо пахнет этой сарпинкой и загорелым телом, обнаженные коричневые круглые руки точно отполированы...» (с. 48).

Этот портретный пассаж заменяет рассказу новеллистическое «вдруг». Доктор осознает, чем вызван натиск жены, однако выяснив, что сбежать от него она не собирается (не с кем и не на что), успокаивается сам и успокаивает ее. В финале же окажется, что она в чем-то права: в тесной комнате южного пансиона стоит страшная духота. И не спасающий от духоты зонтик возвращается в финале основной психологической деталью.

Перед нами смесь новеллы и краткого рассказа (точнее, это некий свободный жанр, комбинирующий черты двух традиционных жанров), использующая остановку в середине действия, чтобы дать герою (и читателю) возмож-

\footnotetext{
16 Там же.

17 Там же.
} 
ность что-то осознать в процессе проходного разговора. Разговор этот, как часто бывает в жизни, значит совсем не то, о чем сообщают произнесенные слова. В нем отражается вся история отдыхающей на море семьи: неудовлетворенность женщины, наигранное спокойствие все понимающего, но не способного изменить ситуацию мужчины. Просматривается и будущее супружеской пары. При этом внутренняя ироничность разговора и самой ситуации снижает тот пафос, который казался трагическим в чеховские времена, и вообще уводит от «проблемы пола», исключительно актуальной для модернистского искусства. Это сама жизнь, внезапный взгляд со стороны.

Рассказ «„Когда я впервые...“» $(1944 ; 1961)$ заводит ту же ситуацию дальше. Изменены обстоятельства разговора: дело происходит в богатом доме, в Петербурге. Для характеристики обстановки использована всего одна деталь: у мужа большой кабинет (потом добавится вторая деталь: он тщательно одет для выезда). Изменены и отношения супругов - это последняя стадия перед разрывом.

Она хотела «просто и честно» (в речь повествователя вводятся слова героини, благодаря этому он перестает быть наблюдателем и растворяется в действии) признаться в любви к другому. Он тоже готов к окончательному объяснению. Но ее уводит в сторону театральность положения, она начинает произносить красивые фразы, в которых запутывается. Он же, поначалу готовый спокойно объясниться раз и навсегда, в конце рассказа сидит, «уже бледнея от злобы». Указание на бессмысленность обвинений (в «Алупке» служившее для успокоения взволнованной женщины) становится последней фразой героя и пуантом рассказа (граница между сознанием героя и повествователя тоже весьма условна). В центре текста - снова пауза, в которую вклинивается портрет роскошной женщины в ее жизненном расцвете, причем его и ее чувства проступают сквозь этот портрет: «Внезапно вошла к нему в халате, после ванны, вся пахнущая миндальным мылом, с красиво убранными блестящими волосами, и сама чувствует, что должен чувствовать он, глядя на движения ее высокого тела под мягкой фланелью, подпоясанной длинным шнуром, на то, как открываются от быстрой ходьбы ее долгие ноги в натянутых черных чулках». 18

Эротизированный портрет здесь, в отличие от «Алупки», призван подчеркнуть не просто привлекательность героини, но и ее нынешнюю недоступность для героя и в то же время сложную природу его желания, смешанную со злобой и ненавистью. Ирония, которой пропитан диалог, направлена большей частью на женскую речь (с точки зрения гендерного анализа, можно сказать, что повествователь солидаризируется с мужским сознанием), финальная реплика героя усиливает иронию до сарказма. Дискурсивная поэтика, таким образом, позволяет заменить пресловутую «проблему пола» на вполне бытовую женскую неверность (для полноты гендерного анализа следует заметить, что и о мужской неверности Буниным написано немало), соединенную с весьма жизненной театрализацией объяснения. Отказ от модернистских эффектов проявляется в первую очередь в том, что в рассказах круга «Темных аллей» (в отличие от «Парохода „Саратов“», например) никто не стреляет и даже не произносит «последних слов».

Еще интереснее диалог любовников в рассказе «Крем Леодор» (1944; 1947). Как и в «Алупке», значимыми деталями оказываются внешность и костюмы, а также манера говорить («...начинает говорить - страстно, старательно, книжно, выделяя запятые и придаточные предложения» ${ }^{19}$ ). Здесь

18 РАЛ. MS 1066/140.

19 Бунин И. А. Крем Леодор // Новоселье. 1947. № 31-32. С. 3. 
театрализованность речи передана герою (добавляют эффект театрализации его взгляды в зеркало и «сумасшедшие глаза»). Дискурс усложнен тремя цитатами из эмигрантской газеты - ее просматривает героиня, чтобы уйти от ненужной беседы. Кроме того, газета сама по себе притягивает ее женское внимание. Газета превращается во второго собеседника героини (функционально заменяющего любовника, за фривольные отношения с которым упрекает ее говорящий), а в финале - в суфлера, подающего реплики. Цитаты, не имеющие абсолютно никакого отношения к предмету беседы, призваны передать само течение безразличной к происходящему жизни.

Перед нами - почти постмодернистский текст, построенный на вторжении газетного текста в диалог и иронически неверном использовании цитаты (вместо «запутался в противоречиях <...> звериного зова разнузданной плоти», как сказано в тексте объявления, она произносит «запутался в противоречиях разнузданного зова» ${ }^{20}$ ).

Само название указывает на первостепенную важность газеты. «„В такую ночь...“» выносило в заглавие фразу из Шекспира, претворяя литературу в быт. "„Когда я впервые...“» цитирует уже бытовой разговор, но подчеркивает при этом некоторую пафосность говорящей. «Крем Леодор» расширяет диапазон бунинских заглавий: цитируется рекламное объявление, которое наиболее заинтересовало героиню. В художественный текст входит нехудожественный - входит, как сама жизнь. И преображает текст, как откровение, сама преображаясь в художественном горниле.

В рассказе «Новая шубка» $(1944 ; 1981$; датировка последней редакции: конец 1940-х - начало 1950-х годов) в функции опорного (для диалога героев) текста используется ресторанное меню - еще менее художественный текст, чем рекламное объявление. Вынесенная в заглавие «новая шубка» использована в функции знака, определяющего отношения персонажей. Знаки и намеки взаимодействуют в поздней поэтике Бунина, создавая необычайный жизненный эффект этой поэтикой недоговоренности.

Поворот дискурсивного рассказа в сторону экзотики представлен в «Кибитке» $(1944,1987$; датировка последней редакции: конец 1940-х - начало 1950-х годов). Экзотика уже не требует Испании и Иудеи, а проявляется посреди России при помощи имеющей сложные интертекстовые связи (от Пушкина до Толстого) цыганской темы. Герой рассказа - живущий в родительском имении гимназист, тема - потеря невинности. Интертекст обогащается автоцитатой-напоминанием о «Митиной любви». Подробный портрет цыганки неопределенного возраста (кожа старая, а зубы молодые) вносит в текст коннотации, сближающие героиню с ведьмой (поверхностно-несерьезно, как звучала русалочья тема в «Лите»): «...виден изгиб коричневой от загара старой ключицы; но зубы в оскале сизых губ молодые, блестящие...». ${ }^{21}$ Гимназист, как и Митя, испытывает наваждение. Наконец, заношенная, но экзотическая одежда, напоминающая о древности и половой свободе, звучит автоцитатой из «Камарги». Однако основу рассказа составляет не игра символистским подтекстом, проявившимся в вагонном быту, как это было в «Камарге», а игра словесная, которую опытная цыганка ведет с наивным юношей. Представления о нравственном и постыдном у них абсолютно разные - таким образом в дискурсе проступает и глубинное различие культур, и психология соблазнения.

Некоторые рассказы, сохраняя дискурсивность, выводят повествование на уровень глобальных жизненных обобщений. Так, в «Далеком пожаре»

\footnotetext{
20 Там же. C. 5.

21 РАЛ. MS 1066/131.
} 
(1944; 1981; датировка последней редакции: конец 1940-х — начало 1950-х годов) пожар становится частью пейзажа, из созерцания которого проистекает «спокойная грусть непонятности всего». ${ }^{22}$ Далее следует усложненный метатекстом (существенно различающийся в двух редакциях) диалог. В первой редакции вопрос героя звучит обычным приглашением к повторению любовных слов: «Ты меня любишь? ${ }^{23}$ Во второй редакции добавляется дополнительный смысл: «Ты меня еще любишь?» ${ }^{24}$ Учитывая, что это их первое лето вместе, можно подумать, что у любовников что-то не ладится. Она отвечает, как мудрая женщина, почти по-матерински - этот материнский тон во многом объясняет сложности их совместной жизни. В первой редакции ответ звучит философски:

«- Люблю, милый. И все пройдет, все пройдет!

- Что пройдет?

- Все. Эта ночь и вся наша коротенькая жизнь. Все, все...»..$^{25}$

Во второй редакции ответ более не разбивается его репликой, а к мотиву уходящей жизни добавляется и мотив уходящей любви: «- Люблю, милый. И все пройдет! Все пройдет: и моя любовь, и этот далекий пожар, и эта прекрасная и оттого такая печальная ночь». ${ }^{26}$

Ночь получает традиционно-бунинские эпитеты, а проходящая любовь выходит на первый план. Смысл финала меняется: это не обычная меланхолия на тему быстро утекающей жизни, это размышление об их любви, вызванное созерцанием пожара: все прогорит, все пройдет, даже наша любовь. Помимо сохранившейся, но предельно лаконичной дискурсивности, здесь можно отметить нерасторжимую связь диалога и пейзажа, а также философскую сентенцию, выступающую в качестве пуанта. Случайный эпизод превращается в эпизод, подытоживающий жизнь.

Таков же рассказ «Модест» $(1944 ; 1962$; датировка последней редакции: конец 1940-х - начало 1950-х годов) - за исключением сентенции и подчеркнутого несоответствия имени и облика героя его профессии. Складывается впечатление, что оба персонажа - лошадник и его содержанка - живут не своей жизнью. И слово «покутить», и распространенное название увеселительного заведения «Тиволи» (с легкой аллюзией на чеховскую «Душечку») заимствованы из барского языка. Молчащая содержанка (дискурсивность здесь, как ни странно, монологична ${ }^{27}$ ) высказывается своим портретом.

«Мария Стюарт» (1944 и 1948; 1987; датировка последней редакции: конец 1940-х - начало 1950-х годов) развивает тему чужой жизни. Заглавие использует принцип обманутого ожидания, как в ряде рассказов книги «Темные аллеи». Фамилии артистов, идущие длинным списком, все ненастоящие это сценические псевдонимы. ${ }^{28}$ Финальная реплика актера Градова ( А эта Мария Стюарт задницу через ять пишет!» ${ }^{29}$ ) завершает тему; пропасть между шотландской королевой и играющей ее актрисой подчеркивается совпадением их имен. Мощный дискурсивный подтекст создается цитированием

22 РАЛ. MS 1066/101; РАЛ. MS 1066/102.

23 РАЛ. MS 1066/101.

24 РАЛ. MS 1066/102.

25 РАЛ. MS 1066/101.

26 РАЛ. MS 1066/102.

27 Вариантом реализации этого приема можно назвать рассказ «Au secours!» $(1944 ; 1987)$. Этот текст создан в духе кратких рассказов 1930 года - он значительно более прост, чем многие другие.

28 В папке набросков ко второму тому «Жизни Арсеньева» встречается список фамилий «для актера» (Лит. наследство. Т. 110. Кн. 1. С. 197). Технический прием писательской записной книжки превращается в полноценный художественный прием.

29 РАЛ. MS 1066/171, 172. 
полного газетного объявления, затем взятыми в кавычки словами, которые могут и попасть в заметку репортера, и просто быть произнесены околоартистической публикой - «бурного успеха и бесконечных вызовов», «отдыхает», - и наконец, серией реплик во время ужина, которые принадлежат неопределенным людям, сказаны всеми сразу, и резким, но ярким и остроумным замечанием Градова в финале. Создается интересный эффект: здесь нет диалога в прямом смысле слова, но чужая речь кипит вокруг молчащей главной героини, и рассказ принципиально диалогичен на различных уровнях.

Основное различие двух сохранившихся авторских редакций финала состоит в том, что в первом случае сказано о «мужском бессилии» Градова, и реплика «Стара стала, слаба стала» явно отнесена им на свой счет. ${ }^{30}$ В другом «мужское бессилие» вычеркнуто, ${ }^{31}$ и тогда «Стара стала, слаба стала» обретает многозначность. ${ }^{32}$

В рассказе «Письма» $(1944 ; 1987$; датировка последней редакции: конец 1940-х — начало 1950-х годов) бросившая мужа жена читает любовнику письма супруга. Цитата и в этом тексте становится конструктивной деталью: она обсуждается, комментируется и интерпретируется, создавая метатекст. Цитаты из писем, заменяющие любовникам утреннюю газету (любовник читает письма вслух за завтраком), оказывают и психологический эффект: они сближают их героев, хотя мужчина уже слегка тяготится этой связью:

"- Гренков хочешь? Еще горячие.

- Да, да. „И вот, во имя нашего прошлого, нашей былой любви...“. Ты знаешь, он все это откуда-нибудь списывает.

- Вероятно. Из каких-нибудь романов...»..$^{33}$

В диалоге звучат три голоса, создавая вербальный любовный треугольник. Ее и его внешность вступают в диалогические отношения с цитируемым текстом. Диалог завершается молчаливыми действиями, замещающими финальные реплики: «Голая подмышка его волнует. Встает, подходит к ней сзади, поднимает ее лицо, впивается в жирные губы. Она закатывает глаза, толчками дышит в ноздри». ${ }^{34}$

В некоторых рассказах диалог пропадает как ненужный. «Un petit accident» $(1949 ; 1950)$ показывает нам маску смерти - то ли внезапную смерть за рулем, то ли сознательное самоубийство. Дискурс создает сама вечерняя жизнь Парижа (предчувствие смерти рассыпано в великолепных картинах Площади Согласия: «сияние канделябров», «траурно», «в темноте», «кроваво вспыхивающих»), а сюжет - само точечное событие, не имеющее ни истории, ни завершения. Тайна бытия (небытия) проявляется в символических намеках ( «огненный Вавилон», «стройно правит чья-то незримая рука его оркестром», с. 21). В этом тексте повествование переходит грань между случайностью и притчей, литературой и жизнью. Таков же рассказ «В Альпах» $(1949 ; 1950)$, сюжет которого сводится к случайному моменту: вырванный из темноты автомобильными фарами деревенский кюре куда-то шагает по дороге. Ощущается дискурсивность описательной миниатюры: она намечена риторическими вопросами «шагает куда, зачем?» (с. 22). Случайные детали: кюре, площадь, фонтан, одинокий фонарь - растворяются во тьме ночи. Возможности домысливания этих сюжетов практически безграничны, сюжет ста-

30 РАЛ. MS 1066/172.

31 РАЛ. MS 1066/171.

32 Примечательно, что В. Н. Бунина в старости использовала эту фразу как поговорку, сообщая о состоянии своего здоровья (см.: «...Когда переписываются близкие люди». С. $272,343,375$, 402).

33 РАЛ. MS 1066/235.

34 Там же. 
новится вариативным, а «идея текста» сводится к общим представлениям о красоте и тайне жизни.

Чуть иначе выстроен рассказ «Легенда» $(1949 ; 1953)$, в котором в новой эстетике отразились мысли рассказов «Именины», «Музыка», «В некотором царстве» и финала «Жизни Арсеньева». Звучание органа в соборе (важный мотив «Жизни Арсеньева») вызывает в повествователе видение - средневековую девушку, ходившую молиться в этот собор, венчавшуюся в этом соборе и отпетую здесь же. Она - вымысел, но ее (как племянницу, когда-то представленную Ивлевым; как Лику в финале «Жизни Арсеньева») можно "увидеть» и «почувствовать». Реальность видения раньше требовала серии модернистских приемов, направленных на осязательный эффект: повествователь рисовал портрет и обстановку с предельной остротой зрения, филлигранно выписывал детали, вплоть до воздуха в комнате, как на картинах Вермеера. Теперь Бунину достаточно слов «увидел» и «почувствовал». Слова эти настолько емкие, что все прочие писательские ухищрения оказываются излишними. Повествователь проживает свое видение абсолютно так же, как когда-то Ивлев во «В некотором царстве»: «...весь день думаю о ней, живу ее жизнью, ее временем» (с. 23). Длинной предварительной истории, как там, не требуется: история свернута до нескольких фраз конспекта. ЖКизненность на сей раз обретена и в смерти ( Она умерла рано, как часто умирают милые и веселые женщины...», с. 23), к ней приобщен и повествователь: ему вскоре предстоит лечь в ту же землю, в которой (благодаря «действительным» формам глагола героиня обретает историческую реальность) лежит и его выдумка. Жћивущие после нас когда-нибудь будут жить мечтами о нас - так замыкается круг легендарного времени, включивший в себя прошлое, настоящее и будущее. Женское очарование выдуманной героини, средневековые кости, лежащие вокруг собора, тело повествователя, которому предстоит лечь здесь же, будущие поколения, которые придут в этот собор, - все соединяется в круговороте, воплощающем жизнь вообще.

Сохраняя весь круг прежних размышлений, поздний бунинский рассказ перестраивает весь бунинский мир: он поистине становится микрокосмом. Огромная «Жизнь Арсеньева» сливается с небольшим «В некотором царстве» и умещается на половине страницы, при этом текст не несет ощущения «спресованности», как проза Пушкина, он легко выходит за свои пределы и развивается в читательском сознании. Личность повествователя, четко ощущаемая поначалу, растворяется к концу текста в том бытийном круге, который, собственно, и есть предмет повествования.

Одним из последних бунинских шедевров, открывающим новые возможности письма, становится рассказ «Ривьера» $(1944 ; 1962$; датировка последней редакции: 1946-1948 годы). В нем находит отражение большая часть тенденций, намеченных в прочих рассказах круга «Темных аллей» .

Открывается текст рекламным объявлением огромного богатого отеля. $\mathrm{Pe}$ клама создает ощущение роскоши и полноты жизни, которое не отпускает до конца рассказа. За ним следует описание гостиницы, которое движется по маршруту только что приехавшего гостя: залы первого этажа, парк, спуск к пляжу. Тенистый и безлюдный парк противопоставлен безвкусному огромному зданию, три коннотации особо важны: это бывшее монастырское поместье, парк похож на «старый пальмовый лес», к морю ведет «великолепная кипарисовая аллея». Завершается пейзажная часть вечерним видом на «розовые огни Бордигеры» .

Следующая часть повествует о героях, выделенных из публики, «в тесноте <...> нарядного люда». ${ }^{35}$ Оба красивы и изысканны, их общая черта -

35 РАЛ. MS 1066/256. 
недоступность. В героине особо отмечен змеевидный изгиб тела, напоминающий о женщине в «Камарге», звучит легкий намек на соблазн: «...ее высокое тело изгибается так, точно оно без костей». ${ }^{36}$ В герое интересны аристократически тонкие ноги и старомодное пенсне. Обобщенный рассказ о том, как они проводят дни и вечера, растягивается на два абзаца, поездки по окрестностям создают цепочку топонимов. Новый абзац переводит время в абсолютное настоящее: «Вот уже густо синеет жаркий южный вечер». ${ }^{37}$ Повествование неторопливо, будто сам текст наслаждается хорошим обедом, кофе, сигарой. Следующий абзац - медленный выход на террасу - завершается ленивопривычным, типовым восклицанием: «Mon Dieu, quelle beauté!» .

Третья часть возвращает нас к парку, в который сошли герои. Прелестный ночной пейзаж разворачивается на несколько предложений. Завершается часть повтором из первой пейзажной части, замыкающим текст в кольцо: «...розовые огни Бордигеры». Разорвет кольцо неожиданный финал. Пара замрет в страстном поцелуе, за которым, вероятно, последует страстное продолжение: об этом свидетельствует черновой автограф и несколько попыток от руки завершить машинописный текст. ${ }^{38}$ Или не последует ничего.

«Ривьера» перерастает темы «Темных аллей» и более раннего бунинского творчества, растворяя стаффажных персонажей в божественной красоте средиземноморской ночи. Не сразу найденное заглавие ${ }^{39}$ указывает на подлинного героя. Молчащая ночная тайна оказывается важнее персонажей. Похоже был растворен в ночи персонаж «Цикад» $(1925,1925)$, однако там он был субъектом повествования. Здесь перед нами повествование, почти лишенное субъекта и субъективности. Движение рассказа замедляется и останавливается совсем, как в финале «Позднего часа», но не для того, чтобы с остановившимся сердцем уйти за грань жизни, а для того, чтобы «забыться и заснуть». Рассказ очень похож на лермонтовское «Выхожу один я на дорогу...»: и ночным пейзажем, и скрытыми основными темами (речь идет не о тайных любовниках, а о тайнах бытия), и медитативным ритмом - и исключительной важностью в рамках всего творчества писателя.

Рассказы круга «Темных аллей» - вершина творчества Бунина. Воспринимаемые по отдельности, они кажутся случайными. Но собранные в круг «Темных аллей», эти рассказы с очевидностью демонстрируют новые принципы повествования, разрушая не просто исключительность героев, но сам институт героев; не просто линейность сюжета, но сюжет как таковой; не просто личность повествователя, но само личностное начало. Повествование превращается в бытийный дискурс, из которого выступают отдельные жизни и предметы.

36 Там же.

37 Там же.

38 Бунин долго ищет форму описания страстного полового акта, пока не останавливается на поцелуе. Последним окончательно вычеркнутым вариантом был следующий текст: «Он своей сухой рукой с золотым перстнем отстегивает под жилетом шелковые подтяжки, садится на скамью. Она, откидывая назад голову, закрыв глаза, высоко поднимает подол, раскорячивает туго обтянутые выше колен шелковыми чулками ноги в серебряных туфельках, толчками задышав сквозь ноздри...» (Там же).

39 Черновой автограф и окончательная машинопись дают нам два предшествующих варианта - оба формально связаны с рекламным объявлением начала, но второе уже акцентирует внимание на пальмах парка: "Hôtel des Palmiers et de la Plage», "Hôtel des Palmiers» (PAЛ. MS 1066/255; РАЛ. MS 1066/256). 


\section{ПУБЛИКАЦИИ И СООБЩЕНИЯ}

DOI: $10.31860 / 0131-6095-2020-3-153-164$

(ㄷ) Л. В. Соколова

\section{ИСТОРИЯ ВОЗНИКНОВЕНИЯ И ОСОБЕННОСТИ ПАМЯТНИКОВ КУЛИКОВСКОГО ЦИКЛА}

Важное значение Куликовской битвы, состоявшейся 640 лет назад между войском Мамая и объединенными русскими полками, возглавляемыми московским великим князем Дмитрием Ивановичем, осознавали уже ее современники и их близкие потомки. Об этом свидетельствует создание целого ряда древнерусских произведений, образующих так называемый Куликовский цикл. Это летописные повествования о битве (краткая летописная залетка, летописный рассказ, летописная повесть), «Сказание о Мамаевом побоище» и «Задонщина». Произведения эти, известные в разных редакциях и вариантах, различны по своему жанру, целям, содержанию и объему сообщаемой информации. По вопросам взаимоотношений памятников Куликовского цикла, их датировки и по большинству других проблем единого мнения не существует. Споры обусловлены прежде всего сложностью текстологических связей как между памятниками, составляющими весь цикл, так и между их редакциями и вариантами. Между тем четкое представление о взаимоотношении памятников Куликовского цикла чрезвычайно важно для понимания того, как складывался этот цикл, какие задачи, цели ставил автор каждого из произведений, в каком из них впервые появились те или иные сообщения. Именно этим вызвана необходимость комплексного рассмотрения всего цикла в целом, чему и посвящена настоящая статья. В ней предлагается новый взгляд на последовательность возникновения памятников Куликовского цикла.

Исследование летописных памятников Куликовского цикла ${ }^{1}$ привело нас к выводу, что краткая залетка о состоявшемся сражении на Куликовом поле была включена под 1380 годом в московский великокняжеский летописец Дмитрия Донского (предполагаемый «Летописец великий русский», завершавшийся, очевидно, 1392 годом). ${ }^{2}$ B 80-е годы XIV века, вероятно до смерти Дмитрия Донского (1389), в его окружении была создана как самостоятельное (внелетописное) произведение не дошедшая до нас в превоначальном виде повесть (назовем ее Внелетописная повесть о Куликовской битве), довольно подробно рассказывавшая о происходивших в 1380 году событиях. Рассказ о Куликовской битве в своде 1408 года (отраженном в сгоревшей Троицкой

1 Итоги этого исследования см.: Соколова Л. В. 1) Летописные повествования о Куликовской битве (К вопросу о взаимоотношении памятников) // Труды Отдела древнерусской литературы. СПб., 2014. Т. 63. С. 305-353; 2) Об источниках рассказа о Куликовской битве в своде 1408 г. (Троицкой летописи) // Академик А. А. Шахматов: Жиинь, творчество, научное наследие: Сб. статей к 150-летию со дня рождения ученого. СПб., 2015. С. 294-308.

2 Эта заметка, по нашему мнению, дошла в составе Московско-Академической летописи (или Московско-Академическом списке Суздальской летописи). См.: Соколова Л. В. Летописные повествования о Куликовской битве. С. 306. Вот текст этой заметки: «В льто 6888. Ордыньскыи князь Мамаи, събравъ воя многы, поиде на великого князя Дмитрея Ивановичя. То же слышавъ князь великии, събра воя многы и поиде противу. И стрђтошася за Дономъ на усть Непрядвы. И бысть съча зла, ака же не бывала в Руси. И поможе Богъ князю великому Дмитрею Ивановичю. И ту убьени быша на суимъ князь Федоръ Романовичь Бълоозерьскыи, сынъ его князь Иванъ, Семенъ Михаиловичь, Микула Васильевичь, Михаило Ивановичь, Ондръи Серкизовъ, Тимофъи Волуи, Михаило Бреньковъ, Левъ Морозовъ, Семенъ Меликъ, Олександр и инии мнози. Князь же великыи Дмитреи Ивановичь съ прочими князи рускыми и воеводами ставъ на костех и похвали Бога и того всенепорочную матерь. И възвратися въ свою отчину, побъдивъ своя врагы» . 
летописи) является сводным текстом: краткая залетка, читавшаяся в «Летописце великом русском», была дополнена некоторыми сообщениями, заимствованными из Внелетописной повести о Куликовской битве. ${ }^{3}$ А в свод митрополита Фотия 1418 года была включена уже сама Внелетописная повесть о Куликовской битве, при этом существенно отредактированная. ${ }^{4}$ Этот текст известен нам как «Летописная повесть о Куликовской битве», читающаяся в восходящих к своду Фотия Софийской I летописи, Новгородской IV летописи и во второй подборке Новгородской Карамзинской летописи.

Если рассказ в летописном своде 1408 года (Троицкой летописи) носил информационный характер, сжато рассказывал о приходе Мамая, о выступлении к Дону московского князя Дмитрия Ивановича и о битве, то «Летописная повесть о Куликовской битве», а также «Сказание о Мамаевом побоище» и «Задонщина» являются литературными текстами, написанными с определенными политическими целями. Л. В. Черепнин проанализировал различия в освещении событий разных произведений о Куликовской битве и отметил, что на характер этих повествований наложили свой отпечаток разные политические тенденции в среде русской знати. ${ }^{5}$ Рассмотрим поочередно три литературных памятника Куликовского цикла: «Летописную повесть о Куликовской битве», «Сказание о Мамаевом побоище» и «Задонщину». Именно в таком хронологическом порядке появились, по нашему мнению, эти произведения.

\section{Повесть о Куликовской битве}

О недошедшем тексте Внелетописной повести о Куликовской битве мы можем судить лишь по «Летописной повести», в которой, однако, обнаруживаются значительные редакторские добавления, о чем пойдет речь далее. Если вычленить их, то с определенной долей условности можно восстановить первоначальный текст, созданный в окружении Дмитрия Донского. В нем довольно подробно освещались события 1380 года. Сообщалась причина прихода Мамая на Русь, говорилось о его союзе с литовским князем Ягайло. Далее рассказывалось о сборе русского войска, о благословении Дмитрия Ивановича на битву коломенским епископом Герасимом (местоблюстителем Московского митрополичьего престола в 1379-1381 годах), о маршруте русского войска к месту сражения. Указывалось, что князь Владимир Андреевич и воевода Тимофей Васильевич позднее выехали из Москвы и присоединились к русскому войску у Оки, уточнялось, что Дмитрий Иванович «со своим двором» переправился через Оку не в воскресенье, как все войско, а в понедельник. Назывались точные даты, даже часы сражения. В Повести говорилось об участии в походе литовских князей - братьев Ольгердовичей, о спорах в окружении Дмитрия Донского по поводу того, следует переходить Дон или нет, описывалась битва, назывались имена убитых русских князей и воевод. Все эти сведения выглядят достоверными, полученными от участников похода. В заключение сообщалось о событиях, произошедших после битвы: об ограблении рязанцами русских воинов, возвращавшихся с битвы, и пленении некоторых из них, о реакции на это Дмитрия Ивановича, о судьбе Мамая, о воцарении в Орде Тохтамыша, о поездке к нему русских послов с дарами.

${ }^{3}$ Составитель летописного митрополичьего свода 1408 года, протографом которого, по мнению А. А. Шахматова и М. Д. Приселкова, был «Летописец великий русский», подверг последний обработке, в том числе, как полагал М. Д. Приселков, расширил его.

4 Это подтверждается характером работы составителя свода Фотия. Он, по наблюдению М. Д. Приселкова, «привлек для своей работы немало новых материалов, в большинстве случаев внелетописного характера (сказания, повести, послания, грамоты), которые должны были придать новому своду характер не только исторического обзора прошлых судеб Русской земли, но и назидательного чтения» (Приселков М. Д. История русского летописания XI-XV вв. СПб., 1996. С. 207). Вошедшие в свод Фотия внелетописные материалы составили основную часть второй подборки Новгородской Карамзинской летописи. Их перечисление см.: Бобров А. $Г$. Новгородские летописи XV в. СПб., 2001. С. 160-162.

5 Черепнин Л. В. Образование Русского централизованного государства в XIV-XV веках: Очерки социально-экономической и политической истории Руси. М., 1960. С. 596-623. 
Основным литературным источником Внелетописной повести, ближайшим образцом ее литературной формы была Повесть об Александре Невском. ${ }^{6}$ Целью создания Внелетописной повести было рассказать о событиях 1380 года и прославить первую большую победу над ордынцами объединенного русского войска во главе с московским великим князем Дмитрием Ивановичем. По этой причине подчеркивался масштаб Куликовской битвы, говорилось (вероятно, преувеличенно) о многочисленности войска Дмитрия Донского: в Коломне собралось 100000 и 50000 воинов, - «от начала миру

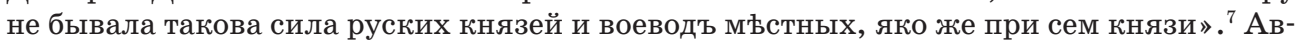
тор Повести акцентирует ожесточенность битвы, ее исключительность: «И бысть сеча зла и велика и брань крњпка, трусъ великъ зъло, яко же от начала миру съча не была такова великим князель руским, яко же сему великому князю всеа Руси». ${ }^{8}$

В Повести особо отмечается храбрость и мужество князя Дмитрия Ивановича, организатора похода против Мамая. Сообщается, что начал он сражение в Сторожевом полку, который первым вступил в бой, а потом, «не долго попустя», отъехал в Великий полк. ${ }^{9}$ После перечисления имен убитых на поле битвы русских князей и воевод автор Повести пишет, что у великого князя «в(е)сь доспьхъ его битъ и язвен, но на тълеси его не бъше язвы ни коея же, а бился с тотары в лице, ставъ напреди, на первом суимъ. О сем убо мнози князи и воеводы многажды глаголаше ему: „Княже, господинъ! Не ставися напреди битися, но назади или крилъ, или нњгдъ въ опришнњмь мъсть“. Он же отвъщьвааше им: „Да како азъ възглаголю: «Братьаа моа, да потягнем вси съ единого», - а самъ лице свое почну крыти и хоронитися назади? Не могу в том быти, но хощу яко же словом, такожде и дълом напереди всъх и пред всими главу свою положити за свою братью и за вся крестьяны, да и прочьи, то видњвше, приимут съ усердием дрьзновение“. Да яко же рече, и тако сътвори: бьяшеся с тотары тогда, ставъ напреди всъх. А елико одъсную и ошюю его дружину его биша, самого же въкругъ оступиша около, аки вода многа обаполы, и многа ударениа ударишася по главъ его и по плещема его и по утробъ его, но от всъх сих Богъ заступил его въ день брани щитом истинным и оружеем благоволениа осъниль есть над главою его, десницею своею защитил его, и рукою крњпкою и мышцею высокою Богъ избавилъ есть, укрњпивый его, и тако промежи ратными многыми цъл съхраненъ бысть». ${ }^{10}$

Подобно другим древнерусским произведениям о нашествиях на Русь иноплеменников, в Повести приход Мамая объясняется карой за грехи: «Се же бысть грђх ради наших: въоружаются на ны иноплеменници, да быхом ся отступили от своих неправдъ, от братоненавидениа, и от сребролюбиа, и в неправду судящих, и от насильа. Нъ милосердъ бо есть Богъ чловъколюбець: не до конца прогнъвается на ны, ни въ въки враждуеть» ${ }^{11}$

Проведенный нами текстологический анализ «Летописной повести» показывает, что ее составитель внес существенные дополнения в свой протограф - Внелетописную повесть.

Во-первых, это несколько вставок, касающихся действий Олега Рязанского. Автор «Летописной повести» гневно обличает рязанского князя Олега Ивановича как союзника Мамая, якобы посылавшего ему на помощь свои «силы». Он сравнивает Олега с Иудой и Святополком Окаянным, предрекает рязанскому князю Божью кару за его измену.

Учитывая гневные выпады против Олега Рязанского, некоторые исследователи полагали, что «Летописная повесть» написана при жизни Олега (ум. 1402). Указав на

${ }^{6}$ Об источниках Повести см.: Саллина М. А. «Летописная повесть» о Куликовской битве и «Задонщина» // «Слово о полку Игореве» и памятники Куликовского цикла: К вопросу о времени написания «Слова». М.; Л., 1966. С. 364-370. ники»).

7 Сказания и повести о Куликовской битве. Л., 1982. С. 17 (сер. «Литературные памят-

8 Там же. С. 20-21. Здесь и далее в цитатах курсив наш. - Л. C.

9 Там же. С. 20.

10 Tам же. С. 22.

11 Там же. 
«крайне страстный, негодующий тон повествования», «в высшей степени резкую характеристику Олега», а также на фразу о посмертном суде («придетъ ему день Господень в судъ»), А. Марков высказал мысль, что Повесть написана еще при жизни Олега, т. е. до июня 1402 года. ${ }^{12} \mathrm{C}$ тем, что об Олеге повествуется как о живом и еще опасном противнике, согласились А. А. Шахматов, М. Н. Тихомиров, С. Н. Азбелев, А. К. Зайцев.

Однако текстологический анализ «Летописной повести» приводит к выводу, что все фрагменты об Олеге (за исключением одного, читающегося в эпилоге) - позднейшие вставки в текст Внелетописной повести. ${ }^{13}$ Как представляется, в авторском тексте Внелетописной повести упоминалось лишь о том, что Олег Рязанский грабил и брал в плен воинов Дмитрия Донского, возвращавшихся домой по землям Рязанского княжества. Этот факт зафиксирован в договоре («Докончании») Дмитрия Ивановича с Олегом Рязанским 6 августа 1381 года, где говорится о необходимости возвращения пленных. ${ }^{14}$ В первоначальную фразу о грабеже и взятии воинов в плен позднее (в предполагаемом нами Дополненном виде Внелетописной повести) было внесено сообщение о посылке Олегом на помощь Мамаю своей «силы», читающееся и в «Летописной повести» $:^{15}$ «Повъдаша князю великому, что князь Олегъ Рязаньский [посылалъ $M a$ лаю на полощь свою силу, а саль] на ръкъ перьмъталъ мостъ, а кто поъхалъ с Доновьскаго побоища домов сквозъ его отчину, Рязаньскую землю, боляре или слуги, а тъх вельль имати и грабити и нагих пущати». ${ }^{16}$

Фраза о действиях Олега Рязанского после битвы была, с внесенным добавлением, заимствована в рассказ о битве, читающийся в своде 1408 года, следовательно, вставка о посылке Олегом войск Мамаю сделана до этого времени.

Читавшееся в протографе «Летописной повести» сообщение о действиях Олега после битвы, в том числе о посылке им своего войска Мамаю, и послужило, вероятно, побудительным мотивом для составителя «Летописной повести» обвинить рязанского князя в союзе с Мамаем и внести в текст вымышленные эпизоды о его действиях до и во время битвы.

Фрагментами об Олеге Рязанском составитель «Летописной повести» значительно усилил ее публицистичность. ${ }^{17}$ Страстными обвинениями рязанского князя в предательстве русских интересов, пособничестве врагам Русской земли читателю внуша-

12 Марков А. [Рец. на:] С. Шамбинаго. Повести о Мамаевом побоище. СПб., 1906 (СОРЯС. Т. 81, № 7) // ЖЖурнал Министерства народного просвещения. 1908. Ч. 14. № 4. С. 434-435.

13 Анализ фрагментов «Летописной повести» с упоминанием Олега Рязанского см. в статье: Соколова Л. В. Что сообщалось об Олеге Рязанском в авторском тексте Повести о Куликовской битве? (К вопросу о позднейших вставках в «Летописной повести») // Труды Отдела древнерусской литературы. СПб., 2019. Т. 66. С. 76-109.

14 Собрание государственных грамот и договоров, хранящихся в государственной Коллегии иностранных дел. М., 1813. Т. 1. С. 54 (грамота 32).

15 Сообщение во второй части (эпилоге) о посылке Олегом войска Мамаю не могло быть внесено одновременно со вставками об Олеге в первой, основной части «Летописной повести», так как противоречит им. Согласно первой части «Летописной повести», Дмитрий Иванович еще до битвы знал об измене Олега, о его союзе с Мамаем. А по сообщению об этом в эпилоге, Дмитрий Иванович узнал о посылке Олегом своего войска Мамаю после битвы, вернувшись в Москву. Это наводит на мысль, что вставка в эпилоге была сделана до «Летописной повести» - в предполагаемом нами Дополненном виде Внелетописной повести. В этом же Дополненном виде, вероятно, было добавлено сообщение о составе войска Мамая. Подробнее об этом см.: Соколова Л. В. Что сообщалось об Олеге Рязанском в авторском тексте Повести о Куликовской битве? С. 80-82.

16 Сказания и повести о Куликовской битве. С. 23. Вставку выдает и построение фразы: внесенный фрагмент присоединен к последующему тексту словами «а сам», в результате получается, что Олег сал, в одиночку разрушил мост.

17 На публицистичность древнерусской литературы обращал внимание Д. С. Лихачев: «Единство государства постоянно нарушалось раздорами феодалов. <...> Чтобы удержать единство, требовалась высокая общественная мораль, высокое чувство чести, верности, самоотверженности, высокое патриотическое самосознание и высокое развитие словесного искусства - жанров политической публииистики» (Лихачев Д. С. «Слово о полку Игореве» и культура его времени. Л., 1985. С. 15). 
лась мысль о необходимости объединения всех русских князей перед общим врагом. При этом автор создал риторическое восхваление Дмитрия Ивановича, который, выступая защитником Русской земли, «не убоялся» выступить против трех врагов: «поганого» Мамая, литовского князя Ягайло и «поборника бессерменьского» Олега Рязанского, «не снабдевшего своего крестьяньства»: «О, крђпкыа и твердыа дерзости мужество! О, како не убояся, ни усумняся толика множества народа ратных? Ибо въсташа на нь три земли, три рати: первое - тотарьскаа, второе - литовьскаа, третьее - рязаньскаа. Но обаче всъх сих не убояся, никако же не устрашися, но, еже к Богу върою въоружився...» ${ }^{18}$

Еще одной вставкой в первоначальный, внелетописный текст Повести является сообщение «Летописной повести» о благословенной грамоте Сергия Радонежского. По «Летописной повести», когда князь Дмитрий подошел к Дону, ему была вручена грамота от Сергия Радонежского, содержавшая благословение на битву с Мамаем. На вставку указывает противоречие в тексте «Летописной повести», возникшее в результате вставки. ${ }^{19}$ Эта легенда имела важное общественно-политическое значение для своего времени: она убеждала, что Сергий Радонежский своим духовным авторитетом оправдывал и благословлял выступление русских князей против ордынцев, тем самым побуждая к дальнейшей борьбе за независимость Руси от Орды.

Есть основания полагать, что присутствующие в «Летописной повести» риторические пассажи, а также пространные молитвы и благочестивые рассуждения Дмитрия Ивановича тоже внесены в текст воинской Внелетописной повести при включении ее в свод Фотия 1418 года, поскольку отмеченные особенности являются характерной чертой этого митрополичьего свода. ${ }^{20}$

Последовательно проведенная мысль о том, что победа одержана русскими благодаря вмешательству небесных сил, молитвы к которым возносил Дмитрий Иванович, риторический характер вставок в «Летописную повесть», искусное использование ее составителем фразеологии псалмов и цитат из других библейских книг позволяют видеть в нем профессионального церковного писателя. Столь же искусное составление своего текста из фразеологии псалмов и риторические пассажи находим в Житии Стефана Пермского, написанном монахом Троицкого монастыря Епифанием Премудрым.

Если учесть также вставку составителя «Летописной повести» о благословляющей грамоте игумена Троицкого монастыря Сергия Радонежского (учителя Епифания Премудрого), полученной Дмитрием Донским перед переправой через Дон, то есть основание предполагать, что составителем «Летописной повести о Куликовской битве» был именно Епифаний Премудрый, создавший распространенную, риторическую по стилю редакцию ранее существовавшей Внелетописной повести о Куликовской битве, т. е. «Летописную повесть». ${ }^{21}$

Свод 1418 года определенно связывается с именами и деятельностью митрополита Фотия и Епифания Премудрого. Г. М. Прохоров считал, что Епифаний Премудрый до самой смерти «мог служить своим пером <...> митрополиту Фотию», ${ }^{22}$ выполняя его заказы, в том числе с написанием целого ряда повестей для летописного свода 1418 года. «Литературные достоинства „Свода 1418 г.“ в первую очередь определялись, -

18 Сказания и повести о Куликовской битве. С. 20.

19 См. об этом: Соколова Л. В. Как складывалось литературное предание о благословении Сергием Радонежским Дмитрия Донского на Куликовскую битву // IX Чтения по истории и культуре древней и новой России (К 700-летию преподобного Сергия Радонежского): Материалы науч. конф. (Ярославль, 25-27 сентября 2014 г.). Ярославль, 2016. С. 62-89.

20 При публикации «Летописной повести» предполагаемые нами вставки (риторические пассажи) выделены, их вставной характер обоснован в подстрочных примечаниях. См.: Соколова Л. В. Что сообщалось об Олеге Рязанском в авторском тексте Повести о Куликовской битве? C. 100-109.

21 Соколова Л. В. Что сообщалось об Олеге Рязанском в авторском тексте Повести о Куликовской битве? О Епифании как редакторе см. на с. 94-99.

22 Прохоров Г. М. Памятники переводной и русской литературы XIV-XV веков. Л., 1987. C. 88-122. 
по словам А. Г. Боброва, - вкладом именно этого писателя (Епифания Премудрого. Л. C.)». ${ }^{23}$ Все повести, впервые читающиеся в этом своде и, как полагают исследователи, написанные или отредактированные для него, объединяет общий риторический стиль. Прохоров обосновал предположение, высказанное ранее А. В. Соловьевым, что «Слово о житии и преставлении великаго князя Дмитрия Ивановича», включенное в свод Фотия под 1389 годом, создано Епифанием Премудрым. ${ }^{24} \mathrm{~B}$ числе повестей, подготовленных для летописного свода 1418 года, называлась и «Летописная повесть о Куликовской битве». ${ }^{25}$ Однако, учитывая, что в тексте «Летописной повести» нами обнаружены позднейшие вставки, больше оснований полагать, что Епифаний Премудрый не написал, а отредактировал в характерном для него риторическом стиле ранее существовавшую Внелетописную повесть о Куликовской битве, созданную, вероятно, при жизни Дмитрия Донского, в 80-е годы XIV века.

На то, что «Летописная повесть» принадлежит перу Епифания Премудрого, косвенным образом указывают и некоторые библейские цитаты в ней, присутствующие и в произведениях Епифания Премудрого. Приведем лишь два примера. Риторический фрагмент «плач Мамая» заимствован составителем «Летописной повести» из апокрифа «Слово на Рождество Христово о пришествии волхвов», на что указала В. П. Адрианова-Перетц. ${ }^{26}$ Показательно, что этот же фрагмент был использован в «Слове о житии и о преставлении великаго князя Дмитрия Ивановича, царя Русьскаго», тоже включенном в свод Фотия 1418 года и написанном, как предполагается, Епифанием Премудрым. В эпизоде прощания с воинами в «Летописной повести» упоминается плач Рахили о детях своих (Иер. 31: 15), сравнение с плачем Рахили присутствует и в Епифаниевском Житии Стефана Пермского, в Плаче Церкви Пермской.

«Летописная повесть» неоднократно перерабатывалась, текст ее одними летописцами сокращался, а другими расширялся. ${ }^{27}$ Так, составитель Новгородской летописи Дубровского расширил «Летописную повесть» заимствованиями из «Сказания о Мамаевом побоище». ${ }^{28}$

\section{Сказание о Малаевол побоище}

Следующим по времени произведением о Куликовской битве было, с нашей точки зрения, «Сказание о Мамаевом побоище». Это произведение значительно больше по объему, чем «Летописная повесть», в нем много новых фактов. ${ }^{29}$ "Сказание» охотно переписывалось, дошло более 100 списков этого произведения. Оно сохранилось в не-

23 Бобров А. Г. Летописный свод митрополита Фотия (Проблема реконструкции текста) // Труды Отдела древнерусской литературы. СПб., 2001. Т. 52. С. 137. Исследователь пишет: «Исполнителем работы по написанию ряда повестей для включения в этот выдающийся памятник летописания был, по всей вероятности, инок Троице-Сергиева монастыря Епифаний Премудрый, а „заказчиком“ создания произведения в целом - митрополит киевский и всея Руси Фотий, поэтому мы и называем его „Летописный свод митрополита Фотия“».

24 Соловьев A. B. Епифаний Премудрый как автор «Слова о житии и преставлении великаго князя Дмитрия Ивановича, царя русьскаго» // Труды Отдела древнерусской литературы. М.; Л., 1961. T. 17. С. 85-106; Прохоров Г. М. Памятники переводной и русской литературы XIV-XV веков. С. 88-122.

${ }^{25}$ См.: Саллина M. А. Повесть о Куликовской битве летописная // Словарь книжников и книжности Древней Руси. Л., 1989. Вып. 2 (вторая половина XIV-XVI в.). Ч. 2. Л-Я. С. 244$246 ;$ Бобров А. Г. Летописный свод митрополита Фотия. С. 132-133.

${ }_{26}$ Адрианова-Перети, В. П. Слово о житии и преставлении великаго князя Дмитрия Ивановича, царя Русьскаго // Труды Отдела древнерусской литературы. М.; Л., 1947. Т. 5. С. 87.

27 О переработках «Летописной повести» см.: Саллина М. А. «Летописная повесть» о Куликовской битве и «Задонщина». С. 344-355.

28 С. Н. Азбелев ошибочно считал текст «Летописной повести о Куликовской битве» в составе Новгородской летописи Дубровского первоначальной редакцией Повести. См.: Азбелев C. H. Повесть о Куликовской битве в Новгородской летописи Дубровского // Летописи и хроники: 1973. М., 1974. С. 164-172.

${ }^{29}$ См. об этом: Саллина M. A. К вопросу о датировке «Сказания о Мамаевом побоище»// Труды Отдела древнерусской литературы. Л., 1974. Т. 29. С. 121-123. 
скольких редакциях, наиболее ранними являются Основная, Летописная, Киприановская, Распространенная. ${ }^{30}$

Несколькими исследователями уже высказывалась мысль, что «Сказание» создано после «Летописной повести» и на ее основе ${ }^{31}$ М. А. Салмина указала на целый ряд сюжетных совпадений в «Летописной повести» и «Сказании», сделав вывод: «...оба памятника настолько близки друг другу и в сюжетной линии, и в композиционном построении, и в обращении к одним и тем же фактам, к одним и тем же мотивам, что представляется несомненным - или эти памятники влияли друг на друга, или они восходили к одному источнику».32 Исследователь привела также шесть примеров текстуальной зависимости «Сказания» Основной редакции от «Летописной повести» и пришла к выводу, что между памятниками прямая связь, а именно - «Сказание» создано на основе «Летописной повести». ${ }^{33}$ Л. А. Дмитриев, признавая, что в «Сказании» и в «Летописной повести» действительно много общего в освещении и интерпретации фактов, тем не менее полагал, что попытки М. А. Салминой доказать текстуальную зависимость между обоими памятниками являются неубедительными, и считал более обоснованным высказанное А. А. Шахматовым соображение, что оба памятника пользовались каким-то общим источником. ${ }^{34}$ По мнению Б. М. Клосса, «перекличка образов, композиционной структуры, отдельных фрагментов текста „Сказания“ и Летописной повести настолько бросается в глаза, что предполагать их независимое происхождение невозможно»..$^{35}$ Исследователь полагает, что автор «Сказания» пользовался списком «Летописной повести», входящей в Софийскую I летопись старшего извода. Но к сожалению, он привел лишь один пример большей текстологической близости «Сказания» к Софийской I летописи старшего извода, нежели к Новгородской IV летописи. ${ }^{36}$

«Сказание», на наш взгляд, написано не просто позже «Летописной повести» оно полемизирует с ней. Если в «Летописной повести» великий князь московский Дмитрий Иванович, в соответствии с традицией, является, по сути дела, единственным героем битвы, ${ }^{37}$ то в «Сказании» активно действуют и другие герои. Более того, роль Дмитрия Ивановича в сражении автор «Сказания» сознательно искажает. Поэтому нельзя, по нашему мнению, согласиться с утверждением Л. А. Дмитриева, что Дмитрий Донской - главный герой «Сказания», что он изображен идеальным князем, мудрылм государственным деятелем и опытнылм полководцем, что автор подчеркивает его личную доблесть и лужество, ${ }^{38}$ что «Сказание» - «это не только рассказ о битве с татарами, но своего рода панегирик великому князю московскому, приближающийся к агиографическим похвалам», что публицистической задачей «Сказания» было «показать первенство великого князя московского». ${ }^{39}$ Правы, как

${ }^{30}$ См.: Длитриев Л. А. Обзор редакций Сказания о Мамаевом побоище // Повести о Куликовской битве. М., 1959. С. 449-480.

${ }^{31}$ См.: Шалбинаго С. К. Повести о Мамаевом побоище. СПб., 1906. С. 151; Мингалев В. С. Летописная повесть - источник «Сказания о Мамаевом побоище» // Труды Московского государственного историко-архивного института. 1966. Т. 24. Вып. 2. С. 55-72. Шамбинаго думал, что в основе «Сказания» лежит «Летописная повесть», читающаяся в Новгородской летописи Дубровского. Однако это неверно. Напротив, текст «Летописной повести» в летописи Дубровского расширен за счет вставок из «Сказания» .

32 Салмина М. А. К вопросу о датировке «Сказания о Мамаевом побоище». С. 119.

33 Там же. С. 120-121.

34 Дмитриев Л. А. 1) Литературная история памятников Куликовского цикла // Сказания и повести о Куликовской битве. С. 342-347; 2) Сказание о Мамаевом побоище // Словарь книжников и книжности Древней Руси. Вып. 2. Ч. 2. С. 378.

35 Клосс Б. М. Об авторе и времени создания «Сказания о Мамаевом побоище» // In memoriam: Сборник памяти Я. С. Лурье. СПб., 1997. С. 254.

36 Там же. С. 254-255.

37 Когда великий князь принимал личное участие в битве, то она изображалась в памятниках как великокняжеское предприятие.

38 Дмитриев Л. А. Литературная история памятников Куликовского цикла. С. 347-348.

39 Длитриев Л. А. К литературной истории Сказания о Мамаевом побоище // Повести о Куликовской битве. С. 426-427. Сходную точку зрения высказал А. Н. Робинсон, см.: Робинсон $A . H$. 
представляется, М. Н. Тихомиров, ${ }^{40}$ Л. В. Черепнин ${ }^{41}$ и Р. Г. Скрынников, ${ }^{42}$ увидевшие в «Сказании» руку недоброжелателей московского великого князя Дмитрия Ивановича. По «Сказанию», Дмитрий Иванович, по сути дела, отказался от руководства сражением. Перед началом битвы Михаил Андреевич Бренко (Бренок) обменялся с Дмитрием Ивановичем доспехами и конем и занял место великого князя под его «чермным» стягом. Это обстоятельство вынуждает читателя предположить, что именно он, боярин и воевода, и командовал русским войском в начале великой битвы с татарами за рекой Доном. В «Сказании» затем подчеркнуто, что под княжеским знаменем и погиб Михаил Андреевич «за великого князя», - по сути дела, вместо него. Л. В. Черепнин полагал, что ранение, заставившее Дмитрия Ивановича фактически выбыть из строя в часы боя, было использовано врагами Московского княжества из числа русских правителей (исследователь назвал рязанского и тверского князей) и противниками Дмитрия Донского из числа московских и не московских бояр для его опорочения. Но скорее всего, никакого ранения Дмитрия Ивановича не было. Созданная в его окружении и для его прославления «Летописная повесть» говорит о том, что великий князь не был ранен, и не потому, что оберегал себя (он сражался в первых рядах), а потому, что Бог охранял его. Версия о ранении изобретена автором «Сказания», чтобы приуменьшить роль Дмитрия Ивановича в битве и показать героическую роль других участников сражения.

Принижая роль Дмитрия Ивановича в победе на Куликовом поле и даже выставляя его в невыгодном свете, автор «Сказания» всячески подчеркивает роль в битве его двоюродного брата, второго лица в московском княжеском доме Владимира Андреевича Серпуховского. В отличие от «Летописной повести о Куликовской битве», где имя Владимира Серпуховского названо всего четыре раза с упоминанием при этом и «всех князей русских», ${ }^{43}$ в «Сказании» имя Владимира Серпуховского постоянно фигурирует рядом с именем Дмитрия Ивановича. По «Сказанию», Владимир Андреевич возглавляет Засадный полк, благодаря которому произошел перелом в битве и татары обратились в бегство. Именно полк Владимира Андреевича преследует воинов Мамая до их стана. Возвратившись же на поле битвы, Владимир Андреевич «стал на костях» под княжеским знаменем, по сути дела как выигравший сражение князь, за которым осталось поле битвы. При этом Владимир Андреевич «не обрел брата своего», великого князя Дмитрия Ивановича. Он расспрашивает о нем и узнает, что видели его сражавшимся с четырымя «печенегами», а потом - раненым, идущим пешим с поля битвы. Князя Дмитрия долго ищут и наконец находят его «бита велми» в дубраве, «отдыхающа под сеченым деревом». Владимир Андреевич сообщает великому князю о победе и поздравляет его с честью победителя, по праву принадлежащей, как вытекает из «Сказания», ему самому.

Рядом с Дмитрием Ивановичем, затмевая его, в «Сказании» выступает не только его двоюродный брат Владимир Андреевич Серпуховской, но и братья жены Владимира Андреевича Елены - литовские князья Андрей и Дмитрий Ольгердовичи, а также опытный воевода Дмитрий Боброк Волынский, «уряжающий полки» перед битвой

Эволюция героических образов в повестях о Куликовской битве // Куликовская битва в литературе и искусстве. М., 1980. С. 10-38.

40 По мнению Тихомирова, «Сказание» прославляло «литовских князей Ольгердовичей, а также Владимира Андреевича серпуховского как героев битвы. Наоборот, Дмитрий Донской изображен почти трусом. Это - сознательное искажение действительности, а не простой литературный прием» (Тихолиров М. Н. Куликовская битва 1380 года // Повести о Куликовской битве. C. 346).

41 Черепнин Л. В. Образование русского централизованного государства в XIV-XV веках. С. 619 и др.

42 Скрынников Р. Г. Куликовская битва: Проблемы изучения // Куликовская битва в истории и культуре нашей Родины. М., 1983. С. 68.

43 Вначале Дмитрий призывает в поход брата и всех князей русских, затем обращается к ним с речью, потом говорится о соединении войск Дмитрия Ивановича с войском Владимира Андреевича у Оки, а в конце «Летописной повести» Дмитрий Иванович вместе с братом и со всеми князьями, воеводами и воинами «стоит на костях», принося благодарение Богу. 
и, по сути дела, командующий Засадным полком, решившим исход сражения (именно он удерживает Владимира Андреевича от преждевременного вступления в бой и указывает ему, когда нужно ринуться в битву). Участию братьев Ольгердовичей в походе на Мамая придается большое значение: их присоединение к войску Дмитрия описывается как из ряда вон выходящее событие. Приводится авторское обоснование отъезда братьев от отца (при том что Ольгердовичи к этому времени уже были на службе у московского князя), между братьями происходит обмен посланиями, в которых говорится о важности защиты христианства, обосновывается этим выступление сыновей против отца и т. д. Весть о приезде Ольгердовичей к Дону великий князь посылает в Москву митрополиту Киприану, который по этому поводу повелел «сугубо молитву творити день и нощь к вседръжителю Богу». Известие об их прибытии отправлено и в обитель игумена Сергия, и к великой княгине Евдокии, которая в молитвах возносит благодарение Богу. Если в «Летописной повести» при обсуждении вопроса о целесообразности переправы через Дон решительным сторонником мнения о необходимости перейти Дон выступает великий князь, произносящий пылкую речь (по мнению Черепнина, «здесь налицо определенная политическая тенденция, вообще характерная для Летописной повести, — изобразить весь поход как предприятие княжеское»), ${ }^{44}$ то по «Сказанию» вопрос о переходе на другую сторону Дона был решен после того, как в необходимости этого убедили московского князя литовские князья Андрей и Дмитрий Ольгердовичи: переправившись через Дон, воины лишат себя пути к отступлению и им придется либо победить, либо умереть. После возвращения в Москву сам Дмитрий Иванович с почетом провожает братьев восвояси.

Для создания нужного представления о героях сражения на Дону автор «Сказания» сознательно допускает анахронизмы, в частности, заменяет имя литовского князя Ягайло, готовившегося выступить на стороне Мамая, именем его отца Ольгерда, умершего за три года до Куликовской битвы. Называя союзником Мамая Ольгерда, который несколько раз нападал на Москву и слыл опасным врагом, автор «Сказания», по мнению Дмитриева, подчеркивал силу и мощь московского князя. ${ }^{45}$ Существовала, вероятно, и более важная причина намеренной замены имени: это позволяло составителю «Сказания» обосновать мысль о том, что защита христианства оправдывала выступление сыновей против отца. Данный тезис подчеркивается в «Сказании» ссылками на Священное Писание.

Этот и другие анахронизмы «Сказания» (включение в число персонажей митрополита Киприана, которого в 1380 году не было в Москве, а также сообщение о том, что великий князь перед походом молился перед иконой Владимирской Богоматери, перенесенной из Владимира в Москву лишь в 1395 году, во время движения на Русь войск Тимура) указаны и объяснены в работах Дмитриева. ${ }^{46}$

Многие эпизоды «Сказания» справедливо вызывают у исследователей сомнение в их достоверности. Это и рассказ о посещении Дмитрием Ивановичем Троицкого монастыря, и сведение о благословенной грамоте Сергия Радонежского, доставленной московскому великому князю перед переправой через Дон, ${ }^{47}$ и эпизод с переодеванием Дмитрия Ивановича, ${ }^{48}$ и эпический эпизод поединка Пересвета с Челубеем (или

44 Черепнин Л. В. Образование Русского централизованного государства в XIV-XV веках. C. 613 .

45 Дмитриев Л. А. Куликовская битва 1380 года в литературных памятниках Древней Руси // Русская литература. 1980. № 3. С. 23. 339 .

46 Дмитриев Л. А. Литературная история памятников Куликовского цикла. С. 333, 338-

47 См. об этом: Кучкин В. А. Дмитрий Донской и Сергий Радонежский в канун Куликовской битвы // Церковь, общество и государство в феодальной России: Сб. статей. М., 1990. С. 103-109, 114-120; Соколова Л. В. Как складывалось литературное предание о благословении Сергием Радонежским Дмитрия Донского на Куликовскую битву. С. 71-77.

${ }^{48}$ Как отметил Скрынников, легенда о переодевании Дмитрия Донского «поражает своими несообразностями». Снять с себя наиболее прочный княжеский доспех, отлично подогнанный по фигуре, отдать испытанного боевого коня за считанные минуты до сечи - это означало подвергнуть себя наибольшей опасности. См.: Скрынников Р. Г. Куликовская битва. С. 68. 
«печенегом») ${ }^{49}$ Не всем ученым кажется реалистичной и история с Засадным полком под руководством Владимира Андреевича и Дмитрия Волынского, призванная возвысить их роль в сражении на Дону. ${ }^{50}$ (Ранее в «Сказании» вслед за «Летописной повестью» сказано, что при уряжении полков в Коломне Владимир был поставлен во главе полка Правой руки, как и полагалось ему по статусу $\left.{ }^{51}\right)$.

Перечисленные фрагменты «Сказания» являются плодом вымысла его автора и носят литературный характер. Источником фрагментов о Сергии Радонежском послужили «Летописная повесть о Куликовской битве» и Житие Сергия Радонежского, а эпизоды с переодеванием князя, с Засадным полком и др. навеяны, по мнению А. Е. Петрова, «Сербской Александрией», с которой автор был, несомненно, знаком. ${ }^{52}$ Эпизод поединка Пересвета с ордынским богатырем заставляет вспомнить о «Повести временных лет», где эпизоды поединков перед битвой встречаются дважды.

Исходя из того, как изображены автором «Сказания» участники Куликовской битвы, А. А. Шахматов ${ }^{53}$ и другие исследователи предполагали, что автор «Сказания» был связан с удельным князем Владимиром Андреевичем и его родственниками литовскими князьями Ольгердовичами. Ученые привели убедительные аргументы в пользу того, что «Сказание» создано в Троицком монастыре, расположенном на землях княжества Владимира Серпуховского, который делал богатые вклады в монастырь. ${ }^{54}$ Этим объясняется и повествование о Сергии Радонежском, и рассказ о монахах этого монастыря, Пересвете и Осляби, принявших участие в битве по благословению Сергия Радонежского.

По поводу того, когда было написано «Сказание», сейчас существуют три основные точки зрения. Дмитриев ${ }^{55}$ и Скрынников ${ }^{56}$ датировали «Сказание» первой третью $\mathrm{XV}$ века, Кучкин ${ }^{57}$ и Клосс ${ }^{58}$ - почти на сто лет позднее, началом или первой третью XVI века. Петров относит составление «Сказания» к последнему десятилетию XV ве-

49 О вымышленном характере сообщения о поединке Пересвета см.: Соколова Л. В. Как складывалось литературное предание о благословении Сергием Радонежским Дмитрия Донского на Куликовскую битву. С. 81-83.

50 Д. А. Моисеев, например, сомневается в правдивости известий о построении полков, в том числе в существовании «засадного полка». См.: Моисеев Д. А. К вопросу о построении русских полков на Куликовом поле // http://www.russiancity.ru/hbooks/h064.htm; дата обращения: 15.04.2020.

51 При этом рассказ о Засадном полку носит правдоподобный характер: войско в то время действительно могло состоять из 5 полков, одним из которых был запасной, Засадный, вступавший в битву со свежими силами в определенное время после начала битвы. В. А. Кучкин со ссылкой на летопись указывает, что «пятичленное деление и построение полков (то есть, вероятно, на сторожевой полк, Великий полк, полки правой и левой руки и запасной, арьергардный полк) в XIV в. было русским известно» (Кучкин B. A. Победа на Куликовом поле // Вопросы истории. 1980. № 8. С. 15). По мнению исследователя, рассказ «Сказания» о Засадном полке заслуживает доверия (Там же. С. 15-16).

52 Автор «Сказания» упоминает героя «Сербской Александрии» Ависа. См.: Петров A. E. «Александрия Сербская» и «Сказание о Мамаевом побоище» // Древняя Русь: Вопросы медиевистики. 2005. № 2 (20). С. 60.

53 Шахматов А. А. Отзыв о сочинении С. Шамбинаго «Повести о Мамаевом побоище». СПб., 1906 // Отчет о двенадцатом присуждении Имп. Академией наук премий митрополита Макария в 1907 году. СПб., 1910. С. 181.

${ }^{54}$ См., например: Скрынников Р. Г. Куликовская битва. С. 68 ; Клосс Б. М. Об авторе и времени создания «Сказания о Мамаевом побоище». С. 259-260.

55 Длитриев Л. А. 1) О датировке «Сказания о Мамаевом побоище» // Труды Отдела древнерусской литературы. М.; Л., 1954. Т. 10. С. 185-199; 2) К литературной истории «Сказания о Мамаевом побоище». С. 406-448; 3) Сказание о Мамаевом побоище. С. 371-384.

56 Скрынников Р. Г. Куликовская битва. С. 43-70.

57 Кучкин В. А. Дмитрий Донской и Сергий Радонежский в канун Куликовской битвы. C. $113-114$.

${ }^{58}$ Клосс Б. М. 1) Об авторе и времени создания «Сказания о Мамаевом побоище». С. 253262 ; 2) Сказание о Мамаевом побоище // Клосс Б. М. Избр. труды. М., 2001. Т. 2. Очерки по истории русской агиографии XIV-XV веков. С. 344-345. 
ка. ${ }^{59}$ Аргументы сторонников позднего происхождения «Сказания» рассмотрены нами в специальной статье. ${ }^{60}$

Исследование памятников Куликовского цикла привело нас к выводу, что «Сказание» было создано в 1440 -е годы или в самом начале 1450 -х годов. Нижней границей является время создания Четвертой Пахомиевской редакции Жития Сергия Радонежского (она датируется Б. М. Клоссом 1444-1445 годами ${ }^{61}$ ). В Четвертой редакции Жития, а вслед за ней в «Сказании» соединились два эпизода: эпизод приезда Дмитрия Ивановича в Троицкий монастырь к Сергию за благословением на битву с Мамаем (читающийся в Первой Пахомиевской редакции; в Жиитии он краток) и эпизод с благословенной грамотой (заимствованный Пахомием в Житие из «Летописной повести»). ${ }^{62}$ Причем, по «Сказанию», Дмитрий Иванович получает благословенную грамоту, как и в ЖКитии Сергия, непосредственно перед битвой (в «Летописной повести» - перед переходом через Дон).

До сих пор многие исследователи уверены, что «Сказание» создано после «Задонщины», поскольку в нем есть вставки из последней. Однако, как показывает проведенный нами текстологический анализ «Сказания», этих вставок не было в авторском тексте, они внесены позднейшими редакторами. ${ }^{63}$ Напротив, есть основание считать, что «Сказание» создано до «Задонщины», в которой содержатся туманные намеки на события, о которых подробно повествуется в «Сказании». Кроме того, некоторые фрагменты «Сказания» первичны по отношению к параллельным фрагментам «Задонщины». ${ }^{64}$ Следовательно, «Сказание» не могло быть написано позже 1475 года, которым датируется список «Задонщины», переписанный Ефросином Белозерским. Если учесть, что «Задонщина» была создана, скорее всего, не позднее 1453-го (года падения Константинополя), ${ }^{65}$ то составление «Сказания» можно ограничить 1444/1445-1453 годами.

Учитывая то, что «Сказание о Мамаевом побоище», по всей вероятности, написано в Троицком монастыре в $1445-1453$ годах, можно предположить, что его автором был Пахомий Серб, пребывавший в Троицком монастыре (в первый период) с 1440 до 1459 года. В 1440-1445 годах он трудился над Жћитием Сергия Радонежского и создал несколько редакций этого произведения. Проблеме атрибуции «Сказания» мы посвятим специальную работу. ${ }^{6}$

Итак, «Сказание о Мамаевом побоище», в основу которого положена «Летописная повесть о Куликовской битве», полемизирует с ней, дает иное, нежели «Летописная повесть», представление о роли в Куликовской битве ее участников.

59 Петров A. E. 1) К вопросу о датировке «Сказания о Мамаевом побоище» // Тезисы докладов и сообщений конференции молодых специалистов РГБ по итогам научно-исследовательской работы за 1992 год. М., 1993. С. 30-31; 2) Проблема датировки «Сказания о Мамаевом побоище» в связи с «Повестью о походе Ивана III на Новгород в 1471 году» // Румянцевские чтения: К 240-летию со дня рождения Н. П. Румянцева: Тезисы докладов и сообщений научно-практической конф. (14-15 апреля 1994 г.): В 2 ч. М., 1994. Ч. 2. С. 49-51; 3) «Александрия Сербская» и «Сказание о Мамаевом побоище». С. 54-64.

60 Соколова Л. В. К вопросу о датировке и авторстве «Сказания о Мамаевом побоище» // Труды Отдела древнерусской литературы. СПб., 2020. Т. 67 (в печати).

${ }^{61}$ Клосс Б. М. Избр. труды. Т. 1. Житие Сергия Радонежского. С. 174.

62 См. об этом: Соколова Л. В. Как складывалось литературное предание о благословении Сергием Радонежским Дмитрия Донского на Куликовскую битву. С. 73-76. Следует отметить, что соединение двух эпизодов видим и в Третьей Пахомиевской редакции (по классификации Клосса), но другие исследователи сомневаются в принадлежности этой редакции Пахомию Сербу.

${ }^{63}$ См. об этом: Соколова Л. В. Содержал ли авторский текст «Сказания о Мамаевом побоище» вставки из «Задонщины»? (К вопросу о взаимоотношении памятников) // Труды Отдела древнерусской литературы. СПб., 2017. Т. 65. С. 101-121.

64 Доказательства см.: Соколова Л. В. К вопросу о датировке и авторстве «Сказания о Мамаевом побоище».

65 Аргумент см. в статье: Соколова Л. В. Первоначальна ли Краткая редакция «Задонщины»? (В связи с новейшими работами о взаимоотношении «Слова о полку Игореве» и «Задонщины») // Труды Отдела древнерусской литературы. СПб., 2014. Т. 62. С. 710-711.

66 Некоторые предварительные доводы в пользу авторства Пахомия Серба см.: Соколова Л. B. К вопросу о датировке и авторстве «Сказания о Мамаевом побоище». 
Заключительным произведением Куликовского цикла была, с нашей точки зрения, «Задонщина». Она была создана, по нашему мнению, книжником, знакомым и с «Летописной повестью», и со «Сказанием». «Задонщина» по своей идее, своему замыслу существенно отличается и от «Летописной повести», и от «Сказания» .

По догадке Д. С. Лихачева, «центральная идея „Задонщины“ - идея реванша» . Именно этим объяснялось, по мнению ученого, обращение ее автора к «Слову о полку Игореве», а не простым подражанием его стилю. В сближении событий прошлого и настоящего - «пафос исторического замысла» «Задонщины» ${ }^{67}$

Однако автор «Задонщины» пишет свое произведение не с целью рассказать о Мамаевом побоище или прославить того или иного участника Куликовской битвы - он создает публицистическое произведение, в котором события 1380 года оцениваются с государственных позиций. Его задача - вдохновить русских на окончательное свержение ордынского ига. Автор «Задонщины» стремится изобразить Куликовскую битву как общерусское предприятие, поэтому считает нужным объяснить, почему новгородцы не смогли принять участие в сражении, и умолчать «об измене» русского князя Олега Рязанского, чтобы не нарушать картину единодушия русских князей.

Все произведения Куликовского цикла за исключением его заключительного звена - Краткой редакции «Задонщины», известной по списку, переписанному Ефросином в 1475 году, незадолго до 100-летия сражения с Мамаем, - описывают Куликовскую битву как несомненную и очень важную победу объединенного русского войска над Мамаем. Явные свидетельства того, что и в протографе Краткой редакции Куликовская битва изображалась как победа русских, имеются в тексте этой редакции (пролог, приметы будущей победы). ${ }^{68}$

В заключение отметим, что Куликовская битва действительно стала переломным моментом во взаимоотношениях Руси с Ордой, несмотря на то что ордынское иго продолжалось еще долгих сто лет. Победа на Куликовом поле пробудила историческое самосознание русского народа, дала надежду на освобождение, способствовала созданию этнической общности. По выражению Л. Н. Гумилева, «этническое значение происшедшего в 1380 г. на Куликовом поле оказалось колоссальным. Суздальцы, владимирцы, ростовцы, псковичи пошли сражаться на Куликово поле как представители своих княжеств, но вернулись оттуда русскими, хотя и живущими в разных городах. И потому в этнической истории нашей страны Куликовская битва считается тем событием, после которого новая этническая общность - Московская Русь - стала реальностью, фактом всемирно-исторического значения». ${ }^{69}$ Широко известен и афоризм В. О. Ключевского о том, что Московское государство «родилось на Куликовом поле, а не в скопидомном сундуке Ивана Калиты». ${ }^{70}$

67 Лихачев Д. С. 1) Национальное самосознание Древней Руси. М.; Л., 1945. С. 76-78; 2) «Задонщина» // Лихачев Д. С. Великое наследие. М., 1975. С. 250-251.

68 О причинах, побудивших Ефросина сократить вторую часть «Задонщины», повествующую о победной части боя, см.: Соколова Л. В. Первоначальна ли Краткая редакция «Задонщины»? С. 721-723.

69 Гулилев Л. Н. От Руси к России. М., 2015. С. 206.

70 Ключевский В. О. Боярская дума Древней Руси. Пб., 1919. С. 521. 
DOI: $10.31860 / 0131-6095-2020-3-165-182$

(ㄷ) А. Ю. Веселова, () М. П. Милютин

\section{МЕМУАРЫ А. Т. БОЛОТОВА: ИСТОРИЯ СОЗДАНИЯ}

Мемуары А. Т. Болотова создавались на протяжении более 50 лет и включают в себя около 50 отдельных, зачастую дублирующихся, рукописей. ${ }^{1}$ Целью настоящей статьи является определение места отдельных рукописей в комплексе болотовских воспоминаний, что можно сделать путем реконструкции и изучения истории их создания. ${ }^{2}$

От всего корпуса мемуарных текстов по ряду признаков принципиально отличается рукопись, хранящаяся в ОПИ ГИМ (Ч. 2. Ф. 349. Ед. хр. 2), ${ }^{3}$ которая ранее почти не привлекала внимания исследователей. В XIX веке она вошла в состав собрания Н. С. Киселева и описывалась владельцем следующим образом: «2) Приключения А. Б. с 1752-1758 (частью в письмах, частью в связном рассказе; содержание этого томика есть сокращение частей II-V «Записок», за исключением 1751 г., которого у меня вовсе нет)». ${ }^{4}$ На наш взгляд, данная Киселевым характеристика рукописи как сокращения мемуаров не верна. Такое сокращение было бы практически уникальным в рукописном наследии Болотова. Для мемуаров же наблюдается противоположная тенденция. Болотов неоднократно высказывал сожаления о том, что его воспоминания слишком краткие,${ }^{5}$ и на позднем этапе работы предпринимал попытки их дополнения. ${ }^{6}$

Заголовок рассматриваемой рукописи содержит хронологическую неточность, так как ее текст заканчивается описанием осени 1757 года. Вероятно, план довести изложение до событий 1758 года изменился в ходе работы, так как рукопись получилась объемной (264 листа, больше любых иных частей мемуаров). Если предположить, что «Приключения» составлялись как сокращение уже написанных воспоминаний, то Болотов, скорее всего, оставил бы в тексте пометы об окончании и начале соответствующих частей, но их нет. С другой стороны, эта рукопись сама является частью более обширного сочинения, первая часть которого до нас не дошла. Без какого-либо вступления Болотов начинает с описания событий лета 1752 года: «Не успел я получить известие о кончине моей матери...» (Ч. 2. ОПИ ГИМ. Ф. 349. Ед. хр. 2. Л. 8; л. 2 об. -7 об. пустые). Завершается текст формализованным финалом, предполагающим продолжение: «Сим заблагоразумно кончить сию вторую часть описания моей жизни. В третьей сообщу вам то, что со мною далее случилось. А между тем остаюсь

1 Всего дублируется 16, т. е. около половины сохранившихся частей мемуаров. Ни одна часть не имеет более одной копии.

${ }^{2}$ Настоящая статья является продолжением: Веселова А. Ю., Милютин М. П. О составе корпуса мемуаров А. Т. Болотова // Русская литература. 2020. № 1. С. 65-75. В связи со значительным объемом рукописного материала, авторы данной статьи не ставили перед собой цель охарактеризовать каждую рукопись мемуаров и ограничиваются примерами, важными для общих выводов об истории их создания.

3 Здесь и далее ссылки на рукописи мемуаров приводятся в тексте с указанием номера части, места хранения, единицы хранения и листа. Полное их описание см.: Веселова А. Ю., Милютин М. П. О составе корпуса мемуаров А. Т. Болотова. Табл. 1-4.

${ }^{4}$ Опись см.: Болотов М. П. Андрей Тимофеевич Болотов: жизнь его с 1796 по 1833 г. // Русская старина. 1873. Т. 8. Ноябрь. С. 748.

5 См., например, в дневниковых записях 1802 года (Болотов А. Т. 65-й год моей жизни // ИРЛИ. Ф. 537. Ед. хр. 11. Л. 2-3 об.).

6 Такой характер имеют две незаконченные рукописи: развернутое примечание к первому письму воспоминаний (Болотов $A$. T. Некоторые замечания и дополнения к истории моей жизни (1827 год, 12 л.) // ИРЛИ. Ф. 537. Ед. хр. 26) и уточненный вариант истории предков Болотова, который отнюдь не выглядит «сокращенным» по сравнению с соответствующим фрагментом мемуаров (Болотов А. T. Краткое описание моей жизни, состоящее в сокращенных записках всего того, что со мною во все годы продолжения моей жизни достопамятного или несколько особливого происходило (1810-1820-е годы, 8 л.) // ИРЛИ. Ф. 537. Ед. хр. 27). 
ваш и прочее» (Там же. Л. 264). Но никаких сведений об этой «третьей части» мы не имеем, по-видимому, она не была написана.

Эта ситуация соответствует указаниям Болотова на существование раннего варианта мемуаров. Сообщая о начале работы над итоговыл вариантол в январе 1789 года, он пишет: «Дело сие начато было у меня уже очень давно, но все прерывалось $<\ldots>$ У меня написано было уже два тома $<\ldots>$, но как первая часть оной во время пожара у меня сгорела, а вторая часть была уже переплетена, то вздумалось мне написать опять вновь и первую, а буде можно — то и всю жизнь...». ${ }^{7}$ Таким образом, можно говорить о первом, раннел богородицкол этапе написания мемуаров, который начался до мая 1782 года, когда в Богородицке, где Болотов с 1773 по 1797 год служил управляющим императорской волости, был упомянутый им пожар (III, 1034-1050). На этом этапе были написаны две части, равные по охваченному временному периоду пяти итоговым. Первая из них была утрачена в 1782 году, а второй, очевидно, и является сохранившаяся рукопись «Приключений». По-видимому, о работе над ней Болотов упоминает при описании событий декабря 1787 года: «...получил я охоту описать всю мою жизнь, наипаче начать продолжать давно уже учиненное тому начало...» (IV, 198).

Этот вывод можно подкрепить рядом наблюдений. Если итоговый вариант болотовских мемуаров разделен на последовательно пронумерованные письма, то в «Приключениях» деление на письма начинается только с л. 181, и они не нумерованы. Видимо, идея эпистолярной стилизации воспоминаний появилась у Болотова в процессе создания этой рукописи. Название «Приключения Андрея Болотова», на наш взгляд, свидетельствует о том, что Болотов лишь со временем пришел к пониманию ценности описания частной жизни. Первоначально он старался делать акцент на событиях ( «приключениях»), свидетелем и участником которых он был, особенно исторических. Не случайно половина всего текста (с л. 132) посвящена описанию апраксинского похода 1757 года, а значительную его часть (л. 181-233) - описанию Гросс-Егерсдорфского сражения. Практически весь текст «Приключений» был перенесен в итоговый вариант, но неравномерно. Например, в письмах, содержащих описание битвы при Гросс-Егерсдорфе, дополнений почти нет. В других случаях текст, перенесенный из «Приключений», занимает лишь малую часть. Следовательно, Болотов создавал итоговый вариант, используя раннюю версию мемуаров, но не путем механического переписывания. Помимо существенных по объему новых фрагментов текста, он вносил различные фактические уточнения (имен, названий, времени действия и т. д.), стилистическую правку, а также небольшие вставки, усиливающие эмоциональное воздействие на читателя. Представить себе обратное соотношение этих текстов, т. е. от более полного к краткому, на наш взгляд, невозможно.

Рукопись «Приключений» содержит исправления: зачеркивания, вставки на полях и над строкой. Они относятся ко времени создания текста, так как не коррелируют с дополнениями, внесенными в итоговый вариант воспоминаний. ${ }^{8}$ Но Болотов, очевидно, не рассматривал эту рукопись как черновик, ${ }^{9}$ в чем убеждает и ее оформление: она написана четким почерком, исправления не мешают чтению текста. В рукопись

7 Жизнь и приключения Андрея Болотова, описанные самим им для своих потомков. СПб., 1873. Т. 4. Стлб. 506-507. Далее ссылки на это издание под редакцией М. И. Семевского, до сих пор являющееся наиболее полной публикацией, выполненной с комплекта рукописей, хранящихся в РНБ (Ф. 89. Ед. хр. 1-5, 7-29), приводятся в тексте с указанием номера тома и столбца.

8 Примеры правки текста в этой рукописи и подробное сопоставление ее с итоговым вариантом болотовских мемуаров см.: Абралова A. A. Ранняя редакция мемуаров А. Т. Болотова из собрания Отдела письменных источников ГИМ // Слово.ру. Балтийский акцент. 2020. № 2. С. 114122. Автор статьи приходит к выводам, аналогичным предложенным в данной статье. Мы также выражаем благодарность А. А. Абрамовой за участие в работе над рукописями мемуаров в ОПИ ГИМ.

9 Очевидно, что для Болотова понятие «черновик» не отличалось от общепринятого: «черновик» - это предварительная версия текста, отражающая процесс работы над ним и рассматриваемая автором как рабочий вариант. Текст, который создается как завершенный, итоговый, но впоследствии использованный в более поздних сочинениях, «черновиком» не является. 
вклеена закладка-ляссе, корешок у нее кожаный, с тиснением. По внешнему виду и характеру правки рукопись «Приключений» похожа на оригиналы итогового варианта воспоминаний.

Судя по названию, ранний вариант не был прямо адресован потомкам автора: к началу 1780-х годов дети Болотова были еще малы. Представляется, что импульсом для начала работы над мемуарами в данном случае была свойственная Болотову рефлексия, наиболее очевидным поводом для всплеска которой было достижение 40-летнего возраста в 1778 году. Он вообще придавал очень большое значение круглым датам и прочим рубежам своей жизни. ${ }^{10}$ Таким образом, ранний богородицкий этап написания воспоминаний продолжался около 10 лет, работа над мемуарами у Болотова шла с большими перерывами и, по-видимому, к концу 1780-х годов перестала удовлетворять автора.

Начало нового, основного богородицкого этапа имеет точную датировку: 24 января 1789 года Болотов заново приступил к написанию мемуаров, текст которых и стал их итоговым вариантом (IV, 506-507). Продолжался этот этап до 1792 года, и за это время были написаны части с 1-й по 6-ю и два с половиной письма 7-й. Из них сохранились 1-я и 6-7-я части, являвшиеся в XIX веке частью киселевского собрания, а ныне хранящиеся в ОПИ ГИМ, и 5 -я, находящаяся в РНБ. ${ }^{11}$ Все эти части обычно рассматривались как черновики. ${ }^{12} \mathrm{~B}$ них есть небольшая правка (обычно зачеркивание, замена отдельных слов и надстрочные вставки), но, как и более ранняя рукопись «Приключений», это были не черновые материалы для дальнейшей работы, а, как сообщается в «Предуведомлении» к 1-й части, «прямо набело писаное сочинение» (Ч.1. ОПИ ГИМ. Ф. 349. Ед. хр. 1. Л. 5). Такая формулировка характеризует и интенсивность работы Болотова: с этого момента он писал мемуары быстро. Хотя график его работы может быть точно установлен только для более позднего периода, когда Болотов жил в Дворянинове, вряд ли в Богородицке он был принципиально иным. Его письменная работа имела преимущественно сезонный характер (с ноября по февраль, реже с октября по март), перерывы в работе над мемуарами внутри одного сезона были редки и, как правило, связаны с отвлечением на другие писательские проекты. Приступив к написанию новой части, Болотов работал ежедневно, сразу оформляя беловой вариант с минимальной авторской правкой.

Существенное значение в это время имела служебная занятость Болотова, из-за которой основной объем работы над первыми частями мемуаров пришелся уже на зиму 1789-1790 годов. В приведенном в мемуарах письме сыну Павлу от 10 декабря 1789 года Болотов пишет: «Третьего дня окончил я и третью часть истории моей жизни, и она получила также в 13 дней свое существование» (IV, 696). Следовательно, 2-я и 3 -я части были написаны в начале этого писательского сезона, к которому, по-видимому, относятся также 4-я и 5-я части. Судя по тому, что на оригинале 5-й части нет отметок о времени ее написания, недатированными были и 2-4-я части, т. е. ситуация была аналогичной «Приключениям», 2-я часть которых не датирована. На 6-й части, однако, содержится помета о ее написании осенью 1790 года. ${ }^{13}$ Таким образом, 6 -я часть была написана уже в начале следующего сезона 1790-1791 годов, с чем, по-видимому, и было связано появление пометы о времени ее создания. Обращает также на себя внимание продолжительность работы над ней - более месяца, т. е. в три раза больше, чем у 2-й и 3-й частей, которые в значительной степени опирались на текст «Приключений» .

К написанию 7-й части Болотов приступил только в ноябре 1792 года, однако хронологические рамки создания этой части оказались самыми широкими за все время работы над мемуарами: завершена она была лишь в 1800 году. Тогда Болотов еще не датировал отдельные письма, и на оригинале 7-й части нет иных помет, кроме

10 Подробнее см.: [Веселова А. Ю.]. Дни рождения А. Т. Болотова // Von Wenigen = От немногих. СПб., 2008. С. 92-124.

11 Об истории этой рукописи (РНБ. Ф. 89. Ед. хр. 6) после раздела архива Болотова в ХІХ веке у нас нет информации.

12 Рукопись оригинала 5-й части и в описи обозначена как «черновой автограф».

13 Пометы о времени написания этих частей сведены ниже в Таблице 1. 
указания на общую продолжительность написания рукописи. Однако на сделанной в 1801 году ее копии такие пометы есть: в конце 75-го письма стоит «Декабря 10, 1797 года» (I, 912). Таким образом, осенью 1792 года Болотов написал первые два (73-е и 74-е) письма этой части, а также зачеркнутый впоследствии текст начала 75-го письма (Ч. 7. ОПИ ГИМ. Ф. 349. Ед. хр. 4. Л. 45 об. - 46). Завершено это письмо было уже после возвращения Болотова в Дворяниново в 1797 году.

Этот перерыв в пять лет стал самым долгим за все время создания мемуаров. Чтобы попытаться выяснить его причины, необходимо рассмотреть мотивы, которыми руководствовался Болотов, заново приступая к работе над воспоминаниями. Наступившее осенью 1788 года 50-летие должно было восприниматься Болотовым как важнейший жизненный рубеж, так как никто из его ближайших предков и родственников (дед, отец, мать, сестры) не дожил до этого возраста. Его явно посещали мысли о возможности скорого завершения отпущенного ему жизненного срока: в 1792 году, во время поездки в Дворяниново, он определил себе место для погребения и обсуждал с сыном идею установки посмертного монумента в дворяниновском саду (IV, 930-931). Это отразилось на отношении к воспоминаниям. В приведенной выше цитате о продолжении работы над воспоминаниями в 1787 году Болотов указывает, что уже тогда имел «охоту описать всю мою жизнь», чему «Приключения» не вполне соответствовали. В описании же начала работы над итоговым вариантом в 1789 году он дважды подчеркивает, что основным его замыслом теперь стало описание всей жизни $(\mathrm{IV}, 495,506) .{ }^{14}$

Реализация этого замысла привела к четкому структурированию текста мемуаров, которые Болотов начал разделять на пронумерованные части и письма. Отдельные части получили название и общую логику изложения материала, выстроенную по этапам биографии автора (например, «История моего малолетства» или «История моей военной службы»). Следствием новой концепции мемуаров стало заметное увеличение их объема за счет личных воспоминаний. Например, сюжет всего 18-го письма (отъезд Болотова из Петербурга после получения известия о смерти матери) занимает в «Приключениях» лишь страницу (Ч. 2. ОПИ ГИМ. Ф. 349. Ед. хр. 2. Л. 8). В итоговый же вариант Болотов добавил новеллы о «смешном происшествии» с учителем в доме генерала Маслова (I, 188-191) и о праздновании тезоименитства Елизаветы Петровны (I, 191-197). Они составляют три четверти этого письма, остальное же занято описанием чувств мемуариста. Глубоко личные эпизоды, подчас довольно спорные с точки зрения общественной морали, повышали эмоциональную составляющую мемуаров и формировали характерную для них атмосферу исповедальности, что, по-видимому, соответствовало замыслу автора.

Еще одним новшеством этого этапа стала адресация воспоминаний потомкам, что отразилось в названии «Жизнь и приключения Андрея Болотова, описанные самим им для своих потомков» (оно воспроизводится с 1 по 29-ю и, вероятно, по утраченную 30-ю часть). Как «порядочное описание всей моей жизни в пользу моих детей и потомков» $(\mathrm{IV}, 495)^{15}$ Болотов их характеризовал и позднее. Главным читателем мемуаров в это время был подросший сын Павел, и особенно актуальным стало приобщение сына к отцовскому жизненному опыту в связи с его отъездом на службу в Петербург в октябре 1789 года. Впрочем, читали воспоминания и другие члены семьи Болотова $(\mathrm{IV}, 696)$. Поэтому жизнеописание приобретало выраженный дидактический характер, пополняясь нравоучительными сентенциями и подробностями биографии автора, имеющими воспитательное значение.

Однако вскоре после начала основного богородицкого этапа происходит «кризис» читательской аудитории. С одной стороны, уже в начале 1790 года П. А. Болотов вышел в отставку и возвратился к семье. Теперь аналогии между молодым Андреем Тимофеевичем, находящимся на службе в далеком Кенигсберге, и его сыном просматривались слабо. С другой, в эти же годы разъезжаются дочери Болотова, Анастасия

14 Ср. «Автобиографию», где мемуары определяются как «памятник о всех случившихся в жизни его с ним происшествиях» (НИОР РГБ. Ф. 475. Карт. 1.1. Л. 7).

$15 \mathrm{Cp}$. в «Автобиографии»: «К сему обширному сочинению побуждали его желание оставить своим родным и потомкам, для коих собственно он и писал оное...» (Там же). 
и Ольга, которых он выдал замуж (Елизавета вышла замуж раньше). В такой ситуации дидактическое значение мемуарного текста, очевидно, несколько снизилось.

В замысле описания всей своей жизни, возникшем у Болотова в конце 1780 -х годов, важную роль играли дневники: при необходимости они могли служить «продолжением» мемуаров (IV, 495), так как тогда Болотов не предполагал, что сможет заниматься составлением воспоминаний еще более 30 лет. К началу 1791 года «Жиизнь и приключения» были внушительным сочинением, состоявшим из шести частей, объемом более тысячи листов. Но описание событий дошло лишь до начала 1759 года, и перспективы работы должны были казаться Болотову необъятными. Насыщенный служебными, творческими и семейными событиями текущий период жизни, в сравнении с молодыми годами, по-видимому, имел в глазах Болотова не меньшее (если не большее) значение. Именно тогда он временно смещает акцент в создании своего жизнеописания на дневниковые записки.

К регулярному ведению дневников Болотов приступил еще в 1766 году, обычно его дневниковые записи имели название «Домашний исторический журнал» или «Подневные записки». Он продолжал их вести и в начале 1790 -х годов. ${ }^{16}$ Однако наряду с ними с 1791 года появляются дневники, имеющие название «Продолжение описания моей жизни». ${ }^{17}$ Это вторичные по отношению к обычным «подневным запискам» рукописи, при создании которых Болотов экспериментирует с оформлением, очевидно пытаясь включить их в корпус текстов жизнеописания. Так, дневник за 1791 год он разделяет на главы и некоторым из них дает названия, например: «Глава 1. Доказывающая, что человек всего скорее может в мыслях своих обмануться. Новый год и новые заботы» и т. д. ${ }^{18}$ Однако необходимость использовать эти дневниковые записи как продолжение воспоминаний не возникла. Сам Болотов впоследствии определял их как материалы к мемуарам (IV, 495), используя информацию, в них зафиксированную, при написании соответствующих частей.

На наш взгляд, нет оснований включать их в комплекс болотовских воспоминаний или рассматривать как черновики «Жизни и приключений». Обширные заимствования из дневниковых записей естественны (как и, например, из переписки), но при этом Болотов проводил работу по отбору сюжетов, подвергал их литературной обработке, комментировал, вставлял диалоги или чужую речь. Даже оформленные как «Продолжение жизнеописания», дневники остаются принципиально иным по характеру текстом, в частности, содержащим информацию, которую Болотов через 20 с лишним лет опускал при составлении воспоминаний (от повседневных приемов пищи до списков приобретенных книг). Тем более невозможно рассматривать как часть мемуарного наследия Болотова дневники других периодов его жизни, которым сам автор не придавал значения продолжения воспоминаний.

Однако повышенное внимание к дневникам на последнем этапе службы в Богородицке могло привести к временному оттеснению собственно мемуаров на второй план и возникновению длительного перерыва в работе над ними. В этой ситуации обращение Болотова к написанию 7-й части осенью 1792 года представляется незначительным эпизодом, когда любая помеха в работе могла привести к ее остановке. Что и произошло при написании 75-го письма, посвященного началу военной кампании 1759 года. Этот текст, являющийся частью обширного очерка истории Семилетней войны, ${ }^{19}$

16 Болотов А. Т. Настольный журнал 1791. Краткие домашние записи 1791-1793 // НИОР БАН. Ф. 69. № 10.142 л.

17 Сохранились такие дневники за 1791 (РНБ. Ф. 608 (Собр. И. В. Помяловского). Оп. 2. Ед. хр. 88/6), 1792 (НИОР БАН. Ф. 69. № 25), 1793-1794 (ИРЛИ. Ф. 537. Ед. хр. 7) и 1795 (РНБ. Ф. 89. Ед. хр. 33) годы.

18 Описание жизни Андрея Болотова, сочиненное самим им для его потомков. Продолжение // РНБ. Ф. 608. Оп. 2. Ед. хр. 88/6. Л. 4. Рукопись сохранилась плохо, включает в себя описание только начала 1791 года, отдельные листы отсутствуют.

19 В «Приключениях» этот очерк отсутствовал, в раннем варианте мемуаров Болотов описывал только те военные события, участником которых он был. В итоге очерк истории Семилетней войны содержится в различных письмах 4-10-й частей воспоминаний. 
очевидно, не устроил Болотова, поскольку письмо не было им тогда закончено, а написанное начало было впоследствии вычеркнуто. На этом работа над мемуарами на основном богородицком этапе завершилась.

Следующий, третий, ранний дворяниновский этап приходится уже на время жизни Болотова в Дворянинове после отставки и охватывает 1797-1802 годы. К работе над воспоминаниями Болотов обратился в первый же писательский сезон в Дворянинове, который совпал с началом 60-го года его жизни. Но этот новый приступ к мемуарам вновь оказался коротким: в сезон 1797-1798 годов он написал только письма с 75-го по 80-е. Последние два письма 7-й части (81-е и 82-е) были написаны в ноябре 1800 года. ${ }^{20}$ Возвращаясь к работе над мемуарами, Болотов зачеркнул ранее сочиненное начало 75-го письма и написал посвященные военным действиям 1759 года 75-77-е письма. Он также предпринял редакцию 6-й части мемуаров, сделав к ней четыре примечания к 65-му и 66-му письмам, в которых описывается военная кампания 1758 года. Текст примечаний был размещен в конце рукописи (Ч. 6. ОПИ ГИМ. Ф. 349. Ед. хр. 3. Л. 211-219 об.), после пометы о ее завершении в декабре 1790 года (Там же. Л. 210 об.). Смысл такого редактирования, очевидно, был тот же, что и при исправлении 75-го письма, но осуществлено оно была позднее: бумага вставок имеет водяной знак 1800 года. Это может быть дополнительным аргументом для определения работы Болотова над мемуарами в сезон 1797-1798 годов как краткого эпизода, тем более что первые годы после переезда Болотова в Дворяниново были весыма насыщенными домашними делами.

Лишь в 1800 году работа над мемуарами вновь приобретает интенсивный характер. За сезон 1800-1801 годов Болотов не только закончил, наконец, 7-ю часть, но и написал 8-11-ю (Ч. 8, 10-11. ОПИ ГИМ. Ф. 349. Ед. хр. 5-7). ${ }^{21}$ Интересно, что если 8-я и 9-я части были написаны очень быстро (за один ноябрь 1800 года, то есть большинство писем этих частей писались за один день), то затем этот срок увеличивается: на написание 10-й и 11-й части Болотов потратил приблизительно по месяцу. Еще больший общий срок (более двух месяцев) понадобился Болотову для написания 12-й части, к которой он обратился только в 1802 году (Ч. 12. ОПИ ГИМ. Ф. 349. Ед. хр. 8). Сразу после ее завершения были написаны два письма 13-й части, ${ }^{22}$ после чего в работе над мемуарами последовал новый, трехлетний перерыв.

Неравномерность работы над мемуарами на раннем дворяниновском этапе была связана с главным новшеством этого времени: Болотов начал снимать копии с уже написанных частей. Первая датированная копия (6-й части) имеет помету о переписывании в 1801 году. Тем же годом датированы копии 7-й и 8-й частей. ${ }^{23}$

Необходимость в копировании, по всей видимости, была обусловлена очередным изменением представлений Болотова о востребованности мемуаров. Мысль о том, что его воспоминания могут быть интересны широкому кругу читателей, приходила ему в голову и раньше. Еще в декабре 1789 года в письме сыну, сообщая о завершении 3-й части, Болотов писал: «Книжки будут прекрасные! Настасья только и говорит, что не толькоде нам, но и иным любопытны» (IV, 696). Но в период службы в Богородицке расширить аудиторию читателей вряд ли представлялось возможным отчасти по причине удаленности от Богородицка соседних дворянских усадеб, отчасти из-за официального положения Болотова как управляющего. ${ }^{24}$ После возвращения в Дворяниново этот круг

20 Об этом свидетельствуют пометы в начале этих писем в копии 1801 года: «ноябрь 4 д. 1800 » и «Ноября 6 д. 1800 г.» соответственно (I, 981, 995). Кроме того, в оригинальной рукописи эти письма написаны на бумаге, отличающейся от предыдущей, с отчетливо читаемым водяным знаком «1800» (Ч. 7. ОПИ ГИМ. Ф. 349. Ед. хр. 4. Л. 176-204, текст 81-го письма начинается с л. 172).

21 Оригинал 9 -й части не сохранился.

22 В начале 132-го письма стоит помета: «Писано октября 31-го, 1802» (II, 776).

23 В описи все эти рукописи (РНБ. Ф. 89. Ед. хр. 7-9) датируются временем написания оригиналов, несмотря на содержащиеся в них четкие указания на время их «переписывания» .

24 Соответствующие замечания Болотова неоднократно встречаются на страницах его мемуаров, посвященных богородицкому этапу жизни. Ср. также с характеристикой «весьма немногочисленного» богородицкого общества в дневнике Павла Болотова (Болотов П. А. ЗЖурнал, 
расширился за счет деревенских соседей и родственников. Сохранились свидетельства о том, что в Дворянинове Болотов зачитывал свои мемуары вслух родственникам, друзьям и соседям, а также давал их читать на дом. ${ }^{25} \mathrm{C}$ другой стороны, с этого времени все больше становится актуальной адресация к весьма увеличившемуся потомству. Теперь Болотов не мог не задумываться о том, что востребованность его воспоминаний может пережить его самого, что и подтолкнуло его к копированию мемуаров.

В большинстве случаев копии, снятые рукой самого Болотова, почти не отличаются от оригинала по содержанию, а вносимая при копировании правка минимальна и носит технический характер (исправлены описки, кое-где изменена разбивка по абзацам и т. д.). Зато существенно отличается оформление. Копии выполнены лучше и чище, более разборчивым почерком, корешок и уголки крышки у них обычно кожаные, а не картонные, обрез бумаги окрашен, в начале и конце каждой части помещаются рисованные тушью заставки и виньетки, колонтитулы оформлены в рамку, а не просто отчеркнуты. Это позволяет рассматривать авторские копии как «парадные» версии воспоминаний, ориентированные на «внешнего» читателя. Не случайно именно копии были выбраны наследниками из всего комплекса рукописных мемуаров Болотова, когда появилась перспектива их публикации.

Открытым остается вопрос о точном времени, с которого Болотов начал снимать копии. В начале 1-й части «парадного» варианта указывается лишь «писано в 1789 году». Эта помета повторяет дату написания оригинальной 1-й части 1789 года и не может быть датирующим свидетельством. На последующих частях, со 2-й по 5-ю, выполненных в таком же стиле «парадной» копии, время копирования также не указано. Как уже отмечалось, даты написания на оригиналах $2-5$-й частей, по-видимому, вообще не были проставлены. Указание Болотовым на копиях этих частей времени написания их оригиналов имело уточняющий характер и было аналогично датированию отдельных писем в копии 7-й части, несмотря на отсутствие помет в оригиналах этих писем. Вообще снятие копий, по-видимому, сыграло организующую роль в работе Болотова над мемуарами, структура которых становится все более упорядоченной. Начиная с 9-й части, Болотов начинает разделять части своих воспоминаний строго на 10 писем. С 10-й части он дает отдельным письмам названия (в оригинале этой части озаглавлены 8 из 10 писем, причем не имевшие в оригинале названия 107-е и 109-е получили их в копии). ${ }^{26}$ Более упорядоченным становится размер писем, что нашло отражение в изменении заголовков писем 10-й части. Например, название 101-го письма в оригинале выглядит «Первый [осень] в деревне день», а 105-го - «Московская первая жизнь [и езда в Кашин]» (Ч. 10. ОПИ ГИМ. Ф. 349. Ед. хр. 6. Л. 4, 88). ${ }^{27}$ Изменение содержания писем в процессе их написания лишний раз подчеркивает характер болотовских мемуаров, как «прямо набело писанного» сочинения. Именно в копиях Болотов впервые начал указывать точные даты создания отдельных писем (при копировании 7-й части в 1801 году). В оригинале такая дата (16 сентября 1802 года) встречается впервые в конце 123-го письма (Ч. 12. ОПИ ГИМ. Ф. 349. Ед. хр. 8. Л. 74 об.). Обычной эта практика становится только на следующем этапе работы над мемуарами. Точному указанию времени копирования Болотов, очевидно, уделял меньшее значение, чем (в итоге) дате написания оригиналов. На первых пяти частях копий время

или Ежедневные записки препровожденного времяни и всем приключениям, случившимся со мною в 1789 году // ОПИ ГИМ. Ф. 349. Ед. хр. 16. Л. 2).

25 См. свидетельство внука и письма соседей М. И. Семевскому: Болотов М. П. Андрей Тимофеевич Болотов. С. 748-749; Письмо от А. И. Цвиленева от 22 августа 1872 года // ИРЛИ. Ф. 537. Ед. хр. 42. Л. 1; Письмо от С. Н. Кругликова (б. д.) // ИРЛИ. Ф. 537. Ед. хр. 46. Л. 1.

26 В дальнейшем названия у отдельных писем в оригиналах встречаются лишь эпизодически, обычно в заглавии соответствующего письма отмечается начало нового календарного года. В копии названия писем встречаются значительно чаще.

27 В квадратных скобках помещен зачеркнутый текст. В итоге событиям осени 1762 года оказались посвящены также и последующие письма (в копии: «Первый день в деревне», II, 299), а описание путешествия в Кашин было перенесено в следующее письмо (в копии: «Московская первая жизнь», II, 362). 
их «переписывания» вообще не указано, а в дальнейшем эти указания не отличаются точностью.

Таблица $1^{28}$

\begin{tabular}{|c|c|c|c|c|c|}
\hline Часть & \multicolumn{3}{|r|}{ Оригинал } & \multicolumn{2}{|r|}{ Копия } \\
\hline \multirow[t]{2}{*}{1} & $\mathrm{~T}$ & \multirow{2}{*}{$\begin{array}{l}\text { ГИМ } \\
\text { № } 1\end{array}$} & 1789 & \multirow{2}{*}{$\begin{array}{l}\text { РНБ } \\
\text { № } 1\end{array}$} & писано в 1789 году \\
\hline & $\mathrm{K}$ & & - & & - \\
\hline \multirow[t]{2}{*}{2} & $\mathrm{~T}$ & & \multirow{2}{*}{ Не сохранилась } & \multirow{2}{*}{$\begin{array}{l}\text { РНБ } \\
\text { № } 2\end{array}$} & написана в 1789 г. \\
\hline & K & & & & - \\
\hline \multirow[t]{2}{*}{3} & $\mathrm{~T}$ & & \multirow{2}{*}{ Не сохранилась } & \multirow{2}{*}{$\begin{array}{l}\text { РНБ } \\
\text { № } 3\end{array}$} & написана в 1789 г. \\
\hline & К & & & & - \\
\hline \multirow[t]{2}{*}{4} & $\mathrm{~T}$ & & \multirow{2}{*}{ Не сохранилась } & \multirow{2}{*}{$\begin{array}{l}\text { РНБ } \\
\text { № } 4\end{array}$} & написана в 1789 г. \\
\hline & K & & & & - \\
\hline \multirow[t]{2}{*}{5} & $\mathrm{~T}$ & \multirow{2}{*}{$\begin{array}{l}\text { РНБ } \\
\text { № } 6\end{array}$} & - & \multirow{2}{*}{$\begin{array}{l}\text { РНБ } \\
\text { № } 5\end{array}$} & 1790 \\
\hline & K & & - & & - \\
\hline \multirow[t]{2}{*}{6} & $\mathrm{~T}$ & \multirow[t]{2}{*}{$\begin{array}{l}\text { ГИМ } \\
\text { № } 3\end{array}$} & $\begin{array}{l}\text { Начата ноября } 16.1790 . \\
\text { Окончено декаб. } 24 \text { того ж } \\
\text { года }\end{array}$ & \multirow[t]{2}{*}{$\begin{array}{l}\text { РНБ } \\
\text { № } 7\end{array}$} & соч. 1790 , переп. 1801 г. \\
\hline & K & & окончана 24 декаб. 1790 & & - \\
\hline \multirow[t]{2}{*}{7} & $\mathrm{~T}$ & \multirow[t]{2}{*}{$\begin{array}{l}\text { ГИМ } \\
\text { № } 4\end{array}$} & $\begin{array}{l}\text { Начата ноября } 16 \text { дня } 1792 . \\
\text { Кончена в ноябре } 61800\end{array}$ & \multirow[t]{2}{*}{$\begin{array}{l}\text { РНБ } \\
\text { № } 8\end{array}$} & $\begin{array}{l}\text { соч. } 1792-1800, \text { переп. } \\
1801 \text { г. }\end{array}$ \\
\hline & К & & окончено 6 ноября 1800 & & - \\
\hline \multirow[t]{2}{*}{8} & $\mathrm{~T}$ & \multirow[t]{2}{*}{$\begin{array}{l}\text { ГИМ } \\
\text { № } 5\end{array}$} & $\begin{array}{l}\text { Начата нояб. } 7.1800 . \text { Конче- } \\
\text { на нояб. } 19\end{array}$ & \multirow[t]{2}{*}{$\begin{array}{l}\text { РНБ } \\
\text { № } 9\end{array}$} & соч. 1800 , переп. 1801 г. \\
\hline & K & & Написано в 11 дней & & 7 нояб. 1801 \\
\hline \multirow[t]{2}{*}{9} & $\mathrm{~T}$ & & \multirow{2}{*}{ Не сохранилась } & \multirow[t]{2}{*}{$\begin{array}{l}\text { РНБ } \\
\text { № } 10\end{array}$} & $\begin{array}{l}\text { сочинена } 1800, \text { переписана } \\
1805 \text { года }\end{array}$ \\
\hline & К & & & & $\begin{array}{l}\text { Сочинена в ноябре } 1800, \text { пе- } \\
\text { реписана в октябре } 1805 .\end{array}$ \\
\hline \multirow[t]{2}{*}{10} & $\mathrm{~T}$ & \multirow[t]{2}{*}{$\begin{array}{l}\text { ГИМ } \\
\text { № } 6\end{array}$} & $\begin{array}{l}\text { Начата декабря } 2 \text { дня 1800, } \\
\text { окончена генв } 121801\end{array}$ & \multirow[t]{2}{*}{$\begin{array}{l}\text { РHБ } \\
\text { № } 11\end{array}$} & 1801 \\
\hline & К & & кончена генваря 121801 года & & $\begin{array}{l}\text { Сочинена в генваре } 1801 \text {, пе- } \\
\text { реписана в ноябре } 1805 \text { года }\end{array}$ \\
\hline \multirow[t]{2}{*}{11} & $\mathrm{~T}$ & \multirow[t]{2}{*}{$\begin{array}{l}\text { ГИМ } \\
\text { № } 7\end{array}$} & $\begin{array}{l}\text { Начата генваря } 14 \text { 1801, кон- } \\
\text { чена февр } 91801\end{array}$ & $\begin{array}{l}\text { РНБ } \\
\text { № } 12\end{array}$ & $\begin{array}{l}\text { Сочинена 1801, переписана } \\
1805\end{array}$ \\
\hline & К & & кончена февраля 9 дня 1801 & & $\begin{array}{l}\text { Сочинена в феврале } \\
1801 \text { года, переписана в де- } \\
\text { кабре } 1805 \text { года }\end{array}$ \\
\hline 12 & $\mathrm{~T}$ & $\begin{array}{l}\text { ГИМ } \\
\text { № } 8\end{array}$ & $\begin{array}{l}\text { Начата августа } 231802, \text { кон- } \\
\text { чена октября } 30\end{array}$ & $\begin{array}{l}\text { РНБ } \\
\text { № } 13\end{array}$ & $\begin{array}{l}\text { Сочинена 1802, переписана } \\
1805\end{array}$ \\
\hline & K & & кончена октября 30 дня & & $\begin{array}{l}\text { Сочинена } 1802 \text {, а переписана } \\
\text { в } 1805 \text { году в декабре. }\end{array}$ \\
\hline
\end{tabular}

Начиная с 9-й части в конце копий обычной становится уточняющая помета с указанием на месяц и год как написания, так и копирования части. Особенно показателен случай 10-й части, в титуле которой Болотов пренебрег годом переписывания, хотя

28 Номер соответствует номеру рукописи в описи фонда указанного архива. «Т» — помета о времени написания на титульном листе, «К» - в конце текста рукописи. Сохранен аутентичный вид помет. 
в конце сделал соответствующее указание. Таким же, по-видимому, был его подход к оформлению титулов $1-5$-й частей копий.

Единственным явным датирующим признаком этих рукописей является бумага, и, на первый взгляд, она свидетельствует о достаточно раннем времени их создания: все они написаны на синеватой бумаге одного типа (филигрань БОФАУ - Богородского округа фабрика Александра Угрюмова) 1786 и 1787 годов. ${ }^{29}$ Это обстоятельство, в сочетании с авторскими пометами о написании, по-видимому, снимало у публикаторов все вопросы о датировке данных рукописей. Однако первая точно датированная 1801 годом копия 6-й части написана на той же самой бумаге (1787 года), что, на наш взгляд, является явным свидетельством в пользу отнесения «парадных» копий 1 6-й частей к одному времени, а именно, к раннему дворяниновскому этапу работы над мемуарами. Начало копии 7-й части также написано на этой бумаге (Ч. 7. РНБ. Ф. 89. Ед. хр. 8. Л. 1-22). Лишь последующий текст копии 7-й части и копия 8-й части написаны на бумаге более позднего времени: очень похожей на предыдущую по типу, но чуть более темной и плотной бумаге 1799 года (филигрань БОФЕБ - Богородского округа фабрика Елизаветы Баташевой — та же фабрика, сменившая владельца). ${ }^{30}$ Единство оформления копий как «парадной» серии подчеркивает еще одна деталь: переплет копий $1-5$-й частей снабжен коричневым кожаным корешком с золотым тиснением, у 1-й и 2-й частей этот корешок сохранился, у 3 -й, 4 -й и 5-й был позднее заменен черным коленкоровым, на который наклеен фрагмент старого кожаного корешка с тиснением «Жизнь Андрея Болотова» и номером части. У оригинальных частей мемуаров всех этих признаков не наблюдается. В частности, ни в одной из сохранившихся рукописей оригиналов 1789-1792 годов не использовалась бумага, на которой были написаны копии этих частей. Каждая из этих рукописей написана на бумаге разных видов (в основном двух), преимущественно белой, по водяным знакам датируемой между 1784 и 1787 годами (за исключением конца рукописи 6-й части, представляющей собой, как это было показано выше, позднейшую вставку на бумаге 1800 года).

На первый взгляд, существенное отличие копий от оригиналов заключается в том, что копии частично проиллюстрированы: первые три части копий содержат сюжетные миниатюры тушью в начале и в конце каждого письма (значительная их часть была воспроизведена в издании Семевского). В первый томик вклеены также два цветных рисунка акварелью: известный портрет Болотова в кабинете, размещенный на фронтисписе (Ч. 1. РНБ. Ф. 89. Ед. хр. 1) и иллюстрация к рассказу об одном из болотовских предков (Там же. Л. 28). В оригиналах ни сюжетных миниатюр, ни цветных рисунков нет. Однако идея иллюстрирования мемуаров, несомненно, появилась у Болотова еще в Богородицке. В уже цитировавшемся письме сыну Павлу о 3-й части (декабрь 1789 года) Болотов сообщает: «Я пишу их прямо набело на самой белой бумаге и украшаю начальные слова каждого письма, вместо виньеток, рисуночками пером-тушью, имеющими отношение к материям, в письме содержащимся» (IV, 696). В феврале 1790 года вернувшийся в Богородицк Павел ознакомился с рукописью мемуаров (1-4-й частями) и тоже пожелал «украсить ее несколькими картинками», в том числе нарисовал «при начале первой части» портрет отца в кабинете (IV, 729). По-видимому, идея была новой (в «Приключениях» рисунки отсутствовали ${ }^{31}$ ) и появилась у Болотова уже после написания 1-й части, редкие рисунки в оригинале которой имеют характер дополнительного оформления текста (виньетки, рамки колонтитулов и т. д.) и не связаны с его содержанием. Судя по тому, что ни в 5-й, ни в последующих частях оригиналов сюжетных миниатюр нет, Болотов довольно быстро

${ }^{29}$ Клепиков С. А. Филиграни и штемпели на бумаге русского и иностранного производства XVII-XX вв. М., 1959. С. 41. № 96. Часть 1 (РНБ. Ф. 89. Ед. хр. 1) включает два вида бумаги, 1786 (л. 67-199) и 1787 годов (л. 1-66); части 2-5 (РНБ. Ф. 89. Ед. хр. 2-5) написаны на бумаге 1787 года.

30 Клепиков С. А. Филиграни и штемпели... С. 41. № 97.

31 Кроме трех планов битвы при Гросс-Егерсдорфе с «изъяснениями» (ОПИ ГИМ. Ф. 349. Ед. хр. 2. Л. 185 об. - 186 об., 197, 231 об. - 232 об.). 
охладел к этой идее (впрочем, как и вообще к работе над мемуарами на основном богородицком этапе). Проиллюстрированы, скорее всего, были только оригиналы 24-й частей, но они не сохранились. ${ }^{32}$

При написании копий Болотов вернулся к иллюстрированию текста, причем вставил в копию первой части два старых рисунка, сделанных сыном в 1790 году. Рисунки подклеены к специально оставленному для них обрезу листа, и это подтверждает предположение, что они были выполнены отдельно и при копировании первой части для них было оставлено место вклейки. Вероятно, Павел Андреевич предполагал сделать больше иллюстраций (или Андрей Тимофеевич на это надеялся), так как в 1-2-й и 4-й частях оставлено несколько таких обрезов. Незавершенность замысла снабжения «парадных» копий вклеенными цветными иллюстрациями, на наш взгляд, также является аргументом в пользу датирования этих рукописей концом 1790-х годов. В Богородицке, после возвращения Павла со службы, ничего не мешало бы выполнению этого плана. Но после женитьбы Павла и его отъезда из Дворянинова в 1798 году, его участие в создании рисунков оказалось под вопросом, и к иллюстрированию мемуаров отца Павел больше не вернулся. Идея иллюстрирования копий также просуществовала недолго. С 4-й части копии Болотов, видимо, не успевал делать иллюстрации: он оставляет для них незаполненные места, отчеркивая их карандашом, или делает карандашные наброски, которые сейчас почти не видны. В 4-й части встречаются также вырезанные места, возможно это были неудачные миниатюры, которые Болотов рассчитывал впоследствии переделать. С 5-й части количество и качество сюжетных миниатюр резко сокращается (в издание Семевского они обычно не включены), что можно связать с их отсутствием в оригиналах соответствующих частей. Во всяком случае, наличие сюжетных миниатюр не может быть аргументом против использования термина «копия» по отношению к рукописям соответствующего ряда: в тех частях, где в копиях миниатюры имеют существенное значение (2-4-я части), они, скорее всего, были перенесены из оригиналов. Лишь в копии 1-й части значительное число миниатюр не находит соответствия в оригинале.

В ней же фиксируется единственное существенное содержательное отличие оригинала от копии. При копировании 1-й части Болотов почти полностью отказался от первого письма оригинала, представлявшего собой этикетную полемику с «любезным приятелем», который якобы «неотступно» уговаривает автора приняться за описание собственной жизни. Эта полемика имела краткое продолжение в начале 2-го, 3-го, 4-го и 5-го писем и тоже не была воспроизведена при копировании (Ч. 1. ОПИ ГИМ. Ф. 349. Ед. хр. 1. Л. 6-9 об., 34 об. - 35, 44 об. - 45, 53-53 об.). Вероятно, в конце 1790-х годов в таком самооправдании Болотов уже не видел необходимости, так как у него сложилась своя аудитория, и его мемуары в этот период находили своих читателей.

Хотя точное время создания копий 1-5-й частей остается не до конца ясным, по нашему мнению, эти рукописи можно датировать временем около 1800 года. Зимой 1797-1798 и 1798-1799 годов Болотову было сложно заниматься писательскими трудами из-за хозяйственных и семейных хлопот, работы над переводами и завершением ранее начатых сборников. К 1800 же году относится возвращение к работе над воспоминаниями.

Следующий, основной дворяниновский этап (1805 - ок. 1816) начался после перерыва в работе над мемуарами на очень насыщенные событиями годы: закончилась большая тяжба, в которую Болотов был вовлечен много лет назад. На новом этапе было написано 18 новых частей (13-29-я и, по-видимому, несохранившаяся 30-я). Причем почти половину из них Болотов написал всего за два сезона (зима 1809-1810 и 18101811 годов). Поскольку не только части, но и почти все письма, написанные в это время, точно датированы, история работы Болотова над мемуарами на этом этапе хорошо реконструируется. В приведенной таблице сведена информация о создании болотовских воспоминаний в этот период.

32 Предложить объяснение тому, что были утрачены именно те части оригиналов, которые, по-видимому, содержали сюжетные миниатюры, мы в настоящее время не можем. 
Таблица $2^{33}$

\begin{tabular}{|c|c|c|c|c|c|c|c|c|c|}
\hline & Сент. & Окт. & Нояб. & Дек. & Янв. & Февр. & Март & Aпр. & Май \\
\hline $1805 / 06$ & & $\begin{array}{l}9 \text { ч. } \\
133- \\
137\end{array}$ & $\begin{array}{l}138-140 \\
10 \text { ч. }\end{array}$ & $\begin{array}{l}11 \text { ч. } \\
12 \text { ч. }\end{array}$ & & & & & \\
\hline \multicolumn{10}{|l|}{$1806 / 07$} \\
\hline $1807 / 08$ & & & $141-144$ & \begin{tabular}{|l|}
$145-150$ \\
151,152
\end{tabular} & 153 & & & & \\
\hline 1808/09 & & & & $\begin{array}{l}154-160 \\
161-170 \\
171-174\end{array}$ & $\begin{array}{l}175-180 \\
181-189\end{array}$ & 190 & & & \\
\hline $1809 / 10$ & & & $191-197$ & $\begin{array}{l}198-200 \\
15 \text { ч. } \\
16 \text { ч. } \\
201-210\end{array}$ & $\begin{array}{l}211-215 \\
16 \text { ч. }\end{array}$ & $\begin{array}{l}216-220 \\
16 \text { ч. } \\
221,222\end{array}$ & & & \\
\hline 1810/11 & $\begin{array}{l}223, \\
224\end{array}$ & $\begin{array}{l}225- \\
230 \\
17 \text { ч. }\end{array}$ & $\begin{array}{l}17 \text { ч. } \\
18 \text { ч. }\end{array}$ & $\begin{array}{l}18 \text { ч. } \\
231-240 \\
241-243\end{array}$ & $244-250$ & \begin{tabular}{|}
$251-260$ \\
$261-264$
\end{tabular} & $265-270$ & 19 ч. & $\begin{array}{l}20 \text { ч. } \\
21 \text { ч. }\end{array}$ \\
\hline \multicolumn{10}{|l|}{$1811 / 12$} \\
\hline $1812 / 13$ & & $\begin{array}{l}271- \\
273\end{array}$ & \begin{tabular}{|l|}
$274-280$ \\
$281-283$
\end{tabular} & $284-286$ & 287 & & & & \\
\hline 1813/14 & & & $288-290$ & $291-294$ & 295 & 296 & & & \\
\hline \multicolumn{10}{|l|}{$1814 / 15$} \\
\hline \multicolumn{10}{|l|}{$1815 / 16$} \\
\hline $1816 / 17$ & $\begin{array}{l}297, \\
298\end{array}$ & $\begin{array}{l}299, \\
300\end{array}$ & & & & & & & \\
\hline
\end{tabular}

Некоторые из частей были написаны Болотовым очень быстро. Рекордной, по-видимому, стала 16 -я часть, которую он написал за 9 дней. ${ }^{34}$ На этом этапе при сочинении мемуаров Болотов опирался на свои дневниковые записи и письма, которые он иногда переносил в текст воспоминаний целиком или в отрывках. От объема таких заимствований зависела и скорость написания новых частей.

На копирование одной части при работе без перерыва он тратил в этот период около двух недель. Хотя даты снятия копий встречаются не всегда (для отдельных писем они скорее исключение), и при этом обычно указывается лишь год и месяц переписывания, к такому выводу можно прийти, проследив динамику создания копий: есть два случая, когда за месяц были написаны полные копии двух частей (декабрь 1805-го и май 1811 года). ${ }^{35}$ Причем ни на какую другую письменную работу времени у Болотова, по-видимому, не оставалось, в отличие от тех месяцев, за которые он копировал только одну полную часть. Этот же вывод можно сделать, если посмотреть на известный по воспоминаниям М. П. Болотова режим дня Андрея Тимофеевича в преклонные годы, когда на собственно писательскую работу (без учета повседневных дневниковых

33 Оригинальные части приведены в виде писем (все части состояли из 10 писем, 141150-е письма - 14-я часть и т. д.), копии указаны по частям. В случае, если работа над частью продолжалась в разные месяцы, она указана во всех соответствующих ячейках. Порядок, в котором письма и части приведены в одной ячейке, в большинстве случаев отражает последовательность работы над ними в рамках данного месяца.

34 На титуле оригинала в качестве даты начала работы указывается 18-е, а завершения 28 декабря 1808 года, после чего делается неожиданный вывод: «сочинена в 12 дней» (Ч. 16. ИРЛИ. Ф. 537. Ед. хр. 3. Л. 2). Однако помета в конце рукописи - «26 декабря 1808» (Там же. Л. 196 об.), та же дата указана в конце копии (III, 362).

35 Похожая ситуация была в ноябре 1810 года, когда за месяц Болотов успел закончить копию 17-й и начать копию 18-й части. 
и метеорологических записей и выписок из газет) у него зимой уходило около четырех часов. ${ }^{36}$ Учитывая характер оформления копий, за день он вряд ли мог скопировать больше одного письма. Изредка в копиях этого времени появляются миниатюры и вклейки с планами и рисунками усадебного дома и садов. ${ }^{37}$

Вообще, изменение отношения Болотова к собственному мемуарному наследию на основном дворяниновском этапе связано, главным образом, с копиями. В начале Болотов явно ставил перед собой цель снять копии с написанных ранее частей и иметь «законченный» комплект мемуаров. Эта задача была им, по-видимому, решена уже в сезон 1805-1806 годов, что, однако, привело к появлению своеобразной по ряду характеристик 13-й части. Ее рукопись существует в единственном экземпляре (Ч. 13. РНБ. Ф. 89. Ед. хр. 14), и, хотя почти все письма в ней точно датированы, указания на время написания рукописи в целом крайне беспорядочны. На титуле дата «1802» (132-е письмо датировано 31 октября 1802 года, недатированное 131-е письмо, видимо, было написано около этого времени) соседствует с указанием «Начата октября 30, кончена ноября 5-го 1805» (даты написания 137-140-го письма) (II, 763-764, 776, 846, $859,880,899)$, между тем 133-136-е письма датированы 26-29 октября 1805 года (II, 797, 813, 820, 834). Формулировка пометы о завершении рукописи уникальна: «Сочинена и писана прямо набело дней в 10 и более в 1805 году» (II, 926). На наш взгляд, небрежность связана с экспериментальным характером этой рукописи: вернувшись осенью 1805 года к ее продолжению (между снятием копий с 9-й и 10-й частей), Болотов решил сразу оформить ее в «парадном» стиле и не тратить время на копирование.

Однако этот опыт поначалу не получил продолжения. 14-я часть вновь имеет оригинал и копию. Если 13-ю часть Болотову удалось написать «прямо набело дней в 10 », то с 14-й было иначе: на ее написание он потратил более месяца ${ }^{38}$ и работа шла сложно: рукопись оригинала содержит правку, небольшие вставки над строками и на полях, почерк беглый (Ч. 14. ИРЛИ. Ф. 537. Ед. хр. 1). Копия этой части (Ч. 14. РНБ. Ф. 89. Ед. хр. 15) имеет все признаки «парадного» стиля (вставлены отсутствующие в оригинале названия отдельных писем, добавлен рисунок тушью), ${ }^{39}$ но не имеет пометы о переписывании ни на титуле, ни в конце рукописи. Можно лишь осторожно предположить, что это связано со снятием копии в тот же сезон 1807-1808 годов, в который был написан оригинал этой части.

В следующий сезон Болотов не снял ни одной копии, по-видимому увлекшись написанием новых частей, которых было почти четыре (Ч. 15-16. ИРЛИ. Ф. 537. Ед. хр. 2-3; Ч. 17-18. ОПИ ГИМ. Ф. 349. Ед. хр. 9-10). В дальнейшем он пытался сократить возникшее отставание, но безуспешно. Показательным в этом смысле стал сезон 1809-1810 годов, когда Болотов одновременно работал над новыми частями и копировал написанные ранее. ${ }^{40}$ В результате, например, рекордная по скорости создания 16-я часть была скопирована через год за полтора месяца, с перерывами на написание писем 20-й и 21-й частей.

Очевидно, что у Болотова не хватало сил и времени на копирование новых частей, и в следующем сезоне он пришел к выводу о его нецелесообразности. 22-я часть стала последним оригиналом в «непарадном» исполнении. По-видимому, копия с него

36 Болотов М. П. Андрей Тимофеевич Болотов. С. 741-742.

37 Отдельные рисунки тушью и карандашом появляются в копиях 10-й, 11-й, 14-й, 17-й частей. В 12-й, 15-16-й и 18-20-й частях миниатюры отсутствуют и в оригинале, и в копии.

38 Титульный лист и 141-е письмо отсутствуют. Начало написания 142-го письма датировано 19 ноября 1807 года (Л. 4), помета в конце рукописи: «Конец 14 части. Декабря 20 дня 1807 года» (Л. 176 об.). Работа над отдельными письмами оказалась весьма продолжительной, так начало 144-го письма имеет дату 23 ноября (Л. 47), 145-го - 4 декабря (Л. 66), 146-го — 10 декабря (Л. 86).

39 143-е - «Путешествие в Москву», 148-е — «1771», 149-е — «7-го марта» (II, 963, 1057, 1074). Рисунок усадьбы с церковью перед началом 145 -го письма (II, 1002).

40 Например, 13 декабря 1809 года он написал 203-е письмо (Ч. 20. ОПИ ГИМ. Ф. 349. Ед. хр. 12. Л. 58 об.), 15 декабря отмечено завершение копирования 15-й части (III, 202) и начало копирования 16-й (III, 201), а уже 16 декабря — написание 204-го письма (Ч. 20. ОПИ ГИМ. Ф. 349. Ед. хр. 12. Л. 84 об.). 
в дальнейшем так и не была снята. ${ }^{41}$ Начиная с 23 -й части, Болотов сразу оформляет оригинальные рукописи мемуаров в «парадном» стиле, и это не привело к увеличению продолжительности работы над частями. ${ }^{42}$ После 1811 года копии больше не снимаются, и дублирование текста воспоминаний на основном дворяниновском этапе создания мемуаров завершается.

К этому моменту воспоминания были доведены до 1787 года, и Болотов сосредоточился на том, чтобы как можно больше успеть написать, а не переписывать имеющееся. Вскоре $^{43}$ Болотов дошел до того периода, описывая который, он получил возможность опереться на свои дневниковые записи позднего богородицкого времени, созданные двадцать лет назад как возможное продолжение жизнеописания. Активное использование этих записей ${ }^{44}$ не привело к принципиальным изменениям в работе над мемуарами. Более того, последние части, написанные на основном дворяниновском этапе, явно давались Болотову с трудом: 28 -я и 29 -я части потребовали соответственно 68 и 60 дней работы (без учета перерывов на сезоны), о продолжительности работы над 30 -й частью, вероятно написанной в рамках сезона 1816-1817 годов, данные отсутствуют. ${ }^{45}$

Затягивание работы над этими частями, как и пропуски отдельных сезонов, объясняются прежде всего тем, что Болотов был занят работой над другими сочинениями. ${ }^{46}$ Существенную роль играл и почтенный возраст Болотова, сказывавшийся на интенсивности его работы. Этот фактор стал иметь определяющее значение на последнем, позднел дворяниновскол этапе написания мемуаров (ок. 1818 - ок. 1829). Так как из десяти написанных на этом этапе новых частей сохранилось менее половины, мы имеем о нем самые неясные представления. Когда именно Болотов приступил к 31-й части своих воспоминаний, неизвестно. Возможно, импульсом к возобновлению работы над мемуарами вновь стало достижение символически значимого возраста, на этот раз 80-летия, в 1818 году. Внешним выражением отношения Болотова к этому этапу как к новому стала корректировка названия и появление двойной нумерации частей. Дошедшие до нас 35-37-я части названы «Продолжение описания жизни Андрея Болотова, описанной им для своих потомков» и нумерованы «часть 5 , а от начала 35 » и т. д. На утраченную 31-ю часть, по всей видимости, пришлось наступление нового периода в жизни Болотова после его окончательной отставки со службы и переезда в Дворяниново. Судя по 35-й части, не сохранившиеся 31-34-я части были написаны между 1818 (?) и весной 1821 года и содержали письма с 311 по 346, описывающие события за 1797-1799 годы. ${ }^{47}$

Рукопись 35-й части по внешнему виду соответствует «парадному» стилю более ранних частей мемуаров: твердый картонный переплет, четкий, разборчивый почерк, оформление текста виньетками и заставками, иногда встречаются рисованные карандашом миниатюры. Однако с предшествующими ей утраченными частями дело,

41 В комплекте из 29 частей, который был издан Семевским, копия этой части уже отсутствовала (IV, 174).

42 Средняя продолжительность написания 23-27-й частей -25 дней.

43 То есть с последних писем 24 -й части, соответствующее замечание Болотова находится в 248-м письме (IV, 495).

44 Например, текст дневника «Описание жизни Андрея Болотова, сочиненное самим им для его потомков. Продолжение» (РНБ. Ф. 608. Оп. 2. № 88/6) хорошо соотносится (часто вплоть до дословных совпадений) с описанием начала 1791 года в 271-м письме (IV, 787-794), что, впрочем, не позволяет нам присоединиться к прямолинейной трактовке этой рукописи, написанной на 20 лет раньше соответствующей части болотовских воспоминаний, как к «черновому наброску» мемуаров (Абралович Д. И. Каталог собрания рукописей профессора И. В. Помяловского, ныне принадлежащих Императорской Публичной библиотеке. СПб., 1914. С. 51).

45 Учитывая, что на этом этапе Болотов весьма методично распределял свои воспоминания по частям (последние включали в себя описание от года до двух лет его жизни) и устойчиво делил их на 10 писем, можно с высокой степенью вероятности предполагать, что 30-я часть включала в себя 301-310-е письма и была посвящена событиям 1796 - начала 1797 года вплоть до отъезда Болотова из Богородицка в Дворяниново.

${ }^{46}$ Подробнее см.: Болотов А. Т. Автобиография // НИОР РГБ. Ф. 475. Карт. 1. Ед. хр. 1. Л. 7.

47 Рукопись 35-й части (ИРЛИ. Ф. 537. Ед. хр. 4) имеет дату начала написания 19 мая 1821 года и начинается с 347-го письма, в котором продолжается описание событий 1799 года. 
по-видимому, обстояло иначе. В письме к жене 1833 года Павел Болотов отмечает, что пропавшие части «писаны начерно и так сведены, что постороннему трудно и даже нельзя много разобрать» ${ }^{48}$ Еще более любопытна информация об этих частях в воспоминаниях М. П. Болотова, который, указывая на их уничтожение матерью, увеличивает число частей до восьми и отмечает, что они были «чистенько переписанные рукою внучки Бородиной». ${ }^{49}$ Если предположить, что М. П. Болотов верно запомнил, сколько частей было уничтожено, то все эти сведения можно согласовать между собой следующим образом: уничтожены были оригиналы 30-34-й частей и три их копии, переписанные внучкой. Копии были сняты, по-видимому, с последних трех частей (32-34), которые были написаны мало разборчивым почерком.

Причиной ухудшения внешнего вида рукописей, несомненно, были проблемы со зрением, которые начались у Болотова в конце 1810 -х годов. ${ }^{50}$ Судя по всему, выход был найден в копировании «начерно» написанных воспоминаний внучкой Болотова, Александрой Бородиной (1797 г. р.), которая, рано оставшись сиротой, с 1811 года жила в Дворянинове. ${ }^{51}$ Таким образом, возобновилось дублирование оригиналов копиями, и это единственные прижизненные копии мемуаров (увы, утраченные), сделанные не самим Болотовым. В 1821 году А. Ф. Бородина вышла замуж и покинула Дворяниново, после чего Болотову пришлось обходиться без ее помощи. Как видно по рукописи 35-й части, в начале 1820 -х годов ему еще удавалось писать «прямо набело», но это требовало значительного времени: без учета сезонного перерыва эта часть (из 9 писем) писалась около 45 дней. ${ }^{52}$

Приступив в марте 1822 года к написанию 36-й части (Ч. 6/36. ИРЛИ. Ф. 537. Ед. хр. 5), ${ }^{53}$ Болотов очень скоро прервал работу. Осенью 1824 года он писал, что из-за ухудшившегося здоровья (особенно зрения) вынужден «сочинять ее наперед уже начерно а потом уже переписывать набело» (Ч. 6/36. РНБ. Ф. 89. Ед. хр. 30. Л. 2-3). Черновик 36-й части, в котором содержится это рассуждение, был закончен только через год, хотя в основном (359-364-е письма) был написан менее чем за месяц в ноябре 1825 года - скорость, соответствующая прежним этапам работы над мемуарами. Выработанные годами навыки письма «набело» давали о себе знать: текст написан неровным и трудно разбираемым крупным почерком, но правки в нем почти нет, кроме двух добавлений, которые оформлены как сноски (Там же. Л. 177-178). В рукописи есть колонтитулы, она переплетена в картон.

Практически так же можно охарактеризовать черновую рукопись следующей, 37-й части: она отличается только бо́льшим числом входящих в нее писем и встречающимися зачеркиваниями (Ч. 7/37. РНБ. Ф. 89. Ед. хр. 31). Работа над ней продолжалась также около года. Первые 4 письма (365-368-е) были написаны сразу после окончания черновика предыдущей части в конце ноября - начале декабря 1825 года, приблизительно за две недели, затем последовала пауза, после которой Болотов вернулся к работе над воспоминаниями в октябре 1826 года и оставшиеся десять писем (369-378-е) писал без перерывов на протяжении двух месяцев. Последнее письмо, озаглавленное «65-й год моей жизни» было закончено 12 декабря 1826 года (Там же. Л. 200). Воспоминания в 37-й части были доведены до 1802 года.

48 Козлов С. А. Русская провинция в дневниках Павла Болотова: «Настольный календарь 1787 года». СПб., 2006. С. 41.

49 Письмо М. П. Болотова М. И. Семевскому от 14 октября 1873 г. // ИРЛИ. Ф. 537. Ед. хр. 40. Л. 1 об.

50 Подробнее о потере зрения мемуаристом см.: Болотов А. Т. Краткие записки о значительнейших происшествиях со мною в 82 год моей жизни... // РНБ. Ф. 89. Ед. хр. 53. Л. 2 об., 24.

51 Болотов М. П. Андрей Тимофеевич Болотов. С. 742.

52 Относительно времени завершения работы над этой частью в рукописи противоречивые сведения: на титуле указано 14 мая 1822 года (ИРЛИ. Ф. 537. Ед. хр. 4. Л. 2), помета в конце рукописи - 14 марта 1822 года (Там же. Л. 206 об.). При этом окончание всех писем, за исключением последнего, датировано, и предпоследнее (354-е) имеет дату 18 марта 1822 года (Там же. Л. 187 об.). 22 или 26 марта Болотов приступил к написанию следующей части, и нам представляется наиболее вероятным, что он начал писать 36 -ю часть сразу после завершения 35-й.

${ }^{53}$ На титульном листе помета: «Начата 26 марта 1822, кончена 19 нояб. 1825» (Л. 2). 
Всплеск активности в работе над воспоминаниями осенью 1826 года, по-видимому, был связан с возвращением в Дворяниново П. А. Болотова ${ }^{54}$ и должен был продолжиться после завершения черновика 37-й части. Об этом можно говорить, исходя из общего числа частей мемуаров ( 39 и «начатая» 40-я), а также принимая во внимание рукопись с воспоминаниями Болотова о событиях 1805 года. ${ }^{55}$ Эта рукопись является единственным и, на наш взгляд, бесспорным претендентом на роль 40-й части мемуаров. Хотя текст ее, по-видимому, был завершен, ${ }^{56}$ она имеет все признаки чернового наброска: представляет собой одно письмо (без номера), описывающее все события 1805 года, титульный лист с названием отсутствует, нет помет о дате написания, переплет бумажный, скорее всего сделанный позднее и, вероятно, уже после смерти Болотова, поскольку помета на корешке «Отрывок А. Т. Б.» явно перекликается с надписью под крышкой переплета: «Отрывок из продолжения истории жизни А. Т. Болотова (1805 года) скончавшегося 3 окт. 1833». На вопрос о дате ее создания может быть дан лишь приблизительный ответ, основывающийся на общем представлении о времени завершения работы над мемуарами. По воспоминаниям М. П. Болотова, в 1830 году его дед был практически полностью слепым. ${ }^{57}$ Поскольку текст воспоминаний о событиях 1805 года написан самим Болотовым (причем почерк довольно разборчивый, а правка почти отсутствует), то крайним временем его создания может быть 1829 год. В начале рукописи Болотов отмечает: «Продолжая описывать историю вечера дней моих или последние годы моей жизни, скажу вам, что как изобильны были важными происшествиями все предследовавшие пред сим три года, так напротив того скуден был оными сей 1805 год» (ИРЛИ. Ф. 537. Ед. хр. 8. Л. 1). Очевидно, что предшествующие три года $(1802-1804)$ к этому времени уже были описаны, по крайней мере, в черновом варианте. Это соответствует нашим представлениям об утраченных 38 -й и 39 -й частях. Объем описанных событий приблизительно равен предыдущим частям (по полтора года на каждую). Если предположить, что Болотов приступил к написанию 38 -й части сразу по завершении черновика 37-й и сохранял прежнюю интенсивность работы, то написание черновика 38 -й части следует датировать временем от декабря 1826-го по начало 1828 года, а черновика 39-й - от начала 1828-го до начала 1829 года.

Как показывает опыт осени 1826 года, Болотов был способен и к более быстрой работе, но написание черновиков мемуаров не являлось и в последние годы творческой деятельности единственным видом его писательских трудов. Немалого времени требовало и написание чистовых вариантов. Например, при возвращении осенью 1825 года к работе над воспоминаниями, он сначала переписал в чистовую рукопись 36 -й части текст, написанный год назад в черновике, ${ }^{58}$ и только затем приступил к продолжению самого черновика. Однако этот случай остается единственным. В остальном расхождения между черновиками и чистовиками 36 -й и 37 -й частей отсутствуют, отличаются они разборчивостью почерка, а также дополнительными элементами оформления (виньетки и заставки). По сути, это еще одна попытка уже привычного для Болотова копирования ранее написанной части, с поправкой на то, что если прежде на снятие копии у него уходило около двух недель, то теперь этот срок увеличивался. Отсутствие помет о переписывании в чистовике 36 -й части, ${ }^{59}$ скорее всего, свидетельствует о том, что работа по ее завершению была проделана в тот же сезон, когда был закончен

54 Ср.: «...побудил меня сын мой к продолжению описания моей жизни...» в черновике 36-й части (РНБ. Ф. 89. Ед. хр. 30. Л. 2 об.).

55 Болотов А. Т. Продолжение описания моей жизни. 1805. 72 л. // ИРЛИ. Ф. 537. Ед. хр. 8. Для сравнения, дневник Болотова за 1805 год был по объему в два раза больше: Болотов А. T. Домашний исторический журнал. 1805. 150 л. // РНБ. Ф. 89. Ед. хр. 38.

56 Рукопись завершается фразой: «Сим кончился наш 1805 год: а вместе с сим дозвольте мне окончить письмо сие и сказать вам что я есмь ваш... и прочая» (ИРЛИ. Ф. 537. Ед. хр. 8. Л. 72 об.).

${ }^{57}$ Болотов М. П. Андрей Тимофеевич Болотов. С. 749. Последние датированные рукописи Болотова относятся к 1827 году.

58 356-е и 357-е письма в черновике датированы осенью 1824 года (Ч. 6/36. РНБ. Ф. 89. Ед. хр. 30. Л. 17, 45), в чистовике - октябрем 1825-го (Ч. 6/36. ИРЛИ. Ф. 537. Ед. хр. 5. Л. 19 об., 51 об.).

59 На титуле временем завершения значится 19 ноября 1825 года (Там же. Л. 2), но это дата окончания работы над черновиком. В конце рукописи пометы о времени ее завершения нет. 
черновик, т. е. в декабре 1825-го и начале 1826 года, когда возникла пауза в написании черновика 37-й части. С чистовиком же 37-й части (Ч. 7/37. ИРЛИ. Ф. 537. № 6) дело обстоит сложнее. Очевидно, что эта рукопись была написана после декабря 1826 года, когда был закончен черновик данной части. Однако она не имеет ни титульного листа, ни особых помет о времени создания. ${ }^{60}$ Это позволяет сопоставить ее с рукописью воспоминаний о 1805 годе и предположить, что работа Болотова над ней затянулась (по объему она оказалась одной из самых больших во всем комплексе его воспоминаний) и так и не была доведена до конца, хотя рукопись и была переплетена в картон как законченная. Утраченные 38-39-я части, вероятно, не имели чистовых вариантов.

Подводя итоги, следует сказать, что деление мемуарного наследия Болотова на чистовики и черновики, утвердившееся со второй половины XIX века и использующееся по сей день, в том числе в архивных описях, справедливо (и то с некоторыми оговорками) только для 36-37-й частей. В остальном оно не соответствует ни функциональному назначению рукописей, представлявших собой полноценные рукописные книги, а не материал для дальнейшей работы, ни авторским определениям этих текстов. В ряде случаев характеристика болотовских рукописей как черновых вариантов воспоминаний лишь отражает недостаточную степень изученности мемуарного наследия Болотова и, в частности, приводит к неверному отождествлению дневниковых записей с воспоминаниями. Предложенное в данной статье распределение этих рукописей, во-первых, по этапам работы Болотова над мемуарами, во-вторых, по принципу «оригинал - копия», на наш взгляд, позволяет как упорядочить общие представления о весьма объемном и неоднородном комплексе его воспоминаний, так и уточнить или по-новому охарактеризовать отдельные рукописи, составляющие этот комплекс. В целом, следует отметить, что «писаные набело» оригиналы воспоминаний, создававшиеся на протяжении длительного времени, на всех этапах работы Болотова над мемуарами (а это, в общей сложности, более чем половина столетия), неодинаковы и по своему заглавию, и по оформлению рукописей, и по почерку, кроме того, в них может встречаться правка. Копии имели «парадный» характер, были написаны на относительно коротком отрезке времени (ок. 1800-1811 годов) и поэтому более однородны. В приведенной ниже таблице мы постарались свести воедино данные о рукописях болотовских мемуаров.

Таблица $3^{61}$

\begin{tabular}{|c|c|c|c|c|c|}
\hline Часть & Годы & $\begin{array}{c}\text { Ранний } \\
\text { вариант }\end{array}$ & Черновик & Оригинал & Копия \\
\hline 1 & до 1750 & \multirow[t]{2}{*}{$\begin{array}{l}\text { Утрачена } \\
\text { (до 1782) }\end{array}$} & & $\begin{array}{l}\text { ГИМ № } 1 \\
\text { (1789) }\end{array}$ & $\begin{array}{l}\text { РНБ № } 1 \\
\text { (ок. 1800?) }\end{array}$ \\
\hline \multirow[t]{2}{*}{2} & \multirow[t]{2}{*}{$1750-1755$} & & & \multirow[t]{2}{*}{$\begin{array}{l}\text { Утрачена } \\
\text { (1789) }\end{array}$} & \multirow[t]{2}{*}{$\begin{array}{l}\text { РНБ № } 2 \\
\text { (ок. 1800?) }\end{array}$} \\
\hline & & \multirow[t]{4}{*}{$\begin{array}{l}\text { ГИМ № } 2 \\
(\text { ок. 1787) }\end{array}$} & & & \\
\hline 3 & $1755-1757$ & & & $\begin{array}{l}\text { Утрачена } \\
\text { (1789) }\end{array}$ & $\begin{array}{l}\text { РНБ № } 3 \\
\text { (oк. 1800?) }\end{array}$ \\
\hline 4 & 1757 & & & $\begin{array}{l}\text { Утрачена } \\
(1789)\end{array}$ & $\begin{array}{l}\text { РНБ № } 4 \\
\text { (ок. 1800?) }\end{array}$ \\
\hline 5 & $1757-1758$ & & & $\begin{array}{l}\text { РНБ № } 6 \\
(1790)\end{array}$ & $\begin{array}{l}\text { РНБ № } 5 \\
\text { (ок. 1800?) }\end{array}$ \\
\hline
\end{tabular}

60 Даты написания всех писем совпадают с черновиком. В описи рукопись датирована 1826 годом.

61 Номер соответствует номеру рукописи в описи фонда указанного архива. В скобках указываются годы написания рукописи, которые представляются верными авторам данной статьи и не во всех случаях соответствуют рукописным пометам самого Болотова (такие даты отмечены курсивом). Полужирным шрифтом выделены рукописи, изданные Семевским в 1870-1873 годах. 


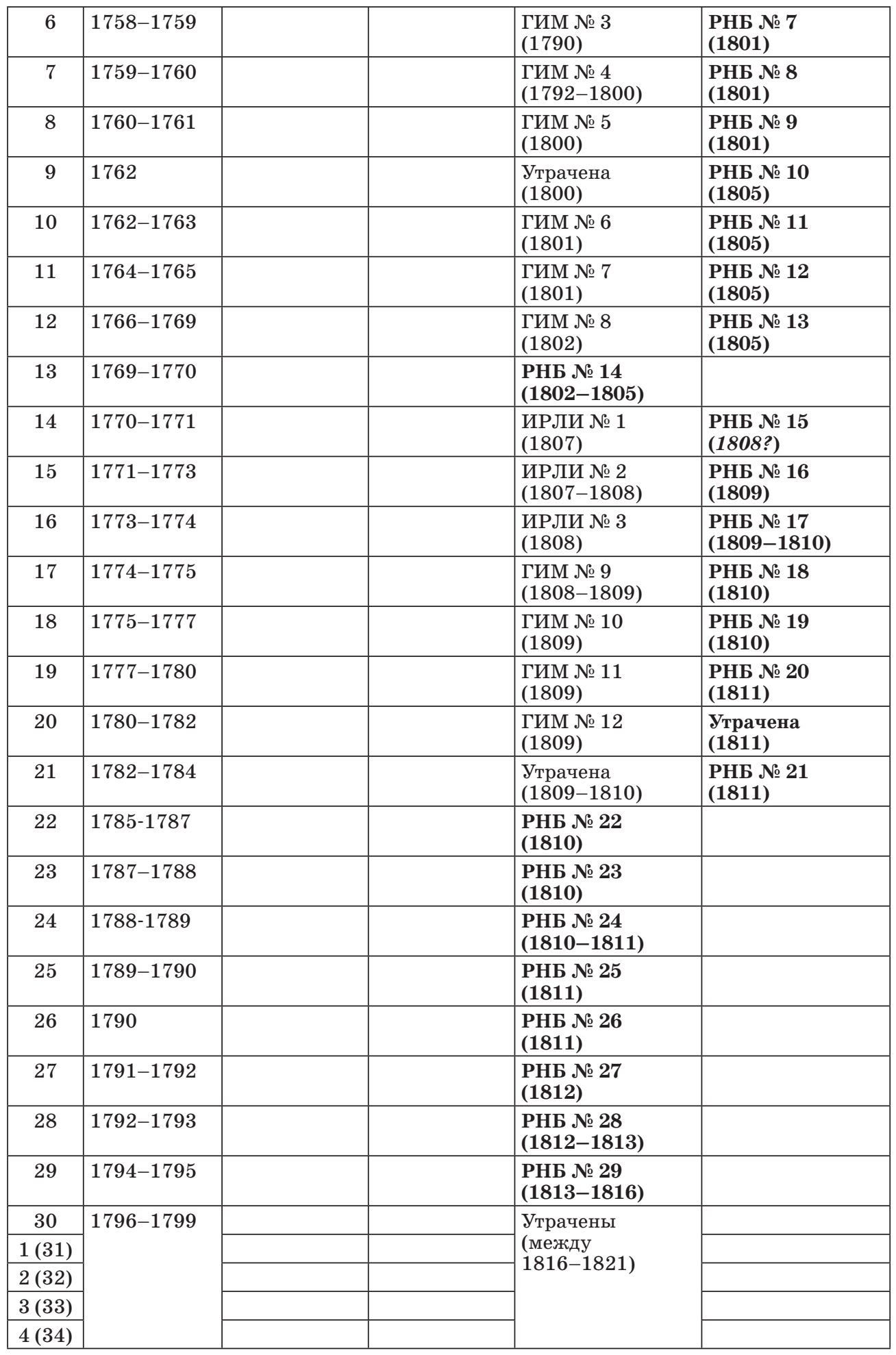




\begin{tabular}{|c|l|l|l|l|l|}
\hline $5(35)$ & $1799-1800$ & & & $\begin{array}{l}\text { ИРЛИ № 4 } \\
(1821-1822)\end{array}$ & \\
\hline $6(36)$ & $1800-1801$ & & $\begin{array}{l}\text { РНБ № 30 } \\
(1824-1825)\end{array}$ & $\begin{array}{l}\text { ИРЛИ № 5 } \\
(1825-1826 ?)\end{array}$ & \\
\hline $7(37)$ & $1801-1802$ & & $\begin{array}{l}\text { PНБ № 31 } \\
(1825-1826)\end{array}$ & $\begin{array}{l}\text { ИРЛИ № 6 } \\
(1827-1829 ?)\end{array}$ & \\
\hline $8(38)$ & $1802-1804$ & & $\begin{array}{l}\text { Утрачены } \\
(1826-1829 ?)\end{array}$ & & \\
\cline { 3 - 6 } & & & $\begin{array}{l}\text { ИРЛИ № 8 } \\
\text { (1829?) }\end{array}$ & & \\
\hline 40 & 1805 & & & & \\
\hline
\end{tabular}

DOI: $10.31860 / 0131-6095-2020-3-182-198$

(ㄷ) М. Э. Баскина (Маликова), () А. В. Волков

\section{ЧТО ЖЕ ПИСАЛ О ПЕРЕВОДАХ ЗКИТЕЛЬ ВЫБОРГСКОЙ СТОРОНЫ}

Хорошо известно, что написанное в начале 1824 года программное проромантическое предисловие П. А. Вяземского к «Бахчисарайскому фонтану» А. С. Пушкина озаглавлено «Разговор между Издателем и Классиком с Выборгской стороны или с Васильевского острова». ${ }^{1}$ В переписке Вяземский именовал его также «Разговором между издателем и классиком с Выборгской стороны», ${ }^{2}$ как будто подчеркивая значение второго из «жителей»-классиков. Также достоверно известно, что предположение Вяземского: «Какой-то шут Цертелев или Сомов лается на меня в „Благонамеренном“ под именем Жителя Васильевского острова или Выборгской стороны», ${ }^{3}$ - наполовину верно: в 1820-1821 годах в «Благонамеренном» под псевдонимом Житель Васильевского острова с нападками на «новую школу словесности» выступал князь Н. А. Цертелев, что, безусловно, подтверждается многочисленными эпистолярными свидетельствами. ${ }^{4}$ Что касается Жителя Выборгской стороны, которого Вяземский называет в одном ряду с Жителем Васильевского острова / Цертелевым как «классика» (т. е., условно, представителя лагеря, противного «романтикам»), то под этим псевдонимом вышла только одна большая, в трех номерах того же «Благонамеренного» за 18221823 годы, статья «О переводах», ${ }^{5}$ и подлинное имя ее автора до сих пор не названо. Вероятно, на основании процитированного письма Вяземского в комментарии в сборнике «Пушкин в прижизненной критике» статья «О переводах» без оговорок атрибутирована Цертелеву. ${ }^{6}$ Действительно, отведенное ей место в журнале и реакция Вяземского, обессмертившего Жителя Выборгской стороны в истории русского романтизма, заставляют предположить в ней программное выступление, в характерном для «Бла-

1 [Вяземский П. А.]. Разговор между Издателем и Классиком с Выборгской стороны или с Васильевского острова. Вместо предисловия <к «Бахчисарайскому фонтану»> // «Бахчисарайский фонтан» А. Пушкина. М., 1824. С. I-XX (без подписи).

2 Письмо П. А. Вяземского А. И. Тургеневу 17 января 1824 года, см.: Остафьевский архив князей Вяземских. Переписка князя П. А. Вяземского с А. И. Тургеневым. СПб., 1899. Т. 3. С. 4.

${ }^{3}$ Письмо П. А. Вяземского А. И. Тургеневу 10 сентября 1823 года, см.: Там же. Т. 2. С. 346.

${ }^{4}$ См.: Масанов И. Ф. Словарь псевдонимов русских писателей, ученых и общественных деятелей: В 4 т. М., 1956. Т. 1. С. 378.

${ }^{5}$ Благонамеренный. 1822. Ч. 20. № 41. С. 47-64; № 42. С. 81-91; 1823. Ч. 22. № 8. С. 97109. Далее ссылки на эту статью даются в тексте сокращенно, с указанием части $(1,2,3)$ и страницы.

6 См. комм. Е. О. Ларионовой к этой статье Вяземского в сб.: Пушкин в прижизненной критике. 1820-1827. СПб., 2001. С. 406-408. 
гонамеренного» этих лет антиромантическом духе, на тему перевода — что первоначально привлекло наш интерес к этому тексту.

Поскольку достоверных данных о личности автора статьи «О переводах» нет, можно путем внимательного чтения реконструировать позицию имплицитного автора и, поставив высказывание в контекст литературных споров эпохи, сделать предположения о реальной фигуре, скрытой под псевдонимом, чему и посвящена настоящая статья.

Житель Выборгской стороны собственно на Вяземского не «лается», но действительно делает несколько задиристых антиромантических выпадов. Вначале, рассуждая об этимологии слова «перевод», он замечает, что по-русски оно «в самой древности соединяло в себе два понятия, а именно: во-первых, вести кого-нибудь с одного места на другое; а во-вторых, извести, истребить», заимствуя это этимологическое рассуждение у адмирала Шишкова, ${ }^{7}$ и потом направляет его против «Арзамаса»: «Например <...> у меня перевелись Арзамасские гуси, индейки тоже пошли на перевод; он великой переводчик бумаги, и т. п. <...> $(1,48-49$; здесь и далее курсивы в цитатах из статьи Жћителя Выборгской стороны принадлежат ее автору). Оканчивает он статью общими местами антиромантической критики, говоря об «условных красотах сего рода романтической поэзии <...>: таинственный, сладострастный, былое, туланная даль, лолодая жизнь - глаза, не зря слотрящие - уста, без слов говоряшие - руки, развеваюшие персты, и т. п.» $(3,106) .{ }^{8}$ Кроме того, введя не оригинальное, но вполне справедливое разделение переводов на «перевод-творение», «подражание» и «рабский» $(1,51)$, Житель иронически характеризует первые два как романтические: перевод«твоение» - это «порыв Гения, стремящегося хотя по одному назначению с подлинником, но в бурном полете своем разрушающего все препоны, которые встречаются ему на пути» $(1,52-53)$, перевод-«подражание» - «также отпечаток Гения. Он хотя и следует за подлинником, но издали и не всегда по прямой дороге» $(1,61) .{ }^{9}$ Обрамляя критику этих «романтических» переводов легко узнаваемыми примерами из Тредиаковского («Тилемахиды», ${ }^{10}$ и «Поэтического искусства» Буало $(1,63-64)$ ), З九итель

7 Критикуя в «Разговоре между двумя приятелями о переводе слов с одного языка на другой» (1805) калькирование «состава чужих слов», А. С. Шишков говорит, что «это называется переводить, и название сие сугубо прилично сему действию, потому что оно в самом деле перево$\partial u m$, то есть истребляет собственные свои, и вводит в язык чужие несвойственные ему слова» (Собр. соч. и переводов адмирала Шишкова. СПб., 1825. Ч. 4. С. 312).

8 Ср. в «Епиграмме» некоего «Ф. Ф. Ф.»: «Везде влияние чудесной видим моды! <...> а ныне - все толпой / Летим в туланну даль, с отиветшею душой...» (Вестник Европы. 1821. Ч. 116. № 1. С. 35); эпиграмме Б. М. Федорова «Союз поэтов»: «Условныя желанья, / Нелья ожиданья, / Кипящия лобзанья / И сладострастье нег / Твердите и твердите!» (Благонамеренный. 1822. Ч. 19. № 39. С. 513-514, подп. «Д. Врс-въ»); в рецензии близкого к редакции «Благонамеренного» критика, писавшего в журнале под псевдонимом «И. Истов», на идиллию Н. И. Гнедича «Рыбаки»: «В редком из новейших стихотворений <...> не встретишь кстати и некстати: <...> туланной или таинственной дали; также как лладой жизни, легкокрылой мечты, былых лет и т. п. <...> они тем неприятнее в мелких стихотворениях нашей Парнасской молодежи, что показывают < ...> какое-то жалкое обезьянство» (Истов И. Разбор идиллии: «Рыбаки» (Продолжение) // Там же. Ч. 18. № 21. С. 314-315) и проч.

9 «Эмблемою для сих переводов могут служить те зеркала, которые или увеличивают, или уменьшают отражающиеся в них предметы, соблюдая однако ж наружность и черты, свойственные сим предметам» $(1,61)-$ А. А. Бестужев, критикуя переводы В. Перевощиковым идиллий Броннера и Гердера, в которых тот стремился передать «в улучшенном виде красоты оригиналов», также использовал оптическую аналогию, впрочем более изощренную: «... так дневной луч, проходя сквозь кристальную призму, отражается цветною радугою» (Сын отечества. 1822. Ч. 80. № 36. C. 113).

10 «Тилемахида» (1766), перевод стихами романа Фенелона «Приключения Телемака», служит иллюстрацией того, что «если сочинение написано в прозе, то переводчик перелагает его стихами» $(1,53)$. Рядом с Тредиаковским приводятся еще примеры из авторов XVIII века - вероятно, просто ради комизма «кунсткамерного» типа: заглавие вольной вариации С. А. Смирнова на темы «Мессиады» Клопштока - «Необходимость Мессии, доказанная разумом. Поэма в 5 песнях. Российское сочинение» (1803) - становится подтверждением того, что «переводчик-творец» «старается назвать сочинение так, как сочинителю его и в голову не приходило» $(1,53)$. В разделе «переводов-подражаний» цитата из «Енея» Василия Петрова (перевода «Энеиды», 
Выборгской стороны отчетливо подверстывает себя к другим антиромантическим «жителям» «Благонамеренного» — Ж Кителю Петербургской стороны / А. А. Бестужеву-Марлинскому, объявившему о своем намерении собрать «литературную кунсткамеру», ${ }^{11}$ Жиителю Галерной Гавани / Оресту Сомову и Жителю Васильевского острова / князю Цертелеву, поместившим на свои виртуальные шкафы «с литтературными уродцами», выбранными из стихотворений Жуковского, Дельвига, Вяземского и Баратынского, девизы из «Тилемахиды». ${ }^{12}$ Во второй части статьи ЖЖитель прямо говорит о том, что приводимые им примеры из переводов предназначены для этой «литературной кунсткамеры»: «...некоторые из Любителей Кунсткалеры Русского Слова уже занимаются составлением двух Словарей, из коих первый содержать будет слова и выражения вновь составленные на Русском языке разными писателями; а второй слова и выражения иностранные, введенные в Русский язык неусыпными трудами наших сочинителей и переводчиков» $(2,86-87)$.

Таким образом, статья содержит несколько вторичных, но однозначно маркирующих «партийную» приверженность критика как «антиромантическую» высказываний, которые, вероятно, и дали основание Вяземскому записать его, наряду с Жиителем Васильевского острова, в «классики». Однако центральная часть статьи, содержащая собственно критику переводов, не развивает эти декларативные антиромантические выпады и имеет совсем иную прагматику и риторику.

Разделы, посвященные каждому из трех типов перевода - творческому, подражательному и рабскому - построены по одной схеме: несколько иронически сформулированных «правил» иллюстрируются цитатами. При этом имена переводчиков и названия произведений не указываются, поэтому, чтобы понять смысл статьи, нам пришлось их атрибутировать. Свои претензии к текстам критик не формулирует, а только выделяет не понравившиеся ему слова и фразы курсивами, вопросительными и восклицательными знаками, - что, вероятно намеренно, сбивает критический прицел и ослабляет полемический заряд.

В разделе о «переводах-творениях» как пример того, что «если сочинение писано стихами, то переводят его прозою», называется «Освобожденный Иерусалим» Тассо, «несколько раз на Русской язык переведенный» $(1,53) .{ }^{13}$ К этому времени поэма переводилась на русский трижды и всегда прозой: М. И. Поповым (1772), С. А. Москотильниковым (с французского, сделан в 1800-1812 годах, опубл. 1819) и А. С. Шишковым. Единственной относительно актуальной причиной для обращения к обсуждению переводов поэмы Тассо могли служить выступления адмирала Шишкова - статья «О переводе классических стихотворцев» (Дух журналов. 1817. Ч. 23. Кн. 46. С. 867-893), направленная против стихотворного перевода 15-й песни поэмы А. Ф. Мерзляковым, ${ }^{14}$ и сделанный самим Шишковым с итальянского подлинника, но тоже прозой, перевод поэмы (1818-1819). Можно было бы предположить, что Жћитель тут выступает на стороне Мерзлякова, автора стихотворного перевода, но это не так: далее он критически

1780-е годы): «Там вихрем хлябь корабль три раза вкруг вращает, / Урча и клокоча, со щоглой поглощает» $(1,62)$ - приводится как пример того, что «если подлинник написан слогом высоким, то его должно перевести слогом надутым» $(1,62$; отметим, что А. С. Шишков, напротив, считал эти строки из перевода Петрова примером удачной передачи звукоподражания подлинника (Шишков А. С. О звукоподражании (1805) // Собр. соч. и переводов адмирала Шишкова. Ч. 4. C. 346)).

${ }_{11}$ Марлинский А. Письмо к издателю // Благонамеренный. 1820. Ч. 11. № 6. С. 398-408.

12 Житель Васильевского Острова. Письмо к г. Марлинскому // Там же. № 13. С. 16; Житель Галерной Гавани. Письмо к г. Марлинскому // Невский зритель. 1821. Ч. 5. № 1. С. 57.

13 Следующее правило, дублирующее это утверждение: «Если сочинение заключает в себе красоты стихотворческие, то его должно перевести как можно более прозаически» $(1,54)$ - отсылает, возможно, к переводам такого рода, как тоже уже совершенно неактуальное прозаическое переложение фрагментов «Ночных размышлений» и поэмы «Страшный суд» Э. Юнга, сделанное Михаилом Паренаго по антологии с характерным для эпохи заглавием «Beauties of Edward Young» (1802) и парадоксально, для восприятия читателей позднейшей эпохи, озаглавленное переводчиком «Стихотворческие красоты Эдуарда Йонга» (1806).

14 Перевод Мерзлякова опубл.: Амфион. 1815. Кн. 5. 
приводит целый ряд цитат из перевода Мерзлякова - и именно те, которые использовал в своей статье Шишков, в целом характеризовавший перевод Мерзлякова как пример превращения «простого в надутое, великолепного в убогое, громкого в тихое» («таковой перевод стихами хуже перевода из слова в слово, и столько вреден <...> $\left.{ }^{15}\right),-$ т. е. того, что Житель иронически именует «творческим переводом», ср.:

1. «Быстрейший некий ветр, дхновенье тайной силы, / Чудесно надувал его блестящи крылы <...>» (Мерзляков).

\section{Житель}

«переводчик-творец» обязан переводимую «Здесь нет ни одной мысли, ни одного фразу одеть «в такой хаос слов и выраже- выражения, которое бы соответствовало ний, чтоб автор, если б он разумел по-рус- подлиннику и могло назваться перевоски, сам не мог догадаться, какой смысл дом». ${ }^{16}$ она заключала...» $(1,57)$.

2. «Как страстный голубок на бирюзовой вые / Меняет перышков оттенки золотые, / Когда вкруг милыя он вьется в яркий день; / Миг всякой цвет другой, или другая тень: / То кажется она рубиновым монистом, / То блещет в ней смарагд, обделан в злате чистом: / То слиты купно все для зрителей цветы, / Многообразныя отливов красоты» (Мерзляков).

\section{Житель}

Шишков

переводчик «усеевает по местам перево- «В подлиннике перья на шее не означены димое им сочинение цветами собственного сада» $(1,58)$.

3. «И се, их ставит вал на холм прибрежный...» (Мерзляков).

Житель

«Если подлинник написан слогом слиш- «Переводчик везде приятную простоту сию ком гладким; то в сем случае переводчикуподражателю позволяется делать скачки» $(1,62)$.
Шишков никаким определенным цветом, для того что они безпрестанно меняют свой цвет $<\ldots>$ ».

превращает в неуместное восклицание: И се! их ставит вал на холм песка прибрежный! Какой вал? какой холл песка прибрежный? откуда они взялися? у Тасса их нет. В подлиннике тишина и спокойство, а в переводе волны и бури». ${ }^{18}$

Таким образом, прагматика упоминания переводов «Освобожденного Иерусалима» в начале статьи состоит не в защите единственного на тот момент стихотворного перевода Мерзлякова, а, вероятно, в оммаже мнениям и сочинениям почтенного президента Российской Академии.

Следующий пример, иллюстрирующий правило: когда оригинальное сочинение «писано гладкою и ясною прозою, тогда переводчик обязан дать ему отрывистый, кудреватый слог и выражения, свойственные стихотворению» $(1,54),-$ взят из «Федры» Расина:

Но что? О лютый стыд!... открыть любовь могла!

И не невольно я, ты мнишь, сие рекла?...

О сын, в ком одну могу надежду видеть,

Пришла просить тебя его не ненавидеть;

15 Шишков А. С. О переводе классических стихотворцев // Собр. соч. и переводов адмирала Шишкова. Ч. 4. С. 360 .

16 Там же. С. 380.

17 Там же. С. 374.

18 Там же. С. 369-370. Ср. также: 1, 60-61 - с: Шишков А. С. О переводе классических стихотворцев. С. $375-377$. 
Но сердце не могло противиться себе:

Тебе вещала я лишь о самом тебе.

$$
(1,54)
$$

Трагедия Расина, конечно, написана в оригинале не «гладкою и ясною прозою», а александрийским стихом - этот ляпсус и разительная неадекватность примера правилу заставляет заподозрить, что правила сочинялись одним лицом, а примеры подбирались другим. Довольно неуклюжая цитата взята из перевода 5-го явления трагедии И. Б. Чеславским (впервые: Благонамеренный. 1821. Ч. 11. № 17. С. 322; прочитан автором на собрании ВОЛСНХ 21 апреля 1821 года ${ }^{19}$ ). Тут Жนитель как будто включается в новейшие споры вокруг многочисленных в те годы переводов «Федры» (как заметил О. М. Сомов в отклике на перевод М. Е. Лобанова (1823): «Сколько нам известно, это уже одиннадцатый полный перевод Федры на Русском языке, и из сих одиннадцати Федр почти половина была напечатана» ${ }^{20}$ ). По словам автора статьи о Чеславском в словаре «Русские писатели» И. С. Булкиной, переводы «Федры» в те годы «определяют „линию напряжения“ между „классиками“ и „романтиками“, „архаистами“ и „новаторами“. Перевод Чеславского находился на „крайнем правом“ фланге, он более других злоупотреблял грамматическими рифмами и славянизмами».$^{21}$ Однако выделенная курсивом стилистическая претензия Жћителя - скопление «не» («не невольно», «не ненавидеть») - не читается как реплика против «классика» и «архаиста». ${ }^{22}$ Критическая прагматика Ж⿱ителя, очевидно, не полностью описывается категориями «архаисты» versus «новаторы», «классики» versus «романтики», хотя и заявлена как таковая в обрамляющих статью выпадах против «Арзамаса» и «новой школы» поэзии.

Как представляется, упоминание одного из переводов «Федры» соотносится с деятельными усилиями редактора «Благонамеренного» А. Е. Измайлова сделать свой журнал местом полемики о ставших актуальными в 1810-1820-е годы переводах Расина и таким образом привлечь к нему читателей и поправить дела. ${ }^{23}$ В $1820-1823$ годах Измайлов напечатал в «Благонамеренном» фрагменты перевода Чеславского; ${ }^{24}$ резкий

19 Архив ВОЛСНХ в НБ СПб ГУ. Д. 204. № 6. Л. 9-9 об.; № 21. Л. 39-40. См.: http://www. library.spbu.ru/rus/Volsnx/prot/prot21.html; дата обращения: 15.04.2020.

20 Сын отечества. 1823. Ч. 89. № 46. С. 260 (подп. О. С.). Похвалы Сомова как переводу Лобанова («Скажем мимоходом, что здесь Переводчик наш превзошел Расина. Стих его гораздо живее, гораздо вернее выражает отчаяние Федры, нежели стих Расина»; Там же. С. 247), так и игре исполнявшей главную роль трагической актрисы Е. С. Семеновой, ученицы Н. И. Гнедича, «столь преувеличены <...>, что подчас звучат как иронические» (Зубков Н. Н. Лобанов Михаил Евстафиевич // Русские писатели. 1800-1917. М., 1994. Т. 3. С. 376).

21 Булкина И. С. Чеславский Иван Богданович // Русские писатели. Т. 6. С. 643.

22 Кроме того, трагедии Расина, воспринимавшиеся как образцово классицистические, легитимировали в целом «высокий», даже архаический стиль переводов, в том числе использование славянизмов (см.: Сигал Н. А. Из истории русских переводов «Федры» Расина // Русско-европейские литературные связи: Сб. статей к 70-летию ак. М. П. Алексеева. М.; Л., 1966. С. 454-455), что подтверждает и приводимый далее Зћителем пример: «Как громом по полю разгнанныя говяда!» (со специальным уточнением: «перевод Расинова стиха» - и параллельной французской фразой; 1, 57-58), - злосчастные «говяда» из перевода А. А. Жандром «Гофолии» Расина (Северный наблюдатель. 1817. № 14) уже были многократно осмеяны (см.: Князь Цертелев. Отрывок из письма к N. N. // Благонамеренный. 1819. Ч. 8. № 23/24. С. 349; Ю. П. Явление Гиперборейского Духа // Сын отчества. 1817. Ч. 41. № 43. С. 196. Дружески относившийся к Зандру А. С. Грибоедов в письме П. А. Катенину назвал рифму на библейское слово «говяда» «богомерзкой»: Грибоедов А. С. Полн. собр. соч. / Под ред. и с прим. Н. К. Пиксанова. Пг., 1917. С. 124).

23 О позиции Измайлова как издателя «Благонамеренного» в начале 1820-х годов, соединявшей попытки (неудавшиеся) остановить падение читательского интереса к журналу хотя бы критической полемикой на его страницах, и нараставшую, под влиянием Цертелева, Федорова, Остолопова, отчасти Сомова и др., антиромантическую направленность, см.: Проскурин O. A. Литературные скандалы пушкинской эпохи. М., 2000. С. 264-266.

24 Благонамеренный. 1820. Ч. 11. № 17. С. 316-323; Ч. 12. № 22. С. 240-248; 1821. Ч. 14. № 7 и 8 . С. 10-14. 
разбор «Рассказа Терамена», ${ }^{25}$ только что вышедшего в «Вестнике Европы» в переводе А. И. Писарева, ${ }^{26}$ - переводчик откликнулся критическим разбором опубликованного в «Благонамеренном» перевода Чеславского, ${ }^{27}$ при этом дав понять, что считает помещенную в этом журнале критику «известного публициста господина Истова» написанной самим Измайловым или кем-то из его круга; ${ }^{28}$ перепечатал целиком фрагмент «Смерть Ипполита» из перевода «Федры» М. Е. Лобановым (впервые: «Полярная звезда» на 1823 год; перепеч.: Благонамеренный. Ч. 23. № 13. С. 39-43) - только чтобы сопроводить его критическими «Замечаниями» Г. А. Окулова (Там же. С. 43-61), ${ }^{29}$ на которые тут же выразил готовность поместить антикритику (Там же. С. 61), и вскоре напечатал перевод самого Окулова (Там же. 1823. Ч. 24. № 22). В гуще этой «благонамеренной» полемики о «Федре» (в целом склоняющейся, конечно, в пользу Чеславского, а не Лобанова) в статье Жителя возникает - в разительном рассогласовании с «правилом», которое она должна иллюстрировать (перевод прозы стихами), - цитата из перевода Чеславского, что можно объяснить, кажется, не тем, что Житель принципиально предпочитает ему перевод Лобанова, а тем, что эту цитату дал тот, кто собственно и публиковал перевод Чеславского, - сам Измайлов.

Предполагаемое участие Измайлова в написании статьи «О переводах» позволяет объяснить и следующий случай: для иллюстрации правила «мысль Автора должна быть выражена так, чтобы казавшееся в ней белым, в переводе казалось черным» $(1$, 56), приводится, с параллельным латинским текстом, действительно довольно темная фраза «Воскрес Атрид и мстит за смерть свою Орестом (Aut Agamemnonius, scenis agitatus Orestes)» $(1,56)$. Она взята из трагедии к 1822 году забытого драматурга А. Н. Грузинцева ${ }^{30}$ «Электра и Орест» (СПб., 1810, постановка 1809), вернее, даже не из самого драматического текста - это отдельная фраза из «Энеиды» Вергилия (IV, 471), которую Грузинцев приводит в примечании в собственном переводе и с параллельным латинским текстом, ${ }^{31}$ - точно как цитирует ее Житель. Почему Житель вспомнил эту случайную цитату, помещенную в издании плохой пьесы десятилетней давности уже умершего драматурга?

Неблестящая трагедия Грузинцева была в свое время предметом насмешек, ${ }^{32}$ заключительным выступлением стала откровенно издевательская реплика А. Ф. Воейкова, который, в частности, привел эту фразу из Вергилия, переведенную Грузинцевым

25 Там же. 1822. Ч. 18. № 14. С. 12-26 (подп. И. Ис-въ). О традиции переводить отдельно фрагмент «Рассказ Терамена», начиная с перевода А. П. Сумарокова в 1756 году, см.: Делин А. О. 1) Перевод рассказа Терамена из трагедии Ж. Расина «Федра" и оригинальное творчество Г. Р. Державина // XVIII век. СПб., 2008. Сб. 25. С. 159; 2) Рассказ Терамена в переводе Гнедича // Из истории русской переводной художественной литературы первой четверти XIX века: Сб. статей и материалов. СПб., 2017. С. 285-291.

26 Вестник Европы. 1822. Ч. 122. № 3. С. 180-183 (подп. Псрвъ). Критик «Благонамеренного», в частности, предпочитает буквальный, стих в стих, перевод В. Г. Анастасевича (1805), однако же называет его «рабским»: «Они лучше по крайней мере тем, что в них соблюдена бо́льшая точность: те же почти слова, что в подлиннике. Однако же каковы они в сравнении с ним?... Что же значит и рабский перевод слов?» (Благонамеренный. 1822. Ч. 18. № 14. С. 24).

27 Замечания на новый перевод Федры // Вестник Европы. 1822. Ч. 122. № 8. С. 290-298 (подп. П.с.р. въ).

28 Там же. С. 290.

29 Окулов, в частности, замечает превосходство перевода Чеславского (Благонамеренный. 1821. № 7 и 8) в передаче «известного звукоподражательного стиха Расина» «Se croupe se recourbe en replies tortueux». У Лобанова: «Вращая ошибом, крутился, прядал он...» (ср. прим. 18 наст. статьи) - Чеславский «перевел гораздо лучше и ближе к подлиннику: Сгибаясь и горбясь, влачит змиеподобный, / Вья в кольцы ошиб свой...» (Там же. 1823. Ч. 23. № 13. С. 50).

30 В биографическом словаре «Русские писатели. 1800-1917» дата его смерти дается приблизительно: «не ранее мая 1819, не позднее 1821» (Русские писатели. 1800-1917. М., 1992. Т. 2. С. 51 ; статья А. А. Ильина-Томича).

31 Электра и Орест. Трагедия в 5 действиях Александра Грузинцова. СПб., 1810. С. 20.

32 В основном из-за неумеренных похвал, которые расточали ей сам драматург и его издатель А. А. Шаховской, см.: Цветник. 1809. Ч. 4. № 11. С. 255-263; 1810. Ч. 7. № 8. С. 298-315; Вестник Европы. 1811. Ч. 56. № 7. С. 205-222; № 9. С. 32-39. 
неверно (по словам Воейкова, она означает просто «или Агамемнонов на сцене мучимый Орест»), как свидетельство того, что драматург «не знает по-латински, худо знает по-гречески и подражал не греческому трагику, но французскому», ${ }^{33}$ т. е. не Софоклу, а Вольтеру. Житель, вероятно, взял эту случайную фразу не из издания пьесы, а из критической статьи Воейкова, которую ему теперь, более десяти лет спустя, мог напомнить либо сам Воейков (что, впрочем, мало вероятно, поскольку далее в статье «О переводах» критикуется перевод Воейковым «Георгик» Вергилия), либо, скорее, Измайлов, который издавал в свое время «Цветник», где в 1809-1810 годах разворачивалась основная часть полемики об «Электре и Оресте». ${ }^{34}$

Один из явных bête-noir Жителя - Н. И. Гнедич: его переводы цитируются четырежды - один раз из «Илиады» и трижды из расиновой «Андромахи». Цитата из второй песни «Илиады» в переводе Гнедича, напечатанной еще в 1816 году, выбрана из множества публиковавшихся в 1813-1819 годах фрагментов, кажется, совершенно произвольно, и критическим курсивом в ней выделены два вполне обычных выражения:

$$
\begin{aligned}
& \ldots \ldots \ldots \ldots \ldots \ldots \ldots \ldots \ldots \text {. } \\
& \text { Как семейства пчелиные, вставши густыми роями, } \\
& \text { Идут от горных пещер и растущие купа за купой, } \\
& \text { В образе гроздий златых по цветам благовонным виются } \\
& <\ldots .> \\
& \text { К сонму спеша; и Молва меж толпами их, Ангел Зевеса, } \\
& \text { Мчалась пылкая... }
\end{aligned}
$$

«Илиада» помещена в раздел «творческих» переводов, совершенно неподходящий для этого филологически точного труда: в том же 1822 году, что статья «О переводах», в «Сыне отечества» вышел разбор некоего N. N., где перевод Гнедича был скрупулезно сверен с греческим текстом и показано, что это перевод исключительно точный, «почти слово в слово ${ }^{36}-$ понятно, что наш Житель не сравнивал перевод с оригиналом. В цитатах из «Андромахи», которые составляют почти целиком раздел o «переводе-подражании» $(1,62-63)$, также трудно разобрать смысл претензий. ${ }^{37}$

33 Воейков А. Ответ господину М. С. на его возражения // Вестник Европы. 1811. № 9. С. 4849. Ср. также упоминание Грузинцева в «Доме сумасшедших» Воейкова (уже в ранней редакции 1811-1817 годов): «Вот Грузинцев! Он в короне / И в сандалиях, как царь, / Горд в мишурном он хитоне. / Держит греческий букварь. / „Верно, ваше сочиненье?“ - / Скромно задал я вопрос. / „Нет, Софоклово творенье“, - отвечал он, вздернув нос» .

${ }^{34}$ См. прим. 32.

35 Сын отечества. 1816. Ч. 31. № 27. С. 22. Одно выражение, действительно не совсем удачное, «ангел Зевеса», в окончательном варианте было заменено на "вестница Зевса» (ср.: «Слово „ангел“ здесь, конечно, крайне неуместно: не всякому из русских читателей известное в своем исходном греческом значении («вестник»), оно вызывало совершенно негомеровские религиозные представления и зрительные образы, подсказанные церковной живописью" (Егунов А. Н. Гомер в русских переводах XVIII-XIX веков. М., 2001. С. 207)); второе же, «купа за купой» (в окончательном варианте «за купою новая купа»), вполне нормативно: помимо распространенного «купа дерев», А. Бестужев-Марлинский в «Письмах из Дагестана» (1831) использует выражение «купа всадников», В. М. Головин в «Путешествии вокруг света...» (1822) пишет о «купе островов» .

${ }^{36} N$. N. Некоторые замечания на отрывок из пятой песни Илиады, напечатанной в 45 № Сына отечества // Сын отечества. 1822. № 51. С. 229-237.

37 Перевод Гнедича из «Андромахи» опубл.: Сын отечества. 1820. Ч. 65. С. 31-38; смысл критических курсивов в цитате из него Жителя трудно объяснить: «Ты в старца меч вонзя, искал в сей жертве бед / Оставшейся крови, залерзнувшей от лет; / Ты залил кровию пылающую Трою; / Ты Поликсену сал разбойника рукою / Зарезав, ненависть во всех к себе вселил»; «Изменой сам тебе служу я, может быть»; «Зачем ты не прочел души моей смятенной?»; «Люблю неверного; что ж если б был ты верен? / И в миг, в сей даже миг, как ты, коварствол черен, / Спокойно произнес мой жребий роковой; / Злодей, колеблюсь я, ты не любим ли мной. - / Но Государь...» $(1,62-63)$. Ряд переводов Гнедича начинается с цитаты из перевода Мерзляковым «Освобожденного Иерусалима» $(1,62)$, однако возникает подозрение, что это случилось по ошибке, вызванной тем, что у Мерзлякова фигурирует «старец» («Там, старца по словам, явился вождь надежный»), как и в следующем примере из «Андромахи» («Ты в старца меч вонзя <...>»). 
Такая настойчивая нелюбовь критика к Гнедичу, при отсутствии собственно переводоведческих мотивировок, дала В. Г. Базанову основания предположить, что автором статьи «О переводах» был сам издатель «Благонамеренного» и направлена она была прежде всего против Гнедича: «...Измайлов напечатал статью „О переводах“, где пытался обесславить переводы Гнедича из „Илиады“, назвав самого Гнедича „великим переводчиком бумаги“», ${ }^{38}$ а поводом, вероятно, было известное выступление Гнедича на собрании ВОЛРС 13 июня 1821 года, воспринятое как противовес позиции В. Н. Каразина и А. Е. Измайлова и принесшее Гнедичу высокое положение в Обществе и вражду «измайловцев». ${ }^{39}$ Последнее действительно объясняет, вероятно, нелюбовь Жителя к Гнедичу и дает основание предполагать, что критик был ангажирован внутренними конфликтами ВОЛРС, однако статья «О переводах» не сводится к критике Гнедича ( «великим переводчиком бумаги» назван отнюдь не только и не собственно Гнедич, а «арзамасские гуси»). Отметим также, что Измайлов в эти годы был жителем не Выборгской стороны, а Песков, о чем регулярно упоминал, делая этот бытовой факт литературным, ср. в его (сделанном, по обыкновению, некстати) примечании к статье другого автора, где критиковалось выражение «На песках» вместо "на песке»: «...песками называется какое-нибудь целое пространство - место, наполнено песком, например: <...> пески здесь в Петербурге*» - «*Где живет Издатель Благонамеренного. Прим. Изд.»;40 с удовольствием им приводимую «очень удачную пародию из Дунканова вечера», сочиненную Дельвигом: «На рассвете поднявшись, извозчика взял / Александр Ефимоч с Песков...» ${ }^{41}$ и проч.

В разделе «творческих» переводов для иллюстрации правила о том, что «более всего должно избегать ясности <...>. Переводчик-творец есть Сфинкс, которого чудесных загадок не всякой Эдип понять в состоянии» $(1,59-60)$, приводятся один пример из стихотворения Жуковского «Желание» - перевода «Sehnsucht» («Томление») Шиллера, и два - из «Ольги» Катенина (вольного перевода «Леноры» Бюргера), в которых, впрочем, нет ничего загадочно-непонятного. ${ }^{42}$ Приходится предположить, что упоминание Жуковского ${ }^{43}$ и Катенина ${ }^{44}$ сводится просто к разметке литературного

38 Базанов В. Г. Ученая республика. М.; Л., 1964. С. 237.

39 Там же. С. 230-238.

40 Благонамеренный. Ч. 23. № 13. С. 60.

41 Цит. по: Левкович Я. Л. Литературная и общественная жизнь пушкинской поры в письмах А. Е. Измайлова к П. Л. Яковлеву // Пушкин: Исследования и материалы. Л., 1978. Т. 8. С. 167; ср.: Там же. С. 159.

42 В обоих случаях конкретные претензии критика неясны: во фразе из перевода Жћуковского (опубл.: Вестник Европы. 1813. Ч. 68. № 7-8. С. 197): «Верь тому, что сердце скажет: / Нет залогов от Небес! / Нам лишь чудо путь покажет / В сей (?) прелестный край чудес» $(1,59)$ - почему-то выделено местоимение «сей», совершенно нормативное в ту эпоху. В цитатах из Катенина: «Прости, Господи! несчастной, / В суд с безулной не входи; / Разум, слову непричастной, / От греха ты отведи!», «Так! упоеннолу / В гордой мечте его <...> Мрамором светится / Дом беззаботного» (впервые: Вестник Европы. 1816. № 9. С. 16; испр. вариант: Сын отечества. 1816. № 24. С. 187), - отмечены курсивом субстантивированные прилагательные ( ббезумная», «упоенный», «беззаботный»), действительно несколько избыточные, но отнюдь не загадочные.

43 По мнению, выраженному, в частности, О. М. Сомовым, у Жћковского «все немецкое, кроме букв и слов» (Житель Галерной Гавани. Ответ на (так названный) ответ Господина Ф. Б. ... жителю Галерной Гавани // Невский зритель. 1821. Ч. 5. № 3. С. 278), «немецко-русскую» балладу Жуковского «Рыбак» Сомов уподоблял «Тилемахиде» и предлагал поместить в «шкаф Литтературных редкостей» (Житель Галерной Гавани. Письмо к г. Марлинскому. С. 58). А. А. Бестужев упрекал переводчика в том, что тот «дал многим из своих творений германский колорит, сходящий иногда в мистику, и вообще наклонность к чудесному» (Бестужев А. Взгляд на старую и новую словесность в России [1823] // Полярная Звезда, изданная А. Бестужевым и К. Рылеевым / Изд. подг. В. А. Архипов, В. Г. Базанов и Я. Л. Левкович. М.; Л., 1960. С. 20 (сер. «Литературные памятники»)). По словам Цертелева, Жуковского «можно было бы назвать даже классиком, если бы он - особливо в последних своих сочинениях — дорожил более языком и предавался менее таинственным мечтаниям» в немецком духе (Житель Васильевского Острова. Спор (отрывок из моего Журнала) // Благонамеренный. 1820. Ч. 9. № 6. С. 397).

44 О полемике 1822 года Катенина с Сомовым о языке в связи с октавой; с Бестужевым, Гречем и Сомовым по поводу «Опыта краткой истории русской литературы» Греча, а также о резкой 
«поля боя», где на «противной» стороне - Гнедич, Мерзляков, Жуковский, Катенин, Жандр (а также случайно, кажется, сюда присоединенные Чеславский и Грузинцев) вместе с Тредиаковским как знаком их принадлежности $\mathrm{k}$ «литературной кунсткамере». «Положительная» позиция Ж ителя менее определенна: он явно выступает в интересах «Благонамеренного» и, вероятно, пользуется полученными от А. Е. Измайлова примерами, ориентирован на ВОЛРС с его внутренними разделениями 1819 1820 годов, вызванными выступлением В. Н. Каразина. ${ }^{45}$

Разобранная нами часть статьи, посвященная «творческим» переводам и «переводам-подражаниям», вся помещена в одном номере «Благонамеренного» и составляет самую содержательную из трех частей этого сочинения. Две другие части, напечатанные в следующих номерах журнала, отведены рассмотрению «переводов рабских", которым критик дает довольно удачную характеристику: «Перевод рабский есть $<\ldots>$ верный сколок подлинника. $<\ldots>$ Здесь я $<\ldots>$ говорю $<\ldots>$ в особенности о тех (случаях. - M. Б., А. В.), коих введением переводчик обогащает нашу словесность» $(2,81){ }^{46}$

Житель делит их «по языкам, с которых они взяты» $(1,51)$, начиная с латинского и греческого, а именно: А. Г. Огинского (переводы «Войны мышей и лягушек» ${ }^{47}$ и Первой олинфской речи Демосфена ${ }^{48}$ ), Я. В. Толмачева (перевод «Панегирика Траяну» Плиния Младшего ${ }^{49}$ ) и А. Ф. Воейкова ( «Георгики» Вергилия $\left.{ }^{50}\right)$. Предметом критических выпадов автора статьи в данном случае становятся не только и не столько переводы как таковые, сколько принципы, продекларированные переводчиками: так, Огинский в предисловии к переводу «Батрахомиомахии» довольно пространно излагает установки, которыми он руководствовался в работе, и, вероятно, это обстоятельство в известной мере послужило причиной обращения критика к тексту десятилетней давности (впрочем, литературная активность Огинского продолжалась и во время, и много после выхода статьи, до середины 1830-х годов): «Переводя в прозе с еллинского языка на славено-русский, выражения и красоты подлинника в точности сохранить можно. Сие доказывает перевод книг церковных. Сохранять в точности выражения подлинника должно тогда, когда он, по мнению веков, сделался образцовым. Кто же вящее на сие стяжал право, как не бессмертный Омир?

Что-либо в нем переменить, прибавить или убавить значило бы дерзко нарушать должное к нему уважение, тем более что славено-русский язык совершенно соответствен еллинскому в выразительности, обилии и многих других свойствах. В сем переводчик обретает для себя новые силы, новое ободрение, новые побуждения, восхищаясь языка своего совершенствами, которые он усматривает в языке Омировом!!!

Желая перевод мой сделать во многих отношениях полезнейшим, в особенности же для обучающихся еллинскому языку, я старался сохранить, где только возможно было, даже расположение слов подлинника.

критике Бестужевым его переводов и оригинальных стихотворений см.: Мордовченко Н. И. Русская критика первой четверти XIX века. М.; Л., 1959. С. 318-325, 333-337.

45 См.: Базанов В. Г. Ученая республика. С. 119-134.

46 Также довольно удачны и частные, хотя и иронически поданные «правила»: все слова должны быть «на тех же самых местах, как они находятся в подлиннике» $(2,82)$; «сколь бы длинен ни был период подлинника, переводчик не должен сокращать или разделять его, но стараться слово в слово передать его на нашем языке. Он не заботится о том, что некоторые читатели будут жаловаться на запутанность и безпонятность его перевода» $(2,82-83)$, «выражения подлинника, которых по свойству нашего языка у нас еще не было, чрез буквальный перевод оных, должны сделаться нашею собственностию» $(2,83)$

47 Омирова брань лягушек и мышей / Пер. с греч. Алексей Огинский. СПб., 1812.

48 Первая Олинфийская речь Демосфена, переведенная г. Огинским // Дух журналов. 1817.

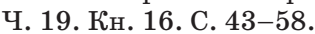

49 Похвальное слово императору Траяну. Сочинение младшего Плиния, переведенное с латинского ординарным профессором Императорского Санкт-Петербургского университета Яковом Толмачевым. СПб., 1820.

50 Отрывок из второй песни Виргилиевых Георгик / [Пер.] Александр Воейков // Труды Казанского Общества любителей отечественной словесности. Казань, 1815. Кн. 1. С. 263-267. 
Нужно ли было мне иметь сие в виду, зная, что некоторые слова и выражения покажутся, быть может, неприятными слуху, неприобыкшему к славено-русскому языку, предаю на суд знатоков, истинно и с толикою пользою пекущихся о поддержании достоинств русского слова, коих чужды многие европейские языки» ${ }^{51}$

Излагая свою позицию, Огинский заблаговременно признает возможность критических нападок, что, пожалуй, несколько ослабляет остроту высказываний Жителя Выборгской стороны, который, в сущности, выстраивает свой разбор «рабских переводов» не столько на анализе текстов, сколько на пародировании переводческих принципов, выдвинутых Огинским; формулируя «правила», по которым выполняются «рабские переводы», он пересказывает мысли, весьма созвучные тем, что приведены в процитированном выше отрывке, сопровождая их издевательскими пуантами. Первые параграфы этих «правил» выглядят вполне серьезно, под ними мог бы подписаться тот же Огинский или Толмачев:

«§ 1. Всякое предложение должно быть составлено таким образом, чтобы все слова были на тех же самых местах, как они находятся в подлиннике; а по сему

$\S 2$. Все обороты, приличные языку, на котором писан подлинник, должны быть удержаны в переводе» $(2,82$; ср. вышеприведенное высказывание Огинского: «...я старался сохранить, где только возможно было, даже расположение слов подлинника»).

Но уже следующий параграф критик заключает критической остротой: «§ 3. Сколь бы длинен ни был период подлинника, переводчик не должен сокращать или разделять его, но стараться слово в слово передать его на нашем языке. Он не заботится о том, что некоторые читатели будут жаловаться на запутанность и безпонятность его перевода» $(2,82-83)$.

Перечисленные три пункта Житель Выборгской стороны иллюстрирует двумя цитатами из «Первой олинфийской речи Демосфена» в переводе Огинского, выбранными, как представляется, совершенно произвольно: в них никак не обозначены ни якобы сохраненные в переводе «обороты, приличные языку, на котором писан подлинник», ни случаи, подтверждающие стремление переводчика соблюсти порядок слов и построение периодов оригинала; с точно таким же успехом критик мог бы поменять приведенные примеры местами или же использовать в доказательство своих суждений другие фрагменты. Впрочем, ниже, приводя выдержки из «Брани лягушек и мышей», критик выделяет курсивом ряд слов и выражений, которые, очевидно, вызвали у него нарекания сами по себе, без сопоставления с подлинником: «Плесницы во-первых на ноги свои возложили, сокрушив бобы зеленые и славно их уготовав... Щит свечная светильня (?), копия долгие иглы, все медяное дело рук Арея; шлем скорлупа орехов» $(2,84)$.

Этим фрагментом он иллюстрирует следующее «правило»: «§ 4. Выражения подлинника, которых по свойству нашего языка, у нас еще не было, чрез буквальный перевод оных должны сделаться нашею собственностию» $(2,83)$; однако едва ли выделенные слова и словосочетания могут служить примерами подобных переводческих

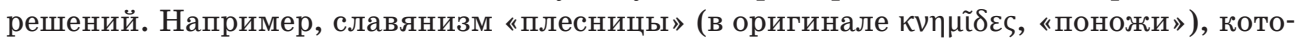
рым впоследствии неоднократно пользовался Гнедич в переводе «Илиады», невнятная тавтология «свечная светильня» и множественное число в словосочетании «скорлупа орехов», вероятнее всего, смутили критика сами по себе, без сопоставления с подлинником. На слабое знание им гомеровской традиции (пародируемой в поэме)

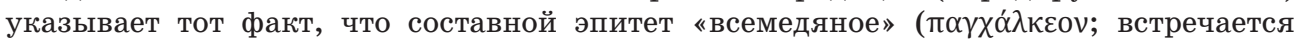
и в гомеровских поэмах, в частности: Одиссея, VIII, 403; в переводе В. А. Жуковского - «целомедный») из перевода Огинского в цитате разбит на два слова: «все медяное»; по той же причине критик осмеивает не вполне удачную, но довольно смелую и заслуживающую внимания попытку Огинского воспроизвести составные эпитеты, в данном случае уже открыто пародийные по отношению к Гомеру (впрочем, в переводе пародийное звучание они приобрели скорее помимо воли переводчика): «Исходят внезапно холмоспинные, кривоклешние, косошествующие, согбенные, остроустные,

51 Омирова брань лягушек и мышей. С. 6-8. 
черепокожные, костеродные, широкохребетные, раменоблестящие, выдутоикрые, крепкожилые, свирепоглядые, осьмоногие, двуглавые, безрукие, по имени Раки» $(2$, 84-85).

В предваряющей эту цитату реплике критик издевательски именует метод воспроизведения составных эпитетов «словошвением», а саму работу Огинского характеризует как «еллино-славяно-росский перевод», обыгрывая неоднократно употребляемый самим Огинским термин «славяно-российский язык». ${ }^{52}$

Если знакомство критика с древнегреческим языком и литературой вызывает небезосновательные сомнения, то в области латинского языка и словесности он выказывает несколько большую осведомленность. Подразделяя «рабских переводчиков» с классических языков на «еллино-греков» и «латинян», первых он характеризует довольно общими словами как «удерживающих древние красоты греческого языка» $(2$, 89), тогда как вторых описывает значительно пространнее, говоря, что они «соблюдают иногда краткость и силу Горациев и Тацитов, иногда же пышность и плодовитость Цицеронов и Плиниев, заставляя сих великих писателей говорить по-русски слово в слово то, что они говорили по-латине» $(2,90)$. В приведенном пассаже критик обнаруживает определенное знакомство с особенностями стиля некоторых римских авторов; упоминание же именно этих авторов можно расценивать как выпад в сторону их переводчиков, при этом основной мишенью становится, вероятно, профессор Петербургского университета Я. В. Толмачев, перу которого принадлежат переводы почти из всех перечисленных писателей (кроме Горация), появлявшиеся в «Журнале древней и новой словесности» в 1818-1819 годах. Пространные, на две с лишним страницы выдержки из «Панегирика Траяну» в его переводе ЖКитель Выборгской стороны приводит в качестве образчика творчества переводчиков-латинян; при этом он осуществляет некоторое сопоставление перевода с подлинником: помещает в подстрочных примечаниях соответствующие фрагменты оригинала и тем самым, вероятно, пытается нагляднее показать, сколь «рабски» переводчик воспроизводит грамматический и синтаксический строй подлинника, рискуя сбиться в невнятицу. Впрочем, в иных случаях (помимо воли критика) доказывается совсем противоположное; например, отметив фразу: «Сам же ты с каким дружеством встречаешь, с каким (?) ожидаешь всех», - критик приводит ее в оригинале: «Ipse autem, ut excipis omnes! ut expectas!» $(3,98)$; из сравнения видно, что причиной столь неуклюжего и маловразумительного перевода стало стремление переводчика не соблюсти дословную точность, а, напротив, истолковать, прояснить это место. В других местах критик просто выделяет некоторые выражения из перевода Толмачева курсивом, не предлагая сличить их с оригиналом (как при разборе перевода Огинского). Выпады Жћителя именно против Толмачева представляются неслучайными; их объектом вновь становится текст, уже вызывавший критические отзывы. Довольно нелицеприятная рецензия на только что опубликованный «Панегирик Траяну» в переводе Толмачева была помещена в «Сыне отечества» (еще за два года до статьи в «Благонамеренном»); претензии, предъявленные Толмачеву в данной рецензии, вероятно, и послужили поводом для Жителя Выборгской стороны включить его работу в свой разбор: «В сем переводе находим мы многие выражения, не родившиеся в русском языке, но перенесенные в него переводами с латинского, выражения, которые, наравне с германизмами и пр., никогда не найдут у нас права гражданства. Сверх того останавливала нас на каждой странице латинская конструкция, противная русскому чувству и слуху» ${ }^{53}$ (ср. у Жителя: «...3аставляя сих великих писателей говорить по-русски слово в слово то, что они говорили по-латине»).

52 Впоследствии сам Огинский вошел в число авторов «Благонамеренного», поместив в журнале переводы из Гесиода (Пять веков героических / (Отрывок из Гезиодовой поэмы: Работы и дни); с греческого А. Огинский // Благонамеренный. 1824. Ч. 26. № 7. С. 37-42) и Цицерона (Письмо Цицерона: Книга II, письмо 8 / С лат. А. Огинский // Там же. № 12. С. 406-410); оба они выполнены значительно более ясным и удобочитаемым языком, и не исключено, что в этом определенную благотворную роль сыграла критика Жителя Выборгской стороны; впрочем, столь же вероятно, что сказалась переводческая эволюция самого Огинского.

${ }^{53}$ Сын отечества. 1820. Ч. 63. № 27. С. 38. 
Еще одним переводчиком с латинского, вызвавшим нападки Жћителя Выборгской стороны, стал А. Ф. Воейков, работавший над «Георгиками» Вергилия. Критик останавливается не на каком-либо из многочисленных фрагментов «Георгик», появлявшихся в «Вестнике Европы», а на единичной публикации отрывка II книги поэмы в «Трудах Казанского Общества любителей отечественной словесности»;54 создается впечатление, что объектом своих нападок критик намеренно стремится сделать как можно менее заметное издание (хорошо известное, впрочем, членам столичного отделения этого общества ${ }^{55}$ ). Перевод, который критикует Житель, был выполнен Воейковым еще в 1812 году:

Семени, павшу на зеллю, оно разверзается тихо,

Внуков наших покрыть обещая тенью своею,

Яблонь от семени взросшая, скоро приятные свойства

Позабывает, и сладких плодов, одичав, не приносит...

$(3,98-99)$

В первом случае критика явно смущает дательный самостоятельный, который, вероятнее всего, воспринимается им как откровенный славянизм (над которыми Житель уже иронизировал); вторая претензия, очевидно, связана с тем, что переводчик не сохраняет употребленный в оригинале страдательный залог, т. е. как раз-таки отходит от буквы подлинника, не допуская при этом значительных смысловых искажений. Сличение приведенного фрагмента с помещенным в сноске оригиналом едва ли позволяет говорить о Воейкове как о "рабском переводчике»: он не пытается воспроизвести латинский текст дословно и калькировать синтаксис, напротив - старается прояснить текст в своем переводе, который из-за этого разрастается по сравнению с оригиналом. Вероятно, причиной причисления Воейкова к «рабским переводчикам», как и в случае с Огинским, послужило то обстоятельство, что он сам же продекларировал собственные переводческие принципы; еще в 1812 году, в статье «Об описательных и дидактических поэмах и в особенности о Виргилиевых Георгиках» он писал: «Утвердительно сказать можно, что переводы знаменитых писателей более самых сочинений приносят языку пользы. Они, сближая нас с понятиями других народов, знакомят с способом выражать их, и нечувствительно переносят в наш язык тысячу оборотов, картин, выражений, которые прежде казались ему чуждыми, но которые, сближаясь по сходству, сперва делаются терпимы, а потом красоту составляют. Те, кои пишут на своем языке, употребляют обороты и выражения уже принятые, бросают свои идеи в старые и часто даже стертые от времени формы. Писать на своем языке значит, если смею так выразиться, истощать собственное сокровище; переводить значит обогащаться сокровищами чуждыми». ${ }^{56}$

Эта же статья была перепечатана в 1821 году в «Сыне отечества» (Ч. 72. № 36) и предваряла пространный, на несколько номеров выполненный тем же Воейковым «Разбор Виргилиевой поэмы „Георгики или о земледелии“, переведенной с латинского на российский язык г. Раичем»; схожие мысли о буквальном переводе содержатся и в самом «Разборе...»: «...надобно сражаться и победить язык и заставить его принять тысячу выражений и оборотов, кои до тех пор его пугали». ${ }^{57}$

В связи с переводами античных классиков Житель также высказывается против перевода «размером подлинника», впадая, впрочем, в гиперболизацию: «Тщательный

54 Труды Казанского Общества любителей отечественной словесности. Казань, 1815. Ч. 1. С. 265. Благодарим за указание на источник цитаты А. Ю. Балакина.

55 Отметим также, предвосхищая высказываемое нами в конце статьи предположение об авторстве статьи о переводах, что членом Казанского Общества любителей отечественной словесности был с 1818 года Б. М. Федоров, см. статью о нем А. А. Костина в словаре «Русские писатели. 1800-1917»: Т. 6. С. 413.

56 Труды Общества любителей российской словесности при Императорском Московском университете. 1812 . Ч. 3. Кн. 5. С. 260.

${ }^{57}$ Сын отечества. 1821. Ч. 72. № 36. С. 260. 
переводчик должен сохранить не только все меры стихов и всякое слово подлинника на том же самом месте, но даже и звуки каждого слова. <...> У нас сим достоинством отличаются многие отрывки из Гомера и Виргилия, переведенные размером подлинников» (2, 87-88). Выступление Жителя против гекзаметра как такового представляется достаточно архаичным: к началу 1820-х годов этот размер вошел в русскую поэзию довольно прочно, о чем свидетельствует, в частности, напечатанное в «Благонамеренном» в том же 1822 году «Письмо к издателю „Благонамеренного“» (за подписью N. N.), в котором критикуется статья о гекзаметре из «Словаря древней и новой поэзии» Н. Ф. Остолопова. Автор «Письма...» предполагает, что эта статья основана на «Замечаниях на опыт о русском стихосложении г-на В<остокова>» Н. И. Гнедича, опубликованных в «Вестнике Европы» в 1818 году; при этом к самому Гнедичу критик относится с исключительным пиететом, и правомерность использования гекзаметра в русской поэзии вопросов у него не вызывает. Главным предметом нападок Жителя становится Воейков - именно из «Выписки из рассуждения А. Ф. Воейкова», входящего в состав статьи из словаря Остолопова, заимствованы все примеры, обнаруживающие излишнюю близость с «Замечаниями...» Гнедича. N. N. открыто ставит под сомнение владение Воейкова классическими языками: «Но переводя Эклоги и Георгики Виргилиевы из Дефонтеня (я не говорю уже о Греческом языке), по какому праву можно присвоить себе замечание, при коем опытное и основательное познание древних языков и поэзии есть условие необходимое? „ ${ }^{58}$ Столь же пренебрежительно отзывается он и о стихотворческом искусстве Воейкова, ставя его на один уровень с Тредиаковским: «Не видим ли мы в Тилемахиде и в экзаметрическом переводе Виргилиевых Георгик, что и самый экзаметр под пером неискусным делается нескладен, вял, груб и сжат? "59 Вполне вероятно, что «Письмо...» не в последнюю очередь послужило для Жиителя Выборгской стороны поводом к нападкам на Воейкова.

В гуще «рабских» переводов с латинского и греческого встречаются совершенно неожиданные примеры: рядом с цитатами из «Батрахомиомахии» приводятся выдержки из напечатанной «иждивением переводчика» брошюры «Прогулки девицы $\mathrm{M}^{* * *}$ Кр. ${ }^{* * * *}$ ныне г-жи Ск..., или Окрестности города Вильна» (СПб., 1808), перевод «с французской рукописи ея» В. Г. Анастасевича, - чувствительного описания Вильно со всеми приличными жанру меланхолическими мотивами сельского уединения, руины, заброшенного кладбища и проч. Причем из этой крохотной книжки приводится целых шесть цитат $(2,83-84,85,87)$, где в выделенных критиком курсивом словах и фразах нет совершенно ничего особенного. ${ }^{60}$ Приходится предположить, что эта разительно неуместная и почти не опознаваемая для читателя атака на Анастасевича адресована лично ему и его кругу и вызвана тем, что Анастасевич как член ВОЛРС играл в 1820 году значительную роль в конфликте вокруг В. Н. Каразина. ${ }^{61}$

Также находящаяся внутри раздела латинских переводов критика «некоторых ученых систематиков», которые «употребляют и вводят в Российской язык иностранные слова и выражения, как то: анализировать идеи; абсолютная идея; рефлекс, отражающийся на абсолютной идее; рефлекс, не отражающийся на абсолютной идее;

58 Благонамеренный. 1822. Ч. 18. № 16. С. 91.

59 Там же. С. 90.

60 «Блистает там юный вертоград, где любезнейшая наука расположена искать доказательств в чашке розы или в стебле мирты... там растения, цветы всех стран, сочетавая свои краски, запахи, наполняют благовонием воздух, чаруют взор и своим кратко-дневным существованием приводят нам на мысль скудельность собственного нашего жребия», «На другом конце города, на час пути отстоит селение тел прелестнее, что оно кажется отделено от всего све$m a »(2,83-84)$; «Гора, на коей воздвигнуты сии палаты, возвышается кругозорол (амфитеатром), увенчанным разными деревьями, которых зеленый верх качают ветры» $(2,85)$; «Истинная $n y m$ лянка (лабиринт), в коей столь приятно запутаться!» $(2,85)$, «Но где кончится сия прогулка, коея удовольствие не допускает утомиться? Увы! На неизбежнол праге утех и горестей», «Взойдем на сию гору, владычествующую над городом» $(2,87)$. См.: Прогулки девицы $\mathrm{M}^{* *}$ Кр. ${ }^{* * *}$ ныне г-жи Ск..., или Окрестности города Вильна. Перевод с франц. рукописи ея В. Анч. СПб., 1908. C. $5,6,8-9,11,12$.

${ }^{61}$ См.: Базанов В. Г. Ученая республика (по указ.). 
контрактивный полюс магнитной линии; экспансивная сторона электрического круга» и т. д. $(2,86)$, состоит в пространной выписке, начало которой нами процитировано, из натурфилософского сочинения одного из первых русских шеллингианцев Д. М. Велланского «Биологическое исследование природы в творящем и творимом ее качестве, содержащее основные начертания всеобщей физиологии» (СПб., 1812). ${ }^{62}$ В своем пафосе отрицания заимствованных слов критик следует известному мнению А. С. Шишкова о том, что нужно не пользоваться латинской научной номенклатурой иностранных языков, а производить необходимые понятия из корней русского языка: вместо «квадрат» или «экватор» писать «уравнитель», вместо «арифметика» - «числительница» и проч. ${ }^{63}$

Третья, заключительная, часть статьи вышла только спустя несколько месяцев и номеров «Благонамеренного», в марте 1823 года. В ней, завершив двумя пространными приведенными выше цитатами из Толмачева и Воейкова раздел о «рабских» античных переводах $(3,97-99)$, критик переходит к «рабским» переводчикам с новых языков.

Он начинает с «галлоланов», которые «пишут по-русски так, как в блестящем кругу света говорят наши модники и модницы, то есть: удерживая фразологию и вмешивая иногда слова и выражения единственного, несравненного Французскаго языка. Иногда, не вразумев смысл подлинника, или поняв его не так, как понимал сочинитель, они, так сказать, передразнивают сего последнего на Русском языке, что составляет особое украшение их слога, известное вообще под названием галиматьи» $(3$, 99). В качестве иллюстрации галломанской «галиматьи» (расхожего определения нового слога ${ }^{64}$ ) критик приводит десяток разнородных, но почему-то последовательно пронумерованных цитат, все, что для него нехарактерно, с параллельными французскими пассажами. Первые две - совершенно, кажется, для читателя-современника неопознаваемые: «Сей последний был худ и бледен жалким образол; но его физиономия и черты лица обнаруживали большой уж», «Она имела к слову: гений, и к требованию на оный такое отвращение, которое доходило до ужаса» $(1,99-100),-$ из опубликованного без указания имени автора сентиментального нравоучительного английского романа «Лудовик, или Сын человека с гением» («The Son of a Genius», 1812), переведенного с французского перевода-посредника ${ }^{65}$ князем Шаликовым

62 Благодарим Д. В. Кузьмина за указание на источник цитаты. Новые для России умозрительная философия и терминология Велланского, как в этой книге, так и в его диссертации «Проклюзия к медицине как основательной науке» (СПб., 1805), уже были неоднократно подвергнуты критике, в том числе в рецензии, помещенной в «Санкт-Петербургском вестнике» (1812. Ч. 2. № 4. С. 78-99, подпись Ф. [И. М. Фовицкий]); эта рецензия и ответное письмо автора книги с возражениями были прочитаны на заседании ВОЛСНХ, соответственно, 16 мая и 13 июня 1812 года, в присутствии, в частности, Измайлова (Архив ВОЛСНХ в НБ СПбГУ. Д. 204. № 21. Л. 181182 об.; № 26. Л. 194-195; см.: http://www.library.spbu.ru/rus/Volsnx/prot/prot12.html; дата обращения: 15.04.2020).

63 Соревнователь просвещения и благотворения. 1821. № 14. С. 100.

${ }^{64} \mathrm{Cp}$. раздел «Прозаическая галиматья (Подражание новейшим Елегическим Поетам)» в «Вестнике Европы» (1822. № 19. С. 231-232), содержавший анонимные пародии (подписанные «У. и А.») на романтическую элегию («Минутный гость на жизненном пути, я вяну! - И веселье не веселит меня! и сердце, больное грустию, дремлет. - Увы и ах! <..> И былое - как пустынная стрела - пролетело! и грядущее - дикий мрак, туманная даль! и в слепой тоске моей я исчезаю, я терзаюсь! Увы и ах!» и проч.); объявление в «Сатирической газете» А. Е. Измайлова в «Благонамеренном»: «В новооткрывшемся галиматическом магазине отдаются напрокат разные первого сорта отборные галиматические выражения, как то: баловень, сладострастие, упоение, чаши, былое... Тут же можно получить также напрокат причастия и существительные имена, совершенно противуположные между собою, например: веющее дыхание, веющий сон, грустящая ночь <...>» (Благонамеренный. 1823. № 3. С. 237). О намеренном культивировании в карамзинистском языке и в «Арзамасе» «галиматьи» см.: Лотлан Ю. М., Успенский Б. А. Споры о языке в начале XIX в. как факт русской культуры («Происшествие в царстве теней, или Судьбина российского языка» - неизвестное сочинение Семена Боброва) // Успенский Б. А. Избр. труды. М., 1994. Т. 2. С. 508 (прим. 39).

${ }^{65}$ Ludovico, ou le fils d'un homme de Génie / Trad. de l'anglais par Madame La Baronne de Montolieu. Vienne, 1817. Автор романа - Барбара Хофленд (Barbara Hofland, 1770-1844). 
(М., 1820. Ч. 1; цит. на с. 4, 20). Претензия Жителя к выделенным им курсивом французским оборотам, калькированным переводчиком («d'une manière pathétique», «découvert un grand esprit»), и галлицизму «гений» («génie»), к двадцатым годам уже вполне вошедшим в состав русского языка, указывает на архаичность его критики: антикарамзинский пафос, направленный против созидания русского языка «на скудном основании французского языка», ${ }^{66}$ Житель в 1823 году переадресует эпигону Карамзина князю Шаликову, таким образом производя ослабленную и совершенно безопасную критику второй степени.

Следующие два примера взяты из комедии в стихах Алексиса Пирона «Метромания, или Страсть к стихотворству» в вольном переводе Н. В. Сушкова $(1820$, поставлена в 1819 году) - вернее, вероятно, из рецензии на нее А. А. Бестужева, где эти цитаты, и тоже с параллельным французским текстом, были приведены именно как пример галлицизмов, ср.:

Житель: «„Пространства и огня вам мало на земли“. Или: „Бедняжка задрожит как мертвый лист" <...> ...N'ayant sur l'horizon: / Ni feu ni lieu qui puisse alonger votre nom» $(3,100)$;

А. А. Бестужев: «В пример галлицизмов предлагаю два стишка: „...n'ayant sur l'horizon / Ni feu ni lieu qui puisse alonger votre nom“, etc. <...>. „Пространства и огня вам мало на земли“. Или: „Бедняжка задрожит тогда, как мертвый лист“. В оригинале вовсе нет сего стиха, но буквальное подражание французскому эпитету: feuillemorte, очень видно». ${ }^{67}$

Последующие несколько цитат $(3,100-101)$ взяты из перевода «Поэтического искусства» Буало Д.И.Хвостовым (озаглавленного им «Наука о стихотворстве», многократно с исправлениями переизданного), отвергнутого Российской Академией и уже безбожно всеми осмеянного. ${ }^{68}$ Атака на Хвостова вызвала неучтенную, кажется, в «хвостовиане» антикритику - письмо «Господину издателю Благонамеренного», подписанное псевдонимом «Константин Нелестюхин». ${ }^{6}$ Письмо посвящено только этому фрагменту статьи Жителя Выборгской стороны о переводе Хвостова и выдержано в характерном для хвостовианы тоне преувеличенных похвал, скрывающих издевательскую критику, адресованных тут Измайлову как издателю «Благонамеренного» и как баснописцу: «Вы, озаряя лучами Критики переводы Классических Авторов $<. .>$. Вы сами Автор, Поэт, Баснописец и знаменитый в своем роде; а Благоналеренный ваш, обогащаемый часто примечаниями вашими, есть венец вашей славы. Забудьте на час о известной скромности вашей, то увидите сами: какое пространное поле вы открыли себе и всем достойным вас подражателям! - Но увы! кто осмелится исполинскими шагами идти за вами к безсмертию?... Так точно; один Благоналеренный будет достопамятными критиками своими сиять тысящи веков на поле Отечественной Словесности! ${ }^{70}$ и проч. Автор антикритики ясно дает понять, что знает о том, что Житель Выборгской стороны - если не сам Измайлов, то его журнальный alter ego, который «для вас (т. е. Измайлова. - M. Б., A. B.) и под эгидою вашею похвально трудится в Благонамеренном». ${ }^{71}$ Измайлов, как известно, издавал свой журнал «по-домашне-

${ }^{66}$ Судя по НКРЯ, Карамзин действительно в 1802-1803 годах маркированно часто употреблял слово «гений», ср. также: «обнаруживать их душу» в его переводе из г-жи Жанлис «Женщина-Автор» (Вестник Европы. 1802. № 20-21; там же: «Гений Тюреня»); у К. Н. Батюшкова: «Ноги и руки жалкил образол высохли и пожелтели» («Прогулка по Москве» [1811-1812], впервые опубл. в «Русском архиве» в 1869 году; курсив наш. - М. Б., А. В.).

67 Сын отечества. 1821. Ч. 67. № 7. С. 314; ср. прим. Бестужева к выделенному им (и Жителем) выражению «мертвый лист»: «буквальное подражание французскому эпитету: feuillemorte, очень видно» (Там же).

68 Поскольку Житель и тут приводит параллельные французские места, что делает обычно, только когда списывает их из чужих рецензий, можно предположить, что критика перевода Хвостова тоже им откуда-то заимствована, но мы пока не обнаружили источник.

69 Благонамеренный. 1823. Ч. 22. № 12. С. 225-234.

70 Там же. С. 226-227.

71 Там же. С. 232. Весьма вероятно, конечно, что защитник Хвостова имел в виду Н. Ф. Остолопова, в эти годы близкого сотрудника «Благонамеренного» и при этом критика басен Хвостова 
му», экономно, практически без помощников, ${ }^{72}$ поэтому нетрудно будет далее сделать предположение, кого тут имел в виду, вероятно, осведомленный защитник графа Хвостова.

Переводчиков «тевтоно-россов и британо-россов» $(3,102)$ критик объединяет в русле известной мысли о немецком и английском влияниях в русском романтизме: «...переводы их имеют между собою какое-то романтическое сродство» $(3,102)$. Однако весь раздел примеров небрежно составлен из пространных, по две страницы, выписок всего из двух (по обыкновению неназванных) переводчиков, совсем молодых и малоизвестных, - двадцатилетнего И. Г. Покровского (переводы из Шиллера, «Перчатка» («Der Handschuh») и «Мать убийца» («Die Kindermörderin»)) ${ }^{73}$ и девятнадцатилетнего В. Н. Григорьева (перевод элегии Ламартина «Вечер» («Le Soir»)). ${ }^{74}$ Кажется, единственная причина упоминания текста Григорьева - в связи с которым критик сам признается, что это перевод не с немецкого и не с английского, «но совершенно в духе Романтической Поэзии, каким отличаются переводы новой школы» $(3,106)-$ то, что он был напечатан в одном номере «Благонамеренного» с переводом Покровского, буквально на соседних страницах, и просто попался критику на глаза. Очевидно, что ни Григорьев, ни Покровский никак не могут представительствовать за «новую», романтическую, школу словесности. ${ }^{75}$

Итак, можно утверждать, что статья Жителя Выборгской стороны «О переводах» составлена из нескольких гетерогенных элементов и имеет мозаичное авторство. Первый и исходный элемент, задающий каркас статьи, - не оригинальная, но вполне рациональная дифференциация типов переводов и иронически сформулированные "правила» для них, а также завершающее наблюдение о протейности переводчика. ${ }^{76}$ Иллюстрирующие эти «правила» цитаты из переводов - второй элемент статьи разительно им неадекватны, собственно критики не содержат и в основном происходят из «Благонамеренного». Наконец, на эту двусоставную структуру навешено в сущности никак с ней не связанное обрамление из вторичных антиромантических выпадов против «арзамасских гусей» и «новой школы» поэзии.

Мы согласны с В. Г. Базановым в том, что одним из авторов статьи, вероятно, был Измайлов, весьма небрежно и поспешно подобравший из запасов своей редакторской памяти цитаты, руководствуясь в основном желанием поместить в «Благонамеренном» заметное, по меньшей мере пространное, высказывание на актуальную тему перевода и придать ему хотя бы внешний характер полемического антиромантического выпада.

Что касается переводоведческого каркаса статьи, то он, как мы предполагаем, принадлежит Б. М. Федорову - деятельному члену ВОЛРС и постоянному автору «Благонамеренного», который 5 июня 1822 года на заседании Общества читал свое сочинение «Несколько слов о переводе и подражании», одобренное и избранное единогласно. ${ }^{77}$ Возможно, именно это сочинение было использовано в качестве основы

(см., в частности: О-в [Остолопов Н. Ф.]. О баснях графа Хвостова // Благонамеренный. 1820. Ч. 10. № 9. C. 176-182).

72 См.: Проскурин О. А. Литературные скандалы пушкинской эпохи. С. 267.

73 Переводы Покровского опубл.: Благонамеренный. 1822. Ч. 17. № 6. С. 238-241; № 7. C. 270-274.

74 Перевод Григорьева опубл.: Там же. С. 275.

75 В цитируемых переводах критик выделяет самые обыкновенные лирические топосы: «<звездочка> на небесах потухших / Затеплилась в таинственнол огне», "В сторожевой покойной тишине», "Украдкой веющий в ветвях», "сирыли гробали», "пришлеи, нежданный», «тайный глас», «надежды милой взгляд», "Дарить меня беседою нелой», «небеса ночные», «сладострастно», «страж убийства» и проч. $(3,106-108)$.

76 «Не всегда переводчик бывает одинаков с начала до конца. Часто, в одном и том же переводе, делается он истинным Протеем, являясь попеременно то творцом, то подражателем, то рабским последователем своего подлинника. Такая пестрота составляет нередко существенное достоинство перевода, показывая читателям, сколь разнообразны способы и дарования переводчика» $(3,109)$.

77 Базанов В. Г. Ученая республика. С. 417. 
статьи «О переводах». Низкий литературный статус «Борьки» Федорова, которого презирал даже Измайлов, и его зависимость от разных «патронов» (в этот период - Измайлова и Цертелева) объясняют разительную ничтожность, неопределенность фигуры имплицитного автора статьи. ${ }^{78}$

Таким образом, статью «О переводах», кажется, следует атрибутировать все же не собственно Цертелеву, как в сборнике «Пушкин в прижизненной критике», а Измайлову, как это сделал Базанов, и, под вопросом, Федорову (вспомним тут характеристику Бестужевым «партии» Цертелева в ВОЛРС: «...у ней голова князь Цертелев, а хвост (тела нет) - Борис Федоров» $\left.{ }^{79}\right)$. Интереснее то, что мы видим тут своеобразный механизм функционирования литературного поля в сфере «романтики» versus «классики», в очередной раз демонстрирующий слишком общий характер этого разделения: знаменитое, программное высказывание Вяземского в его предисловии к «Бахчисарайскому фонтану» оказывается не только post festum интегрировано в полемику с фигурами мелкими и говорящими вздорно и о мелочах, как отвечавший Вяземскому М. А. Дмитриев, т. е. «литературными Мирмидонами», «меньшими братьями в авторстве», ${ }^{80}$ «литтературными Лиллипутами», которые «только тогда получат гражданство Муз, когда издастся известный вам в рукописи Литтературный Словарь безконечно мальх», ${ }^{81}$ - но и в значительной степени порождено «мелкими букашками» (если воспользоваться возможно относящимся к Федорову определением Пушкина из его «Собрания насекомых»), «поэтами 15 класса», одного из которых - Жителя Выборгской стороны - Вяземский обессмертил в своем предисловии к «Бахчисарайскому фонтану», таким образом способствовав созданию «Литературного Словаря бесконечно малых", в самом деле необходимого для истории литературы.

78 Авторство Федорова объясняет и то, почему Житель не приводит ни одного перевода с английского в разделе о переводах «британо-россов»: Федоров, если верить докладной записке о нем, составленной Ф. В. Булгариным в 1828 году для III Отделения, «никогда, ничему и нигде не учился. <..> не знает никаких языков, с французского языка он еще может переводить при помощи лексикона, но немецкого и английского вовсе не понимает» (цит. по: Вацуро В. Э., Гиллельсон М. И. Сквозь умственные плотины. Очерки о книгах и прессе пушкинской поры. М., 1986. С. 178; также: Рейтблат А. И. Видок Фиглярин. М., 1998. С. 346). В пользу возможного участия Федорова в написании статьи говорит и то обстоятельство, что после выхода предисловия Вяземского к «Бахчисарайскому фонтану» Федоров, кажется, старался поддерживать существование литературной фигуры Жителя Выборгской стороны, выведя ее в своем построенном в форме «разговора» антиромантическом разборе стихотворения В. И. Туманского «Черная речка»: характеризуя фигуру «критика», своего alter ego, Федоров заметил, что это «должен быть или Житель Васильевского Острова, или Житель Выборгской стороны, или с Петербургской стороны. Все сии жители не расположены к стихотворениям такого рода, как „Черная речка“” (Д. В. p. cm-въ [Федоров Б. М.]. Разговор о романтиках и о «Черной речке» // Благонамеренный. 1823. Ч. 23. № 15. С. 170; ср. также письмо Федорова Цертелеву о предисловии Вяземского к «Бахчисарайскому фонтану»: Письма в Тамбов о новостях русской словесности. Письмо I // Благонамеренный. 1824. Ч. 26. № 7. С. 53-67; № 8. С. 95-106).

79 Лит. наследство. 1956. Т. 60. Кн. 1. С. 204-205 (письмо П. А. Вяземскому от 23 мая 1823 года).

80 «...троньте одного, и вы тронули всех; а тем более, если коснулись до главы единочувственного племени. <...> у нас меньшие братья в авторстве складываются, чтобы написать нелепость! Кто после возьмет на себя головоломный труд отыскивать в этих журнальных мозаиках вкладчину каждого? Гораздо короче и благоразумнее расплатиться напрямки с собирателем, или составителем мозаики, предоставляя ему расчесться с своими поставщиками и воздать каждому свое» (Князь Вязелский. Разбор Второго Разговора, напечатанного в 7 № Вестника Европы // Дамский журнал. 1824. № 8. Апрель. С. 64).

81 «...безплотная фаланга друзей, которые сами собою не существуют, но как Лиллипутные эхи вторят чужие слова и после истаявают в воздухе. <...> Все они только тогда получат права гражданства в области Муз, когда издастся известный вам в рукописи Литтературный Словарь безконечно мальх; а покамест они существуют в силу правила товарищества, или устава общества для взаимного застрахования» (Л. М. [Вяземский П. А.]. Письмо в Париж // Московский Телеграф. 1825. Ч. 6. № 22. С. 175-176). 


\section{В. Ф. ХОДАСЕВИЧ В 1905-1907 ГОДАХ: СТРАТЕГИЯ КРИТИКА И СТАНОВЛЕНИЕ ЛИТЕРАТУРНОЙ РЕПУТАЦИИ}

В. Ф. Ходасевич известен не только как поэт, но и как критик, один из наиболее заметных авторов русской эмиграции. Хотя важнейшие рецензии и очерки были написаны им в 1920-1930-х годах, необходимо обратить внимание на начало его пути. Создание первых рецензий совпало с периодом поэтического «ученичества» Ходасевича, получения признания в писательских кругах и своего места в литературном поле. Уже в автобиографии 1915 года, ${ }^{1}$ перечисляя значимые рецензии, он не назовет ни одну из написанных до 1914 года. Несмотря на явную вторичность, статьи 19051907 годов кажутся нам важными в свете формирования репутации и эстетических взглядов критика.

В начале своего литературного пути Ходасевич тяготел к лагерю символистов, наиболее авторитетным современным литератором для него был В. Я. Брюсов. В мемуарах о В. Гофмане поэт вспоминал об отношении уже третьего поколения символистов к «мэтру» в начале 1900-х годов: «Перед Брюсовым Гофман благоговел, как мы все когда-то благоговели». ${ }^{2}$ На явное влияние литературного редактора «Весов» на раннюю поэзию Ходасевича в научной литературе неоднократно указывалось. ${ }^{3}$ «Ученичество» Ходасевича, желание занять свое место в лагере символистов проявлялось не только в стихотворных опытах, но и в первых рецензиях.

Начинающий критик принадлежал к категории литераторов, которых Н. И. Петровская называла «мальчиками» Брюсова: ${ }^{4}$ в их числе можно упомянуть Н. С. Гумилева, Муни (С. Я. Киссина), Б. А. Садовского. О влиянии Брюсова на их поэтические опыты хорошо известно, но особенности рецепции эстетических взглядов «мэтра» и его критического стиля пока остаются малоисследованными. ${ }^{5}$ Тем более интересно, как произошло становление Ходасевича - в будущем крупного критика. Ходасевич публиковался в журналах «Искусство», «Золотое руно», «Перевал». В ряду изданий 1900 -х годов они конкурировали с «Весами», и многие темы рецензий Ходасевича дублируют критические очерки Брюсова, посвященные третьестепенным авторам. Восемь из четырнадцати рецензий, написанных Ходасевичем в 1905-1907 годах, были опубликованы под псевдонимом «Сигурд». В статье мы проанализируем внутрилитературные обстоятельства, с которыми связывается появление этого псевдонима, - позиция ученика и, одновременно, оппонента Брюсова (насколько эта характеристика применима к начинающему литературному критику) является важнейшим из них. Представляется, что, определив тактику использования псевдонима, можно нюансировать не только особенности сотрудничества Ходасевича с периодикой первого десятилетия XX века, но и то, как он взаимодействовал с поэтикой критики Брюсова, ${ }^{6}$ как

1 Автобиография написана 23 апреля 1915 года для П. Я. Заволокина (см.: РГАЛИ. Ф. 1068. Оп. 1. Ед. хр. 169. Л. 2).

2 Ходасевич В. Ф. Виктор Гофман. К двадцатипятилетию со дня смерти // Ходасевич В. Ф. Собр. соч.: В 4 т. М., 1997. Т. 4. С. 286.

${ }^{3}$ См., например: Успенский П. Ф. Творчество В. Ф. Ходасевича и русская литературная традиция (1900-е гг. - 1917 г.). Тарту, 2014. С. 59-72; Богололов Н. А. ЖКизнь и поэзия Владислава Ходасевича // Ходасевич В. Стихотворения. Л., 1989. С. 5-48 (Библиотека поэта. Большая сер.).

${ }^{4}$ Из переписки Н. И. Петровской / Публ. Р. Л. Щербакова и Е. А. Муравьевой // Минувшее: Исторический альманах. М.; СПб., 1993. Вып. 14. С. 373, 383.

5 Исключение составляет изучение Гумилева-критика, см.: Чабан А. Н. С. Гумилев - критик поэтов-символистов: динамика оценок и эволюция критического языка. Тарту, 2018.

${ }^{6}$ На двойственность позиции начинающего автора, занимаемой по отношению к Брюсову, в своих комментариях к переписке Ходасевича указала И. П. Андреева: «Оглядка на В. Брюсова угадывается в любом замысле Ходасевича этих лет, он ученик-бунтарь» (Ходасевич В. Ф. Собр. соч.: В 4 т. T. 4 . С. 603). 
формировался его язык и стиль, как складывалась его литературная репутация в годы работы над первым поэтическим сборником «Молодость». В наши задачи также входит определить, как взгляды Ходасевича коррелировали с политикой того издания, в котором он печатался.

\section{1}

В 1905 году Ходасевич написал первые рецензии для журнала «Искусство», ${ }^{7}$ где секретарем состоял В. В. Гофман, ${ }^{8}$ а место редактора занял Сергей Кречетов (С. А. Соколов), глава издательства «Гриф», объединявшего многих начинающих поэтов-символистов. Между «Весами» и «Искусством», а позже - и «Золотым руном» существовали известные в литературном мире разногласия, которые можно свести к неприятию Брюсовым эпигонства авторов и сравнительно низкого культурного уровня литературного отдела. Об этом в мемуарах упоминал и сам редактор «Весов»: «Как это часто бывает в родственных группах, между двумя издательствами и редакциями существовало некоторое соперничество и род антагонизма». ${ }^{9}$

В «Искусстве» печатались тексты молодых авторов, которых привлекал к сотрудничеству Гофман. Среди них - семь критических очерков Ходасевича, два из которых напечатаны под псевдонимом «Сигурд» - в рецензии на «Стихотворения» Тана (В. Г. Богораза) он появился впервые. Этим псевдонимом Ходасевич подписывал большинство рецензий 1900-х годов, о его генезисе упомянем ниже. Безусловно, как заметил А. В. Лавров, Ходасевич пользовался псевдонимом отчасти по рациональным соображениям и для видимости наполнения журнала материалами разных сотрудников. ${ }^{10} \mathrm{~K}$ примеру, в № 5/7 журнала появились четыре очерка Ходасевича: два под его именем и два под псевдонимом. Но, как кажется, в выборе рецензий, печатаемых не под настоящим именем автора, прослеживается определенная закономерность, продиктованная не только лишь прагматическими соображениями. Ж урнал «Искусство» был задуман редакторами как противостоящий эстетическим взглядам «Весов» (здесь сыграло важную роль и соперничество между Соколовым и Брюсовым). Можно предположить, что Ходасевич, начиная литературную карьеру, делал ставку на авторитет Сергея Кречетова. Поэтому, обозначая принадлежность к кругу литераторов, близких издателю, он публиковал рецензии со своей подписью. Если же Ходасевич совпадал с оценкой Брюсова, то мог подписывать очерки псевдонимом, поддерживая установленный в литературных кругах взгляд на журнал. Таким образом, в «Искусстве» и «Золотом руне» Ходасевич был поэтом и критиком из лагеря Соколова, часто полемизирующим с «Весами», а Сигурд - рецензентом, повторяющим суждения «мэтра». ${ }^{11} \mathrm{~B}$ свете этого важно отметить, что Ходасевич связывал создание репутации поэта-символиста и критика только с текстами, подписанными своим именем, и, как покажем далее, в первых рецензиях подчеркивал близость взглядам Соколова.

7 В 1905 году вышло восемь номеров журнала, затем он перестал существовать по финансовым причинам. Значительная часть редакции перешла в новое издание - «Золотое руно». Подробнее см.: Лавров А. В. «Золотое Руно» // Лавров А. В. Русские символисты: Этюды и разыскания. М., 2007. С. 457-459.

${ }^{8}$ См.: Ходасевич В. Ф. Виктор Гофман. К двадцатипятилетию со дня смерти // Ходасевич В. Ф. Собр. соч.: В 4 т. Т. 4. С. 285-291; Лавров А. В. Виктор Гофман: между Москвой и Петербургом // Писатели символистского круга: Новые материалы. СПб., 2003. С. 193-222.

9 Брюсов В. Я. Мои воспоминания о Викторе Гофмане // Брюсов В. Я. Среди стихов, $1894-$ 1924: Манифесты. Статьи. Рецензии. М., 1990. С. 512.

10 Лавров А. В. «Золотое Руно». С. 457. О финансовых обстоятельствах Ходасевича см.: Шубинский В. И. Владислав Ходасевич: Чающий и говорящий. М., 2012. С. 121-122 (сер. «Жизнь замечательных людей»).

11 Сходную практику работы с псевдонимами описывает М. С. Макеев, говоря о Н. А. Некрасове в 1840 году, см.: Макеев $M$. С. Николай Некрасов: Поэт и Предприниматель (очерки о взаимодействии литературы и экономики). М., 2008. С. 34-40. 
Тексты Сигурда писались, во-первых, для дополнительного заработка, как типичная для журнальной работы «литературная поденщина». Во-вторых, для автора они могли служить удобным способом для экспериментов с собственным положением на литературном поле - перед выходом «Молодости» эстетические взгляды Ходасевича и Сигурда поменяются местами. ${ }^{12}$

Приведем несколько примеров. Разгромная рецензия Ходасевича (в этот раз «Сигурда») на «Стихотворения» Тана совпадает с оценкой «Весов». Так, Брюсов в рецензии назвал поэзию Тана «рифмованными упражнениями не очень грамотного и далеко не образованного человека», ${ }^{13}$ так же «Стихотворения» оценил и Ходасевич: «O стихах г. Тана с внешней стороны говорить не приходится. Скиталец - пишет лучше». ${ }^{14}$ Можно обратить внимание не только на совпадение в оценке поэзии, но и на сходство структуры рецензии. Ходасевич строил свой текст, явно имея в виду «образец» : он следовал от оценки недостатков поэзии, ее подражательности, к заключительному пассажу: «Для тех, кто идет, не отступая, есть иные, более благородные, хотя порой менее безопасные способы, чем дозволенное цензурой насилие над искусством...». ${ }^{15}$ Той же мыслью завершил свой критический очерк и Брюсов: «А пересказывать своими словами наивные стихи Надсона <...> вовсе не значит „служить“ какомуто освободительному делу, а просто - мазать кистью по заготовленному трафарету». ${ }^{16}$ Подобный пассаж и у Ходасевича, будущего автора статьи о Надсоне, может прочитываться как отсылка к творчеству этого поэта и к гражданственной поэзии второй половины XIX века в целом. Под этим текстом критик не поставил своего имени, видимо, из-за необходимости соответствовать политике издания.

Приведем пример противоположной стратегии. В рецензии на «Литургию красоты. Стихийные гимны» К. Д. Бальмонта Ходасевич ссылается на отзыв Брюсова на первый том «Собрания стихов» и «Литургию красоты», появившийся месяцем ранее в «Весах»: ${ }^{17}$ «...Бальмонту тщатся указать его „истинные пути“, вернуть к „нежным напевам“...» ${ }^{18}$ Высказывая суждение о поэзии Бальмонта, открыто противоречащее позиции «Весов», Ходасевич не использовал псевдонима. Интересно, что эстетическим ориентиром для начинающего критика все же оставался Брюсов, хотя в этом случае он и оспаривает позицию мэтра. В письме А. Я. Брюсову Ходасевич упоминал об этой рецензии: «Стихи его (В. Я. Брюсова. - Д. Л.) очень хороши <...> Впрочем, я с ним (пока - между нами) затеваю полемику, вне чистой литературы. Как и что - объяснять долго, но советую тебе прочесть в № 4 „Весов“ его заметку о „Литургии Красоты“, а после, когда выйдет № 5 „Искусства“ - в нем мою заметку о том же...» ${ }^{19}$ Как кажется, Ходасевич имел в виду «полемику» не только на уровне оценочных суждений, но и на уровне языка рецензии. В этом очерке он воспроизводил модель импрессионистической рецензии, характерную для Бальмонта-эссеиста. ${ }^{20}$ Рядом с этой рецензией опубликована статья

12 Используя термины «литературное поле», «символический капитал», мы опираемся на работу П. Бурдье «Поле литературы», см.: Бурдье П. Поле литературы // Новое литературное обозрение. 2000. № 45. С. 22-87. Понятие «литературная репутация» взято из монографии И. Н. Розанова «Литературные репутации», см.: Розанов И. Н. Литературные репутации. M., 1990. Здесь же стоит отметить, что между взглядами ученых заметны очевидные пересечения.

13 Брюсов В. Я. Тан. Стихотворения // Весы. 1905. № 5. С. 44-45; ср.: Брюсов В. Я. Среди стихов. С. 146.

14 Сигурд [Ходасевич В. Ф.]. Тан. Стихотворения // Искусство. 1905. № 5/7. С. 169-170; ср.: Ходасевич В. Ф. Собр. соч.: В 8 т. М., 2010. Т. 2. Критика и публицистика (1905-1927). С. 28.

15 Там же.

16 Брюсов В. Я. Тан. Стихотворения // Весы. 1905. № 5. С. 44-45; ср.: Брюсов В. Я. Среди стихов. С. 147.

17 Брюсов В. Я. К. Бальмонт. Собрание стихов, т. I; К. Бальмонт. Литургия Красоты // Весы. 1905. № 4. С. 50-52; ср.: Брюсов В. Я. Среди стихов. С. 14.

18 Ходасевич В.Ф. К.Д. Бальмонт. Литургия Красоты. Стихийные гимны // Искусство. 1905. № 5/7. С. 164-165; ср.: Ходасевич В. Ф. Собр. соч.: В 8 т. Т. 2. С. 26.

19 Ходасевич В. Ф. Собр. соч.: В 4 т. Т. 4. С. 379.

20 Таким же языком будут написаны рецензии 1906 года на 7-й, 10-й и 11-й сборники товарищества «Знание», «Тяжелые сны» Ф. Сологуба. Известно, что Брюсов решительно не 
о «Нижегородском сборнике»: ${ }^{21}$ хотя Ходасевич подписывает ее своим именем, в ней практически повторяется содержание рецензии Брюсова, но без прямых цитат. ${ }^{22}$

Следующий текст - рецензию на «Мрак» Арнольда Ариэля в № 8 «Искусства» Ходасевич подписал своим именем, и нам он интересен как пример, эксплицирующий отношения между литературными редакторами «Весов» и «Искусства». В № 3 «Весов» Соколов рецензировал книгу стихов и рассказов «Долой женщин!» того же автора, а в № 7 появился отзыв Брюсова о «Мраке». ${ }^{23}$ Ходасевич же в своей статье отметил, что первую книгу автора рецензировал С. Кречетов, но не назвал статьи Брюсова, ${ }^{24}$ поскольку упоминание рецензии ведущего критика не могло появиться на страницах журнала, редактор которого полемизирует с «Весами» и решительно настроен против мэтра.

В начале 1906 года Соколов стал главой литературного отдела «Золотого руна», нового журнала, в который перешел и Ходасевич. Издание финансировал Н. П. Рябушинский - многие свидетели эпохи и исследователи упоминали о скептическом отношении к этому меценату в литературных кругах ${ }^{25}$ полемика между «Весами» и «Золотым руном» исчерпывающе полно изучена, ${ }^{26}$ поэтому отметим лишь наиболее важные для нашей темы факты. «Золотое руно», литературным отделом которого руководил Соколов-Кречетов, придерживалось тех же литературно-эстетических взглядов, что и «Весы». Как объявлялось в первом номере, одна из задач журнала - «с особенной чуткостью и вниманием» отнестись к «молодым дарованиям». ${ }^{27} \mathrm{C}$ первых же выпусков установилось общее мнение о том, что печатающиеся в издании С. Кречетова начинающие авторы (Ходасевич, С. Городецкий, С. Ауслендер, П. Потемкин, M. Волошин $)^{28}$ не привнесут в литературу ничего нового. Журнал считали непритязательной, безвкусной копией «Весов». Подчеркнем, что такая оценка могла сложиться и по прагматическим причинам. Сам Соколов видел истинную причину конфликта не в слабости литературного отдела издания, а в утрате «Весами» положения единственного символистского ежемесячного журнала: «...слишком уж недвусмысленно звучит в их словах нота оскорбленного монополизма». ${ }^{29}$

После ухода Соколова Рябушинский предложил место редактора Брюсову, надеясь, что его издательский опыт поможет упрочить позиции «Золотого руна». ${ }^{30}$ Мэтр разделял общее мнение о «вторичности» журнала: в апреле 1906 года в письме Д. С. Мережковскому он сделал совершенно определенное заключение: «,Золотое Руно“, кажется мне, безнадежно». ${ }^{31}$

принимал поэтику публицистики Бальмонта: «Это, конечно, не критика, а поэтические картинки» (Лит. наследство. 1991. Т. 98. Валерий Брюсов и его корреспонденты: В 2 кн. Кн. 1. С. 96).

${ }^{21}$ Ходасевич В. Ф. Нижегородский сборник // Искусство. 1905. № 5/7. С. 171-172; ср.: Хо дасевич В. Ф. Собр. соч.: В 8 т. Т. 2. С. 28-29.

22 Брюсов В. Я. Сборник товарищества «Знание» на 1904 г. Кн. IV и V; Нижегородский сборник // Весы. 1905. № 4. С. 47-50; ср.: Брюсов В. Я. Среди стихов. С. 140.

${ }_{23}^{23}$ Брюсов В. Я. Арнольд Ариэль. Мрак // Весы. 1905. № 7. С. 59-60; ср.: Брюсов В. Я. Среди стихов. С. $155-156$.

24 Ходасевич В. Ф. Арнольд Ариэль. Мрак // Искусство. 1905. № 8. С. 78-79; ср.: Ходасевич В. Ф. Собр. соч.: В 8 т. Т. 2. С. 29.

${ }^{25}$ См.: Ходасевич В. Ф. О меценатах // Ходасевич В. Ф. Собр. соч: В 4 т. Т. 4. С. 330-331.

${ }^{26}$ См.: Лавров А. В. «Золотое Руно». С. 459-485; Богололов Н. А. К истории «Золотого Руна» // Богомолов Н. А. От Пушкина до Кибирова: Статьи о русской литературе, преимущественно о поэзии. М., 2004. С. 41-83.

27 От редакции // Золотое руно. 1908. № 1. С. 99.

28 Лавров А. В. «Золотое Руно». С. 457.

29 Кречетов С. Апологеты культуры // Золотое руно. 1906. № 3. С. 131.

30 В декабре 1905 года Соколов писал Брюсову: «Николаю Павловичу Рябушинскому хотелось бы познакомиться с Вами. Если Вы разрешите, мы приедем к Вам вместе с ним завтра, в 1 час дня» (РГБ. Ф. 386. Карт. 103. Ед. хр. 16). Андрей Белый в книге «Между двух революций» вспоминает о сотрудничестве с журналом следующим образом: «Рябушинский <...> держал Соколова в заведующих литературным отделом; последний едва уломал сотрудничать Брюсова и меня» (Бельй А. Между двух революций. М., 1990. С. 98).

31 Лавров А. В. «Забытые» фрагменты переписки Брюсова и Мережковского // От Кибирова до Пушкина: сборник в честь 60-летия Н. А. Богомолова. М., 2011. С. 214. 
Роскошное двуязычное издание Рябушинского восприняли настороженно-скептически, устная критика быстро перешла на страницы «Весов». Уже в № 2 в статье «Золотое руно» за подписью «Товарищ Герман» (автором рецензии была 3. Н. Гиппиус) говорилось об «обветшавшем декадентствовании» журнала. ${ }^{32}$ В № 3 «Золотого руна» последовала ответная реплика С. Кречетова, ${ }^{33}$ и в № 5 «Весов» - еще одна рецензия Товарища Германа (на этот раз В. Я. Брюсова), справедливо подчеркивавшего напыщенность стиля статьи «Апологеты искусства». ${ }^{34}$ Полемика продолжалась до 1909 года, но ее развитие для нас не столь важно: с лета 1906 года и Кречетов, и Ходасевич уже не сотрудничали в «Золотом руне».

В 1906 году появилось шесть рецензий Ходасевича. В первом и втором номерах журнала было напечатано по одной рецензии, которые автор подписал своим именем. ${ }^{35}$ Политика «Золотого руна» близка «Весам», и в двух первых рецензиях Ходасевича пока еще нет оценок, противоречащих брюсовским: псевдоним «Сигурд» появился только в третьем номере, выход которого совпал с началом открытой полемики с «Весами» - им подписаны три рецензии. ${ }^{36} \mathrm{~B}$ этом издании рецензии Ходасевича снова соответствовали эстетическим установкам Соколова-Кречетова. В частности, последний советовал Ходасевичу написать рецензию на поэтический сборник С. Головачевского «Мене текел фарес» «серьезную и без глума, хотя в общем, конечно, отрицательную <...> Хорошо бы взять общую мысль, что есть „стихотворство“ (фабрикация стихов), а есть „поэзия“ - но это вещи разные». ${ }^{37}$ В том же ключе была написана короткая рецензия Брюсова - Соколов руководствовался ей, давая рекомендации Ходасевичу. Интересно и прямое текстуальное совпадение - Ходасевич писал о Головачевском: «Стих заполняется словечками вроде „все“ и „уж“»" ${ }^{38}$ - это предложение было взято им из рецензии Брюсова на стихи Тана, о которой мы писали выше, и показывает, сколь внимательным читателем Брюсова был Ходасевич.

Единственный раз Ходасевич отклонился от избранной им стратегии в рецензии на «Полное собрание стихотворений» Д. Ратгауза, ${ }^{39}$ последнем тексте, напечатанном им в «Золотом руне». Он предпослал статье эпиграф из «Urbi et Orbi» Брюсова и использовал в тексте цитату из его стихотворения «Отвержение» (1903): «заветный хлам». ${ }^{40}$ Рецензия с явными отсылками к поэзии Брюсова, фактически повторявшая его критические суждения о Ратгаузе, появилась за подписью автора без псевдонима - несмотря на оживленную полемику между журналами Ходасевич, по-видимому, декларировал ученическую позицию по отношению к «мэтру» и, в какой-то мере, ориентацию на его критику.

Подведем промежуточные итоги. Начиная карьеру литературного критика в журналах «Искусство» и «Золотое руно», редактируемых Соколовым-Кречетовым, Ходасевич

32 Товарищ, Герлан [Гиппиус 3. Н.]. Золотое руно // Весы. 1906. № 2. С. 81-83.

33 Кречетов С. Апологеты культуры // Золотое руно. 1906. № 3. С. 131-132.

34 Товарищ, Герлан [Брюсов В. Я.]. Золотому руну // Весы. 1906. № 5. С. 88.

35 Ходасевич В. Ф. Сборник Товарищества «Знание». Книга VII // Золотое руно. 1906. № 1. С. 154-155; ср.: Ходасевич В. Ф. Собр. соч.: В 8 т. Т. 2. С. 31-32; Ходасевич В. Ф. Федор Сологуб. Тяжелые сны // Золотое руно. 1906. № 2. С. 130-131; ср.: Ходасевич В. Ф. Собр. соч.: В 8 т. Т. 2. C. 33-34.

${ }^{36}$ Сигурд [Ходасевич В. Ф.]. 1) И. Ф. Анненский. Книга отражений // Золотое руно. 1906. № 3. С. 137-138 (ср.: Ходасевич В. Ф. Собр. соч.: В 8 т. Т. 2. 34-35); 2) VIII Сборник Товарищества «Знание»; IX Сборник Товарищества «Знание» // Золотое руно. 1906. № 4. С. 111-112 (ср.: Ходасевич В. Ф. Собр. соч.: В 8 т. Т. 2. С. 35-36); 3) С. Головачевский. «Мене текел фарес» (Стихотворения) // Золотое руно. 1906. № 5. С. 92-94 (ср.: Ходасевич В. Ф. Собр. соч.: В 8 т. Т. 2. 38-40).

37 Цит. по: Брюсов В. Я. Среди стихов. С. 677.

38 Ходасевич В. Ф. С. Головачевский. «Мене текел фарес» // Золотое руно. 1906. № 5. С. 93; ср.: Ходасевич В. Ф. Собр. соч.: В 8 т. Т. 2. С. 39.

39 Ходасевич В. Ф. Д. Ратгауз. Полное собрание стихотворений. 2 тома // Золотое руно. 1906. № 4. С. $112-113$; ср.: Ходасевич В. Ф. Собр. соч.: В 8 т. Т. 2. С. $36-37$.

40 Брюсов В. Я. Собр. соч.: В 7 т. М., 1973. Т. 1. С. 320. «Заветный хлам витий» станет эпиграфом к стихотворению «Старинные друзья» в сборнике «Молодость», см.: Ходасевич В. Ф. Собр. соч.: В 8 т. T. 1. C. 42 . 
акцентировал свою принадлежность к кругу этих изданий и подчеркивал несогласие с эстетическими взглядами Брюсова. Последний номер «Золотого руна» и следующий издательский проект Соколова заставляют предположить, что критик радикально поменяет стратегию: теперь он будет подчеркивать ориентацию на эстетические взгляды Брюсова, а не на политику редактора журнала. Возможно, важную роль в этом сыграли и прагматические обстоятельства: Ходасевич, более года сотрудничая в периодических изданиях, не мог не заметить, что литературная часть журналов Соколова значительно уступает «Весам», поэтому не следует делать ставку на его сомнительный авторитет в символистских кругах.

\section{2}

Описав стратегию Ходасевича - оппонента, а затем - ученика Брюсова, вернемся к вопросу о генезисе псевдонима «Сигурд». Ю. Колкер упоминал, что поэт заимствовал псевдоним из драмы 3. Красинского «Иридион» (Сигурд — второе имя главного героя, грека Иридиона ${ }^{41}$ ) - за ним, по мысли эссеиста, угадывается интерес Ходасевича к польской классике и напоминание о польских корнях. ${ }^{42}$ Позже, в 1910 году, поэт перевел «Иридиона» и опубликовал с собственным предисловием, а через два года планировал издать собрание сочинений Красинского. ${ }^{43}$ Рассуждая о генезисе псевдонима Ходасевича, необходимо пояснить, во-первых, почему в «Иридионе» появляется отсылка к скандинавской мифологии, во-вторых, как псевдоним соотносится с символистскими культурными кодами.

Говоря о генезисе псевдонима, недостаточно упомянуть, что он взят из «Иридиона» 3. Красинского. Необходимо указать, почему Ходасевич использует не псевдоним «Иридион», прямо указывающий на польские корни критика, а подписывается как «Сигурд» - выбор такого имени требует обращения к сюжету пьесы и литературному контексту 1900-х годов. В центре сюжета «Иридиона» - борьба христиан против античного Рима, аллегорически изображающая борьбу Польши с завоевателями, польское восстание 1830-1831 годов. Главный герой, Иридион, - сын грека и жрицы Одина, его родословная символизирует союз языческого мира и будущих христиан. ${ }^{44}$ По мнению Стефана Моравского, Красинский обращается к скандинавской мифологии потому, что в Польше не было традиционного для европейских государств культа римской античности, которая идентифицировалась с деспотией, и польские авторы искали истоки культуры в скандинавской древности. ${ }^{45}$

Если прибегнуть к психологическому объяснению генезиса псевдонима «Сигурд», то можно предположить, что выбор имени главного героя, борющегося с завоевателями-римлянами, переносит сюжет драмы на современную литературную почву: грек Иридион-Сигурд и римлянин Брюсов. ${ }^{46}$ Используя этот псевдоним, а не, к примеpy, «Иридион», Ходасевич имел возможность не только указать на свои польские кор-

41 Ср.: «...назвала тебя именем деда: „Сигурд, будь грозою гордых“...» (Красинский З. Иридион / Пер. с польского и предисловие В. Ходасевича. М., 1910. С. 24).

42 Колкер Ю. Айдесская прохлада: Очерк жизни и творчества В. Ф. Ходасевича // Ходасевич В. Ф. Собр. стихов: В 2 т. Paris, 1983. Т. 2. С. 287.

${ }^{43}$ Козляков В. Владислав Ходасевич и Зыгмунт Красиньский // Начало века: Из истории международных связей русской литературы. СПб., 2000. С. 320-327.

${ }^{44}$ Lednicki W. Blok's «Polish poem»: A Literary Episode in the History of Russian-Polish Relations // Bulletin of the Polish Institute of Arts and Sciences in America. 1944. Vol. 2. № 2. P. 461500 .

45 Morawski S. Polish Theories of Art between 1830 and 1850 // The Journal of Aesthetics and Art Criticism. 1957. Vol. 16. № 2. P. 217-236.

46 Для такого именования поэта достаточно вспомнить университетские увлечения Брюсова римской историей и литературой, один из его псевдонимов «Аврелий» и позднейшее определение М. И. Цветаевой «Брюсов был римлянином» (из воспоминаний «Герой труда», 1925), ставшее общеизвестным к середине 1920-х годов. 
ни, но и обозначить положение «ученика-бунтаря» даже в тех случаях, когда разделял эстетические взгляды «мэтра». Это могло подчеркнуть, что он включен в круг авторовсимволистов и считывает «жизнетворческий» подтекст. Важно отметить, что в середине 1900-х годов Ходасевич близко дружил с Н. И. Петровской и, как можно судить по «Некрополю», уже должен был знать о реальной основе сюжета романа Брюсова «Огненный ангел», о моделировании «мэтром» отношений с младшими поэтами. ${ }^{47}$ Возможно, Ходасевич мог рассчитывать на то, что редактор «Весов» заметит эту модель, похожую на его собственную литературную игру, и как-либо отреагирует на публикации Ходасевича, - разумеется, этот прецедент повлиял бы на литературное имя начинающего критика, но этого не произошло - слишком велика была разница в положении между состоявшимся автором, редактором «Весов», и начинающим рецензентом.

Для Ходасевича значимым должно было быть и то, что скандинавский сюжет стал важной составляющей символистского жизнетворчества, одной из заметных тем в поэзии Брюсова и Бальмонта. ${ }^{48}$ В 1890 -х — начале 1900-х годов интерес к нему актуализировался из-за рефлексии над творчеством Р. Вагнера: к примеру, музыка этого композитора, его концепция «синтетического произведения» нового искусства обсуждалась на «Средах» Иванова, критиковавшего Брюсова за небольшой объем материалов о композиторе, появляющийся на страницах «Весов».49 Псевдоним, таким образом, выполнял несколько функций: указывал на «инородчество» Ходасевича и его интерес к польской литературе, и одновременно подчеркивал, что автор - символист, продолжатель поэтической традиции, понимавший негласные правила литературной игры Брюсова и культурный язык эпохи. ${ }^{50}$

В июле 1906 года произошла ссора Соколова с Рябушинским. ${ }^{51}$ Соколов сделал свой уход из журнала громкой новостью в литературных кругах, разослав сотрудникам издания копии своего письма Рябушинскому с заявлением о выходе из «Золотого руна». ${ }^{2}$

После ухода из «Золотого руна» Соколов основал журнал «Перевал», который согласился финансировать ярославский поэт В. Линденбаум. ${ }^{53}$ В первом номере объявлялось

47 См.: Лавров А. В., Гречишкин С. С. О работе Брюсова над романом «Огненный ангел» // Лавров А. В., Гречишкин С. С. Символисты вблизи. Очерки и публикации. СПб., 2004. С. 6777. В этом контексте вспомним более раннее стихотворение Брюсова «Бальдеру Локи» 1904 года, в котором автор обращается к скандинавской мифологии, обыгрывая жизнетворческий сюжет.

48 Перечислим некоторые стихотворения: «Царю северного полюса» (1898-1900), «Старый викинг» (1900) Брюсова, «У скандинавских скал» (1894), «Исландия» (1899), «Сигурд» (1903) Бальмонта (название последнего текста могло обратить на себя внимание Ходасевича). В «Скорпионе» публикуются переводы Г. Ибсена, К. Гамсуна и А. Стриндберга.

49 Bartlett R. Wagner and Russia. Cambridge: Cambridge University Press, 1995. P. 118-119. См. также воспоминания А. Белого о том, как О. М. Соловьева интерпретировала его встречу с Мережковским в «вагнерианских» терминах: Белый - Зигфрид, который должен победить «вредоносного змия» Мережковского (Белый А. Начало века. М., 1990. С. 205-208).

50 Добавим, что при этом наша реконструкция, конечно, не предполагает, что Брюсов должен был угадывать в критике Сигурде героя «Иридиона» Красинского, считывать дополнительный смысл псевдонима, связанный с сюжетом драмы. Скорее, скандинавского обертона в данном случае было достаточно для того, чтобы псевдоним маркировал символистские пристрастия критика.

${ }^{51}$ Подробнее см.: Лавров А. В. «Золотое Руно». С. 467-468; Богололов Н. А. К истории «Золотого Руна». С. 42-46.

52 Там же. С. 42.

53 «Был у меня Линденбаум <...>, - сообщал Соколов Ходасевичу 12 июня 1906 года. Осенью переезжает в Москву, имеет кое-какие самостоятельные деньги. Хочет издавать двухнедельный журнальчик, где сочетались бы и политика, и искусство. Просит меня устроить и наладить. Что ж? <...> Вообще полезно будет иметь под рукой „свой“ журнальчик» (РГАЛИ. Ф. 537. Оп. 1. Ед. хр. 78). В мемуарном очерке «О меценатах» (1936) Ходасевич выскажет суждения 
о поддержке «вольного творчества в его борьбе с традицией и застывшим академизмом $<. .>$ вне всяких принудительных социальных форм». ${ }^{54}$ По замыслу редактора политизированный «Перевал. Журнал свободной мысли» должен был противопоставить себя чисто-художественным «Весам» и «Золотому руну». ${ }^{55}$ Однако обещанный журнал «с направлением» стал заурядным изданием, содержание критических рецензий на которое можно свести к суждению Н. М. Минского: «Грустно то, что этот журнал не только без программы, но и без всякого направления, т. е. как будто без всякой цели». ${ }^{56}$

Вышло двенадцать номеров журнала «Перевал» (с ноября 1906-го по октябрь 1907 года), в них Ходасевич, секретарь издания, опубликовал только три рецензии. Этот небольшой материал иллюстрирует новую для критика закономерность работы. Если в «Искусстве» и «Золотом руне» он печатался под псевдонимом, соглашаясь в оценках с Брюсовым (исключение - вышеупомянутая рецензия о Ратгаузе), то в «Перевале» он ставил под рецензией свою фамилию, когда его мнение совпадало с позицией «мэтра». Сразу оговоримся: такой пример в «Перевале» только один - очерк о 10-м и 11-м номерах сборников Товарищества «Знание». ${ }^{57}$ Конечно, в рецензиях на сборники «Знания» Ходасевич следует не только за Брюсовым, но и за общесимволистской традицией критики «знаньевцев». Подчеркнем, однако, сходство композиции этой рецензии и текста Брюсова о 10-й книге серии: ${ }^{58}$ от разбора пьес Андреева автор переходит к «остальному содержанию „Сборника“” и завершает очерк анализом недостатков переводов из Э. Верхарна. Противоположный пример - рецензия Ходасевича на «Сонеты» А. Федорова. Ходасевич-Сигурд называет автора «несомненным талантом $<$...> хотя ему предстоит еще большая работа: освободиться от влияния Бунина», ${ }^{59}$ Брюсов же в своем критическом очерке говорит о многих недостатках сборника. ${ }^{60}$

Эта рецензия станет последней напечатанной Ходасевичем в «Перевале». В конце 1907 года Ходасевич не публиковал рецензий в периодике. Возможно, одной из причин этого было окончание работы над книгой «Молодость» - в июле 1907 года он написал из Лидина Г. Малицкому: «Пишу порядочно <...> для книги, которую выпускаю, вероятно, в сентябре-октябре». ${ }^{61}$

\section{4}

В заключение рассмотрим смену траектории Ходасевича-критика и его писательских стратегий. На рубеже 1907-1908 годов Ходасевич напечатал несколько рецензий в провинциальных изданиях, одну из них, «О последних книгах К. Бальмонта», можно назвать первым текстом, где он позволил себе достаточно прямолинейно высказываться против Брюсова, но пока под псевдонимом. Предыдущие примеры

о Линденбауме и Соколове, несколько противоречащие его близости к «Грифу» в 1900-е годы (см.: Ходасевич В. Ф. О меценатах. С. 328-329).

${ }^{54}$ От редакции // Перевал. 1906. № 1. С. 3.

55 Соколов сообщал в более раннем письме И. Ф. Анненскому (от 1 октября 1906 года): «...я вообще часто расхожусь с пониманием „олимпийцев“ из „Весов“, за что и предан там анафеме <...> за скобками „чистого“ искусства не таил политического реакционерства» (РГАЛИ. Ф. 6. Оп. 1. Ед. хр. 363).

${ }^{56}$ Цит. по: Лавров А. В. «Перевал» // Лавров А. В. Русские символисты: этюды и разыскания. М., 2007. С. 489 (письмо Н. М. Минского к Л. Н. Вилькиной от 7 января 1907 года).

57 Ходасевич В. Ф. Х Сборник Т-ва «Знание»; ХІ Сборник Т-ва «Знание»// Перевал. 1906. № 1. С. 50-52; ср.: Ходасевич В. Ф. Собр. соч.: В 8 т. Т. 2. С. 41-45.

58 Брюсов В. Я. Сборник «Знания», кн. Х // Весы. 1906. № 6. С. 63; ср.: Брюсов В. Я. Среди стихов. С. 200-201.

59 Сигурд [Ходасевич В. Ф.]. А. Федоров. Сонеты // Перевал. 1906. № 1. С. 52; ср.: Ходасевич В. Ф. Собр. соч.: В 8 т. Т. 2. С. 45.

60 Брюсов В.Я Я. Иван Рукавишников. Стихотворения. Книга IV. Л. Вилькина-Минская. Мой сад. Сонеты и рассказы. А. Федоров. Сонеты // Весы. 1907. № 10. С. 69-73; ср.: Брюсов В. Я. Среди стихов. С. 223.

61 Ходасевич В. Ф. Собр. соч.: В 4 т. Т. 4. С. 380. 
иллюстрируют скорее полемику на уровне отдельных утверждений, в этом же очерке «защита» Бальмонта стала весьма прямолинейной критикой «мэтра» Ходасевичем: «А между тем то, с чем разделываются „тонкие“ критики так модно и так жалко, есть глубокая, больная и печальная трагедия...». Бальмонт «стал или, вернее, захотел стать певцом там, где другой поэт сумел бы остаться литератором. Предположим, Валерий Брюсов обратился бы, как Бальмонт, к народному русскому эпосу. Конечно, он решил бы свою задачу чисто литературно». ${ }^{2}$ Здесь Ходасевич к тому же имплицитно цитирует более раннюю рецензию Брюсова на сборник «Будем как солнце» (1903): «В жизни он „стихийный гений“ <...> в поэзии он раньше этого литератор».$^{63}$

В 1908 году вышел первый поэтический сборник Ходасевича «Молодость». Дебютная книга для молодого автора - возможность превратиться из «ученика» в настоящего поэта-символиста. ${ }^{64}$ "Молодость» получает несколько положительных откликов, в том числе и Брюсова. ${ }^{65}$ Хотя выход книги изменил положение Ходасевича в литературном поле, его репутация была двусмысленной - Ходасевич принадлежал уже к третьему поколению символистов, и, по верному заключению С. Г. Бочарова, ",младший“ в его случае не так далеко от представлений о подражательности и почти эпигонстве». ${ }^{6}$ Ходасевич переместился в круг «несколько более высокого уровня, и продолжает в нем вращаться приблизительно до революции» ${ }^{67}$ - поясним, что поэт сблизился с более значимыми и известными впоследствии авторами - среди них Б. Садовской, Г. Чулков. Смена эстетических взглядов Ходасевича заметна в критике 1908-1910 годов и, отчасти, в стихотворениях «Счастливого домика» (1914).

По-видимому, попытка вписаться в круг символистов, выйти из положения «ученика» и третьестепенного поэта не удовлетворила Ходасевича, и рецензии, появляющиеся с 1908 года, можно рассматривать как постепенное удаление от критической поэтики «Весов» и «Грифа» (нужно отметить, что этот период совпал с упадком «Весов», прекращением издания «Перевала», но Ходасевич не примкнул к другим символистским журналам - например, не вернулся в «Золотое руно»). Прежде всего, он начал сотрудничать с периодическими изданиями, имеющими более широкую аудиторию, переключился на иного читателя: после появления «Молодости» Ходасевич публиковался в газетах «Руль» (с 1908 года), «Раннее утро» (с 1909 года), «Утро России» (с 1910 года). В этих изданиях псевдоним «Сигурд», если не ставший узнаваемым, то ассоциировавшийся с определенными изданиями круга символистов, появится только один раз.

Впервые Ходасевич высказал осторожную критику прозы Брюсова-поэта, подписав рецензию своим именем, в 1913 году в отзыве на сборник прозы «Ночи и дни. Вторая книга рассказов и драматических сцен». ${ }^{68}$ Параллельно Ходасевич искал новый поэтический голос.

Проследив закономерность использования псевдонима «Сигурд» в критике Ходасевича 1905-1907 годов, мы можем под иным углом посмотреть на начало его литературной карьеры и пояснить, как он зарабатывал символический капитал, пытаясь

62 Георгий Р-н [Ходасевич В. Ф.]. О последних книгах К. Бальмонта // Южный край. 1907. 23 дек. № 9628; ср.: Ходасевич В. Ф. Собр. соч.: В 8 т. Т. 2. С. 48-49.

${ }^{63}$ Брюсов В. Я. Бальмонт // Мир искусства. 1903. № 7-8; ср.: Брюсов В. Я. Среди стихов.

64 Успенский П. Ф. Творчество В. Ф. Ходасевича и русская литературная традиция (1900-е гг. - 1917 г.). С. 42-46; Богололов H. А. Вл. Ходасевич в московском и петроградском литературном кругу // Новое литературное обозрение. 1995. № 14. С. 119-130.

65 См.: Тимофеев А. В. Ходасевич // Руль. 1908. 23 апр. № 87. С. 3; Гофлан В. Владислав Ходасевич. Молодость. Стихи 1907 г. // Русская мысль. 1908. № 7. С. 143; Брюсов В. Я. Дебютанты // Брюсов В. Я. Среди стихов. С. 260-265.

66 Бочаров С. Г. «Памятник» Ходасевича // Бочаров С. Г. Сюжеты русской литературы. М., 1999. C. $420-421$.

67 Богололов Н. А. Вл. Ходасевич в московском и петроградском литературном кругу. С. 120.

68 Ходасевич В. Ф. Лед и пламень // Голос Москвы. 1913. 18 мая. № 114; ср.: Ходасевич В. $\Phi$. Собр. соч.: В 8 т. Т. 2. С. 111-113. 
занять место в литературном поле. Известное мнение о том, что одним из «образцов» для начинающего автора была критика Брюсова, можно несколько нюансировать. В первых рецензиях в «Искусстве» и «Золотом руне» Ходасевич полемизировал с отдельными утверждениями «мэтра» и, отчасти, с обычным для критики Брюсова стилем, языком. Подписывая тексты своим именем, он старался соответствовать политике Соколова-Кречетова: так Ходасевич подчеркивает свою принадлежность кругу издательства «Гриф» и независимость от взглядов «мэтра», хотя даже при этом в композиции, в отдельных фразах его рецензий заметен внимательный читатель критических статей Брюсова.

С другой стороны, в некоторых рецензиях, опубликованных в «Искусстве» и «Золотом руне», Ходасевич совпадал с взглядами Брюсова. В этом случае текст печатался под псевдонимом "Сигурд» - как мы писали выше, он мог иметь несколько дополнительных функций, к примеру, указывать на то, что автор - «свой» в кругу символистов, а также включен в полемику между «Весами» и «Грифом». Ходасевич в литературном мире объявлял о принадлежности кругу Соколова, Сигурд же позволял себе быть «учеником Брюсова» .

Стратегия Ходасевича меняется с пятого номера «Золотого руна» и в «Перевале»: критик больше не стремился соответствовать политике журнала и взглядам своего «патрона», a, напротив, подчеркивал позицию «ученика» Брюсова. Эта перемена совпала с работой над первым сборником стихов - видимо, Ходасевич полагал, что имя критика, лояльного «Весам», с большей вероятностью принесет успех книге, нежели имя автора круга «Грифа». «Молодость», несмотря на весьма благоприятные отзывы, сам Ходасевич не считал удачной, к тому же его имя по-прежнему ассоциировалось с кругом малоизвестных молодых литераторов из группы, сформировавшейся вокруг журналов С. Кречетова. После выхода первого сборника Ходасевич, как кажется, поменял свою стратегию: с 1908 года он начал публиковаться в журналах с широкой аудиторией. А также становится более заметным разделение поэзии, рецензий, позволяющих заработать символический капитал, и критических очерков на окололитературные темы: стихи пишет Ходасевич, а рецензии «для заработка» подписываются различными псевдонимами - с марта 1908 года «Сигурд» среди них не появлялся.

DOI: $10.31860 / 0131-6095-2020-3-208-217$

(ㄷ)

\section{ИЗБРАННЫЕ СТРАНИЦЫ ИЗ АЛЬБОМА А. М. РЕМИЗОВА «ЗАРУБЕЖНАЯ ЦЕНЗУРА»: ПОЛИТИКА И ЭТИКА}

Первые годы, проведенные Ремизовым в эмиграции, стали не только временем кардинальных перемен в жизни писателя, но и началом значительной трансформации его творческого метода, сложившегося в дореволюционные годы. ${ }^{1}$ Смещение ремизовского повествовательного модуса в область автобиографического материала, проявившееся еще в книгах, изданных в Берлине в 1922-1923 годах, таких как «Ахру. Повесть петербургская», «Корявка» и «Кукха. Розановы письма», приобрело доминантные формы уже в «контексте» русского Парижа. ${ }^{2}$ Несмотря на отшельнический образ

1 Библиография исследовательской литературы, посвященной дореволюционной прозе Ремизова, обширна. См., в частности: Доценко С. Проблемы поэтики А. М. Ремизова: Автобиографизм как конструктивный принцип творчества. Tallinn, 2000; Грачева A. М. ЗЖанр романа и творчество Алексея Ремизова (1910-1950-е годы). СПб., 2010.

2 Парижский период эмиграции Ремизова начался 7 ноября 1923 года. 
жизни, который писатель вел, сторонясь общественной и политической деятельности диаспоры, он стремился оставаться в центре читательского внимания. Несомненно, публикационная активность Ремизова прежде всего определялась финансовой необходимостью, которая, впрочем, не противоречила и глубокой внутренней потребности быть участником большого литературного процесса. Как писал в своих воспоминаниях Борис Зайцев, «главная была его страсть: печататься».$^{3}$

Литературная ситуация внутри русской диаспоры, сложившаяся вокруг Ремизова, возможно, обретет необходимую глубину и объем, если мы постараемся сфокусировать наше внимание на позиции писателя в его диалоге с редакциями некоторых эмигрантских органов печати. В этом смысле особенное значение приобретает единственный в своем роде артефакт, сохранившийся в его архиве, - авторский альбом под названием «Зарубежная цензура», ${ }^{4}$ начатый, судя по датировке на титульном листе, в 1925 году. Содержание альбома составили документы различного происхождения, объективирующие проблему цензуры в эмигрантской печати вообще и казусы столкновения Ремизова с политикой отдельных изданий в частности. В самодельном конволюте собраны печатные тексты и фрагменты автографов писателя из наборных рукописей с редакторскими пометами и «цензурными» изъятиями, а также оригиналы писем, полученных им из редколлегий.

Несомненно, альбом характеризует особенности литературного быта, позволяющие выявить сразу несколько уровней отражения индивидуального творчества в истории эмигрантской литературы. Обычно исследовательские выводы о взаимоотношениях Ремизова с деятелями периодической печати опираются в той или иной мере на опосредованные материалы: критику, мемуаристику, переписку и художественную прозу самого писателя. Благодаря его архиву мы можем составить приближенное к реальности представление о том, какие замечания, требования или критика вызывали болезненную реакцию Ремизова, а также о самых уязвимых формах его творческого самовыражения с точки зрения реципиентов из числа профессиональных литераторов.

Репрезентация материалов в альбоме практически лишена оценочных категорий: историю и мотивы, по которым тексты оказались «подцензурными», Ремизов либо оставил без комментариев, либо ограничился единичными спорадическими подчеркиваниями ключевых смыслов и весьма лапидарными пояснениями (одно из которых позволяет датировать завершение процесса пополнения альбома 1931 годом).

В настоящей статье мы рассмотрим три объекта ремизовской подборки, которые в суггестивной форме объективируют тему политической и этической цензуры. Расположение документов в альбоме подчинено авторской логике, которую удалось восстановить, определив тематические локусы «цензурных» преследований. Наша исследовательская задача предполагает как реконструкцию историко-литературных сюжетов, связанных с публикационной историей отдельных произведений писателя, так и уточнение позиции Ремизова к редакционной политике, бытовавшей в разных изданиях эмигрантской периодической печати.

Приступая к описанию альбома «Зарубежная цензура», являющегося в своем роде авторской версией избранных страниц истории литературы Русского Зарубежья, важно подчеркнуть, что, судя по подборке материалов, с понятием «цензура» писатель связывал разнообразные ущемления его творческого самовыражения, а также редакционную политику и политико-идеологическую обструкцию. ${ }^{5}$ Вывод о последнем

3 Зайцев Б. Мои современники / Сост. Н. Б. Зайцевой-Соллогуб; вступ. статья Б. Филиппова. London, 1988. С. 137.

4 Amherst College. Center for Russian Culture (USA). Alexei Remizov and Serafima RemizovaDovgello Papers. Series 2. B. 16. F. 29. Далее ссылки на материалы архива приводятся сокращенно: Amherst, с указанием шифра.

5 В соответствии с иными нормами в дореволюционной России цензурным преследованиям подверглись повесть Ремизова «Часы» и его сказка «Что есть табак». Подробнее об этом, а также библиографию по теме см.: На вечерней заре: письма А. М. Ремизова С. П. РемизовойДовгелло: 1908 год / Вступ. статья, подг. текста и комм. Е. Р. Обатниной // Русская литература. 
смысловом значении термина «цензура» в ремизовском понимании опирается на конкретный печатный документ, содержание которого указывает на взаимосвязь таких актуальных для русской эмиграции первой волны явлений, как авторская политическая идентификация и редакционная политика в отношении к Советской России:

(1) ${ }^{6}$ Газетные вырезки с указанием выходных данных рукой Ремизова: «Дни. № 873. 7.12.1925. Paris»:

1) фрагмент редакционного вступления к публикации статьи Бернарда Шоу из газеты «Дни»: «Бернард Шоу послал в петербургскую „Правду“ статью о процессе коммунистов. Напечатает ли ее „Правда“, неизвестно. Поэтому, не будет лишним напечатать ее пока в „Днях“, тем более что если „Правда“ и напечатает ее, то вряд ли без обычных для большевицкой печати замазываний и смазываний. Отметим, что Бернард Шоу - трудно сказать, иронически или всерьез - именует себя „коммунистом“. Статья эта напечатана в „Нью Лидер“ от 4 декабря» .

2) редакционное примечание, в котором в связи с просоветскими симпатиями ирландского нобелевского лауреата утверждались следующие принципы руководителей газеты «Дни»: «...в нашем распоряжении нет, не было и никогда не будет цензурного аппарата. Мы только пользуемся и всегда будем пользоваться правом, присущим всякой свободной редакции, уважающей своих читателей: мы будем печатать, как и печатали до сих пор, обычно статьи, соответствующие идеям и идеалам, которым мы служим. Однако, зная трудность пребывания писателей и публицистов в эмиграции, где технические возможности публичного высказывания крайне ограничены - лы шире, чем обычно это принято в свободной европейской журналистике, предоставляем свои страницы для инакомыслящих до тех пор, пока они остаются в рамках корректности.

Мы также не считаем „репрессией“ нежелание той или иной независимой общественной группы иметь в своем составе то или иное лицо. Но мы уже неоднократно писали о том, что эмигранты и беженцы, желающие общественно-честными путями вернуться в Россию, не должны подвергаться никаколу нравственнолу осуждению и что ил должна быть предоставлена полная возложность открыто организовываться и добиваться от правительства СССР своего „права на родину “ — Ред.». ${ }^{7}$

Размещая эти заметки в альбоме, Ремизов вряд ли интересовался содержанием письма Б. Шоу. Его внимание, очевидно, привлекала сама интерпретация такого общественного инструмента, как цензура, а также декларируемый газетой «Дни» принцип отказа от нее. В контексте альбома редакционное примечание, которое, в сущности, могло занять место на страницах любого другого периодического издания Парижа и Берлина (за исключением просоветских и сменовеховских) как двух основных центров эмиграции, приобретало глубоко личный смысл. Имея вполне отчетливые представления, насколько непреодолимым был раскол эмигрантского общественного сознания «по водоразделу» мы - они, ${ }^{8}$ писатель поставил под сомнение не только утверждение об отсутствии цензуры в эмигрантской печати, но и редакционную толерантность к «инакомыслящим» (т. е. тем, кто не разорвал связей с советской Россией).

2014. № 3. С. 146, 148-149. О столкновениях Ремизова с цензурными преследованиями его переводов пьес западноевропейских драматургов; пьес «Бесовское действо» и «Трагедия о Иуде принце Искариотском» см. в новелле Ремизова (под псевд. Э. Туриг) «Хождение по цензурным мукам», в статье А. М. Грачевой «„Охваченный жаждой новых форм для выражения вечных тайн...“ (Алексей Ремизов и метаморфозы русского театра первой четверти XX века)», а также в комментариях И. Ф. Даниловой и Е. Р. Обатниной (Релизов А. М. Собр. соч. СПб., 2016. Т. 12. Русалия).

6 Здесь и далее аннотации к отдельным документам альбома «Зарубежная цензура» мы будем обозначать цифрой в скобках, нумеруя их в соответствии с логикой наших рассуждений.

7 Публикация статьи была озаглавлена « „Коминтерн хуже Распутина“ (Бернард Шоу о процессе коммунистов)» (Дни. 1925. 7 дек. № 873. С. 2-3). Курсив в тексте принадлежит редакции печатного источника.

${ }^{8}$ См.: Вишняк M. В. На родине (Мы и они) // Современные записки. 1922. Кн. Х. С. $324-$ 343. 
Наверное, даже приняв решение остаться в эмиграции, ${ }^{9}$ уже находясь в Париже, он не переставал проецировать ситуацию возвращения в Петроград на себя лично, уже не раз убедившись в том, что зарубежные оппоненты новой России придерживались принципа «кто не с нами, тот против нас» ничуть не в меньшей степени, чем идеологи Октябрьского переворота. Как оказалось, Ремизову было нелегко преодолеть предубеждения некоторых редакций, подозревавших писателя не только в сотрудничестве с советсвики литераторами, но и в симпатиях к победившей власти. Его неохотно печатали в таких ведущих изданиях Парижа, как «Современные записки» и «Последние новости». ${ }^{10}$ В одном из писем к С. П. Ремизовой-Довгелло за 1925 год, писатель выразил отношение к идеологическому прессингу, имевшему место внутри эмигрантского сообщества: «Но ты понимаешь (я не большевик, смешно говорить), но я всем сердцем из самой глуби отвергаю здешних не большевик $<$ ов $>$, „врагов большевика“ и от сердца часто говорил (теперь я молчу!) резко». ${ }^{11}$

Объективности ради отметим, что, несмотря на восприятие Ремизова как просоветского писателя, в Париже, с 1921 по 1926 год (до начала издания журнала «Версты»), ${ }^{12}$ он явных недоброжелателей среди соотечественников себе не нажил. Вместе с тем его индивидуальный литературный стиль предполагал способность критиков принять и его манеру писать только о себе (так называемый автобиографический принцип его прозы), и широкий спектр культурных традиций его творчества, и его принципиальную «аполитичность». ${ }^{13}$ Сохранение политического нейтралитета стало основным условием писателя при заключении договоров с редакциями печатных органов, возникших в 1925-1927 годах. Так, редактор рижского еженедельного художественнолитературного журнала «Наш огонек» В. В. Васильев (Гадалин), характеризуя образованное им издание, в обращении к Ремизову заверял: «...журнал выходит без содействия-участия каких-либо политических партий и не преследует никаких политических целей. В задачу журнала входят: 1) дать читателю художественно-литературный материал, 2) осветить культурную жизнь Балтийских республик, 3) освещать мировую жизнь в иллюстрациях, 4) самое главное дать возможность заработать нуждающимся русским писателям и журналистам». ${ }^{14}$

Притеснения по политическим мотивам, разумеется, не имели документального подтверждения (их в альбом не подошьешь) и всегда могли быть списаны за счет мнительности писателя. Иначе обстояло дело с требованиями к конкретному художественному тексту, содержание которого при определенном ракурсе прочтения с очевидностью выявляло в авторе «инакомыслящего», для которого откуда ни возьмись возникала никому не ведомая в эмиграции «цензура». Вполне вероятно, что идея альбома зародилась как раз благодаря редакционным примечаниям газеты «Дни».

9 Подробнее об этом см.: Обатнина E. Р. Этюды к творческой биографии А. М. Ремизова: начало эмиграции. 1921-1922 гг. // Литературный факт. 2019. № 11. С. 8-35.

10 Случаи 1924-1925 годов, когда Ремизов испытывал притеснения в ведущих печатных органах Парижа, описаны в статье: Обатнина E. Р. Этюды к творческой биографии А. М. Pемизова: «La vie», или жизнь «чудесным образом». Париж, 1924-1925 // Там же. № 4 (14). C. 12, $37-38$.

11 «На вечерней заре». Глава из рукописи; Письма к С. П. Ремизовой-Довгелло. 1925 / Комм. Е. Р. Обатниной; подг. текста Е. Р. Обатниной и А. С. Урюпиной // Там же. 2020. № 1 (15). С. 95. Cp. позднейшую редакцию этого письма: «Но ты понимаешь, смешно говорить, я „большевик“, как меня тут величают (а в России я «бело-бандит»), но я всем сердцем из самой глуби отвергаю здешних „не-большевиков“, врагов „большевиков“ и от сердца и из корней голоса произношу резко. Теперь я молчу» (Там же. С. 35).

12 О поднятой в прессе травле евразийского проекта «Версты», активным участником которого выступил Ремизов, см.: «...c Вами беда - не перевести»: Письма Д. П. Святополк-Мирского к Ремизову (1922-1929) / Публ. Р. Хьюза // Диаспора. Париж; СПб., 2003. [Вып.] V. С. 335-401.

${ }_{13} \mathrm{Cp}$. высказывание П. Пильского в рецензии на книгу Ремизова «Образ Николая Чудотворца. Алатырь - камень русской веры» (Париж, 1931): «А. М. Ремизова нельзя просто читать: его надо любить (тогда - понимание) или не любить, чуждаться, ощущать его тяжеловатость, в конце концов, ничего в нем не понимать» (П. [Пильский П. М.]. Келья А. М. Ремизова // Сегодня. 1931. 7 июля. № 185. С. 8).

14 Amherst. Series 1. B. 3. F. 15. 
Как показывает ремизовская подборка, в парижских редакциях самым раздражающим свойством его прозы считалось последовательное стремление писателя снять границы между личной жизнью и литературным текстом и вписать в художественный сюжет имена реальных лиц, зачастую даже не догадывавшихся о своих приключениях на страницах его рукописей. Именно поэтому он неоднократно сталкивался с осторожным или откровенно негативным отношением редакторов к использованию имен современников из эмигрантского литературного окружения в его произведениях, часто изобилующих вымышленными событиями или воссоздающих с документальной точностью особенности литературного быта.

Даже благожелательные критики последовательно относили «правдоподобие» сюжетов из личной жизни Ремизова, созданное до некоторой степени за счет упоминаний известных литераторов, к наиболее вредным для него самого и быстро наскучившим читателям повествовательным приемам. Мих. Осоргин, вспоминая эпизод из повести «По карнизам», героем которого оказался он сам, изменил ракурс рассмотрения ремизовского бытописания, поставив в центр проблемы не нарушение личного пространства литераторов, ставших невольными героями художественных кунштюков писателя, а интересы рядовых читателей: «Возможно <...>, что на подобные выходки никто из друзей Ремизова не обижается (лично я не испытал обиды от предположения Ремизова, что если я уж украду телефон, то во всяком случае беспроволочный). ${ }^{15} \mathrm{Pe}^{-}$ мизов к этому же умеет задобрить словами тех, кого он интимно упоминает, зная, что, по слабости человеческой, многим приятно, когда он их в своих талантливых писаниях „увековечивает“. Поскольку все это пишется для друзей, - это можно и понять и принять. Но ведь не для друзей же все это печатается в газетах и журналах! И как ни модно презирать читателя (да и модно ли, впрочем!), все же не мешает подумать и об его правах». ${ }^{16}$

Надо признать, что Ремизов чутко реагировал на мотивации критиков. По-видимому, аргументы Осоргина, приведенные в связи с упоминанием реальных лиц в главе «Gespenst», были восприняты конструктивно, потому что окончательная редакция в книге «По карнизам» (1929) - была полностью освобождена от имен собственных. ${ }^{17}$ Этот жест доброй воли не остался без дружеского внимания Осоргина, который в рецензии на издание 1929 года отметил, что многие главы были «изменены сравнительно с их прежним текстом, в частности, автор, очевидно, вник печатным жалобам, заменил раздражающие подлинные фамилии - вымышленными. Ремизов стал добрее и проще». ${ }^{18}$

В свой сборник «цензурных» преследований Ремизов поместил лишь случаи, затронувшие его авторские принципы, в особенности потому что в конечном счете редакционные трбования сказались в нежелательной правке его реалистических рассказов. История публикаций отобранных писателем произведений в большинстве случаев осталась за рамками альбома - в переписке с издателями. Собственно тексты, представленные наборными рукописями или в виде страниц из печатных источников, фактически являются «документами», демонстрирующими тенденциозность эмигрантской редакционной политики. Самый ранний прецедент «цензуры», ограничивший «документализм» ремизовской прозы, датируется публикацией 1923 года,

15 Речь идет о журнальной редакции главы «Gespenst» из книги «По карнизам» (1929). В сюжете, описывающем обстоятельства пропажи телефона из квартиры, фигурировали фамилии ремизовских друзей из литературного окружения. Ср.: «Но кто же мог взять? Накануне был Лев Шестов - приехал из Парижа, но ему не для чего телефон: Париж - город бестелефонный! Заходил Поляков-Литовцев, к телефону прицеливался, это я заметил, но зачем ему отбирать у меня телефон, ведь он же пришел, чтобы выручить меня из беды: завтра срок - платить за квартиру! Был еще Осоргин, походя что-то в руках вертел, может, Осоргин в карман как нечаянно, нет, Осоргин не позарится на такое, ему, уж если - подавай беспроволочный! Спички пропали! Но это Бердяев - эти курильщики постоянно!» (Современные записки. 1925. Кн. 23. С. 99).

16 Осоргин Мuх. Дядя и тетя: «Благонамеренный». Книга 2-ая. Брюссель. 1926 г. // Последние новости. 1926. 29 апр. № 1863. С. 3.

17 См. прим. 15.

18 Последние новости. 1929. 7 нояб. № 3151 . С. 3. 
а по логике организации материала является иллюстрацией к приведенной нами выше редакционной заметке из газеты «Дни» (1):

(2) Рассказ «Кум (допотопное)». Вырезка из парижской еженедельной газеты «Звено» (опубл.: 1923. 7 мая. № 14. С. 2-3), под общим заголовком «Юбилейный рассказ» .

Даже не обращаясь к личной переписке Ремизова, в недрах которой мы обнаружили материал, свидетельствующий о подавлении его авторской воли, печатная история этой бытовой новеллы с очевидностью подтверждает, что в тексте была произведена замена настоящего имени на якобы «вымышленное». В основу повествования легли реалии жизни, связанные с петроградским бытом второй половины 1910 -х годов. Особый pointe в ситуацию вокруг рассказа «Кум» вносило то обстоятельство, что текст представлял собой расширенную редакцию рассказа «Исаич», уже опубликованного в 1915 году. ${ }^{19}$ Центральный персонаж - сосед по Таврической улице Зиновий Исаевич Гржебин. Многолетние деловые контакты Ремизова с издателем, укрепившиеся в течение 1910-1912 годов, когда «Шиповник» выпускал тома его Сочинений, впоследствии переросли в более чем дружеские, поскольку писатель стал крестным трех дочерей Гржебина. Новое название, поставленное в заголовок рассказа в 1923 году, также как и журнальная рубрика ( Юбилейный рассказ»), теперь подчеркивали почти родственный характер описанных автором взаимоотношений. В окончательной редакции, в отличие от текста 1915 года, где центральный персонаж назван его собственным именем - Зиновий Исаевич, герой, также без фамилии, оказался поименован Семеном Соломоновичем. ${ }^{20}$

Обстоятельства этой публикации проясняются в переписке Ремизова с Львом Шестовым. Философ лояльно относился к ремизовским литературным выходкам, не смущаясь тем, что писатель с 1908 года использовал его имя в публикациях абсурдистских «снов». ${ }^{21}$ Тем не менее непосредственное участие ремизовского ближайшего друга в продвижении этого рассказа на страницы парижской прессы повлекло за собой неожиданные последствия для авторского текста. История началась с письма, в котором Шестов, заботившийся о заработках Ремизова, описал появившуюся возможность печататься в новой газете «Звено», выходившей в Париже с февраля 1923 года. Все вопросы, касающиеся гонорара и жанровых предпочтений редакции, были заранее обговорены с главным редактором М. М. Винавером. Как один из первых читателей книги о Розанове, Шестов считал Ремизова талантливым мемуаристом, поэтому он в письме от 25 февраля 1923 года предлагал: «По-моему хорошо было бы, чтобы ты что-нибудь из „воспоминаний“ прислал. Так строчек на $350<$...>. Если воспоминания - то можно и для двух номеров (только пойдешь не подряд)». ${ }^{22}$

Вскоре Ремизов выполнил заказ, направив рассказ «Кум» в редакцию «Звена». Как выясняется из последующего письма Шестова, его экспозиция, сходная с рассказом «Исаич», ${ }^{23}$ в рукописи имела расхождения с окончательным печатным вариантом.

19 Впервые: Речь. 1915. 25 дек. № 355. С. 6-7.

20 См. текст первой редакции рассказа и комментарий в изд.: Релизов $A$. M. Собр. соч. М., 2000. Т. 3. Оказион. С. 315-323; 639-640.

21 Цикл миниатюр в жанре «снов» под названием «Бедовая доля» дважды публиковался Ремизовым с посвящением «Л. Шестову» - в авторском сборнике «Рассказы» (1910) и в третьем томе Сочинений (СПб.: Шиповник, [1911]). В контексте данного сюжета обращает на себя внимание факт, что осенью 1925 года в газету «Звено» был принят к печати цикл «Мои сны», который состоял из миниатюр, озаглавленных именами писателей-эмигрантов. Одна из них — «Лев Шестов» (Звено. 1925. 26 окт. № 143. С. 3).

22 Amherst. Series 1. B. 2. F. 9.

$23 \mathrm{Cp}$. начало рассказа в редакции 1915 года, где за именем первого из названных персонажей угадывалось имя его «прототипа» из литературного окружения Ремизова - Евгения Германовича Лундберга: «Рассказать ли вам о страннике Евгении, ходившем по Петербургу под видом немого, и как заговорил он чудесным образом, или о Зиновии Исаевиче, добром и неизменном соседе нашем? Нет, лучше я расскажу вам про Зиновия Исаевича» (цит. по: Релизов А. M. Собр. соч. Т. 3. С. 315$)$. 
В частности, текст начинался с пассажа, в котором упоминалось полное имя философа. В обеих версиях (1915 и 1923 года) авторская тактика была рассчитана на узнаваемость имен персонажей в литературных кругах, а тема памяти о «допотопной» жизни в Петрограде Ремизову, очевидно, казалась реликтовой для всех соотечественников, независимо от последующих политических расхождений. По логике Ремизова, Шестов, дореволюционное Собрание сочинений которого также вышло в издательстве «Шиповник», был героем петербургских незапамятных времен, как и многие другие литераторы. В своем «зачине» к сюжету о Гржебине писатель стремился создать впечатление свободного выбора субъекта и сюжета повествования во всем разнообразии сложившихся связей и событий прожитых лет жизни. Неслучайно он имитировал стиль гоголевского дьячка из «Пропавшей грамоты», как бы рисуя образ рассказчика, адресующего свои «прибаутки» дружескому кругу. Первоначальная парижская редакция с упоминанием Шестова не сохранилась, поэтому для того, чтобы гипотетически представить, в каком контексте могло появиться имя философа, приведем начало рассказа «Кум» по публикации в газете «Звено»: «Рассказать ли Вам о Я. С. Бахрахоме, о его новом изобретении $<. .>$ и как однажды, делая опыты, попал он в обезьянью палату и что из этого вышло или о Семене Соломоновиче, куме и неизменном соседе нашем?

Нет, лучше я расскажу вам о Соломоне Семеновиче: ведь сегодня его юбилейный день, сегодня исполнилось, как говорится, ровно двадцать пять лет! ${ }^{24}$

Следующее письмо Шестова от 22 апреля достаточно неожиданно разрешило эту «проблему выбора». В частности, Шестов писал: «Видел сегодня М. М. Винавера. Он показал мне твой рассказ о Гржебине. Рассказ-то сам по себе и ему и мне понравился. Но не понравилось, что Гржебин фигурирует. Очень от него большевизмом пахнет. И вот мы предлагаем тебе заменить Зиновия Исаевича другим именем. Думаю, что тебе все равно и возражать ты не будешь. А я от себя еще вот о чем попрошу пропустить первые строчки: не хочу даже и в тот раз вместе с большевистским человеком быть, если он и под псевдонимом. Думаю, что и против этого возражений у тебя не встретится. А пропущенные строчки ты приладишь к другому рассказу и убытку тебе не выйдет. Напиши ответ поскорей <...>» . $^{25}$

По драматизму момента реакция Ремизова на письмо друга, вероятно, могла быть сопоставима с известной сакраментальной фразой: «И ты, Брут?», - потому что на этот раз именно Шестов взял на себя обязанности «цензора» и поддержал позицию редактора Винавера. Таким образом, из корреспонденции Ремизова выясняется, что история цензурных изменений в тексте рассказа имела не столько этическую, сколько политическую подоплеку и была связана с тем одиозным ореолом, который окружил имя Гржебина в общественном мнении эмиграции. Случай с обновленной версией рассказа «Кум» показал, что политическая атмосфера русского Парижа заставила Шестова учитывать настроения, опирающиеся на авторитет непримиримых оппонентов большевизма, для которых Гржебин являлся едва ли не агентом советского правительства и спекулянтом, умудрявшимся торговать на европейском и советском книжных рынках одновременно. Такое отношение сформировалось благодаря длительному шлейфу пересудов и тяжб. Еще в декабре 1920 года разразился громкий скандал, инициированный Д. С. Мережковским и 3. Н. Гиппиус, которые обвинили издателя в финансовых махинациях и нарушении авторских прав писателей, продавших ему свои рукописи. ${ }^{26}$ Ремизов, не имея решительно никаких претензий к Гржебину, был единственным, кто в печати защитил человека, многие годы поддерживавшего его финансово и способствовавшего укреплению его литературного статуса. ${ }^{27} \mathrm{~K}$ тому же в эмиграции писатель и сам разделял принцип из-

24 Звено. 1923. 7 мая. № 14. С. 2.

25 Amherst. Series 1. В. 2. F. 9.

${ }^{26}$ См. подробнее: Динерштейн Е. А. Синяя птица Зиновия Гржебина. М., 2014. С. 293-316 (гл. «Репутация издателя»).

${ }^{27}$ См.: Релизов А. Письмо в редакцию: Редактору «Русской книги» проф. А. С. Ященко: I. Благодарность ( От книжников благодарность за берлинскую „Русскую книгу“...»); II. О Гржебине // Русская книга. 1921. № 9. Сентябрь. С. 22. В этом слове в защиту Гржебина Ремизов впер- 
дателя «не отрываться» от России и выпускать книги в том числе и для советских читателей. ${ }^{28}$

Весной 1923 года Ремизов, стоявший перед драматической дилеммой: вернуться в Россию или продолжить эмиграцию, ${ }^{29}$ хотел ясно себе представлять «горизонт ожидания» авторитетных парижских редакторов в отношении своего творчества. Контакты с тем же Гржебиным и советскими писателями в Берлине породили кривотолки о его симпатиях к большевистской власти. Шестов, принявший сторону редакции газеты «Звено», стремился избежать политических дискуссий, очевидно понимая, что рассказ «Кум» вызовет новый виток едва утихших разбирательств. Тем не менее, еще надеясь на присущую Шестову самоиронию, писатель спросил повторно: «И может, ты согласишься оставить первые строчки?» - и на всякий случай предложил две другие кандидатуры для имен второстепенных героев - инженера Я. С. Шрейбера или журналиста А. В. Бахраха. ${ }^{30}$ Новый вариант, по-видимому, был отклонен уже в редакции, которая потребовала изменения всех настоящих фамилий. Так в первых строках рассказа появился неудобочитаемый симбиоз Я. С. Бахрахол, составленный из инициалов Якова Самойловича Шрейбера и фамилии молодого журналиста Александра Васильевича Бахраха в творительном падеже. По-прежнему проецируя свой рассказ на дружеское окружение, писатель не поддался только лишь на формализацию художественной ономастики, примирительно утвердив на место Зиновия Исаевича другого современника: «Вместо З. И. пускай будет Семен Соломонович, - (в честь Юшкевича)», - написал он Шестову. ${ }^{31}$ В результате редактуры неприкосновенность была обеспечена только домашним именам детей издателя - Ляли, Бубы и Капочки. Возможно, Ремизов даже остался доволен полученным художественным эффектом: гоголевский прием удвоился, поскольку принцип изобретения новых фамилий буквально повторял незабвенные строчки «Женитьбы»: «Если бы губы Никанора Ивановича да приставить к носу Ивана Кузьмича, да взять сколько-нибудь развязности, какая у Балтазара Балтазарыча...».

Вся история с дебютом Ремизова в газете «Звено» раскрывает несомненный провокативный характер его литературного поведения. Гипотетически мы можем расценить ремизовское предложение для печати совершенно невинного по содержанию рассказа, абсолютно лишенного политических коннотаций, содержащего лишь имя (даже не фамилию) «большевистского» 3. И. Гржебина, - как своего рода «пробный шар», запущенный на небосклон литературного Парижа для проверки на идеологическую толерантность. Исход этой аферы был безрадостным, особенно принимая во внимание роль в редактуре текста Льва Шестова. Писателю пришлось пойти на компромисс во избежание идеологического афронта, который и без того окружал его имя. Упорство он проявил только в сохранении собственных художественных принципов. Хотя и с потерями,

вые называет издателя своим «кумом». О предшествующих данному выступлению Ремизова в печати причинах см.: Динерштейн E. А. Синяя птица Зиновия Гржебина. С. 297-298.

${ }_{28}$ См.: Там же. С. 295; Обатнина E. Р. Этюды к творческой биографии А. М. Ремизова: «...или в Россию, или в Париж...» 1923 г. // Литературный факт. 2019. № 11. С. 8-35.

29 Подробнее об этом см.: Там же. С. $25-32$.

30 См. письмо Ремизова Шестову от 25 апреля 1923 года (Переписка Л. И. Шестова с А. М. Ремизовым / Вступ. заметка, подг. текста и прим. И. Ф. Даниловой и А. А. Данилевского // Русская литература. 1993. № 3. С. 114-115). Заметим, что Шестов угадал необязательность привязки конкретных имен собственных в рассказе «Кум», возможно, зная, как Ремизов работал над текстом глав «Взвихренной Руси», наводненных «снами» с участием берлинских знакомых. Имена, в частности в романе, нередко носили формальный характер, являясь неким «залогом» «документальности». Вариативность смены фамилий подтверждается в переписке писателя с женой. В отдельных письмах Ремизов обсуждает с ней возможную взаимозаменяемость реальных имен упоминаемых лиц. Характерно, что первоначально, внедряя свой «документализм», писатель спрашивал у владельцев разрешения на использование имени в художественном тексте: «...увижу и Погосьяна, может, он захочет „прославиться“. Барладьян очень звучно. Ну, конечно, можно на крайний случай Лундберга пустить...» («На вечерней заре». Главы из рукописи; Письма к С. П. Ремизовой-Довгелло. 1921-1922 гг. (окончание) / Комм. Е. Р. Обатниной; подг. текста Е. Р. Обатниной и А. С. Урюпиной // Литературный факт. 2018. № 8. С. 21).

31 Переписка Л. И. Шестова с А. М. Ремизовым. С. 114. 
Ремизов отстоял личный творческий курс на «документальность» автобиографического нарратива. В дальнейшем парижская редакция рассказа, пройдя цензурные препоны, затерялась на страницах газеты. Ремизов никогда больше не возвращался к этому тексту.

Через два года после публикации рассказа «Кум» случилось очередное столкновение с редакционной «цензурой». На этот раз проявился двойной стандарт этической щепетильности - различный для писателей «посюсторонних» и «потусторонних»:

(3) Наборная рукопись рассказа "Анна Каренина». Автограф с вымаранным в тексте именем Д. С. Мережковского в контексте о выдаче дополнительных дров: «...надо идти к товарищу такому-то, и называют учреждение:

- Мережковский (слово зачеркнуто. - E. O.) и Сологуб давно получают -

Понимаю, и Мережковский (слово зачеркнуто. - E. O.) и Сологуб известные писатели, а мое дело маленькое - меня мало кто знает! - и рассчитывать мне на исключение не годилось бы...» .

Сверху текста сохранилась редакционная помета рукой М. Алданова: «В воскресный нолер. 20 IX, литературный отдел».

Опубл.: Дни. 1925. 20 сент. № 806. С. 5, под общим заголовком «Из книги „Взвихренная Русь“(1919-1920)».

Рассказ основан на сюжете из биографии Ремизова, относящемся к ноябрю-декабрю 1919 года, и содержит доподлинное описание обстоятельств жизни писателей в Петрограде. Упоминание товарищей по литературному цеху в этом контексте было естественным и закономерным, тем более что роман «Взвихренная Русь», для которого и была написана главка «Анна Каренина», представлял собой хронику революционной эпохи. М. Алданов как редактор газеты «Дни» и, возможно, автор приведенных нами выше примечаний к письму Бернарда Шоу (1), и на сей раз выступил блюстителем «корректности» - в отношении имен известных современников. Ремизову ничего не оставалось сделать, как согласиться и изъять фамилию писателя-эмигранта. Примечательно, что привлечение имени названного следом за Мережковским, ${ }^{32}$ также здравствующего (но только по ту сторону границы) Федора Сологуба не показалось «цензору» этически рискованным. Выпуская роман книжным изданием (Париж: ТАИР, 1927), писатель восстановил первоначальную редакцию. ${ }^{33}$

В ремизовской коллекции мотивов, запрещающих использование собственных имен, случаи подавления авторской воли, представленные публикациями рассказов «Кум» и «Анна Каренина», являются документальной констатацией некоторых политических предубеждений эмигрантских редакций и сомнительных этических принципов, ориентированных на авторитет единичных литературных имен, ради которых искажениям подвергался индивидуальный авторский стиль. Мы не решимся утверждать, что Мережковский был бы фраппирован, обнаружив свое имя в контексте рассказа «Анна Каренина». Не исключено, что редакционная охранительная функция, ограждающая известных литераторов от ремизовской «документальности», была иной раз излишней, поскольку сами «жертвы» бытописаний Ремизова весьма редко реагировали на приемы писателя болезненно, умея прочитывать в его произведениях более существенные смыслы. В 1925 году Ремизов опубликовал серию новелл в жанре «снов», и героями одного из них стали супруги Мережковские, названные в тексте подлинными именами. ${ }^{34}$ После публикации двух рассказов из состава «Взвихренной Руси» («Труддезертир» и «По „бедовому“ декрету») в журнале «Современные записки», в которых так же, как и в рассказе "Анна Каренина», был воссоздан быт простых жителей Петрограда зимой 1919-1920 года, а имена на сей раз имели литературное происхождение, Гиппиус в письме жене Ремизова передавала отзыв о прочитанном: «Скажите Ал<ексею>

32 Мережковский и Гиппиус в сопровождении Д. В. Философова и В. А. Злобина покинули Петроград в ночь на 24 декабря 1919 года.

${ }_{33}$ См.: Релизов А. М. Собр. соч. М., 2000. Т. 5. Взвихренная Русь. С. 242-246.

34 Релизов А. Мои сны // Звено. 1925. 26 окт. № 143. С. 3. 
Мих <айлови >чу, что мне так понравились его рассказы в $<$... Совр $<$ еменных $>3<$ писках >; Дм< <итрию $>$ C <ергееви $>$ чу особенно нравится там первый, ${ }^{35}$ вот бы, говорит, французам его перевести, поняли бы нашу жизнь. А то как дубины». ${ }^{36}$

Со своей стороны Мережковский в личном письме, адресованном писателю 24 февраля 1931 года, , редко сообщаясь с Ремизовым, не преминул высказаться о его последних творческих работах, и в частности о повести «По карнизам» $(1929)$ - своего рода манифесте художественных принципов автобиографической прозы, соединяющей документальность, вымысел и сновидения:

«Дорогой Алексей Михайлович!

$<. .>$ Я недавно прочел Ваши книги „Зга“ и „По карнизам“ с большим интересом и сочувствием. Вы плаваете в той же глубокой воде, что и В. В. Розанов, увы, эти воды доступны немногим. Вы чувствуете реальность и личность Зла, которую так немногие чувствуют <...>

Искренне Ваш, Дмитрий Мережковский». ${ }^{37}$

Учитывая этот и другие доброжелательные отзывы литераторов, многие из которых были причастны к редакциям ведущих журналов Парижа, Ремизов порой стоически, порой иронически относился к издательским требованиям до тех пор, покуда они не затрагивали его творческих интенций. В целом коллекция, собранная на страницах альбома «Зарубежная цензура», представляет собой единственный в своем роде опыт аналитического подхода Ремизова к проблеме собственных взаимоотношений с литературным сообществом эмиграции, которое в свою очередь стремилось сохранить целостность благодаря негласно узаконенному кодексу этических, эстетических и политических норм.

35 Речь идет о двух рассказах Ремизова, опубликованных в двадцать шестой книге журнала «Современные записки», которая вышла из печати в декабре 1925 года: «Труддезертир» (с. 161183), «По „бедовому“ декрету» (с. 183-194).

${ }^{36} \mathrm{Lampl} \mathrm{H}$. Zinaida Hippius an S. P. Remizova-Dovgello // Wiener Slawistischer Almanach. 1978. Bd 1. S. 176.

37 Amherst. Series 1. B. 6. F. 4.

DOI: $10.31860 / 0131-6095-2020-3-217-231$

(C) А. А. Кобринский

\section{МАСТЕР ПЕТР: НЕСКОЛЬКО ШТРИХОВ К БИОГРАФИЧЕСКИМ МИФАМ ДАНИИЛА ХАРМСА}

Так получилось, что графику, декоратору и театральному художнику Петру Павловичу Снопкову (1900-1942), выпускнику Высшего художественно-технического института, выпало на некоторое время стать одним из углов в треугольнике, где двумя другими были Даниил Хармс и художница, ученица П. Н. Филонова А. И. Порет, причем именно ему удалось жениться на Порет, хотя брак и не был долговечным. Поэтому имя Снопкова прочно укоренилось в воспоминаниях Алисы Порет о Хармсе, которые впервые были опубликованы еще в 1980 году. ${ }^{1}$

* Исследование выполнено при финансовой поддержке РФФИ в рамках научного проекта № 18-012-00479.

1 Порет А. Воспоминания о Д. И. Хармсе / Предисловие В. Глоцера // Панорама искусств. 1980. Сб. 3. С. 347-359. В настоящей статье эти воспоминания цитируются по публикации: Поpem А. И. Воспоминания о Данииле Хармсе // Даниил Хармс глазами современников: Воспоминания. Дневники. Письма / Под ред. А. Л. Дмитренко и В. Н. Сажина. СПб., 2019. С. 353-371, в которой восстановлены купюры, сделанные в издании 1980 года. 
Эти воспоминания были крайне негативно встречены людьми, которые знали Хармса и его друзей лично и были тогда еще живы. «Путаница», «искажение событий», «ложь», «восхваление себя» - такие характеристики давались ими мемуарам Алисы Порет. ${ }^{2}$ Между тем не учитывался явно игровой, художественный стиль этой книги, где реальные факты легко переходили в вымысел, слух или сплетня подавались как истина, а некоторые повествуемые события являлись очевидным порождением ее фантазии. При этом мемуары были наполнены яркими, интересными деталями, точными характеристиками, легко узнаваемыми мелочами, которые внушали читателю ощущение безусловной правдивости автора.

Когда в 1991 году впервые были опубликованы дневниковые записи Даниила Хармса, ${ }^{3}$ оказалось возможным сопоставить одни и те же события с двух сторон. Речь идет о центральной сюжетной линии мемуаров: влюбленности Хармса в Порет в 1932 году после его возвращения из ссылки.

Из дневников Хармса становится ясно, что в ноябре 1932 года он переживает очередной всплеск любви к своей бывшей жене Эстер Русаковой. Эта любовь, однако, наталкивается на ее полное равнодушие, а прекрасный образ разрушается в душе Хармса под воздействием реальных встреч. «У Эстер очень истасканный и развязный вид»; «Боже! <...> Какая у нее блядская рожа!» - записывает он свои впечатления при посещении семейства Русаковых 28 ноября 1932 года. ${ }^{4}$

На следующий день Хармс приглашает Порет к себе, и с этого момента они общаются очень интенсивно: встречаются практически ежедневно, ходят в кино, ездят за город, вместе проводят время вплоть до марта 1933 года. И практически одновременно Хармс начинает все чаще упоминать в дневниках и записных книжках имя Петра Павловича Снопкова (он пишет его фамилию искаженно: «Снабков»).

Сначала Снопков просто фигурирует там как знакомый Порет. Он входит в их небольшую компанию, сопровождает их на концерты и в кино. Записи в дневнике фиксируют его появления достаточно спокойно. Напротив, художнику Павлу Михайловичу Кондратьеву, который уже шесть лет был безответно влюблен в Алису Ивановну, Хармс посвящает целый абзац, где описывает его мучения $(2,214)$.

По мере приближения к 1933 году Хармс все больше и больше влюбляется в Порет. Однако Новый год он встречает с ее подругой - художницей Татьяной Николаевной Глебовой. А затем к ним приезжают Порет со Снопковым - и уже не просто как друзья: «Они целовались, и мне было это мучительно видеть», - записывает Хармс $(2,216)$.

С этого момента Снопков воспринимается им как соперник, хотя подробно в дневнике об этом не говорится. Несмотря на все это, 1 февраля Хармс признается Порет в любви, и их роман продолжает развиваться. С каждым днем они сближаются все больше, и Хармс с физиологическими подробностями фиксирует в дневнике особенности этого сближения. 13 февраля Хармс вписывает в записную книжку просьбу к Всевышнему о том, чтобы Алиса стала его женой. ${ }^{5}$ Но он чувствует, что ничего не выходит: «Я вижу, как Алиса Ивановна ускользает от меня» $(2,176)$.

${ }^{2}$ См.: Глебова Т. Н. Воспоминания. Дневники. Письма. / Вступ. статья, подг. текстов, комм. E. С. Спицыной // Experiment = Эксперимент. A Journal of Russian Culture. 2010. Vol. 16. Part 2. P. 421; Викторов Б. Александр Введенский и мир, или «Плечо надо связывать с четыре». Харьков, 2009. С. 194 (письмо Т. А. Липавской автору книги); Заметка Н. Б. Шанько о воспоминаниях А. И. Порет // Даниил Хармс глазами современников: Воспоминания. Дневники. Письма. С. 371.

3 Дневниковые записи Даниила Хармса / Публ. А. Устинова и А. Кобринского // Минувшее. Исторический альманах. М.; СПб., 1994. [Т.] 11. С. 417-583; Харлс Д. Горло бредит бритвою: случаи, рассказы, дневниковые записи / Сост. и комм. А. Кобринского и А. Устинова; предисловие А. Кобринского. М., 1991 (Глагол. Литературно-художественный журнал. Вып. 4).

${ }^{4}$ Харлс Д. Полн. собр. соч. Записные книжки. Дневник: В 2 кн. / Сост. В. Сажина и Ж.-Ф. Жааккара; прим. В. Сажина. СПб., 2002. Кн. 2. С. 212. Далее ссылки на это издание даются в тексте сокращенно, с указанием номера книги и страницы.

5 Для более яркой иллюстрации происходившего имеет смысл привести цитату из дневника И. П. Ювачева, отца Хармса, от 21 февраля 1933 года: «У Даниила Алиса (Порет). Повадилась она ходить к нему по ночам» (Даниил Хармс глазами современников. Воспоминания, дневники, письма. С. 426). 
Объяснение происходит в конце февраля - начале марта. Хармс узнает, что «она любит Петра Павловича и живет с ним» $(2,218)$. Но и это не сразу останавливает их отношения: очевидно, что Порет тоже испытывала к Хармсу определенные чувства и не могла решиться сделать окончательный выбор.

История, рассказанная самой Порет, - совершенно иная.

Судя по ее воспоминаниям, впервые Хармс проникся к ней чувствами еще до своего ареста в декабре 1931 года. ${ }^{6}$ Затем, по ее словам, находясь в ссылке в Курске, он постоянно писал ей стихи и вспоминал их встречи ${ }^{7}$ (между тем, исходя из перечня в записной книжке Хармса этого периода, Алисе Порет было отправлено лишь одно письмо, которое, видимо, не сохранилось, как не дошли до нас и написанные ей там стихи, если они вообще писались).

А потом следует рассказ о том, как Снопков, воспользовавшись отсутствием Хармca, ее «как-то окрутил»: «Я совершенно не помню даты и когда что было по порядку, вспоминала Порет, - но я знаю, что стала скрывать от Д. И. мои прогулки с П. (Снопковым. - $A . \kappa$.), его приходы и то, что он уговаривал меня, наконец, спасти его, взять к себе, чтобы он опять стал художником <...>.

Он был со мной вечно одинаково мил и галантен, и как-то не сразу был обнародован наш брак ,à la fourchette“. Где-то у меня было тайное чувство, что на этот раз я обыграла Д. И. Но он был очень проницателен и нервен, и поведение его сильно изменилось. Он в течение многих лет никогда не говорил мне комплиментов, держал себя очень чопорно и руку целовал наспех и тут же бросал таким жестом, как стряхивают градусник. Не знаю, как колдовал Д. И., но он всегда приходил, когда не было Снопкова» ${ }^{8}$

Порет акцентирует в своих воспоминаниях внимание на якобы магических способностях Хармса, благодаря которым он получил странную власть над ее отношениями со Снопковым. Мемуары пронизаны рассказами о том, как Хармс - некий злой гений - неожиданно появлялся в разные моменты их жизни и накладывал своего рода заклятья, которые должны были заставить их вскоре расстаться (что и произошло через два года после свадьбы, состоявшейся в начале 1933 года). ${ }^{9}$ Судя по ее свидетельствам, Хармс присутствовал и «пророчествовал» на свадьбе - и продолжал пытаться вернуть ее даже после замужества. Более того, Алиса Ивановна говорит о том, как он якобы магическим путем воспрепятствовал попытке Снопкова воссоздать их семью через три года после развода. ${ }^{10}$ Простой подсчет показывает, что это должен был быть 1938 год.

Все это, конечно, плод фантазии.

10 сентября 1933 года Хармс заносит в записную книжку: «Как часто мы заблуждаемся! Я был влюблен в Алису Ивановну, пока не получил от нее всего, что требует у женщины мужчина. Тогда я разлюбил Алису. Не потому, что пресытился, удовлетворил свою страсть, и что-либо тому подобное. Нет, просто потому, что узнав Алису как женщину, я узнал, что она женщина неинтересная, по крайней мере, на мой вкус. А потом я увидел в ней и другие недостатки. И скоро я совсем разлюбил ее, как раз тогда, когда она полюбила меня. Я буквально удрал, объяснив ей, что ухожу, ибо она любит Петра Павловича. Недавно я узнал, что Алиса вышла замуж за Петра Павловича. О как я был рад!» ${ }^{11}(2,218)$.

Судя по всему, Хармсу удалось получить «то, что требует у женщины мужчина», когда Порет уже жила со Снопковым. Но из этой записи следует самое важное: общение между Хармсом и Порет прервалось незадолго до ее свадьбы, и Хармс не только не

6 Порет А. И. Воспоминания о Данииле Хармсе. С. 357.

7 Там же.

8 Порет А. И. Записки. Рисунки. Воспоминания: В 2 кн. М., 2016. Кн. 2. С. 192.

9 Порет А. И. Воспоминания о Данииле Хармсе. С. 368.

10 Там же.

11 Любопытно, что отголоски начинавшегося «соперничества» со Снопковым, видимо, отразились в стихотворении Хармса «Колесо радости жена» (1933): «Отойди от меня мастер Петр». См. об этом: Шатова И. «Колесо радости жена»: анаграмматическая трактовка // Russian Literature. 2011. Vol. 69. № 2-4. P. 440. 
присутствовал на ней, но и узнал об этом событии уже постфактум. Каким был характер их отношений в последующие годы, лучше всего демонстрирует сохранившееся письмо Хармса к Порет, в котором он просит вернуть книгу Г. Майринка «Голем» на немецком языке, которую однажды дал ее брату Виктору. Вначале он всячески извиняется за сам факт обращения к ней и сообщает, что «проделал все, чтобы избежать этого», а затем предлагает послать книгу по почте (разумеется, о встрече речь даже не идет). ${ }^{12}$ Письмо не датировано, но Хармс указывает свой адрес: ул. Маяковского, д. 11, кв. 8. Это означает, что письмо отправлено не ранее 1936 года, так как Надеждинская улица приобрела свое сегодняшнее название 16 января 1936 года. Следовательно, оно было написано уже после следующего замужества А. И. Порет: в 1935 году она вышла замуж за композитора Б. С. Майзеля. К этому моменту отношения между ней и Хармсом были уже окончательно прекращены, вот почему письмо примерно наполовину состоит из извинений за сам факт обращения.

В доме Порет Снопкова прозвали «Мастер Петр»: все, за что бы он ни брался, он делал в совершенстве. ${ }^{13}$ Однако брак их продолжался всего два года, после чего распался.

О дальнейшей судьбе Снопкова практически ничего не было известно. Однако как специалисты по творчеству Даниила Хармса, так и просто интересующиеся его биографией всегда особо обращали внимание на тот фрагмент воспоминаний Порет, где она рассказывает о последних годах своего бывшего супруга: «Даниил Иванович и Петя еще раз встретились во время блокады Ленинграда в тюрьме. И оба они умерли от голода. Даниил Иванович там же, а П. П. был выслан на лесозаготовки, один раз не выполнил норму, ему сократили паек, на следующий день тоже, и так до конца». ${ }^{14}$

Эта легенда оказалась живучей.

Между тем хранящееся в архиве Управления ФСБ по Санкт-Петербургу и Ленинградской области дело Петра Павловича Снопкова помогает восстановить не только факты его биографии, но и прояснить обстоятельства его ареста и смерти, сверив легенду с реальной жизнью. Следует заметить, что значительная часть листов дела остается засекреченной (включая и текст приговора!), однако и доступных материалов вполне хватает для установления истины.

Дело Петра Павловича Снопкова содержит довольно незначительное количество биографических деталей, которые можно дополнить не менее скудной информацией, известной о нем ранее. Он родился в 1900 году в Санкт-Петербурге. У его родителей Павла и Марии Снопковых - было двое детей: Петр и его младшая сестра Вера (в замужестве Карманова). Отец умер в возрасте 62 лет в 1927 году.

Снопков учился (вместе с Алисой Порет) во ВХУТЕИНе, который закончил в 1922 году. Работал театральным художником, художником по костюмам в различных театрах, был декоратором и художником по афишам. Участвовал в оформлении детских книг (в частности, в 1925 году вместе с Б. Б. Малаховским ${ }^{15}$ он иллюстрировал детскую книжку Н. Н. Асеева «Песни пищика»). В 1934 году работал художником на съемках фильма А. М. Файнциммера ${ }^{16}$ «Подпоручик Киже» по сценарию Ю. Н. Тынянова. Сов-

12 Харлс Д. И. Неизданный Хармс. Полн. собр. соч. Трактаты и статьи. Письма. Дополнения: не вошедшее в т. 1-3 / Сост., прим. В. Сажина. СПб., 2001. С. 73.

13 «Первое, что сделал Мастер Петр - он вышиб из седла Хармса. Он починил в маминой комнате электропроводку, отполировал шкаф красного дерева, сам настроил рояль (у него был абсолютный слух), переплел десятки книг с невероятным изяществом, готовил лучше Паши. Знал 13 способов приготовления яичниц. Достал 3 увесистых тома „Жизнь растений“. Добился полного доверия и любви маминой собачки „Шекки“, а Хокусавна уже ни с кем не хотела ходить гулять, т. к. никто не мог так ловко и далеко бросать ей палку или мяч» (Порет А. И. Записки. Рисунки. Воспоминания. Кн. 2. С. 198).

14 Порет А. И. Воспоминания о Данииле Хармсе. С. 370.

15 Малаховский Бронислав Брониславович (1902-1937) - художник, архитектор, окончил ВХУТЕМАС-ВХУТЕИН. Работал как карикатурист, сотрудничал с детскими журналами, в том числе - «жжм» и «Чижом». 27 августа 1937 года расстрелян как «польский шпион».

16 Файнциммер Александр Михайлович (1906-1982) - кинорежиссер, лауреат двух Сталинских премий третьей степени. 
местно с учеником П. Н. Филонова В. А. Сулимо-Самуйлло ${ }^{17}$ занимался оформлением массовых праздников, так, в частности, ими были выполнены эскизы павильонов, карнавальных колесниц и костюмов участников Первого ленинградского карнавала в 1937 году. Был членом Ленинградского Союза советских художников.

В 1939 году Снопков стал одним из основателей Ленинградского театра эстрады и миниатюр (тогда же туда пришел работать в качестве конферансье А. И. Райкин, чье имя театр, переехавший в Москву и ныне называющийся «Сатирикон», носит с 1992 года).

К началу войны Снопков проживал с матерью и женой Марией Владимировной по адресу: пл. Искусств, д. 5/4, кв. 50. Снопков работал художником в театре им. Ленинского комсомола, а жена - в поликлинике им. Софьи Перовской.

Далее мы уже обращаемся собственно к делу № 903 по обвинению Снопкова Петра Павловича, хранящемуся в архиве УФСБ по Санкт-Петербургу и Ленинградской области. Начинается оно с постановления на арест и обыск, датированного 21 февраля 1942 года и подписанного младшим лейтенантом госбезопасности Балашовым. Рассмотрев не уточненные «материалы о его преступной деятельности», Балашов нашел, что: «СНОПКОВ П. П. ведет антисоветскую агитацию и распространяет клевету о советской власти, положении интеллигенции в СССР и советском государственном устройстве. Восхваляя вооруженные силы фашистской Германии и распространяя антисоветскую клевету о Красной Армии, СНОПКОВ П. П. ведет пораженческую пропаганду и высказывается за необходимость изменения политического строя в нашей стране» .

На основании изложенного младший лейтенант госбезопасности постановил подвергнуть Снопкова аресту и обыску. Визу на документе поставил заместитель начальника секретно-политического отдела УНКВД Ленинградской области старший лейтенант госбезопасности В. И. Миничев, а утверждено постановление было заместителем начальника управления НКВД Ленинградской области старшим майором госбезопасности С. И. Огольцовым. На следующий день арест санкционировал военный прокурор Ленинграда А. И. Панфиленко. ${ }^{18}$

В тот же день Балашов издал постановление об избрании Снопкову меры пресечения в виде содержания под стражей.

Снопков был арестован 23 февраля 1942 года. В протоколе обыска в его квартире перечисляются изъятые у художника документы. Первое - удостоверение из театра им. Ленинского комсомола. Из других материалов следует, что Снопков, что называется, сидел на чемоданах в ожидании эвакуации, так как 19 февраля ему уже было выдано театром командировочное удостоверение вместе с бумагой о закреплении за ним остающейся в Ленинграде жилой площади. Более того - в день ареста Снопков даже получил обходной лист для последующего увольнения. Кроме этих документов, у него были изъяты трудовое соглашение от 8 августа 1941 года, договор от 6 декабря 1941 года, письмо от 9 декабря 1941 года, блокнот с разными записями, 11 фотокарточек, а также - финский и испанский ножи и радиоприемник ЭЧС. Последние предметы оказались дополнительными штрихами для карательной системы и «обогатили» приговор: хранение холодного оружия было запрещено, а радиоприемники с начала войны граждане были обязаны сдать - такое постановление Совнарком СССР издал еще 25 июня 1941 года.

К протоколу обыска была приложена справка, гласившая, что паспорт и военный билет Снопкова находятся у начальника штаба по эвакуации театра им. Ленинского комсомола. Другая справка подтверждала, что перед арестом он даже сдал по месту службы свои хлебные карточки «на предмет эвакуации». Это означало, что отъезд

17 Сулимо-Самуйлло Всеволод Ангелович (1903-1965) - художник, график, живописец, скульптор. Ученик П. А. Мансурова и П. Н. Филонова, участник объединения «Мастера аналитического искусства». Занимался оформительской деятельностью (в том числе - на массовых праздниках), работал как театральный художник.

18 Панфиленко Антон Иванович (1898-?) — бригвоенюрист, прокурор Ленинграда в 19411943 годах. 
художника за пределы Ленинграда, где его бы, конечно, никто искать не стал, должен был состояться буквально через три дня (судя по дальнейшей информации в деле, 26 февраля). Этих трех дней ему и не хватило для спасения.

О причинах ареста Снопкова ходили разные слухи, включая донос, якобы написанный соседями, о нарушении им светомаскировки. Однако все было гораздо банальнее. В тот же день, когда художник был арестован, начальник 11 отделения СПО НКВД Ленинградской области лейтенант госбезопасности Челноков допросил в качестве свидетеля по его делу Евгения Михайловича Рокотова, фотографа. Допрос был начат в 23.45.

«Вопрос: Вы Снопкова знаете?

Ответ: Снопкова Петра Павловича, работающего художником-декоратором в различных театрах г.г. Москвы и Ленинграда, я знаю около 20 лет, а более близко - около 4-х лет. Последнее время между нами были приятельские отношения, и мы с ним встречались не только в театре, но и в быту, посещая квартиры друг друга. Каких-либо неприязненных отношений, а также личных счетов и вражды между нами не было.

Вопрос: Что Вам известно о Снопкове?

Ответ: Снопков - талантливый художник с большими знакомствами и связями, но одновременно он является человеком без твердых политических убеждений, неустойчивым в своих взглядах, резко меняющим свое отношение к происходящим событиям в зависимости от личных переживаний и настроений. Последнее время Снопков начал проявлять пессимистические настроения и неоднократно допускал <в $>$ беседах со мною различные антисоветские, пораженские высказывания и распространял различные клеветнические измышления о советской действительности. Наиболее характерной в этом отношении является беседа между мной и Снопковым, которая имела место 2-го января с/г.

2 января с/г Снопков был у меня на квартире, и мы с ним в течение длительного времени беседовали на различные темы. В процессе этой беседы обмениваясь мнениями о ходе военных действий, Снопков мне заявил:

„Ни мы вперед, ни немцы вперед, да, как будто мы начинаем двигаться, что меня радует очень мало. Остается пустить себе пулю в лоб“.

Тут же Снопков мне рассказал о своем приятеле-журналисте, который якобы был в Германии и видел, как там якобы все, везде, даже в концентрационных лагерях, хорошо организовано. Который якобы рассказал, как их высылали из Германии после объявления войны, как быстро их доставили в Болгарию. „Все это заняло одну неделю“, а что у нас они от Одессы до Москвы добирались целый месяц.

Тут же Снопков мне со слов летчика-англичанина, с которым он якобы разговаривал, рассказывал о том, как хорошо организовано питание в Англии и противопоставлял все это советской действительности. Снопков клеветнически мне заявил:

„О мирном населении у нас не заботятся, и миллион мирного населения в расчет не принимается. Для Ленинграда было бы лучше, если бы Ленинград был занят немцами“.

Вопрос: Кто присутствовал при этой антисоветской беседе, которую вел Снопков?

Ответ: Помимо меня при этой беседе присутствовал ТУМАНОВ Юрий Евгеньевич, ${ }^{19}$ работающий в Ленкультторге.

Вопрос: Какие еще факты ведения Снопковым антисоветской пропаганды вам известны?

Ответ: В процессе той же беседы Снопков мне советовал мою пьесу „Пятую колонну“ для постановки не давать, так как если придут немцы, они за нее повесят.

Помимо этого имел место еще ряд отдельных мелких фактов антисоветских со стороны Снопкова высказываний, припомнить которые я сейчас затрудняюсь» .

Допрос был окончен в два часа ночи.

Закрепив официально протоколом допроса информацию, которая, конечно, была известна ему и ранее, Челноков начал 25 февраля первый допрос Снопкова. Он, как это было зачастую принято в НКВД, проходил также ночью.

19 Неустановленное лицо. 


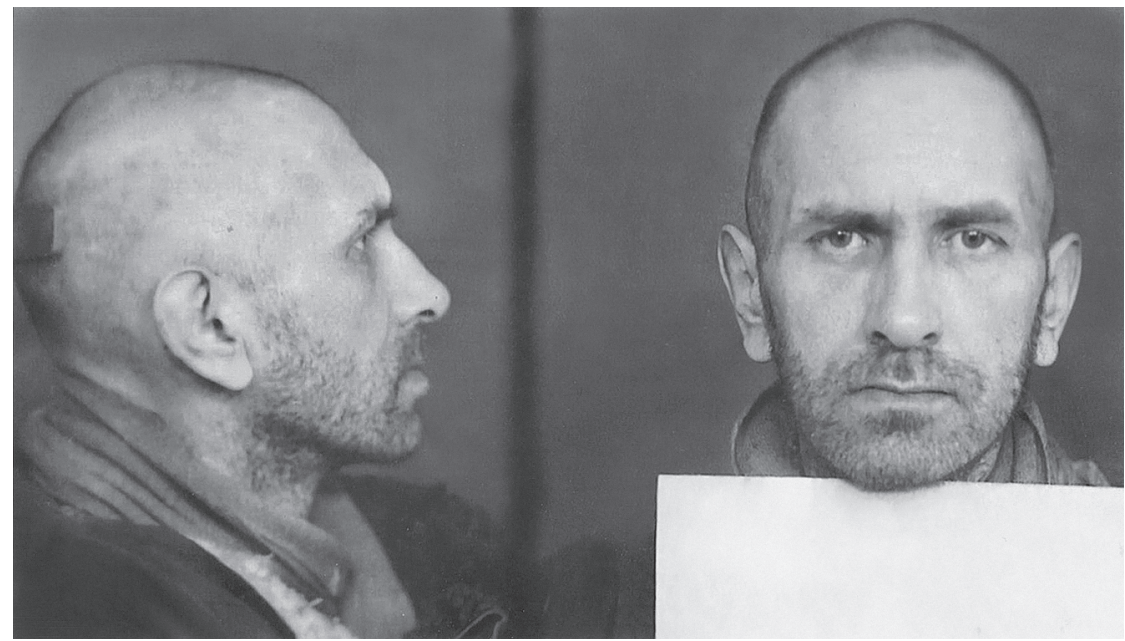

Фотография из следственного дела Петра Павловича Снопкова

«Вопрос: Кто из ваших родственников был репрессирован?

Ответ: В годы НЭПа в Ленинграде проживал мой дядя Снопков Андрей Иванович, занимавшийся коммерческой деятельностью и имевший какую-то свою комиссионную контору. В последующие годы, но когда точно, не помню, он был арестован и выслан на Север. Где он находится в настоящее время и даже жив ли вообще, мне совершенно неизвестно.

Вопрос: Перечислите ваших близких знакомых.

Ответ: Моими близкими знакомыми, с которыми я поддерживаю наиболее хорошие, дружественные отношения, являются: художник Акимов Николай Павлович, ${ }^{20}$ в настоящее время из Ленинграда эвакуировался и, где находится, я не знаю. Режиссер Гарин Эраст Павлович ${ }^{21}$ - уехал из Ленинграда еще до объявления войны между Советским Союзом и фашистской Германией. Режиссер Чежегов Михаил Викторович $^{22}$ - эвакуируется из Ленинграда 26 февраля вместе с театром. Художник Сулимо $<$ так!> Всеволод Ангелович - из Ленинграда эвакуировался, и журналист Нейман Михаил Германович ${ }^{23}$ - в настоящее время служит в РККА.

Вопрос: Кто из ваших знакомых репрессировался?

Ответ: Из моих близких друзей и знакомых репрессиям никто не подвергался.

Вопрос: Вы арестованы за контрреволюционную деятельность. Расскажите, в чем ваша преступная деятельность заключалась?

Ответ: Я никакой преступной деятельностью не занимался и каких-либо контрреволюционных настроений никогда не имел» .

Эти четыре коротких вопроса и ответа на них, если судить по протоколу, заняли 2,5 часа - с 2.00 до 4.30 ночи.

Второй допрос проходил 27 февраля, уже в обычное время - с 16.45 до 18.55. После традиционного запугивания арестованного информацией о том, что «у следствия достаточно фактов, изобличающих его в проведении к/р пораженческой пропаганды»,

20 Акимов Николай Павлович (1901-1968) - народный артист СССР, театральный режиссер, педагог, художник.

21 Гарин Эраст Павлович (наст. фам. - Герасимов; 1902-1980) - народный артист СССР, актер, режиссер театра и кино.

22 Чежегов Михаил Викторович (1898-1965) - театральный режиссер, драматург. В 19411949 годах - главный режиссер театра им. Ленинского комсомола.

23 Нейман Михаил Германович (1906-?) - журналист, офицер запаса, в 1941 году был призван в армию. В звании капитана воевал на Ленинградском фронте. 
и ответа Снопкова, в котором он снова категорически это обвинение отверг, следователь решил приоткрыть карты. Кстати, этот допрос проводил уже не Челноков, а практикант СПО УНКВД ЛО по фамилии Репин. Судя по всему, сотрудники секретнополитического отдела даже в самую страшную блокадную зиму не успевали работать с арестованными за «агитацию» ленинградцами - приходилось задействовать практикантов.

«Вопрос: Вы знаете Рокотова Евгения Михайловича?

Ответ: Да, знаю. Это мой знакомый. Знаю его с 1941 года по совместной работе в Театре эстрады и миниатюр в Ленинграде как хорошего фотографа.

Вопрос: Какие у вас с Рокотовым взаимоотношения? Были ли когда-либо ссоры и т. П.?

Ответ: Взаимоотношения с Рокотовым у меня самые нормальные, более того, дружеские. Никаких ссор и неприязненных отношений между нами не было и нет.

Вопрос: Вам предъявляются показания свидетеля Рокотова Евгения Михайловича, который на допросе показал, что вы в беседе с ним высказывали клеветнические измышления о советской действительности, проводили антисоветскую пораженческую пропаганду. Вы подтверждаете эти показания Рокотова?

Ответ: Показания Рокотова я отвергаю, так как они не соответствуют действительности. Я клеветническими антисоветскими измышлениями не занимался. В начале января м-ца 1942 <года> действительно имел факт посещения квартиры Рокотова, куда я был приглашен на чашку чая, но антисоветских клеветнических измышлений я там не вел. Был разговор о трудном положении с питанием, где я сказал, что чем помирать голодной смертью, лучше отравлюсь морфием» .

Строго говоря, высказанное намерение покончить самоубийством - уже само по себе тянуло на «пораженческие высказывания», ибо советский человек даже в шаге от голодной смерти должен был отдавать все силы на борьбу с врагом. Самоубийство в этой парадигме фактически означало дезертирство. Однако следствию этого было, конечно, мало. 28 февраля Челноков вместе с практикантом Репиным проводят очную ставку. После того, как Рокотов и Снопков заявили об опознании друг друга и подтвердили отсутствие вражды и личных счетов, очная ставка началась.

«Вопрос обвиняемому Снопкову: Расскажите, какой характер имели ваши встречи с Рокотовым?

Ответ Снопкова: С Рокотовым я встречался в театре, в служебной обстановке и, помимо того, периодически бывал у него на квартире. Мои посещения квартиры Рокотова имели полуделовой характер, так как меня интересовали имеющиеся у Рокотова книги и в других случаях - фотографии с ранее сделанных мною постановок. Длительность наших встреч была обычно порядка 30-40 минут, и происходили они, как правило, или в отсутствие третьих лиц, или в присутствии жены Рокотова, которая периодически заходила в комнату, где находились мы. Последний раз я был на квартире у Рокотова в первых числах января м-ца 1942 года, одновременно со мною в это время был какой-то на квартире у Рокотова неизвестный мне гражданин. В этот раз встреча с Рокотовым носила бытовой характер и находился я у Рокотова около полутора часов.

Вопрос свидетелю Рокотову: Показания Снопкова о характере ваших встреч и взаимоотношений соответствуют действительности?

Ответ Рокотова: Да, показания Снопкова по этому вопросу соответствуют действительности.

Вопрос Снопкову: Расскажите, какой характер и какое содержание имела беседа между вами и Рокотовым во время вашего посещения квартиры Рокотова в первых числах января.

Ответ Снопкова: Наша беседа во время этого посещения мною квартиры Рокотова имела бытовой характер. В частности, я помню, что я в процессе этой беседы высказывал недовольство своим личным положением в связи с недостаточностью питания и заявлял, что я предпочитаю голодной смерти самоубийство. В частности, я говорил, что у меня из продуктов питания остались два сухаря и полстакана гороха, 
съев которые, я могу покончить с собой, либо приняв морфий, либо отравившись угарным газом.

Вопрос Снопкову: Какие антисоветские высказывания имели место в процессе этой беседы с вашей стороны?

Ответ Снопкова: Никаких антисоветских высказываний с моей стороны в процессе этой беседы не было.

Вопрос свидетелю Рокотову: В процессе этой беседы со стороны Снопкова антисоветские высказывания были?

Ответ Рокотова: Во время посещения моей квартиры Снопковым в начале января 1942 года Снопков беседовал, главным образом, с присутствовавшим тогда же у меня Тумановым Юрием Евгеньевичем. Я же очень часто по хозяйственным делам отлучался из комнаты и полностью участия в этой беседе между Снопковым и Тумановым не принимал. Должен сказать, что Снопков в процессе этой беседы находился в каком-то озлобленном состоянии и в резкой форме высказывал свое недовольство существующим положением и советской действительностью. В частности, из тех отрывков бесед, на которых я присутствовал, я помню, что Снопков высказывал недовольство тем, что Красная Армия перешла в наступление, и заявлял:

„Кажется, мы начинаем одерживать верх. Меня это радует мало. Для Ленинграда это хуже “.

„О мирном населении у нас не заботятся, и миллион мирного населения в расчет не принимается“".

„Для Ленинграда было бы лучше, если бы Ленинград был занят немцами“.

И, противопоставляя советской действительности положение в Германии и Англии, Снопков рассказал случай о советском журналисте, оказавшемся в Германии в момент объявления войны, и об известном якобы ему положении с питанием в Лондоне, восхваляя в процессе этих рассказов английскую и германскую организованность.

Вопрос обвиняемому Снопкову: Факты ваших антисоветских высказываний вы признаете?

Ответ Снопкова: Нет. Показания Рокотова я отрицаю. В действительности рассказывал и о журналисте, оказавшемся в Германии в момент объявления войны, и о снабжении питанием в Лондоне. Но мои высказывания совершенно не имели антисоветского характера и, рассказывая эти факты, известные мне со слов других, я совершенно не противопоставлял английскую и германскую организованность советской действительности.

Вопрос обвиняемому Снопкову: Вы говорили: „О мирном населении у нас не заботятся и миллионы мирного населения в расчет не принимаются“?

Ответ Снопкова: Нет. Этого я не говорил.

Вопрос Рокотову: Снопков это говорил?

Ответ Рокотова: Да, Снопков это говорил.

Вопрос Снопкову: Вы продолжаете отрицать то, что вами было высказано это клеветническое измышление?

Ответ Снопкова: Я говорил в процессе этой беседы, что у нас миллионы мирного населения находятся в тяжелом положении, но я не говорил, что о мирном населении у нас не заботятся, и, говоря, что миллионы мирного населения находятся в тяжелом положении, я не подразумевал весь Советский Союз, а говорил только о положении населения в Ленинграде.

Вопрос: Заявляя, что у нас миллионы мирного населения находятся в тяжелом положении, и тут же рассказывая якобы известные вам факты организации снабжения продуктами населения Лондона, вы этим самым противопоставляли советской действительности английскую организованность и этим самым вели антисоветскую пропаганду. Вы это знаете?

Ответ Снопкова: Хотя эти высказывания с моей стороны и имели место, я не считаю, что я в процессе этой беседы вел антисоветскую пропаганду, направленную против органов Советской власти. 
Вопрос Снопкову: Вы утверждали: „Для Ленинграда было бы лучше, если бы Ленинград был занят немцами“"?

Ответ Снопкова: Нет. Этого я не говорил.

Вопрос свидетелю Рокотову: Снопков это заявлял?

Ответ свидетеля Рокотова: Да. Снопков это заявлял.

Вопрос Снопкову: Вы признаете, что, отрицая этот факт вашего антисоветского высказывания, а также отрицая и антисоветский характер ваших высказываний на квартире Рокотова в начале января 1942 года, вы даете ложные показания?

Ответ Снопкова: Я заявляю, что характер моих высказываний в процессе этой беседы в показаниях Рокотова искажен и что мои высказывания какого-либо антисоветского характера не имели.

Вопрос свидетелю Рокотову: Свои показания об антисоветском характере высказываний Снопкова Вы подтверждаете?

Ответ Рокотова: Да. Я свои показания подтверждаю».

Очная ставка проходила с 10.45 до 13.10.

Судя по всему, очная ставка (видимо, вкупе с угрозами и обещаниями смягчить наказание в случае признания) сломила сопротивление Снопкова. На допросе 2 марта он дает (явно под диктовку следователя) подробные признательные показания, называя при этом еще нескольких людей, в разговорах с которыми он якобы вел антисоветскую пропаганду:

«Вопрос: Несмотря на неоднократные предложения следствия рассказать о своей антисоветской деятельности, вы правдивого ответа не дали. Предлагаем сейчас сделать это.

Ответ: Я должен сознаться, что с моей стороны имел место целый ряд антисоветских и клеветнических заявлений по адресу советских властей. Эти заявления были сделаны в беседах с некоторыми из моих знакомых, в частности в беседах с ЗАИКИНЫМ ВЛАДИМИРОМ АЛЕКСАНДРОВИЧЕМ, ${ }^{24}$ РОКОТОВЫМ Евгением Михайловичем, художником УШИНЫМ Николаем Алексеевичем ${ }^{25}$ и случайным моим знакомым корреспондентом ЛЕОНИДОВЫМ. ${ }^{26}$ Совершенно естественно, что в разговорах с моими собеседниками очень часто обсуждались вопросы, связанные с положением Ленинграда, находящегося в блокаде.

Я вел себя при таких беседах весьма активно и истолковывал сложившиеся в результате блокады трудности как результат беззаботности в отношении советских властей к нуждам населения и противопоставлял в беседе с РОКОТОВЫМ обстановке, сложившейся под влиянием блокады в Ленинграде, положение в Англии в период войны, уверяя при этом моих собеседников - РОКОТОВА, его жену и еще какого-то знакомого РОКОТОВА в том, что в Англии правительственные органы не в пример советским властям проявляли заботу о населении, которое лишений войны не испытывало.

Подобное же сравнение, также обращенное на дискредитацию советских властей, было сделано мною по вопросу об обеспечении населения бомбоубежищами. Опять мною восхвалялась Англия и порицалась мнимая беззаботность советских властей.

Мною высказывались и пораженческие взгляды на судьбы Ленинграда в войне. Я особенно это проявлял в беседах с В. А. ЗАИКИНЫМ, человеком близким мне по пораженческо-антисоветским взглядам, - заявлял, что Ленинград неизбежно падет и будет занят немцами.

ЗАИКИН не только поддерживал меня, но и высказывался более определенно, обнаруживая вообще в своих заявлениях о судьбе Ленинграда желание не покидать его даже в случае оккупации. Хотя планов своей жизни в случае оккупации ЗАИКИН мне и не от-

24 Заикин Владимир Александрович — специалист в области звукозаписи. В конце 1920-х начале 1930-х годов звукорежиссер ленинградского Радиокомитета. В середине 1930-х годов заведовал кинотеатром общества «Друг детей». Создатель ряда предприятий по записи грампластинок.

25 Ушин Николай Александрович (1898-1942) - театральный художник, книжный график. Выпускник ВХУТЕИНа. Умер от голода во время блокады.

${ }^{26}$ Неустановленное лицо. 
крывал, но к немецкой оккупации, в неизбежности которой он был уверен, он относился без тени беспокойства. Каждая неудача Красной Армии нами встречалась глумливоантисоветски, и мы комментировали подобные сообщения в антисоветском духе, расценивая их как результат неспособности советского командования. Ядовитыми антисоветскими замечаниями снабжались мною и ЗАИКИНЫМ сводки Советского Информбюро об успехах Красной Армии, мы считали их не соответствующими действительности.

В беседах с РОКОТОВЫМ мы обсуждали перспективы жизни населения в случае оккупации города фашистскими войсками. Этот вопрос меня живо интересовал, так как, повторяю, я был убежден в неизбежности оккупации Ленинграда. Однако какихлибо определенных мнений по вопросу о возможных формах управления в случае оккупации города немцами - не существовало, высказывались различные предположения, на этом дело и кончалось.

О судьбе Ленинграда я беседовал с ЛЕОНИДОВЫМ, которому я заявлял о том, что Ленинград якобы всеми брошен на произвол судьбы и низведен на положение захудалого провинциального города, до которого никому нет дела. Неоднократно в беседах с ЗАИКИНЫМ, ЛЕОНИДОВЫМ, РОКОТОВЫМ я заявлял, что интеллигенцию оставили совершенно без внимания и заботы, в результате чего, заявлял я, гибнут лучшие ее представители. Особенно рьяно выступал я с антисоветскими заявлениями в связи со смертью художников БИЛИБИНА ${ }^{27}$ и Семена ПАВЛОВА. ${ }^{28}$ Я в резкой форме заявлял, что они погибли в результате бездушного отношения к интеллигенции со стороны советских властей.

Я заявлял, кажется, ЛЕОНИДОВУ, что в СССР отсутствует демократическая, как я говорил, связь между правительственными кругами и интеллигенцией. Беседуя с ЗАИКИНЫМ, я заявлял, что Советская власть старается держать интеллигенцию в атмосфере удушья и всячески препятствует проникновению свежих влияний из-за границы. Я весьма резко нападал по этому вопросу на политику советских властей и заявлял, что в настоящее время мы наблюдаем возврат к допетровским временам.

Как я уже говорил, с моей стороны имели место резкие антисоветские заявления в связи со смертью художников БИЛИБИНА и ПАВЛОВА. Помимо уже названных мной лиц, я высказывался по этому поводу в беседе с художником УШИНЫМ. Все эти беседы, в которых с моей стороны имели место резкие антисоветские заявления, происходили в последние два с половиной - три месяца.

Я не ручаюсь, что рассказал о всех антисоветских проявлениях, имевших место с моей стороны, и считаю нужным заявить, что я не упускал ни одного случая, чтобы не использовать его для антисоветского заявления и распространения клеветы о политике Советской власти».

5 марта было вынесено постановление о предъявлении Снопкову обвинения - по части 2 статьи 58-10 УК РСФСР: «Пропаганда или агитация, содержащие призыв к свержению, подрыву или ослаблению Советской власти или к совершению отдельных контрреволюционных преступлений <..> , а равно распространение или изготовление или хранение литературы того же содержания <...> при массовых волнениях или с использованием религиозных или национальных предрассудков масс, или в военной обстановке, или в местностях, объявленных на военном положении...» .

В условиях военного времени эта статья предусматривала расстрел или - при смягчающих обстоятельствах — лишение свободы на срок не ниже трех лет с конфискацией.

27 Билибин Иван Яковлевич (1876-1942) - художник, книжный иллюстратор, участник объединения «Мир искусства». С 1920 по 1936 год — в эмиграции. Умер от голода в больнице Всероссийской Академии художеств в блокадном Ленинграде.

28 Павлов Семен Андреевич (1893-1941) - художник, график. Выпускник ВХУТЕИНа. В 1920-е годы - член объединения «Община художников». С 1929 года — преподаватель ВХУТЕИНа (затем - ВХУТЕМАСа). Умер во время блокады Лениграда. 23 декабря 1941 года художник и кинорежиссер Михаил Цехановский записал в дневнике: «Умер Семен Павлов, кото$\mathrm{p}<$ ого > еще не так давно видел в $\mathrm{A}<$ кадемии $>\mathrm{X}<$ удожеств $>$, по дороге в убежище. Утром не проснулся, сердце не выдержало» (Цехановский $M$. Какой день нет бомбежки? // http://seance.ru/ articles/tsehanovskyi-diary; дата обращения: 15.04.2020). 
Можно себе представить, какой простор был у следователя для давления на арестованного! От трех лет до расстрела, а все зависит от того, укажет ли следователь смягчающие обстоятельства.

6 марта обвинение Снопкову было предъявлено. Бороться он уже больше не пытался, единственное, что он продолжал отрицать, - это фашистский характер своей «пропаганды».

«Вопрос: Вам предъявлено постановление о привлечении вас к уголовной ответственности в пр<еступлениях $>$ пр <едусмотренных $>$ ст. 58-10 ч. 2 УК РСФСР. Вам понятно предъявленное вам обвинение?

Ответ: Да, понятно.

Вопрос: Вы признаете себя виновным в инкриминируемом вам преступлении?

Ответ: Да, я признаю себя виновным в том, что я в период войны между Советским Союзом и фашистской Германией, комментируя среди своего окружения в контрреволюционном духе события, происходящие как во внутренней жизни Советского Союза, так и ход военных действий между СССР и фашистской Германией, высказывал пораженческие настроения по вопросу <так!> о занятии немцами города Ленинграда, противопоставлял советской действительности положение в буржуазно-демократических странах и, в частности, в Англии и распространял различные клеветнические измышления о командовании Красной Армии, о советской печати, об отношении руководителей партии и правительства к нуждам трудящихся и о положении советской интеллигенции. Признавая себя в этом виновным, заявляю, что я не считаю и не могу признать, что моя пропаганда носила профашистский характер, так как я лично фашистских идей никогда не разделял и никогда не сочувствовал.

Вопрос: В присутствии кого еще, помимо тех лиц, которых вы указали в своих показаниях 2 марта, вы вели антисоветскую пропаганду?

Ответ: Были ли такие случаи, когда бы я допускал какие-либо антисоветские высказывания в присутствии других лиц, помимо тех, о которых я уже показал 2 марта с/г года, я не помню, но если такие случаи имели место, то они носили настолько случайный характер, что я сейчас не в состоянии их припомнить.

Вопрос: В своих показаниях 2-го марта с/г года вы заявили: „Я не упускал ни одного случая, чтобы не использовать его для антисоветского заявления и распространения клеветы о политике Советской власти. Я не ручаюсь, что рассказал о всех антисоветских проявлениях, имевших место с моей стороны“. Какие еще факты ведения антисоветской пропаганды, помимо тех, о которых вы уже дали показания 2-го марта с/г года, имели место?

Ответ: Я не припоминаю больше ни одного факта ведения мною антисоветской пропаганды» .

Следующий хранящийся в деле материал является прекрасной характеристикой деятельности палачей НКВД во время блокады. Это был допрос свидетеля Ушина, проведенный 30 марта следователем того же 11 отдела СПО УНКВД Ленинградской области младшим лейтенантом госбезопасности Ефименко. В принципе, в самом по себе допросе свидетеля нет ничего необычного, тем более что имя художника Ушина Снопков называл в качестве адресата своей «антисоветской пропаганды». Но все дело в том, что этот допрос проходил на квартире Ушина (на 2-й линии Васильевского острова, д. 62, кв. 30), поскольку, как указывалось в приложенной справке, свидетель Ушин «болен, находится на домашнем лечении и в постельном режиме, и в УНКВД ЛО явиться не может». На обычном языке эти эвфемизмы означали, что Николай Алексеевич Ушин от голода находился в крайней степени дистрофии и допрашивал следователь умирающего человека. Скончался художник через неделю после этого допроса, который занял полтора часа.

Возможно, что именно это ощущение близкой смерти придало Ушину силы, и он отказался подтвердить какие бы то ни было факты «антисоветских высказываний» Снопкова:

«Вопрос: На допросе от 2 марта 1942 года Снопков сам показал, что в беседах с вами вел резкие антисоветские заявления <так!> в связи со смертью художников 
Билибина и Павлова. Кроме того, Снопков показал, что с его стороны в Вашем присутствии имел место целый ряд антисоветских и клеветнических заявлений по адресу советских властей. Припомните, какие антисоветские высказывания вел Снопков в разговоре с вами?

Ответ: Как я уже показал, я с 1937 года я видел Снопкова один раз в феврале м-це 1942 года в Союзе Советских художников. Припоминаю разговор, который имел <место > между нами в присутствии художника Хижинского Леонида Семеновича. ${ }^{29}$ Мы стояли у окна в коридоре и вели беседу только о том, кто как живет и как себя чувствует. Разговор был очень коротким, и никаких антисоветских высказываний со стороны Снопкова я не слышал. С этого времени я Снопкова больше не встречал.

Вопрос: Почему же тогда Снопков показывает, что он в беседе с вами вел антисоветские и клеветнические заявления <так!> по адресу советских властей?

Ответ: Я не знаю, почему он так показывает, но в этот раз и вообще никаких антисоветских клеветнических высказываний со стороны Снопкова я не слышал».

Помимо обвинения в «клеветнических антисоветских высказываниях» 29 марта было подписано новое постановление - о предъявлении Снопкову дополнительных обвинений по статье 59-6 и части 4 статьи 182 УК РСФСР. Статья 59-6 была вменена Снопкову за несдачу радиоприемника, и выглядела она так: «Отказ или уклонение в условиях военного времени от внесения налогов или от выполнения повинностей (в частности, военно-автотранспортной, военно-конской, военно-повозочной и военно-судовой) влекут за собою лишение свободы на срок не ниже шести месяцев, с повышением, при особо отягчающих обстоятельствах, вплоть до высшей меры социальной защиты - расстрела, с конфискацией имущества».

Часть 4 статьи 182 УК РСФСР гласила: «Изготовление, хранение, сбыт и ношение кинжалов, финских ножей и тому подобного холодного оружия без разрешения Народного комиссариата внутренних дел в установленном порядке - лишение свободы на срок до пяти лет с конфискацией оружия» .

30 марта новые обвинения были предъявлены Снопкову. Он признал себя виновным в хранении у себя радиоприемника ЭЧС-3 и холодного оружия.

«Вопрос: С какой целью вы после опубликования правительственного постановления о сдаче радиоприемников ${ }^{30}$ не сдали в соответствующие организации имевшийся у вас радиоприемник?

Ответ: Это произошло совершенно случайно. После опубликования постановления о сдаче радиоприемников я его отсоединил и поручил сдать своей матери, но моя мать по ошибке вместо приемника сдала динамик, который сдавать было не нужно, а приемник поставила под стол и сказала мне, что приемник она сдала. Ошибку матери я обнаружил только за несколько дней до своего ареста и исправить ее, сдав радиоприемник, не успел, поэтому приемник и находился у меня.

Вопрос: Где ваша мать находится в настоящее время?

Ответ: По моим предположениям, она умерла, так как в момент моего ареста она находилась в очень тяжелом состоянии и, по заявлению врача, - безнадежном положении.

Вопрос: С какой целью вы незаконно хранили у себя на квартире холодное оружие: финский и испанские ножи?

Ответ: В прошлом я занимался коллекционированием холодного оружия, и у меня была небольшая коллекция, которую я несколько лет тому назад, точно не помню, когда вышло постановление о запрещении хранения холодного оружия, продал как реквизит в Большой драматический театр, оставив у себя только испанский нож,

${ }^{29}$ Хижинский Леонид Семенович (1896-1972) - советский художник, график. Выпускник ВХУТЕИНа.

30 Постановлением Совета народных комиссаров СССР от 25 июня 1941 года № 1750 «О сдаче населением радиоприемных и радиопередающих устройств» всем гражданам было предписано в пятидневный срок сдать имеющиеся у них радиоприемники в органы Наркомсвязи. Это мотивировалось возможным их использованием «вражескими элементами». Сдача приемников оформлялась как «прием на хранение» - до окончания войны. 
являвшийся подарком одного моего знакомого. Этот нож последнее время я использовал для колки лучины. Финский нож был мною приобретен недавно на рынке с рук, так как я, собираясь эвакуироваться, слышал, что в дороге необходимо иметь нож для колки дров и лучины с целью топки печей, имеющихся в вагоне. Для этого я его и купил. Никаких преступных целей в хранении изъятого у меня указанного здесь холодного оружия у меня не было» .

Диалог завершился очередным предложением Снопкову назвать новые имена своих собеседников по «антисоветским разговорам», помимо тех, которые уже были им названы 2 марта. Снопков снова ответил, что вспомнить больше ничего не может.

Этот последний допрос интересен несколькими деталями. Прежде всего, из нескольких слов Снопкова, записанных равнодушным канцелярским слогом следователя, вырастает новая трагедия: оказывается, он был арестован в тот момент, когда его мать была уже близка к смерти от голода. Кроме того, подтверждается содержавшаяся в воспоминаниях Алисы Порет информация о том, что Снопков коллекционировал холодное оружие. Таким образом, не исключено, что ее рассказ о том, как он подарил ей на день их свадьбы настоящий самурайский меч из своей коллекции, ${ }^{31}$ соответствовал действительности, хотя, как выше было показано, описание того, как Хармс якобы отдал за него символическую монету, конечно, являлось плодом вымысла.

2 апреля 1942 года следствие было окончено, а уже 3 апреля было подписано обвинительное заключение. В нем перечислялось все то же: на квартире Рокотова высказывал в резкой форме свое недовольство существующим положением, восхвалял положение в буржуазно-демократических странах и критиковал советскую действительность с контрреволюционных позиций. Приплюсованы к обвинению были также пункты УК РСФСР, касающиеся несданного радиоприемника и холодного оружия.

14 апреля военный трибунал войск НКВД Ленинградского округа приговорил П. П. Снопкова к лишению свободы на срок 10 лет с конфискацией имущества и с поражением в правах на срок 5 лет после отбытия основной меры наказания.

Насколько соответствовали реальности воспоминания Алисы Порет, которая сообщала, как Снопкова в лагере отправили на лесозаготовки и регулярно сокращали ему паек за невыполнение нормы, пока он не умер от голода? Судить об этом сложно, разумеется, мемуаристка передавала окольные слухи. Справка УФСБ по Санкт-Петербургу и Ленинградской области сухо сообщает, что «Снопков П. П. умер 20 июля 1942 года, отбывая наказание в Усольском ИТЛ (г. Соликамск). Определением Военного трибунала Ленинградского военного округа от 24 декабря 1958 года приговор <...> от 14 апреля 1942 года в отношении Снопкова П. П. отменен, и дело производством прекращено за недоказанностью обвинения. Снопков П. П. реабилитирован» .

Таким образом, видно, что Снопков прожил в лагере меньше трех месяцев. Думается, что ни о каком лесоповале речи не шло: он явно прибыл туда уже в том состоянии, которое блокадники именовали медицинским термином "дистрофия», а лагерный жаргон точно определял словом «доходяга» .

Какова же была судьба Рокотова, чьи показания отправили Снопкова в лагерь, а затем и в могилу?

В деле Снопкова имеется список лиц, вызываемых в судебное заседание военного трибунала, где его должны были судить. Этих лиц было всего двое: сам художник и свидетель Рокотов. Так вот - в сведениях о Рокотове было указано: «Содержится под стражей во внутренней тюрьме УНКВД ЛО» - т. е. там же, где и содержался сам Снопков.

Это означало, что Рокотов не был внештатным стукачом НКВД, работавшим за прибавку к пайку. Судя по всему, он так же, как и Снопков, был арестован по чьему-то доносу, а затем, уже сломленный, начал давать показания на своих знакомых.

Я попытался ознакомиться и с делом Рокотова, но неожиданно получил отказ. Вот что сообщило УФСБ по Санкт-Петербургу и Ленинградской области: «Из материалов архивного уголовного дела, находящегося на хранении в архивных фондах УФСБ России по городу Санкт-Петербургу и Ленинградской области следует, что Рокотов Ев-

31 Порет А. И. Записки. Рисунки. Воспоминания. Кн. 1. С. 92. 
гений Михайлович, 1902 г. р., уроженец Ленинграда, приговором военного трибунала войск НКВД СССР Ленинградской области от 27 февраля 1942 года по ст. 16 и 58-7 УК РСФСР с санкции ст. 58-2 УК РСФСР осужден к лишению свободы в исправительнотрудовых лагерях сроком на 7 лет с поражением в правах $<. . .>$ сроком на 3 года после отбытия наказания и без конфискации имущества.

Постановлением Президиума Ленинградского городского суда от 10 января 1990 г. вышеуказанный приговор изменен и переквалифицирован со ст. 16 и 58-7 УК РСФСР на ст. 95 ч. 2 УК РСФСР. Рокотову Е. М. назначено 2 года лишения свободы. Рокотов Е. М. не реабилитирован».

Далее сообщалось, что в соответствии с законом ознакомлению подлежат прекращенные уголовные дела в отношении реабилитированных граждан, а знакомство с делом нереабилитированных невозможно.

Что же стоит за приведенными цифрами?

Во-первых, подтверждается предположение, что из Рокотова выдавливали показания, угрожая расстрелом и обещая смягчение в случае «чистосердечного признания». Допрос Рокотова в качестве свидетеля состоялся 23 февраля 1942 года поздно вечером в день ареста Снопкова. А уже через 4 дня Рокотов получил приговор, причем не самый тяжелый. Судя по справке ФСБ, Рокотову удалось лагерь пережить.

Во-вторых, статья 58-7 УК РСФСР предусматривала наказание за «подрыв государственной промышленности, транспорта, торговли, денежного обращения или кредитной системы, а равно кооперации, совершенный в контрреволюционных целях путем соответствующего использования государственных учреждений и предприятий или противодействие их нормальной деятельности, а равно использование государственных учреждений и предприятий или противодействие их деятельности, совершаемое в интересах бывших собственников или заинтересованных капиталистических организаций». Уже сама по себе диспозиция этой статьи была сформулирована так, что практически любое действие в указанных областях, признанное неудачным, легко под нее подпадало. Но этого мало: трибунал в приговоре сослался еще на статью 16 УК РСФСР, а она гласила: «Если то или иное общественно-опасное действие прямо не предусмотрено настоящим Кодексом, то основание и пределы ответственности за него определяются применительно к тем статьям Кодекса, которые предусматривают наиболее сходные по роду преступления».

Проще говоря, Рокотов был арестован и судим за не предусмотренные Уголовным кодексом действия, которые были следствием и Военным трибуналом квалифицированы «по аналогии».

Что сделал «перестроечный» Президиум Ленинградского городского суда? Он признал, что Рокотов не совершал инкриминируемых ему преступлений. Однако вместо того, чтобы реабилитировать его, суд признал его виновным по совершенно другой статье. Часть 2 статьи 95 УК РСФСР выглядела так: «Заведомо ложный донос или показание, соединенные: а) с обвинением в тяжком преступлении, б) с корыстными мотивами и в) с искусственным созданием доказательств обвинения, - лишение свободы на срок до двух лет».

Мы не знаем, о чем тут идет речь: о показаниях, данных Рокотовым на Снопкова или на кого-то еще. Мы не знаем, при каких именно обстоятельствах эти показания были даны. И дело недоступно.

Напоследок - о развенчании еще одного мифа, созданного Алисой Порет: Хармс и Снопков, конечно, не могли встретиться в тюрьме в блокадном Ленинграде. И не только потому, что при конвоировании арестованных по коридорам тюрьмы применялись самые строгие меры для исключения их встреч друг с другом (вплоть до помещения в известные «стаканы»), но прежде всего - потому, что Снопков был арестован ровно через три недели после того, как Хармс умер. Наконец, Снопков все время следствия и суда находился во внутренней тюрьме УНКВД ЛО — на ул. Воинова (ныне Шпалерная), д. 25, тогда как Хармс содержался там только до декабря 1941 года, после чего был отправлен в психиатрическое отделение тюремной больницы при «Крестах» (Арсенальная наб., д. 9). 
DOI: $10.31860 / 0131-6095-2020-3-232-241$

\title{
ЗАДУМАНО СТАЛИНЫМ - СДЕЛАНО ХРУЩЕВЫМ (ЕЩЕ РАЗ О ВТОРОМ ВСЕСОЮЗНОМ СЪЕЗДЕ СОВЕТСКИХ ПИСАТЕЛЕЙ СССР)
}

\author{
(ПУБЛИКАЦИЯ ( ) В. Ю. ВЬЮГИНА)
}

\begin{abstract}
Предлагаемая публикация вызвана необходимостью уточнить взгляд на историю Второго Всесоюзного съезда советских писателей СССР с учетом мало известных документов. Находки, о которых идет речь, не опровергают основных тезисов, высказанных в недавно вышедшей книге об этом почти забытом событии, ${ }^{1}$ но все же необходимым образом дополняют их. В упомянутом исследовании съезд обсуждался с самых разных сторон. Первейшее внимание в нем было уделено как эстетическим программам, которые отстаивали писатели, так и государственной политике, проводимой по отношению к литературе после 5 марта 1953 и до конца 1954 года. Материалы, рассматриваемые ниже, касаются главным образом организационных аспектов - почти в чистом виде менеджмента, хотя в конечном счете они, как кажется, помогают составить более четкое представление о характере писательского форума и с точки зрения идеологии.

Как о Первом, так и о Втором Всесоюзных съездах советских писателей ни индивидуальных монографий, ни коллективных трудов до последнего времени не появлялось. Специально посвященных им статей тоже сравнительно немного. Но если конгресс 1934 года издавна привлекал к себе внимание и более или менее устойчивая традиция в подходе к нему уже сложилась - он «вписан» в историю советской литературы, его значение установлено, — то писательский форум 1954 года начал восприниматься как требующее серьезного обсуждения событие лишь с оживлением интереса к «оттепели» в конце 1980-х годов.

Если говорить о значимых открытиях последних десятилетий, для воссоздания истории Второго съезда крайне ценны первопроходческие публикации Р. М. Романовой и Т. В. Домрачевой, ${ }^{2}$ содержащие ряд свидетельств, которые позволяют составить представление о подготовке к этому масштабному собранию с точки зрения закулисных сюжетов. Внушительную документальную базу, касающуюся неафишируемой части предсъездовской кампании, включает в себя том документов под редакцией В. Ю. Афиани "Аппарат ЦК КПСС и культура. 1953-1957». ${ }^{3}$ В связи с фактографией съезда заслуживает внимания книга В. А. Антипиной «Повседневная жизнь советских писателей». ${ }^{4}$ Пониманию политик съезда, безусловно, способствуют работы систематико-хроникального характера - в первую очередь, подготовленная С. И. Чуприниным еще в 1989 году публикация «Оттепель: хроника важнейших событий 1953-1956 годов». ${ }^{5}$ К тому же времени относится появление новых, т. е. посткоммуни-
\end{abstract}

1 Второй Всесоюзный съезд советских писателей. Идеология исторического перехода и трансформация советской литературы. 1954 / Отв. ред. В. Ю. Вьюгин; сост. К. А. Богданов, В. Ю. Вьюгин. СПб., 2018.

2 Роланова Р. Союз писателей СССР перед своим Вторым съездом (по материалам Центра хранения современной документации) // Вопросы литературы. 1993. № 3. С. 215-259; Документы свидетельствуют... «Съезд должен мобилизовать писателей...» / Публ. Т. Домрачевой // Там же. С. 260-301. В «Вопросах литературы» публиковались и другие документы, имеющие отношение к истории Второго съезда писателей.

3 Аппарат ЦК КПСС и культура. 1953-1957: Документы / Сост. Е. С. Афанасьева, В. Ю. Афиани (отв. ред.) и др. М., 2001.

4 Антипина В. А. Повседневная жизнь советских писателей. 1930-1950-е гг. М., 2005. С. 27 28, 47 и др.

5 Хроника важнейших событий // Оттепель. 1953-1956: Страницы русской советской литературы / Сост., автор вступ. статьи и «Хроники важнейших событий» С. И. Чупринин. М., 1989. Только что вышла обновленная и серьезно расширенная версия этого исследования: Чупринин С. И. Оттепель: События (март 1953 - август 1968 года). М., 2020. 
стических, интерпретаций события за рубежом: в 1989 году тема съезда нашла отражение в обобщающей монографии Р. Г. Суни «Советский эксперимент», где ей, правда, было уделено всего несколько строк. ${ }^{6}$

В работах, вышедших позже, оценки значения Второго Всесоюзного съезда писателей варьируются от признания его мероприятием маловлиятельным (и уж точно многократно уступающим по своей важности Первому Всесоюзному форуму советских литераторов) до закрепления за ним статуса вполне различимой на общем фоне публичной инициативы; ${ }^{7}$ от оптимистических суждений о писательском собрании 1954 года как о преддверии оттепели ${ }^{8}$ до упреков скептиков, видящих в нем только казенщину и продолжение ждановщины. ${ }^{9}$ Предлагаемые материалы позволяют уточнить наши представления о том, насколько оправданы существующие, иногда полярные, интерпретации.

Основание для пессимистических оценок можно увидеть не только в самом ходе писательской дискуссии, где постоянно звучали отсылки к XIX съезду КПСС и постановлениям 1940-х годов, но и в тех обстоятельствах, которые касаются ее предыстории. После недавних разысканий появились основания с уверенностью говорить о том, что второй писательский съезд не был спровоцирован смертью Сталина, т. е. ситуацией замешательства и потерей тотального политического контроля, а задумывался еще при жизни диктатора.

Согласно записке, адресованной Сталину и подписанной тремя руководителями Союза писателей, съезд предполагалось провести летом 1953 года, с 15 августа по 1 сентября, предварив его соответствующей кампанией по мобилизации писателей в республиках. Вот содержание соответствующего недатированного документа:

\title{
«<В $>$ ЦЕНТРАЛЬНЫЙ КОМИТЕТ КП СС
}

\author{
Товарищу Сталину И. В.
}

Секретариат Союза советских писателей просит разрешить созвать с 15 августа по 1 сентября 1953 года Второй Всесоюзный съезд советских писателей со следующей повесткой дня:

1. Отчетный доклад Генерального секретаря Союза советских писателей Фадеева А. А. - „Советская литература после первого съезда советских писателей и задачи, стоящие перед ней в свете решений XIX съезда Колмунистической партии Советского Союза“.

2. Доклад ревизионной комиссии.

3. Доклад о состоянии и задачах советской поэзии.

4. Доклад о состоянии и задачах советской драматургии и кинодраматургии.

5. Доклад о состоянии и задачах детской литературы.

6. Доклад о состоянии и задачах советской критики.

[7. Доклад о работе с молодыми писателями.]

[8.] 7 Выборы руководящих органов Союза советских писателей.

Для подготовки проведения съезда просим разрешить созвать 1-го февраля 1953 года Пленум Правления Союза советских писателей, с повесткой дня:

${ }^{6}$ Suny R. G. The Soviet Experiment: Russia, the USSR, and the Successor States. New York, 1998. P. 405.

7 Подробный обзор истории изучения съезда см.: Второй Всесоюзный съезд советских писателей. С. 14-25.

8 Корлилов С. И. Второй съезд советских писателей как преддверие «оттепели» // Вестник Московского университета. Сер. 9. Филология. 2010. № 4.

${ }^{9}$ Золотоносов М. Н. Гадюшник. Ленинградская писательская организация: Избр. стенограммы с комментариями (Из истории советского литературного быта 1940-1960-х гг.). М., 2013. О съезде см.: с. 371-372, 398-399, 586. 
1. „О мероприятиях по подготовке и проведению Всесоюзного съезда Союза советских писателей“.

2. Утверждение повестки дня съезда и кандидатур докладчиков.

Просим разрешить в период марта-июня 1953 года созыв съездов писателей союзных республик.

Секретариат Союза советских
писателей C.C.C.P.

(А. Фадеев)
(А. Сурков)
(А. Софронов)»10

Итак, смерть Сталина лишь отсрочила исполнение намеченной при нем программы, и даже список основных докладов, сформированный в этот момент, тематически не претерпел принципиальных изменений по сравнению с реальной повесткой писательского собрания. Другое дело, что ход их обсуждения пошел не совсем так, как ожидалось в 1953: новое время все-таки дало о себе знать.

О корреспонденции по вопросам съезда, циркулировавшей между руководством Союза писателей и высшими государственными инстанциями позже, пока известно не очень много. Хрущеву идея проведения съезда писателей, согласно опубликованным документам, вероятно, впервые была представлена 11 августа 1953 года в специальной записке, подготовленной тогдашними руководителями союза ${ }^{11}-$ исполняющим обязанности генерального секретаря ССП СССР А. А. Сурковым ${ }^{12}$ и двумя заместителями генерального секретаря К. М. Симоновым и Н. С. Тихоновым, которые просили разрешения провести пленум Правления ССП в октябре 1953-го, а съезд - весной 1954 года. ${ }^{13}$ Чуть позже, 22 августа, Хрущеву написал и сам генеральный секретарь ССП А. А. Фадеев, уточняя повестку дня пленума и программу съезда, который он предложил созвать 20 сентября 1954 года. ${ }^{14}$ По мере развития событий разгоралась как явная, так и подковерная борьба за высокие посты в ССП.

Одно из писем руководства ССП в ЦК, касающихся всесоюзного писательского форума, подготовленное, скорее всего, в марте 1954 года, открывает поворот сюжета в истории съезда, который до сих пор не привлекал специального внимания исследователей. Помимо прочих деталей, в нем отражена расстановка сил среди основных докладчиков, радикально отличающаяся от той, которая сложилась к началу работы съезда:

\section{«Секретарю ЦК КПСС}

товарищу Хрущеву Н. С.

В соответствии с постановлением XV-го Пленума Правления Союза советских писателей СССР от 4-го марта 1954 года, Секретариат Правления Союза советских писателей СССР просит ЦК КПСС:

\section{I.}

Разрешить Правлению ССП СССР созвать Второй Всесоюзный съезд советских писателей 15-го ноября 1954 года.

10 РГАЛИ. Ф. 631. Оп. 30. Ед. хр. 381. Л. 1 (машинопись, вероятно, второй закладки, с правкой синим карандашом). Здесь и далее при цитировании архивных документов курсивом приводятся подчеркивания, в квадратных скобках дается вычеркнутый текст, а полужирным шрифтом - вставки и надписи. Конъектуры и пометы публикатора заключаются в угловые скобки. Тексты воспроизводятся в соответствии с правилами современной орфографии.

11 Роланова Р. Союз писателей перед своим Вторым съездом. С. 216.

12 Генеральный секретарь Фадеев был заменен и. о. в связи с продолжительной болезнью и отпуском.

13 Романова Р. Союз писателей перед своим Вторым съездом. С. 216.

14 Там же. С. 218. 
II.

Утвердить следующую, принятую Пленумом Правления ССП СССР повестку для Второго Всесоюзного съезда советских писателей:

I. Доклад Председателя Правления Союза советских писателей СССР А. А. Фадеева „О состоянии и задачах советской литературьь“.

Содоклады:

„Советская художественная проза“ докладчик В. Т. Лацис.

„Советская поэзия“ докладчик Самед Вургун

„Советская дралатургия“ докладчик А. Е. Корнейчук

„Советская кинодралатургия“ докладчик С. А. Герасимов

„Советская литература для детей и юношества“ докладчик С. Я. Маршак

„Основные проблемы советской литературной критики“ докладчик Б. С. Рюриков

„Художественные переводы литератур народов СССР“ докладчики М. Ф. Рыльский, М. Ауэзов, П. Г. Антокольский

II. „Современная прогрессивная литература мира“ докладчик И. Г. Эренбург

III. Доклад Председателя Ревизионной комиссии Союза советских писателей СССР Ю. Н. Либединского „О работе Ревизионной комиссии“.

IV. Сообщение Комиссии Правления Союза советских писателей СССР „Об изме нениях в Уставе Союза советских писателей“.

V. Выборы руководящих органов Союза советских писателей СССР.

(Тексты докладов и содокладов - будут подготовлены к 10 сентября 1954 г.).

III.

Утвердить следующие нормы выборов делегатов на Второй Всесоюзный съезд советских писателей от республиканских, краевых и областных организаций ССП СССР:

a) от пяти членов ССП СССР - один делегат с правом решающего голоса;

б) от писательских организаций, насчитывающих в своем составе от 3-5 членов ССП СССР - один делегат с правом решающего голоса;

в) от пяти кандидатов в члены ССП СССР - один делегат с правом совещательного голоса.

Выборы делегатов на Второй Всесоюзный съезд советских писателей будут проводиться:

а) в союзных и автономных республиках - на республиканских съездах писателей данной республики;

б) в краях и областях РСФСР - на общих собраниях писателей данного края (области).

IV.

Разрешить Правлению ССП СССР пригласить на Второй Всесоюзный съезд советских писателей в качестве гостей 75-80 иностранных писателей (по особому списку). 
$\mathrm{V}$.

Поручить Министерству финансов СССР рассмотреть и утвердить смету расходов, необходимых на подготовку и проведение Второго Всесоюзного съезда советских писателей и дать указания на места о включении в местный бюджет расходов по созыву республиканских съездов, а также краевых и областных общих собраний писателей.

ПРИЛОЖЕНИЕ: Постановление XV-го Пленума Правления ССП СССР от 4 марта 1954 года.

Секретарь Правления

Союза советских писателей

CCCP

(А. Сурков)» ${ }^{15}$

Сравнение списка докладчиков из этого письма с официальным отчетом о втором съезде, опубликованным только в 1956 году, ${ }^{16}$ показывает, что по ходу развития событий из него выпали имена четырех ведущих советских писателей-функционеров.

Программа съезда предполагала деление выступлений на три типа - доклад, содоклад и речь (эквивалентная заранее подготовленному выступлению в прениях) что соответственно устанавливало символическую субординацию среди ораторов по трем рангам. В результате рокировки все упомянутые лица удостоились чести выступить с речью, т. е. опустились на низшую из возможных иерархическую ступень среди литераторов, допущенных на трибуну. А. А. Фадеева сменил А. А. Сурков, В. Т. Лациса - К. М. Симонов, С. Я. Маршака - Б. Н. Полевой, И. Г. Эренбурга - Н. С. Тихонов.

Неожиданная, на первый взгляд, ротация легко выводится из логики предсъездовских событий. Как известно, смерть диктатора спровоцировала волну манифестов советских творческих работников, где обсуждались вещи по меркам других времен ничуть не радикальные, но все же такие, о которых еще недавно открыто размышлять было просто невозможно. Выступлений самих по себе было не очень много, однако поднявшийся вокруг критический шум, как эхо, заметно умножал их числом.

16 апреля 1953 года в «Литературной газете» О. Ф. Берггольц выступила со статьей «Разговор о лирике», в ноябре «Новый мир» (№ 11-12) начал печатать роман В. Ф. Пановой «Времена года», в декабре в «Новом мире» вышел знаменитый «манифест» В. М. Померанцева «Об искренности в литературе», во втором номере журнала «Театр» за 1954 год появилась пьеса Л. Г. Зорина «Гости». Все эти «либеральные» заявления тут же попали под град осуждений - прежде всего со стороны руководства ССП и дружественной ему критики.

Майский, пятый, номер журнала «Знамя» за 1954 год предложил читателю повесть «Оттепель», благодаря которой ее автор И. Г. Эренбург стал, наверное, самым популярным до и во время съезда писателем. Текст Эренбурга постигла та же участь. Его «провокацию» тут же попыталась дезавуировать «Комсомольская правда» ${ }^{17}$ причем взялась за дело настолько рьяно, что удивила даже кое-кого из верхнего эшелона литераторов-управленцев. Послышались голоса, хоть и возражающие «Оттепели», но одновременно, как характеризовал свою позицию Симонов, не желающие критиковать ее автора «на уничтожение». ${ }^{18} \mathrm{~B}$ результате Эренбурга не уничтожили (настоящие репрессии к этому времени всем порядком надоели), зато радикально понизили в статусе оратора на съезде.

В конце октября 1954 года «Литературная газета» осмелилась опубликовать документ, воспринятый ни много ни мало как незамаскированное покушение на сам Союз

15 РГАЛИ. Ф. 631. Оп. 30. Ед. хр. 381. Л. 2-4 (машинопись не первой закладки без даты и подписи).

16 Второй Всесоюзный съезд советских писателей. 15-26 декабря 1954 года. Стенографический отчет. М., 1956.

17 В жизнеутверждении - сила нашей литературы // Комсомольская правда. 1954. 6 июня. C. 2 .

\footnotetext{
18 Симонов $К$. Письмо в редакцию // Литературная газета. 1954. 23 сент. № 114. С. 3.
} 
советских писателей. Это было открытое письмо, озаглавленное «Товарищам по работе» и подписанное семью литераторами - В. А. Кавериным, Э. Г. Казакевичем, М. К. Лукониным, С. Я. Маршаком, К. Г. Паустовским, Н. Ф. Погодиным и С. П. Щипачевым. «Реформаторы» предлагали сузить правомочия верховных органов Союза и децентрализировать управление литературным процессом, доверив его редакциям отдельных журналов: «Настоящий творческий актив возникает там, - говорилось в послании, - где фактически делается литературное дело, то есть при журнале, издательстве, альманахе. Здесь - и живой интерес писателя, и обмен опытом, и прямая связь литературного производства с общественностью». ${ }^{19}$

Подписанты просили коллег высказаться по поводу этого предложения, и ответ не заставил себя ждать. С одной стороны, против инициативы сразу и решительно выступил В. Н. Ажаев, который усмотрел в ней «туманно выраженную и тем не менее явную мысль о ликвидации самого союза». ${ }^{20} \mathrm{C}$ другой стороны, несколькими днями позже в «Литературной газете» появилась статья Е. И. Катерли «Творческий союз или „литературный департамент“? », поддерживающая идею замены сугубо делопроизводственной активности аппарата Союза писателей творческой, т. е. редакторской.

Ни о каком разгоне Союза Катерли не высказывалась; напротив, в заключении она писала: «Для того, чтобы укрепить Союз писателей и повысить его значение, как коллективной творческой организации, надо так поставить дело, чтобы живые, талантливые силы были прежде всего отданы производственным площадкам, туда, где делается самое главное и самое святое писательское дело - книга». ${ }^{21}$ Тем не менее Отдел науки и культуры ЦК КПСС оценил ее позицию именно как ликвидаторскую, ухватившись за одну-единственную вырванную из контекста фразу: «Прямо предлагая ликвидировать Союз писателей, Е. Катерли пишет: „Заклинания не помогли и помочь не могут, и, на мой взгляд, если ликвидировать весь этот «литературный департамент» с референтами и секретарями, председателями и консультантами, то на количестве и на качестве выходящих книг это никак не отразится“». ${ }^{22}$

Иными словами, идея «бархатной» реформы поддержки не получила, а только напугала. Маршак же, чье имя значилось среди авторов разворошившего муравейник послания, был, как и провинившийся Эренбург, исключен из рядов докладчиков и содокладчиков.

В отличие от Маршака и Эренбурга, Фадеева сбросили с пьедестала не свежие идеи, а обстоятельства «внутриаппаратного» свойства: он проиграл борьбу за руководство Союза своим заместителям - Суркову, Симонову и Тихонову. Совершенно очевидно, что отправленный в отпуск генеральный секретарь старался всеми силами воздействовать на ситуацию. Об этом свидетельствуют его письма, включая то, из которого выясняется, что Эренбург в качестве докладчика был протеже Фадеева:

\section{«В СЕКРЕТАРИАТ \\ СОЮЗА СОВЕТСКИХ ПИСАТЕЛЕЙ}

В дополнение к своим замечаниям по поводу повестки дня съезда писателей, вношу на обсуждение еще некоторые предложения.

Может быть назвать основной доклад так: „Советская литература в художественном развитии человечества“. Или так: „Советская литература в строительстве коммунизма“.

Может быть целесообразно было бы назвать доклад по поэзии таким образом: „Лирика, эпос и драма в советской поэзии“. Исхожу из замечательной статьи Белинского - „Разделение поэзии на роды и виды“. В наших разговорах о поэзии мы,

19 Товарищам по работе // Литературная газета. 1954. 26 окт. № 128. С. 3.

20 Ажаев В. Н. Уважать свой «литературный цех» // Там же. 11 нояб. № 134. С. 2.

${ }^{21}$ Там же. 30 окт. № 130 . С. 3. Курсив мой. $-B . B$.

22 О работе отдела науки и культуры ЦК КПСС над докладом «О подготовке ко Второму всесоюзному съезду писателей СССР». 21 ноября 1954 года / Публ. Т. Домрачевой // Вопросы литературы. 1993. № 3. С. 284. 
например, совершенно обходим драму в стихах, а между тем у нас были и есть такие сильные представители ее, как Маяковский, Сельвинский, Багрицкий, В. Гусев, В. Соловьев, М. Светлов, С. Вургун, Х. Алимджан, Наири Зарьян и др. У нас справедливо выдвигают на рассмотрение вопросы лирики, но забывают, что только с появлением реалистического романа в поэзии ее можно считать вполне зрелой. В число докладчиков по поэзии я включил бы еще кого-нибудь из белорусских или грузинских поэтов и добавил бы, также, Щипачева [и] или Н. Тихонова.

Доклад о кинодраматургии, может быть, полезно было бы сформулировать так: „[Художественный с] Сценарий, как основа развития [советской] художественной кинематографии“. Или так: „Советский художественный сценарий и его место среди других видов литературы“"

Название доклада Корнейчука мне кажется исключительно казенным. Следовало бы поискать название получше, идя, например, по такому пути: „Значение советской драматургии в борьбе нового со старым“. Или: „Вопросы мастерства драматургии в связи с борьбой нового со старым в жизни советского общества“.

Все-таки лучше было бы поставить доклад не о наших связях с прогрессивными писателями других стран, а доклад, который можно было бы, примерно, сформулировать таким образом: „Прогрессивная литература всех стран в борьбе за мир, демократию, социализм“. Тогда основным докладчиком целесообразно было бы выдвинуть Илью Эренбурга.

Все эти мои предложения, конечно, только наметки. Но если Секретариат в своем решении разойдется с этими наметками кардинальным образом, я просил бы довести до сведения ЦК и мои замечания.

Попутно хотел бы выдвинуть дополнение к своим замечаниям по поводу повестки дня Президиума.

Обзор поэзии в журналах за 1953 год не представляет больших трудностей для наших квалифицированных поэтов, ибо поэтических произведений прошло не так уж много и поэты, конечно, их читали раньше. До Президиума осталась еще неделя. Надо настоять чтобы Твардовский, Асеев, Рыльский, С. Вургун и др., кому поручено было выступать, кроме Маршака, выполнили решение Президиума. Если, однако, многие из них откажутся, надо просить срочно подготовить выступления - Щипацева, Н. Тихонова Кулешова, Алигер, Сельвинского[.] при вступительном слове А. Суркова.

„30“ декабря

С приветом <подпись Фадеева > (А. Фадеев)

1953 г.» ${ }^{23}$

Председатель Совета министров Латвийской ССР Лацис был исключен из ораторов, думается, просто в силу своей занятости. Позже, в 1956 году, после ХХ съезда КПСС, он сполна возместил свое скромное участие в истории писательского собрания, став, наряду с Сурковым, М. П. Бажаном и В. А. Смирновым, редактором официального отчета о нем. В результате кропотливой работы над стенограммой, осуществлявшейся под руководством названных литераторов, из нее были вычеркнуты все, кроме единственного (прозвучавшего во время открытия конгресса), прямые упоминания имени Сталина. В результате это историческое событие приобрело как будто бы даже «оттепельное» звучание.

Даты проведения съезда неоднократно переносились - весна, ${ }^{24}$ сентябрь, ${ }^{25}$ ноябрь 1954 года ${ }^{26}$ - пока не были приняты окончательно: 15-26 декабря 1954 года. Среди малоизвестных документов, отражающих это "скольжение», сохранилось по-

23 Машинопись с правкой синими чернилами. РГАЛИ. Ф. 631. Оп. 30. Ед. хр. 381. Л. 50-51.

24 Роланова Р. Союз писателей перед своим Вторым съездом. С. 216.

25 Там же. С. 218.

26 Постановление Совета министров СССР от 31 марта 1954 года № 583. См.: РГАЛИ. Ф. 631. Оп. 30. Ед. хр. 381. Л. 61-62. 
слание Суркова, где говорится об октябре 1954 года. Его записка интересна не только этим, а - в свете рассматриваемого сюжета - еще и тем, что в нем повторяется уже известный нам список основных докладчиков. Судя по неполным датировкам в конце письма: январь, исправленный на март, - еще не успевшие себя скомпрометировать докладчики пребывали в высоком статусе таковых по крайней мере с января 1954 года:

\section{В ПРЕЗИДИУМ ЦК КПСС}

«Секретно

товарищу МАЛЕНКОВУ Г. М.

товарищу ХРУЩЕВУ Н. С.

В соответствии с решением ЦК КПСС о проведении осенью 1954 года - Второго Всесоюзного съезда советских писателей, - Президиум Правления Союза советских писателей СССР просит:

I.

Разрешить Правлению ССП СССР созвать Второй Всесоюзный съезд советских писателей во второй половине октября 1954 года.

II.

Утвердить следующую, одобренную Президиумом Правления ССП СССР, повестку для Второго Всесоюзного съезда советских писателей:

I. Доклад Председателя Правления Союза советских писателей СССР А. А. Фадеева „О состоянии и задачах советской литературы“.

Содокладьи:

— „О советской художественной прозе“ докладчик В. Т. Лацис

— „О советской поэзии“ докладчик Самед Вургун

- „О советской драматургии“ докладчик А. Е. Корнейчук

- „О советской кинодраматургии“ докладчик С. А. Герасимов

— „О советской литературе для детей и юношества“ докладчик С. Я. Маршак

— „Основные проблелы советской литературной критики“ докладчик Б. С. Рюриков

II. „Современная прогрессивная литература мира“ докладчик И. Г. Эренбург

III. Доклад Председателя Ревизионной комиссии Союза советских писателей СССР Ю. Н. Либединского „О работе Ревизионной комиссии“.

IV. Сообщение Комиссии Правления Союза советских писателей СCСР „Об изленениях в Уставе Союза советских писателей“.

V. Выборы руководящих органов Союза советских писателей СССР.

(Тексты докладов и содокладов - будут подготовлены к 10 августа 1954 г.). 
III.

Утвердить следующие нормы для выборов делегатов на Второй Всесоюзный съезд советских писателей от республиканских, краевых и областных организаций ССП CCCP:

a) от пяти членов ССП СССР - один делегат с правом решающего голоса;

б) от пяти кандидатов в члены ССП СССР - один делегат с правом совещательного голоса;

в) от писательских организаций, насчитывающих в своем составе менее пяти членов ССП СССР — один делегат с правом совещательного голоса.

Выборы делегатов на Второй Всесоюзный съезд советских писателей <провести>:

а) в союзных и автономных республиках - на республиканских съездах писателей данной республики;

б) в краях и областях РСФСР - на общих собраниях писателей данного края (области).

\section{IV}

Разрешить Правлению ССП СССР пригласить на Второй Всесоюзный съезд советских писателей $-75-80$ гостей иностранных писателей (по особому списку).

$\mathrm{V}$

Поручить Министерству финансов СССР (т. Звереву) в месячный срок рассмотреть и утвердить за счет госбюджета [-] < примерную> смету расходов на подготовку и проведение Второго Всесоюзного съезда советских писателей. (пр. № 1)

VI

Рассмотреть и утвердить «Мероприятия по оказанию помощи Союзу советских писателей СССР в связи с подготовкой ко Второму Всесоюзному съезду советских писателей» и 20-лети<ем> существования ССП СССР (пр. № 2).

VII

Разрешить Президиуму Правления ССП СССР созвать 1-го марта 1954 года очередной XV-й Пленум Правления CCП CCCP (совместно с руководителями республиканских, краевых и областных организаций Союза советских писателей[) - для об-] и редактор <ами> основных печатных органов ССП СССР) - для обсуждения [практических вопросов, связанных с подготовкой ко 2-му Всесоюзному съезду советских писателей.

На этом же Пленуме, мы предполагаем также заслушать (первым вопросом) доклад тов. Тычины П. Г. „Об исторических связях русской и украинской литератур, в связи с 300-летием воссоединения Украины с Россией“.]

Приложение - Постановление XV-го Пленума Правления ССП СССР от 4-го марта 1954 года

Секретарь Правления

Союза советских писателей CCCP

(А. Сурков)

” “ “января] марта 1954 г.» ${ }^{27}$

Первым из списка основных докладчиков, в июле 1954 года, выбыл Фадеев. Согласно представленному ниже постановлению, взамен ему было предложено открыть съезд. Однако и эту роль бывшему генеральному секретарю Союза сыграть не при-

27 Там же. Л. 5-8 (машинопись частично первой, частично последующих закладок, содержащая карандашную и чернильную правку). 
шлось. В конечном счете его заменили «старейшей», как о ней говорилось, советской писательницей О. Д. Форш:

\section{«СОЮЗ СОВЕТСКИХ ПИСАТЕЛЕЙ СССР ПОСТАНОВЛЕНИЕ [СЕКРЕТАРИАТА] ПРЕЗИДИУМА}

\section{Протокол 6 § 1 «6» июля 1954 г.}

СЛУШАЛИ: І. Сообщение Председателя Правления ССП СССР т. Фадеева А. А. о подготовке ко 2-му Всесоюзному съезду советских писателей.

\section{ПОСТАНОВИЛИ:}

1. В связи с тем, что т. Фадеев А. А. находится в творческом отпуске и работает над новым романом, освободить его от подготовки основного доклада на съезде.

Поручить Председателю Правления ССП СССР тов. Фадееву А. А. открыть съезд вступительным словом.

2. Поручить <подготовку> доклада „О состоянии и задачах советской литературы“ первому секретарю Правления ССП СССР тов. Суркову А. А.

В связи с этим освободить т. Суркова от текущей работы в Союзе сроком на 2 недели (с 8.VII) для составления плана доклада. кладу.

Поручить Секретариату ССП СССР оказать помощь т. Суркову в подготовке к до-

3. По повестке съезда утвердить окончательный состав докладчиков и содокладчиков.

Содоклады:
a) „Советская художественная проза“
б) „Советская поэзия“
в) „Советская драматургия“
г) „Советская кинодраматургия“
д) „Советская литература для детей и юношества“
е) „Основные проблемы советской литературной критики“

Доклад „Современная прогрессивная литература мира“

Доклад „О работе Ревизионной комиссии“

Сообщение Комиссии Правления Союза советских писателей СССР „Об изменениях в Уставе Союза советских писателей“
К. Симонов Самед Вургун

А. Корнейчук

С. Герасимов

С. Маршак

П. Антокольский

М. Ауэзов

М. Рыльский

И. Эренбург

Ю. Либединский

4. Считать обязательным тексты докладов и содокладов представить к 1 октября в письменном виде для коллективного обсуждения на Президиуме ССП.

Верно: <нрзб.>

ПОСЛАНО:

С. Н. Преображенскому» ${ }^{28}$

28 Преображенский Сергей Николаевич (1908-1979) - на тот момент заместитель секретаря Союза писателей. 


\section{ЭПИЗОД ИЗ ИСТОРИИ ЛАГЕРНОЙ ЛИТЕРАТУРЫ: НЕИЗВЕСТНАЯ РЕЦЕНЗИЯ ВАРЛАМА ШАЛАМОВА}

В записных книжках ${ }^{1}$ Варлама Шаламова 1971 года есть короткая заметка: «Мои отношения с „Новым миром“ ухудшились после того, как я рекомендовал большую повесть автора - заключенного врача, но напечатана она не была (1966 год?)». ${ }^{2}$ Шаламов не уточнил, что это была за повесть и почему он рекомендовал ее «Новому миру» . Никаких других деталей этого сюжета в его записях нет. В 1970-е годы он почти не вспоминал и о своих взаимоотношениях с самим журналом, где работал внештатным рецензентом.

В «Новом мире» Шаламов неоднократно рецензировал рукописи непрофессиональных авторов, так называемый «самотек» на лагерную тему, так как в силу своего опыта считался специалистом в ней. После публикации рассказа А. И. Солженицына «Один день Ивана Денисовича» в 1962 годуํㅜㄹких рукописей в редакцию поступало много - как от авторов, имевших лагерный опыт, так и от тех, кто никогда не был репрессирован. В большинстве случаев они отправлялись на имя главного редактоpa - А. Т. Твардовского, но непосредственно к нему не попадали: после рецензирования авторы получали отказ, подписанный редактором. Иногда авторы просили передать свои тексты самому Солженицыну, считая, что именно он может оценить их по достоинству.

Кроме рассказов Солженицына и мемуаров генерала Горбатова ${ }^{4}$ «Новый мир» в этот период не опубликовал ни одного «лагерного» произведения самого Шаламова. Чаще всего мотивацией отказа служило то, что тема лагеря уже исчерпана Солженицыным. Художественная ценность произведений в данном случае не имела значения: тема была заведомо «непроходной». Авторам приемлемых с литературной точки зрения рукописей предлагалось оставить их в мемуарном фонде, тексты низкого качества возвращались.

Среди рецензий на лагерные рукописи, раскритикованные и отвергнутые Шаламовым, в архиве «Нового мира» находится одна положительная, в которой он рекомендовал к публикации рукопись А. П. Чигарина «Всюду жизнь».

Информации об авторе в архиве журнала практически нет - из сопроводительного письма на имя Твардовского можно узнать только то, что Александр Петрович Чигарин жил в Казани и считал эту повесть своим гражданским долгом: ${ }^{5}$

«Глубокоуважаемый Александр Трифонович!

Одновременно с письмом посылаю заказную бандероль с моей работой - повестью „Всюду жизнь“. Обращаюсь с нею к Вам с чувством глубокого доверия и уважения. Вы своими произведениями высокого гражданского долга перед Родиной, Партией, располагаете к тому, что от Вас можно ожидать строгое принципиальное суждение о моей работе. Писал я ее с досадной болью за наш великий советский народ, вынесший тяжелую ношу периода культа личности, в то же время с гордостью за восстановленную честь Родины, ее Партии на XX съезде.

1 Так в Собрании сочинений Шаламова квалифицированы школьные тетради, в которых он делал записи, часто не датированные, отрывочные, с незаконченными фразами. Черновики стихов, рассказов и эссе перемежаются в них записями автобиографического характера.

${ }^{2}$ Шалалов В. Т. Собр. соч.: В 7 т. М., 2013. Т. 6. Переписка. С. 317. В 1966 году Шаламов уже не работал в «Новом мире», эпизод, о котором идет речь, относится к 1964 году.

3 Солженицын А. И. Один день Ивана Денисовича // Новый мир. 1962. № 11. С. 8-74.

4 Горбатов А. В. Годы и войны (Страницы воспоминаний) // Новый мир. 1964. № 3. С. 133157; № 4. С. 99-139; № 5. С. 106-154.

${ }^{5}$ Об этом Чигарин сообщил в сопроводительном письме. 
Ж ду Вашего беспристрастного суда моей работы. Если она ни в коей мере не умаляет достоинство Родины, Партии и советских людей, напечатайте в редактируемом Вами журнале. Описал в своей работе только чистую правду опыта моей жизни. Гражданский долг я выполнил.

Глубоко уважающий Вас

Чигарин А.

Казань, 29

Студенческая ул., 16 кв. 63

Ал-р. Петр. Чигарин

Послано 10/III 64 г.» ${ }^{6}$

Некоторые детали «лагерной» жизни Чигарина вычитываются из рецензии: повесть автобиографична, Шаламов предлагает переделать ее в воспоминания. Сама рукопись, скорее всего, не сохранилась. Ее оставили в «архиве мемуаров» «Нового мира» (впоследствии эта часть фонда журнала, не переданная в РГАЛИ, была утрачена), что следует из ответа Чигарину редактора И. Борисовой:

«13 июля 1964 г.

Уважаемый товарищ Чигарин!

А. Т. Твардовский из-за крайней занятости не мог прочесть Вашу рукопись сам и передал ее в отдел прозы. Мы внимательно ее прочли и должны сказать Вам следующее: Ваша повесть относится к тем человеческим документам, ценность которых определяется главным образом не их литературными достоинствами. Здесь живое свидетельство об испытаниях, пережитых в известные годы, причем свидетельство сильного духом человека, которого эти испытания отнюдь не сломили.

Должны сказать Вам, что напечатать Вашу повесть в настоящее время мы не можем - мы загружены подобными рукописями (особенно после повести Солженицына, написанной на том же примерно материале, но обладающей выдающимися художественными достоинствами). Однако мы, редакция, не хотим просто отклонять эти рукописи. Мы сохраняем их (конечно, с согласия авторов) в нашем архиве мемуаров. Так или иначе, они представляют непреходящий исторический интерес.

Если Вы не возражаете, мы оставим у себя и Вашу рукопись. На большее сейчас, при отсутствии специальных изданий, рассчитывать, к сожалению, не приходится.

Простите, что долго не отвечали Вам.

Желаем всего доброго,

Старший редактор отдела прозы И. Борисова» ${ }^{7}$

Некоторую информацию о А. П. Чигарине можно восстановить по ряду источников и устных свидетельств. ${ }^{8}$ Тем не менее точных сведений о биографии автора, в частности о том, в каком именно лагере находился Чигарин, пока не выявлено. ${ }^{9}$

Александр Петрович Чигарин родился в Казани в 1894 году в семье Петра Ивановича Чигарина, предпринимателя, владельца ресторана Чигарина, знаменитого в Казани. Его мать, вероятно, была дочерью церковнослужителя села Аркатова. Сестра, Ольга Петровна, была первой женщиной, окончившей Казанский университет. В 1913 А. П. Чигарин поступил на терапевтическое отделение медицинского факультета Казанского университета, ${ }^{10}$ откуда вышел в 1917 году. Сведений о его жизни в период революции и гражданской войны не сохранилось. В библиотеке Казанской государственной медицинской академии хранится кандидатская диссертация

${ }^{6}$ Письмо А. П. Чигарина в редакцию журнала «Новый мир». 10.03.1964 // РГАЛИ. Ф. 1702. Оп. 10. № 121. Л. 27-28.

7 Ответ редактора И. Борисовой А. П. Чигарину // Там же. Л. 29.

8 Мы благодарим Р. В. Царевского, сотрудника Музея истории старообрядчества г. Казани, родственника А. П. Чигарина, за сообщенные им сведения.

${ }^{9}$ В рецензии имеется указание на то, что лагерь находился в 30 км от дома. Ближе всего к Казани находилось Свияжское лагерное отделение (Лагерное отделение при Свияжском заводе № 1 Главного управления лагерей железнодорожного строительства).

10 Список студентов, посторонних слушателей и учениц повивального института императорского Казанского университета 1914-1915 г. Казань, 1914. С. 425. 
Чигарина на тему «О функциональном состоянии активной мезенхимы при токсикозах беременности», которую он защитил в 1939 году. А после, перед войной проходил обучение в Государственном институте для усовершенствования врачей им. В. И. Ленина (ГИДУВ) в Казани. ${ }^{11}$ Медицинская специализация Чигарина - акушерство и гинекология, по-видимому, стала причиной его попадания в «женский» лагерь после ареста и суда.

Александр был не первым репрессированным в семье - его старший брат Леонид был арестован в 1921 году, осужден как политически неблагонадежный ${ }^{12}$ и приговорен к заключению в концлагерь до особого распоряжения.

История ареста А. П. Чигарина известна по устным свидетельствам: ${ }^{13}$ в 1941 году он был начальником хирургического отделения Казанского полевого передвижного госпиталя № 257. С началом войны в госпиталь стало поступать много раненых, и Чигарин требовал от своих подчиненных жесткой дисциплины. Некоторые упрекали его в том, что он слишком требователен к порядку, «как немец». За фразу, что он готов быть кем угодно, лишь бы раненые не умирали, Чигарин был арестован и осужден военным трибуналом Казанского гарнизона по статье 58, п. 10 ч. 2. за «пораженческую, профашистскую агитацию, клевету на Красную армию, советскую власть, вождя народов» на десять лет исправительно-трудовых лагерей с конфискацией имущества и поражение в правах на три года. Освободившись в 1951 году, он был вынужден еще два года жить у родственников на окраине Казани перед тем как смог вернуться домой и добиться реабилитации в 1957 году. В рассказе Шаламова «Необращенный» (1963) из цикла «Левый берег» описана судьба освободившихся заключенных, которой не избежал и Чигарин, и сам автор: «Бывшие заключенные, которым лагерь достался легко, - если кому-нибудь лагерь может быть легок, - считают самым трудным временем своей жизни послелагерное бесправие, послелагерные скитания, когда никак не удавалось обрести бытовую устойчивость - ту самую устойчивость, которая помогла им выжить в лагере». ${ }^{14}$

Александр Петрович Чигарин скончался в 1966 году, похоронен на Арском кладбище в Казани.

Рецензия на его рукопись «Всюду жизнь» имеет необычный для этого жанра объем - 11 страниц. Шаламов максимально подробно разбирает каждый заслуживающий внимания эпизод, доказывая достоверность истории, излагаемой Чигариным с точки зрения собственного опыта.

\section{А. ЧИГАРИН «ВСЮДУ ЖИЗНЬ» - повесть ${ }^{15}$}

А. Чигарин взял эпиграфом своей повести «Всюду жизнь» сюжет известной картины Ярошенко с тем же названием... «Всюду жизнь» - наблюдение, составляющее лейтмотив рассказа о десятилетнем заключении репрессированного врача Пескова с 1941 по 1951 год. Повесть автобиографического характера и построена просто и вместе с тем искусно. Первая часть - арест, следствие и суд. Вторая часть - десять лет лагерной жизни. Треть часть - «хождение по мукам» после формального освобождения - до реабилитации.

Повесть имеет важные достоинства. Герой повести, пятидесятилетний врач Песков, выступает как вдумчивый и пытливый наблюдатель того «подземного мира», который вдруг открылся перед ним при столь трагических обстоятельствах. По повести видно: автор поставил себе целью рассказать обо всем, что он видел и понял, со всей добросовестностью историка, не позволяя себе легковесных домыслов и не пропуская ничего, что показалось его герою чересчур страшным. В большой повести в четырнадцать авторских листов нет ни одной страницы, которая была бы фальшива, не нужна,

11 Ныне Казанская государственная медицинская академия.

12 База данных «Жертвы политического террора в СССР». См.: http://base.memo.ru/person/ show/538704; дата обращения: 30.04.2020.

13 Свидетельство Р. В. Царевского.

14 Шалалов В. T. Собр. соч.: В 7 т. Т. 1. С. 272.

15 Текст печатается по авторизованной машинописи (РГАЛИ. Ф. 1702. Оп. 10. № 160. Л. 3646) в соответствии с правилами современной орфографии и пунктуации, с сохранением индивидуальных особенностей написания. Описки и иные погрешности текста исправлены без оговорок. 
незначительна. Повесть - важный документ времени. Написана повесть фрагментарно. Доктор Песков, а вместе с ним и автор (в повести этой не существует грани между рассказчиком и автором) отобрал для рассказа лишь самое важное, самое значительное из великого множества фактов, которые он десять лет наблюдал, над которыми много задумывался.

Доктор Песков большую часть своего срока проработал в женском лагере, более того с т. н. «мамками» (роженицами). Это обстоятельство облегчило судьбу самого заключенного, Пескова, несколько сузило его кругозор. В то же время доктор Песков стал свидетелем, и свидетелем очень надежным, жизни особой, видеть которую случается не каждому при знакомстве с бытом лагерей. Повесть эта особенно ценна своими картинами из жизни «мамок», поведением женщин в этот неизбежно драматический момент их жизни. Сцена с Вязовой, услышавшей крик своего увозимого «на этап» грудного ребенка и вырвавшей из рук «начальства» свое дитя - принадлежит к лучшим, наиболее волнующим страницам повести. Навсегда запомнится и начальник Бичевский, который казенным молоком отпаивал своего ребенка в то время, как грудные дети заключенных голодали. Отлично рассказано о Клаве - блатарке, которую коснулась и вернула в человеческое общество радость материнства.

Не менее выразительно изображена и блатарка Жанна, и сектантка Анна, и Аня Купринова, которая оставила такой теплый след в сердце доктора Пескова.

В повести много замечено верного - и в части общих суждений, и отдельных живых картин, подробностей лагерной жизни. Язык автора лаконичен и строг.

Вот несколько примеров, которые хотелось бы отметить «по ходу действия» повести.

Нескончаемые «гастрономические» разговоры арестантов - это общий психологический закон.

Весьма тонко и верно замечено (37 стр.), что в человеческое понятие, в его психологию, наряду с унижением личности входит «что-то» новое, узкое, ограниченное рамками заведенного на него «дела». Человеческой личности наносится здесь навечный, непоправимый, «необратимый» ущерб - это очень хорошо показано в повести.

Искусно, без малейшего нажима показаны допросы; следователь Измайлов, который равнодушно и терпеливо объясняет з/к Пескову его «новый статус з/к» (должен вставать, когда я встаю, должен называть «гражданин начальник» и как сам Измайлов привычно называет своего подследственного на «ты» и кричит на него. <так!>

На «вы» Пескова назовут через 10 лет - и внимательный врач не пропустит этого изменения «формулы».

Очень хорошо показано сонное состояние утомленного «выстойками» арестанта и расслабление его воли. Эффектны (стр. 47) пирожки с мясом, которые бежит покупать следователь, прервав допрос. Следователь возвращается, откровенно рыгая, и это тоже запомнил доктор навсегда. Вообще весь допрос показан правильно, психологическое состояние следственного изображено очень точно и, хотя это - не «подготовка» к «большим процессам» - это малюсенькое отнюдь не групповое дело волжского города вроде Казани - но все, как и всюду.

На 66 странице рассказано об ошеломительности расстрельного приговора, который получает сосед Пескова по камере. Здесь же доктор Песков говорит точно и умно о «легкомысленном» отношении следственных заключенных к собственным «приговорам» (стр. 74).

Отмечает автор и распространенное - в следственной тюрьме желание скорее попасть в лагерь - желание бессмысленное, иллюзорное, ибо лагерь гораздо страшнее тюрьмы.

Очень хороша по своей психологической верности сцена, где соседи, укравшие хлеб и сало у товарища по камере, спят с ним вместе в обнимку, спасаясь от холода, и сам обокраденный обнимает своих «благодетелей» (77).

Грабеж во время «транзита» (86), который Песков видел в первый (но, увы, не в последний раз), неожиданное звучание улицы (81), больничная палата (81) после шести месяцев следствия - все это очень точно.

Поджаривание хлеба (93) голодными больными хорошо дано и правдиво - желание продлить удовольствие пищи. Скелеты больных, которые смотрит Песков (93), фиксирует с врачебной добросовестностью. 
Ужасна сцена свидания Пескова с женой (через полгода (!) после ареста) — двух стариков (102).

Очень хорошо по своей тонкости приглашение заключенных врачей на врачебную лагерную конференцию (137) и «секретный» конвой. (Участие в таких конференциях специалистов-врачей из з/к разрешалось Москвой). Сама конференция изображена правильно.

Очень хорошо и достоверно описана наивная «борьба» новичка врача Пескова с членовредительством блатарей (146). В/н врач <Швардовский?> очень правильно говорит новичку: «Лагерь - это особый мир, здесь много уродств во взаимоотношениях людей и в отношении к труду». Песков после этого разговора начал приглядываться к внутреннему миру лагеря, и у него возникло много недоумения и вопросов (146).

Песков скоро понял, что иногда «мастырка» спасает жизнь. Он подал начальству сведения о членовредительстве. Арестантов судили, дали им дополнительный срок, блатарям по три года, а «фраеру» Смолину $-58<$ п.> 19 ст. (саботаж) и шесть лет с клеймом политического рецидивиста. Далее в повести следует искренняя фраза: «Песков чувствовал какую-то косвенную вину в судьбе этого юноши» (157).

Эти случаи, очевидно, научили Пескова не поступать и не судить поспешно и опрометчиво о том, чего он еще не понял.

Блестящий портрет в/н врача - шарлатана <Червяковского?> с его аутогемотерапией вместо мяса ${ }^{16}(96)$. Это практиковалось, увы, не только в Казани.

На нескольких страницах рассказано о смертности, о «раздетости», о «доходягах», хотя читатель все время помнит, что работа здесь не добыча золота, а заготовка дров для собственных нужд. Тем не менее люди умирали, болели.

Отличный рассказ на стр. 92 о вступлении кандидата наук, клинициста, врача Пескова в свою первую лагерную врачебную должность.

«В Румынии мы лечили таких больных - просто давали им хлеб и конину» (стр. 97).

Взаимоотношения врачей - все это показано исчерпывающе точно. (110).

Смерть профессора <Метомского?> и все обстоятельства этой смерти - типичны

113-115 - голодный врач Песков, умирающий от пеллагры.

Изображения доходяг правдивы и страшны - но результаты могут быть и гораздо страшнее.

Врач Менделов, нач. <САНО?>17

«Перед вами больные, о которых в университете вам лекций не читали» (107).

Избиение заключенных нарядчиком - все это в высшей степени правдиво.

«С наступлением весны смертность в лагере увеличилась» (111).

Неоспоримый факт лагерной жизни заключается в том, что наивысшую нравственную стойкость в условиях всяческого растления голода и «произвола» показывают религиозники: сектанты, православные священники и т. д. Наблюдательный доктор Песков не может этого не заметить. Он оставляет нам весьма привлекательный портрет Анны, пользующейся всеобим уважением.

Переливание докторской крови (а то и просто раздача донорской крови "per os» ${ }^{18}$ ) важная заслуга Пескова. Бывали лагеря, где начальство заставляло выливать такую кровь, а тех врачей, которые разрешали раздавать больным донорскую кровь и спасали больных - отдавали под суд. И суды осуждали, давали срок.

Выразительно описание типичной лагерной провокации, которая не миновала порядочного человека доктора Пескова (169). Карцер и начальник карцера ЖЖуков описаны в высшей степени правдиво.

Поистине каждая страница повести - это одна из сторон жизни лагеря.

Врач женского лагеря, разумеется, не мог не рассказать о лагерной любви. Все описание (175-176) грустно, трагично, но все это - действительность, и честь и хвала доктору Пескову, что он смог запомнить, оценить и рассказать обо всем этом.

16 Аутогемотерапия - лечение кровью, подкожное или внутримышечное введение пациенту собственной венозной крови. Метод использовался для лечения различных заболеваний до появления антибиотиков.

17 САНО - санитарный отдел.

18 перорально (лат.) 
Всякому запомнятся (или вспомнятся) танцы и бледные тусклые лица танцоров и вся эта мрачная и в то же время трогательная картина.

Уродство лагерной любви $(182-183)$ - все достоверно, все так и было.

Великолепна лекция Пескова о вреде абортов, с цитатой из Эдмонда Ростана. Нужно было быть очень точным, чтобы не перешагнуть границы трагедии в изложении этой юмористической по существу ситуации из «Шантклера» <так! > ц цитатой из Эдмонда Ростана, истолкованного Песковым в высшей степени произвольно, но тем лучше, тем правдивее (186).

Беременность в лагере. Тьма ужасная. Темень еще не бедствия. Песков не может пройти мимо этих печальных картин (158).

Аресты в лагере. Садист Агаманов (20) - вполне рядовая, типичная фигура лагерного начальства, карцер, другой садист Быков. Провокация с побоями и премиями - одна из миллионов подобных провокаций в те годы.

Очень реальна страница-картина обыска, которую делает Быков в карцере из-за украденного у него лично сала (213).

На 214 странице рассказано о хулиганстве - и это правомерно и необходимо без этих картин понять лагеря нельзя.

Правдиво описано окончание войны, надежды, странная амнистия, которая никого, кроме уголовников, не касается (226-228).

Увольнение начальника - садиста Чернековского за самоснабжение.

Дети в лагере. Грудные дети. Тоже тема исключительной остроты, исключительной печали.

Выразительное кормление ребенка начальника Бичевского (236) одно чего стоит.

Кровавым анекдотом веет от приговора врача Блонской (237), получившей 8 лет за то, что увидела Сталина во сне. Увы, случай с Блонской - не единичный. Блонская.

«Лагерь - это пробуждение после сна о Сталине» - выразительно говорит 3/к

Сердечно и тепло описана блатарка Клава, ее материнство, ее возвращение в семью людей, все доброе в ее жизни разбужено родами, материнством, ребенком. Эти подспудные душевные силы человеческого организма очень верно изображены доктором Песковым (241).

Начальник Драборенко очередной садист, заболел туберкулезом неизлечимо и удивительным образом незадолго до смерти превратился в человека.

На 252 странице изложена одна из лучших, самых трагических сцен - отправка детей. Трудно сказать, что лучше, что хуже - отправить ребенка или оставить здесь.

Оскорбления в адрес начальника Бычевского, ребенок которого пожирает все лагерное молоко, сражение Вязовой в лагере за своего ребенка - выигранное сражение. Здесь превосходная, полная глубокого смысла, многоговорящая сцена.

O женщинах 3/к, о матерях доктор Песков рассказал много важного.

Правдиво и грустно говорится о лекции, которой заслушивались люди. Лекция кончилась, а с нею и иллюзия.

Так лаконично и точно записывает в свой «журнал» доктор Песков.

Страница о том, как поправился безнадежный больной Мюльц, до конца хранивший верность и интерес к книге (257).

Столь же лаконично записывается на 263 стр.: <так!>

Хоронили в гробах.

И Песков вспоминает лазарет, где он был в начале заключения (265).

«В лазарете за пайкой хлеба агонизирующего могла протянуться рука вора-рецидивиста и рука профессора».

Все в этой повести верно. Цитаты из Сталина висели на всех лагерных воротах. Очевидно, это были «централизованные» лозунги.

Чего стоит и такая запись: «Заключенных с тяжелыми статьями и большими сроками отправили в далекий этап» (283).

Тяжелые статьи - это 58 статья (все пункты, кроме 10, по которому и был осужден Песков), по которой маленьких сроков не давали. Практически это была изоляция на смерть всей 58 статьи. 
О впечатлении, произведенном заявлением Вышинского на Генеральной ассамблее, рассказывают воры (295). Именно так и реагировал з/к на это газетное сообщение.

Третья часть, хоть и меньше других по объему, не менее интересна. Содержание ее составляют тщетные попытки освобожденного из заключения кандидата наук доктора Пескова устроиться на работу. Все описанное в этой части правдиво столь же, как все, что есть в повести А. Чигарина.

Переписка с ВАК - это быт того времени.

Повесть «Всюду жизнь» - это правдивый рассказ о «подземном мире», своего рода «история болезни», заполненная рукой вдумчивого врача.

В повести очень хорошо обрисован и ее герой - рассказчик. Доктор Песков из тех людей, для которых арест открыл неожиданную страшную сторону жизни, о которой раньше он не думал или не хотел думать. Это показано очень правдиво. Вместе с Песковым эти люди думали, что лагеря - это порождение войны, тогда как в действительности время войны в лагерях - самое легкое время. Ни режим, ни быт не идет ни в какое сравнение с тем, что было ДО войны или ПОСЛЕ войны. Притом «военным временем» легче маскировался произвол. Следует отметить и то, что лагерь из повести «Всюду жизнь» - это лагерь «легкий», один из самых благополучных — общие работы здесь: заготовка лозы, режим здесь слабый, лагерь расположен на Волге, в тридцати километрах друг от друга, родные ездят на свидание. Наконец - это лагерь женский, где «нагрузки» гораздо меньше, чем у мужчин. И сам доктор Песков с исключительно «счастливой» судьбой. Он ни одного дня не работал «на общих работах» - все десять лет по специальности. Все это, конечно, и сам доктор Песков понимает отлично.

Единственный просчет повести - это суждения доктора Пескова о блатарях, о «преступном мире». Это просчет невольный. Доктор Песков мало имел дела с блатарями, знает их только из рассказов (хотя бы и самих блатарей). Этот серьезный вопрос не понят героем повести. Суждения доктора Пескова о ворах-рецидивистах наивны и не поднимаются выше уровня «Старого знакомого» или «Аристократов» Погодина, где блатной мир изображен слишком легкомысленно. Сцена с возвращением очков наивна. Святость «тюремной пайки» - легенда, блатарская легенда. Но эти незначительные просчеты - пустяки по сравнению с большим достоинством повести.

Повесть очень правдива. В ней нет ни одной ложной нотки, ни одной натяжки. Переживания доктора Пескова, его душевные и физические страдания, его сомнения, надежды и наблюдения изображены с полнотой правды, без недомолвок и без сглаживания острых углов. Главное достоинство повести именно в том, что «Всюду жизнь»как бы свидетельское показание, данное со всей ответственностью человеком, хорошим и неглупым, безвинным мучеником доктором Песковым - одной из бесчисленного множества жертв сталинского времени.

Я горячо рекомендую эту повесть журналу.

Возможно, что «Всюду жизнь» следует превратить в мемуары. Расстояние между рассказчиком и автором невелико, и сделать такую переделку будет нетрудно.

В письме, которое сопровождает рукопись, автор пишет: «Я выполнил свой гражданский долг». Да, тов. Чигарин выполнил свой гражданский долг. Долг журнала напечатать эту правдивую повесть.

\section{В. Шаламов}

Москва, А-284, Хорошевское шоссе, 10, кв. 2.

Чигарин и Шаламов не были знакомы, но их связывает и сам лагерный опыт (хотя Чигарин не был на Колыме, а находился в «легком», по мнению Шаламова, лагере), и совпадающее восприятие жизни заключенных. Сопоставляя рассуждения Шаламова в рецензии на повесть «Всюду жизнь» с «Колымскими рассказами», можно обнаружить одинаковые сюжеты и наблюдения, схожие оценки лагерной действительности и ситуаций, в которых оказываются герои повести Чигарина и рассказов Шаламова.

Двух писателей объединяет также интерес к медицине. Чигарин - врач, кандидат наук. Шаламов прошел фельдшерские курсы, работал в лагерной больнице, что спасло ему жизнь. Медицинские сюжеты присутствуют в нескольких рассказах колымского цикла. Из поздних записей Шаламова известно, что он интересовался ме- 
дициной и после лагеря: читал учебники, следил за открытиями в области трансплантологии, в 1957 году написал очерк «В одной лаборатории» о трансплантологе В. П. Демихове. Автор ряда статей о Шаламове, врач М. В. Головизнин, указывает на особое значение медицины в прозе Шаламова: «Исследователи творчества врачей-писателей отмечают, что медицинские „стигматы“ - использование специальных терминов и понятий для аллегорического описания явлений, событий или характеров, присутствуют в сюжетах, если даже автор - медик по образованию, позже ни дня не работал по специальности. Творчество Шаламова подтверждает данное мнение. Среди многочисленных аллегорий его прозы „медицинские метафоры“ во всем их разнообразии занимают центральное место. С их помощью Шаламов описывал реалии лагерного быта». ${ }^{19}$

Заглавие повести А. Чигарина - название картины Н. А. Ярошенко «Всюду жизнь» (1888). Выбор сюжета не случаен: в центре картины женщина с ребенком в арестантском вагоне, Богоматерь, склонившаяся над младенцем, на тюремном этапе. Главный герой повести - доктор Песков отбывает часть срока в женском лагере. В рецензии Шаламов подчеркивает особую ценность изображения лагерного быта «мамок», описания поведения женщин в этот катастрофический момент их жизни. Тема женщины в лагере не является главной у Шаламова, но занимает значительное место в его рассказах. Он находил положение женщины в лагере еще более ужасающим, чем положение мужчины. В системе лагерного рабства женщина была рабой рабов. В рассказе «Необращенный» (1963) Шаламов описал единственный для женщины (кроме смерти) путь выхода из лагерного ада: "- Мужиков водить сюда - трудное дело, — говорила Шура, с грохотом зашвыривая вымытые миски в шкаф. - Но я уж, слава богу, на пятом месяце. Скоро отправят в „Эль-ген“ - освободят! Мамок освобождают каждый год: один у нашего брата шанс.

- Пятьдесят восьмую не освобождают.

- У меня десятый пункт. Десятый пункт освобождают. Не троцкисты. Катюшка тут в прошлом году на моем месте работала. Ее мужик, Федя, сейчас со мной живет.

- Катюшку освободили с ребенком, приходила прощаться. Федя говорит: „Помни, я тебя освободил. Это уж не по сроку, не по амнистии, не по зеленому прокурору, а собственным способом, самым надежным...“ И верно - освободил. Кажется, и меня освободил...

Шура доверительно показала на свой живот». ${ }^{20}$

В рецензии Шаламов упоминает «уродство лагерной любви», достоверно изображенное Чигариным. Сам он неоднократно обращался к этой теме. В рассказе «Уроки любви» (1963) из цикла «Перчатка, или КР-2» блатарь Любов замораживает лагерную пайку хлеба, которая является платой голодной женщине: «Везло мне на баб, грех сказать, везло. Там, где я до Колымы был, - лагерь женский, а мы - плотники при лагеpe, нарядчику брюки почти новые, серые отдал, чтоб туда попасть. Там такса была, пайка хлеба, шестисотка, и уговор - пока лежим, пайку эту она должна съесть. А что не съест - я имею право забрать назад. Давно они уж так промышляют - не нами начато. Ну, я похитрей их. Зима. Я утром встаю, выхожу из барака - пайку в снег. Заморожу и несу ей - пусть грызет замороженную - много не угрызет. Вот выгодно жили... Может ли придумать такое человек? ${ }^{21}$

В рассказе «Прокаженные» (1963) уродство достигает максимальной концентрации в описании страшных голых тел пьяной пары прокаженных, укрывавшихся в норе под полом. Необратимый распад личности, как и необратимый распад тела у больных лепрой, исключает любую возвышенность любви между людьми, находящимися в условиях бесконечного насилия, голода и тяжелого физического труда, в мире, в котором уродливо все. Как следует из рецензии Шаламова, необратимый, навечный

19 Головизнин M. Медицина в жизни и творчестве Варлама Шаламова // «Закон сопротивления распаду»: Особенности прозы и поэзии Варлама Шаламова и их восприятие в начале XXI века. Сб. науч. тр. / Сост. Л. Бабка, С. Соловьев, В. Есипов, Ян Махонин. Прага; М., 2017. C. $199-225$.

${ }^{20}$ Шаламов В. Т. Собр. соч. Т. 1. С. 276.

21 Там же. Т. 2. С. 404. 
ущерб человеческой личности отмечает и герой повести «Всюду жизнь» доктор Песков.

Единственные обитатели лагеря, которым удается противостоять распаду, - «религиозники» или сектанты, это отмечают и Шаламов, и Чигарин. Шаламов - сын священника, хорошо знакомый с историей религии, отмечает эту особенность и в письме к Солженицыну по поводу «Одного дня Ивана Денисовича»: «...если в лагере и были люди, которые несмотря на все ужасы, голод, побои и холод, непосильную работу сохранили и сохраняли неизменно человеческие черты - это сектанты и вообще религиозники, включая и православных попов». ${ }^{22}$ Чигарин был тесно связан со старообрядческой средой, его сестра Ольга Петровна была замужем за сыном старообрядческого священника Петра Залетова. Старообрядцы имели большое значение для Казани - строили школы, больницы, благотворительные учреждения. После освобождения из лагеря Чигарин жил у родственников своей сестры - в известной до революции старообрядческой семье Фоминых. Именно поэтому он хорошо знал и понимал силу религиозного сопротивления насилию лагеря.

Еще одним общим мотивом «Колымских рассказов» и повести Чигарина являются «нескончаемые гастрономические разговоры» постоянно голодающих заключенных. Шаламов называет это психологическим законом. Герой его рассказа «Тайга золотая» (1961) с упоением рассказывает о невероятных китайских пельменях размером с ладонь, герой рассказа «Сгущенное молоко» (1956) задыхается от счастья при мысли о молочных консервах: «Вот и хорошо, хорошо. Обязательно подкормишься. Я принесу тебе... консервов. У нас ведь можно... Есть много консервов на свете - мясных, рыбных, фруктовых, овощных... Но прекрасней всех - молочные, сгущенное молоко. Конечно, их не надо пить с кипятком. Их надо есть ложкой, или мазать на хлеб, или глотать понемножку, из банки, медленно есть, глядя, как желтеет светлая жидкая масса, как налипают на банку сахарные звездочки... Завтра, - сказал я, задыхаясь от счастья, - молочных...». ${ }^{23}$

Чигарин, по мнению Варлама Шаламова, - вдумчивый и пытливый наблюдатель «подземного» мира, сумевший отметить и описать самое важное, что он пережил в лагере. Шаламов цитирует строку из повести «Всюду жизнь»: «Лагерь - это особый мир, здесь много уродств во взаимоотношениях людей и в отношении к труду». Сам он считал точно так же, описывая и уродство лагерной любви, и садизм начальников и конвойных. В повести «Всюду жизнь» встречаются такие персонажи, как Агаманов и Быков, садисты - типичные представители лагерного начальства. В рассказе Шаламова «Ягоды» (1959) такие же садисты - конвоиры Фадеев и Серошапка избивают обессилевшего голодающего заключенного, упавшего под тяжестью бревна. Он говорит им: «Подумай о том, как ты будешь рассказывать своей невесте, что ты делал на Колыме», ${ }^{24}$ но при этом доведен до такого состояния, что не испытывает никаких эмоций по поводу насилия и угроз конвойных застрелить его - его жизнь страшнее смерти. В рассказе «Сухим пайком» (1959) Шаламов описывает это состояние так: «Мы понимали, что смерть нисколько не хуже, чем жизнь, и не боялись ни той ни другой» ${ }^{25}$ В рассказе «Мой процесс» (1960) конвойные «долго и старательно» избивают заключенного из-за того, что он не может идти быстро, а они хотят успеть в кино.

В настоящий момент ни рукопись, ни черновики повести Чигарина «Всюду жизнь» не найдены. По сохранившейся рецензии можно судить о том, что это материал высокой исторической значимости. Художественная ценность утраченной повести, поставленная под сомнение редакцией журнала, подтверждается отзывом Варлама Шаламова, который предъявлял крайне высокие требования к прозе о трагедии ГУЛАГа, ее достоверности.

\footnotetext{
22 Там же. Т. 6. С. 279.

23 Там же. Т. 1. С. 110.

24 Там же. С. 94.

25 Там же. С. 76.
} 


\section{ЗАМЕТКИ}

DOI: $10.31860 / 0131-6095-2020-3-251-252$

(C) О. А. Лекланов

\section{РАСТИТЕЛЬНЫЙ КОД РАССКАЗА ФЕДОРА СОЛОГУБА «НИЧЕГО НЕ ВЫШЛО»}

Рассказ «Ничего не вышло» относится к раннему периоду творчества Ф. Сологуба (первая публикация в № 198 журнала «Петербургская жизнь» от 18 августа 1896 года), но производит впечатление глубоко обдуманного и тщательно отделанного произведения. Фабула внешне очень проста: некто Иван Степаныч Молодилов, пожилой хозяин «дачки», под «чаек с ромом» ${ }^{1}$ рассказывает своим гостям три истории, выразительно иллюстрирующие заглавие рассказа. Каждая из них при этом демонстрирует неудачу Молодилова в определенный возрастной период и в важной жизненной сфере; чтобы подчеркнуть неслучайность этого деления, Сологуб разбивает совсем небольшой рассказ на три части. Детство: гимназисты под предводительством Молодилова собираются, но так и не решаются избить мучающего их учителя. Молодость, любовная сфера: Молодилов делает предложение руки и сердца и получает отказ. Зрелость, сфера деловой самореализации: Молодилов с товарищами учреждает «потребительное общество», которое быстро разваливается. Сразу же отметим, что в названии рассказа Сологуба можно увидеть и ироническое автометаописание. «Ничего не вышло» не только в жизни Молодилова, но и у Молодилова-нарратора: зачин всех трех его историй обещает интересное продолжение, а финал неизменно разочаровывает бессодержательностью и мелочностью.

В каждой из трех частей Сологуб делает специальный акцент на национальной специфике рассказываемых Молодиловым историй и самого́ характера этого персонажа. В первой части он говорит о себе: «Я - человек русский, я там разных этаких экивоков не понимаю, а по-моему, - задумал дело и делай, а на попятный двор ни-ни!» (с. 45). Во второй части это высказывание варьируется так: «Ну, я такой человек, - ухаживать там, канителиться, - это не по моей части, - я по-русски, попростецки решился действовать» (с. 47-48). А в третьей части - так: «...я вижу, дело тянут,

1 Сологуб Ф. Собр. соч.: В 12 т. СПб.: Шиповник, 1911. Т. 11. С. 45. Далее за исключением особо оговоренного случая рассказ цитируется по этому изданию, ссылки даются в тексте сокращенно, с указанием номера страницы. а я мямлить не люблю, я живо, по-русски» (с. 48). Бахвальство умением обделывать дела при абсолютном неумении хотя бы одно дело довести до конца предстает, таким образом, характерно русской чертой, диагнозом, который Сологуб ставит русскому человеку.

В каком направлении будет плодотворно развивать интерпретацию рассказа «Ничего не вышло» дальше? Можно рассмотреть его на фоне русской классической прозы XIX столетия в диапазоне приблизительно от Гоголя до Чехова (или даже - от Пушкина; ср. одну из первых фраз «Ничего не вышло»: «В карты не играли» (с. 45) - со знаменитым началом «Пиковой дамы»: «Однажды играли в карты у конногвардейца Нарумова»). ${ }^{2}$ Можно вспомнить о том, что на 14 мая 1896 года пришлась коронация Николая II, а на 18 мая - Ходынка, и попытаться вписать рассказ в политический контекст тусклой, без надежд на перемены, эпохи. Однако учитывая то обстоятельство, что мы имеем дело с текстом автора-символиста, полезнее всего, наверное, будет обратить внимание на названия населенных пунктов, в которых разворачивается действие каждой из трех историй Молодилова. Это звучащие вполне естественно, но на самом деле отсутствовавшие на карте Российской империи топонимы Кипрейск («Учился я в Кипрейском кадетском корпусе. Знаменитое было заведение, на всю Россию славилось» (с. 45-46)), Бе́дренеи, («Стояли мы с полком в городе Бедренце, пустой городишка, никакой в нем значительности нет» (с. 47)) и Жабрица («Был уже я в отставке и проживал в городе Жабрице, - уездный городишко не из важных» (с. 48)).

Что объединяет между собой эти три топонима? То, что все они образованы от названий растений, соответственно, кипрея, бе́дренца и жабрицы. Но ведь и фамилии всех персонажей рассказа - того же происхождения: Молодилов (от растения молодило), Сабельников (от растения сабельник), Ежевикин (от ежевики) и Лабазников (от растения лабазник). Единственным исключением из ряда фамилий с растительной этимологией оказывается фамилия несостоявшейся невесты Молодилова -

2 Пушкин А. С. Полн. собр. соч.: В 16 т. М.; Л., 1948. Т. 8. Кн. 1. С. 227. 
Леночки Ручейниковой (ручейник - это не растение, а насекомое). Тем не менее и ее фамилия в первом, журнальном варианте рассказа происходила от названия растения - Поручейни$\kappa о в а$ (от растения поручейник). ${ }^{3}$

Этот растительный код рассказа «Ничего не вышло», как кажется, расшифровывается очень просто, особенно если соотнести рассказ с другими произведениями Сологуба: Россия часто предстает у него своеобразным растительным царством, в котором любое новое начинание глушится сорной травой и колючками кустарников и где ядовитые растения дурманят головы несчастных обывателей. Интересно, что единственный реальный топоним, упоминаемый в рассказе «Ничего не вышло» («Выписал я из Питера штуки три

3 Сологуб Ф. Ничего невышло // Петербургская жизнь. 1896. № 198. 18 августа. С. 167. уставов этих самых» (с. 48)), как и в некоторых других произведениях Сологуба, в частности в «Мелком бесе» (где целый ряд фамилий тоже связан с названиями растений), не изображается, а лишь называется. «Питер» - это место, где живет таинственное начальство, оттуда, конечно, можно что-нибудь «выписать», но вот можно ли туда попасть - это большой вопрос.

Остается напомнить, что Сологуб испытывал большой интерес к ботанике и что в его личной картотеке сохранились выписки из ботанических справочников с подробными описаниями внешнего вида и свойств разнообразных растений. ${ }^{4}$

${ }^{4}$ См. об этом: Павлова M. М. Творческая история романа «Мелкий бес»// Сологуб Ф. Мелкий бес / Изд. подг. М. М. Павлова. СПб., 2004. С. 745 (сер. «Литературные памятники»).

DOI: $10.31860 / 0131-6095-2020-3-252-255$

(ㄷ) С. А. Дубровская, () О. Е.Осовский

\section{О ЦИТАТАХ ИЗ ГЕРЦЕНА В ИССЛЕДОВАНИИ М. М. БАХТИНА О РАБЛЕ}

В исчерпывающем комментарии И. Л. Поповой к монографии «Творчество Франсуа Рабле и народная культура средневековья и $\mathrm{Pe}$ нессанса» в Собрании сочинений М. М. Бахтина эпиграф к первой главе из А. И. Герцена «Написать историю смеха было бы чрезвычайно интересно" - сопровождается следующим пояснением: «В P-1940 эпиграф к главе отсутствовал. В $P-1949 / 50$ М. М. Б< <ахтин > добавил строки из Герцена (см.: m. 4 (1), с. 554), впоследствии сохранив их в $T \Phi P »{ }^{1}$

Отметим, что появление и исчезновение отдельных эпиграфов составляет одну из примечательных линий истории правок, вносившихся Бахтиным в рукопись о Рабле в связи с различными обстоятельствами. Как известно, ученый завершил первый вариант иссле-

${ }^{1}$ [Попова И. Л.]. Комментарии и приложение // Бахтин М. М. Собр. соч.: [В 7 т.]. М., 2010. Т. 4 (2). С. 603. Далее все ссылки на это издание даются в тексте сокращенно, с указанием номера тома и страницы. Для удобства читателя поясним: P-1940 - Бахтин $M . M$. Франсуа Рабле в истории реализма // Там же. T. 4 (1). С. 11-506; P-1949/50 - Бахтин M. M. Творчество Рабле и проблема народной культуры средневековья и Ренессанса // Там же. С. 517-604; ТФР - Бахтин M. М. Творчество Франсуа Рабле и народная культура средневековья и Ренессанса. М., 1965. дования о Рабле в 1940 году, предполагая его возможный выход в свет в виде монографии. «Издательский проект» не увенчался успехом, и рукопись была представлена в качестве диссертации и защищена в Институте мировой литературы им. А. М. Горького АН СССР в 1946 году. На рубеже 1940-1950-х годов автор был вынужден подвергнуть ее изменениям и исправлениям в соответствии с требованиями Высшего аттестационного комитета. И только в 1965 году увидела свет монография «Творчество Франсуа Рабле и народная культура средневековья и Ренессанса». Перипетии этой истории описаны Н. А. Паньковым и И. Л. Поповой. ${ }^{2}$

В начале 1960-х годов были предприняты значительные усилия по публикации книги Бахтина. Отправляя в издательство сохранившийся у него текст диссертации, ученый в письме инициатору этого проекта В. В. Кожинову от 7 июля 1962 года пояснял: «Я до-

${ }^{2}$ Подробнее см.: Паньков Н. А. Вокруг «Рабле» // Паньков Н. А. Вопросы биографии и научного творчества М. М. Бахтина. М., 2010. С. 91-355; Попова И. Л. История идей сквозь призму истории текста: Книга М. М. Бахтина о Рабле в 1930-1960-е годы // Попова И. Л. Книга М. М. Бахтина о Франсуа Рабле и ее значение для теории литературы. М., 2009. С. 7 108. 
полнял ее (около 1950 г.) по „указаниям“ экспертной комиссии ВАКа и внес в нее много отвратительной вульгарщины в духе того времени <...> нельзя ли как-нибудь - в сугубо дипломатической форме - предупредить редакцию о той обстановке, в которой я переделывал свою диссертацию». ${ }^{3}$

Все сделанные Бахтиным изменения зафиксированы в соответствующем томе Сoбрания сочинений (4 (2), 591-696). Они коснулись и эпиграфов, значительная часть которых была заменена. Так, три эпиграфа из Гераклита, Гете и Рабле соответственно на древнегреческом, немецком и французском, предварявшие текст рукописи 1940 года $(4(1), 13)$, в последующих редакциях исчезли, им на смену пришли другие, в том числе и эпиграф из Герцена. Установление источника герценовского эпиграфа, равно как и герценовских цитат в «Дополнениях и изменениях к редакции 1949-1950 гг.» и монографии 1965 года, представляется достаточно важным для понимания не только того, каким образом происходит идеологическое «усовершенствование» попавшей под суровую критику ВАКа работы, но и самого механизма расширения Бахтиным ее цитатного поля.

Можно сказать, что Герцен никогда не принадлежал к числу авторов, всерьез привлекавших внимание Бахтина. Правда, в «домашних лекциях» по русской литературе, известных в записи Р. М. Миркиной, при изучении темы «Народничество» дана развернутая характеристика взглядов Герцена на сущность пролетариата и крестьянства. А роман «Кто виноват? » упомянут наряду с произведениями Жорж Санд и Н. Г. Чернышевского в статье «Идеологический роман Л. Н. Толстого». В последующие десятилетия имя Герцена отсутствует даже там, где ссылка на его произведения могла бы показаться вполне уместной, в частности в «русских разделах» бахтинской монографии о романе воспитания.

Имя Герцена появляется в ходе обсуждения диссертации в выступлении М. П. Теряевой во время свободной дискуссии: «Тема диссертации, или вернее название этой темы, делает нас очень требовательными. И если ставится вопрос о реализме, о том основном течении, которое мы поддерживаем, которое поддерживали наши лучшие литературоведы, как Герцен, Белинский, Добролюбов, Чернышевский, Ленин и Сталин, мне кажется(,) нужно было бы поговорить о том, что же отразилось в этой диссертации из этих воззрений наших лучших людей» $(4$ (1), 1027).

Несколько лет спустя фигура Герцена возникает в процессе переработки диссертации, можно сказать, почти в «теряевском дискурсе». Подборку его цитат о смехе Бахтин открывает фразой: «Значение смеха и его революци-

${ }^{3}$ Паньков Н. А. Из переписки М. М. Бахтина и В. В. Кожинова // Паньков Н. А. Вопросы биографии и научного творчества М. М. Бахтина. С. 551. онную роль в истории культуры великолепно понял и определил наш Герцен» - и завершает выводом: «Наша работа в известной мере и является историей смеха, как ее понимал Герцен» (4 (1), 527, 528; выделено Бахтиным. С. Д., О. О.).

Однако появление герценовских цитат в рукописи 1949-1950 годов, в частности того самого эпиграфа, не только дань идеологической конъюнктуре. В истории литературы и конкретных литературных произведений не так уж многочисленны случаи, когда можно с точностью утверждать, когда и откуда была взята автором та или иная цитата. Ситуация с Герценом относится к числу подобных редких примеров. В 2015 году душеприказчица Бахтина, литературовед и один из комментаторов Собрания сочинений Леонтина Сергеевна Мелихова передала Мордовскому государственному университету, в котором в 1936-1937 и 19451961 годах преподавал Бахтин, часть книг и журналов из унаследованной ею библиотеки ученого. Среди этих книг был и сборник статей «А. И. Герцен. 1812-1870», подаренный Бахтину известным историком отечественной словесности, русской и европейской культуры Николаем Павловичем Анциферовым. На форзаце книги Анциферов написал: «Глубокоуважаемому Михаилу Михайловичу Бахтину, автору блестящей работы о Рабле. /„Смех имеет в себе нечто революционное... В церкви и во дворце никогда не смеются, - по крайней мере, открыто... Одни равные смеются между собой. Смех Вольтера разрушил больше плача Руссо“ А. Герцен. T. VI. стр. 20 / на добрую память от Н. Анциферова 15го ноября 1946 г. Москва». ${ }^{4}$

Нельзя не обратить внимание на личность дарителя. Анциферов был знаком с Бахтиным по Ленинграду 1920-х годов, в частности по религиозно-философскому кружку А. А. Мейера и К. А. Половцевой. Бахтин и Анциферов, как и другие участники кружка, были арестованы и проходили по одному сфабрикованному делу об антисоветской религиозной организации. ${ }^{5} \mathrm{O}$ характере их отношений в 1940-е годы свидетельствует письмо Бахтина М. В. Юдиной, хорошо знавшей Анциферова с ленинградских времен и продолжавшей дружить с ним всю последующую жизнь. 20 мая 1945 года Бахтин писал из Савелова в Москву: «Напишите мне с Гал<иной $>$ Ив <ановной>, где сейчас Николай Павлович, приехала ли к нему семья, можно ли мне у него остановиться...» 6

4 А. И. Герцен. 1812-1870: Сб. статей к 75-летию со дня смерти / Под ред. И. Клабуновского и Б. Козьмина. М., 1946. В настоящее время данная книга хранится в Центре М. М. Бахтина (Саранск).

5 Конкин С. С., Конкина Л. С. Михаил Бахтин: Страницы жизни и творчества. Саранск, 1993.

${ }^{6}$ М. М. Бахтин - М. В. Юдиной. 20 мая 1945 года // Юдина М. В. Высокий стойкий дух. Переписка 1918-1945 гг. М., 2006. С. 492. 
Обращает на себя внимание и дата на книге - 15 ноября 1946 года - день защиты Бахтиным диссертации. Несмотря на то что фамилия Анциферова отсутствует в «Стенограмме заседания Ученого совета Института мировой литературы имени Горького», где дан список присутствующих (далеко не полный), не входивших в состав членов совета, можно с уверенностью утверждать, что Анциферов был и на самой защите. По крайней мере, многие годы спустя Юдина писала Бахтину: «...третьего дня хоронили мы Николая Павловича Анциферова, и это общее горе, горе всех „добрых людей“ - не в последнюю очередь горе нас с Вами... <...> после кладбища мы (человек 20 или более) были у Софьи Александровны, многие вспоминали общее с ним детство, потом прекрасный человек Алиса Банг, его ученица с Тенишевского (византинистка), очень много и хорошо рассказывала, потом и я. Вспоминали, конечно, Вас и диссертацию». ${ }^{7}$ Скорее всего, именно Анциферову принадлежит отмеченная в стенограмме защиты "реплика с места», сказанная во время ответа Бахтина на замечания Н. К. Пиксанова и явно поддерживающая позиции соискателя: после слов Бахтина («Эта революционизирующая сила средневекового смеха - это главный герой») прозвучало «с места»: "Смех - великий революционер, - сказал Герцен» (4 (1), 1063). Остается заметить, что у самого Анциферова стойкий интерес к наследию Герцена был продиктован достаточной близостью их идеологических и эстетических воззрений, и еще в 1918 году будущий автор «Души Петербурга» писал политические статьи-декларации, во многом опираясь на тексты и образы великого революционного демократа. ${ }^{8}$

Подаренный Бахтину сборник сохранил вполне конкретные свидетельства знакомства ученого с его содержанием. Характерной особенностью работы Бахтина с книгами и журналами была фиксация на полях тех или иных интересующих его фрагментов. Ученый простым карандашом ставил вертикальные линии на полях страниц. Количество подобных отчеркиваний варьировалось и зависело от важности для читающего той или иной мысли автоpa. ${ }^{9}$ Позднее на основании этих помет состав-

${ }^{7}$ М. В. Юдина - М. М. и Е. А. Бахтиным. 7 сентября 1958 г. // Юдина М. В. Ж Кизнь полна смысла. Переписка 1956-1959 гг. М., 2008. C. 382 .

${ }^{8}$ Анииферов Н. П. Из дум о былом: Воспоминания. М., 1992. С. 336. Очевидно, что и само название книги воспоминаний - отсылка к «Былому и думам» Герцена.

9 См. подробнее: Гоготишвили Л. А. Комментарии // Бахтин М. М. Собр. соч. Т. 6. С. 533$701 ;$ Осовский O. E. М. М. Бахтин читает Ольгу Фрейденберг: о характере и смысле бахтинских маргиналий на страницах «Поэтики сюжета и жанра» // М. М. Бахтин в Саранске: документы, материалы, исследования. Саранск, 2002. C. 24-35. лялся конспект книги или статьи, ${ }^{10}$ в отдельных случаях в выделенном фрагменте косыми чертами отмечалась та часть текста, которая затем цитировалась уже непосредственно в работе самого Бахтина (например, таким образом выделены фрагменты в статье А. В. Луначарского, которые Бахтин цитирует в «Проблемах поэтики Достоевского» $(6,42)) .{ }^{11}$

После высказанных Бахтину претензий по поводу идеологических недостатков его диссертации Герцен становится одной из фигур, которым предстоит подтверждать правильное политическое звучание отредактированного труда. Бо́льшую часть необходимого материала Бахтин находит в опубликованной в сборнике статье Я. Е. Эльсберга «Эстетические взгляды Герцена». Именно в ней цитируется мысль Герцена, воспроизведенная в надписи Анциферова. Приведем этот фрагмент полностью, не исключая и имеющихся внутри цитаты реплик самого Эльсберга: “„Смех, писал Герцен, - одно из самых сильных орудий против всего, что отжило и еще держится, бог знает на чем, важной развалиной, мешая расти свежей жизни и пугая слабых... Смех вовсе дело не шуточное, и им мы не поступимся. В древнем мире хохотали на Олимпе и хохотали на земле, слушая Аристофана и его комедии, хохотали до самого Лукиана. C IV столетия человечество перестало смеяться - оно все плакало, и тяжелые цепи пали на ум середь стенаний и угрызений совести. Как только лихорадка изуверства начала проходить, люди стали опять смеяться. Написать историю смеха было бы чрезвычайно интересно. В церкви, во дворце, во фронте, перед начальником департамента, перед частным приставом, перед немцем-управляющим никто не смеется. Крепостные слуги лишены права улыбки в присутствии помещиков. Одни равные смеются между собой... Смех нивелирует, а этого и не хотят люди, боящиеся повиснуть на собственном удельном весе“.

Герцен подчеркивает, что смех, комическое рождаются из сознания обреченности тех явлений и противоречий, против которых они направлены. В „Письмах из Франции и Италии“ Герцен указывал, что „...предмет, говоря о котором человек не может улыбнуться, не впадая в кощунство, не боясь угрызений совести, - фетиш, и человек подавлен им, он боится его смешать с простою жизнью... смех имеет в себе нечто революционное“.

10 Перлина Н. Еще раз о том, как по ходу работы над книгой о Рабле Михаил Бахтин читал «Поэтику сюжета и жанра» Ольги Фрейденберг // Хронотоп и окрестности: Юбилейный сборник в честь Николая Панькова = Chronotope and Environs: Festschrift for Nikolay Pan'kov / Под ред. Б. В. Орехова. Уфа, 2011. C. $209-227$.

11 Дубровская C. А. «Бахтин почти мой товарищ...»: о специфике последней волны первой русской рецепции «Проблем творчества Достоевского" (в печати). 
Взгляд Герцена на комическое является одним из проявлений его убеждений в громадной активной роли искусства, способного изменять и перестраивать жизнь. „Смех Вольтера разрушил больше плача Руссо“, - заявлял Герцен». ${ }^{12}$ Весь этот фрагмент сопровождается характерным бахтинским отчеркиванием. Впрочем, исследователь не ограничивается исключительно статьей Эльсберга и обращается к первоисточнику, поскольку в редакции 1949-1950 годов герценовский фрагмент получает продолжение - к нему добавляется еще несколько строк: «Если низшим позволить смеяться при высших или если они не могут удержаться от смеха, тогда прощай чинопочитание. Заставить улыбнуться над богом Аписом значит расстричь его из священного сана в простые быки» $(4(1), 528)$. Уже в этом расширенном виде данная цитата воспроизведена и в «Творчестве Франсуа Рабле и народной культуре средневековья и Ренессанса» (1965).

При подготовке рукописи к изданию в первой половине 1960-х годов Бахтин «снимает» некоторые оценочные высказывания, в частности - характеристику теории ЖанПоля: «Но общая концепция смеха у него (Герцена. - С. Д., О. О.) во многом поражает своей глубиной и оригинальностью. Насколько эта концепция и глубже и вернее, чем идеалистическая и формалистическая теория смеха ЖЖанПоля, которая до сих пор еще остается основополагающей для всей буржуазной эстетики!» (4 (1), 528). По внесенным Бахтиным изменениям в текст редакции 1949-1950 годов при работе над монографией можно судить о его

12 Эльсберг Я. E. Эстетические взгляды Герцена // А. И. Герцен. 1812-1870. С. 42. реальном отношении к вносившейся правке. В частности, он отказался от одной из характеристик герценовской философии смеха, противопоставлявшейся им пониманию комического у Жан-Поля. При этом, впрочем, уходит и критическая реплика в адрес Герцена: «Об особом характере и привилегиях средневекового смеха Герцен, конечно, ничего не говорит» $(4(1), 528)$.

В самой монографии 1965 года часть все той же герценовской цитаты сохраняется в виде эпиграфа к первой главе, вся цитата выносится за пределы основного текста и дается как комментарий-опора к своей мысли: «...народнопраздничный смех включает в себя момент победы не только над страхом перед потусторонними ужасами, перед священным, перед смертью, - но и над страхом перед всякой властью, перед земными царями, перед земным социальным верхом, перед всем, что угнетает и ограничивает». ${ }^{13}$

Обращает на себя внимание и то, что изменились источники цитирования. Первая цитата приведена по новому Собранию сочинений Герцена, ${ }^{14}$ вторая - по сборнику «А. И. Герцен. Об искусстве». ${ }^{15}$ При этом следует помнить, что выверку цитат для данного издания по просьбе Бахтина осуществляли Кожинов и другие молодые участники московского круга Бахтина.

13 Бахтин М. М. Творчество Франсуа Рабле и народная культура средневековья и Ренессанса. С. 103. C. 92 .

14 Гериен А. И. Соч.: В 9 т. М., 1956. Т. 3. C. 223 .

\footnotetext{
15 Гериен А. И. Об искусстве. М., 1954.
} 


\section{ОБЗОРЫ И РЕЦЕНЗИИ}

DOI: 10.31860/0131-6095-2020-3-256-257

(ㄷ) П.Р. Заборов

\section{ЦЕННЫЙ ИСТОЧНИКОВЕДЧЕСКИЙ ТРУД*}

Обилие в наших архивах и библиотеках иностранных и иноязычных рукописей - одно из важных и ярких свидетельств интереса образованных русских людей к «чужим» культурам и их личных и эпистолярных контактов с деятелями этих культур, в какой бы сфере они себя ни проявили.

Среди всех этих культур французская занимает, несомненно, одно из первых мест как в силу ее выдающейся роли в европейской (и не только европейской) интеллектуальной и художественной жизни XVIII-XIX веков, так и ввиду широкого распространения в России этого времени французского языка. Так что каждый вновь выявленный автограф французского ученого и писателя, каждая ставшая доступной запись на французском языке в альбоме или дневнике, каждая французская цитата в ранее неизвестном литературном тексте в той или иной степени пополняют наши сведения о взаимодействии двух великих культур.

Тема эта - далеко не новая, к ней в разное время обращались исследователи у нас и за рубежом, и сделано в этой области сравнительно много; однако большие и малые открытия такого рода не только возможны, но и нередко происходят, в чем убеждает и рецензируемый сборник, подготовленный группой сотрудников ИМЛИ РАН с привлечением специалистов из других научных учреждений и изданный под редакцией Е. Е. Дмитриевой и А. В. Голубкова. Книга посвящена памяти Тамары Владимировны Балашовой, видного специалиста по французской литературе XX века.

Сборник (официально он называется коллективной монографией, что вызывает некоторые сомнения) состоит из двух разделов «Новонайденные рукописи и редкие издания» и «Статьи и материалы».

Большую часть первого раздела занимает публикация забытого русского издания, вышедшего в 1768 году. Это перевод-переделка

* Французские и франкоязычные рукописи в России (XVIII - начало XIX в.) / Под ред. Е. Е. Дмитриевой и А. В. Голубкова. М.: ИМЛИ РАН, 2019. 576 с. любопытного памятника французской литературы XVIII века - «Словаря любви» ЗКанаФрансуа Дрё дю Радье («Dictionnaire d'amour», 1741), первый литературный труд А. В. Храповицкого (1749-1801), впоследствии кабинет-секретаря Екатерины II (между прочим, поправлявшего ее сочинения) и талантливого мемуариста.

В сборнике приведены русский и французский тексты словаря, сильно отличающиеся один от другого, причем отличия эти отмечены во вступительной статье Л. И. Сазоновой, содержание которой, впрочем, много шире, поскольку в ней прослежена история галантной литературы во Франции и процесс становления ее в России; кроме того, оригинал словаря снабжен обширным комментарием, весьма полезным и для понимания его русской версии, а отличия суммированы в сводной таблице. Завершает публикацию еще одна статья о словаре Дрё дю Радье, принадлежащая Е. Е. Дмитриевой и особенно интересная соображениями о трудностях перевода этого памятника на русский язык и способах их преодоления, к которым вынужден был прибегнуть Храповицкий.

Следующая публикация - небольшой по объему дневник на французском языке прусской королевы Луизы, в котором она систематически фиксировала свои впечатления от восьминедельного пребывания вместе с супругом Фридрихом-Вильгельмом III в Петербурге в январе-феврале 1809 года в качестве гостей императорской четы. Дневник этот, опубликованный А. В. Голубковым и Е. Е. Дмитриевой, весьма любопытен как своего рода хроника придворной жизни и дворцового быта, который поразил коронованную немецкую гостью русского императорского семейства своей необычайной пышностью и блеском.

Другой материал, относящийся к XIX веку, - совсем иного рода. Это пространное «Письмо к барону де M<ериану>» С. И. Тургенева, младшего из четырех братьев, оставивших столь глубокий след в русской общественной и литературной жизни. Дипломат и активный участник переустройства Европы после падения Наполеона и разрушения его империи, Тургенев был превосходно осведомлен о положении дел в Германии (точнее - 
в различных немецких государствах) и по инициативе его сослуживца и приятеля барона А. Мериана изложил свои мысли об этом в «Письме...», формально адресованном барону, а фактически (по вполне убедительному предположению одного из публикаторов) являвшемся ответом на «Записку о нынешнем положении Германии» А. С. Стурдзы. Интересное само по себе, тщательно подготовленное к печати и переведенное Е. О. Ларионовой, «Письмо...» Тургенева, помимо предварительных пояснений того же автора, снабжено комментарием, в сущности представляющим собой самостоятельное исследование, в основе которого лежит огромное множество немецких источников, перечень их занимает 10 страниц. Автор комментария - М. Ю. Коренева.

$\mathrm{XX}$ век представлен в сборнике лишь одной публикацией в точном смысле слова, принадлежащей А. Ф. Строеву. Речь идет о переписке А. Барбюса и А. В. Луначарского, в основном посвященной изданию международного еженедельника «Monde», создававшегося по инициативе Барбюса и при содействии Луначарского, в то время народного комиссара по просвещению, с целью объединения «революционно настроенной» интеллигенции; журнал этот выходил с 1928-го по 1935 год. Фактически Строев продолжил давние разыскания Ф. С. Наркирьера ${ }^{1}$ и даже частично повторил им сделанное, однако существенно дополнил ранее известный материал и обновил его обработку.

Второй раздел сборника несколько отличается от первого, прежде всего по характеру включенных в него статей. Правда, статья Н. Л. Дмитриевой все же является скорее публикацией, поскольку парижский дневник С. И. Тургенева, фрагменты которого она приводит, никогда не появлялся в печати, и хотя Тургенев вел дневник по-русски, в тексте его, естественно, много разного рода вкраплений на французском языке. Немало их и в двух досконально изученных О. С. Муравьевой дамских альбомах первой половины XIX века, владелицы которых, да и оставлявшие записи участники, как правило, знали французский язык в совершенстве.

Все остальные статьи сборника - в полной мере историко-литературные исследования о русско-французских и русско-бельгийских связях XX столетия. Впрочем, и в них неизменно присутствует пусть иногда не очень объемный, но всегда интересный неизданный французский материал. Это относится к статье В. В. Полонского о формировании репутации 248.
Д. С. Мережковского во Франции: к ней приложен цикл его писем к гр. М. Э. Прозору, дипломату и литератору, сыгравшему первостепенную роль в этом малоизученном процессе. Исследование Е. Д. Гальцовой, посвященное различным аспектам деятельности бельгийского писателя Франца Элленса и его русским связям, проиллюстрировано его письмами к М. В. Веселовской, самой деятельной его переводчице и вообще пропагандистке бельгийской литературы. Наконец, в фундаментальном исследовании Т. В. Балашовой о трудной судьбе в СССР романа Андре ЖЖида «Удел человеческий» («La Condition humaine», 1933) и его пьесы «Робер, или Общее благо» («Robert, ou l'Inérêt général», 1934-1936) использован ряд ранее неизвестных текстов, извлеченных из французских и отечественных архивов.

В книге, столь насыщенной иноязычными материалами, естественно, встречаются всевозможные погрешности. Tак, La salle SaintGeorges в переводе дневника прусской королевы фигурирует то как Георгиевский, то как зал Св. Георгия, хотя речь идет об одном и том же Тронном зале Зимнего дворца (ср. с. 209). «Семирамида», в которой с огромным успехом выступала гастролировавшая в России мадемуазель Жорж, несомненно, трагедия Вольтера (ср. там же). П. Метастазио был прославленным поэтом-либреттистом, на его слова написано множество опер, кантат и концертных арий, но сам он музыки, кажется, не сочинял (ср. там же). Ф.-Ж. Тальма исполнял главные роли не в пьесах Шекспира, а в трагедияхадаптациях Ж.-Ф. Дюсиса (ср. с. 413-414); оставленный без пояснений «Шекспир излюбленный» - комедия А. Дюваля «Влюбленный Шекспир» («Shakespeare amoureux», 1803 ; ср. с. 414), правильное название драмы А.-Ф. Дюмолара - «Венсан де Поль» (cp. c. 422). Название трагедии П. Л. де Беллуа «Габриэль де Вержи» (ср. с. 423). Нарушением академической традиции является транскрипция названий иностранных периодических изданий, как это сделано в публикации переписки Барбюса с Луначарским. Наконец, называть Алексея Николаевича Веселовского академиком неверно, ибо он, в отличие от старшего брата, был почетным академиком, что совсем не одно и то же; к тому же вдова Юрия Алексеевича Веселовского вряд ли могла перепутать отчество своего покойного мужа (ср. с. 466).

В целом же этот труд заслуживает высокой оценки, и выход его в свет может стимулировать дальнейшие разыскания в наших архивохранилищах, богатство которых поистине неисчерпаемо. 
DOI: $10.31860 / 0131-6095-2020-3-258-259$

\section{КУРС ЛЕКЦИЙ В. М. МАРКОВИЧА О РУССКОЙ ЛИТЕРАТУРЕ ПЕРВОЙ ПОЛОВИНЫ ХІХ ВЕКА*}

Из всех курсов, читавшихся Владимиром Марковичем Марковичем (1936-2016), профессором Санкт-Петербургского государственного университета, замечательным теоретиком и историком русской литературы, едва ли не наибольшей популярностью у студентов пользовался цикл лекций, посвященный первой половине XIX века. Для всякого, кто сам когда-то находился в числе его слушателей (подобно автору настоящих строк), вышедший из печати том - яркое напоминание об эпохе, когда интерес к такого рода лекционным курсам был массовыл, когда в аудиторию являлись не только те, кому это полагалось «по программе», но заодно и студенты с других курсов, аспиранты, коллеги, а подчас и посторонние слушатели, не имевшие отношения к филологии. О том, почему подобный культурный феномен (всеобщая тяга к слову лектора-гуманитария) был характерен для последних советских десятилетий, можно было бы рассуждать долго. ${ }^{1}$ Сейчас мы этого делать не станем - иначе возникнет ощущение, будто рецензируемая книга представляет интерес по преимуществу мемориальный. Это далеко не так. Превратившись в факт истории культуры, лекционный курс Марковича не утратил своей актуальности. И не только в том смысле, что классика филологической науки не стареет, но и по другой, еще более веской причине. Дело в том, что профессор напряженно работал над этим курсом также в 2000-е годы; именно в той версии, в какой лекции читались им в 20042009 годах, они вошли в печатное издание. Перед нами, таким образом, совсем еще недавний плод методологических размышлений видного ученого; хочется надеяться, что его слово найдет отклик в современной научной дискуссии. В последнее десятилетие своей жизни Маркович нередко возвращался к мысли написать учебник нового типа, учебник, в котором был бы проанализирован сам «механизм» литературного развития, его имманентная логика. Из-за тяжелой болезни завершить такой учебник Владимир Маркович не успел. Представление о том, каким образом строилась бы его

* Маркович В. М. Русская литература Золотого века: Лекции / Под ред. Е. Н. Григорьевой. СПб.: Росток, 2019. 752 с.

1 Что отчасти уже сделано, в том числе учениками Марковича; см.: Васильева И.Э. Герменевтическое литературоведение как язык культурной эпохи: к дискуссии о кризисе филологии // Вестник Санкт-Петербургского университета. Язык и литература. 2018. Т. 15. Вып. 4. С. 552-566. концепция развития русской литературы, дает последняя опубликованная при жизни статья, посвященная проблемам эволюции лирики. ${ }^{2}$ Перерабатывавшийся Марковичем вплоть до 2009 года обзорный курс лекций - в какой-то мере замена нереализованного учебника.

При том что общее оглавление курса выглядит вполне традиционно (здесь и поэты «элегической школы», и поэты-декабристы, и «Горе от ума» Грибоедова, и басни Крылова, и неизбежная троица: Пушкин, Лермонтов, Гоголь), привычное персональное рассмотрение биографии и творчества отступает на второй план, уступая место анализу закономерностей литературного процесса. Мысль Марковича сосредоточена не столько на истолковании конкретных произведений (как бы ни были блестящи многие из предлагаемых им интерпретаций), а на тех проблемах общего литературного движения эпохи, которые по-своему решал каждый из названных поэтов. Главными действующими лицами такой истории литературы выступают не отдельные персоны, а стили и жанры, лирические формы, структурно разные типы прозаического повествования. Именно за счет их размежеваний, сближений, наложений, синтеза, новых размежеваний и осуществляется, по мнению Марковича, движение литературы. В подобной концепции различима традиция формализма, но, пожалуй, еще отчетливее - более старая и более широкая, неумирающая (потому что она верна?) гегельянская традиция: движение от тезиса к антитезису и снятию противоречия в синтезе. Однако у Марковича акцент делается всякий раз не на снятии противоречий, а на новых проблемных узлах, обнаруживаемых в рамках уже достигнутого, казалось бы, синтеза, - что и делает неизбежным дальнейшее движение. Описываемый таким образом процесс не телеологичен, завершиться на каком-либо достигнутом результате он не может.

При очевидных симпатиях Марковича к школе русского формализма и при определенных структуралистских влияниях (заметных в выстраивании типологии литературных форм) приоритетным остается для него подход герменевтический. Описание структурных изменений является не самоцелью, а ступенькой к постижению сльслла. Более того, в представлении Марковича имманентный подход к изучению литературного текста не исключает желания (и возможности) пробиться к стоящему

${ }^{2}$ Маркович В. М. Трансформации русской лирики в первой трети XIX века // Русская литература. 2015. № 2. С. 5-28. 
за текстом образу действительности - поскольку определенные отношения с действительностью моделируются самими текстами.

В итоге перед нами разворачивается не только картина эволюции стилей, но и просматривающиеся за этими стилями облики действительности. Разговор о литературе становится, таким образом, разговором о неких существенных тенденциях в развитии всей русской культуры первой половины XIX века. Особого упоминания заслуживает тот вклад, который вносит Маркович в изучение утопизла в русской культуре. Нередко полагают, будто утопизм, по большому счету, начинается с позднего Гоголя, со второго тома «Мертвых душ» и «Выбранных мест из переписки с друзьями». Исследователь убедительно показывает, что это не так: различные варианты утопии он обнаруживает уже у поэтов-элегиков, а также в гражданской лирике декабристов, в творчестве позднего Пушкина и даже у Лермонтова. По контрасту с тем он говорит также о другом постоянно возвращающемся лейтмотиве - о безыллюзорности видения реальности, о стремлении выйти к действительности, как она есть. В этом отношении особо выделяется раздел о Крылове (увиденном и истолкованном весьма неожиданно), а также раздел о Грибоедове. Напряженное внимание к осциллированию русской мысли между двумя этими полюсами (утопия vs. безыллюзорность) красноречиво свидетельствует и о масштабе личности самого ученого - человека, глубоко рефлектировавшего трагические противоречия русской культуры в целом.

За то, что курс лекций приобрел книжную форму, следует поблагодарить Е. Н. Григорь- еву - ученицу Марковича и его коллегу по кафедре истории русской литературы СПбГУ. Лекции, транскрибированные ею с аудиозаписей, прошли через ее же редакторскую обработку, притом обработку чрезвычайно бережную, нацеленную на то, чтобы передать специфику устного слова. В соотнесении с работами Марковича, напечатанными при жизни, записи его ораторской речи (изобилующей стилистическими контрастами, иногда намеренно эпатажной, зато всегда доходчивой) дают обильный материал для размышлений над двумя разновидностями научного слова.

Тексты лекций снабжены постраничными примечаниями, содержащими точные указания на источники, к которым отсылал слушателей Маркович. Подобный справочный аппарат существенно обогащает книгу как учебное пособие. В приложении помещена «Автобиография», написанная Марковичем около 2010 года, - текст лаконичный, блистательно остроумный и притом сообщающий чрезвычайно много важного «о времени и о себе». Ярко характеризует атмосферу эпохи и другой документ, опубликованный в «Приложении»: выписка из протокола заседания кафедры истории русской литературы от 22 февраля 1972 года (с обсуждением кандидатуры Марковича на должность преподавателя).

Хочется надеяться, что знаменитый некогда курс лекций благодаря состоявшейся публикации надолго останется хорошим помощником для студентов и преподавателей, для всех, кому интересна не только фактография, но и динамика развития русской литературы XIX века.

DOI: $10.31860 / 0131-6095-2020-3-259-260$

(ㄷ) О. А. Клинг

\section{РАЗГАДКА ТАЙН Н. В. ГОГОЛЯ*}

Юрий Владимирович Манн - ведущий гоголевед. Рецензируемая книга вышла к 90летнему юбилею ученого. Но исследователь не перестает удивляться Гоголю, ищет разгадки все новых и новых его тайн: «Ни к кому так часто $<\ldots>$ не применяется слово „тайна“, таинственный, как к Гоголю» (с. 101). Манн пишет: «...в противоречии - признании великого значения Гоголя для России и непризнании такового для западного мира (как видим, непризнании неоправдавшемся) - скрыт один из величайших парадоксов <...> русского писателя» (с. 7). Это проиллюстрировано в пер-

* Манн Ю. В. Н. В. Гоголь: тайны биографии и тайны творчества. М.: РГГУ, 2019. $143 \mathrm{c}$. вой главе на примере повести «Нос», которую многие (да и сам Гоголь) воспринимали как шутку. Но она приобрела мировое значение. Несмотря на множество предшественников Гоголя (от Гофмана, Рабле до Сервантеса и др.), «рассмотрение повести в контексте мировой литературы привело к осознанию ее исключительной оригинальности» (с. 21). Парадокс «Носа» проявляется еще и в том, что эта повесть по-новому раскрывается в сопоставлении c «Превращением» Кафки, абсурдизмом и сюрреализмом в западной литературе XX века.

Манн считает "смелое сравнение Подколесина с Гамлетом» (с. 14) у А. А. Григорьева ключом к новому пониманию гоголевской «Женитьбы». Правда, Григорьев противопоставлял двух этих героев, а Манн пишет: «Главный 
герой „Женитьбы“ может быть и может не быть Гамлетом» - и отмечает «неустойчивость, изменяемость, переменчивость» (с. 41) связей и поступков героя. Автор указывает на разные грани гоголевского комедийного мира. «Мир персонажей как нечто тривиальное, мелкое и пошлое. И в противовес всему этому - человеческое, гуманное, естественное» (там же). И в этом тайна не только гоголевского Подколесина, но и его творчества в целом. Манн перекидывает мостик от Гоголя к Кьеркегору. Их связи он характеризует словами: «таинственная невстреча» (с. 44). Гоголя и Кьеркегора объединяет «заход за некую незнакомую, незнаемую границу», где "страх страшнее $\mathrm{cmpa-}$ $x a$. Пессимизм отчаяния пессимистичнее пессимизла» (с. 45).

Город, который, по мнению Манна, открыл в литературе именно Гоголь, исследуется в двух главках. Ссылаясь на юнговское объяснение мифологемы города женским началом, автор книги пишет: «Город - и как невеста, ее можно увлечь, обольстить, покорить. В „Ревизоре“ в роли покорителя и обольстителя выступил... Хлестаков! Хотя он так и не понял смысла и причины своей „победы“" (с. 59). Исследователь вспоминает еще одну мифологему Иоанна Златоуста - город как внутренний мир человека, как образ души. Это касается и гоголевской повести «Рим», где ученый видит город «как прибежище поэзии, вдохновения, бескорыстного служения искусству» (с. 74), в то же время отмечает «связанный с Римом культ женщины-красавицы, ее чарующей силы любви и чувственной энергии" (c. 75). Манн считает, однако, что Гоголь разрушает в финале повести «Рим» эту типологию. Тем не менее исследователь в споре с Андреем Белым подчеркивает: «Прошлое погружается в вечность, настоящее переходит во „вневременное измерение“" (с. 80). Город поставил перед Гоголем вопрос о границах искусства: «Нет границы развитию <...> языка, степени проникновения его в бытие мироздания» (с. 72).

От главы к главе Манн открывает новое у Гоголя. «Мертвые души» не утопия, как считал К. В. Мочульский и другие, а «наоборот, отчасти сознательная и, во всяком случае, объективная полемика с жанром утопии» (с. 93). В названии не только этой главы ( „Мертвые души“ - утопия?»), но и других — вопросительный знак. Например, в одной из них: «„Мертвые души“ - наша „Божественная комедия“?». В этом отразилась полемика со своими предшественниками в изучении Гоголя. Ученый тоже отмечает сближение с «Боже- ственной комедией» в трехчастном замысле «Мертвых душ», где первый том - Ад, второй - Чистилище, третий - возрождение героев. Однако у него в связи этим возникают сложные вопросы. Н. И. Надеждин видел в «Божественной комедии» - «вход во внутреннее святилище поэзии романтической» (c. 96). По мнению Манна, у Гоголя нет такой привязки к современности (романтической эпохе), как в «Божественной комедии» Данте. «Однако он разделяет общее представление философской эстетики о движении и преобразовании художественных форм или этапов» (там же). В связи с интересом Гоголя к «Божественной комедии», другим проблемам Манн ставит вопрос в главке «Всемирная отзывчивость Гоголя» об его образованности и опровергает расхожее мнение о том, будто она была поверхностной.

Одной из самых больших тайн Гоголя Манн называет судьбу второго тома «Мертвых душ». Он приводит пять точек зрения относительно второго тома: 1 . Сжег. 2. Не сжигал (Белый считал это метафорой: Гоголь понял, что второй том не состоялся). 3. Уничтожил по ошибке. 4. Рукопись спрятана, утаена друзьями Гоголя. 5. Спрятана врагами писателя, но может еще найтись. Убежденное мнение автора рецензируемой книги: рукопись действительно была уничтожена (с. 102-103). Как считает Манн, «психическое состояние Гоголя, происходящие в глубине души мучительные процессы были связаны с поражением творческим, писательским» (с. 115). Имеется в виду поэма как главный результат его деятельности. «Гоголь видит, что на ней, этой деятельности, уже не почиет Божия благодать» (c. 116).

Атмосферой таинственности окутана так называемая «Прощальная повесть» - «кульминационная точка гоголевской таинственности» (с. 117). В главе об этой повести тоже целый спектр суждений - от Ф. М. Достоевского до современных ученых - о том, миф она или реальность. Ответ Манна: «Да, реальность, но вобравшая в себя элементы мифа, точнее даже мифостроения. Да, мистификация, но выросшая на реальной почве чувств, устремлений и жизненных обстоятельств. Чисто гоголевское совмещение, казалось бы, несовместимого» (с. 134).

Раскрывая тайны Гоголя, Манн представил писателя в своей книге под новым углом зрения. Гоголя, обращенного к сложным, порой противоречивым философским и духовным исканиям. 
DOI: $10.31860 / 0131-6095-2020-3-261-262$

(c) C. В. Федотова

\section{ДОСТОЕВСКИЙ В РАКУРСЕ АКАДЕМИЧЕСКОЙ МЕТАКРИТИКИ*}

В современном достоевсковедении количество научных работ о творчестве писателя настолько велико, что это ставит перед исследователями серьезные проблемы методологического характера. Что нового можно сказать о Ф. М. Достоевском после полуторавекового интенсивного изучения его творчества как в отечественной, так и зарубежной гуманитаристике? С каким методом подойти не только к его художественным текстам, но и к текстам об этих текстах - к разнообразным интерпретациям, критическим, философским, религиозным, литературоведческим и т. д.?

Новая книга В. А. Келдыша, патриарха отечественного литературоведения, отметившего в прошлом году 90-летний юбилей, «Наследие Ф. М. Достоевского в философрской и литературно-критической мысли Серебряного века русской литературы» - уже самим названием задает методологические критерии рассмотрения заявленной темы. Первый из них четко определяет предмет исследования «анализ понятийного мышления о писателе» (с. 8), т. е., по существу, свидетельствует о важности для автора эпистемологического метода «истории понятий», полезного для уяснения основных путей и закономерностей развития мысли о Достоевском.

Второй ограничивает материал изучения порубежной эпохой, называемой в общепринятом литературоведческом узусе Серебряным веком русской культуры. При этом синхроническое рассмотрение дискуссий о значении художественных открытий Достоевского, требующих адекватного метода их осмысления, дополняется диахроническим аспектом, позволяющим оценить степень новизны философско-критической мысли рубежа веков по отношению к предшествующей традиции. Третий методологический критерий - «принцип сугубой избирательности», который предполагает сознательные ограничения в отборе литераторов, писавших о Достоевском, а также их работ, наиболее репрезентативных для решения поставленных автором задач.

Предлагаемую методологию можно назвать академической метакритикой, нацеленной на аналитический обзор резонансных высказываний о художнике, поднимающих серьезные теоретико-литературные и философские проблемы. Основной акцент Келдыш делает «на мысли о писателе, перекинувшей мост между творчеством Достоевского и новым сто-

* Келдыци В. А. Наследие Ф. М. Достоевского в философской и литературно-критической мысли Серебряного века русской литературы. М.: ИМЛИ РАН, 2019. 280 с. летием русской и всемирной духовной жизни» . Подобная генерализирующая установка предопределяет логику рассмотрения материала и результат проделанной автором работы понимание критической мысли о Достоевском как «утверждение всеобщей философичности видения мира в творчестве писателя, пронизывающей всю образную ткань его сочинений» (c. 7).

При всей своей традиционности такой подход дает Келдышу возможность уйти от идеологических и социологических стереотипов. Он тонко отмечает, что рефлексия о творчестве Достоевского не только разводила бывших единомышленников по разные стороны баррикад, но и зачастую сближала идеологических оппонентов в стремлении осознать значение феномена Достоевского для отечественной культуры. Полемическое бурление критических и философских прочтений творчества писателя, его разноречивое восприятие «поверх общественных лагерей», считает исследователь, связано с категорией художественности и разными критериями ее оценки. Сосредоточенность на понятии художественности, при всей вариативности его осмысления, как раз и является «ведущим опознавательным признаком, отличающим прижизненную мысль о писателе» (с. 12).

Сюжет книги строится на столкновении базовых эстетических понятий, определяющих понимание природы искусства и назначения литературы в воззрениях сторонников различных подходов (культурно-исторического, социологического, психологического, религиозно-философского и антропологического) к творчеству Достоевского. Автор прослеживает процесс изменений в восприятии художественного феномена творчества Достоевского в критическом сознании эпохи: от представлений о маргинальности его художнического дара по отношению к общим задачам искусства до признания его органичнейшим явлением русской художественной культуры - при всей особости пролагаемых им путей. Таким образом перед нашими глазами разворачивается весь диапазон позиционирования писателя в критике: от «психопатологического субъективиста», искажающего правду жизни, до «религиозного пророка» и ясновидца «нашей культурной сложности» и сокровенной тайны о человеке. Келдыш не только дает высказаться практически всем ведущим литературным критикам второй половины XIX - начала XX века, но и сам словно бы присутствует при бурном обсуждении наследия писателя, вставляя свои реплики и высказывая оценки, подчеркивающие антиномичность и в то же время целостность 
художественного мира Достоевского. При этом ученый пользуется своим существенным преимуществом перед современниками писателя и «серебряновековцами» - «точкой вненаходимости", обусловленной исторической дистанцией. С этой «смотровой площадки» отчетливо видны противоречивые, зачастую субъективные, идеологически или религиозно-философски ангажированные, но всегда напряженные усилия критической мысли, пытающейся осознать смысл главной эстетической новации Достоевского - «реализма в высшем смысле». «Процесс осмысления наследия писателя, заключает автор, - развивался в ряду оппозиций, каждая из которых больше или меньше обособляла от целого некую сторону, а нередко и абсолютизировала ее. При всем том черты „целостного“ Достоевского присутствовали в литературно-критическом сознании времени» (с. 266). Именно религиозно-философская и мифопоэтическая критика рубежа веков (пристальное внимание уделяется в книге Д. Мережковскому и особенно Вяч. Иванову как «двум полюсам» символистского «второго открытия» Достоевского) - при всех различиях в понимании смыслового содержания произведений писателя - смогла увидеть в «фантастическом» реализме Достоевского, по формули- ровке Келдыша, «соединение творческого метода, освященного классическими традициями, с художественным экспериментом, предсказывающим поэтику грядущего» (с. 269).

Серьезного внимания заслуживает итоговое соображение автора о современном состоянии достоевсковедения, во многом развивающего религиозно-философские идеи Серебряного века. Исходя из известного высказывания Достоевского («через большое горнило сомнений моя осанна прошла»), Келдыш констатирует преобладание сегодня апологетического дискурса - «раскрытие многосмысленного у писателя понятия „осанна“, но при этом другой смысловой комплекс - „горнило сомнений“ - нуждается в большем внимании»: его глубокое изучение «способно значительно крупнее высветлить еще одну, сокровенную, сторону творческой личности гения - подвиг духовного преодоления» (с. 272).

Пафос целостного «узрения» художественного мира Достоевского вдохновляет автора книги, которая отличается не только высокой степенью постижения предмета исследования, но и редкой на сегодняшний день простотой и прозрачностью научного языка, что позволяет увидеть в ней достойный образец отечественной академической метакритики. 


\title{
ХРОНИКА
}

\author{
DOI: $10.31860 / 0131-6095-2020-3-263-269$

\section{ПЕТЕРБУРГСКОЕ УНИВЕРСИТЕТСКОЕ ЛИТЕРАТУРОВЕДЕНИЕ В ЕГО ПРОШЛОМ И НАСТОЯЩЕМ}

3-5 октября 2019 года на Филологическом факультете СПбГУ прошла Международная научная конференция «Петербургское университетское литературоведение: прошлое и настоящее», посвященная 200-летию кафедры истории русской литературы Санкт-Петербургского государственного университета, возникшей еще в 1816 году в составе Главного педагогического института, а в 1819 году вошедшей в состав возрожденного Петербургского университета. В конференции приняли участие исследователи, представляющие университеты и научные организации России и зарубежных стран.

Первое заседание было посвящено отдельным эпохам жизни кафедры и памяти работавших на ней сотрудников. Б. Ф. Егоров (Санкт-Петербург), опираясь на свои дневниковые записи, поделился воспоминаниями о работе на кафедре в 1960-е годы, охарактеризовал ее заведующих той поры (И. П. Еремин, В. Я. Пропп, В. Г. Базанов, Г. П. Макогоненко), нарисовал картину жизни кафедры, за редкими исключениями являвшейся дружным творческим коллективом.

Е. Н. Григорьева (Санкт-Петербург) представила только что вышедшую из печати книгу лекций профессора В. М. Марковича, основанную на расшифровке аудиозаписей разных лет. Закономерности литературного процесса, всегда бывшие в центре внимания историко-литературных и теоретических курсов Марковича, позволили публикаторам издать его лекции под названием «Русская литература Золотого века». В работе прослеживается сюжет становления, а затем и разрушения принципов, которые лежали в основе культуры этой эпохи.

Выступление М. Н. Виролайнен (СанктПетербург) было посвящено книге безвременно ушедшего из жизни талантливого ученого Е. И. Ляпушкиной «Введение в литературную герменевтику: Теория и практика» (2019). По мысли докладчицы, эта книга является одним из лучших образцов популяризации философского знания и в то же время исследованием, в задачу которого входит не изложение философских доктрин, а экспликация философских оснований герменевтики, выяснение исторической преемственности герменевтических теорий и практик, аналитическое описание взаимоотталкивания и взаимозависимости герме- невтических направлений. Анализы произведений, вошедшие во вторую часть издания, демонстрируют возможности практической реализации герменевтических теорий.

А. О. Большев (Санкт-Петербург) рассказал о вкладе в науку профессора Л. Ф. Ершова, возглавлявшего кафедру советской литературы ЛГУ на последнем этапе ее существования. По мнению Большева, основные научные достижения Ершова были связаны со смелым и глубоким анализом романа М. А. Шолохова «Тихий Дон» (для разъяснения метаний Григория Мелехова Ершов предложил концепцию героя-максималиста, жаждущего истины и не находящего ее ни у белых, ни у красных), а также с исследованием творчества Л. Леонова, изощренные тексты которого он подверг основательной дешифровке.

Доклад С. Б. Адоньевой (Санкт-Петербург) «История повседневности в неопубликованных книгах Н. П. Колпаковой» был посвящен двум оставшимся неизданными рукописям этого автора - «Ветер с Севера» (отдельные фрагменты которой Колпакова позднее использовала в своих эссе) и «Мойка 108: История демидовских учебно-воспитательных заведений в Санкт-Петербурге. 1834-1919».

В выступлении И. Н. Сухих (Санкт-Петербург) «Литературовед как литератор: петербургский/ленинградский акцент» были прослежены взаимосвязи художественного и научного дискурсов. Наряду с обращением литературоведов к собственно художественному творчеству, как прозаическому, так и стихотворному, особый интерес представляет тип исследования, в котором выбор предмета основывается на «личном смысле» (Л. Я. Гинзбург). Образцом такого личного литературоведения является научная деятельность Б. М. Эйхенбаума.

Мемориальная тематика конференции была продолжена в следующие дни заседаниями, посвященными памяти профессоров кафедры Н. С. Демковой, И. В. Столяровой и Б. В. Аверина. В ходе первого из них М. В. Рождественская (Санкт-Петербург) в докладе «Н. С. Демкова как исследователь и педагог» выделила основные области интересов ученого - творчество протопопа Аввакума, а также памятники домонгольского периода, их история и поэтика. В изучении литературы средневековой Руси студентами и аспирантами важную 
роль сыграл организованный Н. С. Демковой в 1964 году Семинар по древнерусской литературе и археографическая практика его участников на Русском Севере. Результаты педагогической и исследовательской деятельности Н. С. Демковой позволяют говорить о ее особой «научной школе».

В докладе А. Г. Боброва (Санкт-Петербург) «Наталья Сергеевна Демкова как археограф» речь шла о совершенных ею восьми археографических экспедициях. Первые из них относятся еще ко времени работы в Пушкинском Доме: в Гуслицы (1958) и в Сольцы (1963). Но наиболее плодотворным в этом отношении оказался университетский период: Северная Двина, Пинега, Печора (1967-1974). Всего Н. С. Демкова и руководимые ею экспедиции пополнили собрания Древлехранилища Пушкинского Дома на 450 рукописей $\mathrm{XV}-\mathrm{XX}$ веков. В ходе полевой работы Н. С. Демкова воспитала целую школу «рукописников», привила им вкус к изучению древнерусских и старообрядческих книг, заразила их своей страстью к поискам старинных манускриптов. Начиная с середины 1970-х годов Н. С. Демкова концентрируется не на полевой, а на камеральной археографии, обследуя в числе прочих рукописные собрания Германии и США. Любовь к древним книгам роднила Н. С. Демкову с хранителями рукописной традиции; эта любовь передавалась ее ученикам и дальше - ученикам учеников.

П. Е. Бухаркин (Санкт-Петербург) в докладе «Н. К. Гудзий: облик ученого в исторической ретроспективе» остановился на трех основных проблемах, встающих в связи с обращением к наследию этого филолога. Во-первых, Гудзий являет собой пример резкого несовпадения общекультурной репутации ученого и реального объема сделанного им в науке. Вовторых, хотя Гудзий был традиционалистом, а не новатором, его исследования сохранили актуальность до сих пор, представляя как фактографический, так и теоретико-методологический интерес, оказываясь в некоторых отношениях созвучными важным интенциям современного гуманитарного знания. В-третьих, судьба Гудзия дает материал для осмысления положения успешного и, одновременно, принципиального ученого-гуманитария в условиях 1930-х - начала 1950-х годов, границ его возможностей и неизбежных компромиссов.

И. А. Лобакова (Санкт-Петербург) в докладе «Повторы и их функция в „Повести о разорении Рязани Батыем“» анализировала художественную организацию памятника, поэтические достоинства которого позволяли исследователям соотносить его со «Словом о полку Игореве». Лексические повторы «прошивают» все фрагменты «Повести», образуют сочетания с другими повторами/формулами, включаются повествователем в композиционные рефрены, объединяя все эпизоды воедино. На материале лексического повтора слова «братия» была продемонстрирована его соотнесенность со сквозными темами произведения - мужества, смерти и плача.
Доклад С. А. Семячко (Санкт-Петербург) «Из комментария к Житию Феодосия Печерского и Киево-Печерскому патерику» был посвящен реконструкции дисциплинарного устава Киево-Печерского монастыря в ранний период его существования. Исследовательница оценила степень сохранности источников и меру их репрезентативности. Комментируя Житие Феодосия Печерского, она показала специфику Печерского монастыря на фоне других киевских обителей. Остановившись на обстоятельствах принятия монастырем Студийского устава, С. А. Семячко охарактеризовала его дисциплинарную часть и продемонстрировала пути выявления уставных текстов, сформировавшихся или бытовавших в монастыре и игравших роль своего рода «подзаконных актов» по отношению к Студийскому уставу. В докладе также было рассмотрено бытование фрагмента Послания Симона к Поликарпу, входящего в состав Киево-Печерского патерика в качестве уставного текста.

М. А. Федотова (Санкт-Петербург) в докладе «Первое собрание проповедей Димитрия Ростовского в контексте издательской практики его сочинений» рассмотрела два издания, существенно повлиявшие на эдиционную практику сочинений ростовского митрополита, публикацию «Келейного летописца», осуществленную Н. Новиковым (1784), и «Собрание разных поучительных слов...» (1786). Первое издание ораторских сочинений Димитрия Ростовского было инициативой частного лица Я. А. Татищева, который в 1782 году обратился в Синод с прошением издать их за собственный счет (РГИА. Ф. 796 (Канцелярия Синода). Оп. 63. Д. 264). Как следует из дела, проповеди были отредактированы, основная правка касалась преимущественно нормализации церковнославянской орфографии, но первые редакторы и цензоры признали авторство всех проповедей и сочинений, которые Татищев прислал в Синод. Критический анализ «Собрания...» показал, что из 94 проповедей, приписанных в нем Димитрию Ростовскому, две принадлежат Стефану Яворскому, пять - Симеону Полоцкому, атрибуция еще девяти требует дальнейшего изучения.

Завершили заседание выступления Б. Ломаджистро (Италия) о составе и происхождении Толковой Палеи и М. В. Кужлева (СанктПетербург) об истории старообрядческой рукописной традиции на Вятке в XX веке.

В рамках научного заседания, посвященного памяти И. В. Столяровой, прозвучали выступления ее учеников и соратников по изучению творчества и биографии Н. С. Лескова. Е. В. Душечкина (Санкт-Петербург) осветила шестидесятилетний научный путь исследовательницы, которая, благодаря глубокой заинтересованности в литературной деятельности Лескова, доскональному знанию его текстов и пониманию его места в русской общественной и литературной жизни России середины XIX века, стала одним из крупнейших в мире специалистов-лескововедов. 
С. И. Зенкевич (Санкт-Петербург) в докладе «Второй год службы Н. С. Лескова в Министерстве народного просвещения» обратилась к рецензиям писателя на книги для школ за 1875 год, зафиксированным в журналах заседаний Особого отдела Ученого комитета Министерства народного просвещения (РГИА). Основной акцент был сделан на педагогических взглядах Лескова и на ограничениях, накладывавшихся министерской службой и отразившихся в текстах его отзывов. Эти рецензии войдут в ныне готовящийся 14-й том Полного собрания сочинений Н. С. Лескова, «завещанного» И. В. Столяровой ученикам и последователям.

О. В. Евдокимова (Санкт-Петербург) выступила с докладом «Лесков и Флоренский: о смысле иконостаса», а Н. И. Озерова (СанктПетербург) назвала свое выступление “„На краю света“ Н. С. Лескова: деятельное добро в литературе и жизни».

К самому широкому кругу проблем обратились докладчики, посвятившие свои выступления памяти Б. В. Аверина. В докладе А. В. Лаврова (Санкт-Петербург) были обозначены основные вехи взаимоотношений видного экономиста и публициста, одного из лидеров конституционно-демократической партии П. Б. Струве, бывшего с 1907 года главным редактором ежемесячного литературного и общественно-политического журнала «Русская мысль», и В. Я. Брюсова, заведовавшего его литературно-критическим отделом в 1910-1912 годах. Характер деловых взаимоотношений с почти исчерпывающей полнотой отразился в их переписке, раскрывающей основные параметры совместной работы Брюсова и Струве, особенности их редакционной политики, а также обстоятельства, побудившие Брюсова отойти от участия в руководстве журналом.

В докладе А. М. Грачевой (Санкт-Петербург) «Сновидное озарение как форма творческого синтеза («Дневник мыслей» Алексея Ремизова)» была рассмотрена функция этого эго-документа как фиксатора «творческой лаборатории» писателя. Проведенный анализ выявил, что «Дневник мыслей» Ремизова представляет собой существенный источник для изучения «истории текста» произведений, созданных писателем с середины 1940-х годов до 1957 года. Содержащиеся в нем данные - особый вид подготовительных и черновых материалов к окончательным текстам (планы, наброски, конспекты планируемых или находящихся в работе повестей, легенд, произведений экспериментальных жанров).

Доклад Е. Р. Обатниной (Санкт-Петербург) «Ремизов в борьбе за „сон“» был построен на сюжете 1925-1926 годов, связанном с негативной рецепцией эмигрантской критикой жанра «сна», который писатель считал неотъемлемой частью своей автобиографической прозы. Исследовательницей были использованы редкие архивные документы и малоизвестные печатные выступления Ремизова в парижской русскоязычной периодике.
Предметом рассмотрения в докладе А. Пашкевич (Польша) «Категория памяти в автобиографической прозе русской эмиграции" стали воспоминания А. Даманской «На экране моей памяти». Память присутствует в произведении в фотографической ипостаси (картины прошлого сравниваются в нем с кадрами фильма), а также как форма трансляции и актуализации культурных смыслов. По мнению докладчицы, воспоминания Даманской - активной участницы литературно-общественной жизни Русского Зарубежья - по своей хронологии и широте охвата событий сопоставимы с лучшими образцами эмигрантской мемуаристики.

В сообщении С. Д. Титаренко (Санкт-Петербург) «Научное наследие Д. Е. Максимова и русское литературоведение конца XX - начала XXI века" рассматривались идеи ученого о символизме, творчестве А. Блока, В. Брюсова и других поэтов. Отмечалось значение начинаний Максимова для развития текстологии, научного комментирования, издания собраний сочинений, изучения помет Блока на страницах книг из его личной библиотеки. Было показано, что некоторые положения исторической поэтики формулируются в современной науке на основе понятий, введенных Максимовым («поэтическая модальность», ее виды и подвижность).

В докладе «Солярный мотив в мифопоэтике романа В. Набокова „Дар“» О. А. Дмитриенко (Санкт-Петербург) проследила, каким образом происходит освоение и развитие символистской традиции осмысления солярной мифологии в мифопоэтике произведения писателя. Солярный мотив, связанный с мистикой Демиурга и обновлением мира, в финале романа Набоков использует для автометаописания.

Завершило заседание выступление М. Рубинс (Великобритания), посвященное гуманистическому коду русской культуры и литературе Русского Зарубежья.

Широкий круг проблем был затронут и участниками секционных заседаний конференции. Так, в докладе «Духовные оды И. А. Крылова: об авторской композиции цикла и изданиях XIX-XX веков» В. Л. Коровина (Москва) речь шла о восьми переложениях псалмов, которые И. А. Крылов поместил в начале рукописного сборника своих стихотворений, расположив их не по порядку нумерации в Псалтири, а в иной, диктуемой художественной логикой последовательности. Докладчик указал на беспрецедентность такого решения в русской псалмодической лирике XVIII века и отметил ряд формальных и содержательных моментов, позволяющих оценить оригинальность Крылова как автора духовных од и выяснить, в частности, религиозно-политический смысл, который открывается из рассмотрения их именно как единого цикла, оформленного поэтом в начале царствования Павла I.

В сообщении «Визуальные источники стихотворения Пушкина „Герой“» И. В. Немировский (Санкт-Петербург) рассмотрел в качестве 
претекстов пушкинского произведения картины А.-ЖЖ. Гро, известного как «художник Наполеона». Речь, прежде всего, шла о полотне «Наполеон возле чумных больных в Яффо» (1804). По мнению докладчика, вариативность в иконографии этого события как у самого Гро, так и у современных ему карикатуристов нашла отражение и в пушкинской концепции.

Пушкинская тема была продолжена докладом А. В. Ильичева (Санкт-Петербург) «Пушкин: тайна гения». Выступающий предпринял новую попытку осмыслить необычность пушкинского дара, рассмотрев лицейские художественные открытия поэта в перспективе его дальнейшего развития, обнаруживая, что ранняя творческая интуиция Пушкина во многом предопределила особенности его становления.

В докладе "„Метафизический язык“ как концепт у П. А. Вяземского и Б. Констана" Д. В. Токарев (Санкт-Петербург) предпринял попытку уточнить смысл этого понятия, которое возникает и у Констана, и у переведшего его роман «Адольф» Вяземского как продукт «диалектики ума и чувств». Язык, выражающий эту диалектику, будет метафизическим в той степени, в какой он сможет отразить ее слогом, который, обходясь без риторических излишеств минувшей эпохи, транслирует «истину». Таким образом, язык «современной» метафизики должен быть языком не поэтическим, а практическим, настроенным на коммуникацию, а не на выражение поэтических красот. Это язык политический, философский, военный и одновременно светский, нацеленный на решение прежде всего прагматических задач, язык формирующейся национальной и одновременно космополитичной элиты.

В выступлении А. А. Карпова (СанктПетербург) «,Турецкая цыганка“ А. Белкина (О. И. Сенковского): апроприация чужого текста» была рассмотрена одна из трех повестей писателя, подписанных псевдонимом Сенковского «А. Белкин», скандально соединившим фамилию пушкинского циклизатора с инициалом создателя этого образа. Недавно стало известно, что она представляет собой довольно точный перевод сочинения американского писателя Н. П. Уиллиса «Цыганка из Сардиса» . Однако, русифицируя перевод, привнося в него автобиографические подробности, используя собственную репутацию востоковеда и переводчика, Сенковский заставляет читателя воспринимать текст как собственное оригинальное произведение мемуарного характера.

К проблемам изучения литературы первой половины XIX века обратились и другие участники конференции. В докладе М. Я. Вайскопфа (Израиль) «Проблема модального статуса в сочинениях Гоголя» рассматривалась глубинная философская проблема творчества писателя: текучесть и взаимообратимость бытия и небытия в его произведениях. Нулевая реальность мгновенно или посредством ступенчатых построений оборачивается потенциальной бесконечностью, и, наоборот, бесчисленный набор тех или иных реалий сжимается в ничто. В антропологическом плане человек уравнивается с вещью именно потому, что оба они наделены душой, но душой лишь как минимальной жизненной субстанцией, лишенной духовного ядра и оттого тоже как бы небытийной, почти что нулевой. Ей противостоит дух, оставшийся достоянием самого художника и запечатленный им в сферах нуминозного или прекрасного бытия.

В выступлении Е. Г. Падериной (Москва) «Как и почему Гоголь в 1835 году пародировал жанр повести» была рассмотрена гоголевская «Коляска». Исследовательница продемонстрировала, что комическая стилизация расхожих литературных примет провинциальной глуши, нравов помещиков, привычек и развлечений провинциалов и расквартированных офицеров сочетается у Гоголя с фабульно-композиционными стереотипами, речевыми шаблонами повествователей-рассказчиков и т. д. При этом пародийный уровень литературной шутки Гоголя подчинен самостоятельному литературному сюжету по образцу пушкинского «Графа Нулина», а Чертокуцкий - воплощенная фикция - в своем роде Нулин.

По мнению автора доклада "„Странник“ А. Ф. Вельтмана: проблема жанра» М. В. Отрадина (Санкт-Петербург), суть этого произведения нельзя сводить к его пародийности. Пристального внимания заслуживает пограничная жанровая природа «Странника», соединяющего признаки романа и литературного путешествия. Вельтман строит сюжет, стремясь "освободиться от наскучивших повествовательных традиций» (3. Ефимова), по законам искусства, а не документального рассказа о реальных путешествиях. Опыт «Странника» оказался контрастен по отношению к эстетике и поэтике «физиологий», захвативших литературную авансцену в 1840 -е годы. Именно поэтому некоторые приемы и мотивы Вельтмана оказались близки И. А. Гончарову в период создания книги «Фрегат „Паллада“" .

Гончаровская тема конференции была подхвачена докладом «Писатель и чиновник» С. Н. Гуськова (Санкт-Петербург), предложившего новый взгляд на соотношение писательского пути и служебной карьеры автора «Обломова». Обычное в научной литературе противопоставление службы и творчества как взаимоисключающих жизненных стратегий биографией Гончарова не подтверждается. Две стороны единой личности Гончарова гармонично сосуществовали. Авторитет известного литератора способствовал карьерному росту, а служебный опыт формировал оригинальный писательский взгляд, доставлял материал для творчества, что отразилось в главных текстах Гончарова.

В выступлении Т. И. Печерской (Новосибирск) «Сочинительство как образ жизни: о литературном быте петербургских писателейразночинцев середины XIX века» рассматривались особенности формирования репутации и роль в литературном процессе «второго призыва» писателей-разночинцев из круга «Со- 
временника», а затем "Русского слова» начала 1860-х годов (Н. В. Успенский, А. И. Левитов, Ф. М. Решетников, Н. Г. Помяловский и др.).

Разнообразный и вместе с тем цельный характер носили выступления участников секции «Достоевский и другие». В докладе С. В. Савинкова (Воронеж) «Семиотика середины в повести Достоевского „Двойник“” был рассмотрен идейно-тематический план повести с учетом контекстуальных значений образа титулярного советника. Автор обратил внимание на то, что в рефлексиях Поприщина и Голядкина представление о ничтожности выстраивается на принципиально разных основаниях: у гоголевского героя - на принадлежности к аксиологическому низу социальной жизни, а у героя Достоевского - на принадлежности к середине. Неразличимость как условие и одновременно следствие ординарности при определенных условиях и становится, по Достоевскому, благодатной почвой для образования «наполеоновского» комплекса. Вызванное им желание не быть самим собой станет главной модальностью существования Голядкина, а вслед за ним и Раскольникова.

В докладе "„Федра“ ЖЖ. Расина в романе Ф. М. Достоевского „Идиот“: Об источнике одной незамеченной цитаты» К. А. Баршт (СанктПетербург) выявил источник фразы «Позор преследует меня!», которую произносит в последние мгновения жизни генерал Иволгин. Исследователь предложил анализ аллюзивного плана этой реплики персонажа, а также доказательства версии, согласно которой она является переводом восклицания Федры из трагедии Расина. Достоевский хорошо знал и высоко ценил эту пьесу, а в январе 1861 года, вероятно, видел ее на сцене во время гастролей в Петербурге итальянской актрисы А. Ристори.

В выступлении В. М. Димитриева (СанктПетербург) «Панорама Толстого и картина Достоевского: к истории одной параллели» был проанализирован частный случай, когда живописная аналогия становится источником рассуждения о поэтике. Вяч. Иванов в статье «Достоевский и роман-трагедия» (1911) и А. Жид в лекциях 1922 года демонстрируют различие между художественными манерами Толстого и Достоевского, используя одну аналогию: Толстой может быть уподоблен художнику-пленэристу, который рисует объемные панорамы, где свет рассеян, в то время как Достоевский - колористу-импрессионисту, в его картинах источник света один и распределение света порождает игру теней. В докладе была предпринята попытка ответить на вопросы, мог ли Андре ЗЖид быть знаком со статьей Вяч. Иванова, какие историко-литературные источники могли послужить общим основанием для возникновения этой аналогии в текстах Иванова и Жида, какое методологическое значение имеет это сравнение в критической оптике двух авторов.

В докладе И. А. Кравчука (Санкт-Петербург) «,...Мы могли бы его судить“: к истории „борьбы за Достоевского“ в советском литературоведении» было показано, как имя «про- блематичного» классика стало важной ставкой в борьбе различных интеллектуальных групп за право определять облик новой культуры в послереволюционную эпоху. Последовательно коснувшись работ В. Ф. Переверзева, А. С. Долинина, Г. Е. Горбачева, Л. П. Гроссмана, Н. Л. Бродского и др., докладчик рассмотрел разнообразные подходы к реабилитации Достоевского.

А. В. Кокорин (Санкт-Петербург) в докладе «К проблеме „Олеша и Достоевский“» поставил перед собой задачу ретроспективного соотнесения фактов биографии и творчества двух авторов, представил ряд наблюдений над черновыми рукописями произведений и дневниками Олеши, позволяющими считать, что писатель в течение жизни не только менял отношение к творчеству Достоевского, но и сознательно отталкивался от него, вырабатывая собственный стиль и избегая топосов, возникавших в новой советской литературе.

В докладе Н. А. Гуськова (Санкт-Петербург) «Литературные обитатели Шестилавочной / Надеждинской улицы: из комментариев к прозе XIX века» на примере нынешней улицы Маяковского в Петербурге был поставлен вопрос о литературной репутации различных мест города. До середины XIX века Шестилавочная / Надеждинская представляла собой захолустное предместье столицы, а затем, наоборот, престижный квартал, населенный дельцами, адвокатами, чиновниками - представителями эпохи великих реформ. Докладчик установил предполагаемый адрес проживания главного героя повести Ф. М. Достоевского «Двойник» (нынешний д. 44 или, вероятнее, д. 42).

В докладе О. Табачниковой (Великобритания) «Шестов и Чехов в зеркале английской литературы начала XX века" рассматривалось восприятие творчества А. П. Чехова в России и Великобритании в начале прошлого столетия, в особенности отголоски русского влияния в английской литературе. Основное внимание было уделено трактовке чеховского творчества Л. Шестовым, чья работа о Чехове «Творчество из ничего» (1904) вызвала споры и в России, и за рубежом. Проследив за резонансом, вызванным как идеями Шестова о Чехове, так и непосредственно чеховскими произведениями у Д. Г. Лоуренса, К. Мэнсфилд и Д. М. Марри, докладчица показала, что, несмотря на скептицизм Лоуренса по отношению к обоим - Шестову и Чехову, - с одной стороны, и на восхищение чеховским наследием четы Мэнсфилд-Марри, с другой, именно Лоуренс оказывается ближе по духу к литературному миру Чехова.

В докладе «Чехов и Флобер: проблема объективности" А. Д. Степанов (Санкт-Петербург) поставил вопрос о приоритете открытия особой формы персонального повествования, при котором передается только общая смысловая позиция героя безотносительно к его слову, которую отечественные ученые (прежде всего А. П. Чудаков) связывали с поздними чеховскими шедеврами. Анализ показывает, что 
подобные формы систематически использовались уже в романе Г. Флобера «Госпожа Бовари» (с которым, впрочем, Чехов, судя по всему, не был знаком). Первенство во внедрении в описания излишне укрупненных подробностей также принадлежит Флоберу.

Участники конференции обращались и к теории литературы и текстологии. Так, в выступлении Н. А. Карпова (Санкт-Петербург) «Филология и мифология (к вопросу о методологии и границах гуманитарной науки)» были затронуты проблемы эпистемологии и методологии гуманитарного знания, его соотношение с мифом и мифологическими моделями сознания. Согласно гипотезе докладчика, литературоведение представляет собой гетерогенный, гибридный дискурс, причудливо сочетающий в себе элементы как собственно научного, так и мифологического мышления. Докладчик продемонстрировал разнообразные формы мифологизаторства в рамках филологической науки - такие, как тенденция к мифоориентированной авторефлексии и авторепрезентации, претензия на универсальность, преобладание эстетического мышления над рациональнологическим, наконец, мифологизация самого предмета литературоведения, т. е. писательских фигур и художественных текстов в плане их содержательной составляющей.

В докладе Н. Ю. Грякаловой (Санкт-Петербург) «Новые подходы к изучению помет и маргиналий на книгах из личных библиотек писателей (источниковедческие аспекты)» на примере «фетовского фонда» в личной библиотеке А. А. Блока были продемонстрированы возможности герменевтического анализа идеографических знаков и развернутых текстуальных помет, а также выявлен их семантический потенциал. По мнению докладчицы, они могут рассматриваться как особая форма работы с текстом, требующая осмысления и включения в целостную картину понимания - и не только реконструируемого историко-литературного контекста, но и биографии поэта в ее творческой динамике.

Работу конференции завершили выступления, посвященные проблемам литературы конца XIX - начала XXI века. С. А. Кибальник (Санкт-Петербург) в докладе «Псевдоним как интертекстуальный микротекст (случай Льва Шестова)» поставил под сомнение происхождение псевдонима философа, которое приводит в своих мемуарах А. 3. Штейнберг. Поскольку псевдоним возник еще в 1897-1898 годах, то, скорее всего, он связан с увлечением творчеством Тургенева, о котором Шестов писал тогда книгу. Именем одной из главных героинь романа «Дым» Татьяны Шестовой он назвал свою дочь, родившуюся в 1897 году. Псевдоним «Лев Шестов» был рассмотрен как интертекстуальный микротекст аллюзионного характера, обладающий широким спектром символических значений.

В докладе Е. А. Тахо-Годи (Москва) «Драматургия русских символистов в интерпретации А. Ф. Лосева» была прослежена эволюция взглядов философа на символистскую драма- тургию. Если в середине 1940-х годов А. Ф. Лосев рассматривал трагедию «Лаодамия» И. Анненского как декадентскую и потому уступающую чисто символистской трагедии «Дар мудрых пчел» Ф. Сологуба, то в середине 1970-х годов он уже видит в поэтике Анненского не декадентский, а символико-мифологический колоризм. Аналогично меняется его отношение и к использованию мифа о Дионисе: от критики Вяч. Иванова за уравнивание дионисийства с христианским преодолением смерти и разъятости мирового бытия к принятию идеи преодоления прометеевского титанизма через дионисийское всеединство как космогонической и диалектической картины мировой истории, оригинальной религиозной историософии.

М. Пантина (Франция) в докладе «Экспрессивная риторика в текстах ЖЖ. де Местра, Н. А. Бердяева и М. Хайдеггера», отталкиваясь от дискуссии о политических убеждениях М. Хайдеггера в связи с публикацией его «Черных тетрадей», отражающих изменения мировоззрения философа с 1934 по 1974 год, сопоставила его идеи и способ их выражения с творчеством ЖЖ. де Местра, также нередко оказывающегося в центре подобных споров. В свою очередь, Н. А. Бердяев, осмысляя события революции 1917 года в работе «Философия неравенства», называет де Местра своим учителем и разделяет многие его идеи. В докладе создана картография прочтения спорных для современного читателя произведений трех мыслителей.

Предметом рассмотрения в докладе Г.Н. Беляка (Санкт-Петербург) “„Подлежащее знает, а сказуемое позабыл“ (о стратегиях мифотворчества у Андрея Белого и Андрея Платонова)» были механизмы мифопорождения в романах «Петербург» и «Чевенгур». Докладчик опирался на герменевтические принципы Вяч. Иванова, прежде всего - на его определение мифа как «синтетического суждения, где подлежащему-символу придан глагольный предикат». Понятие предикации, лежащее в основе этого определения, было использовано для того, чтобы продемонстрировать диаметрально противоположную направленность мифотворческих усилий, предпринятых в двух произведениях.

Доклад Е. Д. Толстой (Израиль) «Проза Надежды Бромлей» был посвящен восстановлению литературной биографии Н. Н. Бромлей (1884-1966) - в 1930-1950-е годы маститого ленинградского театрального режиссера, литературное творчество которой было полностью забыто. Бромлей была в свое время близка к петербургскому кружку М. Матюшина и Е. Гуро, дебютировала «протофутуристическими» стихами и стихопрозой в 1911 году, а в 1917 году издала книгу новелл «Повести о нечестивых». Пореволюционные годы Бромлей посвятила Первой Студии МХАТ в Москве, где играла, режиссировала и для которой написала три пьесы. Позднее вышли еще две ее прозаические книги «Исповедь неразумных» (1927) и «Потомок Гаргантюа» (1930). 
Исследовательница находит в прозе Бромлей черты экспрессионизма. Разбирая рассказ «Из записок последнего бога», она также предполагает полемическое соревнование в нем с А. Франсом («Восстание ангелов») и заключает, что этот рассказ, где оккультные эпизоды перемежаются балаганными сценами и цирковыми фокусами, мог быть в числе претекстов «Мастера и Маргариты».

В докладе Д. К. Баранова (Великий Новгород) «Цикл С. Д. Довлатова „Чемодан“: рассказы не о предметах» было продемонстрировано, как резкие смены темы и большое количество отступлений «тормозят» развитие основной сюжетной линии цикла. Рассказываемые истории почти никогда не ведут к получению предмета, вынесенного в заглавие, что нарушает выстраивающуюся схему ожиданий читателя, который, однако, как раз благодаря усложненной «обманчивой» речи повествователя получает эстетическое удовольствие. Так на уровне организации повествования реализуется установка, определяющая и логику построения изображенного мира: какой бы абсурдной ни казалась жизнь, она сама собой наладится, даст человеку ровно то, что нужно.

В своем выступлении «Эволюция эволюционной фантастики во второй половине XX начале XXI века» Л. Д. Бугаева (Санкт-Петербург) обратилась к теме евгеники в утопической и фантастической литературе, основные варианты которой были обозначены Г. Уэллсом в «Острове доктора Моро» и «Современной утопии». После «затишья», последовавшего за расцветом эволюционной фантастики в дореволюционный и ранний советский период, в 1960-1970-е годы происходит ее «второе рождение» (братья Стругацкие, А. Днепров, И. Варшавский, Р. Подольный и др.), а в конце XX начале XXI века тема улучшения природы человека получает новый поворот (C. Лукьяненко, А. Столяров и др.): в фокусе внимания оказывается генетическая инженерия в эпоху становления «новой евгеники» - очередной попытки ускорить эволюционный процесс.
Помимо пленарных и секционных заседаний, в рамках конференции был проведен Круглый стол "Антропонимы в языке и культуре XVIII века». На нем были заслушаны сообщения: "Антропонимы в журнале „Вечера“” О. И. Балакерской (Санкт-Петербург), «Имя в художественном тексте классической эпохи (варианты семантических трансформаций)» П. Е. Бухаркина (Санкт-Петербург), «Имя в когнитивном, деривационном и диахроническом аспекте (на материале риторических трактатов XVIII века)» С. С. Волкова (Санкт-Петербург), «Проблемы статистического описания личных имен в поэзии А. П. Сумарокова» Н. А. Гуськова (Санкт-Петербург), «Антропонимы в грамматических текстах первой половины XVIII века» Н. В. Каревой (Санкт-Петербург), «Антропонимы и поэтика русской торжественной оды» Е. М. Матвеева (Санкт-Петербург), «От исторической личности к образу (на материале антропонимов у Г. Р. Державина)» М. В. Пономаревой (Санкт-Петербург), «Динамика притяжательных прилагательных (на материале сочинений по истории России)» Д. В. Руднева (Санкт-Петербург), «Герои Н. М. Карамзина: жизнь имени в произведении» А. Ю. Тираспольской (Санкт-Петербург), «Антропонимы в панегирическом творчестве Феофана Прокоповича» А. Е. Трофимова (Санкт-Петербург), «Имена легендарных исторических героев в произведениях М. В. Ломоносова: проблемы культурно-исторического комментирования» М. Г. Шарихиной (Санкт-Петербург).

Прошедшая конференция продемонстрировала продуктивность научных подходов, так или иначе связанных с традициями российского академического литературоведения, основы которых были заложены многими поколениями ученых, связанных с кафедрой русской литературы Петербургского университета.

(C) E. Н. Григорвева, () A. A. Kapnoв, (C) H. A. Kapnoв

DOI: 10.31860/0131-6095-2020-3-269-272

\section{МЕЖДУНАРОДНЫЙ БАЛТИЙСКИЙ СЕМИНАР «ГЕОРГИЙ АДАМОВИЧ И... (К ПРОБЛЕМЕ ИЗУЧЕНИЯ КУЛЬТУРЫ РУССКОЙ ДИАСПОРЫ)»}

7-8 ноября 2019 года на факультете Гуманитарных наук Латвийского университета в научно-исследовательском центре Русистики прошел очередной международный Балтийский семинар «Георгий Адамович и... (к проблеме изучения культуры русской диаспоры)» . Семинар в Риге, в работе которого приняли участие специалисты из Латвии, Эстонии,
Литвы, России и Венгрии, вызвал интерес среди студентов, преподавателей вузов и гимназий, латвийской общественности.

В приветственном слове на открытии семинара декан факультета И. Карапетян отметила, что научные чтения проходят в год столетия Латвийского университета. Декан дала высокую оценку научно-исследовательским 
инициативам центра Русистики и подчеркнула особую роль нынешнего семинара, посвященного одной из центральных фигур русской культуры за рубежом, известному поэту, критику и эссеисту, вдохновителю «парижской ноты» и преподавателю литературы во Франции и США Георгию Викторовичу Адамовичу (1892-1972).

Директор академической университетской библиотеки В. Коцере рассказала об архивных материалах и раритетных изданиях, хранящихся в фондах, о русской периодике в Латвии между двумя мировыми войнами и о научных мероприятиях, проводимых сотрудниками.

Диалогичность проблематики, заявленной в заглавии семинара, проявилась в большинстве выступлений, где связывались такие тематические блоки, как Адамович и культура диаспоры, Адамович и советская литература, Адамович - между культурой Серебряного века и Русским Зарубежьем, Адамович и послевоенная литература. Представленные на семинаре сюжеты, актуальные по своей проблематике, так или иначе соприкасаются с ходом работы над 18-томным Собранием сочинений литератора в московском издательстве «Дмитрий Сечин».

Вопросы издательской практики, архивных изысканий и научного комментария вписались в диапазон исследовательских стратегий докладчиков, выступивших в первый день.

О. А. Коростелев (Москва) открыл пленарную секцию докладом «Творческое наследие Адамовича (архивы, библиография, научная эдиция)», в котором были подведены итоги сделанного в области текстологии, издательских практик и в обзоре архивов, где сосредоточено критико-публицистическое и эпистолярное наследие выдающегося эссеиста, а также были определены роль и значение Адамовича в довоенный и послевоенный периоды его деятельности. Особый интерес слушателей был вызван информацией о новых, доселе неизвестных текстах критика, способах их идентификации и проблемах научного комментирования.

Значимыми наблюдениями поделилась с собравшимися В. Н. Терехина (Москва), предложив тему «...,,какой-то новый Гоголь!“ (Адамович о Маяковском)». В докладе доказывалась необходимость всестороннего изучения критики Русского Зарубежья в отношении Маяковского, который привлекал особое внимание эмиграции как олицетворение русского футуризма и как приверженец советской власти. Среди более чем 200 посвященных Маяковскому статей, рецензий, заметок в эмигрантских изданиях почти пятая часть принадлежит Адамовичу. Основываясь на впечатлениях от выступлений Маяковского, Адамович выделял такие свойства его поэзии, как «прекрасный, меткий, сухой, точный - настоящий язык поэта», «ритмический размах», «зоркость глаза», метафорическое богатство. Наиболее ценное в творчестве Маяковского, по мнению Адамовича, - его сатирический пафос: «Решительно, это какой-то новый Гоголь, которому не удается ничего „положительного“». Критик убежден в «равноценности сатирических и вос- торженных страниц» Маяковского. Его суждения во многом позволили поэту оставаться в культурном пространстве эмиграции.

В докладе Т. С. Царьковой (Санкт-Петербург) были представлены новые архивные материалы из личного фонда поэта второй волны эмиграции Д. И. Кленовского, позволяющие сделать дополнения к творческой и личностной судьбе литератора. Фонд Рукописного отдела ИРЛИ включает рукописи Кленовского, большой объем иконографии, мемориальные вещи, рисунки его родителей И. Е. и В. Н. Крачковских, отклики рецензентов, некрологические публикации и многие другие документы, расширяющие наши знания о «настоящем мастере, требовательном, <...> в поэтическом складе которого есть что-то гумилевское: мужественность, стройность композиции, стойкость в раз навсегда принятой литературной позиции» (Адамович).

Г. Н. Боева (Санкт-Петербург) в докладе «Топос Финляндии у Леонида Андреева» исследовала роль геокультурного топоса Финляндия, с которой писатель был связан биографически и творчески последнее десятилетие своей жизни. Выступавшая остановилась на разных аспектах темы: восприятии Андреева в контексте романтико-модернистского комплекса $\mathrm{ce}$ вер и культа Ибсена, жизнетворчества («домостроительство» писателя на Черной Речке рассматривается как жизнестроительный проект в духе модерна), поэтики (в духе произведений финского периода Андреев обращается к локусу Финляндия, моделируя «фьордовое», замкнутое пространство).

Сюжет «Блок и Адамович (urbus в «Игле на ковре»)» представили М. Дёндёши (Венгрия) и Л. Спроге (Латвия). В докладе было замечено, что если в исследованиях о поэтическом творчестве Адамовича эта тема не раз становилась предметом внимания и детально разработана, то в эмигрантской прозе литератора акцент на этой проблеме почти не ставился. Вместе с тем, начиная с «анненской» доминанты о «новогоднем посыльном» с орхидеями, где «закамуфлирована» знаковая полисемия («Вы - БЛОК пивной осатанелый»), и кончая литературными ориентирами, сфокусированными на блоковской «Незнакомке», город в рассказе создан по принципу «реминисцентной поэтики», блоковский колорит «навеян» несколькими "рассказчиками», представляющими вариативные точки зрения на историософию «странных» событий.

П. М. Лавринец (Литва) в докладе «Виленские реплики 1930-х гг. на полемические выступления Адамовича» отметил, что в Вильно межвоенного периода были доступны парижские периодические издания, в которых сотрудничал Адамович («Иллюстрированная Россия», «Последние новости», «Числа»). Об этом свидетельствуют инвентарные книги библиотеки Виленского русского общества, перепечатки и обзоры в виленских газетах. Поэзия Адамовича кратко характеризовалась в обзоре П. Кацепельсона «Поэты „Чисел“» в журнале 
«Утес» (1931). Статья Адамовича «Незнакомка» была целиком перепечатана виленской газетой «Наше время» (1934). Статья С. И. Нальянча (Шовгенова) о неблагополучии в зарубежной русской поэзии и редакционное примечание в той же виленской газете (1934) содержат выписки из статьи Адамовича в «Последних новостях» за август 1932 года и упоминания более ранних полемик с его участием. Приведенные сведения говорят о высокой степени связности поля русской зарубежной литературы, при которой выступления критика в парижских изданиях находили отклики в его периферийных сегментах.

В докладе «Писатель Бубнов» Г. М. Утгоф (Эстония) рассмотрел персонажа романа «Подвиг» как аллюзию на берлинского друга Вл. Набокова И. С. Лукаша, хотя прототипичность Бубнова, как доказал выступающий, может восходить и к другим современникам писателя.

Р. С. Войтехович (Эстония) в докладе «Еще раз о „Цветнике“ Марины Цветаевой» представил принципы отбора цитат, их расположения и комментирования, а также приемы комизма, превращающие текст «Цветника» в художественный. Подробнее рассмотрена фитонимическая лексика, связь имени Цветаевой с лексемами «цветник», «цветок», «роза», термином «Victoria Regia», а также с идеями «антологии», «акмеизма» и т. д. «Цветник» приложение к статье «Поэт о критике» (1926), составленное из высказываний Адамовича, взятых из цикла «Литературные беседы», Цветаева ограничилась подшивкой «Звена» за 1925 год, но использовала не все статьи.

Тему «Одоевцева и Адамович, которого не было на берегах Невы» предложила Ю. В. Март (Эстония). Она рассмотрела образ Адамовича, созданный И. В. Одоевцевой в двух томах ее мемуаров. Книги сопоставляются по количеству упоминаний и особенности «появления» Адамовича в «дилогии». В первой книге Одоевцева не раскрывает характера Адамовича, но описывает его внешность, чего нет во второй. Целостный образ Адамовича складывается из материалов обеих книг. В докладе обсуждалось, почему российские эпизоды общения Одоевцевой с Адамовичем попали во вторую книгу «На берегах Сены», а также стратегия демифологизации образа Адамовича, сложившегося после его смерти.

А. А. Данилевский (Эстония) представил доклад «Адамович и Михаил Иванников (Вокруг «Дороги»)», в котором речь шла о том, как уязвленный сириновской (набоковской) карикатурой на себя Адамович решил принизить в глазах своих читателей автора «Дара» и даже заслонить его (выместив таким образом на периферию читательского сознания) автором печатавшейся в том же номере парижских «Современных записок» повести «Дорога», намеренно завышая при этом талант М. Иванникова и превознося его как своего рода «подлинного В. Сирина». И это в то время, когда Иванников всеми силами тщился не походить на Сирина (хотя и использовал в своей худо- жественной практике некоторые сириновские художественные находки). Комизм ситуации со временем еще более усугубился тем обстоятельством, что довольно скоро после того Адамович не только запамятовал фамилию пестуемого им «конкурента Сирину», но и напрочь утратил представление о его, Иванникова, творческой манере, настолько, что не смог атрибутировать следующий шедевр прозаика - необычайно заинтриговавший этого авторитетного критика рассказ «Правила игры».

А. А. Самарин (Эстония) посвятил выступление теме «Отзыв Г. В. Адамовича о творчестве С. А. Ауслендера», где проследил рецепцию критика на «превращения русских денди в работников на ниве коммунистического просвещения».

В докладе «Музыкант Набоков (о прототипе персонажа книги А. Ремизова «Учитель музыки»)» С. Н. Доценко (Эстония) попытался выяснить, кто у Ремизова является прототипом персонажа под именем «музыкант Набоков». Есть основания полагать, что ремизовский персонаж метит не только в композитора Н. Д. Набокова, но также и в другого известного Набокова - писателя В. В. Набокова (Сирина), отношение к которому на рубеже 19201930-х годов было у Ремизова неприязненным, в том числе после резко отрицательной рецензии Набокова на книгу «Звезда надзвездная» (1928).

И. 3. Белобровцева (Эстония) в докладе "Адамович - mortus и vivus» проследила, как Адамович, которого неоднократно упрекали в предельной субъективности суждений о литературе и делении литераторов на «своих" и "чужих», неожиданно демонстрирует глубокую эмпатию в отношении эстетически чуждого ему автора - представителя молодого поколения Русского Зарубежья Леонида Зурова. И если Набоков в романе «Дар» выбирает Адамовича для карикатурного образа Христофора Мортуса (в словаре Даля первое значение слова - «мертвый»), то в откликах на творчество Зурова можно усмотреть критика с «человеческим лицом», выполняющего функцию Мортуса как служителя при чумных, облегчающего болезнь (второе словарное значение слова). Причина тому - сочувствие писателю, настигнутому душевной болезнью.

Доклад Б. А. Равдина (Латвия) был посвящен молодому ленинградскому поэту Юрию Галю (1921-1947), призванному на фронт в первые месяцы Второй мировой войны, вскоре плененному и на фоне смертельных болезней готовому на любые репутационные издержки ради появления своих стихов на страницах любой печати, пусть и коллаборационистской.

В центре внимания Ю. Л. Сидякова (Латвия) была газета «День», издававшаяся в Риге в 1922 году при ближайшем сотрудничестве проф. К. И. Арабажина. Были представлены главные направления деятельности редакции: участие газеты в политической жизни Латвии 
(выходила в период выборов в 1-й Сейм Латвийской республики), а также публикации, посвященные литературным темам и культурной жизни.

В докладе Т. Е. Барышниковой (Латвия) «Поэзия М. Цветаевой в латышских переводах" на материале переводов, выполненных такими латышскими поэтами, как О. Вациетис, И. Зиедонис, В. Белшевица, А. Айпуриете, рассматривались различные стратегии передачи особенностей поэтических смыслов. Как правило, причиной отступления от оригинала является отсутствие лексического эквивалента в латышском языке. Это относится к переводу этноспецифической лексики, архаизмов, фразеологизмов, лексических единиц, обозначающих те или иные культурные реалии, а также авторских новообразований. Более художественный, тонкий и бережный подход представлен в тех случаях, когда переводчики выступали, прежде всего, как поэты, ведущие творческий диалог с Цветаевой.

И. Т. Народовская (Латвия) раскрыла тему «Адамович vs Вирза: переводы с французского языка». Адамович и латышский поэт, прозаик, публицист и переводчик Эдварт Вирза (18831940) занимались переводами французской поэзии примерно в одно время. В докладе особое внимание было уделено сравнительному анализу переводов стихотворения Ж⿱.-М. Эредиа «Раб», сделанных Адамовичем и Вирзой.

О. В. Проскурова-Тимофеева (Латвия) предложила тему «Издания для детей и юношества рижского акционерного общества „Са- ламандра“ в 1925-1926 гг.». В издательстве «Саламандра» выпускались учебные книги, детская литература, в которых актуализировались представления о родной стране и акцентировалась тема Родины. В силу того, что издания были адресованы разным целевым аудиториям: к детям из «старожильческих» семей, к детям-эмигрантам, проживающим в Латвии, к юным читателям русского рассеяния, проживающим вне Латвии, - можно отметить различные подходы к семантическому наполнению понятия родина. Это подтверждается при исследовании материалов из детского журнала «Юный читатель» под редакцией Л. Кормчего и Е. Андрусовой, из рубрики «Детский уголок» журнала «Перезвоны» (редакторы о. М. Бурнашев и И. Лукаш), а также из сборников для детей «Родина» и «Русь» (редактор о. М. Бурнашев) и из школьных учебников по родиноведению Н. Кузнецова.

При подведении итогов Балтийского семинара позитивно прозвучали отзывы о монотемности чтений, позволявших рассмотреть полифоничность проблем, сопровождающих перспективы изучения культуры Русского Зарубежья, и, как особый стимул при подготовке и выходе в свет многотомного Собрания сочинений, посвятить персональное научное заседание одному из ведущих литераторов своей эпохи - Г. В. Адамовичу.

() Л. В. Cnроге (Л (C) T. C. Цар вков

DOI: $10.31860 / 0131-6095-2020-3-272-274$

\section{МЕЖДУНАРОДНЫЙ НАУЧНО-ИССЛЕДОВАТЕЛЬСКИЙ СЕМИНАР «ИСТОРИЯ ТЕКСТА И ТВОРЧЕСКАЯ ИСТОРИЯ ПРОИЗВЕДЕНИЙ ДОСТОЕВСКОГО» *}

12 ноября 2019 года в Санкт-Петербурге, в Институте русской литературы (Пушкинский Дом) РАН состоялись научно-исследовательский семинар и круглый стол «История текста и творческая история произведений Достоевского». В них приняли участие ведущие специалисты по этим темам из ИРЛИ РАН, Санкт-Петербургского государственного университета, Литературно-мемориального музея Ф. М. Достоевского, Петрозаводского государственного университета, Киото университета (Япония).

* Хроника семинара подготовлена в рамках проекта Российского научного фонда «Рабочие тетради Ф. М. Достоевского: первая полнотекстовая публикация автографов в их динамической транскрипции» (№ 16-18-10034), ИРЛИ РАН.
Доклад Н. А. Тарасовой (Санкт-Петербург) «Проблемы лингвотекстологического из учения языка рукописных и печатных текстов Достоевского» был посвящен анализу рабочих тетрадей писателя 1870 -х годов - вопросам изучения синтаксиса рукописей и печатных текстов писателя, относящихся к указанному периоду. Применительно к рукописям получил обоснование комплексный подход, предполагающий одновременное изучение как собственно языковых характеристик источника, так и графических отличий записей. На ряде примеров было показано, что исследование особенностей начертания слова в совокупности с языковыми признаками позволяет установить смысловые ошибки чтения и воспроизведения рукописного текста в печати, в том числе уточнить прочтение имен собственных, с искажениями напечатанных в публикациях рукописного тек- 
ста. В выступлении получили также характеристику вопросы, связанные с изучением печатных текстов Достоевского. Это прежде всего проблема разграничения авторского и не принадлежащего автору при анализе языковых характеристик прижизненных изданий сочинений Достоевского, а также проблема разграничения «творческих" (вариантных) написаний и «нетворческих» (ошибок набора). Особое значение при решении названных вопросов имеет исследование рукописей Достоевского, дающее представление об особенностях языка и стиля автора, о предпочитаемых им написаниях, а также логико-семантический анализ разночтений между источниками текста.

В. Н. Захаров (Москва, Петрозаводск) в докладе «Синтаксис творческих записей и проблема авторской пунктуации Достоевского» отметил важную роль, которую играют в истории текста и творческой истории произведений Достоевского его рабочие тетради и записные книжки. В отличие от печатного текста они являют принципиально иной тип текста. Слова, словосочетания, оформленные и недооформленные предложения, абзацы, диалоги, каллиграфия, графика образуют сложное синтаксическое высказывание, новое сверхтекстовое единство. Современная пунктуация обедняет семантику рукописного текста. В эдиционной передаче рукописного текста недостаточно точек, запятых, точек с запятой, двоеточий, многоточий, вопросительных и восклицательных знаков, тире, кавычек и скобок разных типов. $K$ ним следует добавить ударения, строчные и прописные буквы, корректурные и индивидуальные знаки разметки текста, которые выступают в роли знаков препинания и обозначают границы предложений. Нужны дополнительные разделители текста (например, прямые, косые и вертикальные линии). Целесообразно графическое усложнение шрифтов и структуры печатного текста. Авторский синтаксис, пунктуация и орфография Достоевского функциональны, тщательно продуманы, и их следует бережно соблюдать.

В докладе Б. Н. Тихомирова (Санкт-Петербург) «Вновь о проблеме „другого“ Свидригайлова: (на материале рабочей тетради Ф. М. Достоевского 1866-1867 гг.)» был акцентирован вопрос о необходимости углубленной текстологической интерпретации трех взаимосвязанных набросков, записанных на с. 8,11 , 14 рабочей тетради 212.1.5. На протяжении 90 лет изучения рукописных материалов из этой тетради исследователи существенно поразному квалифицировали данную «триаду» набросков, то включая, то исключая их из корпуса подготовительных материалов к роману «Преступление и наказание». По-разному решается эта проблема и в двух изданиях академического Полного собрания сочинений Достоевского. Однако решение, принятое в новейшем втором исправленном и дополненном издании (2019), где впервые "триада» взаимосвязанных набросков была разделена и один из набросков оставлен в корпусе подготови- тельных материалов к «Преступлению и наказанию", а два других помещены в раздел неосуществленных замыслов, представляется упрощенным, обходящим существо проблемы. Особенно легковесным кажется данный в примечаниях текстологический комментарий к наброску на с. 14: «Отец, севастополец, все промотал...», - который, с одной стороны, обладает всеми признаками фиксации самостоятельного романного замысла с десятком действующих лиц, своим фабульным каркасом и оригинальной развязкой, а с другой - содержит имя Свидригайлова, героя, фигурирующего в романе «Преступление и наказание». Этому противоречию, требующему углубленного анализа как с учетом текстологического контекста указанной рабочей тетради Достоевского, так и в аспекте творческой истории первого романа из «великого пятикнижия», в примечаниях ко второму ПСС не уделено должного внимания. В докладе предпринята попытка решения этой сложнейшей текстологической проблемы.

С. А. Кибальник (Санкт-Петербург) в докладе «Записные книжки Достоевского, относящиеся к изданию журнала „Эпоха“» проанализировал материал трех записных книжек и одной рабочей тетради писателя. Показано, как в ряде случаев сопоставление их между собой в сочетании с изучением содержания этого журнала в 1863-1864 годах позволяет уточнить их текст. В свою очередь этот уточненный текст позволяет уточнить комментарий, а то и заново прокомментировать некоторые важные моменты из истории издания «Эпохи» братьями Достоевскими.

В докладе В. М. Димитриева (Санкт-Петербург) был предложен сопоставительный анализ источников главы «Бесов» «У Тихона» и продемонстрированы отдельные важные особенности ее творческой истории. С опорой на теоретические идеи Д. С. Лихачева, Ж.. Катто, А. Ковача, О. Ханзен-Лёве, касающиеся темпоральной организации романов Достоевского, рассмотрена исповедь «От Ставрогина». Выдвинуто предположение о том, что исповедальная ситуация в главе «У Тихона» типологически схожа с повествовательными принципами «Моего необходимого объяснения» Ипполита Терентьева (роман «Идиот»), «автобиографией» Аркадия Долгорукого, внутренней речью Рассказчика в «Кроткой». Все эти сюжетные ситуации в той или иной степени характеризуют «внутренняя потребность», сделавшая рассказ необходимым; воспоминание «на коротком приводе»; особая исповедальная установка, не предполагающая покаяние, а сконцентрированная на самом процессе рассказывания; аберрации памяти, связанные с разными формами вытеснения. В исповеди в главе «У Тихона» подробно рассмотрен следующий фрагмент. Уже после самоубийства Матреши, находясь во Франкфурте, Ставрогин покупает фотокарточку "одной девочки», которая напоминает ему Матрешу, а потом, уезжая, забывает ее забрать. Однако далее в этом же эпизоде Ставрогин прямо называет эту 
фотокарточку фотокарточкой самой Матреши. Фрагмент неизменен во всех вариантах главы, в то время как его «окружение» различно представлено в «Гранках" и «Списке» Анны Григорьевны. Знаковый для главы метонимический перенос с карточки «одной девочки» на карточку Матреши проанализирован с опорой на тексты «Гранок», «Списка» и «Подготовительных материалов» к роману «Бесы».

Программу второй половины дня составил круглый стол, посвященный проблемам цифровой текстологии проекта. Вниманию слушателей были предложены два доклада с презентациями, завершившиеся обсуждением.

В первом из них «Актуальные вопросы реализации проекта „Рабочие тетради Ф. М. Достоевского: первая полнотекстовая публикация автографов в их динамической транскрипции“» И. А. Мбого (Санкт-Петербург) отметила, что основной отличительной особенностью «Архива Достоевского» (www.dostoevskyarchive.ru) является публикация большого объема расшифрованных материалов. Ручной режим ввода данных при таких условиях занимает много времени и не представляется оптимальным, поэтому один из важных этапов публикации тетрадей - их предварительная обработка и пакетная загрузка на сайт. Результатом работы текстологов является единый файл на тетрадь в формате MSWord, на сайте каждая страница тетради публикуется в виде отдельной страницы в формате HTML и PDF в двух вариантах транскрипции: оригинальном и современном. Предварительная обработка позволяет разрезать большой файл на страницы и автоматически конвертировать их в форматы HTML и PDF. Хорошо известно, что при конвертации в HTML формат MSWord добавляет большое количество внутренней разметки, зависящей от версии программы и стиля работы автора, поэтому данный этап в основном направлен на очистку результата конвертации. Обработка исходных материалов проводится в MSW с применением встроенного скриптового языка VBScript. В дальнейшем эти файлы используются для пакетной загрузки страниц тетради на сайт.

В. В. Захаркина (Санкт-Петербург) выступила с докладом «Перспективы развития информационной базы проекта „Рабочие тетради Ф. М. Достоевского: первая полнотекстовая публикация автографов в их динамической транскрипции“». Она подчеркнула, что на сайте проекта реализован онлайн инструмент анализа и визуализации сущностей динамической транскрипции в соответствии с выбранным режимом просмотра расшифровки в формате HTML. В результате программного анализа текста с редакторской маркировкой создается HTML-разметка, обеспечивающая манипулирование элементами DOM (Document Object Model) на уровне языка описания стилей визуального отображения CSS (Cascading Stile Sheets) и языка сценариев JavaScript. Так, например, фрагменты, помеченные как вычеркнутые автором, могут быть оформлены перечеркнутым шрифтом либо скрыты; текст, дописанный автором, может быть выделен определенным цветом; редакторские пометы могут быть временно убраны из визуального представления. По умолчанию в выбранном типе расшифровки отображается редакторская разметка. Разработанный инструментарий имеет ряд режимов интерактивного отображения элементов транскрипции: редакторская разметка, цветовое/стилевое оформление транскрибированных элементов, временное скрытие редакторской разметки в зоне просмотра.

Участие в работе круглого стола, помимо докладчиков, приняли также И. И. Евлампиев (Санкт-Петербург) и Наохито Саису (Киото).

(C) C. A. Кибальник

DOI: $10.31860 / 0131-6095-2020-3-274-276$

\section{СИМПОЗИУМ «ЗАГАДКА В СРЕДНЕВЕКОВОЙ СЛАВЯНСКОЙ КУЛЬТУРЕ» В КЁЛЬНЕ}

14-16 ноября 2019 года Славистический институт при Кёльнском университете, один из ведущих академических центров в современной Германии, специализирующихся на изучении славянских языков и литератур, организовал международный симпозиум «Загадка в средневековой славянской культуре». ${ }^{1}$

${ }^{1}$ Программу конференции см.: http://www. slavistik.phil-fak.uni-koeln.de/enigma.html; дата обращения: 30.04.2020.
Инициатором мероприятия выступила доктор Агнес Криза, гумбольдтовский стипендиат и автор серии оригинальных научных трудов, касающихся разных аспектов русской средневековой эстетики. Согласно замыслу, вынесенное в название симпозиума слово «загадка» («enigma») участникам конференции предлагалось обсудить в самом широком диапазоне его значений, начиная от детской «головоломки» и кончая доступной немногим посвященным «мистерией». При всем различии кон- 
кретного материала, разбиравшегося докладчиками, его объединяла принадлежность к православной культуре средневековых славян. Симпозиум собрал наиболее авторитетных специалистов по византийскому и славянскому средневековому наследию - историков, филологов, философов, искусствоведов, представлявших разные научные школы. Междисциплинарный характер симпозиума, по замыслу организаторов, должен способствовать разрешению спорных проблем в истории древних славянских культур. Собрание открыл директор Славистического института профессор Даниэль Бунчич и доктор Агнес Криза, поблагодарившие всех, кто удостоил конференцию своим вниманием, и пожелавшие им плодотворной встречи.

Первым прозвучал доклад М. Ивановой (Великобритания) «Сокрытая истина: Чаша Соломона в Жиитии Константина-Кирилла и византийская интеллектуальная мысль IX века», в котором известный эпизод Жития рассматривается как пример свойственного эпохе патриарха Фотия отношения к мирской мудрости. П. Янева (Болгария) прочитала доклад «Соотношение терминов „загадка“, „тайна“ и „притча“ как ключевых слов в Изборнике Симеона», посвященный лексике так называемого Изборника Симеона-Святослава (старший список 1073 года), который представляет собой один из самых древних славянских переводов и восходит к византийской «вопросо-ответной» компиляции «Сотериос». В своем выступлении под названием «Загадки в апокрифической „Беседе трех святителей“» М. Г. Бабалык (Петрозаводск) поделилась результатами исследования, посвященного истории текста и художественной структуре памятника, жанр которого определяют как «Jоca monachorum» и который, хотя и восходит к греческому оригиналу, получил на русской почве новую жизнь. Краткие выступления были увенчаны более распространенной по форме и, как всегда, фундаментальной по содержанию лекцией Б. А. Успенского (Москва) «Никодимово евангелие и культ св. Лонгина». Лектор проследил возникавшие на протяжении веков вариации в восприятии образа Лонгина у адептов Восточной и Западной церкви, в лоне которых обнаруживаются по этому вопросу многозначительные расхождения.

Второе заседание началось с доклада «Словесные и визуальные загадки в русской средневековой иконографии" А. С. Преображенского (Москва), который представил два параллельных ряда - памятники древнерусской тайнописи, преимущественно XVI-XVII веков, и сообщения реципиенту, зашифрованные в древнерусской иконописи с помощью собственных средств изобразительного искусства. А. Криза (Германия) прочла доклад «Объясняя изображенное: Русские толкования к иконам», взяв в качестве примера толкования икон с изображением Софии, Премудрости Божией, и Христа, представленного «священником по чину Мелхиседека», и доказывая, что средне- вековая герменевтика не стремилась пролить свет на содержание аллегорических иконографических сюжетов. В докладе П. Майер (Германия) «Горящий уголь в видении Исайи: Восприятие и осмысление в поздней русской иконописи» рассматривалась взаимосвязь библейских пассажей (видения пророков Исайи и Иезекииля и предсказание Исайи о рождении Мессии), гимнографических текстов и толкований на литургию.

Третье заседание того же дня конференции началось с доклада «Легенды в процессе эволюции: Загадочная фигура в иконографии Рождества Христова» Д. И. Антонова (Москва), который регистрировал переосмысление персонажа, находящегося рядом с Иосифом Обручником на иконах с изображением Рождества Христова и превратившегося с течением времени в выходца из кромешного мира. М. В. Корогодина (Санкт-Петербург) в своем докладе «Славянские комментарии на Номоканон и сакрализация канонического права на Руси в конце XIII-XVI веках» показала, как переводной византийский Номоканон, оказавшись на русской почве, шаг за шагом утрачивал свою первоначальную функцию справочника по каноническому праву и, напротив, брал на себя по преимуществу символическую нагрузку. П. Хант (США) озаглавила свой доклад «Тайна и загадка креста в московской политической теологии" и продемонстрировала на материале программных памятников московской литературы и живописи середины XVI века, каким образом был использован в них воспринятый из византийского церемониала символ Животворящего Креста.

Второй день симпозиума (четвертое заседание) открылся докладом Р. Штихеля (Германия) «Доступ к Священному Писанию - он сложен, как лабиринт», в котором предлагалась интерпретация символа лабиринта, широко использовавшегося в христианской литературе и искусстве, в том числе в славянских памятниках; изображения лабиринта в некоторых рукописях помещены перед текстом библейских книг. Как явствует из названия доклада М. Димитровой (Болгария) "Христианская экзегеза, определяющая выбор средств выражения славянскими переводчиками", она доказывала, что средневековые переводчики были весьма придирчивы при использовании славянских эквивалентов к греческим терминам, отражавшим основы православной догматики. Как то было и в первый день, череду кратких докладов прервало выступление в иной жанровой форме. На сей раз лекцию «Тайна в ночи: толкования снов в славянских средневековых апокрифах" прочли А. Милтенова (Болгария) и А. Ангушева-Тиханова (Великобритания), привлекшие к сопоставлению серию переводных византийских памятников, в центре повествования которых стоят вещие сны и которые претерпели существенные изменения на славянской почве. 
Пятое заседание включало доклад Т. И. Афанасьевой (Санкт-Петербург), озаглавленный «Толкования на литургию в средневековых славянских источниках: символы и реальность» и суммирующий разыскания автора по поводу эволюции славянской терминологии, которая употреблялась для описания литургического действа, а также доклад Ф. Б. Успенского (Москва) «Культ святых и загадки имянаречения в допетровской Руси», автор которого показал трудности, подстерегающие историка антропонимики в связи с присущим русской традиции феноменом многоименности.

Шестое заседание началось с доклада А. М. Лидова (Москва) «Кавод-Докса: еврейская загадка в славянской церковной иконографии», который предложил собственную интерпретацию довольно распространенного элемента иконографических композиций, представляющего собой вращающийся диск («Слава Божия»). Далее последовал доклад И. А. Шалиной (Санкт-Петербург) «Загадочные мотивы на древнерусских иконах», причем слушателям были показаны нестандартные мотивы, сопровождающие разные иконографические сюжеты, в том числе Богоматерь Коневскую, Рождество Николая Чудотворца и др. Заседание завершилось докладом Дж. Вильсона (США) «Четыре добродетели Соломона в росписях Золотой палаты Ивана IV», в котором предлагалось соотнести изображение добродетелей с унаследованной от Византии семантикой образа царя Соломона, служившего там для прославления мудрости императора.

Седьмое и последнее заседание включало три доклада, из которых первый, «Загадка и загадочные явления в эпиграфике ранней Руси», прочли А. А. Гиппиус (Москва) и С. М. Михеев (Москва). Докладчики подвергли анализу граффити XI-XIII веков на стенах древнерусских храмов, представляющие собой либо загадки в прямом смысле слова, либо надписи, требующие от читающего определенных усилий для их понимания. Д. М. Буланин (СанктПетербург) в докладе «Тайнопись в восточнославянских рукописях конца XIV-XV веков» настаивал на понимании тайнописи как религиозно мотивированного явления, которое получило широкое распространение в русской письменности в связи с возникновением новых форм благочестия. Симпозиум завершился докладом В. Райэна (Великобритания) «Что представляли собой „Аристотелевы врата“, и почему они были под запретом?», где автор указал на необоснованность смешения гадательной книги "Аристотелевы врата» с известным средневековым компендиумом «Secretum Secretorum». Наконец, в дни симпозиума участники его могли познакомиться со стендовым докладом Л. Осинкиной (Великобритания) «Тайна магических поясов дочерей Иова: между словом и изображением» .

Каждый из докладов сопровождался оживленным обсуждением. Третий день мероприятия был отведен путешествию в Музей икон в Реклингхаузене, специальную экскурсию по этой богатейшей коллекции провела ее хранительница Ева Хауштайн-Бартш. В числе других редких экспонатов участники симпозиума увидели в подлиннике и загадочную икону «Распятый серафим», выбранную в качестве иконографической эмблемы кёльнской конференции.

() Д. М. Буланин 


\title{
SUMMARIES
}

\section{Петр Евгеньевич Бухаркин}

профессор Санкт-Петербургского государственного университета

\author{
Petr Yevgenyevich Bukharkin
}

Professor, St. Petersburg State University

p_bukharkin@hotmail.com

\section{Евгений Михайлович Матвеев}

доцент Санкт-Петербургского государственного университета

Evgeniy Mikhaylovich Matveev

Associate Professor, St. Petersburg State University

ematveev@list.ru

\author{
АНТРОПОНИМЫ В РУССКОЙ ЛИТЕРАТУРЕ ХVIII ВЕКА: \\ О НЕКОТОРЫХ АСПЕКТАХ ФУНКЦИОНИРОВАНИЯ ИМЕНИ \\ В ОДЕ И ТРАГЕДИИ
}

\section{ANTHROPONYMS IN THE EIGHTEENTH-CENTURY RUSSIAN LITERATURE: CERTAIN ASPECTS OF APELLATIVES' FUNCTIONALITY IN ODE AND TRAGEDY}

\begin{abstract}
В статье описано функционирование антропонимов в русской трагедии и торжественной оде XVIII века. Показано, как в тексте трагедий соотносятся имена действующих лиц и иные антропонимы, а также как тропологические замещения личного имени актуализируют тему рода. Были исследованы различные формы семантических преобразований личных имен и «антропонимическая формульность» русской торжественной оды, связанная с персонифицированным классицистическим сознанием.
\end{abstract}

Ключевые слова: антропоним, семантика, ода, трагедия, русская литература XVIII века.

The article describes the functioning of anthroponyms in the Russian $18^{\text {th }}$ century tragedies and laudatory odes. It underscores the correlation of the characters' names with the other anthroponyms in the texts of the tragedies, as well as the actualization of "the topic of genus» through the tropological substitutions of a personal name. Various forms of semantic transformations of personal names and the "anthroponymic formulaicity» of the Russian laudatory odes, associated with the personified classicistic mentality, are being investigated.

Key words: anthroponym, semantics, ode, tragedy, Russian literature of the $18^{\text {th }}$ century.

\section{Список литературы}

1. Абралзон T. E. Одический тезаурус антонимов, теонимов и топонимов (на материале 20-ти торжественных од М. В. Ломоносова). Магнитогорск, 2004.

2. Алексеева Н. Ю. Русская ода: Развитие одической формы в XVII-XVIII веках. СПб., 2005.

3. Арнольд И. В. Парадигма антропоцентризма, прагмалингвистика и стилистика декодирования // Арнольд И. В. Семантика. Стилистика. Интертекстуальность. СПб., 1999.

4. Арутюнян M. А. Структура, семантика и прагматика стилистического приема «антономазия» на материалах немецкого языка. Дис. ... канд. филол. наук. М., 2010. 
5. Бочаров С. Г. А мы, Леонтьева и Тютчева... Об одном стихотворении Георгия Иванова // Бочаров С. Г. Филологические сюжеты. М., 2007.

6. Бухаркин П. Е. Автор в трагедии классицизма (предварительные замечания) // Петербургский сборник. СПб., 1996. Вып. 2. Автор и текст / Под ред. В. М. Марковича и В. Шмида.

7. Бытева Т. И. Очерки по русской перифрастике: Монография. М., 2008.

8. Войнова Л. А. Функционально-семантические особенности мифологических собственных имен и показ их в историческом словаре XVIII в. // Проблемы исторической лексикографии / Отв. ред. Ю. С. Сорокин. Л., 1977.

9. Жирмунский В. М. Задачи поэтики // Жирмунский В. М. Теория литературы. Поэтика. Стилистика. Л., 1977.

10. Зинин С. И. Поэтическая ономастика (собственные имена в художественной литературе и фольклоре). Библиография литературы на русском языке 1905-2006 гг. // http://imja.name/ poehtonimy/poehtonimy.shtml.

11. Зорин А. Л. Появление героя: из истории русской эмоциональной культуры конца XVIII начала XIX века. М., 2016.

12. Ковалев $Г$. Ф. Библиография ономастики русской литературы по 2010 год. Воронеж, 2014.

13. Кузнеиов B. A. Поэтические уподобления в русской литературе XVIII в. (к вопросу о персонифицированности классицистического эстетического сознания) // Вестник СПбГУ. Сер. 2. 1993. Вып. 1. № 2.

14. Лолоносов М. В. Полн. собр. соч.: В 10 т. М.; Л., 1950-1983. Т. 7. Труды по филологии 1739-1758 гг.; Т. 8. Поэзия, ораторская проза, надписи, 1732-1764.

15. Лосев А. Ф. Проблема символа и реалистическое искусство. М., 1995.

16. Матвеев E. M. Антропонимы в торжественных одах М. В. Ломоносова и В. П. Петрова // Литературная культура России XVIII века. СПб., 2019. Вып. 8 / Под ред. П. Е. Бухаркина, Е. М. Матвеева.

17. Матвеев E. M. Оды В. П. Петрова и оды М. В. Ломоносова: словесная и ритмико-синтаксическая формульность // Вестник СПбГУ. Язык и литература. 2018. Т. 15. Вып. 3.

18. Михайлов А. В. Поэтика барокко: завершение риторической эпохи // Михайлов А. В. Языки культуры. М., 1997.

19. Петров В. П. Выбор Максима Амелина. М., 2016.

20. Подольская Н. В. Словарь русской ономастической терминологии. 2-е изд., перераб. и доп. М., 1988.

21. Проскурина В. Мифы империи. Литература и власть в эпоху Екатерины II. М., 2006.

22. Радищев А. Н. Ж Ките Федора Васильевича Ушакова // Радищев А. Н. Полн. собр. соч.: [В 3 т.]. М.; Л., 1938. Т. 1.

23. Сазонова Л. И. Имя в риторике и поэзии XVII века у восточных славян // Славяноведение. 2002. № 1.

24. Сулароков А. П. Драматические сочинения / Сост., вступ. статья и прим. Ю. В. Стенника. Л., 1990.

25. Сулароков А. П. Оды торжественныя. Елегии любовныя / Изд. подг. Р. Вроон. М., 2009.

26. Тредиаковский B. K. Сочинения и переводы как стихами, так и прозою / Изд. подг. Н. Ю. Алексеева. СПб., 2009 (сер. «Литературные памятники»).

27. Фонвизин Д. И. [В защиту «Начертания»] // Фонвизин Д. И. Собр. соч.: В 2 т. М.; Л., 1959.

28. Херасков M. М. Избр. произведения / Вступ. статья, подг. текста и прим. А. В. Западова. Л., 1964 (Библиотека поэта. Большая сер.).

29. Херасков М. М. Творения: В 12 ч. М., 1796-1803. Ч. 7.

30. Gagné R. Ancestral Fault in ancient Greece. Cambridge, 2013.

31. Keipert $H$. Nomen est omen. Etymologie als Denkform bei russischen Autoren des 17. Jahrhunderts // Sprache, Literatur und Geschichte der Altglaeubigen. Akten des Heidelberger Symposions vom 28. bis 30. April 1986 / Hrsg. von B. Panzer. Heidelberg, 1988.

32. Kyriakou P. The Past in Aeschylus and Sophocles. Berlin; Boston, 2011.

33. Namen in der russishen Literatur. Имена в русской литературе / Hrsg. von M. Freise. Wiesbaden, 2013 (Opera Slavica. Neue Folge. 57).

34. Ospovat K. Terror and Pity: Aleksandr Sumarovov and the Theater of Power in Elizabethan Russia. Boston, 2016.

35. Tverianovich K. Rhythm and Syntax in Aleksandr Sumarokov's Odes // Quantitative approaches to versification / Ed. by Petr Plecháč, Barry P. Scherr, Tatyana Skulacheva, Helena Bermúdez-Sabel, Robert Kolár. Prague, 2019.

\section{References}

1. Abramzon T. E. Odicheskii tezaurus antonimov, teonimov i toponimov (na materiale 20-ti torzhestvennykh od M. V. Lomonosova). Magnitogorsk, 2004. 2005.

2. Alekseeva N. Iu. Russkaia oda: Razvitie odicheskoi formy v XVII-XVIII vekakh. SPb., 
3. Arnol'd I. V. Paradigma antropotsentrizma, pragmalingvistika i stilistika dekodirovaniia // Arnol'd I. V. Semantika. Stilistika. Intertekstual'nost'. SPb., 1999.

4. Arutiunian M. A. Struktura, semantika i pragmatika stilisticheskogo priema "antonomaziia» na materialakh nemetskogo iazyka. Dis. ... kand. filol. nauk. M., 2010.

5. Bocharov S. G. A my, Leont'eva i Tiutcheva... Ob odnom stikhotvorenii Georgiia Ivanova // Bocharov S. G. Filologicheskie siuzhety. M., 2007.

6. Bukharkin P. E. Avtor v tragedii klassitsizma (predvaritel'nye zamechaniia)// Peterburgskii sbornik. SPb., 1996. Vyp. 2. Avtor i tekst / Pod red. V. M. Markovicha i V. Shmida.

7. Byteva T. I. Ocherki po russkoi perifrastike: Monografiia. M., 2008.

8. Fonvizin D. I. [V zashchitu «Nachertaniia»]// Fonvizin D. I. Sobr. soch.: V 2 t. M.; L., 1959.

9. Gagné R. Ancestral Fault in ancient Greece. Cambridge, 2013.

10. Keipert $H$. Nomen est omen. Etymologie als Denkform bei russischen Autoren des 17. Jahrhunderts // Sprache, Literatur und Geschichte der Altglaeubigen. Akten des Heidelberger Symposions vom 28. bis 30. April 1986 / Hrsg. von B. Panzer. Heidelberg, 1988.

11. Kheraskov M. M. Izbr. proizvedeniia / Vstup. stat'ia, podg. teksta i prim. A. V. Zapadova. L., 1964 (Biblioteka poeta. Bol'shaia ser.).

12. Kheraskov M. M. Tvoreniia: V 12 ch. M., 1796-1803. Ch. 7.

13. Kovalev G. F. Bibliografiia onomastiki russkoi literatury po 2010 god. Voronezh, 2014.

14. Kuznetsov V. A. Poeticheskie upodobleniia v russkoi literature XVIII v. (k voprosu o personifitsirovannosti klassitsisticheskogo esteticheskogo soznaniia) // Vestnik SPbGU. Ser. 2. 1993. Vyp. 1. № 2 .

15. Kyriakou P. The Past in Aeschylus and Sophocles. Berlin; Boston, 2011.

16. Lomonosov M. V. Poln. sobr. soch.: V 10 t. M.; L., 1950-1983. T. 7. Trudy po filologii 17391758 gg.; T. 8. Poeziia, oratorskaia proza, nadpisi, 1732-1764.

17. Losev A. F. Problema simvola i realisticheskoe iskusstvo. M., 1995.

18. Matveev E. M. Antroponimy v torzhestvennykh odakh M. V. Lomonosova i V. P. Petrova // Literaturnaia kul'tura Rossii XVIII veka. SPb., 2019. Vyp. 8 / Pod red. P. E. Bukharkina, E. M. Matveeva.

19. Matveev E. M. Ody V. P. Petrova i ody M. V. Lomonosova: slovesnaia i ritmiko-sintaksicheskaia formul'nost' // Vestnik SPbGU. Iazyk i literatura. 2018. T. 15. Vyp. 3.

20. Mikhailov A. V. Poetika barokko: zavershenie ritoricheskoi epokhi // Mikhailov A. V. Iazyki kul'tury. M., 1997.

21. Namen in der russishen Literatur. Imena v russkoi literature / Hrsg. von M. Freise. Wiesbaden, 2013 (Opera Slavica. Neue Folge. 57).

22. Ospovat K. Terror and Pity: Aleksandr Sumarovov and the Theater of Power in Elizabethan Russia. Boston, 2016.

23. Petrov V. P. Vybor Maksima Amelina. M., 2016. 1988.

24. Podol'skaia N. V. Slovar' russkoi onomasticheskoi terminologii. 2-e izd., pererab. i dop. M.

25. Proskurina V. Mify imperii. Literatura i vlast' v epokhu Ekateriny II. M., 2006.

26. Radishchev A. N. Zhitie Fedora Vasil'evicha Ushakova// Radishchev A. N. Poln. sobr. soch.: [V 3 t.]. M.; L., 1938. T. 1.

27. Sazonova L. I. Imia v ritorike i poezii XVII veka u vostochnykh slavian // Slavianovedenie. 2002. № 1 . L., 1990.

28. Sumarokov A. P. Dramaticheskie sochineniia / Sost., vstup. stat'ia i prim. Iu. V. Stennika.

29. Sumarokov A. P. Ody torzhestvennyia. Elegii liubovnyia / Izd. podg. R. Vroon. M., 2009.

30. Trediakovskii V. K. Sochineniia i perevody kak stikhami, tak i prozoiu / Izd. podg. N. Iu. Alekseeva. SPb., 2009 (ser. «Literaturnye pamiatniki»).

31. Tverianovich $K$. Rhythm and Syntax in Aleksandr Sumarokov's Odes // Quantitative approaches to versification / Ed. by Petr Plecháč, Barry P. Scherr, Tatyana Skulacheva, Helena Bermúdez-Sabel, Robert Kolár. Prague, 2019.

32. Voinova L. A. Funktsional'no-semanticheskie osobennosti mifologicheskikh sobstvennykh imen i pokaz ikh v istoricheskom slovare XVIII v. // Problemy istoricheskoi leksikografii / Otv. red. Iu. S. Sorokin. L., 1977.

33. Zhirmunskii V. M. Zadachi poetiki // Zhirmunskii V. M. Teoriia literatury. Poetika. Stilistika. L., 1977.

34. Zinin S. I. Poeticheskaia onomastika (sobstvennye imena v khudozhestvennoi literature i fol'klore). Bibliografiia literatury na russkom iazyke 1905-2006 gg. // http://imja.name/poehtonimy/ poehtonimy.shtml.

35. Zorin A. L. Poiavlenie geroia: iz istorii russkoi emotsional'noi kul'tury kontsa XVIII nachala XIX veka. M., 2016. 


\title{
Татьяна Николаевна Степанищева
}

научный сотрудник Отделения русской и славянской филологии Тартуского университета (Эстония)

Tatiana Nikolaevna Stepanishcheva

Researcher, Department of Slavic Studies, University of Tartu (Estonia) tatjana.stepanishcheva@ut.ee

\author{
ДЕБЮТ А. А. БЕСТУЖЕВА-ПРОЗАИКА \\ (К ХАРАКТЕРИСТИКЕ «МАРЛИНИЗМА»)
}

\author{
ALEXANDER BESTUZHEV AS A PROSAIC NARRATOR: \\ THE INITIAL POINT (TOWARDS THE CONCEPT MARLINISM)
}

Дебютная повесть А. А. Бестужева «Поездка в Ревель» традиционно рассматривается в контексте литературных «путешествий» и сопоставляется с «Письмами русского путешественника» Н. М. Карамзина и «Письмами об Италии» Дюпати. В настоящей статье представлена реинтерпретация «Поездки». Замысел повести связывается с переводной статьей Бестужева в «Сыне отечества» (1818). Стиль «Поездки» рассматривается как результат разных воздействий, ключевым является ориентация на устную речь и влияние ее индивидуальной манеры у Бестужева. В повести он конструировал специфический стиль, который стал его отличительным знаком и получил особое название.

Ключевые слова: А. А. Бестужев-Марлинский, «Поездка в Ревель», травелог, поэтика прозы, русский романтизм.

The first prose piece by Alexander Bestuzhev Journey to Revel is traditionally considered in the context of literary travelogues and compared with Nikolai Karamzin's Letters of the Russian Traveler and Dupaty's Lettres sur l'Italie en 1785. This article offers a reinterpretation of Journey to Rev$e l$. The outset of the story is connected with Bestuzhev's article published in the magazine Syn Otechestva (1818). The style of Journey to Revel is considered to be the result of various influences, the key one being the orientation on the oral speech and the influence of its individual style on Bestuzhev's works. In the novel, he designed a specific style, that became his distinctive mark and was given a special name.

Key words: Alexander Bestuzhev-Marlinski, Journey to Revel, travelogue, poetics of prose, Russian Romanticism.

\section{Список литературы}

1. [Б. п.]. [Рец. на:] Поездка в Ревель, сочинение А. Бестужева // Сын отечества. 1821. Ч. 73.

2. Базанов В. Очерки декабристской литературы: Публицистика. Проза. Критика. М., 1953.

3. Бестужев-Марлинский А. А. Повести и рассказы. М., 1976.

4. [Бестужев А.]. Поездка в Ревель / Сочинение А. Бестужева. СПб., 1821.

5. Бэгби Л. Александр Бестужев-Марлинский и русский байронизм. СПб., 2001.

6. Исаков С. Г. О «ливонских» повестях декабристов (К вопросу о становлении декабристского историзма) // Труды по русской и славянской филологии. VIII: Литературоведение. Тарту, 1965 (Учен. зап. Тартуского гос. ун-та; вып. 167).

7. Исаков С. Г. О ливонской теме в русской литературе $1820-1830$-х годов // Труды по русской и славянской филологии. III. Тарту, 1960 (Учен. зап. Тартуского гос. ун-та; вып. 98).

8. Исаков С. Г. Путь длиною в тысячу лет: Русские в Эстонии. История культуры. Таллинн, 2008. Ч. 1.

9. Канунова Ф. З. А. А. Бестужев-Марлинский и его «Кавказские повести» // БестужевМарлинский А. А. Кавказские повести. СПб., 1995.

10. Каралзин Н. М. Письма русского путешественника / Изд. подг. Ю. М. Лотман, Б. А. Успенский, Н. А. Марченко. Л., 1984 (сер. «Литературные памятники»).

11. Коварский Н. Ранний Марлинский // «Младоформалисты» : Русская проза / Сост. Я. Левченко. СПб., 2007.

12. Кулешов В. И. Александр Бестужев-Марлинский // Бестужев-Марлинский А. А. Соч.: В 2 т. М., 1981. Т. 1. Повести. Рассказы.

13. Лейтон Л. Г. Марлинизм: история одной стилистики // Russian Literature. 1975. № 12. 
14. Лотлан Ю. М., Успенский Б. А. «Письма русского путешественника» Карамзина и их место в развитии русской культуры // Карамзин Н. М. Письма русского путешественника. Л., 1984 (сер. «Литературные памятники»).

15. Письма Александра Александровича Бестужева к Н. А. и К. А. Полевым, писанные в 1831-1837 гг. // Русский вестник. 1861. № 4.

16. Письма Александра Бестужева к П. А. Вяземскому (1823-1825) / Публ. и комм. К. П. Богаевской; вступ. статья Н. Л. Степанова // Лит. наследство. 1956. Т. 60. Декабристы-литераторы. Кн. 1.

17. Полякова А. А. Творческая история «Поездки в Ревель» А. А. Бестужева // Русская литература. 2019. № 2 .

18. Полякова А. Опыты реконструкции творческих замыслов А. А. Бестужева-Марлинского. Выпускная квалификационная работа (рукопись). СПб., 2018.

19. Попытки братьев А. А. и М. А. Бестужевых издавать журнал (1818-1823 гг.) // Русская старина. 1900. Т. 103. Вып. 8.

20. Роболи Т. Литература «путешествий» // «Младоформалисты»: Русская проза / Сост. Я. Левченко. СПб., 2007.

21. Степанищева T. К истории «Поездки в Ревель» Александра Бестужева (цензура как двигатель авторского развития) // Идеологические контексты русской культуры XIX-XX вв. и поэтика перевода. Wien, 2016 (Wiener Slawistischer Almanach. Sbd. 93).

22. Степанов Н. Дружеское письмо начала XIX в. // «Младоформалисты»: Русская проза / Сост. Я. Левченко. СПб., 2007.

23. Шёнле А. Подлинность и вымысел в авторском самосознании русской литературы путешествий, 1790-1840. СПб., 2004.

24. Hellmann M. Ein bayerischer Diplomat als Geschichtsschreiber Livlands // Bayerische Akademie der Wissenschaften. Sitzungsberichte. H. 3. München, 1978.

25. Leighton L. G. Alexander Bestuzhev-Marlinsky. Boston, 1975.

\section{References}

1. [B. p.]. [Rets. na:] Poezdka v Revel', sochinenie A. Bestuzheva // Syn otechestva. 1821. Ch. 73.

2. Bazanov V. Ocherki dekabristskoi literatury: Publitsistika. Proza. Kritika. M., 1953.

3. Bestuzhev-Marlinskii A. A. Povesti i rasskazy. M., 1976.

4. [Bestuzhev A.]. Poezdka v Revel' / Sochinenie A. Bestuzheva. SPb., 1821.

5. Begbi L. Aleksandr Bestuzhev-Marlinskii i russkii baironizm. SPb., 2001.

6. Hellmann M. Ein bayerischer Diplomat als Geschichtsschreiber Livlands // Bayerische Akademie der Wissenschaften. Sitzungsberichte. H. 3. München, 1978.

7. Isakov S. G. O «livonskikh» povestiakh dekabristov (K voprosu o stanovlenii dekabristskogo istorizma) // Trudy po russkoi i slavianskoi filologii. VIII: Literaturovedenie. Tartu, 1965 (Uchen. zap. Tartuskogo gos. un-ta; vyp. 167).

8. Isakov S. G. O livonskoi teme v russkoi literature 1820-1830-kh godov // Trudy po russkoi i slavianskoi filologii. III. Tartu, 1960 (Uchen. zap. Tartuskogo gos. un-ta; vyp. 98).

9. Isakov S. G. Put' dlinoiu v tysiachu let: Russkie v Estonii. Istoriia kul'tury. Tallinn, 2008. Ch. 1.

10. Kanunova F. Z. A. A. Bestuzhev-Marlinskii i ego "Kavkazskie povesti»// Bestuzhev-Marlinskii A. A. Kavkazskie povesti. SPb., 1995.

11. Karamzin N. M. Pis'ma russkogo puteshestvennika / Izd. podg. Iu. M. Lotman, B. A. Uspenskii, N. A. Marchenko. L., 1984 (ser. «Literaturnye pamiatniki»).

12. Kovarskii N. Rannii Marlinskii // «Mladoformalisty»: Russkaia proza / Sost. Ia. Levchenko. $\mathrm{SPb}, 2007$.

13. Kuleshov V. I. Aleksandr Bestuzhev-Marlinskii // Bestuzhev-Marlinskii A. A. Soch.: V 2 t. M., 1981. T. 1. Povesti. Rasskazy.

14. Leighton L. G. Alexander Bestuzhev-Marlinsky. Boston, 1975.

15. Leiton L. G. Marlinizm: istoriia odnoi stilistiki // Russian Literature. 1975. № 12.

16. Lotman Iu. M., Uspenskii B. A. «Pis'ma russkogo puteshestvennika» Karamzina i ikh mesto v razvitii russkoi kul'tury // Karamzin N. M. Pis'ma russkogo puteshestvennika. L., 1984 (ser. «Literaturnye pamiatniki»).

17. Pis'ma Aleksandra Aleksandrovicha Bestuzheva k N. A. i K. A. Polevym, pisannye v 18311837 gg. // Russkii vestnik. 1861. № 4.

18. Pis'ma Aleksandra Bestuzheva k P. A. Viazemskomu (1823-1825) / Publ. i komm. K. P. Bogaevskoi; vstup. stat'ia N. L. Stepanova // Lit. nasledstvo. 1956. T. 60. Dekabristy-literatory. Kn. 1. 19. Poliakova A. A. Tvorcheskaia istoriia «Poezdki v Revel'» A. A. Bestuzheva // Russkaia literatura. 2019. № 2 .

20. Poliakova A. Opyty rekonstruktsii tvorcheskikh zamyslov A. A. Bestuzheva-Marlinskogo. Vypusknaia kvalifikatsionnaia rabota (rukopis'). SPb., 2018.

21. Popytki brat'ev A. A. i M. A. Bestuzhevykh izdavat' zhurnal (1818-1823 gg.) // Russkaia starina. 1900. T. 103. Vyp. 8. 
22. Roboli T. Literatura «puteshestvii» // «Mladoformalisty»: Russkaia proza / Sost. Ia. Levchenko. SPb., 2007.

23. Shënle A. Podlinnost' i vymysel v avtorskom samosoznanii russkoi literatury puteshestvii, 1790-1840. SPb., 2004.

24. Stepanishcheva T. K istorii "Poezdki v Revel'» Aleksandra Bestuzheva (tsenzura kak dvigatel' avtorskogo razvitiia) // Ideologicheskie konteksty russkoi kul'tury XIX-XX vv. i poetika perevoda. Wien, 2016 (Wiener Slawistischer Almanach. Sbd. 93).

25. Stepanov N. Druzheskoe pis'mo nachala XIX v. // «Mladoformalisty»: Russkaia proza / Sost. Ia. Levchenko. SPb., 2007.

\section{Наталия Николаевна Мазур}

профессор факультета истории искусств

Европейского университета в Санкт-Петербурге

\section{Nataliya Nikolaevna Mazur}

Professor, History of Arts Department, European University at Saint-Petersburg

nmazur@eu.spb.ru

\section{«ПОДОБИЕ ТОГО-СЕГО»: КОННОТАЦИИ ШАМПАНСКОГО В РУССКОЙ ПОЭЗИИ 1810-1830-х ГОДОВ}

\section{A SIMILE OF THIS AND THAT: CONNOTATIONS OF CHAMPAGNE IN THE RUSSIAN POETRY OF THE 1810s - 1830s}

Не только шампанское, но и его трактовка в русской поэзии 1810-1830-х годов имели французский провенанс: сатира Вольтера «Le Mondain» и ее перевод Д. О. Баранова заложили основной мотивный комплекс в описаниях шампанского. «Конъектура» Баранова, убравшего из текста Вольтера аналогию между шампанским и французским характером, побудила русских поэтов заполнять это зияние новыми сравнениями. Начавшееся между ними соревнование в поэтическом мастерстве привело к тому, что шампанское обзавелось шлейфом символических, политических и полемических коннотаций, расшифровке которых и посвящена эта статья.

Ключевые слова: шампанское, terroir, национальный характер, Аи и Бордо, «вино кометы», русская поэзия пушкинской эпохи.

Not only champagne, but also its descriptions in the Russian poetry of 1810 s -1830 s were French by their origin: Voltaire's satire Le Mondain and its translation by Dmitry Baranov provided the motif base for such descriptions. Baranov's decision to omit Voltaire's comparison between the French national character and champagne, encouraged Russian poets to introduce new analogies to fill the gap. Thanks to this competition in versification skills, champagne gained a wide spectrum of symbolic, political and poetic connotations, described in our article.

Key words: champagne, terroir, national character, Ay and Bordeau, "comet wine», Russian poetry of Pushkin's time.

\section{Список литературы}

1. Баратынский E. А. Полн. собр. стихотворений: В 2 т. / Ред., комм. и биографическая статья Е. Н. Купреяновой и И. Н. Медведевой. М.; Л., 1936 (Библиотека поэта. Большая сер.).

2. Боратынский E. А. Полн. собр. соч. и писем. М., 2012. Т. 3. Ч. 1. Стихотворения 18351844 годов / Ред. тома А. С. Бодрова, Н. Н. Мазур.

3. Бодрова A. С. Цензурная политика А. С. Шишкова и история пушкинских изданий 1825-1826 годов // Русская литература. 2019. № 3.

4. Виролайнен М. Н. Две чаши (О дружеском послании 1810-х годов) // Русские пиры. СПб., 1998 (Альманах «Канун»; вып. 3).

5. Вязелский П. А. Стихотворения / Вступ. статья Л. Я. Гинзбург; сост., подг. текста и прим. К. А. Кумпан. Л., 1988 (Библиотека поэта. Большая сер.).

6. Герштейн Э. Г., Ващуро В. Э. Заметки А. А. Ахматовой о Пушкине // Временник Пушкинской комиссии, 1970. Л., 1972. 
7. Давыдов Д. В. Стихотворения / Вступ. статья, сост., подг. текста и прим. В. Э. Вацуро. Л., 1984 (Библиотека поэта. Большая сер.).

8. Давыдов C. Между Аи и Бордо: политические взгляды Пушкина // Записки русской академической группы в США. New York, 2000. Т. 30 (1999-2000).

9. Дельвиг А. А. Соч. / Сост., вступ. статья и комм. В. Э. Вацуро. Л., 1986

10. Забозлаева Т. Б. «Вина кометы брызнул ток...». Шампанское в русской культуре XVIIIХХ веков. СПб., 2007.

11. Катенин П. А. Избр. произведения / Вступ. статья, подг. текста и прим. Г. В. Ермаковой-Битнер. М.; Л., 1965 (Библиотека поэта. Большая сер.).

12. Кюхельбекер В. К. Избр. произведения: В 2 т. / Вступ. статья, подг. текста и прим. Н. В. Королевой. М.; Л., 1967. Т. 1 (Библиотека поэта. Большая сер.).

13. Летопись жизни и творчества Е. А. Боратынского. 1800-1844 / Сост. А. М. Песков; подг. текста Е. Э. Ляминой, А. М. Пескова. М., 1998.

14. Лотлан Ю. М. Роман А. С. Пушкина «Евгений Онегин»: Комментарий. Пособие для учителя // Лотман Ю. М. Пушкин: Биография писателя; Статьи и заметки. 1960-1990; «Егений Онегин»: Комментарий. СПб., 1995.

15. Лямина Е. Э. Об одном жанровом следе в «Евгении Онегине» // Тыняновский сборник. М., 2009. Вып. 13.

16. Мазур H. Н. Поэтический диалог Пушкина и Языкова в середине 1820-х годов: новые перспективы // Пушкинские чтения в Тарту. Тарту, 2019. [Т.] 6. Вып. 1. Пушкин в кругу современников / Отв. ред. Р. Г. Лейбов, Н. Г. Охотин (Acta Slavica Estonica; XI).

17. Набоков В. Комментарий к роману А. С. Пушкина «Евгений Онегин». СПб., 1999.

18. Невский A. Я. Аи // Онегинская энциклопедия: В 2 т. / Под общ. ред. Н. И. Михайловой. M., 2004. T. 1.

19. Невский A. Я. Вдова Клико // Онегинская энциклопедия: В 2 т. / Под общ. ред. Н. И. Михайловой. М., 2004. Т. 1.

20. Невский A. Я. Моэт // Онегинская энциклопедия: В 2 т. / Под общ. ред. Н. И. Михайловой. М., 2004. Т. 2.

21. Невский A. Я. Шампанская бутылка // Онегинская энциклопедия: В 2 т. / Под общ. ред. Н. И. Михайловой. М., 2004. Т. 2.

22. Нечаева В. С. Из архива Боратынского. Остафьевский экземпляр сочинений Боратынского и история одного литературного мотива // Утренники. Пг., 1922. Кн. 1.

23. Поэты 1790-1810-х годов / Вступ. статья и сост. Ю. М. Лотмана; подг. текста М. Г. Альтшуллера; вступ. заметки, биографические справки и прим. М. Г. Альтшуллера и Ю. М. Лотмана. Л., 1971 (Библиотека поэта. Большая сер.).

24. Пушкин А. С. Полн. собр. соч.: В 16 т. М.; Л., 1937-1949. Т. 2. Кн. 1; Т. 3. Кн. 1; Т. 6 ; Т. 7.

25. Резанов $B$. К вопросу о влиянии Вольтера на Пушкина // Пушкин и его современники. Пг., 1923. Вып. 36.

26. Толашевский Б. В., Вольперт Л. И. Сталь // Пушкин: Исследования и материалы. СПб., 2004. Т. 18/19. Пушкин и мировая литература. Материалы к «Пушкинской энциклопедии». 1969.

27. Тынянов Ю. Н. Архаисты и Пушкин // Тынянов Ю. Н. Пушкин и его современники. М.,

28. Эдельлан O. «Счёт Давыдовым» (Эпизод из биографии поэта-партизана) // Россия / Russia. M., 1999. Вып. 3 (11). Культурные практики в идеологической перспективе: Россия, XVIII нач. ХХ века / Сост. Н. Н. Мазур.

29. Языков Н. М. Полн. собр. стихотворений / Ред., вступ. статья и комм. М. К. Азадовского. М.; Л., 1934. Вып. 1.

30. Языковский архив / Под ред. и с объяснительными прим. Е. В. Петухова. СПб., 1913.

31. Liapunov V. «La morale est dans la nature des choses»? // Russian Language Journal / Pycский язык. 1999. Vol. 53. № 174/176.

32. Musset B. Vignobles de Champagne et vins mousseux (1650-1830): Histoire d'un mariage de raison. Paris, 2008.

33. Parker T. Tasting French Terroir: The History of an Idea. University of California Press, 2015.

\section{References}

1. Baratynskii E. A. Poln. sobr. stikhotvorenii: V 2 t. / Red., komm. i biograficheskaia stat'ia E. N. Kupreianovoi i I. N. Medvedevoi. M.; L., 1936 (Biblioteka poeta. Bol'shaia ser.).

2. Bodrova A. S. Tsenzurnaia politika A. S. Shishkova i istoriia pushkinskikh izdanii 18251826 godov // Russkaia literatura. 2019. № 3 .

3. Boratynskii E. A. Poln. sobr. soch. i pisem. M., 2012. T. 3. Ch. 1. Stikhotvoreniia 18351844 godov / Red. toma A. S. Bodrova, N. N. Mazur.

4. Davydov D. V. Stikhotvoreniia / Vstup. stat'ia, sost., podg. teksta i prim. V. E. Vatsuro. L., 1984 (Biblioteka poeta. Bol'shaia ser.). 
5. Davydov S. Mezhdu Ai i Bordo: politicheskie vzgliady Pushkina // Zapiski russkoi akademicheskoi gruppy v SShA. New York, 2000. T. 30 (1999-2000).

6. Del'vig A. A. Soch. / Sost., vstup. stat'ia i komm. V. E. Vatsuro. L., 1986.

7. Edel'man O. «Schët Davydovym» (Epizod iz biografii poeta-partizana)// Rossiia / Russia. M., 1999. Vyp. 3 (11). Kul'turnye praktiki v ideologicheskoi perspektive: Rossiia, XVIII — nach. XX veka / Sost. N. N. Mazur.

8. Gershtein E. G., Vatsuro V. E. Zametki A. A. Akhmatovoi o Pushkine // Vremennik Pushkinskoi komissii, 1970. L., 1972.

9. Iazykov N. M. Poln. sobr. stikhotvorenii / Red., vstup. stat'ia i komm. M. K. Azadovskogo. M.; L., 1934 .

10. Iazykovskii arkhiv / Pod red. i s ob’iasnitel'nymi prim. E. V. Petukhova. SPb., 1913. Vyp. 1.

11. Katenin P. A. Izbr. proizvedeniia / Vstup. stat'ia, podg. teksta i prim. G. V. ErmakovoiBitner. M.; L., 1965 (Biblioteka poeta. Bol'shaia ser.).

12. Kiukhel'beker V. K. Izbr. proizvedeniia: V 2 t. / Vstup. stat'ia, podg. teksta i prim. N. V. Korolevoi. M.; L., 1967. T. 1 (Biblioteka poeta. Bol'shaia ser.).

13. Letopis' zhizni i tvorchestva E. A. Boratynskogo. 1800-1844 / Sost. A. M. Peskov; podg. teksta E. E. Liaminoi, A. M. Peskova. M., 1998.

14. Liamina E. E. Ob odnom zhanrovom slede v «Evgenii Onegine» // Tynianovskii sbornik. M., 2009. Vyp. 13.

15. Liapunov V. «La morale est dans la nature des choses»? // Russian Language Journal / Russkii iazyk. 1999. Vol. 53. № 174/176.

16. Lotman Iu. M. Roman A. S. Pushkina «Evgenii Onegin»: Kommentarii. Posobie dlia uchitelia // Lotman Iu. M. Pushkin: Biografiia pisatelia; Stat'i i zametki. 1960-1990; «Evgenii Onegin»: Kommentarii. SPb., 1995.

17. Mazur N. N. Poeticheskii dialog Pushkina i Iazykova v seredine 1820-kh godov: novye perspektivy // Pushkinskie chteniia v Tartu. Tartu, 2019. [T.] 6. Vyp. 1. Pushkin v krugu sovremennikov / Otv. red. R. G. Leibov, N. G. Okhotin (Acta Slavica Estonica; XI).

18. Musset $B$. Vignobles de Champagne et vins mousseux (1650-1830): Histoire d'un mariage de raison. Paris, 2008.

19. Nabokov V. Kommentarii k romanu A. S. Pushkina «Evgenii Onegin». SPb., 1999.

20. Nechaeva V. S. Iz arkhiva Boratynskogo. Ostaf'evskii ekzempliar sochinenii Boratynskogo i istoriia odnogo literaturnogo motiva // Utrenniki. Pg., 1922. Kn. 1.

21. Nevskii A. Ia. Ai // Oneginskaia entsiklopediia: V 2 t. / Pod obshch. red. N. I. Mikhailovoi. M., 2004. T. 1.

22. Nevskii A. Ia. Moet // Oneginskaia entsiklopediia: V 2 t. / Pod obshch. red. N. I. Mikhailovoi. M., 2004. T. 2.

23. Nevskii A. Ia. Shampanskaia butylka // Oneginskaia entsiklopediia: V 2 t. / Pod obshch. red. N. I. Mikhailovoi. M., 2004. T. 2.

24. Nevskii A. Ia. Vdova Kliko // Oneginskaia entsiklopediia: V 2 t. / Pod obshch. red. N. I. Mikhailovoi. M., 2004. T. 1. 2015 .

25. Parker T. Tasting French Terroir: The History of an Idea. University of California Press,

26. Poety 1790-1810-kh godov / Vstup. stat'ia i sost. Iu. M. Lotmana; podg. teksta M. G. Al'tshullera; vstup. zametki, biograficheskie spravki i prim. M. G. Al’tshullera i Iu. M. Lotmana. L., 1971 (Biblioteka poeta. Bol'shaia ser.). T. 7 .

27. Pushkin A. S. Poln. sobr. soch.: V 16 t. M.; L., 1937-1949. T. 2. Kn. 1; T. 3. Kn. 1; T. 6;

28. Rezanov V. K voprosu o vliianii Vol’tera na Pushkina // Pushkin i ego sovremenniki. Pg., 1923. Vyp. 36.

29. Tomashevskii B. V., Vol'pert L. I. Stal' // Pushkin: Issledovaniia i materialy. SPb., 2004. T. 18/19. Pushkin i mirovaia literatura. Materialy k «Pushkinskoi entsiklopedii». 1969.

30. Tynianov Iu. N. Arkhaisty i Pushkin // Tynianov Iu. N. Pushkin i ego sovremenniki. M.,

31. Viazemskii P. A. Stikhotvoreniia / Vstup. stat'ia L. Ia. Ginzburg; sost., podg. teksta i prim. K. A. Kumpan. L., 1988 (Biblioteka poeta. Bol'shaia ser.).

32. Virolainen $M$. N. Dve chashi (O druzheskom poslanii 1810-kh godov) // Russkie piry. SPb., 1998 (Al'manakh «Kanun»; vyp. 3).

33. Zabozlaeva T. B. «Vina komety bryznul tok...». Shampanskoe v russkoi kul’ture XVIII-XX vekov. SPb., 2007. 


\section{Алина Сергеевна Бодрова}

доцент Национального исследовательского университета «Высшая школа экономики»; научный сотрудник Института русской литературы (Пушкинский Дом) РАН

\section{Alina Sergeevna Bodrova}

Associate Professor, National Research University Higher School of Economics, Research Assistant, Institute of Russian Literature (Pushkinskij Dom), Russian Academy of Sciences

$$
\text { abodrova@hse.ru }
$$

\section{НЕИЗВЕСТНОЕ ПИСЬМО Е. А. БАРАТЫНСКОГО К А. И. ТУРГЕНЕВУ (К ИСТОРИИ ЛИТЕРАТУРНЫХ ОТНОШЕНИЙ)}

\section{E. A. BARATYNSKY'S UNPUBLISHED LETTER TO A. I. TURGENEV (TOWARDS THE HISTORY OF A LITERARY RELATIONSHIP)}

В статье проанализирован ряд эпизодов литературных отношений Е. А. Баратынского и А. И. Тургенева, демонстрирующих особенности их позиции в литературном поле 1820 -х первой половины 1830-х годов. Подробно реконструируя обстоятельства преподнесения Тургеневу дотиражного экземпляра «Стихотворений» 1835 года с опорой на неопубликованное письмо Баратынского, автор статьи также уточняет историю публикации этого сборника.

Ключевые слова: Е. А. Баратынский, А. И. Тургенев, социальная история литературы, литературные отношения.

The article focuses on the history of the literary exchange between E. A. Baratynsky and A. I. Turgenev, demonstrating their standings in the literary field of the $1820 \mathrm{~s}$ - the first half of the 1830s. Analyzing an unpublished letter by Baratynsky, the author offers a detailed reconstruction of the episode where the poet managed to present to Turgenev a pre-print copy of his Collected Poems (Stikhotvoreniia, 1835), and thus clarifies the publication history of this collection.

Key words: E. A. Baratynsky, A. I. Turgenev, social history of literature, literary exchange.

\section{Список литературы}

1. Арутюнова Б. ЗЖизнь в письмах. Княгиня Зинаида Волконская и ее корреспонденты. СПб., 2017.

2. Базанов В. Г. Ученая республика. М.; Л., 1964.

3. Бодрова А. С. Военная служба Е. А. Баратынского: между биографией и поэзией // Чины и музы: Сб. статей / Отв. ред. С. Н. Гуськов, ред. Н. В. Калинина. СПб.; Тверь, 2017.

4. Бодрова A. C. Несвоевременный сборник: «Стихотворения» 1835 года в литературной карьере Баратынского // Летняя школа по русской литературе. 2018. Т. 14. № 1. T. 2. Ч. 1 .

5. Боратынский E. А. Полн. собр. соч. и писем / Рук. проекта А. М. Песков. М., 2002. Т. 1;

6. Бурдье П. Поле литературы / Пер. с фр. М. Гронаса // Новое литературное обозрение. 2000. № 45 .

7. Вязелский П. А. Полн. собр. сочинений. СПб., 1883. Т. 8. Старая записная книжка.

8. Гиллельсон М. И. А. И. Тургенев и его литературное наследство // Тургенев А. И. Хроника русского. Дневники (1825-1826 гг.). М.; Л., 1964 (сер. «Литературные памятники»).

9. Евстифеева Р. А., Зареикий А. Р. Произведения Боратынского, читанные в собраниях Вольного общества любителей российской словесности // Боратынский Е. А. Полн. собр. соч. и писем. М., 2002. Т. 1.

10. Жуковский B. A. Полн. собр. соч. и писем: В 20 т. М., 2019. Т. 16

11. Зареикий A. Р., Песков А. М. История подготовки стихотворений Боратынского для изданий 1827, 1835 и 1842 гг. // Боратынский Е. А. Полн. собр. соч. и писем. М., 2002. Т. 1.

12. Ларионова E. О. Тургенев Александр Иванович // Русские писатели. 1800-1917. Биографический словарь. М.; СПб., 2019. Т. 6.

13. Летопись жизни и творчества Е. А. Боратынского / Сост. А. М. Песков; подг. текста Е. Э. Ляминой, А. М. Пескова. М., 1998.

14. Маркова А. И. Август Семен, типограф, словолитчик, издатель // Библиофилы России. M., 2008. T. 4. 
15. Мартыненко А. И. Е. А. Баратынский и «Ученая республика»: К истории формирования литературной репутации поэта // Пушкинские чтения в Тарту. Tartu, 2020. [Т.] 6. Вып. 2.

16. Модзалевский Б. Л. Август Иванович Семен. СПб., 1903.

17. Окслан Ю. Г. Стихотворения Евгения Боратынского в цензуре // Литературный музеум. Пг., 1922. Т. 1.

18. Осповат A. Л. Несколько справок о людях и текстах 1830-1840-х годов // Замечательное шестидесятилетие: Ко дню рождения Андрея Немзера. [M.,] 2017. Т. 1.

19. Остафьевский архив князей Вяземских. СПб., 1899. Т. 2; Т. 3.

20. Переписка А. И. Тургенева с П. А. Вяземским. Т. 1. 1814-1833 годы / Под ред. и с прим. Н. К. Кульмана. Пг., 1921 (Архив братьев Тургеневых; вып. 6).

21. Полн. собр. законов Российской Империи. 2-е собр. 1825-1881. СПб., 1830. Т. 3.

22. Светлов А. П. Об уникальном экземпляре «Стихотворений» Е. А. Баратынского 1833 г. // Книга: Исследования и материалы. М., 1984. Сб. 49.

23. Хитрова Д. М. Неизвестный стих Баратынского // Тыняновский сборник. М., 2006. Вып. 12. Десятые - Одиннадцатые - Двенадцатые Тыняновские чтения. Исследования. Материалы.

24. Цензоры Российской империи: Конец XVIII — начало XX века: Биобиблиографический справочник. СПб., 2013.

25. Der Briefwechsel zwischen Aleksandr I. Turgenev und Vasilij A. Žukovskij 1830-1845 / Hrsg. H. Siegel. Köln, 2018.

26. Markova A. Auguste-René Semen, imprimeur, éditeur et marchand-libraire parisien à Moscou // La France et les Français en Russie. Nouvelles sources, nouvelles approches (1815-1917). Paris, 2011.

\section{References}

1. Arutiunova B. Zhizn’v pis'makh. Kniaginia Zinaida Volkonskaia i ee korrespondenty. SPb., 2017.

2. Bazanov V. G. Uchenaia respublika. M.; L., 1964.

3. Bodrova A. S. Nesvoevremennyi sbornik: «Stikhotvoreniia» 1835 goda v literaturnoi kar'ere Baratynskogo // Letniaia shkola po russkoi literature. 2018. T. 14. № 1 .

4. Bodrova A. S. Voennaia sluzhba E. A. Baratynskogo: mezhdu biografiei i poeziei // Chiny i muzy: Sb. statei / Otv. red. S. N. Gus'kov, red. N. V. Kalinina. SPb.; Tver', 2017.

5. Boratynskii E. A. Poln. sobr. soch. i pisem / Ruk. proekta A. M. Peskov. M., 2002. T. 1; T. 2. Ch. 1.

6. Burd'e P. Pole literatury / Per. s fr. M. Gronasa // Novoe literaturnoe obozrenie. 2000. № 45.

7. Der Briefwechsel zwischen Aleksandr I. Turgenev und Vasilij A. Žukovskij 1830-1845/ Hrsg. H. Siegel. Köln, 2018.

8. Evstifeeva R. A., Zaretskii A. R. Proizvedeniia Boratynskogo, chitannye v sobraniiakh Vol'nogo obshchestva liubitelei rossiiskoi slovesnosti // Boratynskii E. A. Poln. sobr. soch. i pisem. M., 2002. T. 1.

9. Gillel'son M. I. A. I. Turgenev i ego literaturnoe nasledstvo // Turgenev A. I. Khronika russkogo. Dnevniki (1825-1826 gg.). M.; L., 1964 (ser. «Literaturnye pamiatniki»).

10. Khitrova D. M. Neizvestnyi stikh Baratynskogo // Tynianovskii sbornik. M., 2006. Vyp. 12. Desiatye - Odinnadtsatye - Dvenadtsatye Tynianovskie chteniia. Issledovaniia. Materialy.

11. Larionova E. O. Turgenev Aleksandr Ivanovich // Russkie pisateli. 1800-1917. Biograficheskii slovar'. M.; SPb., 2019. T. 6.

12. Letopis' zhizni i tvorchestva E. A. Boratynskogo / Sost. A. M. Peskov; podg. teksta E. E. Liaminoi, A. M. Peskova. M., 1998.

13. Markova A. Auguste-René Semen, imprimeur, éditeur et marchand-libraire parisien à Moscou // La France et les Français en Russie. Nouvelles sources, nouvelles approches (1815-1917). Paris, 2011.

14. Markova A. I. Avgust Semen, tipograf, slovolitchik, izdatel' // Bibliofily Rossii. M., 2008. T. 4.

15. Martynenko A. I. E. A. Baratynskii i «Uchenaia respublika»: K istorii formirovaniia literaturnoi reputatsii poeta // Pushkinskie chteniia v Tartu. Tartu, 2020. [T.] 6. Vyp. 2.

16. Modzalevskii B. L. Avgust Ivanovich Semen. SPb., 1903.

17. Oksman Iu. G. Stikhotvoreniia Evgeniia Boratynskogo v tsenzure // Literaturnyi muzeum. Pg., 1922. T. 1.

18. Ospovat A. L. Neskol'ko spravok oliudiakh i tekstakh 1830-1840-kh godov // Zamechatel'noe shestidesiatiletie: Ko dniu rozhdeniia Andreia Nemzera. [M.,] 2017. T. 1.

19. Ostaf'evskii arkhiv kniazei Viazemskikh. SPb., 1899. T. 2; T. 3.

20. Perepiska A. I. Turgeneva s P. A. Viazemskim. T. 1. 1814-1833 gody / Pod red. i s prim. N. K. Kul'mana. Pg., 1921 (Arkhiv brat'ev Turgenevykh; vyp. 6).

21. Poln. sobr. zakonov Rossiiskoi Imperii. 2-e sobr. 1825-1881. SPb., 1830. T. 3.

22. Svetlov A. P. Ob unikal'nom ekzempliare «Stikhotvorenii» E. A. Baratynskogo 1833 g. // Kniga: Issledovaniia i materialy. M., 1984. Sb. 49.

23. Tsenzory Rossiiskoi imperii: Konets XVIII - nachalo XX veka: Biobibliograficheskii spravochnik. SPb., 2013. 
24. Viazemskii P. A. Poln. sobr. sochinenii. SPb., 1883. T. 8. Staraia zapisnaia knizhka.

25. Zaretskii A. R., Peskov A. M. Istoriia podgotovki stikhotvorenii Boratynskogo dlia izdanii 1827, 1835 i 1842 gg. // Boratynskii E. A. Poln. sobr. soch. i pisem. M., 2002. T. 1.

26. Zhukovskii V. A. Poln. sobr. soch. i pisem: V 20 t. M., 2019. T. 16.

\section{Никита Глебович Охотин}

старший научный сотрудник

Института русской литературы (Пушкинский Дом) РАН

\section{Nikita Glebovich Okhotin}

Senior Researcher, Institute of Russian Literature (Pushkinskij Dom),

Russian Academy of Sciences

niglox49@gmail.com

\section{ИЗ КОММЕНТАРИЯ К «ПРИМЕТАМ» Е. А. БАРАТЫНСКОГО}

\section{FROM THE COMMENTARY TO E. A. BARATYNSKY'S OMENS}

В статье исследуются лексические рефлексы «Слова о полку Игореве» в позднем стихотворении Е. А. Баратынского «Приметы» (1839), а также концептуальная зависимость этого стихотворения от разбора «Слова» в печатных лекциях М. А. Максимовича (1836).

Ключевые слова: Е. А. Баратынский, М. А. Максимович, «Слово о полку Игореве» .

This article explores certain lexical echoes of the Tale of Igor's Campaign in a late-period poem by Evgeny Baratynsky Omens (1839), and the conceptual dependence of this poem on the analysis of the Tale of Igor's Campaign in the published lectures by M. A. Maksimovich (1836).

Key words: E. A. Baratynsky, M. A. Maksimovich, Tale of Igor's Campaign.

\section{Списоклитературы}

1. Альли И. Л. О поэзии и прозе. 2-е изд., доп. СПб., 2002.

2. Баратынский E. A. Приметы // Утренняя заря, альманах на 1840 год, изданный В. Владиславлевым. СПб., 1840.

3. Бестужев-Марлинский А. А. Кавказские повести / Изд. подг. Ф. З. Канунова. СПб., 1995 (сер. «Литературные памятники»).

4. Боратынский E. A. Полн. собр. соч. и писем / Рук. проекта А. М. Песков. М., 20022012. Т. 2. Ч. 1; Т. 3. Ч. 1.

5. Васильевский Д. Песнь Каменскому второму, написанная по получении известия о его кончине мая 1811 года // Чтение в Беседе любителей русского слова. СПб., 1813. Чтение 9-е.

6. Вельтман А. Ф. Кощей бессмертный, былина старого времени. Ч. І. М., 1833.

7. Виноградов В. В. Стиль Пушкина. М., 1941.

8. Виноградов В. В. Язык Пушкина. М.; Л., 1934.

9. Глинка Ф. Н. Зиновий Богдан Хмельницкий, или Освобожденная Малороссия // Предслава и Добрыня. Историч. повести рус. романтиков / Сост., вступ. ст. и коммент. В. Ю. Троицкого. М., 1986.

10. Гралматин Н. Ф. Слово о полку Игоревом, историческая поема, ... преложенная стихами древнейшего русского размера... М., 1823.

11. Гралмлатин Н. Ф. Надпись к портрету неизвестного сочинителя «Слова о полку Игоревом» // Поэты 1790-1810-х годов / Сост. и вступ. статья Ю. М. Лотмана; подг. текста М. Г. Альтшуллера. Л., 1971 (Библиотека поэта. Большая сер.).

12. Державин Г. Р. Соч. / Издание Императорской академии наук с объяснительными примечаниями Я. К. Грота. СПб., 1865-1866. Т. 2. Ч. 2; Т. 3. Ч. 3.

13. Длитриев Л. А. История первого издания «Слова о полку Игореве». Материалы и исследования. М.; Л., 1960.

14. Жуковский В. А. Полн. собр. соч. и писем: В 20 т. М., 2010. Т. 5. Эпические произведения / Под ред. А. С. Янушкевича.

15. Загорский М. П. Слава. Из Ламартина // Полярная звезда на 1824 год. СПб., 1823.

16. Иезуитова Р. В. ЖЖуковский и его время. Л., 1989. 
17. Ироическая песнь о походе на половцов удельного князя Новагорода-Северского Игоря Святославича, писанная старинным русским языком в исходе XII столетия с переложением на употребляемое ныне наречие. М., 1800.

18. K.-3.-кій. Ода на парение Орла над Российскими войсками при селе Бородине, в Августе 1812 // Сын отечества. 1812. 2-е изд. Ч. 1.

19. Капнист B. В. Собр. соч.: В 2 т. М.; Л., 1960. Т. 2. Переводы. Статьи. Письма / Ред., вступ. статья и прим. Д. С. Бабкина.

20. Каралзин Н. М. История государства Российского: В 12 т. М., 1991. Т. 2-3 / Под ред. В. Ю. Афиани, В. М. Жиивова, В. П. Козлова.

21. Козлов В. П. Кружок А. И. Мусина-Пушкина и «Слово о полку Игореве». Новые страницы истории древнерусской поэмы в XVIII веке. М., 1988.

22. Кюхельбекер В. К. Избр. произведения: В 2 т. М.; Л., 1967. Т. 1 / Подг. текста и прим. Н. В. Королевой (Библиотека поэта. Большая сер.). 1998.

23. Летопись жизни и творчества Е. А. Боратынского. 1800-1844 / Сост. А. М. Песков. М.,

24. Майков А. Н. Избр. произведения / Сост., подг. текста и прим. Л. С. Гейро; вступ. статья Ф. Я. Приймы. Л., 1977 (Библиотека поэта. Большая сер.).

25. Максилович М. А. О границах и переходах царств природы // Библиотека для чтения. 1834. Т. 1. Отд. III.

26. Максилович M. А. Песнь о полку Игореве, критический разбор из лекций о Русской Словесности, читанных 1835 года в Университете Св. Владимира. СПб., 1837.

27. Максилович М. А. Песнь о полку Игореве. Из лекций о Русской Словесности, читанных 1835 года в Университете Св. Владимира. Статьи 1-3 // Журнал Министерства народного просвещения. 1836. Ч. 10. Апрель, Июнь. Отд. II; 1837. Ч. 13. Январь. Отд. II.

28. Максилович-Албодик Н. [Избранные] Эмблемы и Символы / Вступ. статья и комм. А. Е. Махова. М., 1995.

29. Мерзляков А. Ф. Рассуждение о российской словесности в нынешнем ее состоянии // Труды Общества любителей российской словесности. 1812. Ч. 1.

30. Мерзляков A. Ф. О вкусе и его изменениях // Труды Общества любителей российской словесности. 1818. Ч. 10.

31. Милонов М. И. Сатиры, послания и другие мелкие стихотворения. СПб., 1819.

32. Надеждин Н. И. Соч.: В 2 т. / Под общ. ред. З. А. Каменского. СПб., 2000. Т. 1. Эстетика.

33. Палииын A. А. Игорь, героическая песнь. С древней славенской песни, писанной в XII веке. Харьков, 1807.

34. Песнь о полку Игореве, сложенная в конце XII века на древнем Русском языке / Изд. с пер. М. А. Максимовича. Киев, 1837.

35. Песнь об ополчении Игоря, сына Святославова, внука Олегова / Переложение Михаила де Ла Рю. Одесса, 1839.

36. Песнь ополчению Игоря Святославича, Князя Новгород Северского / Пер. А. Ф. Вельтмана. М., 1833.

37. Поход Игоря противу половцов, перевод в стихах русского склада / Пер. [И. И. Сирякова]. М., 1803.

38. Прийла Ф. Я. «Слово о полку Игореве» в русском историко-литературном процессе первой трети XIX в. Л., 1980.

39. Пушкин А. С. Полн. собр. соч.: В 20 т. СПб., 1999. Т. 1. Лицейские стихотворения. 18131817 / Под ред. В. Э. Вацуро.

40. Рейф Ш.-Ф. Русско-французский словарь, в котором русские слова расположены по происхождению, или Этимологический лексикон русского языка. СПб., 1836. Т. 2.

41. Рудакова С. В. Системность художественного мышления Е. А. Боратынского - лирика. Дис. ... докт. филол. наук. Магнитогорск, 2014.

42. Рылеев К. Ф. Полн. собр. соч. / Ред., вступ. статья и комм. А. Г. Цейтлина. М.; Л., 1934.

43. Словарь-справочник «Слова о полку Игореве»: В 6 вып. Л., 1984. Вып. 6.

44. Слово о полку Игореве. [Факсимильное воспроизведение первого изд. 1800 года] / Авторы сопроводительных статей и комм. Л. А. Дмитриев, Н. К. Гаврюшин, В. П. Гребенюк. М., 1988. 45. Тищенко В. И. В. А. ЖЖуковский и «Слово о полку Игореве» // Вопросы русской литературы. Львов, 1984. Вып. 2 (44).

46. Фризлан Л. Г., Лахно С. Н. М. А. Максимович - литератор. Харьков, 2003.

47. Холл Дж. Словарь сюжетов и символов в искусстве. М., 1999.

48. Шарлемань Н. В. Из реального комментария к «Слову о полку Игореве» // Труды Отдела древнерусской литературы. М.; Л., 1949. Вып. 6.

49. Шишков А. С. Примечания на древнее сочинение, называемое Ироическая песнь о походе на половцев или Слово о полку Игоревом // Сочинения и переводы, издаваемые Российской Академиею. СПб., 1805. Ч. 1.

50. Шишков А. С. Собр. соч. и переводов. СПб., 1825. Ч. 5.

51. Язвицкий Н. И. Игорь Святославич. Ироическая песнь // Чтение в Беседе любителей российской словесности. СПб., 1812. Чтение 6. 


\section{References}

1. Al'mi I. L. O poezii i proze. 2-e izd., dop. SPb., 2002.

2. Baratynskii E. A. Primety // Utrenniaia zaria, al'manakh na 1840 god, izdannyi V. Vladislavlevym. SPb., 1840.

3. Bestuzhev-Marlinskii A. A. Kavkazskie povesti / Izd. podg. F. Z. Kanunova. SPb., 1995 (ser. "Literaturnye pamiatniki»).

4. Boratynskii E. A. Poln. sobr. soch. i pisem / Ruk. proekta A. M. Peskov. M., 2002-2012. T. 2. Ch. 1; T. 3. Ch. 1.

5. Derzhavin G. R. Soch. / Izdanie Imperatorskoi akademii nauk s ob'iasnitel'nymi primechaniiami Ia. K. Grota. SPb., 1865-1866. T. 2. Ch. 2; T. 3. Ch. 3.

6. Dmitriev L. A. Istoriia pervogo izdaniia «Slova o polku Igoreve». Materialy i issledovaniia. M.; L., 1960 .

7. Frizman L. G., Lakhno S. N. M. A. Maksimovich - literator. Khar'kov, 2003.

8. Glinka F. N. Zinovii Bogdan Xmel'nitskii, ili Osvobozhdennaia Malorossiia // Predslava i Dobrynia. Istorich. povesti rus. romantikov / Sost., vstup. st. i komment. V. Iu. Troitskogo. M., 1986.

9. Grammatin N. F. Nadpis' k portretu neizvestnogo sochinitelia «Slova o polku Igorevom» // Poety 1790-1810-h godov / Sost. i vstup. stat'ia Iu. M. Lotmana; podg. teksta M. G. Al'tshullera. L., 1971 (Biblioteka poeta. Bol'shaia ser.).

10. Grammatin N. F. Slovo o polku Igorevom, istoricheskaia poema, ... prelozhennaia stikhami drevneishego russkogo razmera... M., 1823.

11. Iazvitskii N. I. Igor' Sviatoslavich. Iroicheskaia pesn’ // Chtenie v Besede liubitelei rossiiskoi slovesnosti. SPb., 1812. Chtenie 6.

12. Iezuitova R. V. Zhukovskii i ego vremia. L., 1989.

13. Iroicheskaia pesn' o pokhode na polovtsov udel'nogo kniazia Novagoroda-Severskogo Igoria Sviatoslavicha, pisannaia starinnym russkim iazykom v iskhode XII stoletiia s perelozheniem na upotrebliaemoe nyne narechie. M., 1800.

14. K. -Z. - kii. Oda na parenie Orla nad Rossiiskimi voiskami pri sele Borodine, v Avguste 1812 // Syn Otechestva. 1812. 2-e izd. Ch. 1.

15. Kapnist V. V. Sobr. soch.: V 2 t. M.; L., 1960. T. 2. Perevody. Stat'i. Pis'ma / Red., vstup. stat'ia i prim. D. S. Babkina.

16. Karamzin N. M. Istoriia gosudarstva Rossiiskogo: V 12 t. M., 1991. T. 2-3 / Pod red. V. Iu. Afiani, V. M. Zhivova, V. P. Kozlova.

17. Kholl Dzh. Slovar' siuzhetov i simvolov v iskusstve. M., 1999.

18. Kiukhel'beker V. K. Izbr. proizvedeniia: V 2 t. M.; L., 1967. T. 1 / Podg. teksta i prim. N. V. Korolevoi (Biblioteka poeta. Bol'shaia ser.).

19. Kozlov V. P. Kruzhok A. I. Musina-Pushkina i «Slovo o polku Igoreve». Novye stranitsy istorii drevnerusskoi poemy v XVIII veke. M., 1988.

20. Letopis' zhizni i tvorchestva E. A. Boratynskogo. 1800-1844 / Sost. A. M. Peskov. M., 1998.

21. Maikov A. N. Izbr. proizvedeniia / Sost., podg. teksta i prim. L. S. Geiro; vstup. stat'ia F. Ia. Priimy. L., 1977 (Biblioteka poeta. Bol'shaia ser.).

22. Maksimovich M. A. O granitsakh i perekhodakh tsarstv prirody // Biblioteka dlia chteniia. 1834. T. 1. Otd. III.

23. Maksimovich M. A. Pesn' o polku Igoreve, kriticheskii razbor iz lektsii o Russkoi Slovesnosti, chitannykh 1835 goda v Universitete Sv. Vladimira. SPb., 1837.

24. Maksimovich M. A. Pesn' o polku Igoreve. Iz lektsii o Russkoi Slovesnosti, chitannykh 1835 goda v Universitete Sv. Vladimira. Stat'i 1-3 // Zhurnal Ministerstva narodnogo prosveshcheniia. 1836. Ch. 10. Aprel', Iiun'. Otd. II; 1837. Ch. 13. Ianvar'. Otd. II.

25. Maksimovich-Ambodik N. [Izbrannye] Emblemy i Simvoly / Vstup. stat'ia i komm. A. E. Makhova. M., 1995.

26. Merzliakov A. F. O vkuse i ego izmeneniiakh // Trudy Obshchestva liubitelei rossiiskoi slovesnosti. 1818. Ch. 10.

27. Merzliakov A. F. Rassuzhdenie o rossiiskoi slovesnosti v nyneshnem ee sostoianii // Trudy Obshchestva liubitelei rossiiskoi slovesnosti. 1812. Ch. 1.

28. Milonov M. I. Satiry, poslaniia i drugie melkie stikhotvoreniia. SPb., 1819.

29. Nadezhdin N. I. Soch.: V 2 t. / Pod obshch. red. Z. A. Kamenskogo. SPb., 2000. T. 1. Estetika.

30. Palitsyn A. A. Igor', geroicheskaia pesn'. S drevnei slavenskoi pesni, pisannoi v XII veke. Khar'kov, 1807.

31. Pesn' o polku Igoreve, slozhennaia v kontse XII veka na drevnem Russkom iazyke / Izd. s per. M. A. Maksimovicha. Kiev, 1837.

32. Pesn' ob opolchenii Igoria, syna Sviatoslavova, vnuka Olegova / Perelozhenie Mikhaila de La Riu. Odessa, 1839.

33. Pesn' opolcheniiu Igoria Sviatoslavicha, Kniazia Novgorod Severskogo / Per. A. F. Vel'tmana. M., 1833.

34. Pokhod Igoria protivu polovtsov, perevod v stikhakh russkogo sklada / Per. [I. I. Siriakova]. M., 1803. 
35. Priima F. I. «Slovo o polku Igoreve» v russkom istoriko-literaturnom protsesse pervoi treti XIX v. L., 1980.

36. Pushkin A. S. Poln. sobr. soch.: V 20 t. SPb., 1999. T. 1. Litseiskie stikhotvoreniia. 18131817 / Pod red. V. E. Vatsuro.

37. Reif Sh.-F. Russko-frantsuzskii slovar', v kotorom russkie slova raspolozheny po proiskhozhdeniiu, ili Etimologicheskii leksikon russkogo iazyka. SPb., 1836. T. 2.

38. Rudakova S. V. Sistemnost' khudozhestvennogo myshleniia E. A. Boratynskogo - lirika. Dis. ... dokt. filol. nauk. Magnitogorsk, 2014.

39. Ryleev K. F. Poln. sobr. soch. / Red., vstup. stat'ia i komm. A. G. Tseitlina. M.; L., 1934.

40. Sharleman' N. V. Iz real'nogo kommentariia k «Slovu o polku Igoreve»// Trudy Otdela drevnerusskoi literatury. M.; L., 1949. Vyp. 6.

41. Shishkov A. S. Primechaniia na drevnee sochinenie, nazyvaemoe Iroicheskaia pesn' o pokhode na polovtsev ili Slovo o polku Igorevom // Sochineniia i perevody, izdavaemye Rossiiskoi Akademieiu. SPb., 1805. Ch. 1.

42. Shishkov A. S. Sobr. soch. i perevodov. SPb., 1825. Ch. 5.

43. Slovar'-spravochnik «Slova o polku Igoreve»: V 6 vyp. L., 1984. Vyp. 6.

44. Slovo o polku Igoreve. [Faksimil'noe vosproizvedenie pervogo izd. 1800 goda] / Avtory soprovoditel'nykh statei i komm. L. A. Dmitriev, N. K. Gavriushin, V. P. Grebeniuk. M., 1988.

45. Tishchenko V. I. V. A. Zhukovskii i «Slovo o polku Igoreve» // Voprosy russkoi literatury. L'vov, 1984. Vyp. 2 (44).

46. Vasil'evskii D. Pesn' Kamenskomu vtoromu, napisannaia po poluchenii izvestiia o ego konchine maia 1811 goda // Chtenie v Besede liubitelei russkogo slova. SPb., 1813. Chtenie 9-e.

47. Vel'tman A. F. Koshchei bessmertnyi, bylina starogo vremeni. Ch. I. M., 1833.

48. Vinogradov V. V. Iazyk Pushkina. M.; L., 1934.

49. Vinogradov V. V. Stil' Pushkina. M., 1941.

50. Zagorskii M. P. Slava. Iz Lamartina // Poliarnaia zvezda na 1824 god. SPb., 1823.

51. Zhukovskii V. A. Poln. sobr. soch. i pisem: V 20 t. M., 2010. T. 5. Epicheskie proizvedeniia / Pod red. A. S. Ianushkevicha.

\section{Наталия Викторовна Чернова}

старший научный сотрудник

Литературно-мемориального музея Ф. М. Достоевского в Санкт-Петербурге

\section{Nataliia Viktorovna Chernova}

Senior Researcher, Literary Memorial Museum of F. M. Dostoevsky in St. Petersburg chernova@dostoevsky.spb.ru

\section{«ЛЮБИТЕ ВЫ УЛИЧНОЕ ПЕНИЕ?»: ОСУЖДЕНИЕ РАСКОЛЬНИКОВА НАРОДНЫМ ХОРОМ}

\section{DO YOU LIKE STREET SINGING?: RASKOLNIKOV CONDEMNED BY THE CHOIR OF THE PEOPLE}

В романе «Преступление и наказание» народный голос и литературное почвенничество являются определяющими в авторской стратегии по отношению к герою-преступнику. Уже в первом выходе героя после преступления на Сенную площадь именно голос народа в двух его ипостасях, peлигиозно-этической и карнавально-площадной, выносит Раскольникову приговор и одновременно поддерживает его в поисках исхода («примкнуть опять к людям»), указывая путь к воскресению.

Ключевые слова: голос народа, литературное почвенничество, народная площадь, Ф. М. Достоевский, «Преступление и наказание» .

The article deals with one of the aspects of the novel Crime and Punishment, where the voice of the people and literary pochvennichestvo are decisive features of the author's strategy in relation to the criminal protagonist. Beginning with his very first arrival to Sennaya Square after the crime, the voice of the people in its two hypostases, religious-ethical and carnival-square, condemns him and at the same time supports him in his search for an outcome («join the people again»), chartering his way to resurrection.

Key words: voice of the people, literary pochvennichestvo, people’s square, F. M. Dostoevsky, Crime and Punishment. 


\title{
Список литературы
}

1. Даль В. И. Толковый словарь живого великорусского языка: В 4 т. М., 1989. Т. 1.

2. Григорович Д. В. Из литературных воспоминаний // Ф. М. Достоевский в воспоминаниях современников: В 2 т. М., 1990. Т. 1.

3. Достоевский Ф. М. Полн. собр. соч.: В 30 т. Л., 1972-1990.

4. Назиров Р. Г. Творческие принципы Ф. М. Достоевского. Саратов, 1982.

5. Пастернак Б. Л. Доктор ЖЖиваго // Пастернак Б. Л. Собр. соч.: В 5 т. М., 1990. Т. 3.

6. Тихолиров Б. Н. «Лазарь! Гряди вон»: Роман Ф. М. Достоевского «Преступление и наказание» в современном прочтении. Книга-комментарий. СПб., 2005.

\section{References}

1. Dal'V. I. Tolkovyj slovar' zhivogo velikorusskogo yazyka: V 4 t. M., 1989. T. 1.

2. Dostoevskij F. M. Poln. sobr. soch.: V 30 t. L., 1972-1990.

3. Grigorovich D. V. Iz literaturnyh vospominanij // F. M. Dostoevskij v vospominaniyah sovremennikov: V 2 t. M., 1990. T. 1.

4. Nazirov R. G. Tvorcheskie printsipy F. M. Dostoevskogo. Saratov, 1982.

5. Pasternak B. L. Doktor Zhivago // Pasternak B. L. Sobr. soch.: V 5 t. M., 1990. T. 3.

6. Tihomirov B. N. «Lazar'! Gr'iadi von»: Roman F. M. Dostoevskogo «Prestuplenie i nakazanie» v sovremennom prochtenii. Kniga-kommentarij. SPb., 2005.

\section{Всеволод Евгеньевич Багно}

научный руководитель

Института русской литературы (Пушкинский Дом) РАН; член-корреспондент РАН; профессор филологического факультета СПбГУ

\section{Vsevolod Ievgenievich Bagno}

Academic Director,

Institute of Russian Literature (Pushkinskij Dom), Russian Academy of Sciences; Corresponding Member, Russian Academy of Sciences; Professor, Department of Philology, St. Petersburg State University vsbagno@gmail.com

\section{ЯСНЫЕ ПОЛЯНЫ И ПЕТЕРБУРГСКИЕ УГЛЫ РОССИИ И РУССКОЙ ЛИТЕРАТУРЫ (ПРОГНОЗЫ И ПРОРОЧЕСТВА Э. ПАРДО БАСАН)}

\section{YASNIIE POLIANY AND PETERSBURG CORNERS \\ OF RUSSIA AND RUSSIAN LITERATURE (PROPHESIES AND PROGNOSTICATIONS OF E. PARDO BAZÁN)}

\begin{abstract}
Статья посвящена концепции русской литературы Э. Пардо Басан, сформулированной в ее книге «Революция и роман в России». Сочинение испанской писательницы рассматривается в контексте «пророческих» высказываний русских писателей XIX века о судьбе русского романа в Европе, а также работ ее предшественников и современников, прежде всего Э.-М. Вогюэ. Прослеживается перспектива восприятия русской литературы за рубежом в XX веке, предугаданная книгой Пардо Басан, отмечаются закономерности в ее сбывшихся и несбывшихся прогнозах, включая спор о Толстом и Достоевском.
\end{abstract}

Ключевые слова: Э. Пардо Басан, «Революция и роман в России», Э.-М. Вогюэ, русский роман, международные связи русской литературы, Ф. М. Достоевский, Л. Н. Толстой.

The article analyzes E. Pardo Bazán's concept of Russian literature, as formulated in her book La Revolución y la Novela en Rusia. The work of the Spanish female writer is considered in the context of the "prophetic» pronouncements of the Russian $19^{\text {th }}$-century writers regarding the fates of the Russian novel in Europe, as well as in the context of her predecessors' and contemporaries' writings, primarily those of E.-M. de Vogüé. The perspective of the perception of the Russian 
literature abroad in the $20^{\text {th }}$ century, as pre-chartered in Pardo Bazán's book, is traced, the patterns of her true and false prognostications are identified, including dispute over Tolstoy and Dostoevsky.

Key words: E. Pardo Bazán, La Revolución y la Novela en Rusia, E.-M. de Vogüé, Russian novel, International connections of Russian literature, F. M. Dostoevsky, L. N. Tolstoy.

\section{Список литературы}

1. Арсентьева Н., Морильяс Ж. Испанское достоевсковедение: истоки, итоги, перспективы // Достоевский. Материалы и исследования. СПб., 2013. Вып. 20.

2. Багно B. E. Пограничные культуры между Востоком и Западом // Багно В. Е. Россия и Испания: общая граница. СПб., 2006.

3. Багно В. Е. Эмилия Пардо Басан и русская литература в Испании. Л., 1982.

4. Валера Х. Письма из России. СПб., 2001.

5. Вогюэ Э.-М. Әе. Русский роман. Предисловие / Вступ. заметка П. Р. Заборова; пер. С. Ю. Васильевой под ред. П. Р. Заборова // К истории идей на Западе: русская идея. СПб., 2010.

6. Гоголь Н. В. Выбранные места из переписки с друзьями / Сост., вступ. статья и комм. В. А. Воропаева. М., 1990.

7. Достоевский. Ф. М. Полн. собр. соч.: В 30 т. Л., 1983. Т. 25.

8. Жид А. Переписка Достоевского // Русская классика: Pro et contra. Между Востоком и Западом. СПб., 2018.

9. Корконосенко $К$. Мигель де Унамуно и русская культура. СПб., 2002.

10. Ленин В. И. Л. Н. Толстой // Ленин В. И. Полн. собр. соч.: [В 55 т.] 5-е изд. М., 1973. Т. 20.

11. Пардо Басан Э. Из книги «Революция и роман в России» // К истории идей на Западе: русская идея. СПб., 2010.

12. Святополк-Мирский Д. П. История русской литературы с древнейших времен по 1925 год. Новосибирск, 2006. Т. 2.

13. Толстой или Достоевский? Философско-эстетические искания в культурах Востока и Запада. СПб., 2003.

14. Цвейг Cm. Полн. собр. соч.: [В 8 т.]. Л., 1929. Т. 7.

15. Clémessy N. Pardo Bazan, romancière. Paris, 1973.

16. Eugène-Melchior de Vogüé, le héraut du roman russe: Textes réunis et prés. par Michel Cadot. Paris, 1989 (Bibliothèque russe de l'Institut d'études slaves. T. 284).

17. Gallego Morell A. Estudios y textos ganivetianos. Madrid, 1971.

18. Icaza F. de. Doña Emilia Pardo Bazán y la novela en Rusia // El Sol. 1925. 28 de enero.

19. Pardo Bazán E. La Revolución y la novela en Rusia. Madrid, 1887.

20. Röhl M. «Le Roman russe» de Eugène-Melchior de Vogüé. Stockholm, 1976 (Acta Universitas Stockholmiensis. Studies in History of Literature; № 16).

21. Unamuno M. de. Obras completas. Madrid, 1966. T. IX.

22. Valera J. Con mjtivo de las novelas rusas. Carta a doña Emilia Pardo Bazán // Valera J. Obras completas. Madrid, 1949. T. 2.

23. Vogüé E.-M. Le roman russe. Paris, 1886.

\section{References}

1. Arsent'eva N., Moril'ias $Z$ h. Ispanskoe dostoevskovedenie: istoki, itogi, perspektivy // Dostoevskii. Materialy i issledovaniia. SPb., 2013. Vyp. 20.

2. Bagno V. E. Emiliia Pardo Basan i russkaia literatura v Ispanii. L., 1982.

3. Bagno V. E. Pogranichnye kul'tury mezhdu Vostokom i Zapadom // Bagno V. E. Rossiia i Ispaniia: obshchaia granitsa. $\mathrm{SPb}, 2006$.

4. Clémessy N. Pardo Bazan, romancière. Paris, 1973.

5. Dostoevskii F. M. Poln. sobr. soch.: V 30 t. L., 1983. T. 25.

6. Eugène-Melchior de Vogüé, le héraut du roman russe: Textes réunis et prés. par Michel Cadot. Paris, 1989 (Bibliothèque russe de l'Institut d'études slaves. T. 284).

7. Gallego Morell A. Estudios y textos ganivetianos. Madrid, 1971.

8. Gogol'N. V. Vybrannye mesta iz perepiski s druz'iami / Sost., vstup. stat'ia i komm. V. A. Voropaeva. M., 1990.

9. Icaza F. de. Doña Emilia Pardo Bazán y la novela en Rusia // El Sol. 1925. 28 de enero.

10. Korkonosenko K. Migel' de Unamuno i russkaia kul’tura. SPb., 2002.

11. Lenin V. I. L. N. Tolstoi // Lenin V. I. Poln. sobr. soch.: [V 55 t.] 5-e izd. M., 1973. T. 20.

12. Pardo Basan E. Iz knigi «Revoliutsiia i roman v Rossii» // K istorii idei na Zapade: russkaia ideia. SPb., 2010.

13. Pardo Bazán E. La Revolución y la novela en Rusia. Madrid, 1887.

14. Röhl M. «Le Roman russe» de Eugène-Melchior de Vogüé. Stockholm, 1976 (Acta Universitas Stockholmiensis. Studies in History of Literature; № 16). 
15. Sviatopolk-Mirskii D. P. Istoriia russkoi literatury s drevneishikh vremen po 1925 god. Novosibirsk, 2006. T. 2.

16. Tolstoi ili Dostoevskii? Filosofsko-esteticheskie iskaniia v kul’turakh Vostoka i Zapada. $\mathrm{SPb}, 2003$.

17. Tsveig St. Poln. sobr. soch.: [V 8 t.]. L., 1929. T. 7.

18. Unamuno M. de. Obras completas. Madrid, 1966. T. IX.

19. Valera J. Con mjtivo de las novelas rusas. Carta a doña Emilia Pardo Bazán // Valera J. Obras completas. Madrid, 1949. T. 2.

20. Valera Kh. Pis'ma iz Rossii. SPb., 2001.

21. Vogiue E.-M. de. Russkii roman. Predislovie / Vstup. zametka P. R. Zaborova; per. S. Iu. Vasil'evoi pod red. P. R. Zaborova // K istorii idei na Zapade: russkaia ideia. SPb., 2010.

22. Vogüé E.-M. Le roman russe. Paris, 1886.

23. Zhid A. Perepiska Dostoevskogo // Russkaia klassika: Pro et contra. Mezhdu Vostokom i Zapadom. SPb., 2018.

\title{
Мария Борисовна Плюханова
}

ординарный профессор Университета Перуджи (Италия)

\author{
Maria Borisovna Plyukhanova
}

Full Professor, University of Perugia, Department of Letters (Italy)

maria.plioukhanova@unipg.it

\section{О ЗНАЧЕНИИ ПАРАЛЛЕЛЬНЫХ СЦЕН И СКВОЗНЫХ МОТИВОВ В «СВЕРХРОМАНЕ» $Ф$. М. ДОСТОЕВСКОГО: ПОИСКИ МЕТОДА МЕЖДУ ИННОКЕНТИЕМ АННЕНСКИМ И «НОВОЙ КРИТИКОЙ»}

\section{ON THE MEANING OF PARALLEL SCENES AND CROSS-CUTTING MOTIVES \\ IN F. M. DOSTOEVSKY'S «SUPER-NOVEL»: THE SEARCH FOR A METHOD BETWEEN INNOKENTY ANNENSKY AND THE «NEW CRITICISM»}

\begin{abstract}
Статья опирается на мысль, по-разному сформулированную Вяч. Ивановым, П. М. Бицилли и другими о единстве пяти романов Достоевского. Выявляются особые сцены и детали, переходящие из одного романа в другой и занимающие важные позиции в структуре целого. Рассмотрены сцены с гробом, в котором лежит жертва - женское или детское тело; специальные меняющиеся значения и функции имеют цветы, муха, птицы. Такие сцены есть в Преступлении и наказании», «Идиоте», «Вечном муже», «Братьях Карамазовых». Соответствиями и контрастами между ними образуется единая композиция «большого романа» или «сверхромана».

Ключевые слова: романы Достоевского, имманентный анализ, «Новая критика», анализ
\end{abstract} сверхроманного единства, метод И. Анненского.

The article is based on the idea that five Dostoevsky's novels can be interpreted as one continuous text. This opinion has already been expressed by Vyacheslav Ivanov, Petr Bitsilli and others, in various frameworks. The article shows how certain scenes and details migrate from one novel to the other, gaining key positions in the novels' structure. Scenes involving a coffin with the body of a victim (a woman, a child), are analyzed: flowers, birds, a fly acquire different functions and meanings in such scenes in Crime and Punishment, The Idiot, The Eternal Husband, The Brothers Karamazov. The concept of one continuous work ("great novel», or «super-novel») takes shape through correspondences and contrasts between such images and details.

Key words: Dostoevsky's novels, immanent analysis, «New criticism», analysis of super-novel continuity, I. Annensky's method. 
Список литературы

1. Анненский И. Достоевский в художественной идеологии // Анненский И. Книги отражений. М., 1979.

2. Бел А. Л. Проблема вины // Бем А. Л. Достоевский. Психоаналитические этюды. Ann Arbor, 1983.

3. Бицилли П. К вопросу о внутренней форме романа Достоевского // Бицили Пьотр. Салимбене и Пушкин / Съставителство, предговор и бележки Галина Петкова. Варна: Електронно издателство LiterNet, 2004.

4. Бочаров С. Г. «Красавица мира»: Женская красота у Гоголя // Бочаров С. Г. Филологические сюжеты. М., 2007.

5. Гоголь Н. В. Вий // Гоголь Н. В. Полн. собр. соч.: [В 14 т.] М.; Л., 1937. Т. 2. Миргород.

6. Иванов В. И. Достоевский и роман-трагедия // Иванов В. И. Собр. соч.: В 4 т. Брюссель, 1987. T. 4.

7. Мережковский Д. С. Толстой и Достоевский. Вечные спутники. М., 1995.

8. Релизов А. М. Сияющая красота // Ремизов А. М. Собр. соч.: В 10 т. М., 2002. Т. 7.

9. Розанов Ю. В. «Вий» Н. В. Гоголя в оценке и интерпретации Алексея Ремизова // http:// domgogolya.ru/science/researches/927.

10. Belloli P. G. Fenomenologia della colpa: Freud, Heidegger, Dostoevskij. Milano, 2001.

11. Tate Al. Dostoevsky's Hovering Fly: A Causerie on the Imagination and the Actual World // The Sewanee Review. 1943. Vol. 51. № 3 .

\section{References}

1. Annenskii I. Dostoevskii v khudozhestvennoi ideologii // Annenskii I. Knigi otrazhenii. M., 1979.

2. Belloli P. G. Fenomenologia della colpa: Freud, Heidegger, Dostoevskij. Milano, 2001. bor, 1983 .

3. Bem A. L. Problema viny // Bem A. L. Dostoevskii. Psikhoanaliticheskie etiudy. Ann Ar-

4. Bitsilli P. K voprosu o vnutrennei forme romana Dostoevskogo // Bitsili P'otr. Salimbene i Pushkin / C'stavitelstvo, predgovor i belezhki Galina Petkova. Varna: Elektronno izdatelstvo LiterNet, 2004.

5. Bocharov S. G. "Krasavitsa mira»: Zpenskaia krasota u Gogolia // Bocharov S. G. Filologicheskie siuzhety. M., 2007.

6. Gogol' N. V. Vii // Gogol' N. V. Poln. sobr. soch.: [V 14 t.] M.; L., 1937. T. 2. Mirgorod.

7. Ivanov V. I. Dostoevskii i roman-tragediia // Ivanov V. I. Sobr. soch.: V 4 t. Briussel', 1987. T. 4.

8. Merezhkovskii D. S. Tolstoi i Dostoevskii. Vechnye sputniki. M., 1995.

9. Remizov A. M. Siiaiushchaia krasota // Remizov A. M. Sobr. soch.: V 10 t. M., 2002. T. 7.

10. Rozanov Iu. V. «Vii» N. V. Gogolia v otsenke i interpretatsii Alekseia Remizova // http:// domgogolya.ru/science/researches/927.

11. Tate Al. Dostoevsky's Hovering Fly: A Causerie on the Imagination and the Actual World // The Sewanee Review. 1943. Vol. 51. № 3 .

\section{Виктор Михайлович Димитриев}

младший научный сотрудник Института русской литературы (Пушкинский Дом) РАН; старший преподаватель Национального исследовательского университета «Высшая школа экономики» (Санкт-Петербург)

\section{Viktor Mikhailovich Dimitriev}

Junior Researcher,

Institute of Russian Literature (Pushkinskij Dom), Russian Academy of Sciences; Senior Lecturer, National Research University Higher School of Economics in St. Petersburg

ganthenbein@gmail.com

\section{«ДОСТОЕВСКИЙ» АНДРЕ ЖИДА В РУССКОМ ЗАРУБЕЖЬЕ DOSTOÏEVSKI BY ANDRÉ GIDE IN RUSSIA ABROAD}

В статье представлена история эмигрантской рецепции книги А. Жида «Достоевский», которая встраивается в более обширный сюжет борьбы за «своего» Достоевского в 1920-е годы, 
в ходе которой Достоевскому-идеологу противопоставлялся Достоевский-художник. Особенное внимание уделено рецепции идей Жћида в критических работах Б. Ф. де Шлёцера, В. В. Вейдле, Г. В. Адамовича и В. С. Варшавского.

Ключевые слова: Ф. М. Достоевский, А. Жид, русская эмиграция, Б. Ф. де Шлёцер, В. В. Вейдле, Г. В. Адамович, В. С. Варшавский, рецепция.

The article deals with the émigré reception of Dostoïevski (1923) by André Gide. The book became an instrument in the fight for Dostoevsky, which was ongoing in the interwar Russia Abroad. Dostoevsky as an ideologist set in opposition to Dostoevsky as an artist. The article focuses on the critical works by Boris de Schlözer, Vladimir Veidle, George Adamovich and Vladimir Varshavsky.

Key words: F. M. Dostoevsky, A. Gide, Russian emigration, B. F. de Schlözer, V. V. Veidle, G. V. Adamovich, V. S. Varshavsky, reception.

\section{Список литературы}

1. Адалович Г. В. Комментарии // Адамович Г. В. Собр. соч.: В 18 т. М., 2016. Т. 14. Комментарии (1967). Эссеистика 1923-1971.

2. Адалович $Г$. В. Люди и книги: Мережковский // Современные записки. 1934. Кн. LVI.

3. Баранова-Шестова Н. Жизнь Льва Шестова. Париж, 1983.

4. Бахтин М. М. Проблемы творчества Достоевского // Бахтин М. М. Собр. соч.: В 7 т. М., 2000. T. 2.

5. Белов С. В. Ф. М. Достоевский // Литературная энциклопедия русского зарубежья. 19181940. М., 2006. Т. 4. Всемирная литература и русское зарубежье.

6. Бердяев Н. А. Миросозерцание Достоевского <1923> // Бердяев Н. А. Философия творчества, культуры и искусства: В 2 т. М., 1994. Т. 2.

7. Бережков Ф. Ф. Достоевский на Западе (1916-1928) // Достоевский. Труды Государственной академии художественных наук. М., 1928.

8. Варшавский В. С. Несколько рассуждений об Андрэ Жиде и эмигрантском молодом человеке // Варшавский В. С. Ожидание: Проза, эссе, литературная критика. М., 2016.

9. Вейдле В. В. Европейские судьбы Достоевского // Возрождение. 1930.20 марта. № 1752.

10. Владилирова А. И. Достоевский во французской литературе XX века // Достоевский в зарубежных литературах / Ред. Б. Г. Реизов. Л., 1978.

11. Гачева А. Г. В поисках нового синтеза: Духовное наследие Ф. М. Достоевского и пореволюционные течения русской эмиграции 1920-1930-х годов // Достоевский и XX век: В 2 т. М., 2007. Т. 2.

12. Дудкин В. В. «Roman Dostoevskien» как новаторская форма жанра и термин (Достоевский во Франции в первой трети ХХ в.) // Достоевский. Материалы и исследования. СПб., 2013. Т. 20.

13. Жид А. Достоевский / Пер. с фр. А. В. Федорова // Жид А. Собр. соч.: В 7 т. М., 2002. Т. 6.

14. Мережковский Д. С. Речь на митинге в Сорбонне // Общее дело. 1921. 25 дек. № 525.

15. Мережковский Д. С. Федор Михайлович Достоевский. 1821-1921 // Руль. 1921. 11 нояб. № 300 .

16. Мочульский К. В. Андре Жиид <1927>// Мочульский К. В. Кризис воображения. Статьи. Эссе. Портреты. Томск, 1999.

17. Поплавский Б. Ю. По поводу... // Поплавский Б. Ю. Собр. соч.: В 3 т. М., 2009. Т. 3. Статьи. Дневники. Письма.

18. Русские эмигранты о Достоевском / Вступ. статья, подг. текста и прим. С. В. Белова. СПб., 1994.

19. Степун $\Phi$. А. Пореволюционное сознание и задача эмигрантской литературы $<1935>/ /$ Критика русского зарубежья: В 2 ч. М., 2002. Ч. 1 / Сост., предисловие, преамбулы, прим. О. А. Коростелева, Н. Г. Мельникова.

20. Фокин С. Л. Культ избирательного сродства в генезисе «Достоевского» Андре Жћида //

Фокин С. Л. Фигуры Достоевского во французской литературе ХХ века. СПб., 2013.

21. Шлёиер Б. де. Памяти Достоевского // Последние новости. 1921. 27 дек. № 521.

22. Шлёиер Б. Ф. Новейшая литература о Достоевском // Современные записки. 1923. Кн. XVII.

23. Яновский B. С. Челюсть эмигранта. Нью-Йорк, 1957.

24. Adamovitch G. André Gide // Le Studio Franco-Russe / Textes réunis et présentés par L. Livak; sous la rédaction de G. Tassis. Toronto, 2005 (Toronto Slavic library. Vol. 1).

25. Cadot $M$. Lectures stratifiée de Dostoïevsky par André Gide // Dostoevsky and the Twentieth Century / Ed. Malcolm V. Jones. Nottingham, 1993.

26. Fayer M. Gide, Freedom and Dostoevsky. Burlington, 1946.

27. Gide A. Essais critiques / Éd. de Pierre Masson. Paris, 1999 (Bibliotheque de la Pleiade).

28. Gide A. Journal. 1889-1939. Paris, 1951 (Bibliotèque de la Pléiade).

29. Livak L. How It was Done in Paris: Russian Émigré Literature and French Modernism. Madison, 2003.

30. Morard A. Varchavski, Gide, Dostoïevski: lectures croisées // Modèle de Gouvernement: ouvrage collectif. Lyon, 2011 (http://institut-est-ouest.ens-lsh.fr/spip.php?article294; дата обращения: 30.04 .2020$)$. 
31. Moutote D. Dostoïevski et Gide // Revue d’Histoire littéraire de la France. 1976. № 5.

32. Pozner V. L'âme slave et l'esprit gaulois // Nouvelles littéraires, artistiques et scientifiques. 1926. June 26. № 193.

33. Saggiomo C. Gide face à Dostoïevski, par-delà le mariage du Bien et du Mal. Montpellier, 2018. 34. Souday P. Le ceintenaire de Dostoïevsky // Le Temps. 1921. 29 déc. № 22062.

35. Suarès A. Centenaire de Dostoïevski // Les Écrits nouveaux. 1922. T. IX. № 1.

36. Tabachnikova O. Dialogues with Dostoevsky from Two Corners: Lev Shestov versus André Gide // New Zealand Slavonic Journal. 2008. Vol. 42.

37. Vacquier T. Dostojevski and Gide: A Comparison // The Sewanee Review. 1929. Vol. 37. № 4.

\section{References}

1. Adamovich G. V. Kommentarii // Adamovich G. V. Sobr. soch.: V 18 t. M., 2016. T. 14: Kommentarii (1967). Esseistika 1923-1971.

2. Adamovich G. V. Liudi i knigi: Merezhkovskii // Sovremennye zapiski. 1934. Kn. LVI.

3. Adamovitch G. André Gide // Le Studio Franco-Russe / Textes réunis et présentés par L. Livak; sous la rédaction de G. Tassis. Toronto, 2005 (Toronto Slavic library. Vol. 1).

4. Bakhtin M. M. Problemy tvorchestva Dostoevskogo // Bakhtin M. M. Sobr. soch.: V 7 t. M., 2000. T. 2.

5. Baranova-Shestova N. Zhizn' L'va Shestova. Parizh, 1983.

6. Belov S. V. F. M. Dostoevskii // Literaturnaia entsiklopediia russkogo zarubezh'ia. 19181940. T. 4. Vsemirnaia literatura i russkoe zarubezh'e. M., 2006.

7. Berdiaev N. A. Mirosozertsanie Dostoevskogo <1923>// Berdiaev N. A. Filosofiia tvorchestva, kul'tury i iskusstva: V 2 t. M., 1994. T. 2.

8. Berezhkov F. F. Dostoevskii na Zapade (1916-1928) // Dostoevskii. Trudy Gosudarstvennoi akademii khudozhestvennykh nauk. M., 1928.

9. Cadot $M$. Lectures stratifiée de Dostoïevsky par André Gide // Dostoevsky and the Twentieth Century / Ed. Malcolm V. Jones. Nottingham, 1993.

10. Dudkin $V . V$. «Roman Dostoevskien" kak novatorskaia forma zhanra i termin (Dostoevskii vo Frantsii v pervoi treti XX v.) // Dostoevskii. Materialy i issledovaniia. SPb., 2013. T. 20.

11. Fayer M. Gide, Freedom and Dostoevsky. Burlington, 1946.

12. Fokin S. L. Kul't izbiratel'nogo srodstva v genezise «Dostoevskogo» Andre Zhida // Fokin S. L.

Figury Dostoevskogo vo frantsuzskoi literature XX veka. SPb., 2013.

13. Gacheva A. G. V poiskakh novogo sinteza: Dukhovnoe nasledie F. M. Dostoevskogo i porevoliutsionnye techeniia russkoi emigratsii 1920-1930-kh godov // Dostoevskii i XX vek: V 2 t. M., 2007. T. 2. 14. Gide A. Essais critiques / Éd. de Pierre Masson. Paris, 1999 (Bibliotheque de la Pléiade).

15. Gide A. Journal. 1889-1939. Paris, 1951 (Bibliotèque de la Pléiade).

16. Ianovskii V. S. Cheliust' emigranta. N'iu-Iork, 1957.

17. Livak L. How It was Done in Paris: Russian Émigré Literature and French Modernism. Madison, 2003.

18. Merezhkovskii D. S. Fedor Mikhailovich Dostoevskii. 1821-1921 // Rul’. 1921. 11 noiab. № 300. 19. Merezhkovskii D. S. Rech’ na mitinge v Sorbonne // Obshchee delo. 1921. 25 dek. № 525.

20. Mochul'skii K. V. Andre Zhid <1927> // Mochul'skii K. V. Krizis voobrazheniia. Stat'i. Esse. Portrety. Tomsk, 1999.

21. Morard A. Varchavski, Gide, Dostoïevski: lectures croisées // Modèle de Gouvernement: ouvrage collectif. Lyon, 2011 (http://institut-est-ouest.ens-lsh.fr/spip.php?article294; data obrascheniia: 30.04.20).

22. Moutote D. Dostoïevski et Gide // Revue d’Histoire littéraire de la France. 1976. № 5.

23. Poplavskii B. Iu. Po povodu... // Poplavskii B. Iu. Sobr. soch.: V 3 t. M., 2009. T. 3. Stat'i. Dnevniki. Pis'ma.

24. Pozner V. L'âme slave et l'esprit gaulois // Nouvelles littéraires, artistiques et scientifiques. № 193. June 26, 1926.

25. Russkie emigranty o Dostoevskom / Vstup. st., podg. teksta i prim. S. V. Belova. SPb., 1994. 26. Saggiomo C. Gide face à Dostoïevski, par-delà le mariage du Bien et du Mal. Montpellier, 2018. 27. Shlëtser B. de. Pamiati Dostoevskogo // Poslednie novosti. 1921. 27 dek. № 521.

28. Shlëtser B. F. Noveishaia literatura o Dostoevskom // Sovremennye zapiski. 1923. Kniga XVII. 29. Souday P. Le ceintenaire de Dostoïevsky // Le Temps. 1921. 29 déc. № 22062.

30. Stepun F. A. Porevoliutsionnoe soznanie i zadacha emigrantskoi literatury $<1935>/ / \mathrm{Kri}^{-}$ tika russkogo zarubezh'ia: V 2 ch. M., 2002. Ch. 1 / Sost., predisl., preambuly, primech. O. A. Korosteleva, N. G. Mel'nikova.

31. Suarès A. Centenaire de Dostoïevski // Les Écrits nouveaux. 1922. T. IX. № 1.

32. Tabachnikova $O$. Dialogues with Dostoevsky from Two Corners: Lev Shestov versus André Gide // New Zealand Slavonic Journal. 2008. Vol. 42.

33. Vacquier T. Dostojevski and Gide: A Comparison // The Sewanee Review. 1929. Vol. 37 . № 4.

34. Varshavskii V. S. Neskol'ko rassuzhdenii ob Andre Zhide i emigrantskom molodom cheloveke // Varshavskii V. S. Ozhidanie: Proza, esse, literaturnaia kritika. M., 2016. 
35. Veidle V. V. Evropeiskie sud’by Dostoevskogo // Vozrozhdenie. 1930. 20 marta. № 1930.

36. Vladimirova A. I. Dostoevskii vo frantsuzskoi literature XX veka // Dostoevskii v zarubezhnykh literaturakh / Red. B. G. Reizov. L., 1978.

37. Zhid A. Dostoevskii / Per. s fr. A. V. Fedorova // Sobr. soch.: V 7 t. M., 2002. T. 6.

\section{Олег Анатольевич Коростелев}

заместитель директора по научной работе

Института мировой литературы им. А. М. Горького РАН

\section{Oleg Anatolievich Korostelev}

Deputy Director for Research,

A. M. Gorky Institute of World Literature, Russian Academy of Sciences

\section{«СМЕРТИ НЕТ!»: Г. В. АДАМОВИЧ О И. А. БУНИНЕ}

\section{THERE'S NO DEATH!: G.V. ADAMOVICH ON I. A. BUNIN}

В статье рассматривается сложная эволюция взглядов «первого критика эмиграции» Г. В. Адамовича на творчество первого русского нобелевского лауреата по литературе И. А. Бунина от ранних статей 1924 года до воспоминаний 1971 года. В приложении впервые вводится в научный оборот не публиковавшийся ранее текст выступления Адамовича на вечере памяти Бунина 1955 года.

Ключевые слова: И. А. Бунин, Г. В. Адамович, рецепция, Русское Зарубежье, литературная критика.

The article discusses the complex evolution of the views of G. V. Adamovich, the «first critic of emigration", regarding the works of the first Russian Nobel Prize laureate in literature I. A. Bunin, from the early articles of 1924 to the memoirs of 1971. In the Appendix, the previously unpublished text of the speech by Adamovich at the Bunin Memorial Evening (1955) is introduced to the academic community.

Key words: I. A. Bunin, G. V. Adamovich, reception, Russian émigré community, literary criticism.

\section{Список литературы}

1. Вокруг «Якоря»: Из архива М. Л. Кантора / Публ. О. Коростелева и А. Устинова // Якорь: Антология зарубежной поэзии / Сост. Г. В. Адамович и М. Л. Кантор; под ред. О. Коростелева, Л. Магаротто и А. Устинова. СПб., 2005.

2. «Если хотите меня печатать, терпите»: И. А. Бунин / Публ. и прим. О. А. Коростелева и М. Шрубы; вступ. статья О. А. Коростелева // «Современные записки» (Париж, 1920-1940). Из архива редакции: В 4 т. / Под ред. О. Коростелева и М. Шрубы. М., 2012. Т. 2.

3. Закружная 3. С., Коростелев О. А. «Сундук с вырезками» Ивана Бунина // Новый филологический вестник. 2019. № 1 (48).

4. Закружная З. С., Коростелев О. А., Фролов М. А. Записи и выписки И. А. Бунина для академического собрания сочинений // Вестник архивиста. 2018. № 1.

5. Коростелев O. А., Кузнецова E. В. Поэтические принципы Ивана Бунина и Александра Блока (на материале маргиналий И. Бунина на однотомнике А. Блока 1946 г.) // Вестник Томского университета. Филология. 2019. № 58.

6. «Литература последних годов - не прогрессивное, а регрессивное явление во всех отношениях...»: Иван Бунин в русской периодической печати (1902-1917) / Предисловие, подг. текста и прим. Д. Риникера // И. А. Бунин: Новые материалы. М., 2004. Вып. 1 / Сост., ред. О. Коростелева и Р. Дэвиса.

7. Лит. наследство. 1973. Т. 84: Иван Бунин: В 2 кн. / Ред. А. Н. Дубовиков и С. А. Макашин при участии Т. Г. Динесман. Кн. 1.

8. Переписка И. А. и В. Н. Буниных с Г. В. Адамовичем (1926-1961) / Публ. О. Коростелева и Р. Дэвиса // И. А. Бунин: Новые материалы. М., 2004. Вып. 1 / Сост., ред. О. Коростелева и Р. Дэвиса.

\section{References}

1. «Esli khotite menia pechatat', terpite»: I. A. Bunin / Publ. i prim. O. A. Korosteleva i M. Shruby; vstup. stat'ia O. A. Korosteleva // «Sovremennye zapiski» (Parizh, 1920-1940). Iz arkhiva redaktsii: V 4 t. / Pod red. O. Korosteleva i M. Shruby. M., 2012. T. 2. 
2. Korostelev O. A., Kuznetsova E. V. Poeticheskie printsipy Ivana Bunina i Aleksandra Bloka (na materiale marginalii I. Bunina na odnotomnike A. Bloka 1946 g.) // Vestnik Tomskogo universiteta. Filologiia. 2019. № 58.

3. «Literatura poslednikh godov - ne progressivnoe, a regressivnoe iavlenie vo vsekh otnosheniiakh...»: Ivan Bunin v russkoi periodicheskoi pechati (1902-1917) / Predislovie, podg. teksta i prim. D. Rinikera // I. A. Bunin: Novye materialy. M., 2004. Vyp. 1 / Sost., red. O. Korosteleva i R. Devisa.

4. Lit. nasledstvo. 1973. T. 84: Ivan Bunin: V 2 kn. / Red. A. N. Dubovikov i S. A. Makashin pri uchastii T. G. Dinesman. Kn. 1.

5. Perepiska I. A. i V. N. Buninykh s G. V. Adamovichem (1926-1961) / Publ. O. Korosteleva i R. Devisa // I. A. Bunin: Novye materialy. M., 2004. Vyp. 1 / Sost., red. O. Korosteleva i R. Devisa.

6. Vokrug «Iakoria»: Iz arkhiva M. L. Kantora / Publ. O. Korosteleva i A. Ustinova // Iakor': Antologiia zarubezhnoi poezii / Sost. G. V. Adamovich i M. L. Kantor: pod red. O. Korosteleva, L. Magarotto i A. Ustinova. SPb., 2005.

7. Zakruzhnaia Z. S., Korostelev O. A. «Sunduk s vyrezkami» Ivana Bunina // Novyi filologicheskii vestnik. 2019. № 1 (48).

8. Zakruzhnaia Z. S., Korostelev O. A., Frolov M. A. Zapisi i vypiski I. A. Bunina dlia akademicheskogo sobraniia sochinenii // Vestnik arkhivista. 2018. № 1.

\section{Антон Владимирович Бакунцев}

доцент факультета журналистики

Московского государственного университета им. М. В. Ломоносова

\section{Anton Vladimirovich Bakuntsev}

Associate Professor, Department of Journalism,

Lomonosov Moscow State University

auctor@list.ru

\section{НЕИЗВЕСТНЫЕ АВТОГРАФЫ И. А. БУНИНА В ФОНДАХ ТЕАТРАЛЬНОГО МУЗЕЯ ИМЕНИ А. А. БАХРУШИНА}

\section{A. BUNIN'S UNKNOWN AUTOGRAPHS IN THE ARCHIVES OF A. A. BAKHRUSHIN THEATRE MUSEUM}

Статья посвящена автографам И. А. Бунина, хранящимся в фондах Архивно-рукописного отдела Государственного центрального театрального музея имени А. А. Бахрушина. Один из этих автографов ранее уже публиковался, остальные четыре доселе оставались неизвестными. Эти последние и составили главный предмет предпринятого автором исследования.

Ключевые слова: И. А. Бунин, А. Ф. Городецкий, А. А. Плещеев, Е. Н. Рощина-Инсарова, Ф. И. Шаляпин, Государственный центральный театральный музей имени А. А. Бахрушина, автографы.

The article is devoted to the autographs of I. A. Bunin, preserved at the Archival and Manuscript Department of A. A. Bakhrushin State Central Theatre Museum. One of these autographs has previously been published, the other four have so far remained in obscurity. These latter formed the main subject of the study undertaken by the author.

Key words: I. A. Bunin, A. F. Gorodetsky, A. A. Pleshcheyev, Y. N. Roshchina-Insarova, F. I. Shaliapin, A. A. Bakhrushin State Central Theatre Museum, autographs.

\section{Список литературы}

1. Бабореко А. К. Бунин: Жизнеописание. М., 2004.

2. Бакунцев А. В. И. А. Бунин в Прибалтике: Литературное турне 1938 года. М., 2012.

3. Бакуниев А. В. И. А. Бунин и Русский культурный комитет в Белграде (1928-1937) // Литературный факт. 2017. № 6.

4. Бунин И. А. Письма 1885-1904 годов / Под общ. ред. О. Н. Михайлова; подг. текстов и комм. С. Н. Морозова, Л. Г. Голубевой, И. А. Костомаровой. М., 2003. 
5. Бунин И. А. Публицистика 1918-1953 годов / Под общ. ред. О. Н. Михайлова; вступ. статья О. Н. Михайлова; комм. С. Н. Морозова, Д. Д. Николаева, Е. М. Трубиловой. М., 2000

6. Бунин И. А. Собр. соч.: В 8 т. / Сост., подг. текстов и прим. А. К. Бабореко. М., 2000. Т. 8.

7. Зайцев Б. К. Отблески вечного: Неизвестные рассказы, эссе, воспоминания, интервью. СПб., 2018.

8. Иван Бунин: Неизвестные письма дореволюционного периода (1897-1901) / Публ., вступ. статья, подг. текста и прим. А. Бакунцева // Москва. 2015. № 1.

9. Кельнер B. E., Познер В. Комитет помощи русским писателям и ученым во Франции (Из архива Соломона Познера) // Russian Studies. Ежеквартальник русской филологии и культуры. СПб., 1994. Т. 1.

10. Летопись жизни и творчества И. А. Бунина. М., 2017. Т. 2. 1910-1919 / Сост. С. Н. Морозов. 11. Лит. наследство. 1965. Т. 72. Горький и Леонид Андреев: Неизданная переписка.

12. Лит. наследство. 1973. Т. 84. Иван Бунин: В 2 кн. / Ред. А. Н. Дубовиков и С. А. Макашин при участии Т. Г. Динесман. Кн. 1.

13. Литаврина М. Г. Русский театральный Париж: 20 лет между войнами. СПб., 2003.

14. Максимова В. А. Е. Н. Рощина-Инсарова в Париже (Первые годы эмиграции) // Диалог культур. Проблемы взаимодействия русского и мирового театра ХХ века: Сб. статей. СПб., 1997.

15. Переписка Тэффи с И. А. и В. Н. Буниными / Публ. Р. Дэвиса и Э. Хейбер // Диаспора: Новые материалы. СПб., 2001-2002. Вып. 2, 3.

16. Путеводитель по рукописным фондам Государственного центрального театрального музея имени А. А. Бахрушина / Отв. сост. и науч. ред. И. С. Преображенская. М., 2002.

17. Российское зарубежье во Франции, 1919-2000: биографический словарь: В 3 т. / Под общ. ред. Л. Мнухина, М. Авриль, В. Лосской. М., 2008-2010. Т. 1, 2.

18. Русское Зарубежье. Хроника научной, культурной и общественной жизни. 1920-1940. Франция: В 3 т. / Под общ. ред. Л. А. Мнухина. Paris; М., 1995. Т. 1.

19. Устами Буниных. Дневники И. А. и В. Н. Буниных и другие архивные материалы: В 2 т. / Под ред. М. Грин; вступ. статья Ю. В. Мальцева. М., 2005. Т. 2.

20. Heywood A. J. Catalogue of Bunin, Bunina, Zurov and Lopatina Collections / Ed. by Richard D. Davies, with the assistance of Daniel Riniker. Leeds: Leeds University Press, 2011.

\section{References}

1. Baboreko A. K. Bunin: Zhizneopisanie. M., 2004.

2. Bakuntsev A. V. I. A. Bunin i Russkii kul'turnyi komitet v Belgrade (1928-1937) // Literaturnyi fakt. 2017. № 6 .

3. Bakuntsev A. V. I. A. Bunin v Pribaltike: Literaturnoe turne 1938 goda. M., 2012.

4. Bunin I. A. Pis'ma 1885-1904 godov / Pod obshch. red. O. N. Mikhailova; podg. tekstov i komm. S. N. Morozova, L. G. Golubevoi, I. A. Kostomarovoi. M., 2003.

5. Bunin I. A. Publitsistika 1918-1953 godov / Pod obshch. red. O. N. Mikhailova; vstup. stat'ia O. N. Mikhailova; komm. S. N. Morozova, D. D. Nikolaeva, E. M. Trubilovoi. M., 2000.

6. Bunin I. A. Sobr. soch.: V 8 t. / Sost., podg. tekstov i prim. A. K. Baboreko. M., 2000. T. 8.

7. Heywood A. J. Catalogue of Bunin, Bunina, Zurov and Lopatina Collections / Ed. by Richard D. Davies, with the assistance of Daniel Riniker. Leeds: Leeds University Press, 2011.

8. Ivan Bunin: Neizvestnye pis'ma dorevoliutsionnogo perioda (1897-1901) / Publ., vstup. stat'ia, podg. teksta i prim. A. Bakuntseva // Moskva. 2015. № 1.

9. Kel'ner V. E., Pozner V. Komitet pomoshchi russkim pisateliam i uchenym vo Frantsii (Iz arkhiva Solomona Poznera) // Russian Studies. Ezhekvartal'nik russkoi filologii i kul'tury. SPb., 1994. T. 1.

10. Letopis' zhizni i tvorchestva I. A. Bunina. M., 2017. T. 2. 1910-1919 / Sost. S. N. Morozov.

11. Lit. nasledstvo. 1965. T. 72. Gor'kii i Leonid Andreev: Neizdannaia perepiska.

12. Lit. nasledstvo. 1973. T. 84. Ivan Bunin: V 2 kn. / Red. A. N. Dubovikov i S. A. Makashin pri uchastii T. G. Dinesman. Kn. 1.

13. Litavrina M. G. Russkii teatral'nyi Parizh: 20 let mezhdu voinami. SPb., 2003.

14. Maksimova V. A. E. N. Roshchina-Insarova v Parizhe (Pervye gody emigratsii) // Dialog kul'tur. Problemy vzaimodeistviia russkogo i mirovogo teatra XX veka: Sb. statei. SPb., 1997.

15. Perepiska Teffi s I. A. i V. N. Buninymi / Publ. R. Devisa i E. Kheiber // Diaspora: Novye materialy. SPb., 2001-2002. Vyp. 2, 3.

16. Putevoditel' po rukopisnym fondam Gosudarstvennogo tsentral'nogo teatral'nogo muzeia imeni A. A. Bakhrushina / Otv. sost. i nauch. red. I. S. Preobrazhenskaia. M., 2002.

17. Rossiiskoe zarubezh'e vo Frantsii, 1919-2000: biograficheskii slovar': V 3 t. / Pod obshch. red. L. Mnukhina, M. Avril', V. Losskoi. M., 2008-2010. T. 1, 2.

18. Russkoe Zarubezh'e. Khronika nauchnoi, kul'turnoi i obshchestvennoi zhizni. 1920-1940. Frantsiia: V 3 t. / Pod obshch. red. L. A. Mnukhina. Paris; M., 1995. T. 1.

19. Ustami Buninykh. Dnevniki I. A. i V. N. Buninykh i drugie arkhivnye materialy: V 2 t. / Pod red. M. Grin; vstup. stat'ia Iu. V. Mal’tseva. M., 2005. T. 2.

20. Zaitsev B. K. Otbleski vechnogo: Neizvestnye rasskazy, esse, vospominaniia, interv'iu. SPb., 2018. 


\section{Татьяна Михайловна Двинятина \\ ведущий научный сотрудник \\ Института русской литературы (Пушкинский Дом) РАН}

Tatiana Mikhailovna Dvinyatina

Leading Researcher, Institute of Russian Literature (Pushkinskij Dom), Russian Academy of Sciences

tatiana.dvinyatina@gmail.com

\section{«ЗА СТЕНАМИ РАЗРУШЕННОГО И ПОРУГАННОГО СИОНА»: И. А. БУНИН В 1917-1921 ГОДАХ \\ OUTSIDE THE WALLS OF ZION DESTROYED AND DEFILED: I. A. BUNIN IN 1917-1921}

В статье восстанавливается биографическая канва И. А. Бунина 1917-1921 годов. Как и в произведениях писателя, в ней очевидны столкновения и резкие переходы между полярными состояниями бытия и жизни: полноты счастья и отчаяния, крушения родного мира и упования на его возрождение в слове. В произведениях Бунина этих лет очевидны аллюзии к ветхозаветным пророчествам, псалмам и евангельским мотивам.

Ключевые слова: И. А. Бунин, биография, эмиграция, архивные источники, дневники, переписка, эсхатология.

This article reconstructs the biographical canvas of Ivan Bunin's life in 1917-1921. Both in the author's works and in his life, there are clearly visible clashes and sharp changes of direction between the polarities of existence and life: complete happiness and despair, the collapse of his familiar world and hope for its rebirth through word. Bunin's works in these years contain obvious allusions to Old Testament prophecies and psalms and to motifs from the Gospels.

Key words: Ivan Bunin, biography, emigration, archive sources, diaries, personal correspondence, eschatology.

\section{Список литературы}

1. Бабореко A. K. Бунин: Жиинеописание. 2-е изд. М., 2009.

2. Бакунцев A. В. И. А. Бунин на страницах одесской печати в годы Гражданской войны // Вестник Московского ун-та. Сер. 10. ЖЖурналистика. 2014. № 5.

3. Бунин И. А. Воспоминания. Париж, 1950.

4. Бунин И. А. Письма 1905-1919 годов / Подг. текстов и комм. С. Н. Морозова; под общ. ред. О. Н. Михайлова. М., 2007.

5. Бунин И. А. Публицистика 1918-1953 годов / Под общ. ред. О. Н. Михайлова; вступ. статья О. Н. Михайлова; комм. С. Н. Морозова, Д. Д. Николаева, Е. М. Трубиловой. М., 1998

6. Бунин И. А. Собр. соч.: В 11 т. Берлин, 1935. Т. 8, 10.

7. Бунин И. А. Собр. соч.: В 9 т. М., 1966-1967. Т. 5, 9.

8. Бунин И. А. Стихотворения: В 2 т. / Вступ. статья, сост., подг. текста и прим. Т. М. Двинятиной. СПб., 2014 (Новая Библиотека поэта).

9. Горький М. Полн. собр. соч. Письма: В 24 т. М., 2006. Т. 12.

10. Двинятина Т. Дневники И. А. Бунина 1920-х гг.: пространство и пределы реконструкции // Avtobiografija. Journal on Life Writing and the Representation of the Self in Russian Culture. 2019. № 8 .

11. Двинятина Т. М. И. А. Бунин в 1914 году // Русская литература. 2015. № 1.

12. Двинятина T. М. Нобелевский год И. А. Бунина (по материалам дневников и семейной переписки) // Литературный факт. 2017. № 4.

13. Зайцев Б. К. Москва. Мюнхен, 1973.

14. Летопись жизни и творчества И. А. Бунина. М., 2011. Т. 1. 1870-1909 / Сост. С. Н. Морозов.

15. Морозов C. Н. «Окаянные дни» И. Бунина: к истории текста // Текстологический временник: вопросы текстологии и источниковедения. М., 2012. Кн. 2.

16. Муролиева-Бунина В. Н. ЖЖизнь Бунина. Беседы с памятью / Вступ. статья и прим. А. К. Бабореко. М., 2007.

17. Новое о Буниных / Публ. Н. Винокур // Минувшее: Исторический альманах. Париж, 1989. $<$ Вып. $>8$ 
18. Устами Буниных. Дневники Ивана Алексеевича и Веры Николаевны и другие архивные материалы: В 3 т. / Под ред. М. Грин. Frankfurt a/M., 1977-1981. T. 1, 2.

\section{References}

1. Baboreko A. K. Bunin: Zhizneopisanie. 2-e izd. M., 2009.

2. Bakuntsev A. V. I. A. Bunin na stranitsakh odesskoi pechati v gody Grazhdanskoi voiny // Vestnik Moskovskogo un-ta. Ser. 10. Zhurnalistika. 2014. № 5.

3. Bunin I. A. Pis'ma 1905-1919 godov / Podg. tekstov i komm. S. N. Morozova; pod obshch. red. O. N. Mikhailova.. M., 2007.

4. Bunin I. A. Publitsistika 1918-1953 godov / Pod obshch. red. O. N. Mikhailova; vstup. stat'ia O. N. Mikhailova; komm. S. N. Morozova, D. D. Nikolaeva, E. M. Trubilovoi. M., 1998.

5. Bunin I. A. Sobr. soch.: V 11 t. Berlin, 1935. T. 8, 10.

6. Bunin I. A. Sobr. soch.: V 9 t. M., 1966-1967. T. 5, 9.

7. Bunin I. A. Stikhotvoreniia: V 2 t. / Vstup. stat'ia, sost., podg. teksta i prim. T. M. Dviniatinoi. SPb., 2014 (Novaia Biblioteka poeta).

8. Bunin I. A. Vospominaniia. Parizh, 1950.

9. Dviniatina T. Dnevniki I. A. Bunina 1920-kh gg.: prostranstvo i predely rekonstruktsii // Avtobiografija. Journal on Life Writing and the Representation of the Self in Russian Culture. 2019. № 8 .

10. Dviniatina T. M. I. A. Bunin v 1914 godu // Russkaia literatura. 2015. № 1.

11. Dviniatina T. M. Nobelevskii god I. A. Bunina (po materialam dnevnikov i semeinoi perepiski) // Literaturnyi fakt. 2017. № 4.

12. Gor'kii M. Poln. sobr. soch. Pis'ma: V 24 t. M., 2006. T. 12.

13. Letopis' zhizni i tvorchestva I. A. Bunina. T. 1 (1870-1909) / Sost. S. N. Morozov. M., 2011.

14. Morozov S. N. «Okaiannye dni» I. Bunina: k istorii teksta // Tekstologicheskii vremennik: voprosy tekstologii i istochnikovedeniia. M., 2012. Kn. 2.

15. Muromtseva-Bunina V. N. Zhizn’ Bunina. Besedy s pamiat'iu / Vstup. stat'ia i prim. A. K. Baboreko. M., 2007.

16. Novoe o Buninykh / Publ. N. Vinokur // Minuvshee: Istoricheskii al'manakh. Parizh, 1989. $<$ Vyp. $>8$.

17. Ustami Buninykh. Dnevniki Ivana Alekseevicha i Very Nikolaevny i drugie arkhivnye materialy: V 3 t. / Pod red. M. Grin. Frankfurt a/M., 1977-1981. T. 1, 2.

18. Zaitsev B. K. Moskva. Miunkhen, 1973.

\section{Сергей Николаевич Морозов}

старший научный сотрудник

Института мировой литературы им. А. М. Горького РАН

\section{Sergey Nikolaevich Morozov}

Senior Researcher, A. M. Gorky Institute of World Literature,

Russian Academy of Sciences

morozov.sn@yandex.ru

\section{РАССКАЗ И. А БУНИНА «ЦИКАДЫ»: ИСТОРИЯ ТЕКСТА}

\section{A. BUNIN'S STORY THE CICADAS: HISTORY OF THE TEXT}

В статье исследуется история текста рассказа И. А. Бунина «Цикады» (более позднее название «Ночь»), рассмотрены все сохранившиеся автографы, все публикации данного текста, а также позднейшие авторские пометы на печатных текстах рассказа. Изучены все этапы работы автора над рассказом (сокращения, правка, дополнения и т. д.). Представлены наиболее показательные примеры разночтений в разных источниках текста.

Ключевые слова: И. А. Бунин, проза, рассказ «Цикады», текстология, датировка, история текста.

The paper investigates the history of the text of I. A. Bunin's story The Cicadas (later called The Night), with all the surviving autographs, publications of this text, as well as the author's later- 
period notes on the printed copies of the story taken into account. All stages of the author's work on the story are studied (cuts, editing, additions, etc.). The most illustrative examples of discrepancies in different sources of the text are presented.

Key words: I. A. Bunin, prose, The Cicadas, textology, dating, text history.

\section{Список литературы} Кн. 84

1. Бунин И. А. Безымянные записки / Публ. Л. Зурова // Новый журнал (Нью-Йорк). 1966.

2. Бунин И. А. Безымянные записки. Книга моей жизни / Публ. А. К. Бабореко // Лит. наследство. 1973. Т. 84. Иван Бунин: В 2 кн. / Ред. А. Н. Дубовиков и С. А. Макашин при участии Т. Г. Динесман. Кн. 1.

3. Бунин И. А. Собр. соч.: В 11 т. Берлин, 1935. Т. 9.

4. Двинятина Т. М. Текстология поэзии И. А. Бунина // Бунин И. А. Стихотворения: В 2 т. / Вступ. статья, сост., подг. текста и прим. Т. М. Двинятиной. СПб., 2014. Т. 1 (Новая Библиотека поэта).

5. «Если хотите меня печатать, терпите»: И. А. Бунин / Публ. и прим. О. А. Коростелева и М. Шрубы; вступ. статья О. А. Коростелева // «Современные записки» (Париж, 1920-1940). Из архива редакции: В 4 т. / Под ред. О. Коростелева и М. Шрубы. М., 2012. Т. 2.

6. Морозов С. Н. Проблема датировки прозы И. А. Бунина // Литературный факт. 2017. № 4.

7. Устами Буниных. Дневники Ивана Алексеевича и Веры Николаевны и другие архивные материалы: В 3 т. / Под ред. М. Грин. Frankfurt a/M., 1981. T. 2.

\section{References}

1. Bunin I. A. Bezymiannye zapiski / Publ. L. Zurova // Novyi zhurnal (N'iu-Iork). 1966. Kn. 84.

2. Bunin I. A. Bezymiannye zapiski. Kniga moei zhizni / Publ. A. K. Baboreko // Lit. nasledstvo. 1973. T. 84. Ivan Bunin: V 2 kn. / Red. A. N. Dubovikov i S. A. Makashin pri uchastii T. G. Dinesman. Kn. 1.

3. Bunin I. A. Sobr. soch.: V 11 t. Berlin, 1935. T. 9.

4. Dviniatina T. M. Tekstologiia poezii I. A. Bunina // Bunin I. A. Stikhotvoreniia: V 2 t. / Vstup. stat'ia, sost., podg. teksta i prim. T. M. Dviniatinoi. SPb., 2014. T. 1 (Novaia Biblioteka poeta).

5. «Esli khotite menia pechatat', terpite»: I. A. Bunin / Publ. i prim. O. A. Korosteleva i M. Shruby; vstup. stat'ia O. A. Korosteleva // «Sovremennye zapiski» (Parizh, 1920-1940). Iz arkhiva redaktsii: V 4 t. / Pod red. O. Korosteleva i M. Shruby. M., 2012. T. 2.

6. Morozov S. N. Problema datirovki prozy I. A. Bunina // Literaturnyi fakt. 2017. № 4.

7. Ustami Buninykh. Dnevniki Ivana Alekseevicha i Very Nikolaevny i drugie arkhivnye materialy: V 3 t. / Pod red. M. Grin. Frankfurt a/M., 1981. T. 2.

\section{Евгений Рудольфович Пономарев}

ведущий научный сотрудник Института мировой литературы им. А. М. Горького РАН; профессор Санкт-Петербургского государственного института культуры

\section{Evgeny Rudolfovich Ponomarev}

Leading Researcher, A. M. Gorky Institute of World Literature, Russian Academy of Sciences;

Professor, St. Petersburg State Institute of Culture

eponomarev@mail.ru

\section{РАССКАЗЫ «КРУГА „ТЕМНЫХ АЛЛЕЙ“»}

\section{THE STORIES OF THE «CIRCLE OF THE DARK AVENUES»}

Круг «Темных аллей» рассматривается в статье как тематико-поэтическое единство — большой цикл рассказов, обрамляющий цикл «Темные аллеи». В нем ярко проявляется экспериментальность прозы Бунина последних лет жизни, формирующая новаторские для эпохи 1940-х годов принципы нарратива.

Ключевые слова: Бунин, «Темные аллеи», круг «Темных аллей» . 
The «Circle of the Dark Avenues» a large body of stories that frame the circle of the cycle Dark Avenues, is examined in the article as a thematic and poetical entity. This entity reveals the experimental and dynamic basis of Ivan Bunin's prose works created in the last years of his life. These stories feature narrative principles that are quite new for the period of the $1940 \mathrm{~s}$.

Key words: I. A. Bunin, Dark Alleys, the Circle of the Dark Alleys.

\title{
Список литературы
}

1. Бунин И. А. Весной, в Иудее. Роза Иерихона. Нью-Йорк: Изд-во им. Чехова, 1953.

2. Бунин И. А. Крем Леодор // Новоселье. 1947. № 31-32.

3. Бунин И. А. Темные аллеи. Нью-Йорк: Изд-во «Новая земля», [1943].

4. «...Когда переписываются близкие люди». Письма И. А. Бунина, В. Н. Буниной, Л. Ф. Зурова к Г. Н. Кузнецовой и М. А. Степун / Сост., подг. текста, научный аппарат Е. Р. Пономарева и Р. Дэвиса; сопроводительные статьи Е. Р. Пономарева. М., 2014 (И. А. Бунин. Новые материалы. Вып. 3).

5. Лит. наследство. 2019. Т. 110. И. А. Бунин: Новые исследования и материалы. Кн. 1.

6. Поноларев E. P. Круг «Темных аллей». Неопубликованный рассказ И. А. Бунина // Вопросы литературы. 2015. № 5 .

7. Reese H. Ein Meisterwerk im Zwielicht: Ivan Bunins narrative Kurzprosaverknüpfung. Temnye Allei zwischen Akzeptanz und Ablehnung. Eine Genrestudie. München, 2003.

\section{References}

1. Bunin I. A. Krem Leodor // Novosel’e. 1947. № 31-32.

2. Bunin I. A. Temnye allei. N'iu-Iork: Izd-vo «Novaia zemlia», [1943].

3. Bunin I. A. Vesnoi, v Iudee. Roza Ierikhona. N'iu-Iork: Izd-vo im. Chekhova, 1953.

4. «...Kogda perepisyvaiutsia blizkie liudi». Pis'ma I. A. Bunina, V. N. Buninoi, L. F. Zurova k G. N. Kuznetsovoi i M. A. Stepun / Sost., podg. teksta, nauchnyi apparat E. R. Ponomareva i R. Devisa; soprovoditel'nye stat'i E. R. Ponomareva. M., 2014 (I. A. Bunin. Novye materialy. Vyp. 3).

5. Lit. nasledstvo. 2019. T. 110. I. A. Bunin: Novye issledovaniia i materialy. Kn. 1.

6. Ponomarev E. R. Krug «Temnykh allei». Neopublikovannyi rasskaz I. A. Bunina // Voprosy literatury. 2015. № 5 .

7. Reese H. Ein Meisterwerk im Zwielicht: Ivan Bunins narrative Kurzprosaverknüpfung. Temnye Allei zwischen Akzeptanz und Ablehnung. Eine Genrestudie. München, 2003.

\section{Лидия Викторовна Соколова}

ведущий научный сотрудник

Института русской литературы (Пушкинский Дом) РАН

\section{Lidiia Viktorovna Sokolova}

Leading Reseacher, Institute of Russian Literature (Pushkinskij Dom),

Russian Academy of Sciences

liiso@mail.ru

\section{ИСТОРИЯ ВОЗНИКНОВЕНИЯ И ОСОБЕННОСТИ ПАМЯТНИКОВ КУЛИКОВСКОГО ЦИКЛА

\author{
ORIGINS AND SPECIAL FEATURES \\ OF THE TEXTS OF THE KULIKOVSKY CYCLE
}

\begin{abstract}
Статья посвящена литературным памятникам, рассказывающим о Куликовской битве и образующим так называемый Куликовский цикл. Это летописные повествования о битве (краткий рассказ в своде 1408 года и «Летописная повесть о Куликовской битве»), «Сказание о Мамаевом побоище» и «Задонщина». Автор излагает свое представление о последовательности возникновения памятников Куликовского цикла, их особенностях и взаимоотношениях.

Ключевые слова: памятники Куликовского цикла, «Летописная повесть о Куликовской битве», «Сказание о Мамаевом побоище», «Задонщина» .
\end{abstract}


The article explores the texts on the Battle of Kulikovo that comprise the so-called Kulikovsky Cycle. The pieces in question are chronicle stories (a short story in the Svod of 1408 and the Chronicle Story of the Battle of Kulikovo), the Story of the Bloody Battle of Mamai, and Zadonshchina. The author suggests a new outlook on the sequence of emergence of these texts, their special features and mutual relations.

Key words: Kulikovsky Cycle, Chronicle Story of the Battlle of Kulikovo, Story of the Bloody Battle of Mamai, Zadonshchina.

\section{Список литературы}

1. Адрианова-Перети В. П. Слово о житии и преставлении великаго князя Дмитрия Ивановича, царя Русьскаго // Труды Отдела древнерусской литературы. М.; Л., 1947. Т. 5.

2. Азбелев C. Н. Повесть о Куликовской битве в Новгородской летописи Дубровского // Летописи и хроники: 1973. М., 1974.

3. Бобров A. Г. Летописный свод митрополита Фотия (Проблема реконструкции текста) // Труды Отдела древнерусской литературы. СПб., 2001. Т. 52.

4. Бобров А. Г. Новгородские летописи XV в. СПб., 2001.

5. Гулилев Л. Н. От Руси к России. М., 2015.

6. Длитриев Л. А. К литературной истории Сказания о Мамаевом побоище // Повести о Куликовской битве. М., 1959.

7. Длитриев Л. А. Куликовская битва 1380 года в литературных памятниках Древней Руси // Русская литература. 1980. № 3.

8. Длитриев Л. А. О датировке «Сказания о Мамаевом побоище» // Труды Отдела древнерусской литературы. М.; Л., 1954. Т. 10.

9. Длитриев Л. А. Обзор редакций Сказания о Мамаевом побоище // Повести о Куликовской битве. М., 1959.

10. Длитриев Л. А. Сказание о Мамаевом побоище // Словарь книжников и книжности Древней Руси. Л., 1989. Вып. 2 (вторая половина XIV-XVI в.). Ч. 2. Л-Я.

11. Клосс Б. М. Об авторе и времени создания «Сказания о Мамаевом побоище» // In memoriam: Сборник памяти Я. С. Лурье. СПб., 1997.

12. Клосс Б. М. Сказание о Мамаевом побоище // Клосс Б. М. Избр. труды. М., 2001. Т. 2. Очерки по истории русской агиографии XIV-XV веков.

13. Ключевский В. О. Боярская дума Древней Руси. Пб., 1919.

14. Кучкин B. А. Дмитрий Донской и Сергий Радонежский в канун Куликовской битвы // Церковь, общество и государство в феодальной России: Сб. статей. М., 1990.

15. Кучкин В. А. Победа на Куликовом поле // Вопросы истории. 1980. № 8.

16. Лихачев Д. С. «Задонщина»// Лихачев Д. С. Великое наследие. М., 1975.

17. Лихачев Д. С. «Слово о полку Игореве» и культура его времени. Л., 1985.

18. Лихачев Д. С. Национальное самосознание Древней Руси. М.; Л., 1945.

19. Марков А. [Рец. на:] С. Шамбинаго. Повести о Мамаевом побоище. СПб., 1906 (СОРЯС. Т. 81, № 7) // Журнал Министерства народного просвещения. 1908. Ч. 14. № 4 .

20. Мингалев В. С. Летописная повесть - источник «Сказания о Мамаевом побоище»// Труды Московского государственного историко-архивного института. 1966. Т. 24. Вып. 2.

21. Петров A. E. «Александрия Сербская» и «Сказание о Мамаевом побоище» // Древняя Русь: Вопросы медиевистики. 2005. № 2 (20).

22. Петров A. E. К вопросу о датировке «Сказания о Мамаевом побоище»// Тезисы докладов и сообщений конференции молодых специалистов РГБ по итогам научно-исследовательской работы за 1992 год. М., 1993.

23. Петров A. E. Проблема датировки «Сказания о Мамаевом побоище» в связи с «Повестью о походе Ивана III на Новгород в 1471 году» // Румянцевские чтения: К 240-летию со дня рождения Н. П. Румянцева: Тезисы докладов и сообщений научно-практической конф. (1415 апреля 1994 г.): В 2 ч. М., 1994. Ч. 2.

24. Приселков М. Д. История русского летописания XI-XV вв. СПб., 1996. 1987.

25. Прохоров $Г$. М. Памятники переводной и русской литературы XIV-XV веков. Л.,

26. Робинсон А. Н. Эволюция героических образов в повестях о Куликовской битве // Куликовская битва в литературе и искусстве. М., 1980.

27. Салмина М. А. «Летописная повесть» о Куликовской битве и «Задонщина» // «Слово о полку Игореве» и памятники Куликовского цикла: $К$ вопросу о времени написания «Слова». М.; Л., 1966.

28. Саллина M. A. К вопросу о датировке «Сказания о Мамаевом побоище» // Труды Отдела древнерусской литературы. Л., 1974. Т. 29.

29. Салмина M. А. Повесть о Куликовской битве летописная // Словарь книжников и книжности Древней Руси. Л., 1989. Вып. 2 (вторая половина XIV-XVI в.). Ч. 2. Л-Я.

30. Сказания и повести о Куликовской битве. Л., 1982 (сер. «Литературные памятники»). 
31. Скрынников Р. Г. Куликовская битва: Проблемы изучения // Куликовская битва в истории и культуре нашей Родины. М., 1983.

32. Собрание государственных грамот и договоров, хранящихся в государственной Коллегии иностранных дел. М., 1813. Т. 1.

33. Соколова Л. В. К вопросу о датировке и авторстве «Сказания о Мамаевом побоище» // Труды Отдела древнерусской литературы. СПб., 2020. Т. 67 (в печати).

34. Соколова Л. В. Как складывалось литературное предание о благословении Сергием $\mathrm{Pa}-$ донежским Дмитрия Донского на Куликовскую битву // IX Чтения по истории и культуре древней и новой России (К 700-летию преподобного Сергия Радонежского): Материалы науч. конф. (Ярославль, 25-27 сентября 2014 г.). Ярославль, 2016.

35. Соколова Л. В. Летописные повествования о Куликовской битве (К вопросу о взаимоотношении памятников) // Труды Отдела древнерусской литературы. СПб., 2014. Т. 63.

36. Соколова Л. В. Об источниках рассказа о Куликовской битве в своде 1408 г. (Троицкой летописи) // Академик А. А. Шахматов: Жиизнь, творчество, научное наследие: Сб. статей к 150-летию со дня рождения ученого. СПб., 2015.

37. Соколова Л. В. Первоначальна ли Краткая редакция «Задонщины»? (В связи с новейшими работами о взаимоотношении «Слова о полку Игореве» и «Задонщины») // Труды Отдела древнерусской литературы. СПб., 2014. Т. 62.

38. Соколова Л. В. Содержал ли авторский текст «Сказания о Мамаевом побоище» вставки из «Задонщины»? (К вопросу о взаимоотношении памятников) // Труды Отдела древнерусской литературы. СПб., 2017. Т. 65.

39. Соколова Л. В. Что сообщалось об Олеге Рязанском в авторском тексте Повести о Куликовской битве? (К вопросу о позднейших вставках в «Летописной повести») // Труды Отдела древнерусской литературы. СПб., 2019. Т. 66.

40. Соловьев А. В. Епифаний Премудрый как автор «Слова о житии и преставлении великаго князя Дмитрия Ивановича, царя русьскаго» // Труды Отдела древнерусской литературы. М.; Л., 1961. Т. 17.

41. Тихолиров M. Н. Куликовская битва 1380 года // Повести о Куликовской битве. М., 1959.

42. Черепнин Л. В. Образование Русского централизованного государства в XIV-XV веках: Очерки социально-экономической и политической истории Руси. М., 1960.

43. Шалбинаго С. К. Повести о Мамаевом побоище. СПб., 1906.

44. Шахматов A. А. Отзыв о сочинении С. Шамбинаго «Повести о Мамаевом побоище». СПб., 1906 // Отчет о двенадцатом присуждении Имп. Академией наук премий митрополита Макария в 1907 году. СПб., 1910.

\section{References}

1. Adrianova-Peretts V. P. Slovo o zhitii i prestavlenii velikago kniazia Dmitriia Ivanovicha, tsaria Rus'skago // Trudy Otdela drevnerusskoi literatury. M.; L., 1947. T. 5.

2. Azbelev S. N. Povest' o Kulikovskoi bitve v Novgorodskoi letopisi Dubrovskogo // Letopisi i khroniki: 1973. M., 1974.

3. Bobrov A. G. Letopisnyi svod mitropolita Fotiia (Problema rekonstruktsii teksta) // Trudy Otdela drevnerusskoi literatury. SPb., 2001. T. 52.

4. Bobrov A. G. Novgorodskie letopisi XV v. SPb., 2001.

5. Cherepnin L. V. Obrazovanie Russkogo tsentralizovannogo gosudarstva v XIV-XV vekakh: Ocherki sotsial'no-ekonomicheskoi i politicheskoi istorii Rusi. M., 1960.

6. Dmitriev L. A. K literaturnoi istorii Skazaniia o Mamaevom poboishche // Povesti o Kulikovskoi bitve. M., 1959.

7. Dmitriev L. A. Kulikovskaia bitva 1380 goda v literaturnykh pamiatnikakh Drevnei Rusi // Russkaia literatura. 1980. № 3 .

8. Dmitriev L. A. O datirovke «Skazaniia o Mamaevom poboishche»// Trudy Otdela drevnerusskoi literatury. M.; L., 1954. T. 10.

9. Dmitriev L. A. Obzor redaktsii Skazaniia o Mamaevom poboishche // Povesti o Kulikovskoi bitve. M., 1959.

10. Dmitriev L. A. Skazanie o Mamaevom poboishche // Slovar' knizhnikovi knizhnosti Drevnei Rusi. L., 1989. Vyp. 2 (vtoraia polovina XIV-XVI v.). Ch. 2. L-Ia.

11. Gumilev L. N. Ot Rusi k Rossii. M., 2015.

12. Kliuchevskii V. O. Boiarskaia duma Drevnei Rusi. Pb., 1919.

13. Kloss B. M. Ob avtore i vremeni sozdaniia «Skazaniia o Mamaevom poboishche» // In memoriam: Sbornik pamiati Ia. S. Lur'e. SPb., 1997.

14. Kloss B. M. Skazanie o Mamaevom poboishche // Kloss B. M. Izbr. trudy. M., 2001. T. 2. Ocherki po istorii russkoi agiografii XIV-XV vekov.

15. Kuchkin V. A. Dmitrii Donskoi i Sergii Radonezhskii v kanun Kulikovskoi bitvy // Tserkov', obshchestvo i gosudarstvo v feodal'noi Rossii: Sb. statei. M., 1990.

16. Kuchkin V. A. Pobeda na Kulikovom pole // Voprosy istorii. 1980. № 8. 
17. Likhachev D. S. «Slovo o polku Igoreve» i kul’tura ego vremeni. L., 1985.

18. Likhachev D. S. «Zadonshchina»// Likhachev D. S. Velikoe nasledie. M., 1975.

19. Likhachev D. S. Natsional'noe samosoznanie Drevnei Rusi. M.; L., 1945.

20. Markov A. [Rets. na:] S. Shambinago. Povesti o Mamaevom poboishche. SPb., 1906 (SORIAS. T. 81, № 7) // Zhurnal Ministerstva narodnogo prosveshcheniia. 1908. Ch. 14. № 4 .

21. Mingalev V. S. Letopisnaia povest' - istochnik «Skazaniia o Mamaevom poboishche»// Trudy Moskovskogo gosudarstvennogo istoriko-arkhivnogo instituta. 1966. T. 24. Vyp. 2.

22. Petrov A. E. "Aleksandriia Serbskaia» i «Skazanie o Mamaevom poboishche» // Drevniaia Rus': Voprosy medievistiki. 2005. № 2 (20).

23. Petrov A. E. K voprosu o datirovke «Skazaniia o Mamaevom poboishche»// Tezisy dokladov i soobshchenii konferentsii molodykh spetsialistov RGB po itogam nauchno-issledovatel'skoi raboty za 1992 god. M., 1993.

24. Petrov A. E. Problema datirovki «Skazaniia o Mamaevom poboishche» v sviazi s «Povest'iu o pokhode Ivana III na Novgorod v 1471 godu» // Rumiantsevskie chteniia: K 240-letiiu so dnia rozhdeniia N. P. Rumiantseva: Tezisy dokladov i soobshchenii nauchno-prakticheskoi konf. (1415 aprelia 1994 g.): V 2 ch. M., 1994. Ch. 2.

25. Priselkov M. D. Istoriia russkogo letopisaniia XI-XV vv. SPb., 1996.

26. Prokhorov G. M. Pamiatniki perevodnoi i russkoi literatury XIV-XV vekov. L., 1987.

27. Robinson A. N. Evoliutsiia geroicheskikh obrazov v povestiakh o Kulikovskoi bitve // Kulikovskaia bitva v literature i iskusstve. M., 1980.

28. Salmina M. A. «Letopisnaia povest" o Kulikovskoi bitve i "Zadonshchina»// "Slovo o polku Igoreve» i pamiatniki Kulikovskogo tsikla: K voprosu o vremeni napisaniia «Slova». M.; L., 1966.

29. Salmina M. A. K voprosu o datirovke «Skazaniia o Mamaevom poboishche» // Trudy Otdela drevnerusskoi literatury. L., 1974. T. 29.

30. Salmina M. A. Povest' o Kulikovskoi bitve letopisnaia // Slovar' knizhnikov i knizhnosti Drevnei Rusi. L., 1989. Vyp. 2 (vtoraia polovina XIV-XVI v.). Ch. 2. L-Ia.

31. Shakhmatov A. A. Otzyv o sochinenii S. Shambinago "Povesti o Mamaevom poboishche». $\mathrm{SPb} ., 1906$ // Otchet o dvenadtsatom prisuzhdenii Imp. Akademiei nauk premii mitropolita Makariia v 1907 godu. SPb., 1910.

32. Shambinago S. K. Povesti o Mamaevom poboishche. SPb., 1906.

33. Skazaniia i povesti o Kulikovskoi bitve. L., 1982 (ser. «Literaturnye pamiatniki»).

34. Skrynnikov R. G. Kulikovskaia bitva: Problemy izucheniia // Kulikovskaia bitva v istorii i kul'ture nashei Rodiny. M., 1983.

35. Sobranie gosudarstvennykh gramot i dogovorov, khraniashchikhsia v gosudarstvennoi Kollegii inostrannykh del. M., 1813. T. 1.

36. Sokolova L. V. Chto soobshchalos' ob Olege Riazanskom v avtorskom tekste Povesti o Kulikovskoi bitve? (K voprosu o pozdneishikh vstavkakh v «Letopisnoi povesti») // Trudy Otdela drevnerusskoi literatury. SPb., 2019. T. 66.

37. Sokolova L. V. K voprosu o datirovke i avtorstve «Skazaniia o Mamaevom poboishche»// Trudy Otdela drevnerusskoi literatury. SPb., 2020. T. 67 (v pechati).

38. Sokolova L. V. Kakskladyvalos' literaturnoe predanie oblagoslovenii Sergiem Radonezhskim Dmitriia Donskogo na Kulikovskuiu bitvu // IX Chteniia po istorii i kul'ture drevnei i novoi Rossii (K 700-letiiu prepodobnogo Sergiia Radonezhskogo): Materialy nauch. konf. (Iaroslavl', 25-27 sentiabria 2014 g.). Iaroslavl', 2016.

39. Sokolova L. V. Letopisnye povestvovaniia o Kulikovskoi bitve (K voprosu o vzaimootnoshenii pamiatnikov) // Trudy Otdela drevnerusskoi literatury. SPb., 2014. T. 63.

40. Sokolova L. V. Ob istochnikakh rasskaza o Kulikovskoi bitve v svode 1408 g. (Troitskoi letopisi) // Akademik A. A. Shakhmatov: Zhizn', tvorchestvo, nauchnoe nasledie: Sb. statei k 150-letiiu so dnia rozhdeniia uchenogo. SPb., 2015.

41. Sokolova L. V. Pervonachal'na li Kratkaia redaktsiia «Zadonshchiny»?(V sviazi s noveishimi rabotami o vzaimootnoshenii «Slova o polku Igoreve» i «Zadonshchiny») // Trudy Otdela drevnerusskoi literatury. SPb., 2014. T. 62.

42. Sokolova L. V. Soderzhal li avtorskii tekst «Skazaniia o Mamaevom poboishche» vstavki iz «Zadonshchiny»? (K voprosu o vzaimootnoshenii pamiatnikov) // Trudy Otdela drevnerusskoi literatury. $\mathrm{SPb} ., 2017$. T. 65.

43. Solov'ev A. V. Epifanii Premudryi kak avtor "Slova o zhitii i prestavlenii velikago kniazia Dmitriia Ivanovicha, tsaria rus'skago» // Trudy Otdela drevnerusskoi literatury. M.; L., 1961. T. 17.

44. Tikhomirov M. N. Kulikovskaia bitva 1380 goda // Povesti o Kulikovskoi bitve. M., 1959. 


\section{Александра Юрьевна Веселова}

старший научный сотрудник

Института русской литературы (Пушкинский Дом) РАН

\section{Aleksandra Iur'evna Veselova}

Senior Researcher, Institute of Russian Literature (Pushkinskij Dom), Russian Academy of Sciences aveselova@inbox.ru

\section{Михаил Павлович Милютин}

преподаватель Академической гимназии

Санкт-Петербургского государственного университета

\section{Mikhail Pavlovich Miliutin}

Teacher, Academic Gymnasium, St. Petersburg State University

miljutin777@yandex.ru

\section{МЕМУАРЫ А. Т. БОЛОТОВА: ИСТОРИЯ СОЗДАНИЯ}

\section{A. T. BOLOTOV'S MEMOIRS: HISTORY OF CREATION}

Мемуары А. Т. Болотова представлены довольно обширным рукописным наследием, хранящимся в нескольких архивах страны. Это около 50 рукописей, часть из которых существует также в авторских копиях. В архивных документах и научной литературе до сих пор встречается много ошибок и неточностей в характеристике этих рукописей и определении их как черновиков, беловиков, сокращений или копий. Данная статья преследует цель систематизировать мемуарное наследие Болотова и установить место отдельных рукописей в общем комплексе воспоминаний. Для этого была проделана работа по реконструкции истории создания мемуаров, которая была разделена на этапы, опирающиеся на биографию Болотова и эволюцию его отношения к собственным запискам.

Ключевые слова: русская литература XVIII - первой трети XIX века, А. Т. Болотов, мемуары, дневники, рукописное наследие.

The memoirs of A. T. Bolotov are represented by a rather extensive manuscript heritage, stored in several Russian archives. There are about 50 manuscripts, some of them are also presented in the author's copies. In archival documents and critical literature, there still are numerous errors and inaccuracies in the description of these manuscripts and their definition as drafts, white papers, originals or copies. The aim of this article is to systematize Bolotov's memoir legacy and establish the place of every manuscript in the overall complex of manuscripts. Therefore, the article reconstructs the history of the creation of memoirs, dividing them into stages based on the life story of Bolotov and the evolution of his attitude to his own memoirs.

Key words: Russian literature of the $18^{\text {th }}-$ first third of the $19^{\text {th }}$ century, A. T. Bolotov, memoirs, diaries, manuscript legacy.

\section{Список литературы}

1. Абралова А. А. Ранняя редакция мемуаров А. Т. Болотова из собрания Отдела письменных источников ГИМ // Слово.ру. Балтийский акцент. 2020. № 2.

2. Абралович Д. И. Каталог собрания рукописей профессора И. В. Помяловского, ныне принадлежащих Императорской Публичной библиотеке. СПб., 1914.

3. Болотов А. Т. Жизнь и приключения Андрея Болотова, описанные самим им для своих потомков. СПб., 1870-1873. Т. 1-4.

4. Болотов М. П. Андрей Тимофеевич Болотов: жизнь его с 1796 по 1833 г. // Русская старина. 1873. Т. 8. Ноябрь.

5. [Веселова А. Ю.] Дни рождения А. Т. Болотова // Von Wenigen = От немногих. СПб., 2008. 
6. Веселова А. Ю., Милютин М. П. О составе корпуса мемуаров А. Т. Болотова // Русская литература. 2020. № 1 .

7. Клепиков C. A. Филиграни и штемпели на бумаге русского и иностранного производства XVII-XX вв. M., 1959.

8. Козлов С. А. Русская провинция в дневниках Павла Болотова: «Настольный календарь 1787 года». СПб., 2006.

\title{
References
}

1. Abramova A. A. Ranniaia redaktsiia memuarov A. T. Bolotova iz sobraniia Otdela pis'mennykh istochnikov GIM // Slovo.ru. Baltiiskii aktsent. 2020. № 2.

2. Abramovich D. I. Katalog sobraniia rukopisei professora I. V. Pomialovskogo, nyne prinadlezhashchikh Imperatorskoi Publichnoi biblioteke. SPb., 1914.

3. Bolotov A. T. Zhizn' i prikliucheniia Andreia Bolotova, opisannye samim im dlia svoikh potomkov. SPb., 1870-1873. T. 1-4.

4. Bolotov M. P. Andrei Timofeevich Bolotov: zhizn' ego s 1796 po 1833 g. // Russkaia starina. 1873. T. 8. Noiabr'.

5. Klepikov S. A. Filigrani i shtempeli na bumage russkogo i inostrannogo proizvodstva XVIIXX vv. M., 1959.

6. Kozlov S. A. Russkaia provintsiia v dnevnikakh Pavla Bolotova: «Nastol'nyi kalendar' 1787 goda». $\mathrm{SPb} ., 2006$.

7. [Veselova A. Iu.] Dni rozhdeniia A. T. Bolotova // Von Wenigen = Ot nemnogikh. SPb., 2008.

8. Veselova A. Iu., Miliutin M. P. O sostave korpusa memuarov A. T. Bolotova // Russkaia literatura. 2020 . № 1 .

\section{Мария Эммануиловна Баскина (Маликова)}

старший научный сотрудник

Института русской литературы (Пушкинский Дом) РАН

Mariia Emmanuilovna Baskina (Malikova)

Senior Researcher, Institute of Russian Literature (Pushkinskij Dom), Russian Academy of Sciences

maria.e.malikova@gmail.com

\section{Александр Викторович Волков}

младший научный сотрудник Института русской литературы (Пушкинский Дом) РАН

\section{Aleksandr Viktorovich Volkov}

Junior Researcher, Institute of Russian Literature (Pushkinskij Dom), Russian Academy of Sciences senderwolf@gmail.com

\author{
ЧТО ЖЕ ПИСАЛ О ПЕРЕВОДАХ \\ ЖИТЕЛЬ ВЫБОРГСКОЙ СТОРОНЫ
}

\section{WHAT THE DWELLER OF THE VYBORG SIDE HAS SAID ABOUT TRANSLATION}

Псевдоним «Житель Выборгской стороны» вошел в историю русского романтизма благодаpя П. А. Вяземскому, озаглавившему свое программное проромантическое предисловие $\mathrm{\kappa}$ «Бахчисарайскому фонтану» А. С. Пушкина «Разговор между Издателем и Классиком с Выборгской 
стороны или с Васильевского острова» (1824). Анализ единственной опубликованной под этим псевдонимом статьи «О переводах», печатавшейся в трех номерах журнала «Благонамеренный» в 1822-1823 годах, показывает, что статья представляла собой вовсе не программное выступление «классиков», вроде Н. А. Цертелева, противников «новой школы словесности», а мелочное, вторичное, внутренне противоречивое высказывание, в сочинении которого, вероятно, принима ли участие Б. М. Федоров и А. Е. Измайлов, сделанное в основном в интересах журнала «Благонамеренный» и внутренней полемики в ВОЛРС. ВОЛРС.

Ключевые слова: переводы, «романтики» и «классики», журнал «Благонамеренный»,

The pseudonym «Dweller of the Vyborg Side» has been written into the history of Russian Romanticism by P. A. Vyazemsky, who gave his programmatic pro-Romantic preface to A. S. Pushkin's poem The Fountain of Bakhchisaray - a title, Conversation Between the Publisher and the Classic from the Vyborg Side or Basil Island (1824). Analysis of the only text published under this pseudonym, the critical article «On Translations», that appeared in three issues of Blagonamerenny magazine in 1822-1823, shows that it was by no means a programmatic attack of the "Classics» of N. A. Tsertelev type, aimed against «the new school of poetry», but a petty, imitative, self-contradictory statement authored presumably by B. M. Fyodorov and A. E. Izmaylov and made primarily in the interests of Blagonamerenny and the inner polemics within VOLRS (Free Society of Champions of Russian Literature).

Key words: Translation, «Romantics» and «Classics», Blagonamerenny magazine, VOLRS (Free Society of Champions of Russian Literature).

\section{Список литературы}

1. Базанов В. Г. Ученая республика. М.; Л., 1964.

2. Бестужев А. Взгляд на старую и новую словесность в России [1823] // Полярная Звезда, изданная А. Бестужевым и К. Рылеевым / Изд. подг. В. А. Архипов, В. Г. Базанов и Я. Л. Левкович. М.; Л., 1960 (сер. «Литературные памятники»).

3. Булкина И. С. Чеславский Иван Богданович // Русские писатели. 1800-1917. М., 2019. Т. 6.

4. Вацуро В. Э., Гиллельсон М. И. Сквозь умственные плотины. Очерки о книгах и прессе пушкинской поры. М., 1986.

5. Велланский Д. М. Биологическое исследование природы в творящем и творимом ее качестве, содержащее основные начертания всеобщей физиологии. СПб., 1812.

6. Велланский Д. М. Проклюзия к медицине как основательной науке. СПб., 1805.

7. Воейков А. Ответ господину М. С. на его возражения // Вестник Европы. 1811. № 9.

8. [Вяземский П. А.]. Разговор между Издателем и Классиком с Выборгской стороны или с Васильевского острова. Вместо предисловия $<$ «Бахчисарайскому фонтану» $>$ // «Бахчисарайский фонтан» А. Пушкина. М., 1824.

9. Грибоедов А. С. Полн. собр. соч. / Под ред. и с прим. Н. К. Пиксанова. Пг., 1917.

10. Д. В. p. cm-въ [Федоров Б. М.]. Разговор о романтиках и о «Черной речке» // Благонамеренный. 1823. Ч. 23. № 15 .

11. Демин А. О. Перевод рассказа Терамена из трагедии Ж. Расина «Федра» и оригинальное творчество Г. Р. Державина // XVIII век. СПб., 2008. Сб. 25.

12. Делин А. О. Рассказ Терамена в переводе Гнедича // Из истории русской переводной художественной литературы первой четверти XIX века: Сб. статей и материалов. СПб., 2017.

13. Егунов A. Н. Гомер в русских переводах XVIII-XIX веков. М., 2001.

14. Житель Васильевского Острова [Цертелев Н. А.]. Письмо к г. Марлинскому // Благонамеренный. 1820. Ч. 11. № 13.

15. Житель Васильевского Острова [Цертелев Н. А.]. Спор (отрывок из моего Журнала) // Благонамеренный. 1820. Ч. 9. № 6.

16. Житель Галерной Гавани [Сомов О. М.]. Ответ на (так названный) ответ Господина Ф. Б. ... жителю Галерной Гавани // Невский зритель. 1821. Ч. 5. № 3.

17. Житель Галерной Гавани [Сомов О. М.]. Письмо к г. Марлинскому // Невский зритель. 1821. Ч. 5. № 1 . T. 3 .

18. Зубков Н. Н. Лобанов Михаил Евстафиевич // Русские писатели. 1800-1917. М., 1994.

19. Ильин-Толич А. А. Грузинцов Александр Николаевич // Русские писатели. 1800-1917. M., 1992. T. 2. № 21 .

20. Истов И. Разбор идиллии: «Рыбаки» (Продолжение) // Благонамеренный. 1822. Ч. 18.

21. Князь Вязелский. Разбор Второго Разговора, напечатанного в 7 № Вестника Европы // Дамский журнал. 1824. № 8. Апрель.

22. Князь Цертелев. Отрывок из письма к N. ․ // Благонамеренный. 1819. Ч. 8. № 23/24.

23. Костин А. А. Федоров Борис Михайлович // Русские писатели. 1800-1917. М., 2019. Т. 6. 
24. Л. М. [Вяземский П. А.]. Письмо в Париж // Московский телеграф. 1825. Ч. 6. № 22.

25. Левкович Я. Л. Литературная и общественная жизнь пушкинской поры в письмах А. Е. Измайлова к П. Л. Яковлеву // Пушкин: Исследования и материалы. Л., 1978. Т. 8.

26. Лит. наследство. 1956. Т. 60. Кн. 1.

27. Лотлан Ю. М., Успенский Б. А. Споры о языке в начале ХІХ в. как факт русской культуры («Происшествие в царстве теней, или Судьбина российского языка» - неизвестное сочинение Семена Боброва) // Успенский Б. А. Избр. труды. М., 1994. Т. 2.

28. Марлинский А. Письмо к издателю // Благонамеренный. 1820. Ч. 11. № 6.

29. Масанов И. Ф. Словарь псевдонимов русских писателей, ученых и общественных деятелей: В 4 т. М., 1956. Т. 1.

30. Мордовченко Н. И. Русская критика первой четверти ХIX века. М.; Л., 1959.

31. $N$. $N$. Некоторые замечания на отрывок из пятой песни Илиады, напечатанной в 45 № Сына отечества // Сын отечества. 1822. № 51.

32. О-в [Остолопов Н. Ф.]. О баснях графа Хвостова // Благонамеренный. 1820. Ч. 10. № 9.

33. Омирова брань лягушек и мышей / Пер. с греч. Алексей Огинский. СПб., 1812.

34. Остафьевский архив князей Вяземских. Переписка князя П. А. Вяземского с А. И. Тургеневым. СПб., 1899. Т. 2, 3.

35. Отрывок из второй песни Виргилиевых Георгик / [Пер.] Александр Воейков // Труды Казанского Общества любителей отечественной словесности. Казань, 1815. Кн. 1.

36. Первая Олинфийская речь Демосфена, переведенная г. Огинским // Дух журналов. 1817. Ч. 19. Кн. 16 .

37. П. с. p. въ [Писарев А. И.]. Замечания на новый перевод Федры // Вестник Европы. 1822 Ч. 122 . № 8 .

38. Письмо Цицерона: Книга II, письмо 8 / С лат. А. Огинский // Благонамеренный. 1824 Ч. 26. № 12 .

39. Похвальное слово императору Траяну. Сочинение младшего Плиния, переведенное с латинского ординарным профессором Императорского Санкт-Петербургского университета Яковом Толмачевым. СПб., 1820.

40. Прогулки девицы $\mathrm{M}^{* *}$ Кр. ${ }^{* * *}$ ныне г-жи Ск..., или Окрестности города Вильна. Перевод с франц. рукописи ее В. Анч. [Анастасевич]. СПб., 1908.

41. Проскурин О. Литературные скандалы пушкинской эпохи. М., 2000.

42. Пушкин в прижизненной критике. 1820-1827. СПб., 2001.

43. Пять веков героических / (Отрывок из Гезиодовой поэмы: Работы и дни); с греческого А. Огинский // Благонамеренный. 1824. Ч. 26. № 7.

44. Рейтблат А. И. Видок Фиглярин. М., 1998.

45. Сигал Н. А. Из истории русских переводов «Федры» Расина // Русско-европейские литературные связи: Сб. статей к 70-летию ак. М. П. Алексеева. М.; Л., 1966.

46. Собр. соч. и переводов адмирала Шишкова. СПб., 1825. Ч. 4.

47. Федоров Б. Письма в Тамбов о новостях русской словесности. Письмо I // Благонамеренный. 1824. Ч. 26. № 7, 8.

48. Электра и Орест. Трагедия в 5 действиях Александра Грузинцова. СПб., 1810.

49. Ю. П. Явление Гиперборейского Духа // Сын отчества. 1817. Ч. 41. № 43.

50. Ludovico, ou le fils d'un homme de Génie / Trad. de l'anglais par Madame La Baronne de Montolieu. Vienne, 1817.

\section{References}

1. Bazanov V. G. Uchenaia respublika. M.; L., 1964.

2. Bestuzhev A. Vzgliad na staruiu i novuiu slovesnost' v Rossii [1823] // Poliarnaia Zvezda, izdannaia A. Bestuzhevym i K. Ryleevym / Izd.podg. V. A. Arkhipov, V. G. Bazanovi Ia. L. Levkovich. M.; L., 1960 (ser. «Literaturnye pamiatniki»).

3. Bulkina I. S. Cheslavskii Ivan Bogdanovich // Russkie pisateli. 1800-1917. M., 2019. T. 6.

4. D. V.r.st-v' [Fedorov B. M.]. Razgovor o romantikakh i o "Chernoi rechke»// Blagonamerennyi. 1823 . Ch. 23. № 15.

5. Demin A. O. Perevod rasskaza Teramena iz tragedii Zh. Rasina «Fedra» i original'noe tvorchestvo G. R. Derzhavina // XVIII vek. SPb., 2008. Sb. 25.

6. Demin A. O. Rasskaz Teramena v perevode Gnedicha // Iz istorii russkoi perevodnoi khudozhestvennoi literatury pervoi chetverti XIX veka: Sb. statei i materialov. SPb., 2017.

7. Egunov A. N. Gomer v russkikh perevodakh XVIII-XIX vekov. M., 2001.

8. Elektra i Orest. Tragediia v 5 deistviiakh Aleksandra Gruzintsova. SPb., 1810.

9. Griboedov A. S. Poln. sobr. soch. / Pod red. i s prim. N. K. Piksanova. Pg., 1917.

10. Il'in-Tomich A. A. Gruzintsov Aleksandr Nikolaevich // Russkie pisateli. 1800-1917. M., 1992. T. 2.

11. Istov I. Razbor idillii: «Rybaki» (Prodolzhenie) // Blagonamerennyi. 1822. Ch. 18. № 21.

12. Iu. P. Iavlenie Giperboreiskogo Dukha // Syn otchestva. 1817. Ch. 41. № 43. 
13. Fedorov B. Pis'ma v Tambov o novostiakh russkoi slovesnosti. Pis'mo I // Blagonamerennyi. 1824. Ch. 26. № 7, 8 .

14. Kniaz’ Tsertelev. Otryvok iz pis’ma k N. N. // Blagonamerennyi. 1819. Ch. 8. № 23/24.

15. Kniaz'Viazemskii. Razbor Vtorogo Razgovora, napechatannogo v 7 № Vestnika Evropy // Damskii zhurnal. 1824. № 8. Aprel’.

16. Kostin A. A. Fedorov Boris Mikhailovich // Russkie pisateli. 1800-1917. M., 2019. T. 6.

17. L. M. [Viazemskii P. A.]. Pis’mo v Parizh // Moskovskii telegraf. 1825. Ch. 6. № 22.

18. Levkovich Ia. L. Literaturnaia i obshchestvennaia zhizn' pushkinskoi pory v pis'makh

A. E. Izmailova k P. L. Iakovlevu // Pushkin: Issledovaniia i materialy. L., 1978. T. 8.

19. Lit. nasledstvo. 1956. T. 60. Kn. 1.

20. Lotman Iu. M., Uspenskii B. A. Spory o iazyke v nachale XIX v. kak fakt russkoi kul'tury ( «Proisshestvie v tsarstve tenei, ili Sud'bina rossiiskogo iazyka» - neizvestnoe sochinenie Semena Bobrova) // Uspenskii B. A. Izbr. trudy. M., 1994. T. 2.

21. Ludovico, ou le fils d'un homme de Génie / Trad. de l'anglais par Madame La Baronne de Montolieu. Vienne, 1817.

22. Marlinskii A. Pis’mo k izdateliu // Blagonamerennyi. 1820. Ch. 11. № 6.

23. Masanov I. F. Slovar' psevdonimov russkikh pisatelei, uchenykh i obshchestvennykh deiatelei: V 4 t. M., 1956. T. 1.

24. Mordovchenko N. I. Russkaia kritika pervoi chetverti XIX veka. M.; L., 1959.

25. N. N. Nekotorye zamechaniia na otryvok iz piatoi pesni Iliady, napechatannoi v 45 № Syna otechestva // Syn otechestva. 1822. № 51.

26. Omirova bran' liagushek i myshei / Per. s grech. Aleksei Oginskii. SPb., 1812.

27. Ostaf'evskii arkhiv kniazei Viazemskikh. Perepiska kniazia P. A. Viazemskogo s A. I. Turgenevym. SPb., 1899. T. 2, 3 .

28. Otryvok iz vtoroi pesni Virgilievykh Georgik / [Per.] Aleksandr Voeikov // Trudy Kazanskogo Obshchestva liubitelei otechestvennoi slovesnosti. Kazan’, 1815. Kn. 1.

29. $O-v$ [Ostolopov N. F.]. O basniakh grafa Khvostova // Blagonamerennyi. 1820. Ch. 10. № 9.

30. Pervaia Olinfiiskaia rech' Demosfena, perevedennaia g. Oginskim // Dukh zhurnalov. 1817. Ch. 19. Kn. 16.

31. Piat' vekov geroicheskikh / (Otryvok iz Geziodovoi poemy: Raboty i dni); s grecheskogo A. Oginskii // Blagonamerennyi. 1824. Ch. 26. № 7 .

32. Pis'mo Tsitserona: Kniga II, pis'mo 8 / S latinskogo A. Oginskii // Blagonamerennyi. 1824. Ch. 26. № 12 .

33. Pokhval'noe slovo imperatoru Traianu. Sochinenie mladshego Pliniia, perevedennoe s latinskogo ordinarnym professorom Imperatorskogo Sankt-Peterburgskogo universiteta Iakovom Tolmachevym. SPb., 1820.

34. Progulki devitsy $\mathrm{M}^{* *} \mathrm{Kr}$.*** $^{* * *}$ nyne g-zhi Sk..., ili Okrestnosti goroda Vil'na. Perevod s frants. rukopisi ee V. Anch. [Anastasevich]. SPb., 1908.

35. Proskurin O. Literaturnye skandaly pushkinskoi epokhi. M., 2000.

36. P. s.r.v' [Pisarev A. I.]. Zamechaniia na novyi perevod Fedry // Vestnik Evropy. 1822. Ch. 122 . № 8 .

37. Pushkin v prizhiznennoi kritike. 1820-1827. SPb., 2001.

38. Reitblat A. I. Vidok Figliarin. M., 1998.

39. Sigal N. A. Iz istorii russkikh perevodov «Fedry» Rasina // Russko-evropeiskie literaturnye sviazi: Sb. statei k 70-letiiu ak. M. P. Alekseeva. M.; L., 1966.

40. Sobr. soch. i perevodov admirala Shishkova. SPb., 1825. Ch. 4.

41. Vatsuro V. E., Gillel'son M. I. Skvoz' umstvennye plotiny. Ocherki o knigakh i presse pushkinskoi pory. M., 1986.

42. Vellanskii D. M. Biologicheskoe issledovanie prirody v tvoriashchem i tvorimom ee kachestve, soderzhashchee osnovnye nachertaniia vseobshchei fiziologii. SPb., 1812.

43. Vellanskii D. M. Prokliuziia k meditsine kak osnovatel'noi nauke. SPb., 1805 .

44. [Viazemskii P. A.]. Razgovor mezhdu Izdatelem i Klassikom s Vyborgskoi storony ili s Vasil'evskogo ostrova. Vmesto predisloviia $<\mathrm{k}$ «Bakhchisaraiskomu fontanu» $>/ /$ «Bakhchisaraiskii fontan» A. Pushkina. M., 1824.

45. Voeikov A. Otvet gospodinu M. S. na ego vozrazheniia // Vestnik Evropy. 1811. № 9.

46. Zhitel' Galernoi Gavani [Somov O. M.]. Otvet na (tak nazvannyi) otvet Gospodina F. B. ... zhiteliu Galernoi Gavani // Nevskii zritel’. 1821. Ch. 5. № 3.

47. Zhitel' Galernoi Gavani [Somov O. M.]. Pis'mo k g. Marlinskomu // Nevskii zritel'. 1821. Ch. 5 . № 1 .

48. Zhitel'Vasil'evskogo Ostrova [Tsertelev N. A.]. Pis'mo k g. Marlinskomu // Blagonamerennyi. 1820. Ch. 11. № 13.

49. Zhitel'Vasil'evskogo Ostrova [Tsertelev N. A.]. Spor (otryvok iz moego Zhurnala) // Blagonamerennyi. 1820. Ch. 9. № 6 .

50. Zubkov N. N. Lobanov Mikhail Evstafievich // Russkie pisateli. 1800-1917. M., 1994. T. 3. 


\author{
Дарья Алексеевна Луговская \\ аспирант Национального исследовательского университета \\ «Высшая школа экономики» \\ Daria Alekseevna Lugovskaia \\ Postgraduate Student, \\ National Research University Higher School of Economics \\ lugovskaya.darya@yandex.ru
}

\title{
В. Ф. ХОДАСЕВИЧ В 1905-1907 ГОДАХ: СТРАТЕГИЯ КРИТИКА И СТАНОВЛЕНИЕ ЛИТЕРАТУРНОЙ РЕПУТАЦИИ
}

\section{F. KHODASEVICH IN 1905-1907: STRATEGY OF A CRITIC AND THE EMERGENCE OF A LITERARY REPUTATION}

В статье анализируются рецензии В. Ф. Ходасевича, написанные в 1905-1907 годах, когда начинающему критику и поэту нужно было занять определенное место в символистском литературном поле. Половина рецензий издана под псевдонимом «Сигурд». Автор рассматривает особенности сотрудничества Ходасевича с периодикой первого десятилетия XX века и внутрилитературные обстоятельства, с которыми связывается появление псевдонима, — положение ученика и одновременно оппонента В. Я. Брюсова является важнейшим из них.

Ключевые слова: В. Ф. Ходасевич, В. Я. Брюсов, литературная критика, Сигурд, символический капитал, генезис псевдонима.

The article analyzes the reviews written by V. F. Khodasevich in 1905-1907, when the young critic and poet was searching for his own place in the Symbolist literary field. Half of the reviews are published under the pseudonym «Sigurd». The author of the article looks into the peculiarities of Khodasevich's work in the Symbolist magazines of the first decade of the $20^{\text {th }}$ century, as well as into the intra-literary circumstances associated with the introduction of the pseudonym. The most important peculiarity is his status of the pupil and, at the same time, the opponent of V. Y. Bryusov.

Key words: V. F. Khodasevich, V. Y. Bryusov, literary criticism, Sigurd, symbolical capital, genesis of a pseudonym.

\section{Список литературы}

1. Белый А. Между двух революций. М., 1990.

2. Белый А. Начало века. М., 1990.

3. Богололов Н. А. Вл. Ходасевич в московском и петроградском литературном кругу // Новое литературное обозрение. 1995. № 14.

4. Богололов Н. А. ЖЖизнь и поэзия Владислава Ходасевича // Ходасевич В. Стихотворения. Л., 1989 (Библиотека поэта. Большая сер.).

5. Богололов Н. А. К истории «Золотого Руна» // Богомолов Н. А. От Пушкина до Кибирова: Статьи о русской литературе, преимущественно о поэзии. М., 2004. 1999.

6. Бочаров C. $Г$. «Памятник» Ходасевича // Бочаров С. Г. Сюжеты русской литературы. М.,

7. Брюсов В. Я. Арнольд Ариэль. Мрак // Весы. 1905. № 7.

8. Брюсов В. Я. Бальмонт // Мир искусства. 1903. № 7-8.

9. Брюсов В. Я. Иван Рукавишников. Стихотворения. Книга IV. Л. Вилькина-Минская. Мой сад. Сонеты и рассказы. А. Федоров. Сонеты // Весы. 1907. № 10.

10. Брюсов В. Я. К. Бальмонт. Собрание стихов, т. І; К. Бальмонт. Литургия Красоты // Весы. 1905. № 4 .

11. Брюсов В. Я. Мои воспоминания о Викторе Гофмане // Брюсов В. Я. Среди стихов, 18941924: Манифесты. Статьи. Рецензии. М., 1990.

12. Брюсов В. Я. Сборник «Знания», кн. Х // Весы. 1906. № 6.

13. Брюсов В. Я. Сборник товарищества «Знание» на 1904 г. Кн. IV и V; Нижегородский сборник // Весы. 1905. № 4.

14. Брюсов В. Я. Собр. соч.: В 7 т. М., 1973. Т. 1.

15. Брюсов В. Я. Среди стихов, 1894-1924: Манифесты. Статьи. Рецензии. М., 1990.

16. Брюсов В. Я. Тан. Стихотворения // Весы. 1905. № 5.

17. Бурдье П. Поле литературы // Новое литературное обозрение. 2000. № 45. 
18. Георгий Р-н [Ходасевич В. Ф.]. О последних книгах К. Бальмонта // Южный край. 1907. 23 дек. № 9628. № 7 .

19. Гофлан В. Владислав Ходасевич. Молодость. Стихи 1907 г. // Русская мысль. 1908.

20. Из переписки Н. И. Петровской / Публ. Р. Л. Щербакова и Е. А. Муравьевой // Минувшее: Исторический альманах. М.; СПб., 1993. Вып. 14.

21. Козляков В. Владислав Ходасевич и Зыгмунт Красиньский // Начало века: Из истории международных связей русской литературы. СПб., 2000.

22. Колкер Ю. Айдесская прохлада: Очерк жизни и творчества В. Ф. Ходасевича // Ходасевич В. Ф. Собр. стихов: В 2 т. Paris, 1983. Т. 2.

23. Красинский З. Иридион / Пер. с польского и предисловие В. Ходасевича. М., 1910.

24. Кречетов C. Апологеты культуры // Золотое руно. 1906. № 3.

25. Лавров A. В. Виктор Гофман: между Москвой и Петербургом // Писатели символистского круга: Новые материалы. СПб., 2003.

26. Лавров А. В. «Забытые» фрагменты переписки Брюсова и Мережковского // От Кибирова до Пушкина: сборник в честь 60-летия Н. А. Богомолова. М., 2011.

27. Лавров А. В. «Золотое Руно» // Лавров А. В. Русские символисты: Этюды и разыскания. M., 2007. 2007.

28. Лавров А. В. «Перевал» // Лавров А. В. Русские символисты: этюды и разыскания. М.,

29. Лавров А. В., Гречишкин С. С. О работе Брюсова над романом «Огненный ангел» // Лавров А. В., Гречишкин С. С. Символисты вблизи. Очерки и публикации. СПб., 2004.

30. Лит. наследство. 1991. Т. 98. Валерий Брюсов и его корреспонденты: В 2 кн. Кн. 1.

31. Макеев M. C. Николай Некрасов: Поэт и Предприниматель (очерки о взаимодействии литературы и экономики). М., 2008.

32. От редакции // Золотое руно. 1908. № 1.

33. От редакции // Перевал. 1906. № 1 .

34. Розанов И. Н. Литературные репутации. М., 1990.

35. Сигурд [Ходасевич В. Ф.]. А. Федоров. Сонеты // Перевал. 1906. № 1.

36. Сигурд [Ходасевич В. Ф.]. VIII Сборник Товарищества «Знание»; IX Сборник Товарищества «Знание» // Золотое руно. 1906. № 4.

37. Сигурд [Ходасевич В. Ф.]. И. Ф. Анненский. Книга отражений // Золотое руно. 1906. № 3 .

38. Сигурд [Ходасевич В. Ф.]. С. Головачевский. «Мене текел фарес» (Стихотворения) // Золотое руно. 1906 . № 5 .

39. Сигурд [Ходасевич В. Ф.]. Тан. Стихотворения // Искусство. 1905. № 5/7.

40. Тилофеев А. В. Ходасевич // Руль. 1908. 23 апр. № 87.

41. Товарищ, Герлан [Брюсов В. Я.]. Золотому руну // Весы. 1906. № 5 .

42. Товарищ, Герлан [Гиппиус 3. Н.]. Золотое руно // Весы. 1906. № 2.

43. Успенский П. Творчество В. Ф. Ходасевича и русская литературная традиция (1900-е гг. 1917 г.). Тарту, 2014. № 1 .

44. Ходасевич В. Ф. Х Сборник Т-ва «Знание»; ХІ Сборник Т-ва «Знание» // Перевал. 1906.

45. Ходасевич В. Ф. Арнольд Ариэль. Мрак // Искусство. 1905. № 8.

46. Ходасевич В. Ф. Виктор Гофман. К двадцатипятилетию со дня смерти // Ходасевич В. Ф. Собр. соч.: В 4 т. М., 1997. Т. 4.

47. Ходасевич В. Ф. Д. Ратгауз. Полное собрание стихотворений. 2 тома // Золотое руно. 1906. № 4 .

48. Ходасевич В. Ф. К. Д. Бальмонт. Литургия Красоты. Стихийные гимны // Искусство. 1905. № 5/7.

49. Ходасевич В. Ф. Лед и пламень // Голос Москвы. 1913. 18 мая. № 114

50. Ходасевич В. Ф. Нижегородский сборник // Искусство. 1905. № 5/7.

51. Ходасевич В. Ф. О меценатах // Ходасевич В. Ф. Собр. соч: В 4 т. М., 1997. Т. 4.

52. Ходасевич В. Ф. Сборник Товарищества «Знание». Книга VII // Золотое руно. 1906. № 1.

53. Ходасевич В. Ф. Собр. соч.: В 8 т. М., 2009-2010. Т. 1, 2.

54. Ходасевич В. Ф. Федор Сологуб. Тяжелые сны // Золотое руно. 1906. № 2.

55. Чабан A. Н. С. Гумилев - критик поэтов-символистов: динамика оценок и эволюция критического языка. Тарту, 2018.

56. Шубинский В. И. Владислав Ходасевич: Чающий и говорящий. М., 2012 (сер. «Жизнь замечательных людей»).

57. Bartlett R. Wagner and Russia. Cambridge: Cambridge University Press, 1995.

58. Lednicki W. Blok's «Polish poem»: A Literary Episode in the History of Russian-Polish Relations // Bulletin of the Polish Institute of Arts and Sciences in America. 1944. Vol. 2 . № 2.

59. Morawski S. Polish Theories of Art between 1830 and 1850 // The Journal of Aesthetics and Art Criticism. 1957. Vol. 16. № 2. 


\section{References}

1. Bartlett R. Wagner and Russia. Cambridge: Cambridge University Press, 1995.

2. Belyi A. Mezhdu dvukh revoliutsii. M., 1990.

3. Belyi A. Nachalo veka. M., 1990. M., 1999 .

4. Bocharov S. G. «Pamiatnik» Khodasevicha // Bocharov S. G. Siuzhety russkoi literatury.

5. Bogomolov N. A. K istorii "Zolotogo Runa» // Bogomolov N. A. Ot Pushkina do Kibirova: Stat'i o russkoi literature, preimushchestvenno o poezii. M., 2004.

6. Bogomolov N. A. Vl. Khodasevich v moskovskom i petrogradskom literaturnom krugu // Novoe literaturnoe obozrenie. 1995. № 14

7. Bogomolov N. A. Zhizn' i poeziia Vladislava Khodasevicha // Khodasevich V. Stikhotvoreniia. L., 1989 (Biblioteka poeta. Bol'shaia ser.).

8. Briusov V. Ia. Arnol’d Ariel'. Mrak // Vesy. 1905. № 7.

9. Briusov V. Ia. Bal'mont // Mir iskusstva. 1903. № 7-8.

10. Briusov V. Ia. Ivan Rukavishnikov. Stikhotvoreniia. Kniga IV. L. Vil'kina-Minskaia. Moi sad. Sonety i rasskazy. A. Fedorov. Sonety // Vesy. 1907. № 10.

11. Briusov V. Ia. K. Bal'mont. Sobranie stikhov, t. I; K. Bal'mont. Liturgiia Krasoty // Vesy. 1905. № 4.

12. Briusov V. Ia. Moi vospominaniia o Viktore Gofmane // Briusov V. Ia. Sredi stikhov, 18941924: Manifesty. Stat'i. Retsenzii. M., 1990.

13. Briusov V. Ia. Sbornik «Znaniia», kn. X// Vesy. 1906. № 6.

14. Briusov V. Ia. Sbornik tovarishchestva «Znanie» na 1904 g. Kn. IV i V; Nizhegorodskii sbornik // Vesy. 1905. № 4 .

15. Briusov V. Ia. Sobr. soch.: V 7 t. M., 1973. T. 1.

16. Briusov V. Ia. Sredi stikhov, 1894-1924: Manifesty. Stat'i. Retsenzii. M., 1990.

17. Briusov V. Ia. Tan. Stikhotvoreniia // Vesy. 1905. № 5.

18. Burd'e P. Pole literatury // Novoe literaturnoe obozrenie. 2000. № 45.

19. Chaban A. N. S. Gumilev - kritik poetov-simvolistov: dinamika otsenok i evoliutsiia kriticheskogo iazyka. Tartu, 2018.

20. Georgii R-n [Khodasevich V. F.]. O poslednikh knigakh K. Bal'monta // Iuzhnyi krai. 1907. 23 dek. № 9628.

21. Gofman V. Vladislav Khodasevich. Molodost’. Stikhi 1907 g. // Russkaia mysl’. 1908. № 7.

22. Iz perepiski N. I. Petrovskoi / Publ. R. L. Shcherbakova i E. A. Murav'evoi // Minuvshee: Istoricheskii al'manakh. M.; SPb., 1993. Vyp. 14.

23. Khodasevich V. F. X Sbornik T-va «Znanie»; XI Sbornik T-va «Znanie»// Pereval. 1906. № 1. 24. Khodasevich V. F. Arnol'd Ariel'. Mrak // Iskusstvo. 1905. № 8.

25. Khodasevich V. F. D. Ratgauz. Polnoe sobranie stikhotvorenii. 2 toma // Zolotoe runo. 1906. № 4 .

26. Khodasevich V. F. Fedor Sologub. Tiazhelye sny // Zolotoe runo. 1906. № 2.

27. Khodasevich V. F. K. D. Bal'mont. Liturgiia Krasoty. Stikhiinye gimny // Iskusstvo. 1905. № $5 / 7$.

28. Khodasevich V. F. Led i plamen’ // Golos Moskvy. 1913. 18 maia. № 114.

29. Khodasevich V. F. Nizhegorodskii sbornik // Iskusstvo. 1905. № 5/7.

30. Khodasevich V. F. O metsenatakh // Khodasevich V. F. Sobr. soch: V 4 t. T. 4. M., 1997. T. 4.

31. Khodasevich V. F. Sbornik Tovarishchestva «Znanie». Kniga VII // Zolotoe runo. 1906. № 1.

32. Khodasevich V. F. Sobr. soch.: V 8 t. M., 2009-2010. T. 1, 2.

33. Khodasevich V. F. Viktor Gofman. K dvadtsatipiatiletiiu so dnia smerti // Khodasevich V. F. Sobr. soch.: V 4 t. M., 1997. T. 4.

34. Kolker Iu. Aidesskaia prokhlada: Ocherk zhizni i tvorchestva V. F. Khodasevicha // Khodasevich V. F. Sobr. stikhov: V 2 t. Paris, 1983. T. 2.

35. Kozliakov V. Vladislav Khodasevich i Zygmunt Krasin'skii // Nachalo veka: Iz istorii mezhdunarodnykh sviazei russkoi literatury. SPb., 2000.

36. Krasinskii Z. Iridion / Per. s pol'skogo i predislovie V. Khodasevicha. M., 1910.

37. Krechetov S. Apologety kul’tury // Zolotoe runo. 1906. № 3.

38. Lavrov A. V. «Pereval»// Lavrov A. V. Russkie simvolisty: etiudy i razyskaniia. M., 2007.

39. Lavrov A. V. Viktor Gofman: mezhdu Moskvoi i Peterburgom // Pisateli simvolistskogo kruga: Novye materialy. SPb., 2003.

40. Lavrov A. V. "Zabytye» fragmenty perepiski Briusova i Merezhkovskogo // Ot Kibirova do Pushkina: sbornik v chest' 60-letiia N. A. Bogomolova. M., 2011.

41. Lavrov A. V. «Zolotoe Runo» // Lavrov A. V. Russkie simvolisty: Etiudy i razyskaniia. M., 2007.

42. Lavrov A. V., Grechishkin S. S. O rabote Briusova nad romanom «Ognennyi angel»// Lavrov A. V., Grechishkin S. S. Simvolisty vblizi. Ocherki i publikatsii. SPb., 2004.

43. Lednicki W. Blok's "Polish poem»: A Literary Episode in the History of Russian-Polish Relations // Bulletin of the Polish Institute of Arts and Sciences in America. 1944. Vol. 2. № 2.

44. Lit. nasledstvo. 1991. T. 98. Valerii Briusov i ego korrespondenty: V 2 kn. Kn. 1. 
45. Makeev M. S. Nikolai Nekrasov: Poet i Predprinimatel' (ocherki o vzaimodeistvii literatury i ekonomiki). M., 2008.

46. Morawski S. Polish Theories of Art between 1830 and 1850 // The Journal of Aesthetics and Art Criticism. 1957. Vol. 16. № 2.

47. Ot redaktsii // Pereval. 1906. № 1.

48. Ot redaktsii // Zolotoe runo. 1908. № 1 .

49. Rozanov I. N. Literaturnye reputatsii. M., 1990.

50. Shubinskii V. I. Vladislav Khodasevich: Chaiushchii i govoriashchii. M., 2012 (ser. "Zhizn' zamechatel'nykh liudei»).

51. Sigurd [Khodasevich V. F.]. VIII Sbornik Tovarishchestva «Znanie»; IX Sbornik Tovarishchestva «Znanie»// Zolotoe runo. 1906. № 4.

52. Sigurd [Khodasevich V. F.]. A. Fedorov. Sonety // Pereval. 1906. № 1.

53. Sigurd [Khodasevich V. F.]. I. F. Annenskii. Kniga otrazhenii // Zolotoe runo. 1906. № 3.

54. Sigurd [Khodasevich V. F.]. S. Golovachevskii. «Mene tekel fares» (Stikhotvoreniia) // Zolotoe runo. 1906. № 5.

55. Sigurd [Khodasevich V. F.]. Tan. Stikhotvoreniia // Iskusstvo. 1905. № 5/7.

56. Timofeev A. V. Khodasevich // Rul’. 1908. 23 apr. № 87.

57. Tovarishch German [Briusov V. Ia.]. Zolotomu runu // Vesy. 1906. № 5.

58. Tovarishch German [Gippius Z. N.]. Zolotoe runo // Vesy. 1906. № 2.

59. Uspenskii P. Tvorchestvo V. F. Khodasevicha i russkaia literaturnaia traditsiia (1900-e gg. 1917 g.). Tartu, 2014.

\section{Елена Рудольфовна Обатнина}

ведущий научный сотрудник

Института русской литературы (Пушкинский Дом) РАН

\section{Elena Rudol'fovna Obatnina}

Leading Researcher,

Institute of Russian Literature (Pushkinskij Dom), Russian Academy of Sciences

lena.eo@mail.ru

\section{ИЗБРАННЫЕ СТРАНИЦЫ ИЗ АЛЬБОМА А. М. РЕМИЗОВА «ЗАРУБЕЖНАЯ ЦЕНЗУРА»: ПОЛИТИКА И ЭТИКА \\ SELECTED PAGES FROM ALEXEY REMIZOV'S ALBUM FOREIGN CENSORSHIP: POLITICS AND ETHICS}

В статье исследуется неизвестный альбом А. М. Ремизова «Зарубежная цензура», составленный из случаев цензурной правки текстов писателя. Анализ избранных страниц альбома представляет собой единственный в своем роде опыт аналитического подхода Ремизова к проблеме собственных взаимоотношений с литературным сообществом эмиграции, которое в свою очередь стремилось сохранить свою целостность благодаря негласно узаконенному кодексу этических, эстетических и политических норм.

Ключевые слова: А. М. Ремизов, личный архив, литературная цензура, литературное поведение, политическая самоидентификация, редакционная политика, литературная этика.

This article explores Remizov's unknown album Foreign Censorship, where the case studies of censorial editing of the writer's texts are collected. The study of the selected pages from the album reveals the unique instance of Remizov's analytical approach to the problem of his own relations with the émigré literary community, which in turn sought to preserve its integrity through an implicitly legalized code of ethical, aesthetic and political norms.

Key words: A. Remizov, personal archives, literary censorship, literary behavior, political selfidentification, editorial policy, literary ethics.

\section{Список литературы}

1. Вишняк M. В. На родине (Мы и они) // Современные записки. 1922. Кн. Х. 2010 .

2. Грачева А. М. Жанр романа и творчество Алексея Ремизова (1910-1950-е годы). СПб. 
3. Динерштейн E. A. Синяя птица Зиновия Гржебина. М., 2014.

4. Доценко C. Проблемы поэтики А. М. Ремизова: Автобиографизм как конструктивный принцип творчества. Tallinn, 2000.

5. Зайцев Б. Мои современники / Сост. Н. Б. Зайцевой-Соллогуб; вступ. статья Б. Филиппова. London, 1988.

6. «На вечерней заре». Глава из рукописи; Письма к С. П. Ремизовой-Довгелло. 1925 / Комм. Е. Р. Обатниной; подг. текста Е. Р. Обатниной и А. С. Урюпиной // Литературный факт. 2020. № 1 (15).

7. «На вечерней заре». Главы из рукописи; Письма к С. П. Ремизовой-Довгелло. 19211922 гг. (окончание) / Комм. Е. Р. Обатниной; подг. текста Е. Р. Обатниной и А. С. Урюпиной // Литературный факт. 2018. № 8.

8. На вечерней заре: письма А. М. Ремизова С. П. Ремизовой-Довгелло: 1908 год / Вступ. статья, подг. текста и комм. Е. Р. Обатниной // Русская литература. 2014. № 3.

9. Обатнина E. Р. Этюды к творческой биографии А. М. Ремизова: «...или в Россию, или в Париж...» 1923 г. // Литературный факт. 2019. № 11.

10. Обатнина E. Р. Этюды к творческой биографии А. М. Ремизова: начало эмиграции. 1921-1922 гг. // Литературный факт. 2019. № 11.

11. Обатнина E. Р. Этюды к творческой биографии A. M. Ремизова: «La vie», или жизнь «чудесным образом». Париж, 1924-1925 // Литературный факт. 2019. № 4 (14).

12. Осоргин Мих. Дядя и тетя: «Благонамеренный». Книга 2-ая. Брюссель. 1926 г. // Последние новости. 1926. 29 апр. № 1863.

13. П. [Пильский П. М.]. Келья А. М. Ремизова // Сегодня. 1931. 7 июля. № 185.

14. Переписка Л. И. Шестова с А. М. Ремизовым / Вступ. заметка, подг. текста и прим. И. Ф. Даниловой и А. А. Данилевского // Русская литература. 1993. № 3.

15. Релизов А. М. Мои сны // Звено. 1925. 26 окт. № 143.

16. Релизов А. М. Собр. соч. М., 2000. Т. 3. Оказион.

17. Релизов А. М. Собр. соч. М., 2000. Т. 5. Взвихренная Русь.

18. Релизов А. М. Собр. соч. СПб., 2016. Т. 12. Русалия.

19. Релизов А. Письмо в редакцию: Редактору «Русской книги» проф. А. С. Ященко: І. Благодарность ( ООт книжников благодарность за берлинскую „Русскую книгу“...»); II. О Гржебине // Русская книга. 1921. № 9. Сентябрь.

20. «...С Вами беда - не перевести»: Письма Д. П. Святополк-Мирского к Ремизову (19221929) / Публ. Р. Хьюза // Диаспора. Париж; СПб., 2003. [Вып.] V.

21. Lampl H. Zinaida Hippius an S. P. Remizova-Dovgello // Wiener Slawistischer Almanach. 1978. Bd 1.

\section{References}

1. Dinershtein E. A. Siniaia ptitsa Zinoviia Grzhebina. M., 2014.

2. Dotsenko S. Problemy poetiki A. M. Remizova: Avtobiografizm kak konstruktivnyi printsip tvorchestva. Tallinn, 2000. 2010.

3. Gracheva A. M. Zhanr romana i tvorchestvo Alekseia Remizova (1910-1950-e gody). SPb.,

4. Lampl H. Zinaida Hippius an S. P. Remizova-Dovgello // Wiener Slawistischer Almanach. 1978. Bd 1.

5. «Na vechernei zare». Glava iz rukopisi; Pis'ma k S. P. Remizovoi-Dovgello. 1925 / Komm. E. R. Obatninoi; podg. teksta E. R. Obatninoi i A. S. Uriupinoi // Literaturnyi fakt. 2020. № 1 (15).

6. «Na vechernei zare». Glavy iz rukopisi; Pis'ma k S. P. Remizovoi-Dovgello. 1921-1922 gg. (okonchanie) / Komm. E. R. Obatninoi; podg. teksta E. R. Obatninoi i A. S. Uriupinoi // Literaturnyi fakt. 2018. № 8 .

7. Na vechernei zare: pis'ma A. M. Remizova S. P. Remizovoi-Dovgello: 1908 god / Vstup. stat’ia, podg. teksta i komm. E. R. Obatninoi // Russkaia literatura. 2014. № 3.

8. Obatnina E. R. Etiudy k tvorcheskoi biografii A. M. Remizova: «...ili v Rossiiu, ili v Parizh...» $1923 \mathrm{~g}$. // Literaturnyi fakt. 2019. № 11 .

9. Obatnina E. R. Etiudy k tvorcheskoi biografii A. M. Remizova: «La vie», ili zhizn" "chudesnym obrazom». Parizh, 1924-1925 // Literaturnyi fakt. 2019. № 4 (14).

10. Obatnina E. R. Etiudy k tvorcheskoi biografii A. M. Remizova: nachalo emigratsii. 19211922 gg. // Literaturnyi fakt. 2019. № 11.

11. Osorgin Mikh. Diadia i tetia: «Blagonamerennyi». Kniga 2-aia. Briussel’. 1926 g. // Poslednie novosti. 1926. 29 apr. № 1863.

12. P. [Pil'skii P. M.]. Kel’ia A. M. Remizova // Segodnia. 1931. 7 iiulia. № 185.

13. Perepiska L. I. Shestova s A. M. Remizovym / Vstup. zametka, podg. teksta i prim. I. F. Danilovoi i A. A. Danilevskogo // Russkaia literatura. 1993. № 3.

14. Remizov A. M. Moi sny // Zveno. 1925. 26 okt. № 143.

15. Remizov A. M. Sobr. soch. M., 2000. T. 3. Okazion. 
16. Remizov A. M. Sobr. soch. M., 2000. T. 5. Vzvikhrennaia Rus'.

17. Remizov A. M. Sobr. soch. SPb., 2016. T. 12. Rusaliia.

18. Remizov A. Pis'mo v redaktsiiu: Redaktoru «Russkoi knigi» prof. A. S. Iashchenko: I. Blagodarnost’ («Ot knizhnikov blagodarnost’ za berlinskuiu „Russkuiu knigu“...»); II. O Grzhebine // Russkaia kniga. 1921. № 9. Sentiabr’.

19. «...S Vami beda - ne perevesti»: Pis'ma D. P. Sviatopolk-Mirskogo k Remizovu (19221929) / Publ. R. Kh'iuza // Diaspora. Parizh; SPb., 2003. [Vyp.] V.

20. Vishniak M. V. Na rodine (My i oni) // Sovremennye zapiski. 1922. Kn. X.

21. Zaitsev B. Moi sovremenniki / Sost. N. B. Zaitsevoi-Sollogub; vstup. stat'ia B. Filippova. London, 1988.

\title{
Александр Аркадьевич Кобринский
}

профессор

Российского государственного педагогического университета им. А. И. Герцена

\author{
Aleksandr Arkad'evich Kobrinskii \\ Professor, Herzen State Pedagogical University of Russia \\ 444-44-4@list.ru

\begin{abstract}
МАСТЕР ПЕТР: НЕСКОЛЬКО ШТРИХОВ К БИОГРАФИЧЕСКИМ МИФАМ ДАНИИЛА ХАРМСА
\end{abstract} \\ MASTER PETER: A FEW SIDELIGHTS \\ ON DANIIL KHARMS'S BIOGRAPHICAL MYTHS
}

В публикации раскрывается судьба театрального художника и декоратора П. П. Снопкова, бывшего мужем художницы А. И. Порет и входившего в круг общения Даниила Хармса. С помощью найденных документов из архива Федеральной службы безопасности удается проследить историю ареста Снопкова в блокадном Ленинграде, установить источник и суть предъявлявшихся ему обвинений. Впервые публикуются материалы следственного дела Снопкова, протоколы допросов и очных ставок.

Ключевые слова: П. П. Снопков, Д. Хармс, А. И. Порет, репрессии, биография.

The publication outlines the lifestory of the stage artist and decorator P. P. Snopkov, the former husband of the artist A. I. Poret and a member of the circle of friends of Daniil Kharms. Using the documents discovered in the archives of the Federal Security Service, the author traces the history of Snopkov's arrest in the besieged Leningrad, in order to establish the sources and essence of the charges against him. The data on the investigation of Snopkov, protocols of interrogations and confrontations have not previously been published.

Key words: P. P. Snopkov, D. Kharms, A. I. Poret, repressions, biography.

\section{Списокл литературы}

1. Викторов Б. Александр Введенский и мир, или «Плечо надо связывать с четыре». Харьков, 2009.

2. Глебова Т. Н. Воспоминания. Дневники. Письма / Вступ. статья, подг. текстов, комм. E. C. Спицыной // Experiment = Эксперимент. A Journal of Russian Culture. 2010. Vol. 16. Part 2.

3. Дневниковые записи Даниила Хармса / Публ. А. Устинова и А. Кобринского // Минувшее. Исторический альманах. М.; СПб., 1994. [Т.] 11.

4. Заметка Н. Б. Шанько о воспоминаниях А. И. Порет // Даниил Хармс глазами современников: Воспоминания. Дневники. Письма / Под ред. А. Л. Дмитренко и В. Н. Сажина. СПб., 2019.

5. Порет А. И. Воспоминания о Д. И. Хармсе / Предисловие В. Глоцера // Панорама искусств. 1980. Сб. 3.

6. Порет А. И. Воспоминания о Данииле Хармсе // Даниил Хармс глазами современников: Воспоминания. Дневники. Письма / Под ред. А. Л. Дмитренко и В. Н. Сажина. СПб., 2019.

7. Порет А. И. Записки. Рисунки. Воспоминания: В 2 кн. М., 2016. 
8. Харлс Д. Горло бредит бритвою: случаи, рассказы, дневниковые записи / Сост. и комм. А. Кобринского и А. Устинова; предисловие А. Кобринского. М., 1991 (Глагол. Литературно-художественный журнал. Вып. 4).

9. Харлс Д. И. Неизданный Хармс. Полн. собр. соч. Трактаты и статьи. Письма. Дополнения: не вошедшее в т. 1-3 / Сост., прим. В. Н. Сажина. СПб., 2001.

10. Харлс Д. И. Полн. собр. соч. Записные книжки. Дневник: В 2 кн. / Сост. В. Сажина и Ж.-Ф. ЖЖаккара; прим. В. Сажина. СПб., 2002.

11. Шатова И. «Колесо радости жена»: анаграмматическая трактовка // Russian Literature. 2011. Vol. 69. № 2-4.

\title{
References
}

1. Dnevnikovye zapisi Daniila Kharmsa / Publ. A. Ustinova i A. Kobrinskogo // Minuvshee. Istoricheskii al'manakh. M.; SPb., 1994. [T.]11.

2. Glebova T. N. Vospominaniia. Dnevniki. Pis'ma / Vstup. stat'ia, podg. tekstov, komm. E. S. Spitsynoi // Experiment = Eksperiment. A Journal of Russian Culture. 2010. Vol. 16. Part 2.

3. Kharms D. Gorlo bredit britvoiu: sluchai, rasskazy, dnevnikovye zapisi / Sost. i komm. A. Kobrinskogo i A. Ustinova; predislovie A. Kobrinskogo. M., 1991 (Glagol. Literaturno-khudozhestvennyi zhurnal. Vyp. 4).

4. Kharms D. I. Neizdannyi Kharms. Poln. sobr. soch. Traktaty i stat'i. Pis'ma. Dopolneniia: ne voshedshee v t. 1-3 / Sost., prim. V. N. Sazhina. SPb., 2001.

5. Kharms D. I. Poln. sobr. soch. Zapisnye knizhki. Dnevnik: V 2 kn. / Sost. V. Sazhina i Zh.-F. Zhakkara; prim. V. Sazhina. SPb., 2002.

6. Poret A. I. Vospominaniia o D. I. Kharmse / Predislovie V. Glotsera // Panorama iskusstv. 1980. Sb. 3 .

7. Poret A. I. Vospominaniia o Daniile Kharmse // Daniil Kharms glazami sovremennikov: Vospominaniia. Dnevniki. Pis'ma / Pod red. A. L. Dmitrenko i V. N. Sazhina. SPb., 2019.

8. Poret A. I. Zapiski. Risunki. Vospominaniia: V 2 kn. M., 2016.

9. Shatova $I$. "Koleso radosti zhena»: anagrammaticheskaia traktovka // Russian Literature. 2011. Vol. 69. № 2-4. 2009.

10. Viktorov B. Aleksandr Vvedenskii i mir, ili «Plecho nado sviazyvat's chetyre». Khar'kov,

11. Zametka N. B. Shan'ko o vospominaniiakh A. I. Poret // Daniil Kharms glazami sovremennikov: Vospominaniia. Dnevniki. Pis'ma / Pod red. A. L. Dmitrenko i V. N. Sazhina. SPb., 2019.

\section{Валерий Юрьевич Вьюгин}

ведущий научный сотрудник

Института русской литературы (Пушкинский Дом) РАН; доцент Санкт-Петербургского государственного университета

\section{Valerii Iurevich Viugin}

Leading Researcher, Institute of Russian Literature (Pushkinskij Dom),

Russian Academy of Sciences;

Associate Professor, St. Petersburg State University

valeryvyugin@gmail.com

\section{ЗАДУМАНО СТАЛИНЫМ - СДЕЛАНО ХРУЩЕВЫМ \\ (ЕЩЕ РАЗ О ВТОРОМ ВСЕСОЮЗНОМ СЪЕЗДЕ СОВЕТСКИХ ПИСАТЕЛЕЙ СССР)}

\author{
CONCEIVED BY STALIN - IMPLEMENTED BY KHRUSHCHEV \\ (MORE ON THE SECOND CONGRESS OF THE SOVIET WRITERS)
}

Предлагаемая публикация вызвана необходимостью уточнить взгляд на историю Второго Всесоюзного съезда советских писателей СССР (1954) с учетом мало известных документов. Материалы, рассматриваемые ниже, касаются главным образом организационных аспектов проведе- 
ния съезда - почти в чистом виде менеджмента. Вместе с тем они помогают составить более четкое представление о характере этого форума литераторов с точки зрения идеологии и настроений его участников.

Ключевые слова: Второй Всесоюзный съезд советских писателей, Союз писателей СССР, литературный менеджмент.

The purpose of the article is to highlight the key moments in the history of the Second Congress of the Soviet Writers (1954). It presents a series of obscure archive documents on various aspects of the organization of the event, which also brings to light the character of the meeting from the per spective of ideology and emotions shared by its participants. ment.

Key words: Second Congress of the Soviet Writers, Union of Soviet Writers, literary manage-

\section{Список литературы}

1. Ажаев В. Н. Уважать свой «литературный цех» // Литературная газета. 1954. 11 нояб. № 134 .

2. Антипина В. А. Повседневная жизнь советских писателей. 1930-1950-е гг. М., 2005.

3. Аппарат ЦК КПСС и культура. 1953-1957: Документы / Сост. Е. С. Афанасьева, В. Ю. Афиани (отв. ред.) и др. М., 2001.

4. В жизнеутверждении - сила нашей литературы // Комсомольская правда. 1954. 6 июня.

5. Второй Всесоюзный съезд советских писателей. 15-26 декабря 1954 года. Стенографический отчет. М., 1956.

6. Второй Всесоюзный съезд советских писателей. Идеология исторического перехода и трансформация советской литературы. 1954 / Отв. ред. В. Ю. Вьюгин; сост. К. А. Богданов, В. Ю. Вьюгин. СПб., 2018.

7. Документы свидетельствуют... «Съезд должен мобилизовать писателей...» / Публ. Т. Домрачевой // Вопросы литературы. 1993. № 3.

8. Золотоносов М. Н. Гадюшник. Ленинградская писательская организация: Избр. стенограммы с комментариями (Из истории советского литературного быта 1940-1960-х гг.). М., 2013.

9. Катерли Е. И. Творческий союз или «литературный департамент» // Литературная газета. 1954. 30 окт. № 130.

10. Корлилов С. И. Второй съезд советских писателей как преддверие «оттепели» // Вестник Московского университета. Сер. 9. Филология. 2010. № 4.

11. Роланова Р. Союз писателей перед своим Вторым съездом (по материалам Центра хранения современной документации) // Вопросы литературы. 1993. № 3.

12. Силонов $K$. Письмо в редакцию // Литературная газета. 1954. 23 сент. № 114 .

13. Товарищам по работе // Литературная газета. 1954. 26 окт. № 128.

14. Хроника важнейших событий // Оттепель. 1953-1956: Страницы русской советской литературы / Сост., автор вступ. статьи и «Хроники важнейших событий» С. И. Чупринин. М., 1989.

15. Чупринин С. И. Оттепель: События (март 1953 - август 1968 года). М., 2020.

16. Suny R. G. The Soviet Experiment: Russia, the USSR, and the Successor States. New York, 1998.

\section{References}

1. Antipina V. A. Povsednevnaia zhizn' sovetskikh pisatelei. 1930-1950-e gg. M., 2005.

2. Apparat TSK KPSS i kul'tura. 1953-1957: Dokumenty / Sost. E. S. Afanas'eva, V. Iu. Afiani (otv. red.) i dr. M., 2001.

3. Azhaev V. N. Uvazhat' svoi «literaturnyi tsekh» // Literaturnaia gazeta. 1954. 11 noiab. № 134.

4. Chuprinin S. I. Ottepel': Sobytiia (mart 1953 - avgust 1968 goda). M., 2020.

5. Dokumenty svidetel'stvuiut... «S'ezd dolzhen mobilizovat' pisatelei...» / Publ. T. Domrachevoi // Voprosy literatury. 1993. № 3.

6. Katerli E. I. Tvorcheskii soiuz ili «literaturnyi departament»// Literaturnaia gazeta. 1954. 30 okt. № 130 .

7. Khronika vazhneishikh sobytii // Ottepel'. 1953-1956: Stranitsy russkoi sovetskoi literatury / Sost., avtor vstup. stat'i i «Khroniki vazhneishikh sobytii» S. I. Chuprinin. M., 1989.

8. Kormilov S. I. Vtoroi s'ezd sovetskikh pisatelei kak preddverie «ottepeli»// Vestnik Moskovskogo universiteta. Ser. 9. Filologiia. 2010. № 4.

9. Romanova $R$. Soiuz pisatelei pered svoim Vtorym s'ezdom (po materialam Tsentra khraneniia sovremennoi dokumentatsii) // Voprosy literatury. 1993. № 3.

10. Simonov K. Pis’mo v redaktsiiu // Literaturnaia gazeta. 1954. 23 sent. № 114 . 1998.

11. Suny R. G. The Soviet Experiment: Russia, the USSR, and the Successor States. New York,

12. Tovarishcham po rabote // Literaturnaia gazeta. 1954. 26 okt. № 128. 
13. V zhizneutverzhdenii - sila nashei literatury // Komsomol'skaia pravda. 1954. 6 iiunia.

14. Vtoroi Vsesoiuznyi s'ezd sovetskikh pisatelei. 15-26 dekabria 1954 goda. Stenograficheskii otchet. M., 1956.

15. Vtoroi Vsesoiuznyi s'ezd sovetskikh pisatelei. Ideologiia istoricheskogo perekhoda i transformatsiia sovetskoi literatury. 1954 / Otv. red. V. Iu. V'iugin; sost. K. A. Bogdanov, V. Iu. V'iugin. $\mathrm{SPb}, 2018$.

16. Zolotonosov M. N. Gadiushnik. Leningradskaia pisatel'skaia organizatsiia: Izbr. stenogrammy s kommentariiami (Iz istorii sovetskogo literaturnogo byta 1940-1960-kh gg.). M., 2013.

\section{Ксения Львовна Филимонова}

докторант Тартуского университета (Эстония)

\section{Ksenia Lvovna Filimonova}

Doctoral Student, University of Tartu (Estonia)

ksenja@gmail.com

\section{ЭПИЗОД ИЗ ИСТОРИИ ЛАГЕРНОЙ ЛИТЕРАТУРЫ: НЕИЗВЕСТНАЯ РЕЦЕНЗИЯ ВАРЛАМА ШАЛАМОВА}

\section{AN EPISODE FROM THE HISTORY OF THE CAMP LITERATURE: VARLAM SHALAMOV'S UNKNOWN REVIEW}

В 1958-1965 годах Варлам Шаламов работал внештатным рецензентом журнала «Новый мир». Среди рукописей «самодеятельных» авторов в журнал поступила одна, которую Шаламов высоко оценил и рекомендовал к публикации. В повести, написанной бывшим заключенным ГУЛАГа, врачом из Казани А. П. Чигариным, много общих тем, сюжетов, художественных оценок с «Колымскими рассказами» Шаламова.

Ключевые слова: Варлам Шаламов, Колымские рассказы, Новый мир, ГУЛАГ, лагерная проза.

In 1958-1965, Varlam Shalamov worked as a freelance reviewer for the Noviy Mir magazine. Shalamov highly estimated and recommended for publication one novel, that came in as a manuscript by an «amateur» author. The story, written by a former GULAG prisoner, a doctor from Kazan A. P. Tchigarin, shares many themes, plots, and artistic assessments with Shalamov's Kolyma Tales.

Key words: Varlam Shalamov, The Kolyma Tales, Noviy Mir, GULAG, prose of the ex-prisoners of GULAG.

\section{Список литературы}

1. Головизнин M. Медицина в жизни и творчестве Варлама Шаламова // «Закон сопротивления распаду»: Особенности прозы и поэзии Варлама Шаламова и их восприятие в начале XXI века. Сб. науч. тр. / Сост. Л. Бабка, С. Соловьев, В. Есипов, Ян Махонин. Прага; М., 2017.

2. Горбатов A. В. Годы и войны (Страницы воспоминаний) // Новый мир. 1964. № 3, 4, 5.

3. Солженицын А. И. Один день Ивана Денисовича // Новый мир. 1962. № 11.

4. Список студентов, посторонних слушателей и учениц повивального института императорского Казанского университета 1914-1915 г. Казань, 1914.

5. Шалалов В. Т. Собр. соч.: В 7 т. М., 2013. Т. 1, 2, 6.

\section{References}

1. Goloviznin M. Meditsina v zhizni i tvorchestve Varlama Shalamova // «Zakon soprotivleniia raspadu»: Osobennosti prozy i poezii Varlama Shalamova i ikh vospriiatie v nachale XXI veka. Sb. nauch. tr. / Sost. L. Babka, S. Solov'ev, V. Esipov, Ian Makhonin. Praga; M., 2017.

2. Gorbatov A. V. Gody i voiny (Stranitsy vospominanii) // Novyi mir. 1964. № 3, 4, 5 .

3. Shalamov V. T. Sobr. soch.: V 7 t. M., 2013. T. 1, 2, 6.

4. Solzhenitsyn A. I. Odin den’ Ivana Denisovicha // Novyi mir. 1962. № 11. 
5. Spisok studentov, postoronnikh slushatelei i uchenits povival'nogo instituta imperatorskogo Kazanskogo universiteta 1914-1915 g. Kazan’, 1914.

\section{Олег Андершанович Лекманов}

профессор фракультета гуманитарных наук

Национального исследовательского университета

«Высшая школа экономики»

Oleg Andershanovich Lekmanov

Professor, Faculty of Humanities,

National Research University Higher School of Economics

lekmanov@mail.ru

\section{РАСТИТЕЛЬНЫЙ КОД РАССКАЗА ФЕДОРА СОЛОГУБА «НИЧЕГО НЕ ВЫШЛО» \\ BOTANICAL KEY TO FEDOR SOLOGUB'S SHORT STORY IT DIDN'T WORK}

В заметке анализируется ранний рассказ Федора Сологуба «Ничего не вышло». Ключом к этому рассказу оказываются названия городов, в которых происходят события, и фамилии персонажей. Все они восходят к названиям растений. И в этом рассказе, и в других произведениях Сологуба Россия часто предстает растительным царством, где сорная и ядовитая флора дурманит головы несчастных обывателей.

Ключевые слова: Ф. Сологуб, символизм, русская проза, ботаника, анализ текста.

The article analyzes Fedor Sologub's early story It Didn't Work. The key to this story is the names of cities in which the events take place, and the names of the characters. All of them are derived from the names of plants. In the works of Sologub, Russia is often presented as a plant kingdom, where the weedy and poisonous flora stupefies the unfortunate inhabitants.

Key words: F. Sologub, Symbolism, Russian prose, botany, text analysis.

\section{Список литературы}

1. Павлова М. М. Творческая история романа «Мелкий бес» // Сологуб Ф. Мелкий бес / Изд. подг. М. М. Павлова. СПб., 2004 (сер. «Литературные памятники»).

2. Пушкин А. С. Полн. собр. соч.: В 16 т. М.; Л., 1948. Т. 8. Кн. 1.

3. Сологуб Ф. Ничего не вышло // Петербургская жизнь. 1896. 18 авг. № 198.

4. Сологуб Ф. Собр. соч.: В 12 т. СПб.: Шиповник, 1911. Т. 11.

\section{References}

1. Pavlova M. M. Tvorcheskaia istoriia romana «Melkii bes»// Sologub F. Melkii bes / Izd. podg. M. M. Pavlova. SPb., 2004 (ser. «Literaturnye pamiatniki»).

2. Pushkin A. S. Poln. sobr. soch.: V 16 t. M.; L., 1948. T. 8. Kn. 1.

3. Sologub F. Nichego ne vyshlo // Peterburgskaia zhizn’. 1896. 18 avg. № 198.

4. Sologub F. Sobr. soch.: V 12 t. SPb.: Shipovnik, 1911. T. 11. 


\title{
Светлана Анатольевна Дубровская
}

профессор кафедры русского языка как иностранного

Национального исследовательского Мордовского государственного университета им. Н. П. Огарева

\section{Svetlana Anatol'evna Dubrovskaia}

Professor, Department of Russian as Foreign Language, National Research Mordovia State University

s.dubrovskaya@bk.ru

\section{Олег Ефимович Осовский}

главный научный сотрудник

Мордовского государственного педагогического института им. М. Е. Евсевьева

\section{Oleg Efimovich Osovskii}

Chief Researcher, Mordovia State Pedagogical Institute

osovskiy_oleg@mail.ru

\section{О ЦИТАТАХ ИЗ ГЕРЦЕНА В ИССЛЕДОВАНИИ \\ М. М. БАХТИНА О РАБЛЕ}

\section{QUOTES FROM HERZEN}

IN M. M. BAKHTIN'S STUDY ON RABELAIS

\begin{abstract}
В заметке указывается основной источник цитат из статей А. И. Герцена, представленных в редакции рукописи М. М. Бахтина о Рабле (1949-1950) и подготовленной на ее основе монографии (1965). Это подаренный Н. П. Анциферовым Бахтину в день его защиты - 15 ноября 1946 года - сборник статей «А. И. Герцен» (1946), с сохранившимися в нем бахтинскими пометами. Цитаты из Герцена были призваны подчеркнуть идеологическую правильность новой редакции диссертации в условиях политических претензий к ней со стороны официальных инстанций.

Ключевые слова: М. М. Бахтин, Н. П. Анциферов, А. И. Герцен, «Франсуа Рабле в истории реализма», комментарий, источники цитат.

The article identifies the main source of quotes from A. Herzen, presented in 1949-1950 version of Bakhtin's manuscript on Rabelais and the monograph prepared on its basis (1965). It is the collection of essays on Herzen given to Bakhtin as a gift by N. Antsiferov on the day of Bakhtin's theses defense (1946, November 15). Bakhtin's marks on its pages offer an insight into his reaction to the official criticism and his attempts to emphasize the ideological correctness of the text.

Key words: M. Bakhtin, N. Antsiferov, A. Herzen, Francois Rabelais in the History of Realism, commentary, sources of quotes.
\end{abstract}

\section{Список литературы}

1. А. И. Герцен. 1812-1870: Сб. статей к 75-летию со дня смерти / Под ред. И. Клабуновского и Б. Козьмина. М., 1946.

2. Анциферов Н. П. Из дум о былом: Воспоминания. М., 1992.

3. Бахтин M. M. Творчество Рабле и проблема народной культуры средневековья и Ренессанса // Бахтин М. М. Собр. соч.: [В 7 т.]. М., 2010. Т. 4 (2).

4. Бахтин M. M. Творчество Франсуа Рабле и народная культура средневековья и Ренессанса. М., 1965.

5. Гериен А. И. Об искусстве. М., 1954.

6. Гериен А. И. Соч.: В 9 т. М., 1956. Т. 3.

7. Гоготишвили Л. А. Комментарии // Бахтин М. М. Собр. соч.: [В 7 т.]. М., 2010. Т. 6. 
8. Дубровская C. A. «Бахтин почти мой товарищ...»: о специфике последней волны первой русской рецепции «Проблем творчества Достоевского» (в печати). 1993.

9. Конкин С. С., Конкина Л. С. Михаил Бахтин: Страницы жизни и творчества. Саранск,

10. Осовский O. E. М. М. Бахтин читает Ольгу Фрейденберг: о характере и смысле бахтинских маргиналий на страницах «Поэтики сюжета и жанра» // М. М. Бахтин в Саранске: документы, материалы, исследования. Саранск, 2002.

11. Паньков Н. А. Вокруг «Рабле» // Паньков Н. А. Вопросы биографии и научного творчества М. М. Бахтина. М., 2010.

12. Паньков Н. А. Из переписки М. М. Бахтина и В. В. Кожинова // Паньков Н. А. Вопросы биографии и научного творчества М. М. Бахтина. М., 2010.

13. Перлина H. Еще раз о том, как по ходу работы над книгой о Рабле Михаил Бахтин читал «Поэтику сюжета и жанра» Ольги Фрейденберг // Хронотоп и окрестности: Юбилейный сборник в честь Николая Панькова = Chronotope and Environs: Festschrift for Nikolay Pan'kov / Под ред. Б. В. Орехова. Уфа, 2011.

14. Попова И. Л. История идей сквозь призму истории текста: Книга М. М. Бахтина о Рабле в 1930-1960-е годы // Попова И. Л. Книга М. М. Бахтина о Франсуа Рабле и ее значение для теории литературы. М., 2009.

15. [Попова И. Л.]. Комментарии и приложение // Бахтин М. М. Собр. соч.: [В 7 т.]. М., 2010. T. 4 (2).

16. Эльсберг Я. Е. Эстетические взгляды Герцена // А. И. Герцен. 1812-1870: Сб. статей к 75-летию со дня смерти / Под ред. И. Клабуновского и Б. Козьмина. М., 1946.

17. Юдина М. В. Высокий стойкий дух. Переписка 1918-1945 гг. М., 2006.

18. Юдина М. В. Жиизь полна смысла. Переписка 1956-1959 гг. М., 2008.

\section{References}

1. A. I. Gertsen. 1812-1870: Sb. statei k 75-letiiu so dnia smerti / Pod red. I. Klabunovskogo i B. Koz'mina. M., 1946.

2. Antsiferov N. P. Iz dum o bylom: Vospominaniia. M., 1992.

3. Bakhtin M. M. Tvorchestvo Fransua Rable i narodnaia kul'tura srednevekov'ia i Renessansa. M., 1965 .

4. Bakhtin M. M. Tvorchestvo Rable i problema narodnoi kul'tury srednevekov'ia i Renessansa // Bakhtin M. M. Sobr. soch.: [V 7 t.]. M., 2010. T. 4 (2).

5. Dubrovskaia S. A. «Bakhtin pochti moi tovarishch...»: o spetsifike poslednei volny pervoi russkoi retseptsii «Problem tvorchestva Dostoevskogo» (v pechati).

6. El'sberg Ia. E. Esteticheskie vzgliady Gertsena// A. I. Gertsen. 1812-1870: Sb. statei k 75-letiiu so dnia smerti / Pod red. I. Klabunovskogo i B. Koz’mina. M., 1946.

7. Gertsen A. I. Ob iskusstve. M., 1954.

8. Gertsen A. I. Soch.: V 9 t. M., 1956. T. 3.

9. Gogotishvili L. A. Kommentarii // Bakhtin M. M. Sobr. soch.: [V 7 t.]. M., 2010. T. 6.

10. Iudina $M$. V. Vysokii stoikii dukh. Perepiska 1918-1945 gg. M., 2006.

11. Iudina M. V. Zhizn’ polna smysla. Perepiska 1956-1959 gg. M., 2008.

12. Konkin S. S., Konkina L. S. Mikhail Bakhtin: Stranitsy zhizni i tvorchestva. Saransk, 1993.

13. Osovskii O. E. M. M. Bakhtin chitaet Ol'gu Freidenberg: o kharaktere i smysle bakhtinskikh marginalii na stranitsakh "Poetiki siuzheta i zhanra» // M. M. Bakhtin v Saranske: dokumenty, materialy, issledovaniia. Saransk, 2002.

14. Pan'kov N. A. Iz perepiski M. M. Bakhtina i V. V. Kozhinova // Pan'kov N. A. Voprosy biografii i nauchnogo tvorchestva M. M. Bakhtina. M., 2010.

15. Pan’kov N. A. Vokrug «Rable»// Pan'kov N. A. Voprosy biografii i nauchnogo tvorchestva M. M. Bakhtina. M., 2010.

16. Perlina N. Eshche raz o tom, kak po khodu raboty nad knigoi o Rable Mikhail Bakhtin chital "Poetiku siuzheta i zhanra» Ol'gi Freidenberg // Khronotop i okrestnosti: Iubileinyi sbornik v chest" Nikolaia Pan'kova = Chronotope and Environs: Festschrift for Nikolay Pan'kov / Pod red. B. V. Orekhova. Ufa, 2011.

17. Popova I. L. Istoriia idei skvoz' prizmu istorii teksta: Kniga M. M. Bakhtina o Rable v 19301960-e gody // Popova I. L. Kniga M. M. Bakhtina o Fransua Rable i ee znachenie dlia teorii literatury. M., 2009. T. 4 (2).

18. [Popova I. L.]. Kommentarii i prilozhenie // Bakhtin M. M. Sobr. soch.: [V 7 t.]. M., 2010. 


\section{Петр Романович Заборов}

главный научный сотрудник Института русской литературы (Пушкинский Дом) РАН

\section{Piotr Romanovich Zaborov}

Chief Researcher,

Institute of Russian Literature (Pushkinskij Dom), Russian Academy of Sciences

p.zaborov@gmail.com

\section{ЦЕННЫЙ ИСТОЧНИКОВЕДЧЕСКИЙ ТРУД}

\section{VALUABLE WORK ON SOURCE CRITICISM}

Рец. на: Французские и франкоязычные рукописи в России (XVIII - начало XIX в.) / Под ред. Е. Е. Дмитриевой и А. В. Голубкова. М.: ИМЛИ РАН, 2019. 576 с.

[Review]: Frantsuzskie i frankoiazychnye rukopisi v Rossii (XVIII - nachalo XIX v.) / Pod red. E. E. Dmitrievoi i A. V. Golubkova. M.: IMLI RAN, 2019. 576 s.

\section{Галина Евгеньевна Потапова}

научный сотрудник Русской христианской гуманитарной академии

\section{Galina Evgen'evna Potapova}

Researcher, Russian Christian Academy for the Humanities

GPotap@list.ru

\section{КУРС ЛЕКЦИЙ В. М. МАРКОВИЧА О РУССКОЙ ЛИТЕРАТУРЕ ПЕРВОЙ ПОЛОВИНЫ ХІХ ВЕКА}

\section{M. MARKOVICH'S LECTURES ON THE RUSSIAN LITERATURE OF THE FIRST HALF OF THE $19^{\mathrm{TH}}$ CENTURY}

Рец. на: Маркович В. М. Русская литература Золотого века: Лекции / Под ред. Е. Н. Григорьевой. СПб.: Росток, 2019. 752 с.

[Review]: Markovich V. M. Russkaia literatura Zolotogo veka: Lektsii / Pod red. E. N. Grigor'evoi. SPb.: Rostok, 2019. $752 \mathrm{~s}$.

\section{Олег Алексеевич Клинг}

заведующий кафедрой теории литературы филологического факультета

Московского государственного университета им. М. В. Ломоносова

\section{Oleg Alekseievich Kling}

Head of the Department of Literary Theory, Department of Philology, Lomonosov Moscow State University okling@yandex.ru

\section{РАЗГАДКА ТАЙН Н.В. ГОГОЛЯ}

\section{THE KEY TO THE SECRETS OF N. V. GOGOL}

Рец. на: Манн Ю. В. Н. В. Гоголь: тайны биографии и тайны творчества. М.: РГГУ, 2019. 143 с. [Review]: Mann Iu. V. N. V. Gogol': tainy biografii i tainy tvorchestva. M.: RGGU, 2019. $143 \mathrm{~s}$. 


\section{Светлана Владимировна Федотова}

ведущий научный сотрудник Института мировой литературы им. А. М. Горького РАН

\section{Svetlana Vladimirovna Fedotova}

Senior Researcher, A. M. Gorky Institute of World Literature, Russian Academy of Sciences lucia-th@yandex.ru

\section{ДОСТОЕВСКИЙ В РАКУРСЕ АКАДЕМИЧЕСКОЙ МЕТАКРИТИКИ}

\section{DOSTOEVSKY FROM THE PERSPECTIVE OF ACADEMIC METACRITICISM}

Рец. на: Келдыш В. А. Наследие Ф. М. Достоевского в философской и литературно-критической мысли Серебряного века русской литературы. М.: ИМЛИ РАН, 2019. 280 с.

[Review]: Keldysh V. A. Nasledie F. M. Dostoevskogo v filosofskoi i literaturno-kriticheskoi mysli Serebrianogo veka russkoi literatury. M.: IMLI RAN, 2019. $280 \mathrm{~s}$.

\section{Елена Николаевна Григорьева}

доцент кафедры истории русской литературы

Санкт-Петербургского государственного университета

\section{Elena Nikolaevna Grigoryeva}

Associate Professor, Department of the History of Russian Literature,

St. Petersburg State University

egrig58@gmail.com

\section{Александр Анатольевич Карпов}

профессор кафедры истории русской литературы

Санкт-Петербургского государственного университета

\section{Alexander Anatolyevich Karpov}

Professor, Department of the History of Russian Literature,

St. Petersburg State University

aleksandrkarpoff@yandex.ru

\section{Николай Александрович Карпов}

доцент кафедры истории русской литературы

Санкт-Петербургского государственного университета

\section{Nikolay Aleksandrovich Karpov}

Associate Professor, Department of the History of Russian Literature,

St. Petersburg State University shakespirr@mail.ru

\section{ПЕТЕРБУРГСКОЕ УНИВЕРСИТЕТСКОЕ ЛИТЕРАТУРОВЕДЕНИЕ В ЕГО ПРОШЛОМ И НАСТОЯЩЕМ}

\section{LITERARY STUDIES AT ST. PETERSBURG UNIVERSITY: PAST AND PRESENT}




\section{Людмила Васильевна Спроге}

заведующая Центром русистики отделения Русистики и славистики факультета Гуманитарных наук Латвийского университета (Латвия)

Liudmila Vasil'evna Sproge

Head of the Center of Russian Studies, Department of Russian and Slav Studies, Faculty of Humanitarian Sciences University of Latvia (Latvia)

ls@lu.lv

\section{Татьяна Сергеевна Царькова}

ведущий научный сотрудник

Института русской литературы (Пушкинский Дом) РАН

Tat'iana Sergeevna Tsar'kova

Leading Researcher,

Institute of Russian Literature (Pushkinskij Dom), Russian Academy of Sciences irliran@mail.ru

МЕЖДУНАРОДНЫЙ БАЛТИЙСКИЙ СЕМИНАР «ГЕОРГИЙ АДАМОВИЧ И... (К ПРОБЛЕМЕ ИЗУЧЕНИЯ КУЛЬТУРЫ РУССКОЙ ДИАСПОРЫ)»

INTERNATIONAL BALTIC SEMINAR GEORGE ADAMOVICH AND... (ON THE PROBLEM OF STUDYING THE CULTURE OF THE RUSSIAN DIASPORA)

[Meeting Abstract]

\section{Сергей Акимович Кибальник}

ведущий научный сотрудник

Института русской литературы (Пушкинский Дом) РАН; профессор Санкт-Петербургского государственного университета

Sergei Akimovich Kibal'nik

Leading Researcher,

Institute of Russian Literature (Pushkinskij Dom), Russian Academy of Sciences; Professor, St. Petersburg State University

Kibalnik007@mail.ru

\section{МЕЖДУНАРОДНЫЙ НАУЧНО-ИССЛЕДОВАТЕЛЬСКИЙ СЕМИНАР «ИСТОРИЯ ТЕКСТА И ТВОРЧЕСКАЯ ИСТОРИЯ ПРОИЗВЕДЕНИЙ ДОСТОЕВСКОГО»}

TEXT HISTORY AND CREATIVE HISTORY OF DOSTOEVSKY'S WORKS

INTERNATIONAL RESEARCH SEMINAR

[Meeting Abstract] 


\section{Дмитрий Михайлович Буланин}

главный научный сотрудник

Института русской литературы (Пушкинский Дом) РАН

Dmitrii Mikhailovich Bulanin

Senior Researcher,

Institute of Russian Literature (Pushkinskij Dom), Russian Academy of Sciences

dmitriibulanin@yandex.ru

\section{СИМПОЗИУМ «ЗАГАДКА В СРЕДНЕВЕКОВОЙ СЛАВЯНСКОЙ КУЛЬТУРЕ»}

В КЁЛЬНЕ

ENIGMA IN MEDIEVAL SLAVIC CULTURE SYMPOSIUM IN COLOGNE

[Meeting Abstract] 
Учредители:

Российская академия наук

Отделение историко-филологических наук РАН

119991, Москва, ГСП-1, Ленинский пр., 32а

Телефон: (495) 938-17-63, факс: (495) 938-17-64

oifn@mail.ru; www.hist-phil.ru

Федеральное государственное бюджетное учреждение науки

Институт русской литературы (Пушкинский Дом) Российской академии наук 199034, Санкт-Петербург, наб. Макарова, 4

Телефон: (812) 328-19-01, факс: (812) 328-11-40

irliran@mail.ru; www.pushkinskijdom.ru

Журнал зарегистрирован

Министерством печати и информации Российской Федерации

Регистрационный номер 0110194 от 4 февраля 1993 г.

Адрес редакции: 199034, Санкт-Петербург, наб. Макарова, 4

Телефон/факс: (812) 328-16-01, rusliter@mail.ru; www.pushkinskijdom.ru

Зав. редакцией И. Ф. Данилова

Редакторы О. В. Макаревич, В. В. Филичева, А. Ю. Соловьев

Корректор Т. А. Руляниева

Компьютерная верстка $E$. A. Назаровой

Оригинал-макет подготовлен ООО «Издательство „Чистый лист“»

Сдано в набор 07.05.20. Подписано к печати 31.07.20. Дата выхода в свет 28.08.20

Формат $70 \times 1001 \%$. Гарнитура SchoolBook. Цифровая печать.

Уч.-изд. л. 29,5. Тираж 330 экз.

Тип. зак. № 17/3а. Цена свободная

Издатель: Российская академия наук

Исполнитель по контракту № 4У-ЭА-040-19

ООО «Интеграция: Образование и Наука»

105082, г. Москва, Рубцовская наб., д. 3, стр. 1, пом. 1314

Отпечатано в ООО «Институт информационных технологий» 